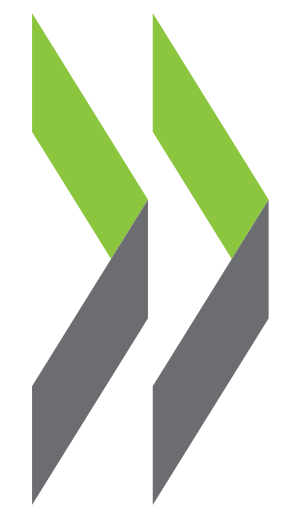

ESAO pārskati par digitālo transformāciju

\title{
Digitalizācija Latvijā
}



Digitalizācija Latvijā

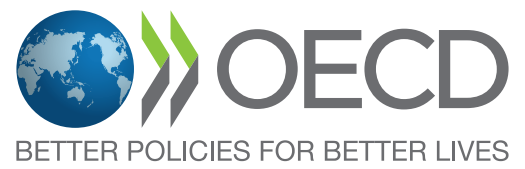


Šis darbs publicēts ESAO ǵenerālsekretāra pārziṇā. Šeit paustie viedokḷli un izmantotie argumenti ne vienmēr atspoguḷo ESAO dalībvalstu oficiālo viedokli.

Šis darbs, kā arī visi tajā iekḷautie dati un kartes neskar nevienas teritorijas statusu vai suverenitāti, starptautisko robežu vai norobežojumu noteikšanu, kā arī jebkuras teritorijas, pilsētas vai apgabala nosaukumu.

Statistikas datus par Izraēlu sniedza, un par tiem atbild Izraēlas attiecīgās iestādes. Šo datu izmantošana ESAO neskar Golānas augstieṇu, Austrumjeruzalemes un Izraēlas apmetṇu statusu Rietumkrastā saskaṇā ar starptautisko tiesību noteikumiem.

\section{Lūdzu, atsaucieties uz šo publikāciju kā:}

OECD (2021), Digitalizācija Latvijā, OECD Publishing, Paris, https://doi.org/10.1787/a58d1c1a-Iv.

ISBN 978-92-64-60703-3 (print)

ISBN 978-92-64-57483-0 (pdf)

Darba oriǵinālu ESAO publicējusi angḷu valodā ar nosaukumu: Going Digital in Latvia @ 2021 OECD (ESAO)

Šis tulkojums tiek publicēts pēc vienošanās ar ESAO. Tas nav oficiāls ESAO tulkojums. Tulkošanas kvalitāte un tā atbilstība darba oriǵinālvalodas tekstam ir vienīgi tulkojuma autora(u) atbildība. Ja rodas neatbilstība starp oriǵinālo darbu un tulkojumu, par derīgu tiek uzskatīts tikai oriǵinālā darba teksts.

Izmantotās fotogrāfijas: Vāka @ Adobe Stock/Attēla dizains @ Taï Marc Le Than. 


\section{Priekšvārds}

Digitalizācija Latvijā ir daḷa no jaunas ESAO valstu pārskatu sērijas. ESAO pārskatos par digitalizāciju skatītas valstu nesenās tendences digitālās ekonomikas jomā, analizēta ar digitalizāciju saistītā politika un sniegti ieteikumi labākai politikas saskaṇotībai šajā jomā.

Dokumentā Digitalizācija Latvijā pētīta nesenā attīstība digitālās ekonomikas infrastruktūrā, telekomunikāciju tirgos un saistītajā regulējumā un politikā Latvijā. Tajā aplūkotas tendences digitālo tehnolog̣iju izmantošanā privātpersonu, uznēmumiem un publiskajā pārvaldē un analizēta politika digitālo tehnoloǵiju ieviešanas veicināšanai. Tajā arī analizētas digitalizācijas radītās iespējas un izaicinājumi galvenajās jomās un novērtēta politika, reageējot uz šādām pārmaiṇām. Tiek apskatìtas jomas, sākot no inovācijas un prasmēm līdz digitālajai drošībai un datu pārvaldībai.

Pārskatā arī aplūkota šāda politika saistībā ar tās ietekmi dažādās jomās, lai veicinātu sinerğiju starp ministrijām un iestādēm, pamatojoties uz ESAO integrēto politikas satvaru digitalizācijai.

Dokuments Digitalizācija Latuijā sagatavots pēc Latvijas Republikas Vides aizsardzības un reǵionālās attīstības ministrijas aicinājuma, kura arī sniedza finansiālo atbalstu. Pārskatu veica ESAO Zinātnes, tehnolog̣iju un inovācijas direktorāts ESAO Digitālās ekonomikas politikas komitejas vadībā.

Pārskatu sagatavoja Vincenzo Spiezia vadīta darba grupa, kuras sastāvā bija Duncan CassBeggs, Ghislain De Salins, Rory O'Farrell, Joshua Polchar, Lorrayne Porciuncula, Elettra Ronchi, Julia Staudt, Jan Tscheke un Akira Yoshida. To uzraudzìja Digitālās ekonomikas nodaḷas iepriekšèjā vadītāja Anne Carblanc un pašreizējā vadītāja Audrey Plonk. Vērtīgas piezīmes šim pārskatam sniedza arī Hermann Garden, Oscar Huerta Melchor, Gernot Hutschenreiter, George Kamiya, Kenza Khachani, Soo-Jin Kim, Aline Matta, Jilian Oderkirk, Atsuhito Oshima un Dirk Pilat.

Autori pateicas par atbalstu un sadarbỉbu Latvijas Republikas Vides aizsardzỉbas un reg̣ionālās attīstības ministrijai, jo īpaši Elitai Zvaigznei, Arnim Skraučam, Laurai Ginterei, Gatim Ozolam, Ārim Dzērvānam, Laurim Linabergam, Mikum Jēkabsonam, Uǵim Biseniekam, Jānim Glazkovam, Margaritai Krišlaukai un Karīnai Eglìtei-Miezītei, kā arī Artim Grīnbergam un prof. Edvīnam Karnītim.

Pārskata pamatā ir rezultāti, kas gūti vairākās intervijās ar dažādām ieinteresētajām personām, kas veiktas divos Latvijas apmeklējumos 2019. gada aprīlī un decembrī, kurās piedalījās: Ainars Andersons, Uldis Apsītis, Mikus Arājs, Armands Aivo Astukevičs, Signe Bāliṇa, Dāvis Baumanis, Daiga Behmane, Edmunds Beḷskis, Iveta Bērtulsone, Lāsma Dilba, Andrejs Dombrovskis, Uldis Donin̦š, Oḷegs Fiḷipovičs, Alnis Garkājis, Jānis Grēvin̦š, Linda Helmane, Gundars Ignats, Aiga Irmeja, Juris Kalējs, Zita Kanberga, Inga Kasicka, Maija Katkovska, Baiba Kḷaviṇa, Sandis Kondrats, Katrinna Kosa-Ammari, Mārcis Kroja, Aivars Lapin̄š, Artis Lapin,š, Rolands Lappuk̦e, Agnese Lukevica, Nellija Mahova, Juris Matvejs, Vismands Menjoks, Gatis Mezītis, Sarmìte Mickēviča, Jel̦ena Muhina, Vita Narnicka, Aleksejs Nipers, Laura Očagova, Jānis Paiders, Inita Pavloviča, Prof. Jurǵis Poriṇš, Vitālijs Rakstiṇš, Zane Rozkalne, Prof. Leo Sel̦āvo, Kristīne Šica, Ilze Sīle, Agnese Šḳēle, Ieva Skujēns-Skujiṇa, Kristaps Soms, Ilze Štrassere, Renāte Strazdiṇa, Rolands Strazdiṇš, Elinna Stungrevica, Laura Treimane, Dainis Valdmanis, Uldis Zarin̦š, Olga Zeile and Sanita Žogota.

2020. ada 15. maijā ESAO padome uzaicināja Kostariku kḷūt par tās biedru. Šīs publikācijas sagatavošanas laikā vēl nebija pieṇemts lēmums par Kostarikas pievienošanās ESAO konvencijai instrumenta ieguldỉjumu, tāpēc Kostarika nav redzama ESAO biedru sarakstā un nav iekḷauta ESAO zonas kopskaitā. 



\section{Satura rādītājs}

Priekšvārds.

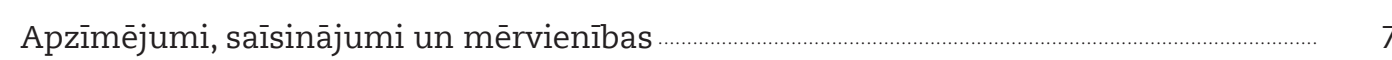

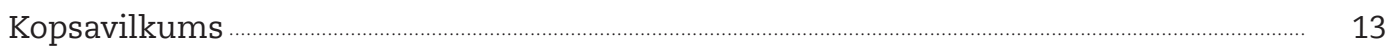

Nodaḷa 1 LATVIJA DIGITĀLAJĀ TRANSFORMĀCIJĀ: IESPĒJAS UN IZAICINĀJUMI Jaunākās ekonomikas un sociālās tendences Latvijā ........................................... 18 Latvijas digitālās transformācijas stratēǵija ................................................................. 22

Digitalizācijas integrētās politikas satvars .............................................................................. 24

Digitalizācija Latvijā ...................................................................................................... 26

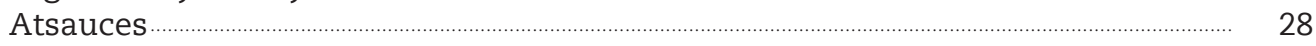

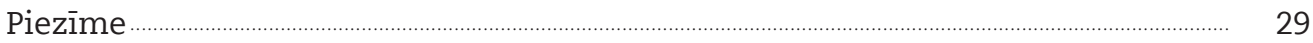

Nodaḷa 2 GALVENĀS NĀKOTNES NENOTEIKTĪBAS DIGITĀLAJĀ TRANSFORMĀCIJĀ UN POTENCIĀLĀS SEKAS LATVIJAI

Ievads.

Kāpēc scenāriji? L Lēmumu pienemšana nenoteiktības kontekstā

Ká izmanto šo nodalu pieñ

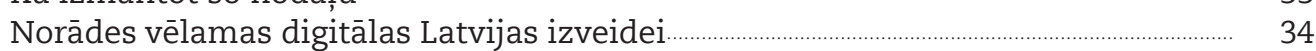

Trīs scenāriji: Latvijas iztēlošanās dažādos nākotnes kontekstos .................................... 35

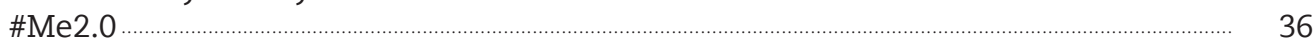

Platformas valdības . . . . . . .

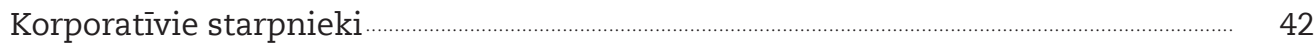

Stratēgiskās perspektīvas, kas jāapsver Latvijai ............................................................. 45

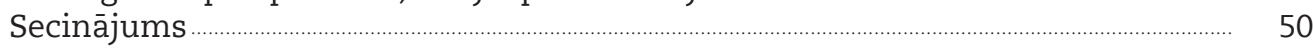

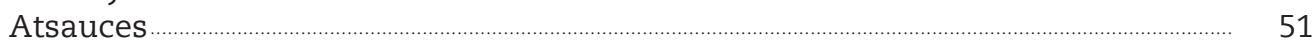

Piezìmes ........................................................................................................................... 51

Nodaḷa 3 INFRASTRUKTŪRAS LATVIJAS DIGITĀLAJAI EKONOMIKAI

Komunikācijas politikas uzdevumi Latvijas digitālajai transformācijai ...................... 54

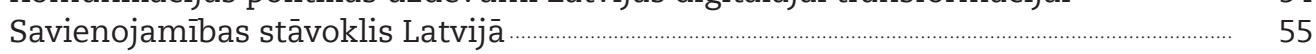

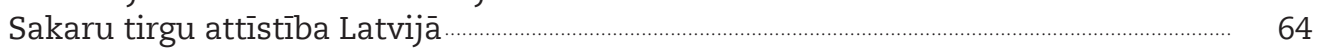

Regulējuma un politikas attīstība Latvijā ......................................................................... 69

Politikas ieteikumi ................................................................................................................ 76

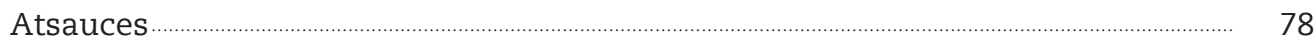

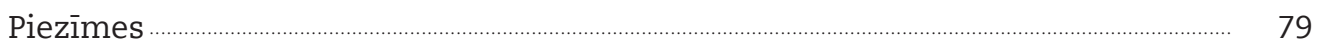

Nodaḷa 4 DIGITĀLĀS TRANSFORMĀCIJAS ATBALSTİ̌̌ANA STARP CILVĒKIEM, UZN̦ĒMUMIEM UN VALDĪBU

Digitālo tehnolog̣iju lietošana iedzīvotāju vidū ................................................................ 82

Digitālo tehnolog̣iju lietošana uzṇēmumos ............................................................................ $\quad 90$

Digitālo tehnolog̣iju lietošana valdībā ................................................................................. 107

Secinājumi un politikas rekomendācijas ........................................................................ 115

Atsauces $\ldots$

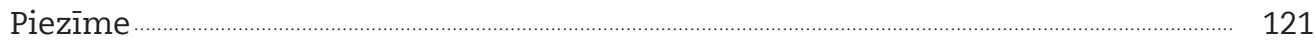

Nodal̦a 5 UZTICAMĪBAS VEICINĀŠANA DIGITĀLAJAI EKONOMIKAI

Latvijas digitālās drošỉbas politika ...................................................................... 124

Uzticamības veidošana ar lielāku privātumu ................................................................ 138

Patērētāju aizsardzība ............................................................................................... 146

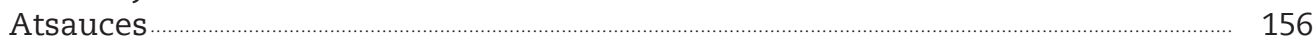

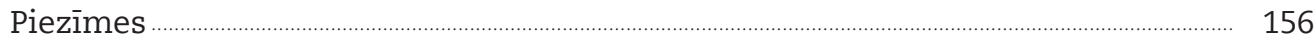


Nodaḷa 6 EKONOMIKAS UN SABIEDRĪBAS DIGITĀLĀS PĀRVEIDES IESPĒJU IZMANTOŠANA

Digitālo inovāciju šḳēršḷu novēršana.

Latvijas Viedās specializācijas stratēǵija ..................................................................... 174

Atsauces

Piezìmes

Nodala 7 DIGITĀLĀS TRANSFORMĀCIJAS POLITIKAS: REKOMENDĀCIJAS VALDİBAS KOPĒJAI PIEEJAI

Digitalizācija Latvijā: Integrētas politikas satvars

Kopīgas valdības līmeṇa pieejas digitālās transformācijas politikas izveide

\section{Follow OECD Publications on:}

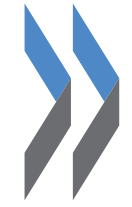

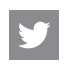

http://twitter.com/OECD_Pubs

http://www.facebook.com/OECDPublications

in. http://www.linkedin.com/groups/OECD-Publications-4645871

Toune http://www.youtube.com/oecdilibrary

http://www.oecd.org/oecddirect/ 


\section{Apzīmējumi, saīsinājumi un mērvienības}

\begin{tabular}{|c|c|}
\hline A-Patch & Autonoms plāksteris infekcijas slimību noteikšanai reāllaikā \\
\hline ADTP & Aktīva darba tirgus politika \\
\hline AHK & Vācijas-Baltijas Tirdzniecības kamera \\
\hline AII & Augstākās izglītības iestāde \\
\hline AIKA & Augstākās izglītības kvalitātes aǵentūra \\
\hline AM & Aizsardzības ministrija \\
\hline$\overline{\mathbf{A}} \mathbf{M}$ & Ārlietu ministrija \\
\hline ANO & Apvienoto Nāciju Organizācija \\
\hline ANSSI & $\begin{array}{l}\text { Francijas Nacionālā kiberdrošības aǵentūra (Agence nationale de la sécurité des } \\
\text { systèmes d'information) }\end{array}$ \\
\hline ĀTI & Ārvalstu tiešie ieguldijumi \\
\hline BBEC & Baltijas Biomateriālu ekselences centrs \\
\hline BCRD & $\begin{array}{l}\text { ES Direktīva par pasākumiem ātrdarbīgu elektronisko sakaru tīklu izvēršanas } \\
\text { izmaksu samazināšanai }\end{array}$ \\
\hline BIF & Baltijas Inovāciju fonds \\
\hline BIOR & Pārtikas drošības, dzīvnieku veselības un vides zinātniskais institūts \\
\hline BIT & Būtiska ietekme tirgū \\
\hline BURVIS & Bezdarbnieku uzskaites un registrēto vakanču informācijas sistēma \\
\hline CAMART2 & Viedo materiālu pētījumu un tehnolog̣iju pārneses ekselences centrs \\
\hline CERT & Informācijas tehnoloǵiju drošības incidentu novēršanas institūcija \\
\hline CFLA & Centrālā finanšu un līgumu aǵentūra \\
\hline CISA & Kiberdrošības un infrastruktūras drošības aǵentūra \\
\hline CMS & Centrālā vadības sistēma \\
\hline CNC & Ciparvadība \\
\hline CRM & Klientu attiecību pārvaldība \\
\hline CSDD & Cel̦u satiksmes drošības direkcija \\
\hline CSIRT & Datordrošības incidentu reaǵēšanas vienība \\
\hline DAI & Datu aizsardzības iestādes \\
\hline DAIF Latvija & Latvijas Drošības un aizsardzības industriju federācija \\
\hline DAKAP & Datu aizsardzības konsultatīvā atbalsta padome \\
\hline DBN & Datos balstīta nācija \\
\hline DDos & Izkliedētais pakalpojuma atteikums \\
\hline DIC & Digitālo inovāciju centri \\
\hline DRR & Strīdu izšḳiršana un tiesiskā aizsardzība \\
\hline DSL & Domēnspecifiska valoda \\
\hline DVI & Datu valsts inspekcija \\
\hline ECC-Net & Eiropas Patērētāju centru tīkls \\
\hline EDAK & Eiropas Datu aizsardzības kolēgija \\
\hline EDSO & Eiropas Drošības un sadarbības organizācija \\
\hline EEZ & Eiropas Ekonomikas zona \\
\hline eIDAS & Elektroniskās identifikācijas, autentifikācijas un uzticamības pakalpojumi \\
\hline EJZF & Eiropas Jūrlietu un zivsaimniecības fonds \\
\hline EK & Eiropas Komisija \\
\hline EKB & Elektronisko komunikāciju birojs (VAS Elektroniskie sakari) \\
\hline ELFLA & Eiropas Lauksaimniecības fonds lauku attīstībai \\
\hline
\end{tabular}




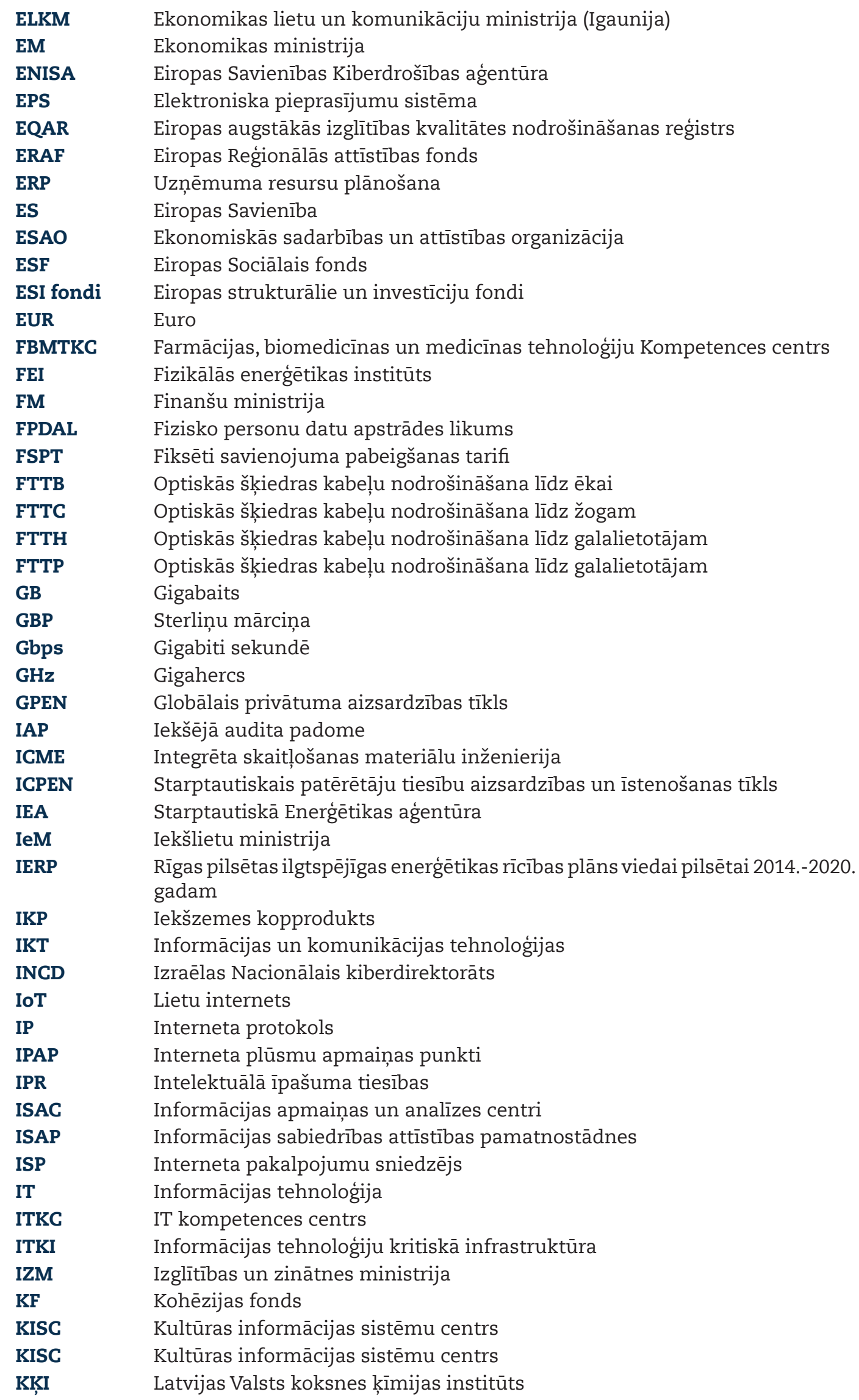




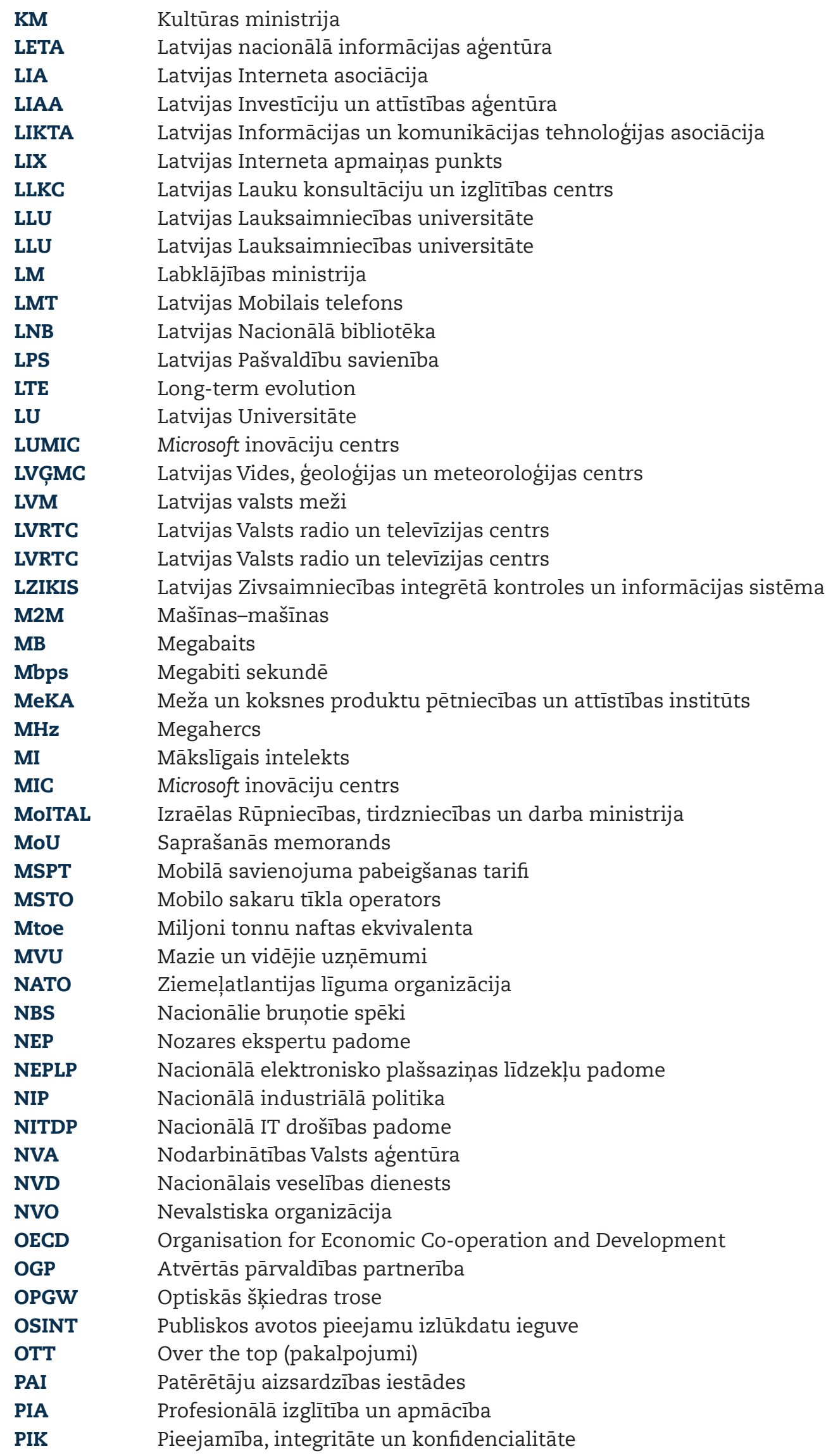




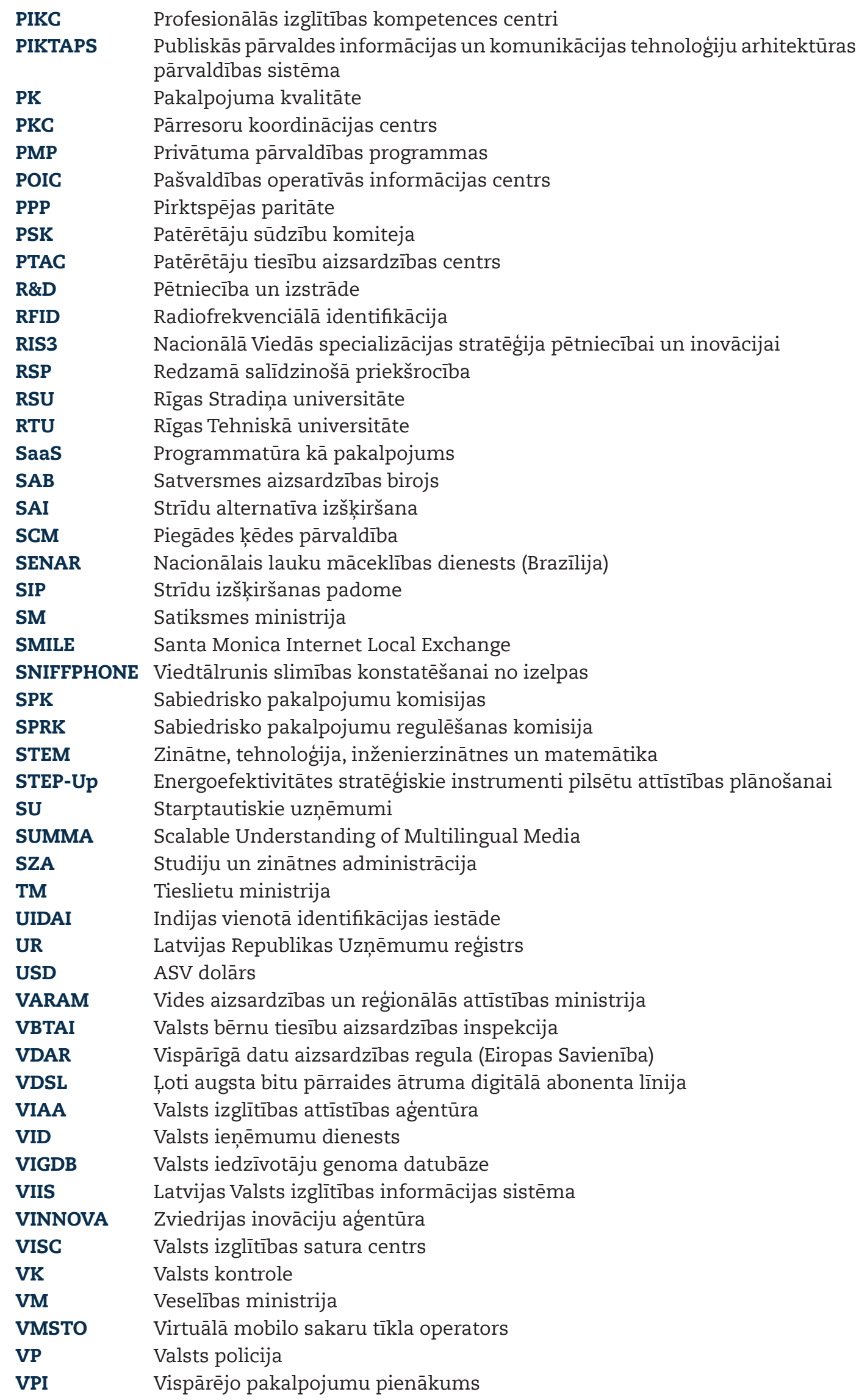




$\begin{array}{ll}\text { VPN } & \text { Virtuāls privāts tīkls } \\ \text { VPVKAC } & \text { Valsts un pašvaldību vienotie klientu apkalpošanas centri } \\ \text { VRAA } & \text { Valsts reǵionālās attīstības aǵentūra } \\ \text { VRAA } & \text { Valsts reğionālās attīstības ağentūra } \\ \text { VTEB } & \text { Valsts tiesu ekspertǐžu birojs } \\ \text { VZD } & \text { Valsts zemes dienests } \\ \text { WFS } & \text { Web Feature Service } \\ \text { WGI } & \text { Pasaules mēroga pārvaldības rādītāji } \\ \text { WMS } & \text { Web Map Service } \\ \text { WSIS } & \text { Pasaules informācijas sabiedrības samits } \\ \text { ZBK } & \text { Uz zinātību balstīts kapitāls } \\ \text { ZKV } & \text { Zemessardzes Kiberaizsardzības vienība } \\ \text { ZM } & \text { Zemkopības ministrija } \\ \text { ZTAI } & \text { Zinātne, tehnoloğiju attīstība un inovācija }\end{array}$





\section{Kopsavilkums}

Latvija kopš 21.gs. pirmās desmitgades sākuma ir strauji augusi un tuvojusies augstākam dzìves līmenim. Taču priekšā vēl ir ievērojami izaicinājumi. Novecošanās un emigrācijas dēḷ iedzīvotāju skaits strauji samazinās, produktivitātes izaugsmē pēc 2008. gada globālās krīzes notika lejupslīde, un Covid-19 pandēmijas ietekmes dēl izaugsmes izredzes ir drūmas.

Politika digitālās transformācijas veicināšanai ir būtiski svarīga, lai minētās problēmas risinātu. Dokumentā Digitalizācija Latvijā analizētas iespējas un izaicinājumi, ko Latvijā rada digitālā transformācija, aplūkota pašreizējā politika un sniegti ieteikumi tās uzlabošanai, pamatojoties uz ESAO integrēto politikas satvaru digitalizācijai. Šajā pārskatā arī vērsta uzmanība uz atsevišḳiem satvara elementiem saskaṇā ar Latvijas minētajām prioritātēm.

\section{Savienojamỉbas uzlabošana}

Latvijai ir labi rezultāti gan stacionāro, gan mobilo ātrdarbīgo platjoslas tīklu izvietošanā. Taču starp pilsētu un lauku apvidiem pastāv atšḳirības savienojamībā. Pastāv arī bažas par konkurenci fiksētās platjoslas tirgū, kurā vēsturiskā dalībnieka daḷa ir 56 \%.

Lai sagatavotos sakaru tehnoloǵiju un tirgu turpmākajai attīstībai, Latvijai vajadzētu:

- novērtēt ieguvumus, ko sniegtu konverǵenta regulatora radīšana gan telekomunikāciju, gan apraides pakalpojumiem;

- ministru līmenī noteikt skaidru prioritāro jomu komunikācijas pakalpojumiem;

- vienkāršot administratīvās procedūras tīkla izvietošanai un palielināt koordināciju starp pašvaldībām un Satiksmes ministriju;

- l̦aut sekundārā spektra tirgum veicināt efektīvāku lietošanu;

- izstrādāt visaptverošu IPv6 stratēǵiju, sadarbojoties ar visām ieinteresētajām pusēm.

\section{Digitālo tehnologiju ieviešanasun izmantošanas palielināšana}

Latvija pēdējo gadu laikā ir guvusi ievērojamu progresu interneta izmantošanā, un valdībai tagad ir līderpozīcijā digitālo valdību jomā Eiropā. Tomēr Latvijas iedzìvotāji internetu joprojām izmanto mēreni, savukārt uzṇēmumi atpaliek no citu ESAO valstu uzṇēmumiem.

Latvijai būtu jāīsteno saskaṇots pasākumu kopums ar šādiem mērḳiem:

\section{Uzlabot digitālās prasmes}

- atjaunināt apmācības projekta "Trešais tēva dēls" ietvaros, apgādāt bibliotēkas ar pietiekamiem IKT resursiem un izveidot uz kopienu balstìtu IKT apmācību programmu;

- atbalstīt modulāro programmu izstrādi augstākajā izglīiībā, kas iekḷauj IKT;

- stiprināt saiknes starp profesionālās izglītības iestādēm un uzṇēmumiem, kas nodarbina IKT speciālistus;

- atbrīvot no darba tirgus pārbaudēm ārvalstu IKT speciālistus, kuriem ir apliecināta pieredze vai kuri ir pabeiguši studijas Latvijā;

\section{Palielināt digitālo izpratni uzṇēmumos}

- izveidot digitālo čempionu programmu, lai atbalstītu MVU nozarēs ar zemu digitālo izpratni; 
- sniegt konsultācijas un pārvaldỉbas padomus, lai palīdzētu uzṇēmumiem neatpalikt no izteikti digitalizētiem uzñēmumiem;

- ieviest stimulus uzṇēmumiem sazināties ar valdību tiešsaistē;

\section{Sekmēt digitālo pārvaldību}

- konsolidēt finansējumu digitālajai pārvaldībai vienā ministrijā, kura pēc tam var noteikt prioritātes saskaṇā ar valsts stratēǵiju;

- izveidot valsts civildienesta apmācību programmu par IKT lietošanu un e-pārvaldības pakalpojumu struktūru un izstrādāt labas prakses rokasgrāmatu;

- veicināt atvērto datu ekosistēmu; izveidot vienotu kontaktpunktu pētniekiem, lai piekḷūtu veselības un sociālās aprūpes datiem.

\section{Uzticỉbas palielināšana digitālā vidē}

\section{Sekmēt digitālo drošību}

Latvijai ir stabils pamats, uz kura balstīties, lai risinātu digitālās drošības problēmas un iespējas. Taču politikā bùtu labāk jāaptver digitālās drošības ekonomiskais un sociālais aspekts, kā arì:

- jāveicina digitālās drošǐbas stratēgiija augstākajā pārvaldības līmenī;

- labāk jāintegrē digitālās drošības stratēgija Informācijas sabiedrības attīstības pamatnostādnēs;

- jāveicina profesionālās pilnveides un darbaspēka apmaiṇas programmas starp valsts iestādēm;

- jāuzlabo vairāku ieinteresēto personu un starptautiskā sadarbība digitālās drošības jomā, jo īpaši ar pārējām Baltijas valstīm.

\section{Uzlabot privātumu}

Latvija ir guvusi ievērojamu progresu privātuma un datu aizsardzības jomā, 2018. gadā ìstenojot ES Vispārīgo datu aizsardzības regulu un Fizisko personu datu apstrādes likumu. Taču ir nepieciešami turpmāki pasākumi privātuma uzlabošanai:

- jānodrošina Datu valsts inspekcijai (DVI) nepieciešamie cilvēku un finanšu resursi, lai tā efektīivi veiktu savus uzdevumus;

- jāizstrādā DVI norādījumi par privātumu un privātuma pārvaldības programmām, pamatojoties uz pastāvošo labo starptautisko praksi;

- jāsekmē sadarbība starp DVI un citām valstīm, piemēram, pievienojoties Globālajam privātuma aizsardzības tīklam;

- jāizveido atbilstoša mākslīgā intelekta un lietu interneta datu pārvaldỉba, turpinot sadarbỉbu ar starptautiskajiem forumiem, piemēram, ESAO.

\section{Uzlabot patērētāju tiesību aizsardzību tiešsaistē}

Latvijas politika patērētāju jomā atbilst ESAO ieteikumam par patērētāju aizsardzību e-komercijā. Valdībai būtu jāveic turpmākas darbības, lai:

- palielinātu patērētāju informētību par jautājumiem saistībā ar e-komerciju;

- uzlabotu pierādījumus par patērētāju sūdzībām saistībā ar e-komerciju un izvērtētu strīdu izšḳiršanas un tiesiskās aizsardzības sistēmas efektivitāti;

- paplašinātu sadarbību pārrobežu izpildē Eiropas Savienībā un ārpus tās.

\section{Digitālās inovācijas iespēju izmantošana}

Lai gan divu pēdējo desmitgažu laikā bija vērojama izaugsme, tomēr darba produktivitāte Latvijā joprojām îr ievērojami zemāka nekā citās ESAO valstīs. Tāpēc inovācijas ir būtiski svarīgas, lai palielinātu produktivitāti un paaugstinātu dzìves līmeni. 
Lai izmantotu digitālās iespējas inovācijām, Latvijai vajadzētu:

- koncentrēties uz digitalizāciju kā būtisku inovāciju un izaugsmes veicinātāju;

- sekmēt digitālās inovācijas, lai risinātu Latvijas sabiedriskās un ekonomiskās problēmas;

- palielināt pētniecības finansējumu ar IKT saistītiem projektiem, tostarp RIS3 projektiem;

- paaugstināt pētniecības kvalitāti, izmantojot uz konkurenci balstītus fondus, lielāku privāto līdzfinansējumu un sistemātisku ex-post novērtējumu;

- izvērtēt IT klastera, IT kompetenču centra un citu ar IKT saistītu struktūru darbības un skaidri noteikt to attiecīgās funkcijas.

\section{Visas valdibas pieejas veidošana}

Lai izmantotu digitalizācijas sniegtos ieguvumus un risinātu tās problēmas, ir vajadzīga koordinācija starp politikas jomām. Lai labāk nodrošinātu saskaṇotu un vienotu visas valdības pieeju digitalizācijas politikai, Latvijai vajadzētu:

- piešḳirt digitalizācijas politikai augstāku prioritāti politikas programmā;

- noteikt skaidras budžeta apropriācijas Informācijas sabiedribas attīstỉbas pamatnostādnēm;

- izveidot institucionālu koordinācijas mehānismu digitalizācijas politikai (piem., uzticot ministru prezidenta biedram koordinatora pienākumus). 



\section{Nodala 1}

\section{LATVIJA DIGITĀLAJĀ TRANSFORMĀCIJĀ: IESPĒJAS UN IZAICINĀJUMI}




\section{Jaunākās elkonomikas un sociālās tendences Latvijā}

Kopš 2000. gadu sākuma Latvija ir pieredzējusi strauju izaugsmi un dzīves standartu paaugstināšanos. Laikposmā no 2000. līdz 2019. gadam IKP pieaugums (3,6\% gadā) bija viens no apjomīgākajiem Eiropas Savienībā (ES28) un daudz augstāks par ESAO vidējo rādītāju (1,8\%). Bezdarbs ir strauji samazinājies no augstākā līmeña 2010. gadā (19,5\%) līdz 6,3\% 2019. gadā, veicinot spēcīgu reālo algu pieaugumu (46\% laikposmā no 2012. līdz 2018. gadam). Neskatoties uz augstākām ražošanas vienības izmaksām, ir palielinājies eksports, īpaši augsto tehnoloǵiju produkcijas jomā.

Neskatoties no šiem sasniegumiem, Latvija saskaras ar būtiskiem izaicinājumiem. Iedzìvotāju skaits valstī strauji samazinās novecošānas un emigrācijas dẹl kā rezultātā rodas prasmju nepietiekamība un neatbilstība. Lìdzīgi kā citās ESAO valstīs pēc 2008. gada globālās krīzes produktivitātes pieaugums samazinājās, īpaši mazajos uznēēmumos, kas veido lielu daḷu Latvijas uzṇēmumu. Izaugsmes perspektīvas ir neskaidras, jo Covid-19 pandēmija ietekmē pasaules ekonomiku (ESAO, 2020a). Reǵionālās atšḳkirības ienākumos uz vienu iedzīvotāju un bezdarba līmenī ir lielas, savukārt nabadzība joprojām ir augsta. Pastāvošā ēnu ekonomikas daḷa mazina produktivitāti un ierobežo darbinieku piekḷuvi apmācībām.

Digitālās transformācijas veicināšanas politikai ir būtiska loma šo problēmu risināšanā. Digitālās tehnoloǵijas veicina inovācijas un produktivitāti uzṇēmumos, īpaši mazajos un vidējos uzṇēmumos (MVU). Digitalizācija var palīdzēt veicināt finansiālo iekḷaušanu un mazināt ēnu ekonomiku (t.i. saimniecisko darbību, kas nav noformēta oficiāli) (ILO, 2015). Tā var palīdzēt paaugstināt nodokḷu sistēmas efektivitāti, piemēram, uzlabojot nodokḷu aprēḳinu un iekasēšanu, tādējādi nodrošinot vairāk resursu valsts politikai. Ātrdarbīgas platjoslas infrastruktūras izveidošana nodrošina pamatu digitālai transformācijai, tādējādi sniedzot iedzīvotājiem un uzṇēmumiem piekḷuvi valsts dienestiem un starptautiskajiem tirgiem un palīdzot mazināt reǵionālās atškirīibas.

Tiešsaistes izglìtības resursi piedāvā jaunus rīkus mācībām un nodrošina iedzīvotājiem un darbiniekiem iespējas mācīties un uzlabot prasmes. İpaši pēc visu skolu un universitāšu slēgšanas COVID-19 pandēmijas laikā Latvijas valdỉba ir veicinājusi attālinātās mācības, lai nodrošinātu mācību procesa nepārtrauktību un vienādas izglītošanās iespējas (4. nodal̦a). Plašākā mērogā atbildes reakcija uz pandēmiju ir izraisījusi plašu pāreju uz attālināta darba režīmu (piem., teledarbs, e-komercija, telemedicīna) visās ekonomikas nozarēs, būtiski paātrinot digitālās transformācijas tempu Latvijā.

Vienlaikus digitālā transformācija var pastiprināt esošo nevienlīdzību, īpaši starp augstas un zemas kvalifikācijas darbiniekiem, lieliem un maziem uzṇēmumiem, kā arī pilsētu un lauku reǵioniem. Politikai ir izškiroša nozīme, lai nodrošinātu, ka potenciālos ieguvumus no digitālās transformācijas izmantotu visa ekonomika un sabiedrība.

\section{Digitālā transformācija var sekmēt produktivitāti}

Kopš tūkstošgades sākuma Latvija ir panākusi ievērojamu ekonomikas progresu, ekonomikas izaugsmes tempam pārsniedzot ES28 un ESAO rādītājus. ${ }^{1}$ Laikposmā no 2000. līdz 2007. gadam izaugsme Latvijā salīdzināmās cenās bija vidēji 8,5\%, un tā bija augstāka nekā citās Baltijas valstīs (8\% Igaunijā un 7,6\% Lietuvā) un ES28 (2,6\%). Globālā krīze 2008. gadā skāra Latviju smagāk nekā kaimiṇu valstis (ar samazinājumu -6,9\% gadā laikposmā no 2008. līdz 2010. gadam), un izaugsme pēc tam atsākās lēnākā tempā (3,6\% gadā) vienmērīgi ar citām Baltijas valstīm, bet vēl joprojām straujāk nekā ES28 (1,6\%) (Conference Board, 2020). Pasākumu COVID-19 epidēmijas ierobežošanai 2020. gadā tiešās ietekmes rezultātā Latvijas IKP salīdzināmās cenās varētu samazināties par 25\% (ESAO, 2020a).

Iedzīvotāju novecošanās un emigrācija kavē izaugsmes potenciālu Latvijā. Laikā no 2000. līdz 2017. gadam ir emigrējuši aptuveni 10\% iedzìvotāju, bet iedzìvotāju darbspējīgā vecumā (15-74 gadi) skaits tajā pašā laikā samazinājis par 21\%, kas ir lielākais samazinājums ESAO. Turklāt izaugsmes virzītājspēks, kas pastāvēja pirms 2008. gada krīzes (t.i. lielas kapitāla ieplūdes, strauja parāda uzkrāšanās un straujš nekustamā īpašuma tirgus uzplaukums) vairs nevar nodrošināt turpmāko izaugsmi (Blanchard, Griffiths un Gruss, 2013), un tā ir atkarīga no produktivitātes pieauguma.

Darba spēka produktivitāte Latvijā saglabājas zemāka nekā citās ESAO valstīs, radot iespējas uzlabojumiem. 2017. gadā vienas darba stundas pienesums IKP bija tikai 54\% no stundas produktivitātes ESAO valstīs ar augstiem ienākumiem (ESAO, 2019a). Taču produktivitātes izaugsme ir būtiski 
palēninājusies salīdzinājumā ar pirmskrīzes periodu. Vidējais darba stundas gada pienesums IKP pieaugumā ir samazinājies no 7,8\% 2000.-2007. gadā līdz 2,9\% 2013.-2018. gadā, lai gan tas saglabājas augstāks nekā citās Baltijas un Centrāleiropas valstīs (1.1. attēls).

\section{1. attēls. Darbaspēka produktivitāte Latvijā un atlasītajās ESAO valstīs, 2000.-2019. gads}

IKP videjjais gada pieaugums par darba stundu (\%)

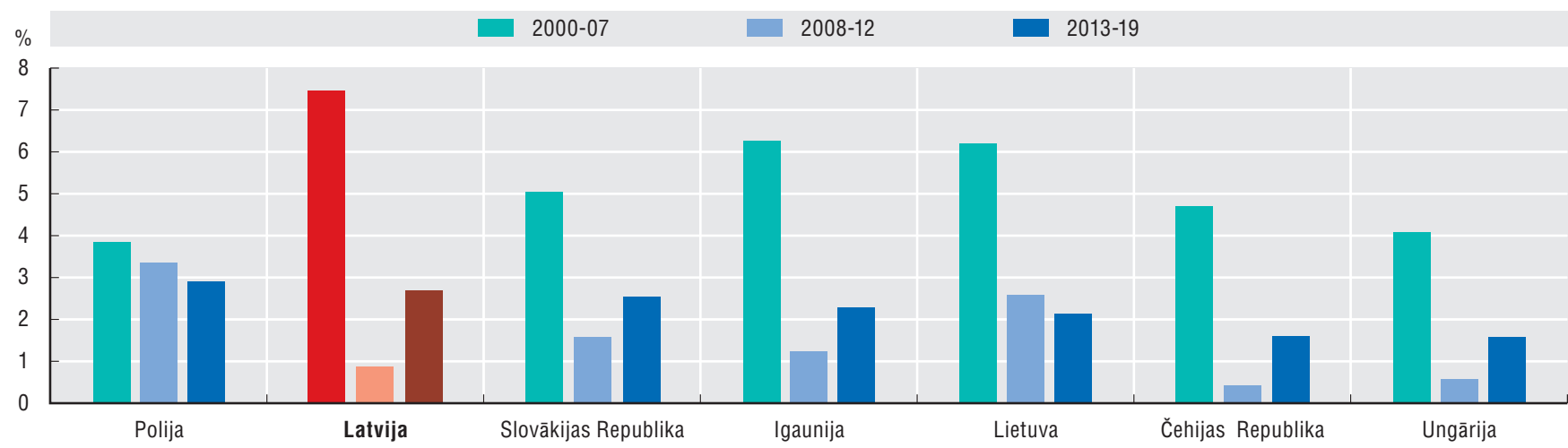

Avots: The Conference Board (2020), The Conference Board Total Economy Database, April 2019, www.conference-board.org/data/economydatabase (piekluve 2020. gada 6. maijā).

Ierobežots inovāciju izmantojums uznēēējdarbībā rada priekšstatu, ka tas ir būtisks faktors, kas nosaka lēno produktivitātes izaugsmi. Tikai nedaudzi Latvijas uzṇēmumi ir ieviesuši jaunas ražošanas tehnoloǵijas, uzsākuši jaunu produktu ražošanu vai jaunas organizācijas metodes. Inovatīvu MVU daḷa ir viena no zemākajām ESAO, Latvijas uzṇēmumiem atpaliekot no citām ESAO valstīm digitālo tehnologiju lietošanas ziṇā, kas aprobežojas ar pamata rīkiem (4. nodaḷa).

Digitālās tehnoloǵijas var uzlabot produktivitāti uzṇēmumos visās ekonomikas nozarēs. Lielie dati un datu analīze var palīdzēt uzṇēmumiem labāk izprast savus ražošanas procesus, klientu vajadzības un kopējo uzṇēmējdarbības vidi. Digitālās tehnoloǵijas var arī uzlabot uzṇēmumu spēju nodot ārpakalpojumu sniedzējiem galvenās uzn̦ēmējdarbības funkcijas un piekḷūt virknei finanšu instrumentu, kas var uzlabot veiktspēju. Visbeidzot, tiešsaistes platformas var uzlabot produktivitāti uznēmumos, kuros maz izmanto tehnolog̣ijas pakalpojumuuznēemumu produktivitāti, piemēram, nodrošinot tiem rezervēšanas iespējas un efektīvus saskaņošanas algoritmus, pamatojoties uz klientu novērtēšanas sistēmām (ESAO, 2019b). Digitalizācijas ieviešanas veicināšanai uzṇēmumos, îpaši MVU sektorā, būtu nepieciešams daudz pūḷu, lai sasniegtu produktivitātes izaugsmi Latvijā (4. nodalıa).

\section{Digitālā inovācija ir produktivitātes atslēga}

Digitalizācija paver jaunas iespējas inovācijām. Taču pētniecības un attīstības (P\&A) izdevumi Latvijā ir zemā līmenī, un aptuveni ceturto daḷ no P\&A finansē Eiropas Savienība. Latvijas uzṇēmumiem ir arī viens no zemākajiem P\&A rādītājiem Eiropā, īpaši informācijas nozarēs (1.2. attēls). Lai paaugstinātu inovāciju uzṇēmumos, Latvija ir pien̦ēmusi vairākas programmas P\&A palielināšanai kā dalı no Nacionālā attīstības plāna 2014.-2020. gadam (4. nodaḷa).

Pētnieku un doktorantūras studiju programmu absolventu skaits ir īpaši zems, un motivācija augstākās izglìtības iestādēm (HEI) sadarboties ar nozari šķiet vāja, kur ievērojams izṇēmums ir Rīgas Tehniskā universitāte (Eiropas Komisija, 2018a). Tikai 7\% Latvijas zinātnisko publikāciju par IKT ir starp 10\% biežāk citētajām (ESAO, 2019a). Lai uzlabotu pētniecības kvalitāti, valdība ir ieviesusi jaunu finansēšanas modeli, koncentrējot resursus efektīvākajās universitātēs un HEI (6. nodaḷa).

Gandrīz puse Latvijas uzṇēmumu norāda, ka finansējums ir šḳērslis investīcijām, kas var būt šḳērslis inovācijām. Kopš 2008. gada krīzes aizdevumi MVU ir saglabājušies zemi. Zinātnes, tehnolog̣ijas attīstỉbas un inovāciju pamatnostādnēs 2014.-2020. gadam ir noteikta Viedās specializācijas stratēgeija ar mērḳi sekmēt ekonomikas strukturālo transformāciju. Stratēǵijas galvenās jomas ir zināšanu ietilpīga bioekonomika, biomedicīna, medicīnas tehnoloǵijas un biotehnologija, viedie materiāli, tehnoloǵijas un inženiersistēmas, Informācijas un komunikāciju tehnolog̣ijas IKT un viedā enerǵētika (6. nodaḷa). 


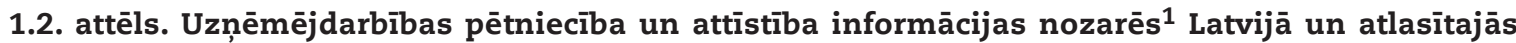 ESAO valstīs, 2016}

Pievienotās vērtības procenti

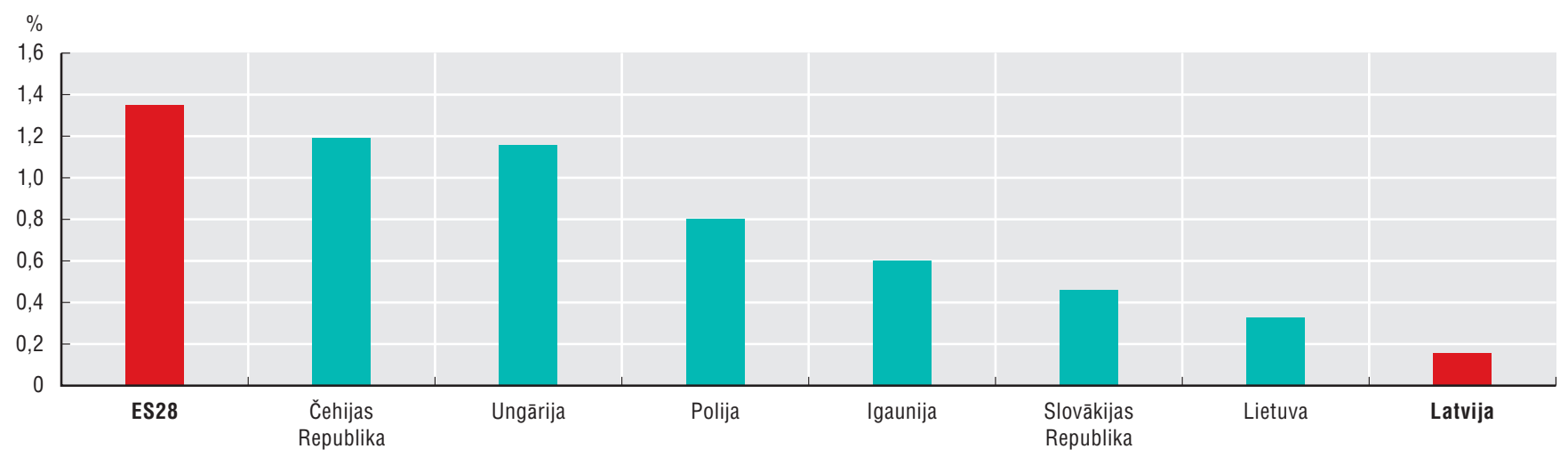

1. "Informācijas nozares" (ISIC Rev.4) ietver "Datori, elektronikas un optikas preces” (26. iedal̦a), "Izdevējdarbība, audivizuālās un pārraides darbības" (58. līdz 60. iedaḷa"), “Telekomunikācijas" (61. iedaḷa) un "IT un citi informācijas pakalpojumi” (62. līdz 63. iedaḷa).

Auots: ESAO (2020c), ANBERD datubāze, http://oe.cd/anberd (piekl̦uve 2020. gada 6. maijā); ESAO (2020d), un Galveno zinātnes un tehnoloǵiju indikatoru (datubāze), http://oe.cd/msti (piekl̦uve 2020. gada 6. maijā).

\section{Aktīua darba tirgus politika var palìdzēt likvidēt digitālo prasmju trūkumu}

Zemas IKT prasmes un papildu prasmes, piemēram, modernas pārvaldības jomā, ierobežo Latvijas uzṇēmumu spēju pēc iespējas labāk izmantot pieejamās digitālās tehnoloǵijas. Piemēram, vairāk nekā pusei iedzīvotāju un $67 \%$ bezdarbnieku trūkst pamata digitālo prasmju. Latvijā ir zemākais nodarbināto IKT speciālistu īpatsvars Eiropas Savienībā, un sieviešu īpatsvars ir samazinājies no 30\% 2008. gadā lìdz 14\% 2018. gadā (1.3. attēls).

\section{3. attēls. Nodarbinātie IKT speciālisti Eiropas Savienībā, 2018}

Procentuāli no kopējās nodarbinātības

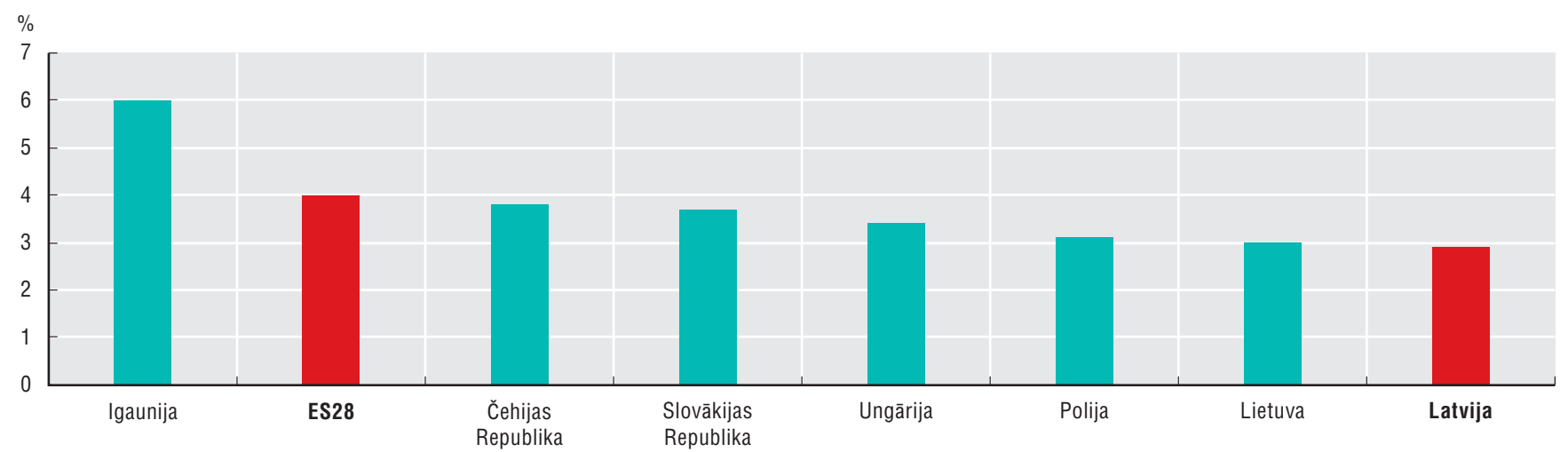

Avots: Eurostat (2020), Digitālā ekonomika un sabiedrība (datubāze), http://ec.europa.eu/eurostat/web/digital-economy-and-society/data/database (piekḷuve 2020. gada 6. maijā).

Latvijas uzṇēmumi salīdzinoši maz iegulda savu darbinieku prasmēs, īpaši attiecībā uz IKT apmācību. Turklāt dalība mūžizglīiībā ir zema un mazkvalificētu darbinieku iesaistī̌šnās pieaugušo izglīīibā ir mazāka. Nepietiekamo prasmju līmeni Latvijā pasliktina politika, kas kavē kvalificētu darbinieku imigrāciju (4. nodalı).

2016. gadā Latvijas valdība iztērēja tikai 0,15\% IKP mērḳtiecīgai apmācībai konkrētām grupām, piemēram, bezdarbniekiem vai neaktīvām personām, vai nodarbinātām personām, kas saskaras ar darba zaudēšanas risku. Šis rādītājs ir salīdzināms ar 0,21\% Igaunijā, 0,24\% Lietuvā un 0,36\% ESAO valstīs (ESAO, 2018a). Lai gan pēdējo gadu laikā ir uzlabojusies bezdarbnieku apmācību sistēma un motivācijas politika, Latvijā ir iespējas uzlabot prasmes, kas nepieciešamas digitāli ietilpīgiem darbiem, palielinot valsts izdevumus aktīvā darba tirgus politikai (4. nodalıa). 


\section{Digitālo rīku izmantošana iekḷaujošas izaugsmes sekmēšanai}

Pēdējo divu desmitgažu laikā kopējais dzīves līmenis Latvijā ir strauji uzlabojies, taču nabadzības līmenis saglabājas augstāks nekā citās ESAO valstīs (1.4. attēls). Ar reformām 2018. gadā iedzīvotāju ienākuma nodoklis tika padarīts progresīvāks, bet nodokḷu ieṇēmumi kā daḷa no IKP ir būtiski zemāki par ESAO vidējo rādītāju. Īpaši nodokḷu ieṇēmumu zaudējumi plaši izplatītās formalitāšu neievērošanas dēl ierobežo valdības iespēju veikt ieguldījumus infrastruktūrā un sociālajos pakalpojumos (ESAO, 2019a).

\section{4. attēls. Personas, kuras dzīvo nabadzīgās mājsaimniecībās Latvijā un ESAO valstīs, 2017}

Procentuāli no kopējā iedzīvotāju skaita

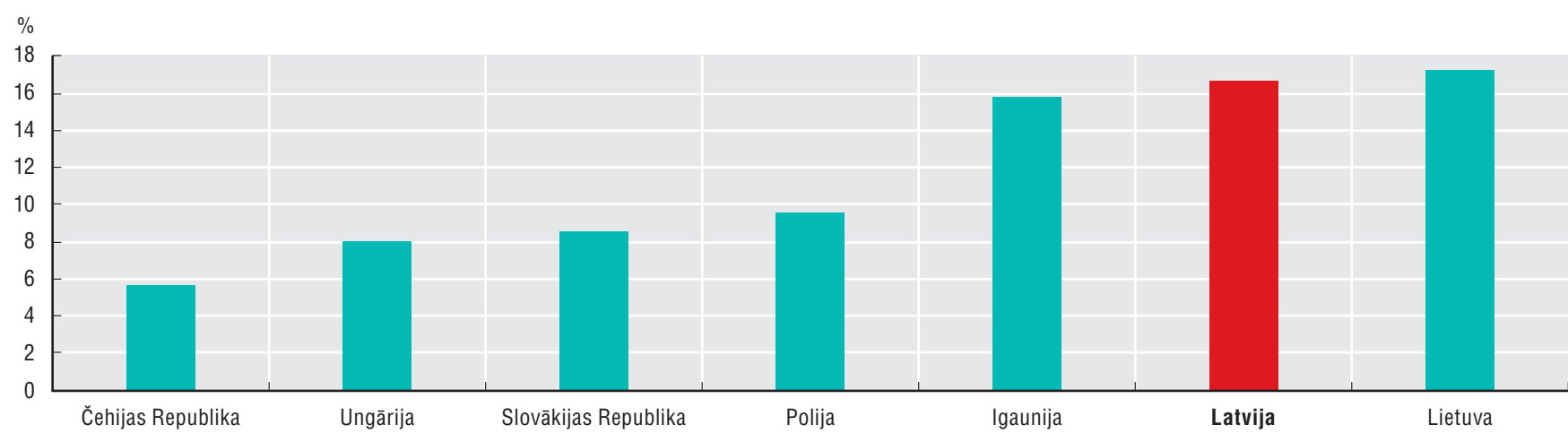

Piezīme: Nabadzības slieksnis ir 50\% no vidējā mājsaimniecības rīcībā esošā ienākuma. Mājsaimniecību ienākumi ir koriǵēti, lai ṇemtu vērā mājsaimniecības lielumu. ESAO izmanto pieejamo valstu vidējo svērto vērtību.

Avots: ESAO (2020e), Ienākumu sadalījuma datubāze (IDD), http://oe.cd/idd (piekḷuve 2020. gada 6. maijā).

Digitālās tehnologijas var palīdzēt stiprināt nodokḷu un darba tiesību aktu izpildi. Nodokḷu administrācijas apkopoto datu analīzes algoritmu izmantošana var uzlabot personu, kas izvairās no nodokḷiem, atklāšanu (ESAO, 2018b), bet labāka informācijas apmaiṇa tiesībsargājošo iestāžu starpā sekmētu to darba efektivitātes paaugstināšanos. Latvijas Valsts ieṇēmumu dienests (VID) ievieš digitālos rīkus un datu analīzes sistēmas, lai labāk vērstu auditus attiecībā pret augsta riska nodokḷ maksātājiem. VID strādā arī pie sistēmas, lai automātiski savietotu no ārvalstu nodokḷu iestādēm saṇemtos datus ar vietējiem datiem. Uzlabojot uzticēšanos valsts iestādēm, ar atvērtajiem valdības datiem var palīdzēt cīṇā pret formalitāšu neievērošanu un uzlabot likumu par nodokḷiem ievērošanu (Mickiewicz, Rebmann un Sauka, 2019). Digitālās darba platformas var palīdzēt uzlabot darba tirgus formālitates, formalizēt mutvārdos noslēgtos darījumus un dot iespēju nodokḷu iestādēm iegūt datus no šādiem darījumiem ar nosacījumu, ja pastāv attiecīgs regulējums.

Pastāv izteiktas reǵionālās atšḳirības ienākumos uz vienu iedzīvotāju un bezdarba līmeni, kas noved pie lielām atšḳirībām pašvaldību nodokḷu ieṇēmumos uz vienu iedzīvotāju.. Turklāt pašvaldības Latvijā ir relatīvi mazas, kas pasliktina kvalitatīvu valsts pakalpojumu, tostarp izglītības un sabiedriskā transporta, nodrošinājumu. Mazo pašvaldību apvienošana palīdzētu konsolidēt līdzekḷus, taču tas ir politiski grūts jautājums. Digitalizācija sniedz iespēju apvienot digitālos resursus un e-pakalpojumus starp vairākām pašvaldībām, palīdzot paaugstināt vietējo sabiedrisko pakalpojumu nodrošinājuma efektivitāti un mazināt pieaugošo plaisu starp pilsētām un laukiem.

Apvienojot labāku transporta infrastruktūru, ātrdarbīgus platjoslas pakalpojumus un labāku digitālo tehnoloǵiju lietojumu, tiktu izveidotas ekonomiskās iespējas darbiniekiem un uzṇēmumiem, īpaši MVU mazāk attīstītos reǵionos (3. nodaḷa).

\section{Labklājības veicināšana digitālās transformācijas procesā}

Lai gan vidējie dzīves standarti Latvijā ir stabili uzlabojušies, labklājības paaugstināšanās progress ir bijis lēnāks, īpaši noteiktām grupām. 2017. gadā savu veselību par sliktu/ḷoti sliktu vai viduvēju uzskatīja 74\% nabadzīgāko mājsaimniecību (zemākā ienākumu kvintile) Latvijā pretstatā 36\% bagātāko mājsaimniecību (augstākā ienākumu kvintile). Šì plaisa (38 procentpunkti) bija ne tikai daudz augstāka par ESAO vidējo rādītāju (21 procentpunkts), bet kopš 2010. gada tā bija palielinājusies par 10 procentpunktiem (ESAO, 2020b). 
Apmierinātības ar dzīvi līmenis saglabājas īpaši zems gados vecāku cilvēku (50+) vidū, kur šì radītājs ir tikai 6,3 (10 punktu skalā) salīdzinājumā ar ESAO vidējo rādītāju 7,3 (1.5. attēls). Visās vecuma grupās Latvijā ir arī viens no augstākajiem mirstības rādītājiem no pašnāvībām un narkotisko vielu lietošanas, galvenokārt saistībā ar alkoholu (turpat).

1.5. attēls. Apmierinātība ar dzīvi ESAO, 2018

Vidējie apmierinātības ar dzīvi rādītāji skalā 0 lìdz 10, pa vecuma grupām

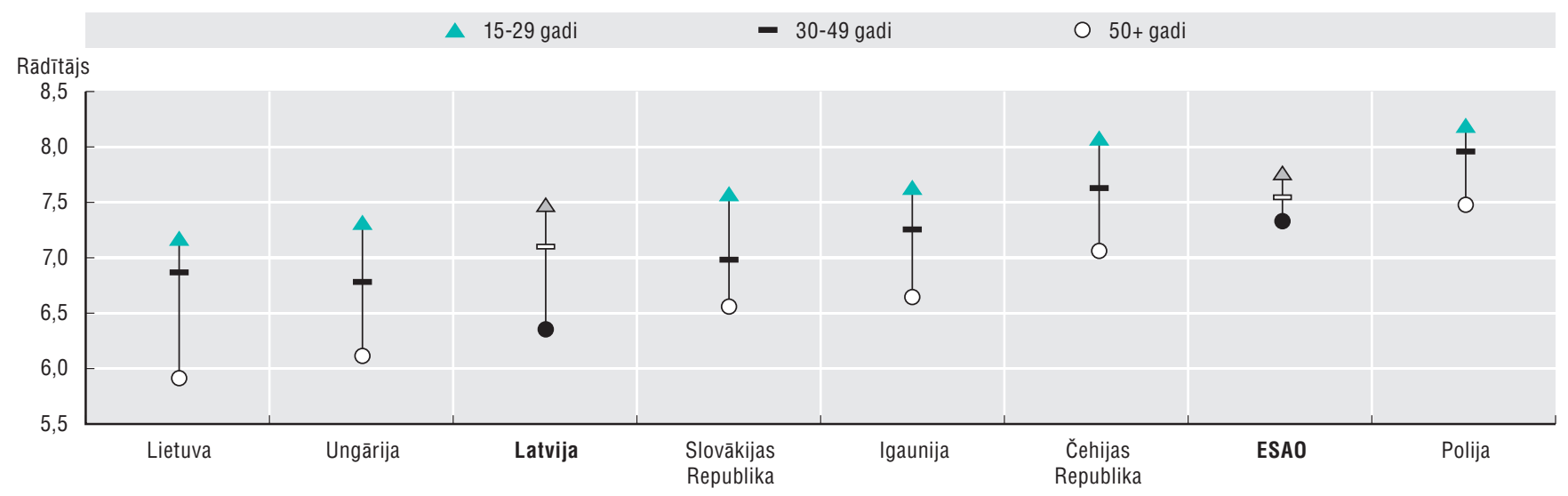

Piezīme: Detalizētas piezīmes par attēlu skatīt: https://doi.org/10.1787/888934081815.

Avots: ESAO (2020b), "Evaluating the initial impact of COVID-19 containment measures on economic activity", https://oe.cd/il/2VU.

Lai likvidētu digitālo plaisu, svarīga ir mērḳtiecīgas digitālās iekḷaušanas politikas (piem., Trešā tēva dēla programma), kā arī turpmāka attālinātās mācīšanās attīstība pēc COVID-19 ierobežojumu atcelšanas (4. nodaḷa). Turpmāka e-veselības un telemedicīnas attīstība var uzlabot piekluvi veselības aprūpei mājsaimniecībām attālos reǵionos, kā arī pašvaldību pakalpojumiem vai aprūpei mājās pilsētu teritorijās.

Visbeidzot, digitālā transformācija var palīdzēt risināt kolektīvos digitālos izaicinājumus, tostarp vides pārvaldības un aizsardzības jomā (ESAO, 2019b). Ekonomikas progress kopš 2010. gada ir palielinājis viena cilvēka materiālo ietekmi Latvijā par vairāk kā 3 tonnām (ESAO, 2020b). Digitālās tehnolog̣ijas var uzlabot ražošanas efektivitāti un mazināt materiālu atkritumus, tādējādi uzlabojot ilgtspēju, vienlaikus paaugstinot dzīves līmeni. Viedajiem materiāliem, viedajai inženierijai un viedajām pilsētām piemìt būtisks potenciāls paaugstināt energoefektivitāti un sekmēt jaunu vides tehnoloǵiju attīstỉbu (6. nodaḷa).

\section{Latvijas digitālās transformācijas stratēgịija}

Informācijas sabiedrības attīstības pamatnostādnēs 2014.-2020. gadam (INFSO) ir noteikta Latvijas digitālā stratēéija (7. nodal̦a). Pamatnostādnes ir vidēja termiṇa attīstības plāns, ko izstrādājusi darba grupa, kuras darbību koordinēja Vides aizsardzības un regiionālās attīstỉbas ministrija un kuras sastāvā bija pārstāvji no 12 nozaru ministrijām, kā arī vairākām citāmvalsts un privātām ieinteresētajām pusēm, tostarp IKT asociācijām, tirdzniecības palātām, vietējām un reǵionālajām pašvaldībām (Ministru kabinets, 2013a).

INFSO 2014.-2020. gadam ir izstrādātas, pamatojoties uz INFSO 2006.-13. gadam izvērtējumu. Lai gan Latvija ir sasniegusi INFSO 2006.-2013. gadam noteiktos mērḳus attiecībā uz piekḷuvi internetam un IKT lietošanu, tā atpaliek attiecỉbā uz IKT nozares lielumu un e-komercijas izmantošanu gan uzṇēmumos, gan privātpersonām, bet kopējais e-veselības izmantošanas apjoms vēl joprojām nav zināms statistikas datu trūkuma dēḷ. Turklāt, neskatoties uz ievērojamo progresu laikposmā no 2006. līdz 2013. gadam, saglabājas ievērojams neizmantots digitālās pārvaldības potenciāls, īpaši saistỉbā ar iekšējo procesu optimizāciju.

INFSO 2014.-2020. gadam mērḳis ir "nodrošināt iespēju ikvienam izmantot IKT sniegtās iespējas, veidot uz zināšanām balstītu ekonomiku un uzlabot kopējo dzīves kvalitāti, sniedzot ieguldījumu valsts konkurētspējai, un ekonomiskās izaugsmes paaugstināšanā un darbavietu radišanā" (turpat).

Ekonomiskā izaugsme un darbavietu radīšana ir stratēgijas pamatā un nosaka katra no septiniiem rīcības plāniem formulējumu, kas izklāstīts pamatnostādnēs: 1) IKT izglītība un prasmes; 2) plaši pieejama piekḷuve internetam;3) moderna un efektīvavalsts pārvalde; 4) e-pakalpojumi un digitālais 
saturs sabiedrībai; 5) pārrobežu sadarbība Digitālā vienotā tirgus izveidē; 6) IKT pētniecỉba un inovācijas; un 7) uzticēšanās un drošība. Katrā rīcības plānā ir vairāki komponenti, kas parādīti 1.1. tabula.

INFSO 2014.-2020. gadam īpaša uzmanība pievērsta atvērto datu principu izmantošanai valsts pārvaldē kā instrumentam, lai uzlabotu sabiedrisko pakalpojumu sniegšanas efektivitāti. E-prasmju uzlabošanai un interneta piekḷuves un ātruma uzlabošanai arī ir būtiska loma kā e-komercijas un e-uzñēmējdarbības veicinošiem faktoriem. Digitālo rīku lietošana, lai mazinātu administratīvo slodzi uznẹēējiem, ìpaši MVU, un paaugstinātu valsts pārvaldes efektivitāti, ir būtisks elements arī INFSO 2014.-2020. gadam.

Pamatnostādṇu īstenošanas progresa novērtējums tika veikts 2019. gada oktobrī (VARAM, 2019). Galīgo novērtējumu Vides aizsardzības un reǵionālās attīstības ministrija iesniegs Ministru kabinetam 2021. gada jūlijā.

Vairāki citi attīstības dokumenti šobrīd tiek gatavoti, un vairākos no tiem uzmanība koncentrēta uz e-pārvaldes pakalpojumu uzlabošanu. To vidū ir Valsts informācijas un komunikācijas tehnolog̣iju pārvaldības organizatoriskais modelis (Ministru kabinets, 2013b), Publiskās pārvaldes informācijas sistēmu konceptuālā arhitektūra (Ministru kabinets, 2015), un informatīvie ziṇojumi par mākoṇdatošanas pakalpojumu izmantošanu valsts pārvaldē (Ministru kabinets, 2018) un Latvijas Atvērto datu stratēgija (Ministru kabinets, 2019) (4. nodaḷā), kā arī informatīvais ziṇojums par mākslīgā intelekta risinājumu attīstību (Ministru kabinets, 2020).

\section{1. tabula. Informācijas sabiedrības attīstības pamatnostādnes 2014.-2020. gadam: Darbības virzieni}

\begin{tabular}{|c|c|}
\hline Darbības virzieni & Komponenti \\
\hline \multirow[t]{5}{*}{ IKT izglîtība un prasmes } & Sabiedrības informētīiba un gatavība lietot e-iespējas \\
\hline & ledzīvotāju un uzņēmēju e-prasmju attīstība \\
\hline & Valsts pārvaldes IKT kompetenču paaugstināšana \\
\hline & IKT praktiķu un profesionālu sagatavošana atbilstoši darba tirgus prasī̄ām \\
\hline & Algoritmiskās domāšanas un informācijpratības veicināšana izglitīibas programmās \\
\hline \multirow[t]{4}{*}{ Plaši pieejama piekluve internetam } & Transporta tīkli \\
\hline & Pēdējā jūdze \\
\hline & Maǵistrālie tīkli \\
\hline & Esošās elektronisko sakaru tīklu infrastruktūras kartēšana \\
\hline \multirow[t]{4}{*}{ Moderna un efektīva valsts pārvalde } & Valsts pārvaldes pamatdarbības procesu modernizācija \\
\hline & Sabiedrības e-līdzdalība un e-demokrātija \\
\hline & Vienota valsts pārvaldes datu telpa \\
\hline & IKT infrastruktūras optimizācija \\
\hline \multirow[t]{8}{*}{ E-pakalpojumi un digitālais saturs sabiedrībai } & Valsts pārvaldes datu un transakciju pakalpojumu atvēršana citiem lietotājiem \\
\hline & Koplietošanas platformu un pakalpojumu attīstība sabiedrisko pakalpojumu sniegšanai \\
\hline & Oficiālu e-pasta adrešu ieviešana iedzīvotājiem un uzņēmējiem \\
\hline & Sabiedrisko pakalpojumu digitalizācija \\
\hline & Automatizēta elektronisko rēķinu izsniegšana un pieņemšana \\
\hline & Kultūras mantojuma digitalizācija un pieejamība \\
\hline & Latviešu valodas lietojuma stimulēšana digitālajā vidē \\
\hline & E-veselības risinājumi efektīvai, drošai un uz pacientu vērstai un integrētai veselības aprūpei \\
\hline \multirow[t]{2}{*}{ Pārrobežu sadarbība digitālajam vienotajam tirgum } & Pārrobežu e-pakalpojumu un datu apmaiņas risinājumu izveide \\
\hline & Bāzes risinājumu attīstība pārrobežu pakalpojumu nodrošināšanai \\
\hline \multirow[t]{2}{*}{ IKT pētniecība un inovācija } & IKT pētniecība \\
\hline & Inovācija \\
\hline \multirow[t]{3}{*}{ Uzticēšanās un drošība } & IKT drošība \\
\hline & Cilvēkdrošība \\
\hline & Uzticēšanās elektroniskajai videi \\
\hline
\end{tabular}

Piezīme: IKT = Informācijas un komunikācijas tehnolog̣ijas.

Avots: Ministru kabinets (2013b), Organizatoriskais modelis sabiedrisko informācijas un komunikāciju tehnologiju pärvaldībai, www.varam.gov.lv/in_site/ tools/download.php?file=files/text/Darb_jomas/elietas//E2269_Organisational_Model_for_the_Management_of_Public_Infor_and_Com_Techn.doc. 
Citos dokumentos, piemēram, Nākamās paaudzes platjoslas elektronisku sakaru tīklu attīstības koncepcijā 2013.-2020. gadam un Elektronisko komunikāciju politikas plānā 2018.-2020. gadam lielāka uzmanība koncentrēta uz IKT piekḷuvi un infrastruktūru (3. nodaḷa). Šim sarakstam var pievienot Intelektuālā īpašuma tiesību aizsardzības un nodrošināšanas pamatnostādnes 2015.-2020. gadam, kā arī Latvijas kiberdrošības stratēǵiju 2014.-2018. gadam. Latvijas kiberdrošības stratēǵija 2019.-2020. gadam tika apstiprināta 2019. gada septembrī (5. nodalı).

Latvijai šobrīd nav vispārējas stratēǵijas par uzṇēmējdarbības digitalizāciju. Taču ir Viedās specializācijas stratēgija, kas ir saistīta ar Zinātnes, tehnolog̣iskās attīstības un inovācijas pamatnostādnēm 2014.2020. gadam (STDI) un Valsts industriālās politikas (NPI) pamatnostādnēm 2014.-2020. gadam. Pēdējā no dokumentiem mērḳis ir veicināt nozares modernizāciju (Eiropas Komisija, 2018b). NPI tika prezentēta 2012. gadā un citu starpā viens no tās mērkiiem ir salāgot darbaspēka piedāvājumu un izglìtību ar ekonomikas attīstības vajadzībām un sekmēt atklātu, radošu un inovatīvu vidi. NPI mērḳi ir formulēti arī Nacionālās inovācijas sistēmas uzlabošanas programmā, ko 2016. gadā apstiprinājusi Nacionālā stratēgiskā pētniecības un inovāciju padome (6. nodaḷa).

\section{Digitalizācijas integrētās politikas satvars}

Kā norādīts Latvijas Informācijas sabiedrības attīstības pamatnostādnēs, digitālā transformācija kompleksi un savstarpēji saistītā veidā skar dažādas ekonomikas un sabiedrības dal̦as, apgrūtinot kompromisu starp valsts politikas mērk̦iem.

ESAO ir izstrādājusi integrētas politikas satvaru, lai atbalstītu valdības kopēju pieeju saskan,otas politikas veidošanai digitālajā laikmetā. Satvarā tehnoloǵiju, datu un uzṇēmējdarbības model̦i ir atzīti kā virzìtājspēki, kas ir digitālās transformācijas pamatā, un apsvērta transformācija daudzās dažādās politikas jomās. Pašā satvarā ir iekḷauti septiṇi integrēti struktūras elementi (1.6. attēls).

\section{6. attēls. Digitalizācijas integrētās politikas satvars}

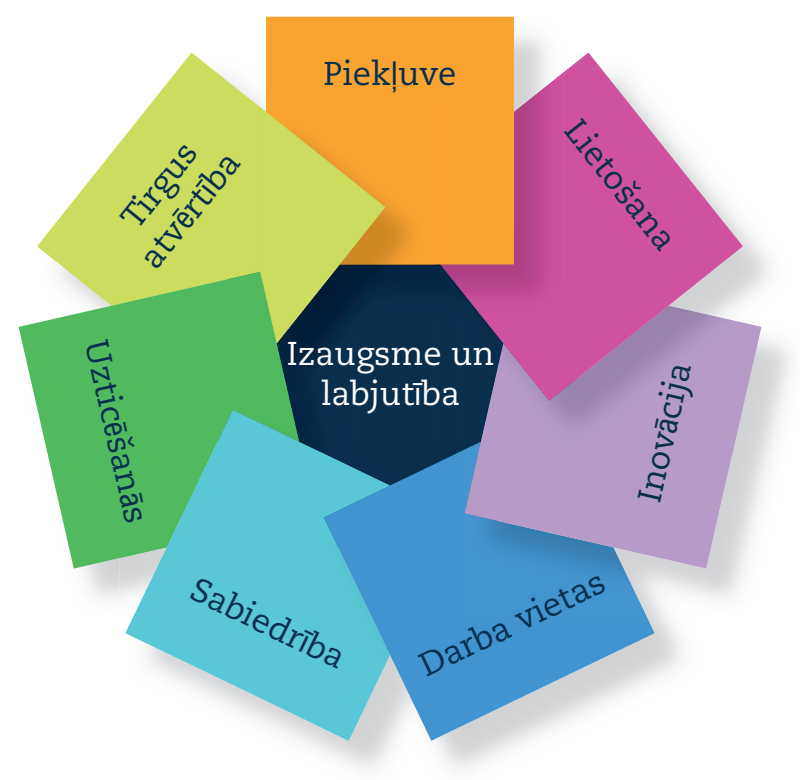

Avots: ESAO (2019b), Going Digital: Shaping Policies, Improving Lives, https://doi.org/10.1787/9789264312012-en.

Šie integrētie struktūras elementi neatbilst noteiktām politikas jomām; drīzāk katrs no tiem apvieno vairākas politikas jomas (papildinformāciju skatīt turpmāk tekstā). Šì konfigurācija uzsver to, ka digitālās transformācijas ieguvumu līdzsvarošanai unproblēmu risināšanai ir nepieciešams noteikt politikas jomas, kas savstarpēji saskaras un kuras nepieciešams koordinēt. Tas paredz arī to, ka digitālās transformācijas darbības nodrošināšanai, lai veicinātu izaugsmi un labklājību, ir nepieciešami visi struktūras elementi. 


\section{Piekl̦ue}

Digitalizācija Latvijā mērḳis ir palīdzēt Latvijai nodrošināt saskaṇotu un koordinētu visas valdības pieeju, lai labāk reaǵētu uz digitālo transformāciju un liktu tai darboties izaugsmes un labklājības veicināšanai.

Droša komunikāciju infrastruktūra un pakalpojumi ir visu digitālo tehnoloǵiju lietošanas pamatā un veicina mijiedarbību starp saistītajiem cilvēkiem, organizācijām un iekārtām. Līdzīgi dati, kas plūst caur tīkliem, digitālajā laikmetā parādās arī kā vērtības avots, lai gan to produktīvā izmantošana ir atkarīga no to pieejamības.

Tā kā uzticamas komunikāciju infrastruktūras un pakalpojumi ir būtiski nozīmīgi digitālajai transformācijai, pirmais integrētais struktūras elements attiecas uz piekḷuvi datiem, komunikāciju infrastruktūrām un pakalpojumiem (piem., optisko šķiedru atvilces maršrutēšana, torni, spektrs, starptautiskie kabeḷi). Tas ietver efektīvus, drošus un plašas piekḷuves platjoslas komunikāciju tīklus un pakalpojumus, un galvenos papildu veicinātājus (piem., koordinēta starptautisko domēnu nosaukumu sistēma, augoša IPv6 interneta adrešu izmantošana, interneta apmain, as punkti (IXP)), datus, programmatūru un aparatūru. Šie komponenti kopā darbojas kā tehniskais pamats atvērtam, savstarpēji savienotam un decentralizētam internetam, kas nodrošina globālu brīvu informācijas plūsmu un vispārīgā izpratnē digitālo transformāciju. Ir jāapsver vairākas politikas jomas, lai nodrošinātu piekḷuvi, tostarp komunikāciju infrastruktūras un pakalpojumi, konkurence, investīcijas un reǵionālā attīstība.

\section{Lietošana}

Piekḷuve digitālajiem tīkliem nodrošina tehnisko pamatu ekonomikas un sabiedrības digitālajai transformācijai. Taču šāda piekḷuve ne vienmēr nodrošina plašu digitālo rīku izplatību un efektīvu lietošanu, kas ir nepieciešama, lai cilvēki, valdības un uzṇēmumi saṇemtu digitālās transformācijas ieguvumus paaugstinātas līdzdalības, inovācijas, produktivitātes un labklājības veidā. Izplatīšanās un efektīva lietošana ir būtiski atkarīga no virknes mainīgo lielumu, kas ietver investīcijas IKT un zināšanās bāzētā kapitālā (ZBK), tostarp datu un organizatoriskas pārmaiṇas; labvēlīgu uznēēmējdarbības vidi (piem., tādu, kas sekmē uznēēējdarbības dinamismu); prasmju pieejamību un sadalījumu; un uzticēšanos. Tāpēc ir jāṇem vērā vairākas politikas jomas, îpaši digitālā pārvaldỉba, investīcijas, uzṇēmējdarbības dinamisms un MVU, izglīīīa un prasmes, kā arī digitālā drošỉba un privātums.

\section{Inovācijas}

Inovācija pārspēj visa iespējamā robežas, veicinot darbavietu radī̌anu, produktivitātes pieaugumu un ilgtspējīgu izaugsmi un attīstību. Īpaši digitālās inovācijas ir radījušas radikālas izmaiṇas veidos, kā cilvēki mijiedarbojas, rada, ražo un patērē. Digitālās inovācijas rada ne tikai jaunus produktus un pakalpojumus, bet arī veido iespējas jaunu uzṇēmējdarbības modeḷu un tirgu attīstībai un var veicināt efektivitātes paaugstināšanos valsts sektorā un ārpus tā. Turklāt digitālās tehnologiijas un dati veicina inovācijas daudzās nozarēs, tostarp izglīīīā, veselībā, finansēs, apdrošināšanā, transportā, enerǵētikā, lauksaimniecībā un zvejniecībā, kā arī pašă IKT nozarē. , Lai veicinātu inovācijas, ir jāapsver vairākas politikas jomas, tostarp uzṇēmējdarbība un MVU, zinātne un tehnologiija, konkurence, digitālā valdība un nozaru politika, piemēram, enerǵētika, finanses, transports, veselība un izglītība.

\section{Darba vietas}

Digitālā transformācija jau ir sākusi mainīt organizāciju un tirgu raksturu un struktūru, radot svarīgus jautājumus par to, kuras darbavietas varētu izzust un kur veidosies jaunas, kādas tās būs un kādas prasmes būs nepieciešamas. Tajā pašā laikā ir radušies jautājumi par to, ko tas varētu skart visvairāk un ko var darīt, lai veicinātu jaunu darbavietu radīšanu un saskaņotu prasmju attīstību ar mainītajām prasībām attiecībā uz prasmēm darbavietās. Tehnologisiskā attīstība un jaunu biznesa modeḷu ieviešana ir radījusi "platformas ekonomiku" un izraisījusi jaunu darba formu parādīšanos, piemēram, "pūla darbs", "gabaldarbs" un cita veida darbaspēku pēc pieprasījuma.. Tas, vai tiks nodrošinās, ka digitālā transformācija rada vairāk un labākas darbavietas, būs atkarīgs no pieṇemtās politikas, ìpaši darba tirgus, izglīiības un prasmju un sociālās aizsardzības jomā. Tā kā ietekme var būt koncentrēta noteiktās nozarēs un reǵionos, svarīga loma būs arī nozaru un reǵionālajai politikai. 


\section{Sabiedrība}

Digitālās transformācijas ietekme uz sabiedrību un kultūru ir kompleksa un savstarpēji saistīti, jo digitālās tehnologijas maina cilvēku, uzṇēmumu un valdību savstarpējās mijiedarbības formu. Lai digitālā transformācija veicinātu izaugsmi un labklājību, ir būtiski, lai valsts politika atbalstītu pozitīvu un iekḷaujošo digitālo sabiedrību. Lai to izdarītu, ir jāapsver vairākas politikas jomas, tostarp sociālā politika (piem., mājokḷi un labklājība), izglītība un prasmes, nodokḷu un pabalstu politika, vide, veselība un digitālā pārvald̄̄ba. Digitālā transformācija maina pabalstu sadali, radot jautājumus par to, kur un kam dzīve uzlabojas, un padara sociālo politiku par svarīgu politikas instrumentu sastāvdaḷu, kas var risināt dažādas digitālās atškirīības.

\section{Uzticēšanās}

Uzticēšanās ir lıti būtiska digitālajai transformācijai. Ja tās nav, cilvēki, uznēmumi un valdības pilnībā neizmantos digitālās tehnologijas un neizmantots paliks būtisks potenciālās izaugsmes un sociālā progresa avots. Valstis var gūt labumu no plašākas pārrobežu sadarbības, izstrādājot visaptverošas un saskan,otas nacionālās stratēǵijas attiecībā uz digitālo drošību un privātumu, lai risinātu tādus jautājumus, kā piemēram, personas datu aizsardzība, būtisko pakalpojumu (piem., ūdens, enerğija, finanses, sabiedrības veselība un drošība), iniciatīvu radīšana (piem., kiberdrošība, publiskie iepirkumi), atbalsts MVU un saistīto prasmju attīstība, konsultējoties ar visām attiecīgajām pusēm. Vienlaikus ir svarīgi turpināt sekmēt efektīvu e-komercijas un citu tiešsaistes darbību patērētāju aizsardzību, jo tas palīdzēs digitālajai ekonomikai attīstīties un kḷūt iekḷaujošākai.

\section{Tirgus atvērtība}

Digitālās tehnoloǵijas pārveido vidi, kurā konkurē, darbojas un investē uzṇēmumi. Tirgus atvērtības politiki, kas ir saistīta ar komercdarbību, investīcijām, finanšu tirgiem, konkurenci un nodokliem, ir svarīga loma, lai nodrošinātu labvēlīgus apstākḷus digitālās transformācijas uzplaukumam. Digitālā transformācija skar arī politiku, kas ir saistīta ar tirgus atvērtību, iespēju veidošanu un izaicinājumu radīšanu. Valdības var gūt ieguvumu, periodiski pārskatot tirgus atvērtības politiku un nepieciešamības gadījumā atjauninot to, lai nodrošinātu, ka tā ir piemērota digitālās transformācijas nodrošināšanai, izaugsmes un labklājības veicināšanai.

\section{Digitalizācija. Latvijā}

Pārskatam ir šāda struktūra:

2. nodaḷā "Galvenie nākotnes nedrošuma aspekti digitālajā transformācijā un potenciālās sekas Latvijā" izmantots skatījums nākotnē, lai analizētu trīs alternatīvus nākotnes scenārijus, kas var veidoties globālās ekonomikas un sabiedrības pašreizējās digitālās transformācijas rezultātā. Šie nākotnes skatījuma scenāriji ir paredzēti, lai palīdzētu Latvijas lēmumu pieṇēmējiem labāk izprast destruktīvās izmaiṇas, noteikt kritiski nozīmīgos nedrošuma aspektus, izstrādāt inovatīvas jaunas stratēgijas un politikas, kā arī veikt esošo plānu un prakses stresa testēšanu.

3. nodaḷā "Latvijas digitālās ekonomikas infrastruktūras" aplūkotas jaunākās izmaiṇas Latvijas komunikāciju tirgū, analizētas institucionālās struktūras, kā arī komunikāciju politikas un regulējums, un sniegtas politikas rekomendācijas.

4. nodaḷā "Cilvēku, uzṇēmumu un valdības digitālās transformācijas veicināšana" apskatītas jaunākās digitālo tehnologiju lietošanas tendences starp cilvēkiem, uzṇēmumos un valdībā Latvijā. Tajā ir analizētas nacionālās programmas, lai likvidētu digitālās atšḳirības starp cilvēkiem un uzṇēmumiem, un sniegtas politikas rekomendācijas, tostarp par digitālo prasmju attīstību.

5. nodaḷā "Uzticēšanās digitālajai ekonomikai veicināšana" analizētas Latvijas digitālās drošības politikas, lai veicinātu ekonomikas izaugsmi un noturību, vērtēti veiktie pasākumi, lai nodrošinātu, ka cilvēki var uzticēties, ka viṇu datu pārvaldībā tiek ievērota konfidencialitāte un tiek aizsargāts privātums, aplūkota Latvijas struktūra digitālo patērētāju aizsardzībai un sniegtas rekomendācijas, lai uzlabotu uzticēšanos digitālajai ekonomikai Latvijā. 
6. nodaḷā "Ekonomikas un sabiedrības digitālās transformācijas potenciāla izmantošana" aplūkotas galvenās tehnoloǵijas tendences, ko nosaka digitalizācija, tostarp P\&A un lielie dati. Tajā analizētas Latvijas inovāciju politika šajā jomā un sniegtas rekomendācijas digitālo inovāciju veicināšanai nacionālās inovāciju sistēmas ietvaros. Aplūkotas arī nesenās pārmaiñas Latvijas galvenajās nozarēs un pakalpojumos un analizētas nacionālā politika ar mērḳi veicināt "viedo" specializāciju, īpaši attiecībā uz Latvijas integrāciju globālajās vērtību k̦ēdēs.

7. nodaḷā "Digitalizācijas transformācijas politikas: Rekomendācijas valdības kopējai pieejai" aplūkota politika, kas analizēta iepriekšējās nodaḷās saistībā ar to saskan,otību dažādās jomās, un sniegtas rekomendācijas, lai veicinātu sinerǵijas starp valdības ministrijām, līmeṇiem un iestādēm, pamatojoties uz ESAO Digitalizācijas integrētās politikas satvaru. 


\section{Atsauces}

Blanchard, O., M. Griffiths un B. Gruss (2013), "Uzplaukums izaugsme, atvesel̦ošanās: Latvijas krīzes ekspertīze” [Boom, bust, recovery: Forensics of the Latvia crisis], Brookings Papers on Economic Activity, Economic Studies Program, Vol. 44, 325.-388. lpp.

Eiropas Komisija (2018a), Latvijas pētniecības finansēšanas sistēma [The Latvian Research Funding System], Eiropas Komisijas Pētniecības un inovācijas ǵenerāldirektorāts, Brisele, https://rio.jrc.ec.europa.eu/en/library/specific-support-latvia-final-report\%E2\%80\%93-latvianresearch-funding-system.

Eiropas Komisija (2018b), Digitālās inovācijas centri - Viedās specializācijas platformas [Digital Innovation Hubs - Smart Specialisation Platforms], Brisele, https://s3platform.jrc.ec.europa.eu/digital-innovation-hubs-tool/-/dih/13295/view (piekḷuve 2020. gada februārī).

ESAO (2020a), Kā klājas? 2020: Labklājības mērījums [How’s Life? 2020: Measuring Well-being], OECD Publishing, Paris, https://dx.doi. org/10.1787/9870c393-en.

ESAO (2020b), “COVID-19 ierobežošanas pasākumusākotnējās ietekmes uz saimniecisko darbību vērtējums” [Evaluating the initial impact of COVID-19 containment measures on economic activity], https://oe.cd/il/2VU (skatīts 2020. gada 28. maijā).

ESAO (2020c), Analytical Business Enterprise Research and Development (ANBERD) datubāze, ESAO, Paris, http://oe.cd/anberd (piekḷuve 2020. gada 6. maijā).

ESAO (2020d), un Galveno zinātnes un tehnologiju indikatoru (datubāze) [OECD Main Science and Technology Indicators (MSTI) (database)], ESAO, Paris, http://oe.cd/msti (piekḷuve 2020. gada 6. maijā).

ESAO (2020e), Ienākumu sadalijuma datubāze (IDD) [OECD Income Distribution Database (IDD)], OECD, Paris, http://oe.cd/idd (accessed on 6 May 2020).

ESAO (2019a), ESAO ekonomikas apskati: Latvija 2019 [OECD Economic Surveys: Latvia 2019], OECD Publishing, Paris, https://doi. org/10.1787/f8c2f493-en.

ESAO (2019b), Digitalizācija: Politikas veidošana, dzīves uzlabošana [Going Digital: Shaping Policies, Improving Lives], OECD Publishing, Paris, https://doi.org/10.1787/9789264312012-en.

ESAO (2018a), "Latvijas salīdzinošais vērtējums.” Jaunā ESAO darba vietu stratēgija: Labas darba vietas visiem mainīgajā darba pasaulē ["How does Latvia compare?" The New OECD Jobs Strategy: Good Jobs for All in a Changing World of Work], OECD Paris, www. oecd.org/latvia/jobs-strategy-LATVIA-EN.pdf.

ESAO (2018b), No digitalizācijas izrietoši nodokḷu izaicinājumi - starpposma ziṇojums 2018: Iekḷaujošais satvars attiecībā uz [BEPS Tax Challenges Arising from Digitalisation - Interim Report 2018: Inclusive Framework on BEPS], OECD/G20 Base Erosion and Profit Shifting Project, OECD Publishing, Paris, http://dx.doi.org/10.1787/9789264293083-en.

Eurostat (2020), Digital Economy and Society (datubāze), http://ec.europa.eu/eurostat/web/digital-economy-and-society/data/database (piekḷuve 2020. gada 6. maijā).

ILO (2015), Rekomendācija Nr. 204 par pāreju no neformālas uz formālu ekonomiku [Recommendation No. 204 concerning the Transition from the Informal to the Formal Economy], Sanāksmes dokuments, www.ilo.org/ilc/ILCSessions/previous-sessions/104/texts-adopted/ WCMS_377774/lang--en/index.htm.

Mickiewicz, T., A. Rebmann un A. Sauka (2019), "Maksāt vai nemaksāt? Uzṇēmuma īpašnieka nodokḷ morāle: Neoinstitucionālā satvara testēšana pärejas vidē" [To pay or not to pay? Business owners' tax morale: Testing a neo-institutional framework in a transition environment, Journal of Business Ethics, Vol. 157, 75.-93. lpp., https://ink.springer.com/article/10.1007/s10551-017-3623-2\#article-info.

Ministru kabinets (2020), Informatīvais ziṇojums “Par mākslīgā intelekta risinājumu attīstību”, Rīga, http://tap.mk.gov.lv/doc/2020_02/ IZ_MI\%5b1\%5d.2.docx.

Ministru kabinets (2019), Latvijas atvērto datu stratēgija, Rīga, 20. augusts, http://polsis.mk.gov.lv/documents/6533.

Ministru kabinets (2018), Mākon,datošanas pakalpojumu izmantošana valsts pārvaldē, Rīga, 20. februāris, http://polsis.mk.gou.lv/ documents/6140.

Ministru kabinets (2015), Informatīvais ziṇojums "Par publiskās pārvaldes informācijas sistēmu konceptuālo arhitektūru”, Rīga, 10. marts, http://tap.mk.gou.lu/mk/tap/?pid=40338790.

Ministru kabinets (2013a), Informācijas sabiedrības attīstības pamatnostādnes - Informatīuā daḷa, Rīkojums Nr. 486, Rīga, 14. oktobris, www.varam.gou.lv/in_site/tools/download.php?file=files/text/Darb_jomas/elietas//Information_Society_Development_Guidelines_ 2014_2020.docx.

Ministru kabinets (2013b), Valsts informācijas un komunikācijas tehnoloǵiju pārvaldības organizatoriskais modelis, Rīkojums Nr. 57, Rīga, 15. janvāris, www.varam.gov.lv/in_site/tools/download.php?file=files/text/Darb_jomas/elietas//E2269_Organisational_Model_for_the_ Management_of_Public_Infor_and_Com_Techn.doc. 
The Conference Board (2020), Konferences padomes kopejjā ekonomikas datu bāze [The Conference Board Total Economy Database], 2019. gada aprīlis, www.conference-board.org/data/economydatabase.

VARAM (2019), Informācijas sabiedrības attīstības pamatnostādṇu 2014. - 2020. gadam starpposma 2. Izvērtējums, Vides aizsardzības un reǵionālās attīstības ministrija, http://polsis.mk.gov.lv/api/file/file7299860066764117769.pdf.

\section{Piezīme}

1. Šajā pārskatā sniegto salīdzinājumu mērḳis nav salīdzināt Latviju ar noteiktu valstu kopumu, bet izprast Latvijas veiktspēju dažādās politikas jomās saistībā ar digitālo transformāciju. Tāpēc salīdzinājumam izvēlētās valstis/ reǵioni var atšḳirities dažādās jomās. 



\section{Nodala 2 \\ GALVENĀS NĀKOTNES NENOTEIKTĪBAS DIGITĀLAJĀ TRANSFORMĀCIJĀ UN POTENCIĀLĀS SEKAS LATVIJAI}




\section{Ievads}

Digitālā transformācija virza straujas bezprecedenta globāla mēroga pārmainas, kas izraisa paaugstinātu nenoteiktību. Šajā kontekstā cilvēki, organizācijas un valdības, kas izstrādā plānus nākamajām desmitgadēm, vairs nevar paḷauties uz pieṇēmumiem, ka nākotnē būtiski līdzināsies tagadnei. Drīzāk tām ir jāpēta un jāgatavojas virknei alternatīvu scenāriju, kas aptver potenciālās pārmainas, un jaunām iespējām un izaicinājumiem, ko tie var izraisīt. Šāda pieeja var palīdzēt nodrošināt, ka šobrīd izstrādātās stratēgijas un politikas satvari būs noturīgi un pielāgojami, saskaroties ar digitālo transformāciju un pārmaiṇu virzienu, tempu un mērogu, ko tā var izraisīt.

Šìs nodaḷas sākumā ir aplūkoti trīs digitālās transformācijas nākotnes alternatīvi scenāriji, kas balstīti uz plašām atšk̦irībām varas struktūrās un attiecībās sabiedrības dalībnieku starpā. Pirmajā scenārijā apsvērta pasaule, kurā aktīvie pilsoṇi ṇem digitalizāciju savās rokās un izveido visaptverošu spēcīgu tiešsaistes kopienu "trešo pīlāru", kas nodrošina pretsvaru valstīm un tirgiem. Otrajā scenārijā raksturota pasaule, kurā valdības izveido digitālās platformas, kas kḷūst par to ekonomiku mugurkaulu, veicinot apmaiṇu starp valstīm, kas lieto vienu un to pašu sistēmu, bet veidojot barjeras ar tām, kas to nelieto. Trešajā scenārijā aplūkota nākotne, kurā daudznacionālas digitālas korporācijas kḷūst tik efektīvas un visaptverošas, apkalpojot savus lietotājus, ka daudzas no lomām, kas tradicionāli pieder valstij, piemēram, izglītību un labklājību, piedāvā nevalstiskas organizācijas.

Atsevišḳi un kā kopums šie scenāriji piedāvā iespēju pārdomāt nepārbaudītos pieṇēmumus par nākotnes trajektorijām un uz to pamata veidotajām politikām. Kādas var būt kopienu un kolegiālo iniciatīvu lomas Latvijas digitālajā nākotnē? Kāda veida digitālo pārvaldību Latvija vēlas realizēt? Kurās stratēgiskajās partnerībās un kolektīvajās iniciatīvās Latvija varētu piedalīties, lai nodrošinātu savu vietu pasaulē? Scenāriji paši par sevi nesniedz atbildes uz šiem jautājumiem, bet drīzāk nodrošina satvaru, kurā var uzdot šādus jautājumus.

Nodaḷas noslēgumā noteiktas vairākas galvenās rīcības perspektīvas, kas izriet no scenāriju analīzes. Šìs rīcības iedalās četrās galvenajās kategorijās: 1) Latvijas digitālās transformācijas stratēgisko partnerību novērtēšana un stiprināšana; 2) viedo pieeju izglītībai un prasmēm noteikšana adaptīviem un kritiskiem Latvijas iedzīvotājiem; 3) ceḷu virzībai uz iekḷaujošu digitālu Latviju atrašana, ko veic cilvēki cilvēkiem; un 4) kapacitātes veidošana, lai gūtu labumu no piekḷuves personas datiem un to izmantošanas, vienlaikus aizsargājot digitālo drošību un privātumu.

\section{Kāpēc scenāriji? Lēmumu pien̦emšana nenoteiktỉbas kontekstā}

Digitālās transformācijas temps un mērogs rada augsta līmeṇa nenoteiktību attiecībā uz nākotni tuvāko gadu laikā. Turpinoties virknei saistītu digitālo tehnoloǵiju attīstībai un tām apvienojoties, rodas radikāli jaunu rīcību un uzvedības modeḷu iespējas, un tās savukārt var izraisīt kaskādes un nenoteiktas sekas visiem sabiedrības, ekonomikas, vides un pārvaldības aspektiem. Atšḳirībā no citām prognozējamākām megatendencēm, piemēram, iedzīvotāju novecošanās, kas var notikt pakāpeniski desmitgažu laikā, tehnoloǵiju izmaiṇas var izraisīt pēkšṇas un dažādas sekas, ko ir grūti paredzēt.

Nav iespējams prognozēt vai pilnībā kontrolēt, kādi jauni uzṇēmējdarbības modeḷi var veidoties, kādas jaunas kolektīvās rīcības formas var kḷūt iespējamas, kādas digitālas valsts iesaistīšanās formas var izrādīties visefektīvākās, kā var attīstīties ekonomikas struktūra un darbība un kā vērtības un spēka rakstura izmaiṇas digitālākā pasaulē var mainīt globālo kārtību. Visas šìs nenoteiktības ir saistītas ar potenciālām pārmaiṇām, kas var radīt milzīgas iespējas uzlabot cilvēku labklājību un risināt kompleksus globālus izaicinājumus, bet var arī radīt būtisku destrukciju un izraisīt jaunus potenciālus draudus.

Efektīvu stratēǵiju un politiku izstrādei vidē, kas ātri mainās un nav prognozējama, kāda ir digitālā transformācija, ir nepieciešama stratēgijas skatījuma pieeja (skatīt 2.1. ielikums). Tas nozìmē skatīties plašāk par pašreizējām tendencēm un cerībām attiecībā uz nākotni un apsvērt virkni dažādu scenāriju. Nākotnes skatījuma scenāriji ir alternatīvu aprakstu kopums par to, kā var izskatīties nākotne, kas 
sagatavots ar mērḳi rīkoties tagad. Tie nav prognozes vai mēginājumi prognozēt, kāda izskatīsies nākotne. Tie nav arī rekomendāciju komplekti vai kādas konkrētas vēlamas nākotnes vīzija. Vienkārši sakot, scenārijos nav pateikts, kas notiks vai kam vajadzētu notikt, bet tikai kas varētu notikt, atstājot jautājumu par to, ko no tiem var mācītiem, atklātu diskusijai.

Šajā nodaḷā izklāstītie nākotnes skatījuma scenāriji ir paredzēti, lai palīdzētu Latvijas lēmumu pieṇēmējiem paredzēt destruktīvas pārmaiṇas, izstrādāt inovatīvas jaunas stratēǵijas un politikas, un pārbaudīt esošos plānus un praksi attiecībā pret virkni iespējamu alternatīvu. Papildu ieguvumi no scenāriju izmantošanas politikas veidošanā ietver spēju atklāt un pārbaudīt netiešus pieṇēmumus par nākotni pašreizējā politikā, savienot politikas jomas, kas iepriekš nodalītas, pārvērst nesaskaṇas ekspertu starpā par aktīvu un apspriest jautājumus, kas citādi būtu pārāk sensitīvi, lai tos ierosinātu.

Scenāriji ir sagatavoti, izmantojot sākotnējā vienas dienas nākotnes skatījuma darbsemināra, kurā bija plaši pārstāvētas Latvijas ieinteresētās puses, kas strādā politikas, tehnoloǵijas, akadēmiskajā un citās jomās, rezultāti. Scenāriju izstrādē tika iekḷauti arī konstatējumi no vairākām intervijām ar Latvijas politikas veidotājiem un ekspertiem, nākotnes skatījuma aptaujas, ESAO iekšējās scenāriju izstrādes un ievadinformācija no ESAO Zinātnes, tehnologiijas un inovāciju direktorāta. Pēc tam tika organizēti divi papildu nākotnes skatījuma darbsemināri, lai precīzi izstrādātu politikas sekas, kas izklāstītas šìs nodaḷas beigās, kā arī definētu būtitiski svarīgos jautājumus Latvijas digitālajai nākotnei.

\section{1. ielikums. Kāds ir stratēǵijas nākotnes skatijiums?}

Stratēǵijas nākotnes skatījums ir disciplīna, kas pārsniedz pašreizējos pieṇēmumus, to vietā ṇemot vērā virkni iespējamu nākotnes notikumu ar mērḳi noteikt sekas attiecībā uz politikas veidošanu. Tajā tiek izmantotas vairākas metodoloǵijas, piemēram, horizonta skenēšana, lai noteiktu iespējamās izmaiṇas, megatendenču analīze un vairāku scenāriju izstrāde.

Stratēǵiskais nākotnes skatījums var palīdzēt valdībām izstrādāt noturīgākas un adaptīvākas stratēgijijas, izmantojot šādas pieejas:

- Ar labāku notikumu paredzēšanu tiek noteiktas izmainas, kas var rasties nākotnē, un jaunas politikas veidošanas iespējas un izaicinājumi.

- Nākotnes pierādišanā tiek izmantoti iespējamie nākotnes scenāriji, lai pārbaudītu esošās stratēǵijas stresa apstākḷos.

- Politikas inovācija attīsta jaunas inovatīvas idejas un politikas, kas ir izturīgas dažādos nākotnes scenārijos.

\section{Kā izmantot šo nodaḷu}

Šì nodaḷa ir paredzēta kā sākumpunkts turpmākai analīzei un digitālās transformācijas nākotnes un tās potenciālās ietekmes Latvijā apsvēršanai. Tās konstatējumus, lai arī tie lielā mērā atbilst pārējam pārskatam, var uzskatīt arī par papildinošiem, un tie var kalpot kā papildu līdzeklis, lai novērtētu, kā vislabāk īstenot citās nodaḷās ietvertās rekomendācijas, īpaši, ja to var ietekmēt negaidīti nākotnes pavērsieni.

Galvenokārt pastāv cerība, ka šī nodaḷa kalpos kā iedvesmas avots un struktūras elements notiekošajam stratēǵiskās nākotnes skatījuma dialogam Latvijā. Tas paredz scenāriju izmaiṇas un jaunu scenāriju izstrādi atbilstoši apstākḷu izmaiṇām, kā arī digitālās transformācijas dzị̄āku krustpunktu ar citiem būtiskiem destruktīvu apstākḷu avotiem, piemēram, COVID-19, analīzi (skatìt 2.2. ielikums). Šādi pastāvīga un līdzdalības stratēǵiska nākotnes skatījuma centieni no Latvijas lēmumpieṇēmēju un plašākas politikas kopienas puses būs neizbēgami turpmākā darbā, lai izstrādātu noturīgas un adaptīvas stratēgijas Latvijas panākumu nodrošināšanai digitālajā laikmetā. 


\section{2. ielikums. Koronavīrusa pandēmijas sekas}

Pēkšṇā COVID-19 globālās pandēmijas sākšanās ir skaidrs atgādinājums par nepieciešamību sagatavoties negaidītajam. Lai gan šādas pandēmijas iespējamība jau sen tika paredzēta, precīzs tās iestāšanās laiks un raksturs ir bijis neprognozējams. Pandēmija tagad izraisa turpmākus destrukcijas viḷnus un nenoteiktību, kas ietekmē visas politikas jomas. Šajā saasinātās turbulences kontekstā nākotnes skatījuma pieejas, kāda ir šajā nodaḷā parādīta, var palīdzēt valdībām izvairīties no riska pieṇemt politikas lēmumus pārmērīgā steigā, vai pamatojoties uz šauriem pieṇēmumiem par nākotni.

Dažas mijiedarbības starp COVID-19 un digitālo transformāciju jau šḳiet skaidras, tostarp pēkšn,ais tiešsaistes darba, mācību, komercijas, izklaides un politikas paātrinājums. Tomēr neskaidrības ir vēl lielākas. Piemēram, vai virtuālā darba pieaugums būs ilgstošs un kā tas var ietekmēt peḷnas un migrācijas modeḷus gan valstu iekšienē, gan starp valstīm? Vai COVID-19 paātrinās deglobalizāciju un atsevišḳu digitālo reǵionu veidošanu, vai radīs iespēju atjaunotai globālai sadarbībai? Vai ekonomiskā krīze pastiprinās lielo tehnoloǵiju uzṇēmumu dominanci, vai radīs jaunas nišas inovatīviem konkurentiem? Vai iedzìvotāji atzinīgi pieṇems vai noraidīs jaunas digitālās izdzīvošanas formas, kuru mērḳis ir sekmēt sabiedrības veselību? Vai bažas par pieaugošo valstu parādu var izraisīt kriptovalūtu pieaugumu? Kādi digitāli iespējotu politisko kustību veidi var izveidoties krīzes pastiprināto sociālo atšķirību rezultātā?

Lai gan šì nodaḷa tika sagatavota pirms COVID-19 pandēmijas, trīs aprakstītie scenāriji var kalpot kā vērtīgs pamats daudzu turpmāko nenoteiktību un iespējamās notikumu attīstības apsvēršanai saistībā ar COVID-19 un digitālās transformācijas mijiedarbību un potenciālajām sekām attiecībā uz Latvijas digitālo stratēǵiju.

\section{Norādes vēlamas digitālas Latvijas izveidei}

Stratēǵiskā nākotnes skatījuma analīzes galīgais nolūks šajā nodaḷā ir palīdzēt Latvijai noteikt cel̦u, lai virzītos uz vēlamo digitālo nākotni, vienlaicīgi apzināti orientējoties nenoteiktības kontekstā. Lai izveidotu pamatu šai diskusijai, darbsemināros tikai iekḷauta viedokḷu apmaiṇa par vispārējām prioritātēm un plāniem attiecībā uz valsts digitālo nākotni. Tie nav uzskatāmi par oficiālu konsolidētu valdības vīziju vai jebkuras personas vai organizācijas oficiālo viedokli. Drīzāk tie atspoguḷo atsevišķus ieskatus nākotnes virzienos, ko Latvijas ieinteresētās puses un politikas veidotāji uzskatīja par labvēlīgiem. Darbības laikā šie virzieni kalpoja kā pirmais solis, lai noteiktu stratēgiskās iespējas, ko valdība varētu apsvērt. Tas ir sākumpunkts diskusijām, liekot pamatu auglīgām debatēm par Latvijas ambīcijām un prioritātēm turpmākajā attīstībā.

Gan ieinteresētās puses, gan politikas veidotāji izteica vēlmi veidot iekḷaujošu digitālu Latviju, ko veidotu cilvēki cilvēkiem. Tas nozīmētu, ka katra lēmuma, programmas vai politikas mērḳa centrā ir jābūt Latvijas iedzīvotāju labklājībai, kā arī Latvijas iedzīvotājiem tiek dota iespēja sadarboties, dot savu ieguldījumu un būt digitāli aktīviem. Latvijas iedzīvotāji ir izteikuši vēlēšanos redzēt tādu digitālo nākotni, kur viṇi var līdzdarboties savā valodā un atbilstoši savām individuālajām vēlmēm un ierobežojumiem. Šìs gaidas nosaka nepieciešamību veidot digitālās iespējas visiem un nodrošināt, ka Latvijas iedzīvotājiem ir nepieciešamās prasmes un rīki, lai tās izmantotu pēc iespējas savā labā. Ieinteresētās puses vēlas iesaistīties un izmantot iespēju dot pienesumu Latvijas digitālās transformācijas procesā. Viens no veidiem, kā nodrošināt iespēju uzklausīt iedzīvotājus, būtu publiskās konsultācijas par digitalizācijas tēmām.

Ar šo plānu cieši saistīta ir vēlme nodrošināt, lai sekmīga digitālā Latvija būtu balstīta uz viedu pieeju izglītībai un prasmēm. Tas ietver adaptīvu un atsaucīgu izglītības nozari, kas reaǵē uz pārmaiṇām, atbalsta digitālās mācības visiem Latvijas iedzīvotājiem gan IKT prasmju apgūšanā (digitālā pratība un datu pratība), gan papildu prasmju, piemēram, informācijas apstrādes un problēmu risināšanas, veidā. Digitāli prasmīga nācija ir tāda, kuras iedzīvotāji gan pilsētās, gan laukos var izmantot digitālās iespējas un zina, kā aizsargāt sevi digitālajā vidē. Tā ir tāda, kur mācību sistēmas visos līmeṇos spēj pielāgoties un attīstīties kopā ar vidi, reaǵējot uz tirgus vajadzībām un tehnoloǵiju attīstību. Tā strādā, lai pilnībā izmantotu strauji uzlabojošās iespējas iesaistīties mūžizglītībā ārpus formālās izglītības sistēmas, ko padara iespējamu tehnologiiskais progress, piemēram, mācīšanās darbā un ikdienas dzīvē. Viedā 
izglītỉba nodrošinātu iespējas izplatīt esošās zināšanas un ekspertīzi un veidoties un sekmīgi attīstīties jaunām partnerībām. Latvijā digitālās prasmes nevajadzētu aplūkot izolēti, bet drīzāk cieši saistīt ar cilvēku personiskajām un profesionālajām ambīcijām un skatīties uz tām kā līdzekli cilvēkkapitāla uzlabošanai visiem iedzīvotājiem.

Vēl viens Latvijas nākotnes plāns ir izveidot saiknes sajūtu, stiprinot valsts iekšējo sadarbību un tīklus. Gan ieinteresētās puses, gan politikas veidotāii ir izteikuši vēlēšanos veidot plašāku sadarbību valsts, privātā sektora, pilsoniskās sabiedrības, akadēmiskās vides pārstāvju un cilvēku starpā, lai labāk savienotu esošās spējas. Pārejot no īsāka termiṇa vienošanām projektu ietvaros uz ilgāka termiṇa partnerattiecībām dažādās jomās, varētu gūt iespēju attīstīt vēl stabilākas attiecības. Šādas partnerības varētu pārsniegt zināšanu apmaiṇas mērkịi, izveidojot produktīvu vidi inovācijas attīstībai. Stratēgiskās saiknes starp virkni sekmīgu projektu digitālajā jomā stiprinātu Latvijas kā mazas un elastīgas valsts statusu. Šāda pieeja varētu arī nodrošināt iespējas darboties kā testa stendam jaunām publisku un privātu partnerību koncepcijām.

Vēl kāds vēlams Latvijas digitālo panākumu aspekts ir pastāvīga spēja aizsargāt digitālo drošību un drošumu. Tas nozīmē iespēju Latvijas iedzīvotājiem lietot tehnoloǵijas droši un aizsargātā vidē, vienlaikus ḷaujot atklāti koplietot datus. Strauji mainīgajos apstākḷos ir nepieciešams pastāvīgi stiprināt digitālo drošìbu un ētikas aizsardzības līdzekḷus, kas sistemātiski iestrādāti lēmumu pieṇemšanas procesos. Vēlamais rezultāts būtu sekmīga digitālo sistēmu kā prioritātes integrācija gan personīgajā, gan institucionālajā drošǐbas sistēmā.

\section{Trīs scenāriji: Latvijas iztēlošanās dažādos nākotnes kontekstos}

Šeit aprakstītie trīs scenāriji ietver alternatīvus nākotnes vides aprakstus, ar kādu var saskarties Latvija turpmākajos gados. Šie scenāriji ar nolūku veidoti ekstrēmi, un izdomātie vienkāršojumi ir paredzēti kā rīks potenciālo jaunu iespēju un izaicinājumu noteikšanai. Neviens no šiem scenārijiem nerealizēsies atbilstoši aprakstītajam, un patiesība visdrīzāk būs neskaidra visu trīs scenāriju un citu faktoru kombinācija. Latvijas sabiedrības un ekonomikas stāvokli katrā no trim scenārijiem var tikai iztēloties, un tas būs atkarīgs no virknes savstarpēji saistītu (re)akciju un attīstības, kā arī dažādām politikas izvēlēm daudzu gadu laikā. Tomēr ir iespējams paredzēt katras "nākotnes Latvijas" noteiktas iezīmes, norādot uz izaicinājumiem, ar kādiem valstij var nākties saskarties, kā arī iespējām, ko tā varēs izmantot.

\section{\#Me2.0}

Cilvēki ir izmantojuši digitālās tehnoloǵijas jaunu reǵionālo un globālo kopienu izveidei, lai labāk istenotu savas intereses.

\section{Šìs kustības ir radījušas} izaicinājumus pārvalžu un uzñēmumu dominancei, veidojot trešo globālās sistēmas pīlāru: pilsonisko sektoru.

Kopienas efektīvi izmanto tehnoloǵijas, lai risinātu vietējos un globālos izaicinājumus.

Vēl joprojām kā izaicinājums saglabājas grupu polarizācija un jautājumi par atbildỉbu.

\section{Platformas valdỉbas}

Valdības strādā ar l̦oti efektīvām un iedarbīgām tiešsaistes platformām, kas atvieglo ekonomikas apmaiñas procesu un lielāko daḷu citu darbību.

Lielākā daḷa valdību pieder pie politiskajiem blokiem ar platformām, kas mijiedarbojas viena ar otru, bet ne citiem blokiem.

Infrastruktūra ir augstākā līmeṇa bažu avots valstu nacionālās attīstības un drošības stratēgiju kontekstā.

Lieli datu apjomi, kas ir valdību kontrolē, ir saistîti ar lielu atbildību un nepieciešamību nodrošināt pārbaudes un lìdzsvaru.

\section{Korporativie starpnieki}

Neliels skaits globālo tehnolog̣iju uzṇēmumu darbojas kā vienas pieturas veikali, nodrošinot visus dzives aspektus.

Izmantojot savu ekonomisko spēku un populāru vēlmju analīzi, tehnoloǵiju korporācijas ir ieguvušas leğitimitāti ieṇemt vietu globālajā pārvaldē.

Daudzas jomas, par kurām iepriekš bija atbildīgas valdības, tagad ir korporāciju rokās.

Korporācijas ir iemantojušas augstu uzticību, un lielākā daḷa cilvēku ir lojāli pret uzṇēmumu, nevis valdību. 
\#Me2.0

\section{Kopsavilkums}

Ir 2035. gads un cilvēki visā pasaulē ir apguvuši digitālās tehnoloǵijas, lai izveidotu jaunas sociālās kustības un kopienu struktūras savu vajadzību apmierināšanai. Ar šīm darbībām viṇi ir apšaubījuši teritoriālo pārvalžu un privātā sektora uzṇēmumu dominanci, izveidojot atjaunotu trešo pīlāru globālajā ekonomikas, sabiedrības un pārvaldes sistēmā: pilsonisko sektoru. Cilvēki arvien aktīvāk izmanto savas tiešsaistes identitātes, lai realizētu ekonomiskās iespējas, pilsonisko līdzdalību un personisko attīstību gan digitālajā, gan fiziskajā telpā. Tehnoloǵiski attīstītas vienādranga organizatoriskās struktūras, vietējās iniciatīvas un pašorganizētas globālās, reǵionālās un vietējās kopienas iedzìvotājiem ir sniegušas vēl nebijušas iespējas..

\#Me2.0

- Cilvēki ir izmantojuši digitālās tehnoloǵijas jaunu reǵionālo un globālo kopienu izveidei, lai labāk ìstenotu savas intereses.

- Šîs kustỉbas ir radijjušas izaicinājumus pārvalžu un uznēemumu dominancei, veidojot trešo globālās sistēmas pīlāru: pilsonisko sektoru.

- Kopienas efektīvi izmanto tehnoloǵijas, lai risinātu vietējos un globālos izaicinājumus.

- Vēl joprojām kā izaicinājums saglabājas grupu polarizācija un jautājumi par atbildību.

Apvienojumā ar vieglāk pieejamām tehnoloǵijām vērtību pārmaiṇas ir likušas cilvēkiem mobilizēties kopīgiem mērḳiem gan atsevišķ k̦os pasākumos, gan pastāvīgi. Pastiprinoties vides degradācijai un no tās izrietošajai nevienlīdzībai, ir būtiski samazinājusies uzticēšanās globālajām institūcijām, lai izstrādātu reālus risinājumus un aizsargātu kopējos resursus. Cilvēki sāk uzṇemties iniciatīvu apvienoties un meklēt jaunus veidus, kā veidot zemas ietekmes dzìves stilu, uzlabot veselības stāvokli un atjaunot kopienas izjūtu. Neliela mēroga eksperimenti un izmēǵinājuma iciatīvas vietējā līmenī, kā arī sadarbība, izmantojot pasaules mērogā savienotas digitālās kopienas, ir l̦āvusi uzsākt jauna veida ceḷu. Šìs jaunās kopienas vairs neiederas iepriekš noteiktajās pilsoniskās sabiedrības organizāciju definīcijās un robežās, daudzām no tām pieṇemot jaunus formātus un pieejas. Dažas apvieno tiešsaistes un ārpus tiešsaistes aktivitātes un ir izaugušas no esošajām struktūrām konkrētu interešu atbalstam; citas rodas pēkšṇi, pamatojoties uz spontānu neapmierinātības izpausmi, stilīgu tēmturi vai pašreizēju notikumu. Kopienas globālos, reǵionālos un vietējos līmen,os kontaktējas, koordinē darbību un konkurē komplicētos transversālos mijiedarbības model̦os.

Taču tā vietā, lai pilnībā atṇemtu vietu valdībām un uzṇēmumiem, šĩs jaunās kustības un organizācijas kalpo kā papildinājums un atsvars, nodrošinot nepieciešamo politisko spiedienu un praktiskus piemērus, lai piespiestu valdības un uzṇēmumus strādāt labāk, apmierinot iedzīvotāju un patērētāju vajadzības. Taču līdz ar šo sabiedrisko kustību un organizāciju augošo spēku ir radušies jauni izaicinājumi, tostarp atšķirīgi iznākumi un polarizēti uzskati dažādu kopienu dalībnieku vidū, kā arī nesaskan,oti caurskatāmības, atbildības un demokrātiskas lēmumu pieṇemšanas standarti.

\section{Signāli: Pašorganizētas kopienas, digitālie kopīgie resursi un izlūkošana, izmantojot atklāti pieejamus avotus}

Stratēǵiskajā nākotnes skatījumā ir izmantoti šobrīd novēroti pārmaiṇu signāli, lai norādītu uz iespējamām jaunām tendencēm vai izzūdošām parādībām, kas varētu veidoties un attīstìties, un kā rezultāts varētu būt nākotnes scenārijs, kas atšḳiras no pašreizējām gaidām. Šeit norādītās pārmaiṇu pazīmes ir jau redzamas un, ja tās turpinās attīstīties, tās var izraisīt iepriekšējā sadaḷā aprakstìto scenāriju.

Pateicoties internetam, ir izveidojusies virkne pašorganizētu kopienu un tiešsaistes masu kopdarbības projektu. Tādi piemēri ir wikis (labāk zināms nosaukums Wikipedia), atvērtās licencēšanas organizācijas, atvērtā koda programmatūras krātuves un kopienas, kā arī koleǵiālie atbalsta tìkli. Paša interneta arhitektūra tika izstrādāta, izmantojot kopienas pieeju, piedaloties grupai datorzinātnieku, inženieru un tehnisko speciālistu. 
Tiešsaistes kopienas organizāciju darbība noveda pie jaudīgas darbības, kas vairs nenorisinājās tiešsaistē, no kurām labāk zināmās ir Arābu pavasaris vai 2009. gada Irānas «Twitter revolūcijas», bet arī «Nākotnes piektdienu» kustības kontekstā, kas rosināja plašāku rīcību, lai risinātu vides krīzi, vai «\#EsArī» kampaṇa, kurā tika aicināts vērsties pret seksuālo vardarbību. Šie tīkli bieži kalpo, lai aizpildītu vadības vai tiesību aktu plaisas, ko atbilstoši nerisina valdības vai uzṇēmumi. Piemēram, savstarpējās palīdzības atbildība ir efektīva reakcija uz vardarbību tiešsaistē tādās platformās, kā piemēram Twitter, un savstarpējās palīdzības konsultāciju tehnolog̣ija var palīdzēt izsekot tiem, kas reaǵē uz mēstulēm, piemēram, Wikipedia (Matias, 2015).

Internets ir devis cilvēkiem iespēju aizsargāt un pārvaldīt kopējos resursus, izmantojot tam jaunus spēcīgus, kopienas virzìtus līdzekḷus (Hess, 2008; Walljasper, 2011). Piemēram, Sarantaporo, kas ir neliels ciemats Grieḳijā, iedzīvotāji izveidoja iniciatīvu, lai izmantotu vietējo platjoslas infrastruktūru kā kopēju resursu, jo telekomunikāciju tīkli vai valdība šādus centienus neizrādīja (Mölleryd, 2015). Citi cilvēki ir izveidojuši paši savus kopējos resursus, lai dalītos ar mūziku un video, tāpat ir rīkojušies zinātnieki, kas izmanto atvērto piekḷuvi, kopienas pārvaldītus resursus, lai publicētu savus pētījumus, kā alternatīvu komerciālajiem izdevējiem. Daudzu citu starpā digitālie kopējie resursi tiek veltīti arī universitātes kursu programmu kopīgošanai un neirozinātnisko pētījumu, kas atrodami tīmeklī, apkopošanai (piem., M.I.T. Open Course Ware).

Tāpat arī cilvēki rīkojas, lai iegūtu kontroli pār mākslīgo intelektu (MI), mašīnmācīšanās metodēm un datu apstrādes un lietošanas veidiem. Populāra kḷūst arī publiskos avotos pieejamu izlūkdatu ieguve (OSINT), kas l̦auj iegūt izmantojamu un prognozējamu izlūkošanas informāciju no sabiedriskiem, neklasificētiem avotiem. Atklāti pieejamo avotu AI tehnolog̣ijas un AI komplekti, kas balstīti uz atklāti pieejamo avotu platformām, padara mašīnmācišanās projektus pieejamus ikvienam. Papildus tam, cilvēki aizvien vairāk vēlas saprast algoritmus, kas darbina ierīces, ko viṇi lieto. Piemēram, AutoPilot, kas ir autonoma automašīnu izstrādes platforma, darbojas ar programmatūru, kas varētu liaut tās lietotājiem redzēt vizuālos elementus, ko AI izseko braukšanas laikā (Nvidia, 2020).

\section{Kā radās šì pasaule}

2019. gadā internetā bija nepieredzētas iespējas uz kopienu balstītai sadarbībai un iespēju radīšanai. Pateicoties pieaugošai aktīvu pieejamībai, piemēram, atvērtā koda programmatūra, plaši informācijas avoti un liela mēroga datubāzes, cilvēki ir ieguvuši iespējas būt radošiem, eksperimentēt un rīkoties efektīvi dažādos veidos. Globālā mērogā uzlabojoties digitālajai pratībai un saistītajām prasmēm, kodēšana un programmatūras izstrāde ir pārvietojusies no ekspertu jomas uz galveno, lielākajai dạ̣ai digitālo ierīču kḷūstot pieejamām ikvienam. Aizvien vairāk cilvēku ir atklājuši, kā tehnolog̣ijas, piemēram, MI, 3D druka un automatizētie žurnāli, var l̦aut viṇiem panākt reālās dzīves uzlabojumus viṇu kopienās.

Virkne datu noplūžu un publicitāte, kas saistīta ar liela mēroga datu manipulācijām, kā arī vides un ētiskie skandāli korporatīvo tehnoloǵiju nozarē, lika aizvien vairāk apsvērt iespēju liegšanu tiešsaistē. Atbildot uz šo, pilsoniskās sabiedrības grupas sāka aizstāvēt caurskatāmāku datu pārvaldības politiku, lietotāji sāka boikotēt noteiktus pakalpojumu sniedzējus, un sāka parādīties kopienas vadīti alternatīvi pakalpojumi un platformas, apdraudot korporatīvo platformu dominanci. Meklējot līdzekḷus uzticēšanās atgūšanai, gan valdības, gan korporācijas lūdza padomu kopienām un konsultējās ar pilsonisko sabiedrību, lai izstrādātu leǵitīmākus un drošākus digitālos produktus un pakalpojumus.

Vienlaikus dziḷa nenoteiktība un nestabilitāte, kas saistīta ar klimata krīzi un nevienlīdzību, izraisīja sociālo nemieru, izjaucot "ierastās kārtības" vietējās un nacionālās politiskās sistēmas. Savlaicīgi tika ìstenotas tikai nedaudzas sistēmiskās izmaiṇas, un lielākajā daḷā pasaules turpināja palielināties piesārn,ojums, atkritumu un emisiju apjoms, bet klimata katastrofas īpaši smagi skāra neaizsargātās kopienas. Cilvēki meklēja veidus, kā aizpildīt solidaritātes plaisu, ko neaizpildīja korporācijas un valdība, un radīja uzticēšanos vietējām iniciatīvām, kopienām un to sastāvdaḷām. Tā rezultātā būtiski paplašinājās pilsoniskais sektors, kā rīcībā bija digitālās tehnologiijas, kas l̦āva šìm grupām pieṇemt savus pārvaldības noteikumus, izstrādāt efektīvus lēmumu pieṇemšanas mehānismus un uz vietas un ilgtspējīgi radīt vērtības. Tādi piemēri ietver AI un uz blokkēēēm balstītu eksperimentu veidošanu, piemēram, labības audzēšanai, drošu aizdošanas sistēmu radīšanai, un izstrādāt ilgtspējīgus mājokḷu modeḷus kopienā. 


\section{Kā izskatās šì pasaule}

Saskaṇā ar \#Me2.0 scenāriju Latvijas pilsoniskā sabiedrība funkcionē kā centrāls jauns pīlārs, kas risina nacionālās un vietējās problēmas, kas iepriekš bija valdības atbildības sfērā. Sabiedrība izmantoja Latvijas digitālās infrastruktūras neizmantoto potenciālu un izveidoja vietējas un pārrobežu domubiedru grupas, lai risinātu problēmas tiešā un individuāli pielāgotā veidā. Tas var ietvert koordinētas darbības vides aizsardzībai un informācijas apkopošanu un kopīgošanu gan tiešsaistē, gan klātienē, izmantojot plaši izplatītu automatizāciju un atvērto avotu AI lietošanu (piem., transportam un loǵistikai). Tā rezultātā Latvijas iedzīvotājiem parasti ir liela pārliecība par savu individuālo darbību potenciālu, lai realizētu pārmaiṇas, kā arī par saskaṇotu centienu potenciālu. Kopienās ar augstu digitālo pratību plaši tiek izmantotas tiešsaistes izglītības iespējas, dodot iespēju iedzīvotājiem specializēties plašā profesionālo jomu klāstā un piekḷūt starptautiskajiem darba tirgiem.

Taču asās paaudžu un lauku-pilsētu digitālās plaisas dēḷ, kas ir izstūmušas dažas kopienas no digitālās emancipācijas procesiem, sabiedrība varētu būt arvien vairāk polarizēta. Tas varētu ietvert pieaugošu dalījumu starp iedzīvotājiem, kas dzīvo vienās un tajās pašās ǵeogrāfiskajās teritorijās, kuru līdzdalība digitālajās kopienās un transversāla sociālā kustība arvien vairāk veido viṇu identitāti un dzivi. Tie, kas novērsās no digitālās sfēras prasmju trūkuma vai pieaugošu grūtību dēḷ atškiirt viltus ziṇas no legitīmas informācijas, tika izstumti un uzskata līdzdalību sabiedrības aktivitātēs par apgrūtinošu. Iedzīvotājiem, kas dzīvo vietējās vai tiešsaistes kopienās, kas nav tik dzirdamas vai tik labi organizētas, ir mazākas iespējas lobēt valdības pakalpojumus un ekonomiskās aktivitātes, un viṇi kḷūst aizvien mazāk aizsargāti pret digitāli organizētu noziedzīgu darbību.

\section{Ieskats Latvijas digitālajā stratēgijāa}

\#Me2.0 scenārijā ir izcelta potenciālā jauno spēlētāju nozīme pilsoniskajā sektorā un ar to saistītās sekas Latvijai. Ir uzsvērti potenciālie ieguvumi, ko sniedz dažādu formu tiešsaistes un ārpus tiešsaistes kopienu un sociālo kustību, kas ir saistītas vietējā un starptautiskā mērogā, formāli organizētas un ad hoc, specifisku, individuāli pielāgotu zināšanu izmantošana. Šādas kopienas var darboties kā spēks, lai radītu atgriezenisko saikni attiecībā uz Latvijas iedzīvotāju dažādām vajadzībām, digitālo izglītību vai sabiedriskajiem pakalpojumiem, pamatojoties uz to dažādajiem reǵioniem, vecuma grupām vai etnisko izcelsmi. Arī uz minoritātēm orientētas sociālās kustības var uzṇemties svarīgu lomu, veicinot sociālo kohēziju ar Latvijas sabiedrību, ǵenerējot datus un sniedzot informāciju, lai uzlabotu iekḷaušanu un dažādotu politiku.

Scenārijā ir norādītas iespējas, kas varētu veidoties, veicinot digitālās kopienas veidošanos iekḷaujoši un ētiski, lai dotu iespējas cilvēkiem un mobilizētu idejas, talantu un enerğiju sabiedrības mērķu sasniegšanai. Taču digitālo kopienu pieaugošais nozīmīgums varētu arī paaugstināt riskus, ko nosaka pieaugošā sašḳeltība un strīdi par vērtībām starp dažādu grupu locekḷiem. Tiešsaistes dalīšanās un polarizācija varētu izraisīt slēgtus komunikāciju ciklus, kuri katrs popularizē savu relatīvo patiesību. Turklāt ātri atklājas riski, kas saistīti ar plašākām organizētas noziedzīgās darbības iespējām. Latvijā bāzētas digitālās kopienas tikpat labi var būt saistītas ar ārvalstu partneriem, mazinot izveidotos nacionālās drošības un ētikas standartus. Kopumā scenārijs rada jautājumu par to, kādas jaunas sadarbības struktūras un satvari ḷautu valstij vislabāk savienot jaunos spēlētājus ar jau pastāvošajiem, lai radītu ekonomisko un sociālo inovāciju, vienlaikus saglabājot iedzīvotāju un kopienu drošību.

Pamatojoties uz \#Me2.0 scenāriju, politikas veidotāji digitālajā jomā varētu apsvērt stratēgisko jautājumu virkni:

1. Kāda loma būtu jāuzṇemas kopienām, vietējām iniciatīvām, koleǵiālajām pieejām un decentralizētai tehnoloǵiju attīstībai?

2. Kādi jauni resursi un atbalsts būtu jādara pieejams pilsoniskās sabiedrības organizācijām, lai palīdzētu tām veidot digitālus sakarus globālā mērogā?

3. Kā var veicināt digitālās kopienas veidošanu, piemēram, izmantojot vietējās iniciatīvas, kas tiek koordinētas un veicinātas tiešsaistē, piemēram, līdzdalības pašvaldības budžeti?

4. Kā varētu noteikt veidojošos strīdus par tehnoloǵiskajām vērtībām un sekmēt godīgu un uz faktiem balstītu diskusiju? 


\section{Platformas valdỉbas}

\section{Kopsavilkums}

Ir 2035. gads un platformas valdībām ir bijusi izšḳirošā loma, veidojot digitālo transformāciju divos galvenajos veidos. Pirmkārt, lielākā daḷa valdību tagad nodrošina un izmanto galveno platformu digitālajām darbībām ekonomikā un sabiedrībā. Otrkārt, daudzas valdības ir integrējušās digitālos megareǵionos, atklāti kopīgojot datus iekšēji, bet saglabājot digitālās robežas ar ārpusi.

\section{Platformas valdibas}

- Valdības strādā ar ḷoti efektīvām un iedarbīgām tiešsaistes platformām, kas atvieglo ekonomikas apmain,as procesu un lielāko dal̦u citu darbību.

- Lielākā daḷa valdību pieder pie politiskajiem blokiem ar platformām, kas mijiedarbojas viena ar otru, bet ne citiem blokiem.

- Infrastruktūra ir augstākā līmeṇa bažu avots nacionālās attīstības un drošības stratēgiju kontekstā.

- Lieli datu apjomi, kas ir valdỉbu kontrolē, ir saistīti ar lielu atbildỉbu un nepieciešamỉbu nodrošināt pārbaudes un līdzsvaru.

Šajā pasaulē valdības platformās tiek organizēta iedzīvotāju, korporāciju un sabiedrības organizāciju digitālā aktivitāte, kas ir process, kas nodrošina iespēju valstij apkopot un analizēt liela apjoma datus. Šāda detalizēta informācija nodrošina iespēju valdībām sniegt efektīvus pakalpojumus un mērḳtiecīgi izstrādāt politikas. Platformas lietotājiem ir kripto-verificēta identitāte, kas nodrošina uzticēšanos, kā arī netraucētu pāreju no analogās uz digitālo pasauli.

Lielākā daḷa platformas valdību ir bloka vai alianses dalībnieki, darbojoties kā daḷa no kopīga digitāla megareǵiona. Katrā reǵionā sabiedrības ir cieši savstarpēji saistītas iekšienē un atdalītas no ārpuses ar digitālu robežu. Katra reǵiona visu dalībnieku starpā notiek brìva datu plūsma, un valdības var izmantot apkopoto datu analīzi uz informāciju balstītas politikas izstrādei. Tas, kas agrāk bija pasaules mēroga tīmeklis, tagad ir sadalījies vairākās nacionālās un pārnacionālās sistēmās no vienas puses un neregulētās digitālās telpās, kas atrodas ārpus jebkādas institucionālās kontroles, no otras puses. Datu, tirdzniecības un investīciju plūsmas reǵionu starpā ir l̦oti ierobežotas un pakḷautas rūpīgai pārbaudei.

\section{Signāli: Digitālie valsts pakalpojumi, iedzīvotāju vērtējums, unikālas identitātes sistēmas, ārvalstu investīciju skrīnings un pakalpojumu sniedzēju regulējums}

Stratēgiskajā nākotnes skatījumā ir izmantoti šobrīd novēroti pārmaiṇu signāli, lai norādītu uz iespējamām jaunām tendencēm vai izzūdošām parādībām, kas varētu veidoties un attīstīties, un kā rezultāts varētu būt nākotnes scenārijs, kas atšḳiras no pašreizējām gaidām. Šeit norādītās pārmaiṇu pazìmes ir jau redzamas un, ja tās turpinās attīstīties, tās var izraisìt iepriekšèjā iedaḷā aprakstìto scenāriju.

Virkne tagadnes signālu parāda, kā valdības sāk ievērot digitālāku pieeju kontaktos ar iedzīvotājiem - digitālo pakalpojumu sniegšanas paplašināšana, unikālas digitālās identitātes nodrošināšana iedzīvotājiem un lielo datu izmantošana vērtēšanas vajadzībām. Turklāt, daudzas valdības ir spērušas soḷus, lai nodrošinātu kontroli pār dažādiem savas digitālās telpas līmeṇiem, izmantojot tādus pasākumus, kā piemēram, ārvalstu investīciju skrīnings, datu lokalizācija un pakalpojumu sniedzēju aizliegšana.

Virkne valstu ir izveidojušas dažādas digitālo pakalpojumu piegādes formas. Igaunijas valdība šajā sakarā risinājumus ieviesa agri, izveidojot valsts mēroga digitālu iniciatīvu e-Estonia, izmantojot digitālus risinājumus, lai atvieglotu iedzìvotāju kontaktus ar valsti. Iedzīvotājiem ir nodrošināta pieeja virknei tiešsaistes pakalpojumu, piemēram, digitālā identifikācija, digitālie paraksti un tiešsaistes medikamentu receptes, kam līdzīgas iniciatīvas pastāv Jaunzēlandē, Singapūrā un Apvienotajā Karalistē. E-Estonia mugurkauls ir pamatā esošā datu apmaiṇas platforma ar nosaukumu X-Road, kas saista visas valdības informācijas sistēmas, lai dati būtu viegli pieejami. Sistēma tika izstrādāta atbilstoši mērogam, 
tiešsaistē parādoties jauniem e-pakalpojumiem un jaunām platformām, kā arī tīklam pievienojoties citām pārvaldēm. Šḳiet, ka valdības ieṇem vadošo lomu arī digitālās valūtas jomā; piemēram, Eiropas Savienība apspriež savas kriptovalūtas ieviešanu (Guarascio, 2019).

Valdības identifikācijas sistēmas attīstās daudzās pasaules daḷās un bieži kā būtisks digitālās valdības komponents. Indija ir izveidojusi pasaulē lielāko biometrisko sistēmu "Aadhaar" ar vairāk nekā 1,2 miljardiem reǵistrēto iedzīvotāju. Indijas Unikālās identifikācijas iestāde (UIDAI) ${ }^{1}$ izdod iedzīvotājiem 12 ciparu numuru, kas nodrošina identitāšu lielāku caurskatāmību un valdības labklājības shēmu un programmu īstenošanu. Aadhaar ir "Digitālās Indijas" galvenais komponents un tika izstrādāta kā stratēgisks politikas instruments, lai uzlabotu sociālo iekḷaušanu un valsts sektora pakalpojumu sniegšanu, kā arī budžeta pārvaldību. Citas nacionālās elektroniskās identitātes programmas ir uzsāktas Alžìrijā, Kamerūnā, Itālijā, Jordānā, Senegalā un Taizemē.

Valdības izmanto digitālus līdzekḷus un lielos datus, lai izveidotu personiskos profilus un vērtētu vai prognozētu uzvedību. K̦ina ir celmlauzis valsts mēroga "sociālā kredīta" sistēmas izstrādē, kurā lielie dati tiek izmantoti, lai fiziskām un juridiskām personām piešḳirtu skaitlisku vērtējumu, pamatojoties uz plašu informācijas avotu klāstu. Sistēma centralizē datus saskaṇā ar vienotu identitāti, piešḳir skaitlisku vērtējumu un attiecīgi pielāgo kontaktus un valsts pakalpojumus. Tà ir paredzēta kā spēcīgs instruments likumu, noteikumu un citu partijas valsts mērḳu izpildes nodrošināšanai (Shi-Kupfer un Ohlberg, 2019). Citas valstis strādā ar līdzīgiem vērtēěanas mehānismiem specifiskās jomās. Piemēram, Kanādas jaunā Ekspress iebraukšanas sistēma, lai atlasītu darba migrantus, piešḳir punktus par plaša sociāli demogrāfiskā raksturojuma dažādiem aspektiem, lai paredzētu sekmīgu integrāciju darba tirgū. Savienotajās Valstīs par vīzas pieteikuma iesniedzējiem tiek prasīta sociālo mediju informācija, lai izveidotu riska profilus.

Daudzas valstis ir pastiprinājušas ārvalstu investīciju pārbaudes, izmantojot to kā līdzekli savu digitālo tirgu aizsardzībai. 2017. gadā K̦īna pien̦ēma Kiberdrošības likumu, kurā plaši definētas galvenās kategorijas, piemēram, "kritiski nozīmīgā infrastruktūra" un "personas dati", iespējams, kā līdzekḷi, lai kontrolētu ārvalstu investīcijas. Ķīnas Kibertelpas administrācija ir pilnvarota veikt visu produktu un pakalpojumu, ko izmanto būtiski nozīmīgajā infrastruktūrā, kiberdrošības pārskati, tostarp pirmkodu atklāšanu (KPGM, 2017). Dažas valdības, piemēram, Vācijas, ir pieṇēmušas precīzāk noteiktu pieeju, atzīstot digitālās problēmas nacionālajā drošībā, bet citas, piemēram, Savienotās Valstis, rūpīgi pārbauda àrvalstu investīcijas digitālajā uzṇēmējdarbībā.

Citi līdzekḷi, ar kuru palīdzību valdības īsteno ietekmi digitālajā telpā, ietver datu lokalizācijas noteikumus, pārrobežu datu plūsmu ierobežojumus un interneta pakalpojumu sniedzēju aizliegumus. Pārrobežu datu plūsmas ierobežojumi var izpausties dažādās formās. Dažās valstīs tiek prasīta expost atbildība no datu eksportētāja puses, ja uz ārvalstīm nosūtītie personas dati tiek izmantoti neatbilstīgi, citās uz datu nodošanu tiek attiecināti dažādu veidu aizsardzības pasākumi, attiecībā uz dažiem nosakot prasību saṇemt aț̣auju katrā atsevišk̦ā gadijumā (Casalini un López González, 2019). Datu lokalizācijas prasības nosaka, ka uzṇēmumiem noteikti digitālie dati ir jāuzglabā uzṇēmējvalstīs un tāpēc jāizveido uzglabāšanas infrastruktūra. Abas prasības kḷūst izplatītākas, un pastāv tendence attiecināt tās uz noteiktiem datu veidiem, ippaši tiem, kas ietver personas vai sensitīvus komponentus. Pakalpojumu sniedzēju aizliegumu piemēri ietver Krievijas "Suverēnā interneta likuma" pieṇemšanu, lai aizvietotu domēnu nosaukumu sistēmu, un valdību aizliegumus attiecībā uz noteiktiem interneta pakalpojumiem kā līdzekli, lai atbalstītu vietējo pakalpojumu sniedzēju izveidošanu (BBC News, 2019).

\section{Kā radās š̄ pasaule}

Laikposmā no 2019. līdz 2035. gadam dažas valdības izmantoja aktīvāku pieeju attiecībā uz digitālo transformāciju, ieviešot digitālās platformas, lai uzlabotu savu darba stilu. Sākotnēji iedzìvotāji un korporācijas izmantoja platformu ierobežotam pakalpojumu skaitam, piemēram, veselïbas pierakstu pārvaldỉba, nodokḷu deklarēšanai un produkta vai uzṇēmuma reǵistrēěanai. Pieaugot apmierinātībai ar šīs pieejas ērtumu, pakalpojumu klāsts pakāpeniski paplašinājās, iekḷaujot tādas jomas, kā piemēram, finanšu grāmatvedība, viedie līgumi un prasmju attīstība. Šì posma laikā nenotika nekādi sistēmas uzlaušanas vai citi pārkāpumi, kas būtu mazinājuši uzticēšanos. Tieši pretēji, uzticēšanās sistēmai un tās lietotāju starpā bija augsta, un unikālo digitālo identitāšu izmantošana uzlaboja tiešsaistes atbildību un izsekojamību. Pieaugot darbību daudzumam, izmantojot platformu, pieauga tās noderīgums, un tās nosaukums sāka kḷūt par sinonīmu internetam. 
Pateicoties pieaugošajam apkopoto datu apjomam un datubāzu savienošanai, valdības ieguva bezprecedenta informāciju par iedzīvotāju un uzṇēmumu uzvedību, vajadzībām un izvēlēm. Politikas veidošana kḷuva mērķtiecīgāka un balstīta uz datiem, ātri, individuāli pielāgotā un elastīgā veidā apmierinot iedzìvotāju un organizāciju vajadzības. Piemēram, slimnīcā dzimuša bērna medicīnas ieraksti tiek automātiski analizēti, izmantojot mākslīgo intelektu, un izmantoti, lai pieškirtu valdības finansiālo atbalstu un noteiktu mācību iespējas jau vairākus gadus uz priekšu. Neskatoties uz bažām par privātumu, lielākā daḷa iedzīvotāju apliecināja augstu apmierinātību ar jauno sistēmu. Palielinājās politiskais atbalsts platformu ìstenošanai, norādot uz labākiem sociālajiem un ekonomiskajiem iznākumiem salīdzinājumā ar kaiminiem, kas tik lielā mērā nebalstījās uz digitāliem risinājumiem.

Pakḷaujoties spiedienam no to valdību puses, kas pirmās ieviesa šos risinājumus, un sabiedrības pieprasījumam, citas valdības sekoja šim piemēram un sāka veidot pašas savas platformas vai pasūtīt jau esošās, lai ieviestu jaunas pieejas. Dažu gadu laikā lielā mērā valdību virzīta pieeja digitālajai transformācijai kḷuva par dominējošo modeli ar vēl vairāk konsolidētām platformām, lai gūtu labumu no mēroga ekonomijas. Šai tendencei nepievienoties izvēlējās tikai nedaudzas valstis, kas izvēlējās pasīvāku pieeju vai izmantoja valdību galvenokārt kā instrumentu, lai palēninātu digitālo transformāciju un tās ietekmi.

Valstis, kas savstarpēji savienotas digitālajos megareǵionos, pakāpeniski ierobežoja datu plūsmas no un uz citiem reǵioniem, lai aizsargātu vietējos pakalpojumu sniedzējus un īstenotu labāku kontroli pār datu pārvaldību. Bažas par drošību izraisīja ierobežojumus ārvalstu investīcijām digitālajā telpā un nodrošināja, ka pretinieku reǵioniem nav finansiālas vai politiskas ietekmes platformā. Tas l̦âva efektīvi aizsargāt iedzīvotāju personisko privātumu un nozares informāciju pret ārējiem apdraudējumiem, kā arī noteica nepieciešamību ieviest spēcīgas digitālās robežas, ko veido ugunssienas un kiberaizsardzība.

Taču šos pasākumus daḷeji kompensēja papildu iespējas, ko šī pieeja radīja vietējiem digitālajiem uzṇēmumiem. Dažas mazākas valstis izveidoja aliansi, aț̣aujot savstarpējas brīvas datu plūsmas, pamatojoties uz kopējiem privātuma standartiem un kopēju datu robežu ar pārējo pasauli. Izveidojās vairākas globālas institūcijas, lai nodrošinātu uzticamas datu plūsmas dažādu valstu vai bloku starpā, ievērojot to dažādos nosacījumus.

\section{Kā izskatās šĩ pasaule}

Saskaṇā ar Platformas valdības scenāriju Latvija kḷūst par digitālas platformas valdību līdzīgi domājošu valstu blokā. Pamatojoties uz augsto sistēmu integrācijas kapacitāti, Latvija izstrādā detalizētu datu vākšanas un apstrādes sistēmu un atbalsta pastāvīgu pakalpojumu ieviešanu valdības platformā. Tas ḷauj iedzīvotājiem, uzṇēmumiem un pilsoniskās sabiedrības pārstāvjiem vieglāk piekḷūt augstas kvalitātes pakalpojumiem, līdz ar to paaugstinot kopējo uzticēšanos valdībai. Taču līdzīgi kā visās valdībās institucionālie mehānismi un motivācijas struktūras ne vienmēr ḷauj Latvijai vislabāk izmantot jaunās datu kopas, un rezultātā paliek neizmantotas iespējas, kā rezultātā gala iznākums nav optimāls.

Latvija veic ciešu koordināciju ar citām valstīm tajā pašā digitālajā blokā, kas var aprobežoties ar Baltijas valstīm vai Ziemel̦valstīm, Eiropas valstīm vai ietvert līdzīgi domājošas partnervalstis, kas geogrāfiski izvietotas visā pasaulē. Lai gan datu apriti valsts vai bloka iekšienē vispārīgi vērtē atzinīgi kā līdzekli pakalpojumu kvalitātes uzlabošanai, pastāv bailes no datu noplūdes personām ārpus Latvijas digitālā reǵiona. Agrāku investīciju visaptverošā kiberdrošības struktūrā trūkuma rezultātā Latvija ir saskārusies ar vairākiem liela mēroga urk̦ēšanas incidentiem un kiberuzbrukumiem. Līdz ar to starptautiskā tirdzniecība (īpaši bloku starpā) tiek uztverta ar paaugstinātu jutību, arvien vairāk saistot to ar nacionālās drošības jautājumiem. Citas platformas valdības, ko kontrolē autoritāra vadỉba, ir izmantojušas savu administratîvo kapacitāti, lai īstenotu pārmērīgu datu vadītu ietekmi uz savu pilsoṇu dzīvi. Tas ir izraisījis paaugstinātu reakciju Latvijā, kur tiek veikti sākotnējie pasākumi, lai mazinātu sistēmas jutību pret jebkāda veida ḷaunprātīgu izmantošanu.

\section{Ieskats Latvijas digitālajā stratēéijā}

Platformas valdību scenārijā raksturoti izaicinājumi un iespējas, kas saistītas ar integrētas digitālās informācijas pārvaldības sistēmas izstrādi valdībai ar nepieciešamajiem drošības pasākumiem gan Latvijas valdības ietvaros, gan starptautiskā līmenī. Tas rada jautājumu par lomu, kādu Latvijas valdība 
vēlas uzṇemties digitālajā ekonomikā un sabiedrībā, un digitālo partneru izvēli, ar kuriem tai vajadzētu veidot ciešākas saiknes. Scenārijā raksturotas digitālās partnerības ar citām valstīm sekas ilgtermiṇā un kopīgu vērtību komplektu un demokrātijas uzskatu nepieciešamība.

Pretēji tam, vāja valdības informācijas sistēma varētu paaugstināt risku, ka Latvija nebūs to valstu vidū, kas vēlas ìstenot stingrākus pasākumus. Investīcijas spējīgākā un integrētā pieejā varētu dot Latvijai iespēju izveidot un pielāgot politikas atbilstoši tās iedzīvotāju vajadzībām, labāk sasniegt ekonomikas inovāciju un iedzīvotāju labklājību, kā arī stiprināt Latvijas iedzīvotāju saikni ar savu valsti. Piemēram, šāda sistēma varētu sniegt Latvijas valdībai precīzu reālā laika informāciju par Latvijas iedzīvotāju un uzṇēmumu spējām, veselību, labklājību, attieksmi un uzvedību, l̦aujot valdībai radìt jaunas un adaptīvas nodarbinātības iespējas, veicināt un uzraudzìt prasmju pilnveidošanu un stratēgiskāk reaǵêt uz Latvijas iedzīvotāju bažām.

Scenārijā arī uzsvērti vairāki būtiski riski, kas saistīti ar integrētās sistēmas l̦aunprātīgu izmantošanu. Ja valdībai ar ekstrēmām tendencēm vai grupām ar noziedzīgiem nolūkiem būtu piekḷuve atslēgām loti precīzai un efektīvai informācijas pārvaldības sistēmai, tās varētu potenciāli daudzējādi izmantot to l̦aunprātīgi. Tas var ietvert vēršanos pret politiskajiem oponentiem, privāto ekonomisko interešu virzīšanu vai manipulēšanu ar iedzīvotāju uzskatiem un rīcību, izmantojot mērk̦tiecīgu politisko reklāmu. Kā atklāj scenārijs, neatkarīgi no tā, kura valdības struktūra veiks apjomīgu iedzìvotāju datu apkopošanu un analīzi, tās efektīvā kontrolē būs būtiska digitālās inteliğences spēja. Kopumā, Latvijai ir rūpīgi jāapsver datu vadišanas iespēju izvēle, ko tā vēlas veidot, un jānovērtē, kā tā varētu izveidot vadības pieeju un nepieciešamās sistēmiskās pārbaudes un līdzsvarus, lai nodrošinātu, ka datu informācija tiek lietota visiem izdevīgu lēmumu pien̦emšanai.

Pamatojoties uz platformas valdību scenāriju, politikas veidotāji digitālajā jomā varētu vēlēties apsvērt stratēǵisko jautājumu virkni:

1. Kādas pārbaudes un līdzsvari ir iestrādāti pašreizējā digitālajā politikā, un vai tie būs pietiekami, lai nodrošinātu uzticēšanos, drošību un atbildību, ja valsts digitālās infrastruktūras mērogs būtiski paplašinās?

2. Vai valsts ǵeopolitiskā vieta pasaulē rada jaunus izaicinājumus no digitālā viedokḷa un kādus lēmumus varētu pieñemt šodien, lai novērstu potenciālās dilemmas?

3. Vai lielāku valsts iesaistišanos digitālajā ekonomikā un brīvākus tirgus var līdzsvarot, lai nodrošinātu lielāku labklājību iedzīvotājiem?

4. Kāda veida digitālo pārvaldi vēlas mūsu valsts?

\section{Korporativie starpnieki}

\section{Kopsavilkums}

Šajā 2035. gada pasaulē neliels skaits globālo tehnoloǵijas uzṇēmumu funkcionē kā vienas pieturas veikali visiem dzīves aspektiem no socializācijas līdz veselības uzraudzībai, mācībām un patēriṇam. Pateicoties to ekonomiskajam spēkam un pastāvīgai populāru vēlmju analīzei, tie ir ien̦ēmuši aktīvāku lomu globālajā pārvaldē. Daudzas valsts sektora darbības tādās jomās, kā piemēram, infrastruktūras ieviešana, skolas mācību programma un drošības nodrošināšana, ir nodotas šiem privātajiem uzṇēmumiem kā ārpakalpojuma sniedzèjiem.

Iedzīvotāji, ko dēvē par iedzīvotājiem-patērētājiem, ir izveidojuši ciešas saiknes ar lielajām digitālajām korporācijām, un lielākās daḷas cilvēku galvenā lojalitāte ir pret uzṇēmumu nevis valdību. Valdības nodokḷu ieṇēmumi ir samazinājušies, un valsts ierēdṇu skaits laika gaitā ir samazinājies vairāk nekā uz pusi. Vispārējā atbildes reakcija ir bijusi vēl vairāk integrēt privātā sektora spēlētājus dažādos politikas forumos. Tehnolog̣iju uzṇēmumu lobētāji atklāti kandidē vietējās un federālajās vēlēšanās, un Apvienoto Nāciju Organizācijas Ģenerālajā Asamblejā tagad ir lielo korporāciju delegācijas. 


\section{Korporativie starpnieki}

- Neliels skaits globālo tehnoloǵijas uzṇēmumu funkcionē kā vienas pieturas veikali visiem dzìves aspektiem no socializācijas līdz veselības uzraudzỉbai, izglìtỉbai un drošībai.

- Korporācijas ir iemantojušas augstu uzticỉbu, un lielākā daḷa cilvēku ir lojāli pret uzṇēmumu, nevis valdību.

- Izmantojot savu ekonomisko spēku un pastāvīgu populāru vēlmju analīzi, tehnoloǵiju korporācijas ir ieguvušas leǵitimitāti ien,emt aktīvāku lomu globālajā pārvaldē.

- Daudzas jomas, par ko iepriekš bija atbildīgas valdības, piemēram, publiskās infrastruktūras nodrošināšana, skolas mācību programmas vai monetārā politika, tagad ir korporāciju rokās.

\section{Signāli: Superzuaigžṇu uzṇēmumi, tirgus koncentrācija un valsts interešu jomas}

Stratēgiskajā nākotnes skatījumā ir izmantoti šobrīd novēroti pārmaiṇu signāli, lai norādītu uz iespējamām jaunām tendencēm vai izzūdošām parādībām, kas varētu veidoties un attīstīties, un kā rezultāts varētu būt nākotnes scenārijs, kas atšḳiras no pašreizējām gaidām. Šeit norādītās pārmainuu pazìmes ir jau redzamas un, ja tās turpinās attīstìties, tās var izraisìt iepriekšējā sadaḷā aprakstìto scenāriju.

Daudzi uzṇēmumi mūsdienās ir būtiski lielāki par lielāko daḷu produktīvu uzṇēmumu pirms vairākām desmitgadēm, un būtiska rūpniecības koncentrācija ir reǵistrēta Eiropā un Ziemel̦amerikā (Bajgar et al., 2019). Dažiem "superzvaigžṇu" uzṇēmumiem ien̦ēmumi ir lielāki nekā veselām valstīm un plašas lietotāju bāzes, kas pieškir to darbỉbai un lēmumiem jaunu globālu mērogu un nozīmi. Šāda "uzvarētājs paṇem lielāko daḷu" dinamika ir palielinājusi neliela uzṇēmumu skaita ekonomisko un politisko spēku, ipaši augsto tehnoloğiju nozarē.

Tīkla ārējie aspekti un patērētāju un nozares datu apjoms ir izraisījis vairāku tirgu koncentrāciju. Korporācijas, kas izmanto digitālās platformas, apkopo detalizētus lietotāju datus apkopotā līmenī, un tādējādi gūst iespēju veidot prognozēšanas modeḷus, ar kuru palīdzību var noteikt patērētāju prioritātes un paredzēt viṇu uzvedību (ESAO, 2018). Uz klientu orientēta uzṇēmējdarbības izlūkošana ir attīstījusies ne tikai kā jauns mehānisms, lai korporācijas iegūtu ekonomisko spēku, bet ir devusi korporācijām bezprecedenta mēroga ieskatu par cilvēku prioritātēm.

Daži no šiem spēcīgajiem uzṇēmumiem ir sākuši uzṇemties lomu politikas institūciju prioritāšu noteikšanā, piemēram, migrācijas jomā. Tehnoloǵiju nozare lielā mērā balstās uz migrāciju, lai apmierinātu vajadzības pēc prasmēm. Piemēram, Silikona ielejā gandrīz 60\% STEM darbavietās nodarbināto cilvēku ar bakalaura vai augstāku izglìtību ir dzimuši ārvalstīs. Programmatūras inženieru amatos šī proporcija pieaug līdz 70\% (Kerr et al., 2016). Spēja viegli ievest ārvalstu strādājošos ir svarīgs faktors uzn̄ēmumiem, izvēloties savu darbības centru atrašanās vietas, un Kanādas un Amerikas pilsētas konkurēja nesenajā Amazon HQ2 konkursā, pamatojoties uz ārvalstu strādājošo iebraukšanas vieglumu.

Turklāt, tehnoloǵiju uzṇēmumiem ir arvien pieaugoša ietekme jautājumos, kas ir sabiedrības interešu lokā, piemēram, izglītības, veselības un mājvietu nozarēs. Šobrīd daudzas skolas un universitātes paḷaujas uz mākoṇpakalpojumiem, ko piedāvā Google vai Microsoft. Pirmais no tiem ir izstrādājis ipašu produktu Google Classroom [Google klase], kas nodrošina iespēju studentiem un pasniedzējiem kontaktēties virtuāli, it kā viṇi atrastos klases telpā. Attiecībā uz veselības aprūpi Google mātesuzṇēmums Alphabet, ir veicis būtiskas investīijas tehnoloǵiju izmantošanā, lai labāk izprastu veselību, kā arī izmanto datu ġenerēšanu, noteikšanu un pozitivas dzìves stila izmaiņas, lai ārstētu saslimšanu, piemēram, iegādājoties Fitbit (CB Insights, 2019). Kas attiecas uz vied pilsētu plānošanu, palielinās liela mēroga korporatīvo projektu daudzums. Taču Toronto piekrastes pārveidošana par viedo pilsētu, ko īstenoja ASV uzṇēmums, paredzot cel̦us ar sniega kausēšanu, pazemes piegādes sistēmu un virkni datu vākšanas sensoru, ir radījusi bažas par privātumu (Deschamps, 2019). 


\section{Kā radās šì pasaule}

Konsolidācijas sākuma posmā, kas ilga līdz 2019. gadam, cinna tehnoloǵiju korporāciju starpā par tirgus daḷu no iedzīvotājiem-patērētājiem un piegādātājiem nodrošināja pietiekamu konkurenci. Tas nodrošināja zemu cenu vai pat bezmaksas pakalpojumu saglabāšanu iedzìvotājiem-patērētājiem un zemas maksas piegādātājiem. Tomēr, tā kā dalība nostiprinājās un jauni konkurenti vairs neparādījās, visas platformas vienlaikus sāka paaugstināt savas cenas un maksas. Nebija pierādījumu par apvienošanos, un nepamatotie apvainojumi tika ātri izṇemti no sociālo mediju vietnēm. Dažiem bija aizdomas, ka tas, kas varētu līdzināties platformu koordinētai darbībai, var būt vienkārši racionālas optimizācijas rezultāts, ko tām ieteikušas attiecīgās uzṇēmējdarbības izlūkošanas MI sistēmas. Produktivitātes pieaugums, kas sākotnēji bija l̦oti augsts, sāk palēnināties daḷēji jauno inovatoru iegādes un iekḷaušanas platformās rezultātā, nepieḷaujot izaugsmi atbilstoši mērogam.

Korporatīvo starpnieku augošajai ietekmei pievienojās jaunas atbildības, taču kopā ar pieaugošu kapacitāti arī iespēja pieṇemt lēmumus par jautājumiem, kas ir sabiedrības interešu lokā. Piemēram, sociālo mediju atsauces telpu, cenzūras un vārda brīvības, kā arī viltus ziṇu izaicinājumus lielā mērā risināja platformas, jo valdībām pietrūka zināšanu un līdzekḷu, lai saglabātu iesaisti. Šīs tendences rezultātā izveidojās vairākas tiešsaistes apspriežu telpas, kas sāka ietekmēt digitālo lēmumu pieñemšanu. Šì jaunā demokrātijas forma, kam raksturīga pastāvīga niansēta tiešsaistes līdzdarbošanās, deva iespēju korporācijām izprast iedzīvotāju jaunās prioritātes labāk nekā jebkad agrāk. Taču platformu nespēja panākt, lai visi lēmumi būtu pareizi, nodrošināja to, ka nacionālā demokrātija turpina pārstāvēt vietējās intereses. Valdības iecēla tehnoloǵiju vēstniekus, lai lobētu un pārstāvētu iedzīvotāju intereses iepretim korporāciju interesēm.

Digitālās korporācijas turpināja maksāt ḷoti zemu uzṇēmumu ienākuma nodokli. Finanšu līdzekḷu trūkuma dēl valdības sāka daudzas savas funkcijas nodot korporatīvajam sektoram kā ārpakalpojumus. Daudzus kvalitātes kontroles noteikumus, piemēram, attiecībā uz taksometriem un viesnīcām, aizstāj vērtēšanas sistēmas, kas balstītas uz kritērijiem un pārbaudēm, ko noteikušas platformas, kas tos saved kopā ar patērētājiem. Gadu gaitā korporatīvie starpnieki bija iesaistījušies arvien lielākā skaitā politikas jomu, sākot ar infrastruktūru līdz izglìtībai, veselībai un drošībai. Pateicoties viṇu sniegto pakalpojumu augstajai kvalitātei, lielākā daḷa iedzīvotāju-patērētāju saglabāja lojalitāti un uzticēja tiem datu vadītu informāciju par saviem ikdienas lēmumiem. Tomēr kustības, kas kritizē korporatīvās ietekmes palielināšanos, turpināja pastāvēt, bet tām bija grūti piesaistīt un sasniegt plašu auditoriju, jo viṇu ziṇojumi bieži pazuda no sociālo mediju kanāliem.

Lìdz 2030. gadam ideja par pilsonību bija ieguvusi daudzas jaunas un atšk̦irīgas nozīmes. Papildus valstspiederībai cilvēki veidoja arvien ciešǎkas saiknes ar lielajiem digitālajiem uzṇēmumiem vai tiešsaistes platformām, kas sniedz plašu pakalpojumu klāstu un atbalstu apmaiṇā pret lojalitāti, personas datiem un maksu par augstākas kvalitātes funkcijām. Pamazām šī jaunā digitālās pilsonības forma kḷuva transnacionāla, tieši tāpat kā uzṇēmumi, kas to piedāvā.

\section{Kā izskatās šĩ pasaule}

Saskaņā ar Korporatīvo starpnieku scenāriju Latvijas ekonomika ir kḷuvusi ḷoti cieši saistīta ar lielajām korporācijām, kas izspiedušas no uzṇēmējdarbības virkni nacionālo, reǵionālo un vietējo uzṇēmumu. Daudzi Latvijas MVU sākotnēji sekmīgi darbojās, integrējoties korporatīvajā ekosistēmā, lai piekḷūtu jauniem globālajiem tirgiem, bet tagad izjūt peḷ,nas samazināšanos, jo lielāku dal̦u paṇem starpnieks. Lai gan ērtības iedzìvotājiem-patērētājiem paaugstinājās, pateicoties līdzsvarotai saskarnei un iekšēji koordinētiem pakalpojumiem, korporācijām ir bijis nepieciešams savākt un kontrolēt būtisku sensitīvu personas datu apjomu. Šie uzṇēmumi ir izmantojuši savu tehnolog̣isko pārākumu, lai piedāvātu spēcīgāku kiberdrošību šādiem datiem, stingri aizsargājot tos pret potenciāliem uzlaušanas mēǵinājumiem vai noplūdi. Taču valdības vai citu piekḷuve šai informācijai sabiedrỉbas labā ir ḷoti augstā mērā ierobežota. Tā rezultātā Latvijas valdība izjūt spēcīgu korporatīvo ietekmi, tā ir pazeminājusies līdz novērotāja pozīcijai, un politikas pārraudzība kḷuvusi daudz grūtāka.

Globālās korporācijas ir izmantojušas iespēju, kas izriet no tā, ka valdības pakalpojumiem arvien vairāk trūkst precizitātes un kvalitātes, lai aizstātu tos ar saviem individuāli pielāgotiem un ērtiem piedāvājumiem. Tā rezultātā daudzi pakalpojumi, ko agrāk nodrošināja valdība, piemēram, infrastruktūra, veselības aprūpe un izglìtība, tagad vismaz daḷēji atrodas korporāciju rokās. Tā kā iedzìvotāju-patērētāju 
apmierinātības līmenis bieži ir augsts, uzticēšanās korporācijām ir kopumā augsta, taču neaizsargātu un ekonomiski nelabvēlīgā situācijā esošu grupu vajadzības bieži ir atstātas novārtā. Līdz ar to Latvija saskaras ar augstu nevienlīdzības līmeni, ko efektīvi mēǵina risināt novājinātā valdība.

\section{Ieskats Latvijas digitālajā stratēǵijā}

Korporatīvo starpnieku scenārijā izcelti izaicinājumi un iespējas, kas saistītas ar augošo lielo globālo tehnolog̣iju uzṇēmumu, kas atrodas ārpus valsts, klātbūtni, to arvien dziḷāko ietekmi uz Latvijas iedzīvotājiem, uzṇēmumiem, valsts politiku un sabiedrību, kā arī to turpmāku iesaistīšanos jomās, kas ir sabiedrības interešu lokā. Potenciālais ar šo scenāriju saistītais risks var palielināties, ja Latvijai būtu jākḷūst atkarīgai no viena vai nedaudziem tehnoloǵiju nodrošinātājiem. Šādi risinājumi ne tikai ierobežo Latvijas iedzīvotāju iespējas noteiktu tehnolog̣iju ietvaros, bet varētu arī vājināt Latvijas sarunu pozīciju, adaptējot sistēmas vēlāk. Turklāt ciešas saites ar konkrētu pakalpojumu sniedzēju varētu ietekmēt Latvijas valdības iespējas attiecībā uz regulējuma un izpildes jautājumiem gan nacionālā, gan daudzpusējā kontekstā.

Plašāk runājot, scenārijā uzsvērta nepieciešamība noteikt politikas sviras nacionālā un daudzpusējā līmenī, lai nodrošinātu, ka tiek saglabāta kontrole pār korporāciju potenciālo ietekmi Latvijas ekonomikā un sabiedrībā. Tam var būt nepieciešamas pastiprinātas stratēgiskas starptautiskās partnerības jomās, kā piemēram, konkurence un datu politika, bet tiek prasīta arī sistemātiska skrīninga darbỉba nacionālās politikas veidošanas procesā. Piemēram, iespējams paredzēt situāciju, ka visas Latvijas skolas, kas izmanto lietotnes no konkrēta tehnolog̣ijas piegādātāja, rada motivāciju pieņemt to pašu ekosistēmu citos personiskos un profesionālos kontekstos vai pat administratīvos jautājumos. Galējā variantā tas varētu radīt atkarības ceḷu, padarot izmaiṇas Latvijas plašākā tehnolog̣ijas iepirkumu stratēgijā arvien dārgākas. Lēmumi stratēgiskās jomās, piemēram, izglìtībā un datu pārvaldībā, var nonākt privāto korporāciju rokās, kur peḷnas virzīta motivācija var būt svarīgāka par vienlīdzīgu iedzīvotāju vajadzību apmierināšanu.

No otras puses, Latvija var izmantot dažādus ieguvumus, ko dod sadarbība ar globālajiem vadošajiem tehnoloǵiju piegādātājiem. Šādas vienošanās var dot iespēju valstij ātrāk ieviest jaunas tehnologíijas un pakalpojumus, vienkāršot iepirkumu sistēmas stabilā partnerībā un izmantot mēroga ekonomijas sniegtās priekšrocības, strādājot ar vienu un to pašu piegādātāju dažādos kontekstos. Šis scenārijs rada jautājumu par to, kuri pasākumi vislabāk nodrošina demokrātiski izvēlētu mērķu ievērošanu un sasniegšanu visās privātajās un publiskajās partnerībās. Kopumā tas pastiprina vajadzību ierobežot ietekmi, kādu privātie spēlētāji var iegūt sabiedrības interešu jomās, un noteikt regulējuma veidus, kas vislabāk nodrošina Latvijas iedzīvotāju un viṇu daudzveidīgo vajadzību un interešu aizsardzību.

Pamatojoties uz korporatīvo starpnieku scenāriju, politikas veidotāji digitālajā jomā varētu apsvērt virkni stratēgéisko jautājumu:

1. Kādas stratēḡiskās partnerības un kolektīvās iniciatīvas dotu Latvijai iespēju maksimāli izmantot situāciju par labu sabiedrỉbas labklājỉbai pasaulē, kur uzṇēmumi kḷūst svarīgāki par valstīm?

2. Kā konkurenci digitālo pakalpojumu starpā var veicināt, lai atvieglotu patērētājiem piegādātāju nomainu?

3. Vai Latvijai vajadzētu veicināt iniciatīvas uzṇēmumu vērtēšanai un klasificēšanai atbilstoši kiberdrošības kvalitātei vai piedalīties tādās iniciatīvās un pieprasīt šāda informācijas sniegšanu kā "digitālā produkta etik̦eti", lai informētu patērētāju par izvēli?

4. Kāda veida piekḷuvi Latvija vēlas dot privātajām korporācijām, kurās politikas jomās?

\section{Stratēgiskās perspektīvas, kas jāapsver Latvijai}

Nākotnes skatījuma process ir balstīts uz Latvijas potenciālās rīcības augstākā līmeṇa sekām katrā no scenārijiem: Cik labi darbotos katra no iespējām dažādos nākotnes kontekstos un vai var noteikt kādu "bez nožēlas" iespēju? Kurus no pašreizējiem uzskatiem un gaidām, kas ietverti politikas veidošanā, var apdraudēt nākotnes izmain,as? 
Aprakstītās iespējas piedāvā papildinājumu specifiskām un tehniskām rekomendācijām, kas aprakstītas šì pārskata turpmākajās nodaḷās. Tās ir paredzētas, lai bagātinātu Latvijas digitālo stratēǵiju, papildinot to ar ilgtermiṇa, stratēgisko domāšanu, kas piedāvā papildu skatupunktu, lai palīdzētu noteikt prioritātes un izvēlēties darbības. Katra no noteiktajām darbībām var dot iespēju pietuvoties kādam no iepriekš minētajiem vēlamajiem nākotnes virzieniem (skatīt "Norādes par vēlamas digitālas Latvijas izveidošanu"), taču vienlaikus stiprinot Latvijas kapacitāti darbam ar potenciālajām pārmaiṇām nākotnē. Katrā no turpmākajiem punktiem būs aprakstītas augsta līmen,a sekas Latvijai un norādīti stratēẹiskās rīcības piemēri, ko šajā kontekstā varētu apsvērt valdība.

Latvija ir valsts ar daudzām stiprajām pusēm, kas var nodrošināt tai iespēju uzplaukt digitālajā nākotnē, tomēr tā saskaras arī ar izaicinājumiem.

- Latvijas iekšējie sakari nodrošina spēju efektīvi sadarboties dažādās politikas un rūpniecỉbas nozarēs. Politikas veidotāju un pētniecības un akadēmiskās jomas kopdarbībai piemīt potenciāls, lai nodrošinātu turpmāko attīstību, īpaši n,emot vērā augsto Latvijas izglìtības kvalitāti.

- Latvijā ir izveidotas dažādas struktūras, kas l̦auj veidot tiešas atgriezeniskās saites lokus starp valdỉbu un sabiedrību. Šiem kanāliem ir kapacitāte, lai generētu vērtīgu ievades informāciju politikas veidotājiem, bet tie arī rada izaicinājumus, kas saistīti ar šīs informācijas transformēšanu uz pierādījumiem balstītas politikas veidošanā un datu vadītas lēmumu pien,emšanas stiprināšanā.

- Latvijas iedzīvotāji labprāt pieṇem digitālās tehnoloǵijas, un viṇiem ir augstas ambīcijas attiecībā uz savu valdību kopumā, vispārīgi uzticoties tās spējai nodrošināt digitālās stratēgijijas îstenošanu. Vienlaikus var būt iespējas dalīties ar lielāku daḷu atbildības ar citām ieinteresētajām pusēm valstî, piemēram, radot jaunus stimulējošus faktorus privātajam sektoram vai labāk izmantojot jau esošos.

- Ieinteresētās puses ir noteikušas risku, ka sasteigts regulējums digitālajā jomā var kavēt inovāciju iespējas.

- Pateicoties tās labi saistītajam relatīvi mazskaitlīgajam iedzìvotāju kopumam, Latvijai piemīt potenciāls, lai kḷūtu par dzīvu, adaptīvu valsti, kas strauji virzās uz priekšu. Taču valstij ir ierobežotas iespējas vadīt starptautisko jautājumu risināšanu, piemēram, globālo korporāciju regulējumu, un tai ir jāspēj stratēgiski reaǵēt uz izmaiṇām ārpus tās tiešās kontroles jomas.

\section{Stiprināt Latvijas iekšējās un ārējās partnerības digitālai transformācijai}

Scenārija diskusijā iepriekšējā iedaḷā tika sniegti dažādi konkrēti nākotnes konteksti, kuros panākumi ir atkarīgi no visas sabiedrības kopīgās pieejas digitālajai transformācijai Latvijā. Tam būtu nepieciešama sadarbības un efektīvas kopdarbības stiprināšana starp valdības, uzṇēmējdarbības un pilsoniskās sabiedrības organizācijām, lai virzītu galvenās digitālās prioritātes. Šãdas partnerības ir nepieciešamas, lai ne tikai izmantotu datus, informāciju un zināšanas, kas ir dažādu partneru rīcībā, bet arī nodrošinātu pastāvīgu veselīgu spēka centru daudzveidību un pārbaudes, un līdzsvaru Latvijas sabiedrībā. Scenārija diskusijā tika norādīts uz stratēǵisko tīklu un partnerību, kas sniedzas ārpus Latvijas robežām, stratēǵisko nozīmīgumu. Šo partnerību stiprināšana l̦aus valdībai izmantot nepieciešamo regulējumu jomās, kur Latvija viena pati var nodrošināt tikai ierobežotu ietekmi, piemēram, datu pārvaldību un konkurences politiku. Partnerības var arī palīdzēt saglabāt Latvijas digitālo ekosistēmu (piem., informācijas pārvaldības sistēmas) savienotu un saderīgu ar līdzīgi domājošiem partneriem, kuriem ir līdzīgs vērtību kopums.

Stratēgiskās datu partnerības. Scenārija diskusijā tika uzsvērta arī liela apjoma datu analīzes vērtība, lai pieñemtu precīzus, pierādījumos balstītus lēmumus dažādās jomās. Visos trīs scenārijos izgaismota politiskā un ekonomiskā ietekme, kas rodas līdz ar piekḷuvi ieskatu sniedzošiem digitālajiem datiem (kopienām, korporācijām vai valdībām). Attiecībā uz Latviju tas uzsver nepieciešamību atbilstoši datu potenciālās sensitivitātes līmenim ievērot atbilstošus ierobežojumus un drošỉbas pasākumus situācijās, kad dažādas personas iegūst piekḷuvi ievērojama apjoma datiem, kas sniedz detalizētu un ieskata informāciju par jebkuru jautājumu. Tas varētu ietvert aǵentūru skaita ierobežošanu, kurām ir piekḷuve specifisku veidu datiem. Viena konkrēta rīcības perspektīva šajā gadỉjumā ir akadēmisko aprindu un nozares kopdarbība.

Attiecīgi datu partnerības ir būtiski svarīgas ieinteresētajām pusēm akadēmiskajā, uzn,ēmējdarbības un attīstības jomā. Lai varētu izmantot lielo datu analīzes ieguvumus, Latvijas ieinteresētajām pusēm ir 
jāizveido stratēǵiskās sistēmas, kas dod iespēju veikt savietojamu, uz vērtību balstītu datu apkopošanu, koplietošanu un analīzi. Rìcības iespējas var ietvert:

- sadarbỉbu ar vadošajām akadēmiskajām iestādēm ārvalstīs un citām pusēm, lai apkopotu datu kritisko masu un uzlabotu datu koordināciju

- tīklu un datu sniedzēju savietojamības nodrošināšanu

- platformas izveidošanu vides datu integrēšanai un koplietošanai ar trešām pusēm, piemēram, pilsonisko sabiedrību un korporācijām, darot to kontrolēti un ētiski, īpaši ṇemot vērā veselības datu vērtỉbu un sensitivitāti

- pastāvīgu digitālās drošỉbas un ētikas aspektu pārbaudes saraksta sistēmas stiprināšanu attiecībā uz visiem valdības lēmumiem, piemēram, publisko iepirkumu jomā

- citu valstu digitālo platformu kopdarbības stratēgijas Ziemeḷeiropā formalizēšanu

- vairāku ieinteresēto pušu (iesaistot akadēmiskās aprindas, privāto sektoru, tehnoloǵisko sabiedrību, pilsonisko sabiedrību, valdību) konsultācijas procedūru izveidošanu attiecībā uz noteikumu radīšanu, lai izvairītos no pārmērīgi striktiem noteikumiem.

Nozaru-universitāšu partnerības. Pastāv potenciāls gūt savstarpēju ieguvumu augstākās izglītības iestādēm un nozarei, pamatojoties uz digitālo zināšanu un prasmju inovatīvu un efektīvu attīstīšanu un koplietošanu Latvijas ekonomikai un sabiedrībai.

Ministriju un universitāšu partnerības. Universitātes ir galvenais potenciālais partneris digitālajā transformācijā, papildinot to ar nepieciešamo neatkarību, objektivitāti, atbildību, padziḷinātu analīzi un pierādījumiem, lai sniegtu informāciju politikas veidošanai, lēmumu pieṇemšanai un digitālās politikas jautājumu ìstenošanai. Šādas partnerības var palīdzēt izveidot nepieciešamās pārbaudes un līdzsvaru, lai Latvija varētu plānot nākotni, ko raksturo uzlabota datos balstīta kontrole, ko cita starpā realizē valdības vai privātā sektora pārstāvji. Šeit minētās darbības varētu palīdzēt attīstīt un stiprināt efektivvas universitāšu un valdības partnerības:

- izmantot priekšrocības, ko sniedz esošā elastỉba politikā, piemēram, iepirkumu un citu finansējumu mehānismi, lai dotu iespēju veidot ilgāka termiņa kopdarbību, lai partneri valsts pārvaldē, universitātēs un institūtos var ieguldīt nepieciešamo zināšanu un attiecību attīstībā, kā arī noteikt un novērst potenciālos šķēeṣ̌̆lus

- aicinājums universitātēm atbalstīt politikas veidošanu, piemēram, veicot politikas īstenošanas analīzi

- personāla rotācijas un apmaiṇas starp universitātēm, uzṇēmumiem un valdỉbu veicināšana, lai palīdzētu novērst nepilnības zināšanāsun ilgtermiṇa perspektīvas plaisas valsts dienestā.

Valodu tehnoloǵijas. Nesenie panākumi valodu rīku izstrādē, piemēram, mašinntulkošana un to atbalstošās tehnoloǵijas, varētu nodrošināt Latvijai potenciālu iespēju turpināt specializēties jomā ar dažādām nākotnes iespējām pilsoniskajā, publiskajā un privātajā sektorā.

Rail Baltica projekta partnerības. Rail Baltica projekts ir liela apjoma pārrobežu partnerība, kas cita starpā piedāvā Latvijai digitālās iespējas. N̦emot vērā projekta inovatīvo raksturu un tehnoloǵiju virzìto plānošanu (piem., attiecībā uz mākonī bāzētu kopīgo datu vidi), Rail Baltica piedāvā iespējas nostiprināt saites ar kaimiṇiem digitālajos jautājumos un vēl vairāk integrēt Latvijas digitālo ekosistēmu. Projekts var kalpot arī kā stresa tests Latvijas kapacitātei sadarboties ar dažādām ieinteresētajām pusēm, nodrošināt digitālos aizsardzības pasākumus un nodrošināt netraucētu publisko unprivāto partnerỉbu. Potenciālie turpmākās attīstības ceḷi ietver:

- sadarbību ar kopienām saistībā ar iespējām, ko piedāvā jaunas augsto tehnoloǵiju ātrgaitas dzelzceḷa stacijas atvēršana

- iepriekšēju iespēju un risku pārskatišsanu saistībā ar tehnoloǵijas atvēršanu un iepirkumu līgumu piedāvāšanu privātiem uzṇēmumiem.

Projekta finansēšanas alianses. Valdībai ir jāvada un turpmāk jākoordinē un jākonsolidē uzṇēmumu, kopienu un akadēmisko aprindu finansēšanas centieni tādās jomās, kā piemēram, liela mēroga digitālā infrastruktūra (piem., transporta vai 5G projekti) un IKT pētniecība un attīstība. Tas ḷautu labāk saskan,ot 
gaidas un radīt sinerǵijas dažādu ieinteresēto pušu starpā, kā arī nostiprināt to pozīcijas, risinot sarunas ar starptautiskajiem partneriem. Apsveramās darbības ir šādas:

- partnerattiecību veidošana ar finanšu un finanšu tehnologiiju ekspertiem, lai izveidotu atvērtā koda koordinācijas sistēmas, kas apvieno finansēšanas partnerus, balstoties uz kopīgiem mērkiem un galvenajiem snieguma rādītājiem, kā arī nodrošinot piekḷuvi pilsoniskajai sabiedrībai un kopienas partneriem

- finansēšanas alianšu kontaktu ar starptautiskajiem partneriem veidošana, piemēram, ES līmenī

- alianšu izmantošana, lai veicinātu zināšanu apmaiṇu privātā sektora, pilsoniskās sabiedrības un akadēmisko aprindu pārstāvju vidū.

\section{Noteikt viedas pieejas izglītībai un prasmēm, lai veidotu adaptīuus un kritiskus Latvijas iedzivotājus}

Sabiedrība ar digitālām iespējām var būt nozīmīgs digitālās inovācijas, uzṇēmējdarbỉbas un produktivitātes avots. Iedzìvotāji ar digitālām iespējām var arī palīdzēt publiskajai pārvaldei, korporācijām un citām organizācijām rēḳināties ar viṇu digitālās politikas izvēlēm un dot iespēju sabiedrībai izprast daudzos ar izaicinājumiem saistītos kompromisus, kas saistīti ar digitālo transformāciju, piemēram, darba automatizācija un personas datu vākšana un izmantošana. Stratēgisiskā nākotnes skatījumā procesā tika izcelts punkts par to, ka digitālā, kompleksā un strauji mainīgajā pasaulē ir augoša nepieciešamība ne tikai pēc "digitālām prasmēm", piemēram, datu vizualizācija vai MI darbināšana, bet arī tādas prasmes kā, piemēram, radošums, problēmu risināšana, pielāgošanās spēja un kritiskā domāšana.

Lietišḳās mācību programmas studentiem. Lai sagatavotos kompleksajai un strauji mainīgajai digitālajai pasaulei, gados jaunajiem Latvijas iedzīvotājiem ir ne tikai jāapgūst teorētiskās IKT prasmes, bet arī praktiski jāmācās par ieguvumiem un arī ne mazāk svarīgajiem apdraudējumiem, ko var radīt digitālā transformācija. No šì skatpunkta raugoties, noderīga varētu būt praktiska sadarbība starp formālās izglìtības sektoru un uzṇēmumiem, pētniecības institūcijām un kopienām Latvijā, un tā varētu īstenoties dažādās formās, piemēram:

- ilgtermiṇa partnerību veidošana starp Latvijas skolām un uzṇēmumiem, lai piedāvātu praktiskas mācīšanās iespējas un stiprinātu saites starp Latvijas talantiem un vietējiem darba devējiem

- situāciju analīzes programmu, inovāciju laboratoriju vai hakatonu piedāvāšana skolās sadarbībā ar Latvijas privātā sektora partneriem, tādējādi dodot iespēju studentiem risināt reālas problēmas, ar kādām saskaras Latvijas uzṇēmumi, un pielietot teorētiskās zināšanas praksē, sagatavojot nākamo paaudzi potenciāliem digitālās transformācijas nākotnes izaicinājumiem, atbalstot viṇu inovācijas kapacitāti un stiprinot Latvijas uzṇēmumu kontaktus ar jaunajiem talantiem, lai nodrošinātu, ka vietējiem MVU un stabiliem uzṇēmumiem spēcīgas starptautiskās konkurences kontekstā ir piekḷuve piemērotam personālam

- šo partnerību izmantošana, lai nodrošinātu ātrāku atgriezeniskās saiknes loku starp praktikiem un izglìtības darbiniekiem, lai pastāvīgi pielāgotu Latvijas iedzìvotāju prasmes un skolu mācību programmas atbilstoši nākotnes vajadzỉbām un labāk sabalansētu esošo kapacitāti uzṇēmumos, izmantojot kontaktus ar akadēmisko aprindu vai kopienas partneriem.

Cilvēkkapitāla investīcijas. Cilvēkkapitāls ir labi zināms ekonomiskās izaugsmes un inovāciju virzītājspēks, un informācijas virzīta digitālā ekonomika ir vēl vairāk uzsvērusi šo dinamiku. Lai izmantotu ekonomikas potenciālu, kas lielā mērā atkarīgs no cilvēkresursiem, Latvijai ir jānodrošina pastāvīga investīciju plūsma, kas paredzēta vērtīgākajam aktīvam - darbiniekiem. Lai atbalstītu pastāvìgu mācišanos arī pēc formālās izglīiības iegūšanas, Latvija varētu izpētīt veidus, kā veicināt uzṇēmumu investīcijas savos darbiniekos. Tas varētu ietvert:

- (turpmāku) programmu īstenošanu darba devēju sponsorētai pastāvīgai profesionālajai apmācībai (t.i. tādai, ko nodrošina vai vismaz dal̦ēji apmaksā uzṇēmumi).

- jaunu stimulu un finansējuma (t.i. uzṇēmuma līmen̦a stimulu) ieviešanu specifiskām uzṇēmumu vadītām mācišanās un apmācību programmām IKT jomā

- sistemātisku politiskās vides novērtējumu Latvijas iedzīvotājiem, kas strādā reizesdarbu ekonomikā [gig economy], tostarp potenciāli novērtēt Latvijas darba politiku, apdrošināšanas shēmu un darba līgumu formātu atbilstību reizesdarbu ekonomikā strādājošajiem.

Digitālās mācīšanās centri. Scenāriju diskusijā, īpaši saistībā ar \#Me2.0 scenāriju, tika izcelts kopienas virzītas digitālās inovācijas potenciāls. Piešḳirot Latvijas iedzīvotājiem visā valstī labāku piekḷuvi 
atvērtā pirmkoda rīkiem un mācīšanās iespējām, lai kḷūtu digitāli izglītoti, viṇiem tiktu dota lielāka ietekme valsts digitālajā attīstībā. Šajā kontekstā darbseminārā tika norādīts uz iespēju turpināt attīstīt Latvijas digitālās mācīšanās centrus, kas ir savienotas ar esošo infrastruktūru, piemēram, reǵionālajām bibliotēkām un izglītỉbas iestādēm, potenciāli izmantojot DigiHubs tỉklu. ${ }^{2}$ Tas l̦autu piedāvāt apmācību iespējas visā Latvijā gan pilsētu, gan lauku teritorijās un varētu kalpot kā digitālo transformāciju paātrinošs faktors. Tādējādi tiktu arī uzlabotas digitālās prasmes visās vecuma grupās un nodrošināta labāka atbildes reakcija uz daudzveidīgām vajadzībām. Ir jāattīsta e-mācišanās platformas (tostarp tehniskā infrastruktūra un mācīšanās saturs), lai palielinātu attālinātās mācǐšanās un e-mācīšanās iespējas.

\section{Noteikt ceḷus uz iekḷaujošu digitālu Latviju, ko veido cilvēki cilvēkiem.}

Scenārijos atklātas digitālās transformācijas abas puses - iespējas, ko tehnologiijas rada cilvēkiem, lai izteiktu savu viedokli un kḷūtu aktīvi, kā arī potenciālie draudi, ko tehnolog̣ija rada vienlīdzìbai, iekḷaušanai un personu kontrolei attiecībā uz saviem datiem un dzìvi. Mērḳtiecīgi centieni var palīdzēt saglabāt iedzīvotāju uzticēšanos un sniegt Latvijas iedzīvotājiem jaunas iespējas izteikt savas vajadzības un piepildīt savus digitālos plānus. Ar šādu centienu palīdzību var izmantot ekonomiskās un sociālās inovācijas no visiem Latvijas reǵioniem, nozarēm un iestādēm.

Sociālās ietekmes finansējums un pūḷa finansējums. Potenciālas iespējas atbalstīt iekḷaujošu ekonomikas attīstību var paredzēt vairākos veidos:

- atvērtu rīku nodrošināšana sabiedrībai, lai finansētāji varētu sekot progresam galveno sociālās veiktspējas indikatoru sasniegšanā

- palīdzība iedzīvotājiem, kopienām un uzṇēmumiem izsekot finansēto projektu progresam un dot pienesumu, lai tos sasniegtu

- jaunu pūḷa finansējuma rīku izstrāde sadarbībā ar kopienas līderiem, piemēram, ar apbalvojumu sistēmu vai spēḷu pieejām.

Tiesību akti datu atkalizmantošanai. Var būt nepieciešams pievērst papildu uzmanību datu atkalizmantošanai un anonimitātei, īpaši saistībā ar medicīnas datu pārdošanu trešām personām un valstīm. Potenciālie pasākumi ir šādi:

- privāto datu noteikšana par preci ar kvantificējamu ekonomisko vērtību, kurā n̦emtas vērā izmaksas cilvēka privātuma un tiesību izteiksmē, tādējādi palīdzot pieṇemt informētus lēmumus par to, kādi pakalpojumi ir kāda datu apjoma vērti.

- caurskatāma ètikas satvara izstrāde un pien̦emšana, lai sniegtu norādes datu tiesību aktu pien̦emšanai.

Korporatīvās uzticēšanās pasākumi. Uzticēšanos korporācijām varētu mērìt līdzīgi kā uzticēšanos publiskai pārvaldei, sniedzot noderīgus ieskatus par Latvijas pieeju attiecībā uz publiskām un privātām partnerībām.

Līdzdalības lēmumu pien̦emšana. Nākotnes kontekstā, kur datos balstīta informācija tiek izmantota arvien vairāk, lēmumu pien,emšanas struktūrās ir jāiekḷauj nepieciešamās atgriezeniskās saiknes un atbildības pasākumi, lai novērstu datu ḷaunprātīgu izmantošanu. Viens no veidiem, kā izstrādāt sistemātiskas pārbaudes un līdzsvarus, varētu būt atbalstīt līderības pieeju, kas nodrošina vairāk telpas visām organizācijas daḷām, lai izteiktu savu viedokli un apšaubītu lēmumus. Izpēte ir parādijjusi, ka sabiedrības līdzdalība lēmumu pienememšanā veicina stingrāku lēmumu un stratēǵiju pieṇemšanu. Šo pieeju varētu uzsākt ar apmācību sēriju par līdzdalības lēmumu pieṇemšanu dažādu nozaru vadītājiem, piedāvājot simulācijas spēles par kolektīvu lēmumu pieṇemšanu skolās, testējot jaunus rīkus publiskām konsultācijām (piem., sadarbībā ar mediju partneriem) vai piedāvājot līderības treniṇus uzṇēmējiem.

\section{Stiprināt kapacitāti personas datu piekḷuvei un lietošanai, vienlaikus aizsargājot digitālo drošību un drošumu}

Scenāriji norāda, ka Latvijas valdība varētu vēlēties pārskatīt savu sistēmu digitālās informācijas piekḷuvei, integrēšanai un analizēšanai nākotnē. Digitālākā pasaulē vērtību radīšana iedzīvotājiem būs daḷeji atkarīga no organizāciju spējas piekḷūt strauji augošajam personas datu apjomam un izdarīt secinājumus par to. Integrētāka un efektīvāka pārvaldes informācijas sistēma arī rada skaidru risku, kas ir jāmazina ar spēcīgiem aizsardzības līdzekḷiem. Tā pati informācija, kas ir būtiski svarīga, lai 
uzlabotu pakalpojumus, uzraugot un ietekmējot iznākumus, nodrošina arī nozīmīgu potenciālu iespēju l̦aunprātīgai izmantošanai. Līdzīgi lielākajai daḷai valstu Latvija saskaras ar izaicinājumu, kā virzīt divas prioritātes, vienlaikus stiprinot pārvaldes digitalizācijas efektivitāti, tajā pašā laikā palielinot drošības pasākumus. Šajā kontekstā ir piemērojams uz cilvēku orientēts princips, saskaṇā ar kuru, ja cilvēks ir datu avots, tad cilvēkam ir tiesības noteikt, kad un kur dati tiek izmantoti.

Integrētas digitālās informācijas sistēmas risku darba grupa. Starpdisciplināra darba grupa varētu analizēt plašu pašreizējo un potenciālo nākotnes risku klāstu, kas saistīts ar spēcīgākas un integrētākas digitālās informācijas sistēmas izveidi. Tas ietvertu:

- situācijas apsvēršanu saistībā gan ar kiberdrošību, gan potenciālu sistēmas l̦aunprātīgu izmantošanu, ko veic lietotāji, kas gan nelikumīgi, gan likumīgi iegūst piekḷuvi

- risku mazināšanas risinājumu izstrādi sadarbībā ar galvenajām ieinteresētajām pusēm, kas nodrošina integrētus datu aizsardzības risinājumus.

Integrētas datu aizsardzības risinājumi. Scenārijā diskusijā tika atkārtoti uzsvērta konsolidētas, pastāvīgas, adaptīvas pieejas attiecībā uz esošajiem un nākotnes aizsardzỉbas pasākumiem, nozīme. Nacionālā koordinētā digitālās drošības stratēǵijā varētu iekḷaut centienus tehnolog̣iskā, institūciju, politiskajā un kultūras līmenī:

- Tehnoloǵiskie risinājumi varētu iekḷaut mehānismus, lai atdalītu datus un glabātu tos vairākās vietās, mehānismus, lai kontrolētu un izsekotu piekḷuvi informācijai, mehānismus, lai iegūtu tikai minimālo datu apjomu, kas nepieciešams konkrētajai vajadzībai, un citus.

- Institucionālie risinājumi varētu iekḷaut stingru un caurskatāmu uzraudzibu un visas datu izmantošanas auditu, kas izpildītu gan iekšējās, gan ārējās uzraudzības funkcijas.

- Politiskie risinājumi varētu ietvert partnerības ar citām valdībām, lai kopīgi auditētu viens otra nacionālos drošỉbas pasākumus.

- Kultūras risinājumi varētu ietvert lielāku informētību iedzīvotāju vidū par riskiem un ḷaunprātīgas izmantošanas pazīmēm, lai iedzìvotāji nepiekristu pārejai uz vājākiem drošības pasākumiem vai to likvidēšanai.

IKT nodrošināšanas zināšanas. Latvija varētu uzlabot kopējo pakalpojumu kvalitāti un savietojamību, uzlabojot ierēdṇu prasmes un zināšanas. Tas varētu ietvert jaunas motivācijas noteikšanu, lai pieṇemtu darbā IKT speciālistus un praktiḳus, piemēram, izmantojot personāla rotāciju ar Latvijas uzṇēmumiem.

\section{Secinājums}

Šajā nodaḷā tika analizēti trīs alternatīvi scenāriji digitālās transformācijas nākotnei un dažas no priekšnoteikumiem sekām attiecībā uz Latvijas digitālo stratēǵiju. Šì nodaḷa ir paredzēta gan kā papildinājums rekomendācijām plašākā pārskatā un kā sākumpunkts turpmākai analīzei un izpētei Latvijā, kā daḷa no notiekošā noturīgu, adaptīvu un sekmīgu stratēǵiju izstrādes (un pārstrādes) procesa.

Kā to pierāda gan šì nodaḷa, gan plašākais pārskats, Latvijā pastāv daudzi no aspektiem, kas nepieciešami, lai gūtu panākumus digitālajā laikmetā. Taču straujo pārmaiṇu un augstās nenoteiktības kontekstā pastāvīgas sekmes nozīmē virzīšanos tālāk par to, ko iepriekš uzskatīja par apmierinošu, un ieguldījumus jauna veida praksē un iespējās. Labas pārvaldības prasību centrā 21. gadsimtā ir spēja sistemātiski strādāt ar nākotnes nenoteiktībām, kā standartu valdības politikas veidošanas procesā ieviešot stratēgiska nākotnes skatījuma pieejas. ESAO aicina publiskās pārvaldes amatpersonas un plašāku politikas kopienu Latvijā balstīties uz savu nākotnes skatījuma pieredzi Going Digital projekta ìstenošanā, lai turpinātu uz nākotni orientēto darbu gan digitālās politikas jomā, gan ārpus tās. 


\section{Atsauces}

Bajgar, M., et al. (2019), "Rūpniecības koncentrācija Eiropā un Ziemel̦amerikā” [Industry concentration in Europe and North America], OECD Productivity Working Papers, Nr. 18, OECD Publishing, Paris, https://doi.org/10.1787/2ff98246-en.

BBC NEWS (2019), “Krievijas internets: stājas spēkā likums, ar kuru ievieš jaunus kontroles pasākumus” [Russia internet: Law introducing new controls comes into force], www.bbc.com/news/world-europe-50259597.

Casalini, F. and J. López González (2019), “Tirdzniecība un pārrobežu datu plūsmas” [Trade and cross-border data flows], OECD Trade Policy Papers, No. 220, OECD Publishing, Paris, https://doi.org/10.1787/b2023a47-en.

CB Insights (2019), "Kā Google plāno izmantot MI, lai no jauna izgudrotu \$3 triljonu vērto ASV veselības aprūpes nozari” [How Google plans to use AI to reinvent the \$3 trillion US healthcare industry], www.cbinsights.com/research/report/google-strategy-healthcare.

Deschamps, T. (2019), “Google māsas uzṇēmums izpauž informāciju par pretrunīgo Toronto projektu” [Google sister company releases details for controversial Toronto project], The Guardian, www.theguardian.com/world/2019/jun/24/google-toronto-smart-citysidewalk-project-alphabet-redevelopment.

Guarascio, F. (2019), “Libra trauksmes signāls, ES plāno apsvērt publiskās digitālās valūtas emisiju: projekts” [Alarmed by Libra, EU to look into issuing public digital currency: draft], Reuters, www.reuters.com/article/us-eu-cryptocurrency-regulations/alarmed-by-libra-euto-look-into-issuing-public-digital-currency-draft-idUSKBN1XF1VC.

Hesse, C. (2008), "Jaunu kopīgo resursu kartēšana” [Mapping the new commons], ziṇojums, kas prezentēts Starptautiskās kopīgo resursu pētniecības asociācijas 12. divgadu konferencē "Governing Shared Resources: Connecting Local Experience to Global Challenges" [Kopīgo resursu pārvaldỉba: vietējo zināšanu saistīšana ar globāliem izaicinājumiem], University of Gloucestershire, Cheltenham, UK, 14-18 July, http://dlc.dlib.indiana.edu/dlc/bitstream/handle/10535/304/Mapping_the_NewCommons.pdf.

Kerr, S.P. et al. (2016), “Globālo talantu plūsmas” [Global talent flows], Harvard Business School Working Papers, No. 17-026, www.hbs. edu/faculty/Publication\%20Files/17-026_a60ac33d-3fd5-4814-a845-137a38066810.pdf.

KPMG (2017), Pārskats par K̦inas kiberdrošỉbas likumu [Overview of China’s Cybersecurity Law], 2017 KPMG Advisory (China), https://assets.kpmg/content/dam/kpmg/cn/pdf/en/2017/02/overview-of-cybersecurity-law.pdf.

Matias, J.N. (2015), “Digitālo kopīgo resursu traǵédija” [The tragedy of the digital commons], The Atlantic, www.theatlantic.com/technology/ archive/2015/06/the-tragedy-of-the-digital-commons/395129.

Mölleryd, B. (2015), "Liela ātruma tīklu attīstība un pašvaldības tīklu loma" [Development of high-speed networks and the role of municipal networks], OECD Science, Technology and Industry Policy Papers, No. 26, OECD Publishing, Paris, https://doi. org/10.1787/5jrqdl7runs3-en.

Nvidia (2020), "Inovācijas virzišana” [Driving innovation], www.nvidia.com/en-us/self-driving-cars.

ESAO (2018), Tirgus koncentrācija [Market Concentration], Issues paper ESAO, Paris, https://one.oecd.org/document/DAF/COMP/ $\mathrm{WD}(2018) 46 / e n / p d f$.

Shi-Kupfer, K. and M. Ohlberg (2019), “Ķinas digitālais uzplaukums” [China's digital rise], MERICS Papers on China, No. 7, https://merics. org/en/report/chinas-digital-rise.

Walljasper, J. (2011), “Elionora Osroma 8 principi kopīgo resursu pārvaldībai” [Elinor Ostrom's 8 principles for managing a commons], On the Commons, www.onthecommons.org/magazine/elinor-ostroms-8-principles-managing-commmons.

\section{Piezīmes}

1. https://uidai.gov.in.

2. https://latlit.eu. 



\section{Nodala 3}

\section{INFRASTRUKTŪRAS LATVIJAS DIGITĀLAJAI EKONOMIKAI}




\section{Komunikācijas politikas uzdevumi Latvijas digitālajai transformācijai}

Gandrīz visas ESAO valstis savu digitālo stratēǵiju ietvaros ir izvirzījušas mērḳus, lai sekmētu piekḷuvi komunikāciju pakalpojumiem un tos izmantotu. Šie valstu mērḳi atšḳiras pēc beigu datumiem, ātruma un aptvertās iedzìvotāju vai telpu proporcijas (3.1. tabula).

\section{1. tabula. Valstu mērḳi attiecībā uz platjoslas pārklājumu ESAO}

\begin{tabular}{|c|c|c|}
\hline Valsts & Gads & Pārklājums \\
\hline Austrālija & 2020 & 90 \% mājsaimniecību un uzņēmumu ar 50 Mb/s/5 Mb/s (lejupielāde/augšupielāde) \\
\hline Austrija & 2020 & 99 \% mājsaimniecību ar $100 \mathrm{Mb} / \mathrm{s}$ \\
\hline Belǵgija & 2020 & $100 \%$ mājsaimniecību ar $30 \mathrm{Mb} / \mathrm{s}$ \\
\hline Kanāda & $2021^{1}$ & $\begin{array}{l}90 \text { \% mājsaimniecību un uznēēmumu ar } 50 \mathrm{Mb} / \mathrm{s} / 10 \mathrm{Mb} / \mathrm{s} \text { un jaunāko mobilo tehnoloǵiju, kas ir pieejama visām } \\
\text { mājsaimniecībām, uzņēmumiem un galvenajiem ceḷiem. }\end{array}$ \\
\hline Čīe & 2020 & 90 \% mājsaimniecību ar $10 \mathrm{Mb} / \mathrm{s}$ \\
\hline Kolumbija & 2022 & 70 \% mājsaimniecību ir savienojums ar internetu, un 32 miljoniem abonentu ātrums pārsniedz 10 Mb/s \\
\hline Čehijas Republika & 2020 & 100 \% mājsaimniecību un uzņēmumu ar 30 Mb/s \\
\hline Dānija & 2020 & 100 \% mājsaimniecību un uzņēmumu ar 100 Mb/s/30 Mb/s \\
\hline Igaunija & 2020 & 100 \% mājsaimniecību ar 30 Mb/s un 60 \% ar 100 Mb/s vai ātrāku \\
\hline Somija & $2015^{2}$ & 99 \% mājsaimniecību, uzņēmumu un valsts iestāžu ar 100 Mb/s \\
\hline Francija & 2022 & 100 \% mājsaimniecību, uzņēmumu un valsts iestāžu ar 30 Mb/s \\
\hline Vācija & 2025 & Pilns gigabitu pārklājums visām mājsaimniecībām un uzņēmumiem \\
\hline Grieksija & 2020 & $100 \%$ mājsaimniecību ar $30 \mathrm{Mb} / \mathrm{s}$ \\
\hline Ungārija & 2018 & $100 \%$ mājsaimniecību ar $30 \mathrm{Mb} / \mathrm{s}$ \\
\hline Islande & 2020 & $100 \%$ mājsaimniecību ar $30 \mathrm{Mb} / \mathrm{s}$ \\
\hline Trija & 2020 & $100 \%$ mājsaimniecību ar $30 \mathrm{Mb} / \mathrm{s}$ \\
\hline Izraēla & 2022 & 100 \% iedzīvotāju ar 30 Mb/s \\
\hline Itālija & 2020 & 100 \% mājsaimniecību ar 30 Mb/s; 100 \% uzņēmumu un 85 \% iedzīvotāju ar 100 Mb/s \\
\hline Koreja & 2022 & $\begin{array}{l}\text { Fiksētais internets ar lejupielādes ātrumu, kas nepārsniedz } 10 \mathrm{~Gb} / \mathrm{s} \text {, līdz 2022. gadam tiks izplatīits } 50 \text { \% pilsētvides } \\
\text { mājsaimniecību ( } 85 \text { pilsētās). }\end{array}$ \\
\hline Latvija & 2020 & 100 \% iedzīvotāju ar $30 \mathrm{Mb} / \mathrm{s}$ mobilo platjoslas savienojumu un 100 \% lauku teritoriju ar optisko atvilces maršrutēšanu \\
\hline Luksemburga & 2020 & 100 \% mājsaimniecību, uzņēmumu un valsts iestāžu ar $1 \mathrm{~Gb} / \mathrm{s} / 500 \mathrm{Mb} / \mathrm{s}$ \\
\hline Nīderlande & 2020 & $100 \%$ mājsaimniecību ar $30 \mathrm{Mb} / \mathrm{s}$ \\
\hline Jaunzēlande & 2025 & 99 \% mājsaimniecību ar $50 \mathrm{Mb} / \mathrm{s}$ un atlikušais $1 \%$ ar $10 \mathrm{Mb} / \mathrm{s}$ \\
\hline Norvēǵija & 2020 & 90\% mājsaimniecību ar 100 Mb/s \\
\hline Polija & 2020 & 100 \% mājsaimniecību un uzņēmumu ar 30 Mb/s \\
\hline Portugāle & 2020 & $100 \%$ mājsaimniecību ar $30 \mathrm{Mb} / \mathrm{s}$ \\
\hline Slovākijas Republika & 2020 & $100 \%$ mājsaimniecību ar $30 \mathrm{Mb} / \mathrm{s}$ \\
\hline Slovēnija & 2021 & 96 \% mājsaimniecību ar 100 Mb/s un atlikušie 4 \% ar 30 Mb/s \\
\hline Spānija & 2020 & 100 \% mājsaimniecību ar 30 Mb/s \\
\hline Zviedrija & 2025 & 98 \% mājsaimniecību un uzņēmumu ar $1 \mathrm{~Gb} / \mathrm{s}$ \\
\hline Šveice & 2020 & $100 \%$ pašvaldību ar $30 \mathrm{Mb} / \mathrm{s}$ \\
\hline Apvienotā Karaliste & 2020 & 95\% mājsaimniecību un uzņēmumu ar 25 Mb/s \\
\hline Amerikas Savienotās Valstis & 2020 & 80 \% mājsaimniecību ar 100 Mb/s / 50 Mb/s \\
\hline
\end{tabular}

Piezìme: $\mathrm{Mb} / \mathrm{s}$ = megabiti sekundē; Gb/s = Gigabiti sekundē

1. Lỉdz 2021. gada beigām, atlikušos 10 \% sasniedzot 10-15 gadu laikā.

2. Valsts platjoslas stratēǵija, kas pašlaik tiek izstrādāta, noteiks mērḳus 2025. un 2030. gadam.

Avots: ESAO (2018a), Bridging the Digital Rural Divide; DEO (2020), Regulatīvā aptauja.

Latvijas mērkis ir piesaistīt $30 \mathrm{Mb} / \mathrm{s}$ mobilās platjoslas pakalpojumiem 100 \% iedzīvotāju un izvietot optiskās šḳiedras atvilces maršrutēšanu visās lauku teritorijās līdz 2020. gadam. Šie mērḳi ir iekḷauti Latvijas 2018.-2020. gada valsts komunikācijas nozares sektora politikas plānā un saskaṇoti ar ātrdarbīga interneta pārklājuma mērḳiem "Eiropas digitalizācijas programmā 2020". Tāpat kā visām citām ES 
valstīm minimālais kopējais mērḳis ir sasniegt 100 \% pārklājumu ar 30 Mb/s un 50 \% mājsaimniecībām ar $100 \mathrm{Mb} / \mathrm{s}$ platjoslas abonentiem lïdz 2020. gadam (Eiropas Komisija, 2010. gads).

Pašlaik vispārējs standarts ir $30 \mathrm{Mb} / \mathrm{s}$ savienojamība, tomēr arvien biežāk kā mērḳis tiek izvirzìti vismaz $100 \mathrm{Mb} / \mathrm{s}$. Lìdz 2020. gadam Amerikas Savienoto Valstu mērḳis ir vismaz platjoslas $100 \mathrm{Mb} / \mathrm{s}$ pieejamība 80 \% mājsaimniecību, bet Norvēǵijas un Austrijas izvirzītie mērḳi ir attiecīgi $90 \%$ un 99 \%. Daži mērkị ir vēl vērienīgāki, piemēram, Luksemburgas mērkis ir $1 \mathrm{~Gb} / \mathrm{s}$ (98 \% līiz 2020. gadam) un (100 \% līdz 2025. gadam), bet Korejai - lejupielādes ātrums $10 \mathrm{~Gb} / \mathrm{s} 50$ \% pilsētvides mājsaimniecību līdz 2022. gadam (ESAO, 2018a).

Turklāt ESAO valstīs ir noteikti savienojamības mērḳi saistībā ar publisko pakalpojumu sniedzējiem un mobilitāti. Eiropas Komisijas (EK) gigabitu sabiedrības uzdevumi paredz: (1) nodrošināt, lai visām skolām, transporta mezgliem un galvenajiem publisko pakalpojumu sniedzējiem, kā arī digitāli ietilpīgiem uzṇēmumiem būtu piekḷuve interneta savienojumiem ar lejupielādes/augšupielādes ātrumu 1 gigabits sekundē; (2) visām lauku un pilsētas mājsaimniecībām būtu piekḷuve tīklam, kas piedāvā lejupielādes ātrumu vismaz $100 \mathrm{Mb} / \mathrm{s}$ un ko var modernizēt līdz 1 gigabitam; (3) visām pilsētvides teritorijām, kā arī galvenajiem cel̦iem un dzelzceḷiem būtu nepārtraukts 5G bezvadu platjoslas pārklājums (Eiropas Komisija, 2016. gads).

Latvijas savienojamības mērḳu pamatā ir tās nacionālā platjoslas stratēǵija "Nākamās paaudzes platjoslas elektronisko sakaru tīklu attīstības koncepcija 2013.-2020. gadam”, kuru Latvijas Republikas Ministru kabinets ir apstiprinājis 2012. gada decembrī un grozījis 2016. gadā. Plāna divas galvenās prioritātes ir optiskās škiiedras atvilces infrastruktūra (vidējā jūdze) vairumtirdzniecības platjoslas pakalpojumiem, tostarp lauku teritorijās, un $4 G$ tīkla pakalpojumu ieviešana visā valstī. Valsts platjoslas stratēǵiju un tās mērḳus uzrauga Satiksmes ministrija (SM), un tie tiek iesniegti Ministru kabineta apstiprināšanai ik pēc diviem gadiem. Galvenā, problēma, kas ietekmē Latvijas stratēgijas ieviešanu, ir saistīta ar savienojamības paplašināšanu lauku teritorijās, jo šeit ir zemi ienākumi un mazs iedzìvotāju blīvums. Papildu izaicinājums ir pieejamo līdzekḷu trūkums pēdējās jūdzes savienojamībai.

Nākamajā platjoslas politikas stratēgiijā, kas aptver periodu pēc 2020. gada, valdība plāno turpināt tīkla izvietošanu lauku teritorijās, tostarp paplašinot vidējās un pēdējās jūdzes pārklājumu. Turklāt paredzams, ka stratēǵijā pēc 2020. gada tiks iekḷauta sakaru tīklu un pakalpojumu plaša kartēšana, lai sekmētu 5G tīklu izvietošanu un infrastruktūras kopīgošanu. SM pašlaik strādā, lai noteiktu finansējuma avotus, un valdība plāno pabeigt jauno stratēgijiju līdz 2020. gada beigām.

\section{Savienojamības stāvoklis Latvijā}

\section{Platjoslas izplatiba}

Mobilās platjoslas abonentu skaits Latvijā, tāpat kā lielākajā daḷā ESAO valstu, turpina pieaugt. No 2017. gada decembra līdz 2018. gada decembrim abonentu apjoms ir pieaudzis par $11 \%$, un 2019. gada jūnijā tas sasniedza 126,9 abonentu uz 100 iedzīvotājiem, Latvijai ierindojoties 7. vietā no ESAO valstīm (3.1. attēls).

2019. gada jūnijā Latvija ziṇoja par 26,7 fiksētās platjoslas abonentiem uz 100 iedzīvotājiem, kas ir tuvu ESAO vidējam rādītājam 31,4. Tomēr Latvija ievērojami atpaliek no vadošajām ESAO valstīm fiksētās platjoslas izplatības ziṇā, piemēram, no Šveices ar 46 un Dānijas ar 43 abonentiem uz 100 iedzìvotājiem (3.2. attēls).

Optiskās šķiedras savienojumu procentuālā daḷa no kopējā fiksētās platjoslas apjoma Latvijā 2019. gada jūnijā sasniedza 68,9 \%, ievērojami pārsniedzot ESAO vidējo vērtību, kas bija 26,8 \% (3.3. attēls). No 2009. gada līdz 2019. gada jūnijam optiskās šḳiedras abonentu daḷa no kopējiem fiksētās platjoslas abonentiem Latvijā ir eksponenciāli pieaugusi no 5 \% līdz 68,5 \% (3.4. attēls). 2019. gada jūnijā Latvija ierindojās piektajā vietā pēc optiskās škiedras savienojumu procentuālās daḷas kopējā fiksētajā platjoslā pēc Korejas (81,6 \%), Japānas (79,0 \%) un Lietuvas (74,6 \%). 


\section{1. attēls. Mobilās platjoslas abonenti uz 100 iedzivotājiem pēc ESAO valstīs, 2019. gada jūnijs}

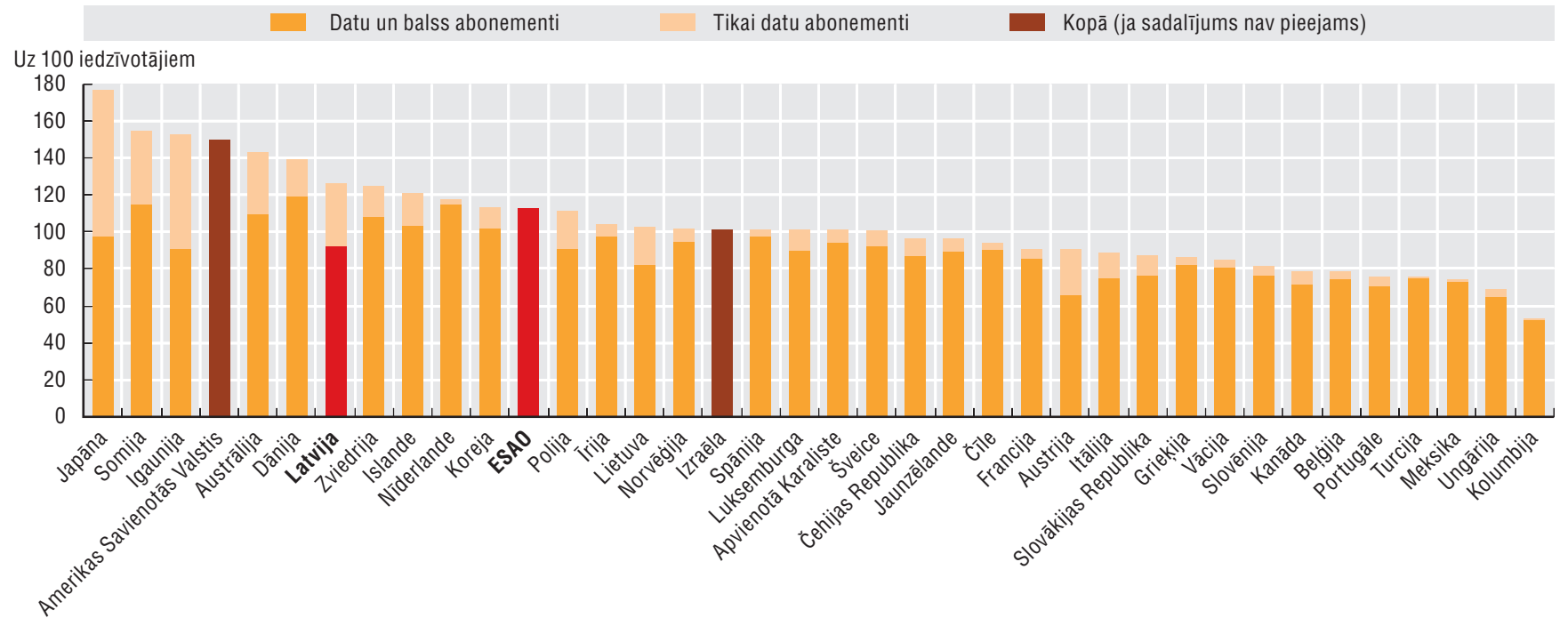

Piezīmes. Austrālija: ziṇotos datus kopš 2018. gada decembra ievāc jauna juridiskā persona, izmantojot atškirīgu metodoloǵiju. No 2018. gada decembra ziṇotie rādītāji aptver sērijas pārtraukumu un nav salīdzināmi ar iepriekšējiem datiem nevienam platjoslas mērījumam, par ko Austrālija ziņoja ESAO.

Avots: OECD Broadband Portal (datubāze), www.oecd.org/sti/broadband/oecdbroadbandportal.htm (piekḷuve 2020. gada 6. maijā).

\section{2. attēls. Fiksētās platjoslas abonenti uz 100 iedzīvotājiem pēc ESAO valstīs, 2019. gada jūnijs}

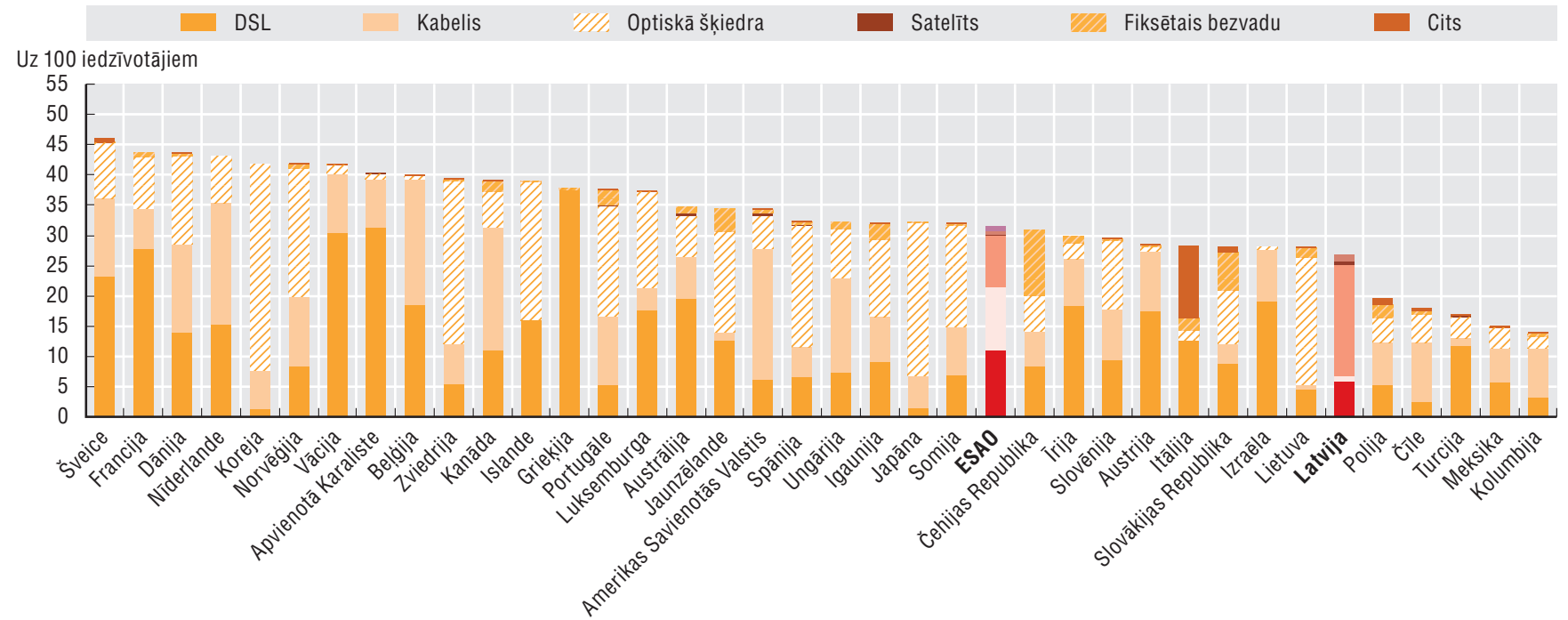

Piezīmes: DSL = Domēnspecifiska valoda. Austrālija: ziṇotos datus kopš 2018. gada decembra ievāc jauna juridiskā persona, izmantojot atšḳirīgu metodoloǵiju. No 2018. gada decembra zinotie rādītāji aptver sērijas pārtraukumu un nav salīdzināmi ar iepriekšējiem datiem nevienam platjoslas mērijumam, par ko Austrālija ziṇoja ESAO. Optiskās šḳiedras kabeḷu ESAO definīcija ievērojami atšḳiras no Austrālijas ziṇojumos parasti izmantotajām optiskās škiedras kabelu klasifikācijām. Šajos attēlos savienojumi, kas Austrālijā ir zināmi kā "Optiskās škiedras kabelu nodrošināšana līdz mezglam" (FTTN) un "Optiskās šḳiedras kabel̦u nodrošināšana līdz žogam" (FTTC), ir aplūkoti kā DSL savienojumi, savukārt "Optiskās šḳiedras kabel̦u nodrošināšana līdz galalietotājam” (FTTP) un “Optiskās šk̦iedras kabel̦u nodrošināšana līdz ēkai” (FTTB) tiek aplūkoti kā optiskās šķiedras savienojumi. Dati par tehnoloǵijas tipu pirms 2016. gada 2. ceturkšņa ir jāuzskata par norādošiem līdz turpmākam paziṇojumam. Avots: OECD Broadband Portal (datubāze), www.oecd.org/sti/broadband/oecdbroadbandportal.htm (piekḷuve 2020. gada 6. maijā). 
3.3. attēls. Optiskās šḳiedras savienojumu procentuālā daḷa kopējā fiksētajā platjoslā ESAO valstīs, 2015. gada 2. ceturksnis - 2019. gada 2. ceturksnis

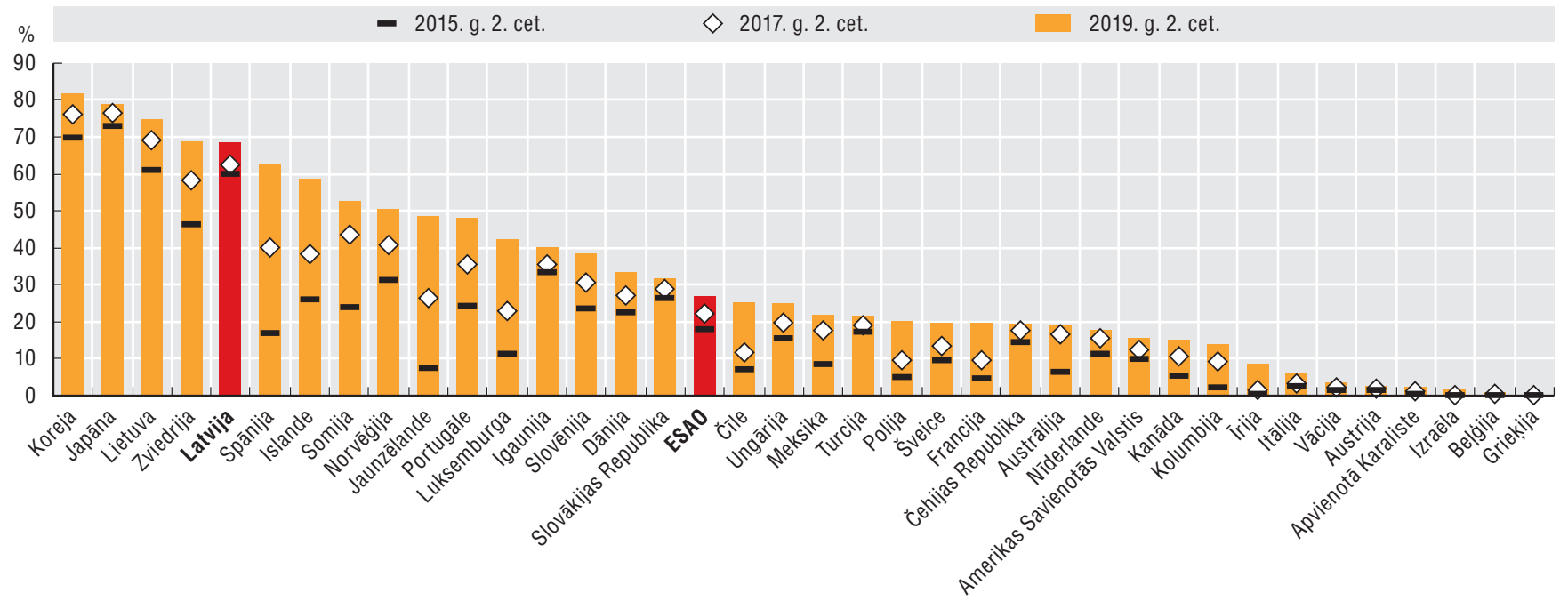

Piezīmes. Austrālija: ziṇotos datus kopš 2018. gada decembra ievāc jauna juridiskā persona, izmantojot atšķirīgu metodoloǵiju. No 2018. gada decembra ziṇotie rādītāji aptver sērijas pārtraukumu un nav salīdzināmi ar iepriekšējiem datiem nevienam platjoslas mērījumam, par ko Austrālija ziṇoja ESAO. Optiskās šḳiedras kabel̦u ESAO definīcija ievērojami atšḳiras no Austrālijas ziṇojumos parasti izmantotajām optiskās šḳiedras kabeḷu klasifikācijām. Šajos attēlos savienojumi, kas Austrālijā ir zināmi kā "Optiskās šḳiedras kabeḷu nodrošināšana līdz mezglam" (FTTN) un "Optiskās šḳiedras kabeḷu nodrošināšana līdz žogam" (FTTC), ir aplūkoti kā DSL savienojumi, savukārt "Optiskās šk̦iedras kabel̦u nodrošināšana līdz galalietotājam" (FTTP) un "Optiskās šḳiedras kabel̦u nodrošināšana līdz ēkai" (FTTB) tiek aplūkoti kā optiskās škiedras savienojumi. Dati par tehnoloǵijas tipu pirms 2016. gada 2. ceturkšņa ir jāuzskata par norādošiem līdz turpmākam paziņojumam. Dati par Izraēlu ir aprēḳināti ESAO. Šveicei un Amerikas Savienotajām Valstīm norādīti pagaidu dati.

Avots: OECD Broadband Portal (datubāze), www.oecd.org/sti/broadband/oecdbroadbandportal.htm (piekḷuve 2020. gada 6. maijā).

\section{4. attēls. Fiksētās platjoslas abonenti Latvijā pēc tehnologijas, 2015. gada - 2019. gada 2. ceturksnis}

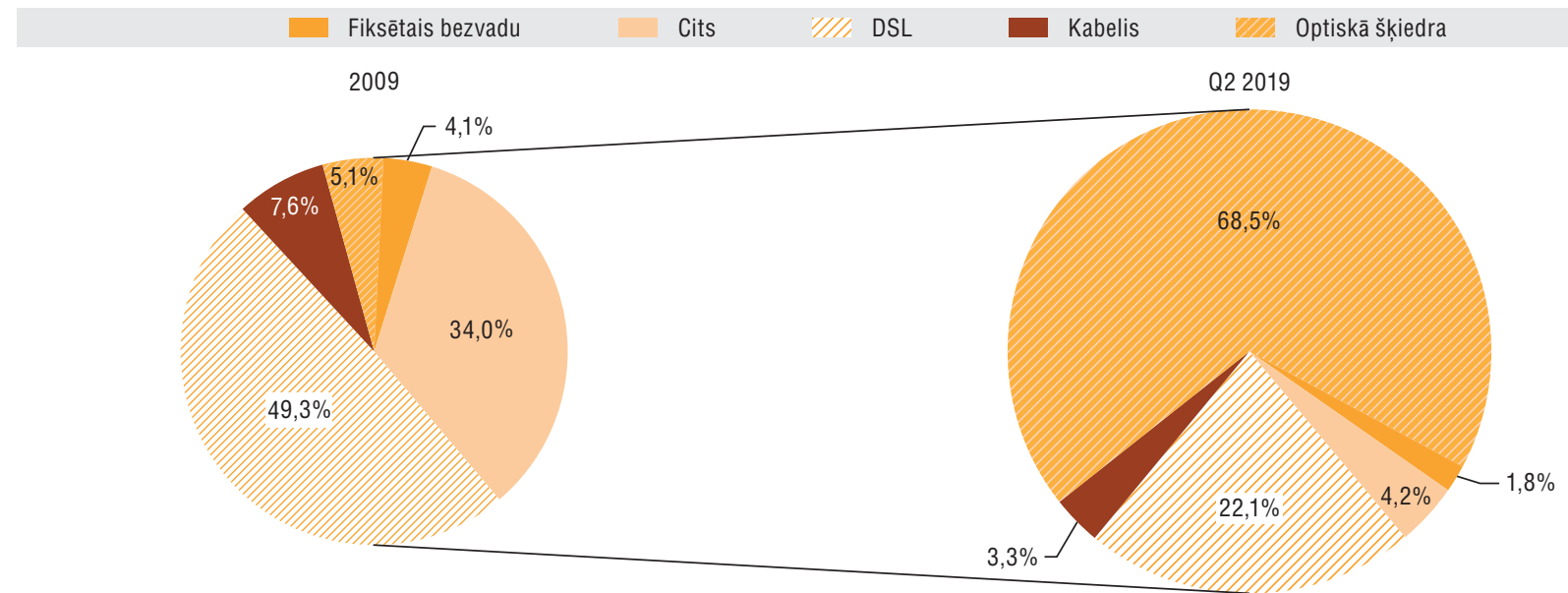

Piezīme: DSL = Domēnspecifiska valoda. Satelīta abonentu skaits Latvijā 2009. gadā bija neievērojams (apmēram 0,01 \% no kopskaita) un 2019. gada jūnijā nulle.

Avots: OECD Broadband Portal (datubāze), www.oecd.org/sti/broadband/oecdbroadbandportal.htm (piekḷuve 2020. gada 6. maijā).

Tomēr Latvijā pastāv atšk̦irības starp pilsētvides un lauku teritorijām, it ìpaši salīdzinot Rīgu ar citiem reǵioniem. Rīgā optiskās šḳiedras savienojumu daḷa ir 80,8 \%, bet ārpus galvaspilsētas — 58,2 \% (3.5. attēls). Šāda reǵionālā atšk̦irība apvienojumā ar faktu, ka gandrīz 20 \% mājsaimniecību nav fiksēto platjoslas savienojumu ar ātrumu virs $30 \mathrm{Mb} / \mathrm{s}$ (3.8. attēls), norāda uz būtisku savienojamības plaisu augstas kvalitātes komunikāciju pakalpojumos, kas Latvijā joprojām pastāv starp pilsētu un lauku teritorijām. Šìs plaisas aizpildīšana būs izšk̦iroši svarīga, lai vispusīgi sekmētu Latvijas ekonomikas un sabiedrības digitālo transformāciju. 
3.5. attēls. Fiksētās platjoslas abonenti Rīgā un ārpus tās pēc tehnoloǵijas, 2018. gads

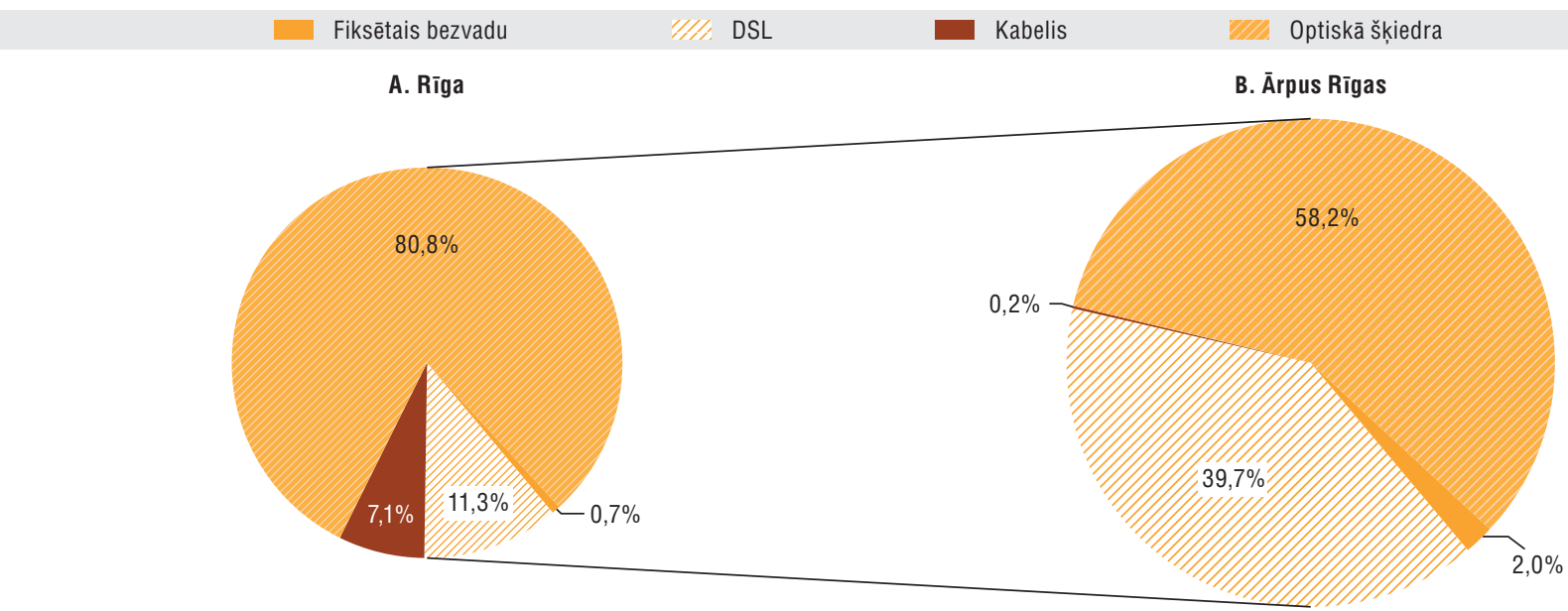

Piezime: DSL = Domēnspecifiska valoda. 2018. gada decembra dati.

Avots: ESAO, pamatojoties uz SPRK informāciju.

\section{Platjoslas ātrumi}

Vairāki ātruma testu avoti piel̦auj dažādus izmērītos platjoslas pakalpojumu lejupielādes ātrumus. Šajā sadaḷā ir izmantoti trīs dažādi avoti: Ookla un M-Lab nodrošina plašāku ieskatu par tīkliem, savukārt tiešsaistes spēḷu platforma Steam nosaka savu lietotāju ātrumus. Saskaṇā ar Ookla datiem par platjoslas sakaru pakalpojumiem Latvija ierindojas 17. vietā no ESAO valstīm ar vidējo faktisko lejupielādes ātrumu 79,8 Mb/s, kamēr ESAO vidējais rādītājs 2019. gada jūlijā ir 78,3 Mb/s (Ookla, 2019). M-Lab un Steam apkopotie dati par fiksētu platjoslas savienojumu vidējiem lejupielādes àtrumiem ierindo Latviju 12. un 16. vietā starp ESAO valstīm attiecīgi ar $32,7 \mathrm{Mb} / \mathrm{s}$ un $35,7 \mathrm{Mb} / \mathrm{s}$ (3.6. attēls).

\section{6. attēls. Fiksēto platjoslas savienojumu pieredzētie lejupielādes caurmēra ātrumi ESAO valstīs, 2019. gada jūlijs}

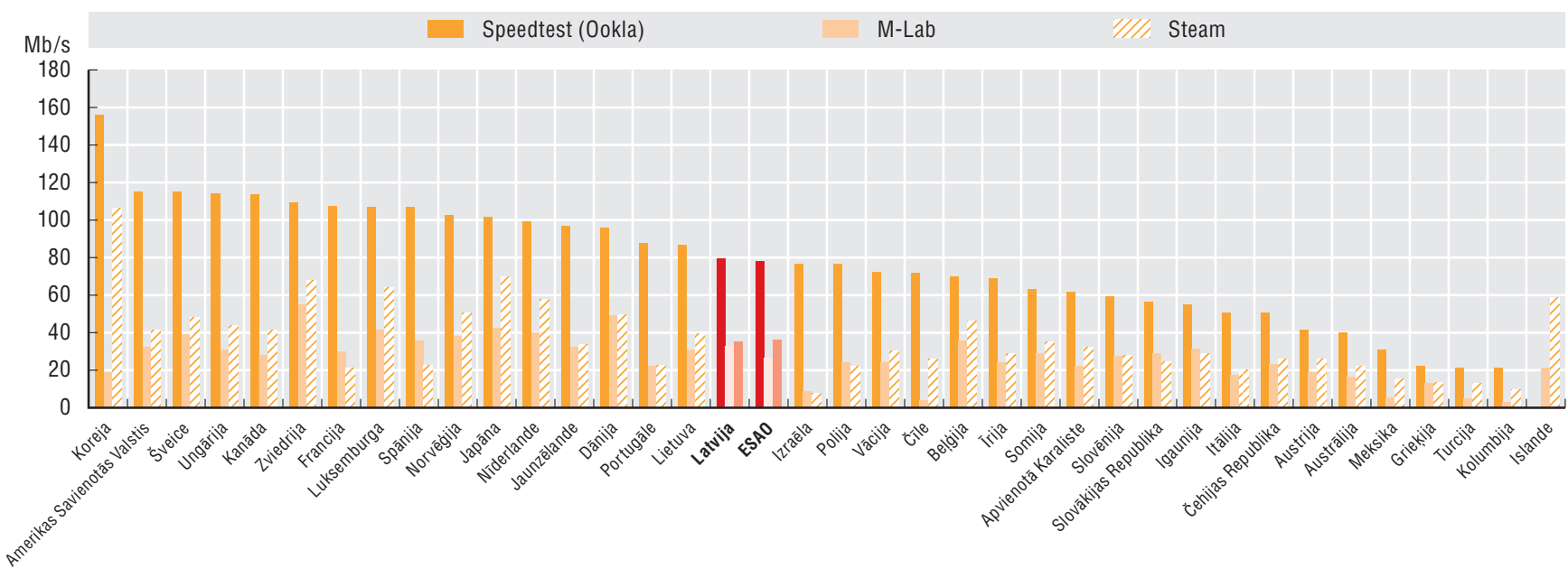

Piezīmes: Mb/s = megabiti sekundē. Ātruma testa (Ookla) dati attiecas uz 2019. gada jūliju. M-Lab (Pasaules platjoslas ātruma līga) ātrumi tika mērīti periodā no 2018. gada 9. maija līdz 2019. gada 8. maijam. Steam dati par 2019. gada jūliju.

Avots: Ookla (2019), “Speedtest”, www.speedtest.net/global-index (piekluve 2020. gada 9. maijā); M-Lab (2019), “Pasaules platjoslas ātruma līga”, www.cable. co.uk/broadband/speed/worldwide-speed-league (piekḷuve 2020. gada 9. maijā); Steam (2019), https://store.steampowered.com/stats/content (piekḷve 2020. gada 9. maijā).

Attiecībā uz abonentiem katram reklamētajam ātruma līmenim Latvijā ir augsta fiksēto platjoslas abonentu dạla ar līgumā noteiktajiem ātrumiem virs $100 \mathrm{Mb} / \mathrm{s}$. Šie abonenti pārstāv 59 \% no kopējiem fiksētās platjoslas abonenti jeb 16 abonentus uz 100 iedzìvotājiem (3.7. attēls). 
3.7. attēls. Fiksētās platjoslas abonenti uz 100 iedzivotājiem ESAO valstīs, pēc ātruma līmeṇiem, 2019. gada jūnijs

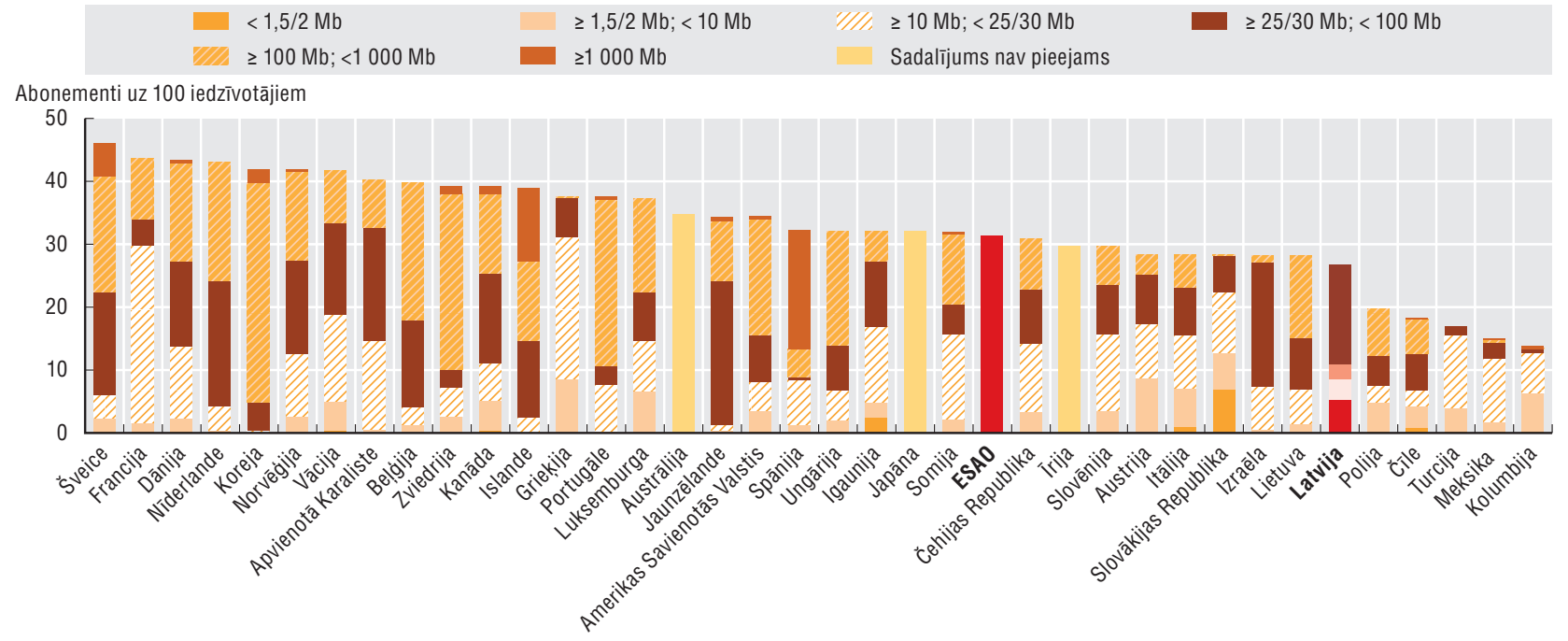

Piezīme: $\mathrm{Mb}=$ megabiti. Šveice un Amerikas Savienotās Valstis: dati par 2019. gada jūniju ir aptuveni.

Avots: ESAO (2020c), OECD Broadband Portal (datubāze), www.oecd.org/sti/broadband/oecdbroadbandportal.htm (piekḷuve 2020. gada 6. maijā).

Kaut arī Latvija ir progresējusi, nodrošinot ātrdarbīgas fiksētās platjoslas pieejamību savā teritorijā, pastāv pārklājuma plaisas (piemēram, savienojumiem virs $30 \mathrm{Mb} / \mathrm{s}$ ) valsts lauku un attālajās teritorijās. 2018. gadā 93 \% Latvijas mājsaimniecību tās kopējā teritorijā atradās vietās (iekḷaujot gan lauku, gan pilsētvides teritorijas), kur pieejamais fiksētas platjoslas savienojumu ātrums bija virs $30 \mathrm{Mb} / \mathrm{s}$, bet līdzīgu pakalpojumu pārklājums lauku teritorijās bija 82,1 \%, proti, atškịīās par apmēram 11 procentpunktiem. Fiksētās platjoslas virs $30 \mathrm{Mb} / \mathrm{s}$ pārklājums Latvijā ievērojami pārsniedz Eiropas vidējo rādītāju (ES 28), kas ir 83,2 \% teritorijā kopumā un tikai 52,3 \% lauku teritorijās, bet atpaliek no vadošajām ESAO valstīm, piemēram, Nīderlandes, Islandes, Beḷgijas, Šveices un Apvienotās Karalistes (3.8. attēls).

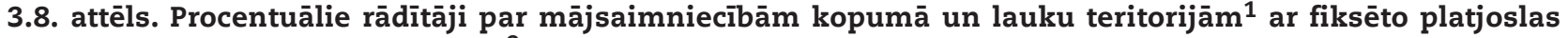
pārklājumu ${ }^{2}$ vismaz $30 \mathrm{Mb} / \mathrm{s}$ ESAO valstīs, 2018. gada jūnijs

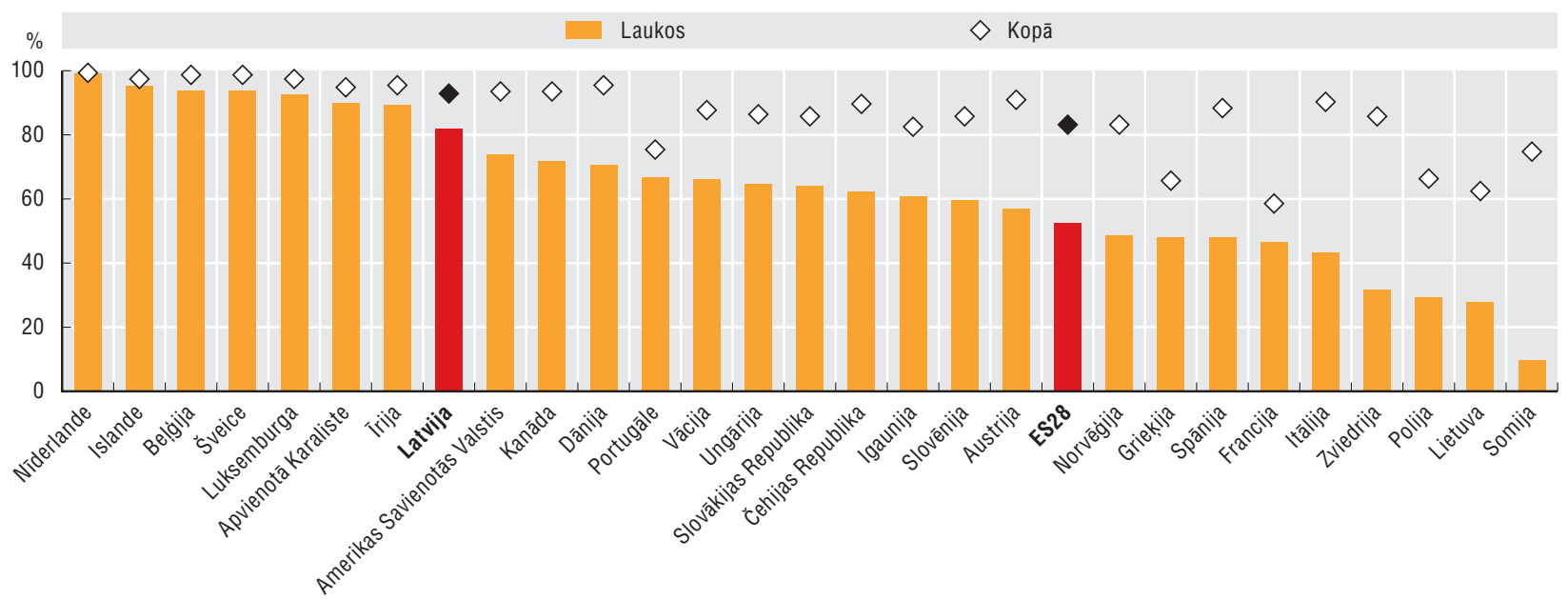

1. Lauku teritorijas: ES valstīs lauku teritorijas ir tās, kurās iedzīvotāju blīvums ir mazāk nekā 100 uz kvadrātkilometru. Kanādā lauku teritorijas ir tās, kurās iedzīvotāju blīvums ir mazāk nekā 400 uz kvadrātkilometru. Amerikas Savienotajās valstīs lauku teritorijas ir tās, kurās iedzīvotāju blīvums ir mazāk nekā 1000 uz kvadrātjūdzi vai 386 uz kvadrātkilometru.

2. Fiksētās platjoslas pārklājums: ES valstīm tika izmantots NGA tehnoloǵiju (VDSL, FTTP, DOCSIS 3.0) pārklājums, kas spēj nodrošināt lejupielādi vismaz $30 \mathrm{Mb} / \mathrm{s}$. Amerikas Savienotajām Valstīm tika izmantots fiksētās virszemes platjoslas pārklājums, kas spēj nodrošināt lejupielādi 25 Mb/s un augšupielādi $3 \mathrm{Mb} / \mathrm{s}$; dati attiecas uz 2016. gadu.

Avots: ESAO aprēk̦ini, kas balstīti uz CRTC (2019), Komunikāciju uzraudzī bas ziṇojumsu [Communications Monitoring Report], https://crtc.gc.ca/eng/ publications/reports/policymonitoring/2019/index.htm; Eiropas Komisiju (2018a), Pétījumu par platjoslas pārklājumu [Study on Broadband Coverage in Europe], https://ec.europa.eu/newsroom/dae/document.cfm?doc_id=62760; FCC (2019), Platjoslas izvietojuma zin,ojumu [Broadband Deployment Report], www.fcc.gou/reports-research/reports/broadband-progress-reports/2019-broadband-deployment-report. 
Tomēr ātrgaitas, ilgtermiṇa evolūcijas (LTE) mobilā pārklājuma ziṇā lauku teritorijās Latvijas sniegums ir zem Eiropas (ES 28) vidējā līmeṇa. LTE pārklājuma ES 28 caurmēra rādītājs ir 96,1 \% lauku teritorijās, savukārt vadošās valstis Dānija un Zviedrija ziṇo par 100 \% LTE pārklājumu šajās teritorijās; tomēr Latvijā LTE aptver tikai 95 \% lauku teritoriju atšḳirībā no 98,6 \% pilsētvides teritorijās (3.9. attēls).

\section{9. attēls. Mājsaimniecību ar LTE mobilo pārklājumu procentuālais rādītājs kopumā un lauku ${ }^{1}$ 2018. gada jūnijs}

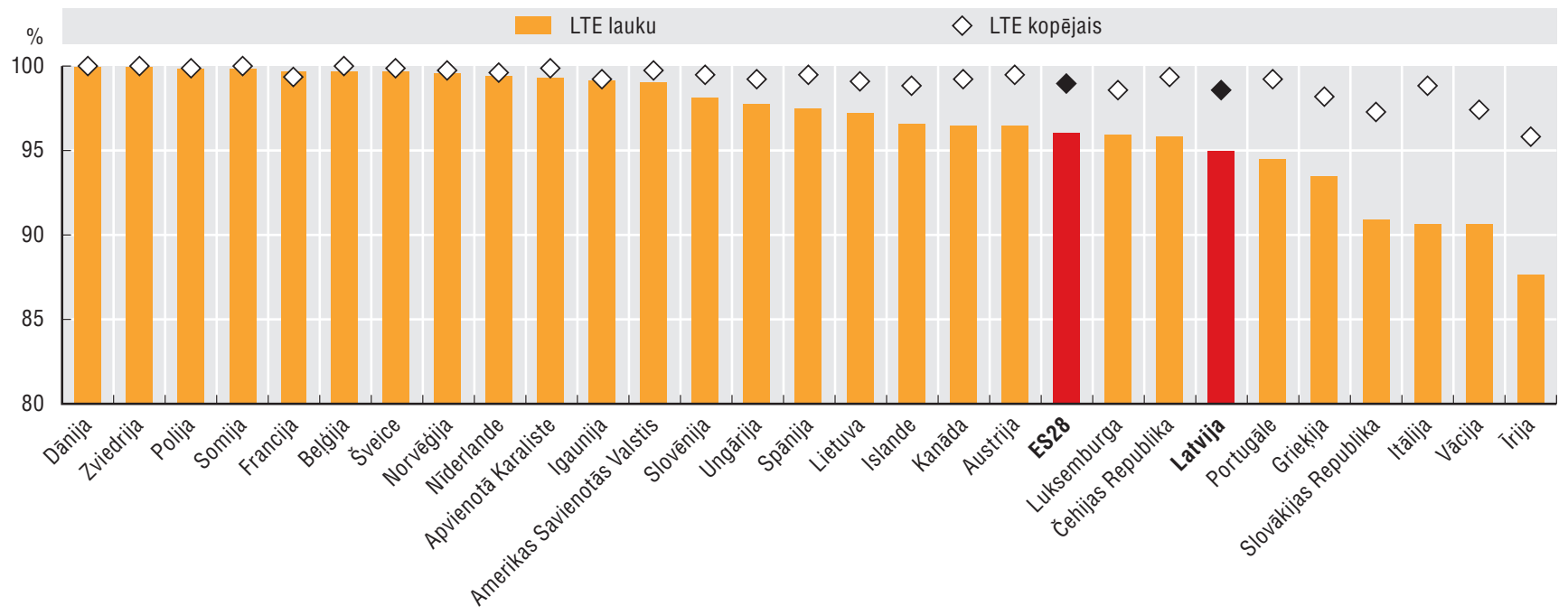

1. Lauku teritorijas: ES valstīs lauku teritorijas ir tās, kurās iedzīvotāju blīvums ir mazāk nekā 100 uz kvadrātkilometru. Kanādā lauku teritorijas ir tās, kurās iedzīvotāju blīvums ir mazāk nekā 400 uz kvadrātkilometru. Amerikas Savienotajās valstīs lauku teritorijas ir tās, kurās iedzìvotāju blīvums ir mazāk nekā 1000 uz kvadrātjūdzi vai 386 uz kvadrātkilometru.

Avots: ESAO aprēḳini, kas balstīti uz CRTC (2019), Komunikāciju uzraudzī bas ziṇojumsu [Communications Monitoring Report]; https://crtc.gc.ca/eng/ publications/reports/policymonitoring/2019/index.htm; Eiropas Komisiju (2018a), Pētījumu par platjoslas pārklājumu [Study on Broadband Coverage in Europe], https://ec.europa.eu/newsroom/dae/document.cfm?doc_id=62760; FCC (2019), Platjoslas izvietojuma zin,ojumu [Broadband Deployment Report], www.fcc.gou/reports-research/reports/broadband-progress-reports/2019-broadband-deployment-report.cymonitoring/2019/index.htm.

\section{Fiksēto un mobilo sakaru platjoslas pakalpojumu cenas}

Fiksēto sakaru platjoslas savienojamības cenas Latvijā ir ievērojami zemākas nekā ESAO caurmērā gan "zema lietojuma" (20 GB), gan "augsta lietojuma" (200 GB) fiksēto sakaru platjoslas grozos. 2019. gada decembrī cenas "zemam lietojumam" (20 GB) un "augstam lietojumam" (200 GB) ir nolimen,otas attiecīgi tuvu pie USD PPP 18,38 un USD PPP 22.59, savukārt ESAO vidējie rādītāji bija USD PPP 31,33 un USD PPP 41,80 katram grozam. Kaut arī ESAO vidējās cenas par fiksēto sakaru platjoslas piekḷvi ir šķietami samazinājušās periodā no 2013. līdz 2019. gadam, Latvijā šāda tendence nav novērota. Tajā pašā periodā cenas par fiksēto platjoslas sakaru piedāvājumu "augsta lietojuma" groziem ir nedaudz pieaugušas no USD PPP16,83 līdz USD PPP 22,89 pašreizējam līmenim, savukārt “zema lietojuma” fiksēto sakaru platjoslas grozu cena ir pieaugusi no USD PPP 11,71 līdz USD PPP 18,38 (3.10. attēls).

Arī attiecībā uz mobilo sakaru savienojamību cenas mobilo sakaru platjoslas pakalpojumiem Latvijā “zema lietojuma” un "augsta lietojuma” groziem ir zemākas nekā ESAO caurmērā, tomēr atšḳirība starp Latvijas cenu līmeṇiem un ESAO vidējiem rādītājiem ir mazāka nekā fiksēto sakaru platjoslas groziem. Pieejamie dati no 2016. līdz 2019. gadam rāda izteiktu cenu pieaugumu visiem groziem. Gan "zema lietojuma" grozam (100 zvani + 500 MB), gan "vidēja lietojuma" grozam (300 zvani + 1 GB) cenas no USD PPP 15,37 2016. gadā ir pieaugušas līdz USD PPP 19,32. "Augsta lietojuma" grozam (900 zvani + 2 GB) cenas ir pieaugušas no USD PPP 20,11 līdz USD PPP 24,58 (3.11. attēls).

\section{Mobilo datu lietojums}

2018. gadā mobilo datu lietojums vienam mobilo sakaru platjoslas abonentam Latvijā bija 12,8 GB mēnesī. Latvijas vidējais mobilo datu lietojums mēnesī ir daudz augstāks par ESAO vidējo, kas ir 4,7 GB mēnesī, un atpaliek tikai no Somijas un Austrijas, kur datu lietojums vienam abonentam mēnesī attiecīgi sasniedz 19,4 GB un 16,4 GB (3.12. attēls). Mobilo datu lietojuma pieaugums atspoguḷo augošo prasību pēc tīkla kapacitātes. 


\subsection{0. attēls. Fiksēto sakaru platjoslas cenu tendences Latvijā un ESAO valstīs, 2013. gada jūnijs - 2019. gada decembris}
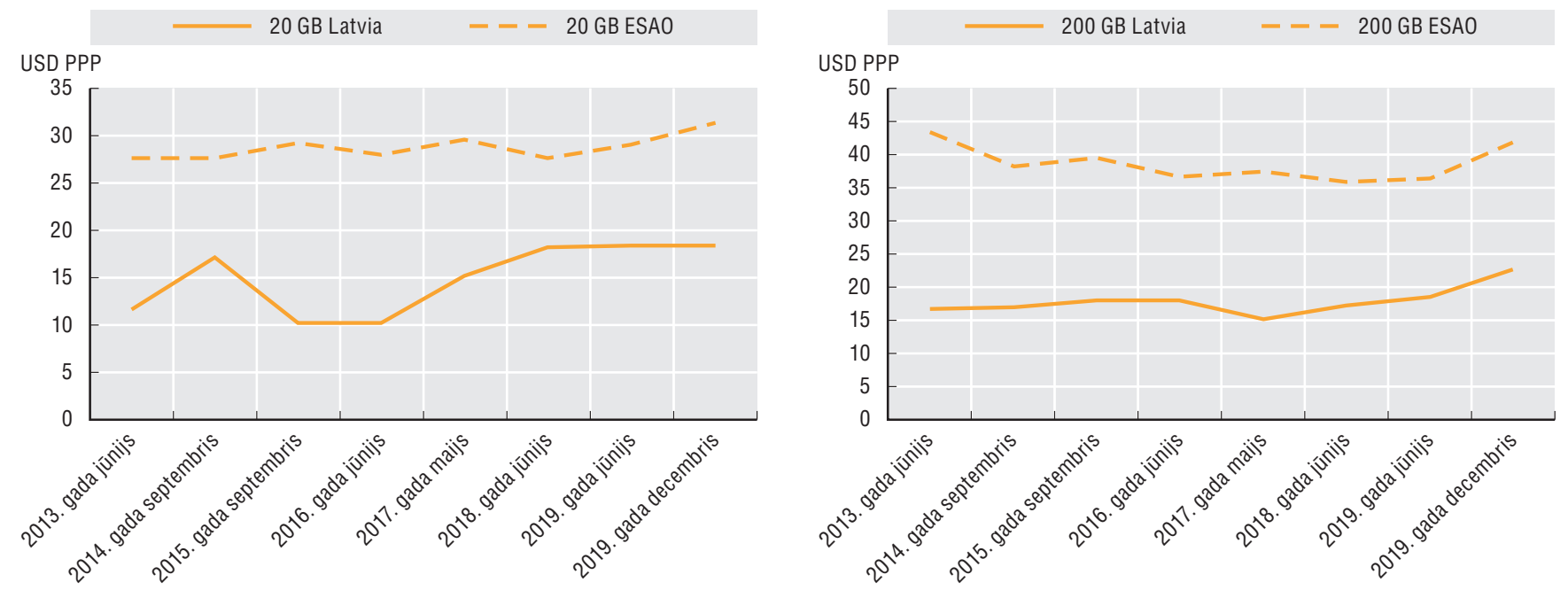

Piezīme: PPP = pirktspējas paritāte; GB = gigabaits. 2019. gada decembra dati.

Avots: ESAO aprēḳini, pamatojoties uz Strategy Analytics sniegtajiem datiem.

3.11. attēls. Mobilo sakaru platjoslas cenu tendences Latvijā un ESAO valstīs, 2013. gada maijs - 2019. gada novembris

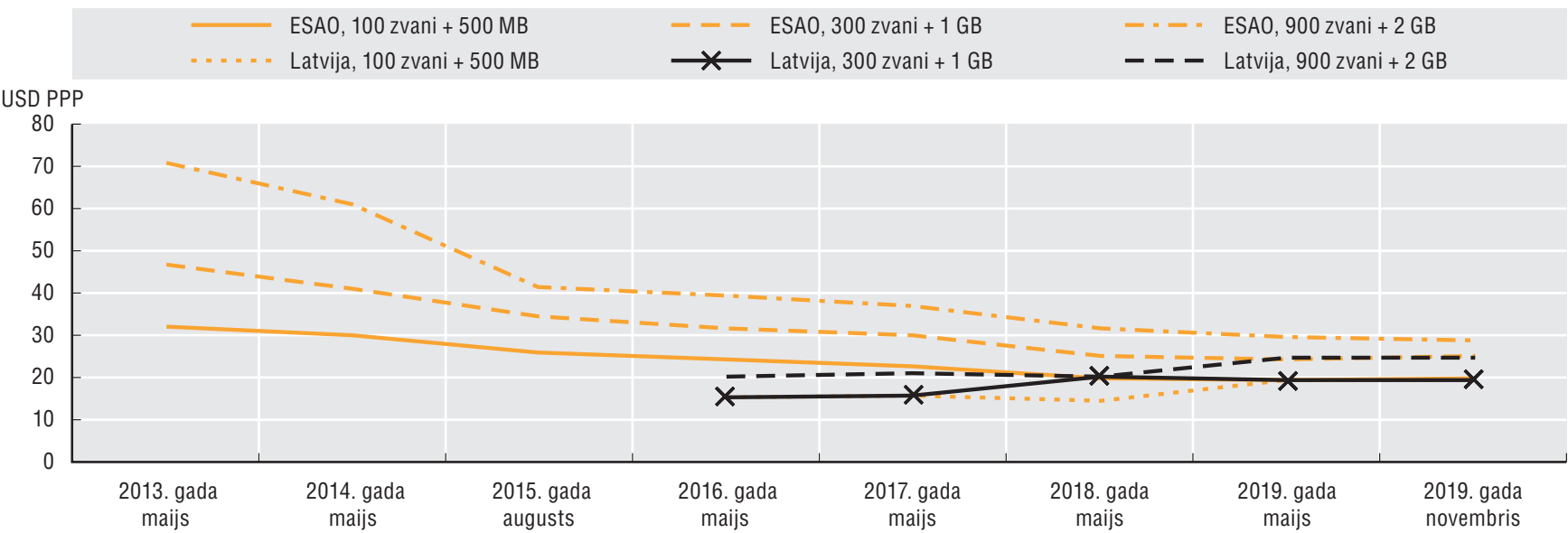

Piezīme: $\mathrm{PPP}=$ pirktspējas paritāte; $\mathrm{MB}=$ megabaits; $\mathrm{GB}$ = gigabaits. 2019. gada novembra dati.

Avots: ESAO aprēḳini, pamatojoties uz Strategy Analytics datiem.

\section{Lietu internets}

Lietu internets (IoT) atspoguḷo nākamo soli informācijas un komunikāciju tehnoloǵiju (IKT), sabiedrības un ekonomikas konverğencē. Kaut arī IoT ietekme uz izaugsmi un produktivitāti ESAO valstīs vēl ir jānosaka sistemātiski (ESAO, 2019a), IoT ir potenciāls sekmēt inovāciju un efektivitāti vietējo un valsts mēroga mērḳu sasniegšanu. Lai šos mērk̦us sasniegtu, jābūt pieejamām komunikāciju tehnologiijām un citiem sekmējošiem faktoriem, kas atbalstītu datu plūsmas.

Latvijā trīs mobilie un trīs fiksētie operatori nodrošina mašinas-mašinas (M2M) abonentus - IoT apakškopu. No 2019. gada jūnija M2M iegulto ierīču ziṇā Latvijai bija 18,5 M2M kartes uz 100 iedzīvotājiem (proti, 360000 M2M kartes kopumā). Latvijas sniegums M2M izplatības ziṇā ir tieši zem ESAO vidējā rādītāja, kas ir 22 \%; tomēr atpaliek no ESAO līderēm, piemēram, Zviedrijas (140,6 \%), Austrijas (48,2 \%), Itālijas, (37,7 \%), Amerikas Savienotajām Valstīm (37,3 \%) un citām (3.13. attēls). Tomēr būtu svarīgi atzīmēt, ka M2M dati dažās ESAO valstīs, piemēram, Zviedrijā, var iekḷaut ierīces, kas iespējams, atrodas citās valstīs (piemēram, SIM kartes automobiḷos). Regulators Latvijā (SPRK) neievāc informāciju, kas attiecas uz operatora nosacījumu par M2M ierīču lietošanu ārvalstīs. 


\subsection{2. attēls. Mobilo datu lietojums uz mobilo sakaru platjoslas abonentu atsevišķās ESAO valstīs, 2016.-2018 gads}

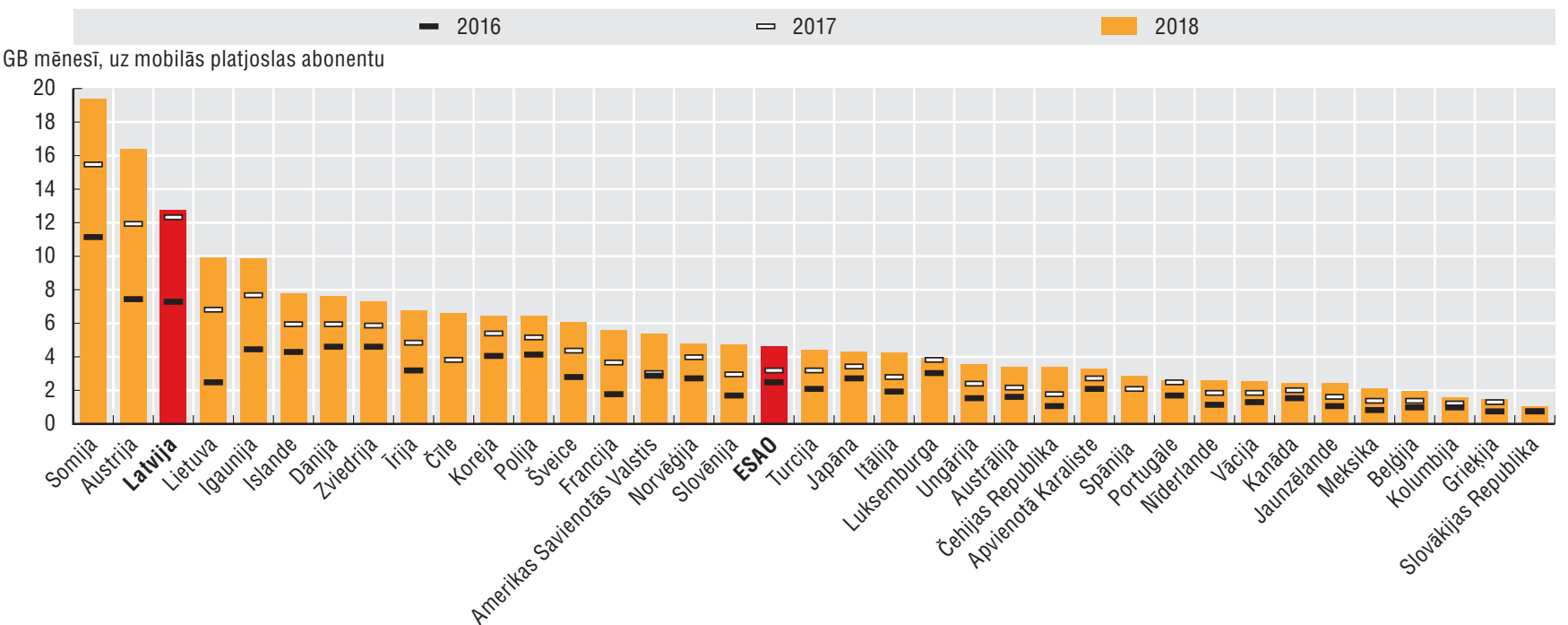

Piezīmes: GB = gigabaits. Austrālija: ziṇotos datus kopš 2018. gada decembra ievāc jauna juridiskā persona, izmantojot atšḳirīgu metodologiiju. No 2018. gada decembra ziṇotie rādītāji aptver sērijas pārtraukumu un nav salīdzināmi ar iepriekšējiem datiem nevienam platjoslas mērỉjumam, par ko Austrālija ziņoja ESAO. Dati par Šveici ir provizoriski.

Avots: ESAO (2020b), OECD Broadband Portal (datubāze), www.oecd.org/sti/broadband/oecdbroadbandportal.htm (piekḷuve 2020. gada 6. maijā).

\subsection{3. attēls. M2M/integrētie šūnu mobilo sakaru abonenti atsevišḳās ESAO valstīs, 2019. gada jūnijs}

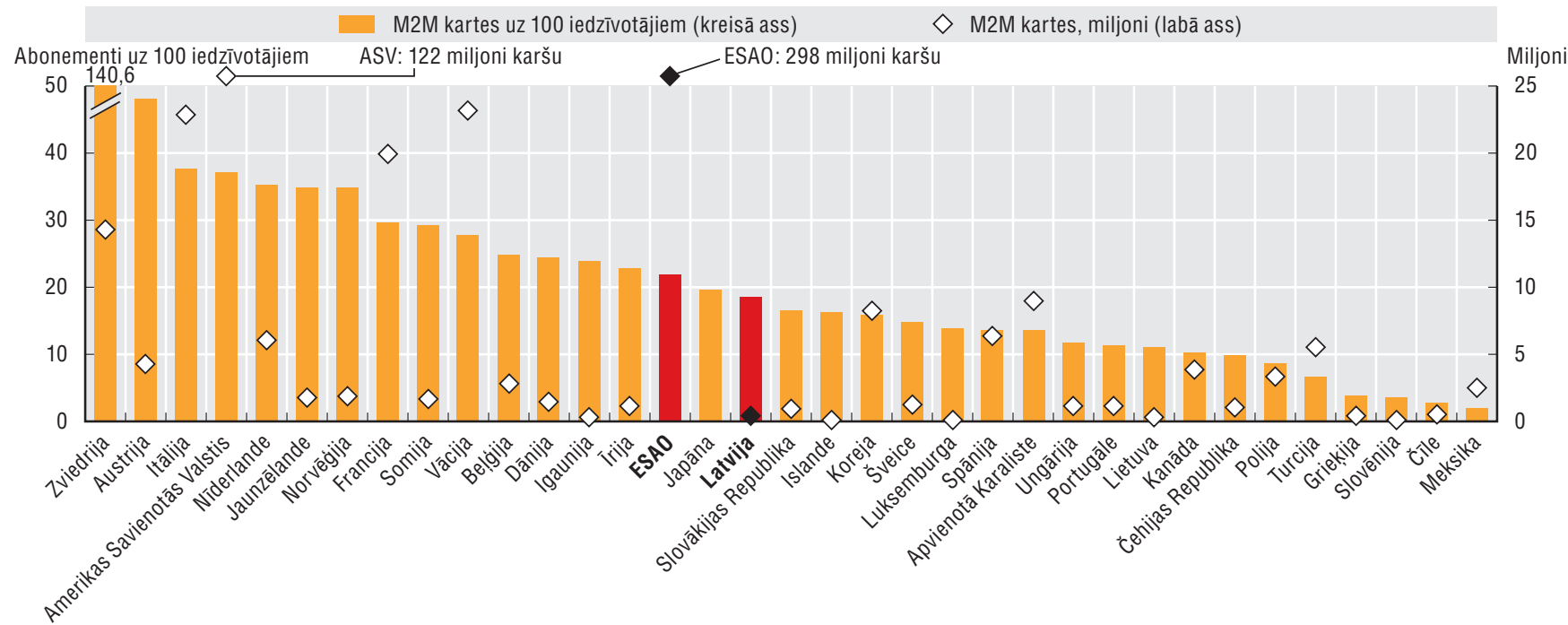

Piezīme. ESAO definē mašīnu-mašīnu (M2M) mobilajos tỉklos kā "lietošanai mašīnās un ierīcēs (automašīnās, viedajās mērierīcēs un patēerētāju elektronikā) pieškirirto SIM karšu skaitu, kas nav patērētāja abonenta daḷa". Tas nozìmē, ka sargspraudṇi mobilo datu un planšetdatoru abonentiem ir jāskaita saskañā ar mobilās platjoslas definīciju, bet SIM kartes personīgajās navigācijas ierīcēs, viedajās mērierīcēs, vilcienos, automobilos un citur ir jāskaita M2M kategorijā. Austrālija: ziṇotos datus kopš 2018. gada decembra ievāc jauna juridiskā persona, izmantojot atšḳirīgu metodoloǵiju. No 2018. gada decembra ziṇotie rādītāji aptver sērijas pārtraukumu un nav salīdzināmi ar iepriekšējiem datiem nevienam platjoslas mērījumam, par ko Austrālija ziṇoja ESAO. Dati par Šveici ir provizoriski. Dati par Amerikas Savienotajām Valstīm ESAO pagaidām ir aptuveni.

Avots: ESAO (2020b), OECD Broadband Portal (datubāze), www.oecd.org/sti/broadband/oecdbroadbandportal.htm (piekḷuve 2020. gada 6. maijā).

Latvijā notiek diskusijas par jaunu numerācijas diapazonu M2M sakariem. Saskaṇā ar esošo regulējumu operatori piedāvā IoT/M2M pakalpojumus, pamatojoties uz tiem pieškiirtās mobilās numerācijas resursiem. Kaut arī pašreizējā numerācijas plānā ir norādīts, ka papildu numerācijas resursu piešķiršana M2M pakalpojumiem nav nepieciešama, nākamajā SM ziṇojumā tiek ieteiktas valsts numerācijas plāna izmaiṇas. Šajā jaunajā priekšlikumā tiek plānots piešķirt 11 ciparu numerācijas resursu IoT/MSM 
eksteritoriālajai lietošanai, kā arī 8 ciparu numuru vietējai lietošanai un pakāpeniski ieviest maksu visiem numerācijas resursiem, kas pašlaik tiek izplatīiti bez maksas.

Turpmāk būs svarīgi nodrošināt IoT proaktīvās politikas attīstību, lai Latvijā saskaṇotu dažādus sektoru, nacionālos un reǵionālos uzdevumus. Valdībai būs svarīga loma, saistoties ar privāto sektoru un vietējām ieinteresētajām pusēm, lai izstrādātu risinājumus vietējām problēmām un IoT kapacitātei, kā arī palīdzētu virzìt IoT pakalpojumu pieprasījumu, vienlaikus nodrošinot arī normatīvo līdzsvaru un digitālās drošības un privātuma risku pārvaldību.

\section{Interneta plūsmu apmaingas punkti}

Labi funkcionējoša sakaru infrastruktūra iekḷauj interneta datplūsmas efektīvu apmaiṇu. Interneta plūsmu apmaiņas punkti (IPAP) ir svarīgi vietējās datplūsmas uzturēšanai (Weller and Woodcock, 2013). IPAP ir svarīgi arī starptautiskajai interneta datplūsmai, jo tie sekmē efektīvu iekšzemes datplūsmas apmainu. Datplūsmu, kas sākas un beidzas iekšzemē, var un vajadzētu maršrutēt vietēji. Šis pašas datplūsmas maršrutēšana caur citām valstīm palielina latentumu un izmaksas un bieži norāda uz interneta datplūsmas apmaiṇas tirgus neoptimālu attīstību konkrētajā valstī.

Latvijai ir trīs IPAP: Santa Monica Internet Local Exchange (SMILE, izveidots 2005. gadā), Latvijas interneta apmaiñas punkts (LIX, izveidots 2007. gadā) un visnesenākais - MSK-IX (izveidots 2018. gadā) Rīgā. Lielākais IPAP pēc biedru skaita ir SMILE.

LIX pieder trim interneta pakalpojumu sniedzējiem (ISP): Tet (iepriekš Lattelecom), Latnet un Telia Latvija. Šḳiet, ka šī IPAP pārvaldība neatbilst labākajai starptautiskajai praksei. Piemēram, LIX ierobežo datplūsmu ar Latvijas prefiksiem, efektīvi novēršot tīklu starpsavienojumu optimizāciju ar starptautiskajiem dalībniekiem. Šis diezgan noslēgtais apmaiṇas plānojums aizkavē ilgtermiṇa datplūsmas izaugsmi, kā arī to organizāciju izaugsmi, kuras veic datplūsmas apmainu šajā apmain̄ā. Turklāt LIX izmanto 3. slāna dizainu (pakešu maršrutēšana kadru pārslēgšanas vietā), kam ir mazāka izmaksu efektivitāte un kas neḷauj tīkliem veidot bilaterālas vienādranga sesijas. Turpretim konkurētspējīgās un dinamiskās IPAP ekosistēmas nodrošina infrastruktūru tỉkla operatoriem, lai pielīdzinātu datplūsmu un veiktu tās apmaiṇu tā, kā tas vinịiem ir ērtāk.

No cenu perspektīvas ikmēneša izmaksas 10 gigabitu portam ar LIX (piemēram, vienādranga pieskaitāmās izmaksas, kas attiecas uz tranzīta izmaksām), ir salīdzinoši diezgan augstas. Cena par 10 gigabitu Ethernet savienojuma 40 \% izmantošanu mēnesī ir 53,20 centi / Mb/s. Salīdzinājumā ar to cena Amsterdamā (AMS-IX) ir 18 centi / Mb/s, bet Maskavā (MSK-IX) - 29,20 centi / Mb/s. ${ }^{1}$ SMILE un MSK-IX cenas nav publiski pieejamas.

SPRK neuzrauga IPAP sniegumu, jo šis uzdevums ir ārpus sakaru regulatora pilnvarām. SPRK ir atbildīga tikai par platjoslas kvalitātes mērījumiem no tīkla pieslēgumpunkta līdz IPAP, kur ir izvietoti regulatora mērījumu serveri. Datplūsmas apmaiṇas stāvoklim Latvijā veltīta analīze varētu palīdzēt noteikt esošās problēmas, izstrādāt iespējamos risinājumus un, ja to veiktu sadarbībā ar ieinteresētajām pusēm, varētu turpināt IPAP snieguma uzlabošanu un vietēji palielināt vietējās datplūsmas apmaiṇas apjomu.

Viens no interneta nākotnes potenciālajiem izaicinājumiem ir spēja savienot desmitiem miljardu ierīču. Galvenais resurss, kas ir nepieciešams ne tikai mērogojamības nodrošināšanai, bet arī drošības uzlabošanai, ir interneta protokola (IP) jaunā versija IPv6, kas aizstāj lielā mērā izsmelto IP priekšteci Ipv4 attiecībā uz nepiešķirto adrešu izplatīšanu. Atbalsts IPv6 izvietošanai ir bijis ilgtermiņa mērḳis ESAO valstīs. Tomēr tā pien̦emšana ir bijusi lēnāka nekā paredzēts, un tas var kavēt jaunu pielietojumu un pakalpojumu attīstību (ESAO, 2014, 2018b).

Attiecībā uz IPv6 ieviešanu vairāki avoti liecina, ka Latvija ievērojami atpaliek no ESAO vidējā līmeṇa. Piemēram, saskaṇā ar Google datiem IPv6 ieviešana 2020. gada jūnijā sasniedza 6,7 \%, salīdzinot ar ESAO vidējo rādītāju, kas ir 22,4 \%). Tajā pašā periodā līmenis Beḷgijā un Vācijā, kas ir ESAO līderes IPv6 ieviešanā, bija attiecīgi 55,7 \% un 49,7 \% (3.14. attēls). APNIC un Akamai 2020. gada jūnija dati parāda, ka IPv6 ieviešana Latvijā bija attiecīgi 6,9 \% un 10,3 \%, bet ESAO vidējie rādītāji $24,4 \%$ un 23,5 \%. Lai sniegtu atbalstu Ipv6 ieviešanai, jaunā 2019.-2020. gada kiberdrošǐbas stratēgija 
ir izvirzijjusi mērḳi, ka līdz 2020. gada beigām SM un Vides aizsardzības un reǵionālās attīstības ministrijai (VARAM) ir jāīsteno pasākumu kopums, kas sekmē IPv6 lietošanu publiskajā sektorā izmantotajam IKT aprīkojumam.

\subsection{4. attēls. IPv6 ieviešana katrā atsevišķās ESAO valstīs, 2020. gads}

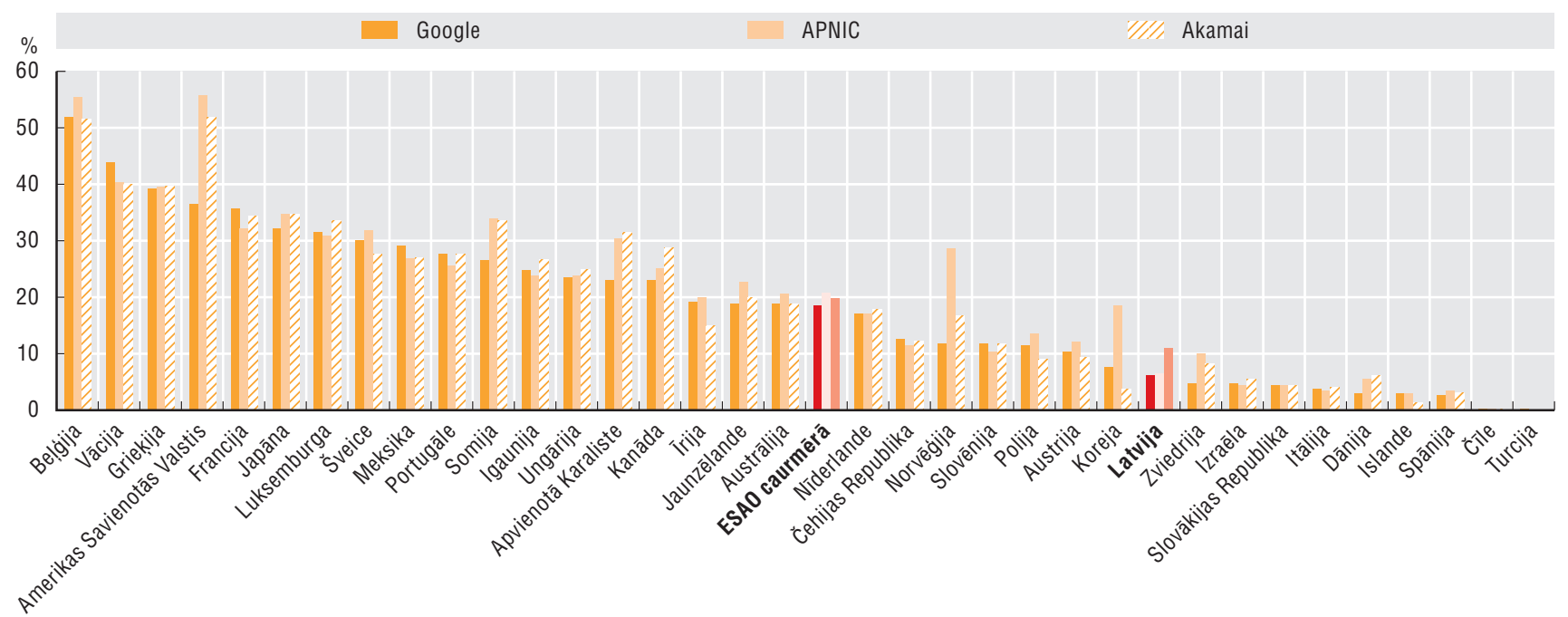

Avots: Google, 2020. gads, "Per-country IPv6 adoption", www.google.com/intl/en/ipv6 (piekḷuve 2020. gada jūnijā); APNIC (2020. g,), "IPv6 Measurement Maps", http://stats.labs.apnic.net/ipv6 (piekl̦uve 2020. gada jūnijā); Akamai (2020. g.), "IPv6 Adoption Visualization", www.akamai.com/uk/en/ourthinking/state-of-the-internet-report/state-of-the-internet-ipv6-adoption-visualization.jsp (piekḷuve 2020. gada jūnijā).

\section{Salkaru tirgu attīstỉba Latvijā}

Kopš 2013. gada ieṇēmumi sakaru sektorā ir bijuši stabili. Līdz 2018. gadam kopējie ieṇēmumi un ieguldījumi sakaru sektorā Latvijā ir attiecīgi bijuši 532 miljoni EUR un 78 miljoni EUR (3.15. attēls).

\subsection{5. attēls. Sakaru ieṇēmumu un ieguldỉjumu tendences Latvijā, 2010-18}

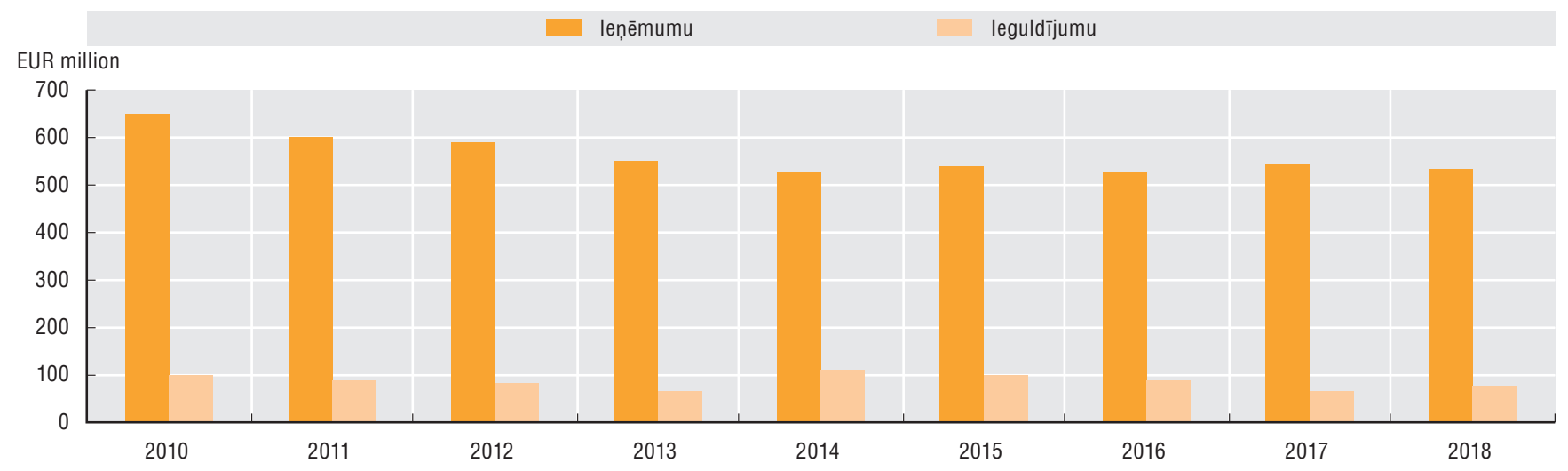

ESAO (2020a), ESAO telekomunikāciju un interneta statistika (datubāze) [OECD Telecommunications and Internet Statistics (database)], https://doi. org/10.1787/data-00170-en (piekḷve 2020. g. 9. jūlijā).

Latvijas sakaru sektorā ir daudzi tirgus dalībnieki, kas piedāvā pakalpojumus gan fiksētajos, gan mobilajos tirgos. Mazumtirdzniecības tirgū ir trīs galvenie dalībnieki fiksēto savienojumu tirgū un četri mobilo savienojumu tirgū (3.2. tabula).

Vairumtirdzniecības sektorā vairumtirdzniecības platjoslas pakalpojumus, kā arī torṇus un mastus nodrošina LVRTC, kas ir pilnībā valstij piederošs uznēemums. Papildus platjoslas pakalpojumiem LVRTC piedāvā mākoṇpakalpojumus, e-paraksta un digitālās drošìbas pakalpojumus. LVRTC ir atbildīgs arī par domēna nosaukuma "gov.lv" reǵistrēšanu un uzturēšanu. ${ }^{2}$ Papildus LVRTC Latvijā vēl četri operatori, kuri darbojas tikai vairumtirdzniecībā, piedāvā valsts un starptautiskos vārtejas pakalpojumus citiem tirgus uzṇēmumiem. 


\section{2. tabula. Latvijas sakaru tirgu galvenie dalïbnieki}

\begin{tabular}{|c|c|c|}
\hline Sakaru dalībnieks & Tirgi & Īpašumtiesību struktūra \\
\hline LVRTC & Tikai vairumtirdzniecības platjoslas pakalpojumi, TV un radio apraide & Latvijas valdība (100 \%) \\
\hline Tet (iepriekš Lattelecom) & $\begin{array}{l}\text { Fiksētās līnijas vēsturiskais piedāvājums fiksētajiem balss sakariem, } \\
\text { fiksētajiem platjoslas pakalpojumiem, maksas televīzijai un elektrībai }\end{array}$ & Latvijas valdība (51 \%) un Telia (49 \%) \\
\hline Baltcom & Fiksētie balss sakari, fiksētie platjoslas sakari, maksas televīijia un elektrīiba & Rpax One S.A. $(96,4 \%)$ \\
\hline Balticom & Fiksētie balss sakari, fiksētie platjoslas sakari, maksas televīiija & Privātīpašums \\
\hline $\csc$ & Fiksētie balss sakari un fiksētie platjoslas sakari & Privātīpašums \\
\hline LMT & Mobilie un fiksētie bezvadu pakalpojumi ${ }^{1}$ & $\begin{array}{l}\text { Sonera Holding }(24,5 \%) \text {, Telia }(24,5 \%) \text {, Tet } \\
(23 \%) \text {, LVRTC (23\%) un Latvijas valdība ( } 5 \%)\end{array}$ \\
\hline Tele2 & Mobilie & Tele2 Sverige Aktiebolag (100 \%) \\
\hline Bite & Mobilie & BITE Lietuva UAB (100\%) \\
\hline Triatel & Mobilie & Telekom Baltija \\
\hline Zetcom (Amigo) ${ }^{2}$ & Mobilie & $x$ \\
\hline
\end{tabular}

1. LMT ir mobilo sakaru operators, kas piedāvā fiksētu bezvadu sakaru pakalpojumus, tostarp balss un platjoslas pakalpojumus, izmantojot mobilās tehnologijas.

2. Zīmols Amigo, kura operators bija Zetcom, pārtrauca darbỉbu 2019. gada jūnijā, un tā klientus pārṇēma LMT.

Piezīme: $\mathrm{x}=$ nav piemērojams.

2018. gada decembrī SPRK bija reǵistrēti 278 sakaru operatori, kas norāda uz 12 \% samazinājumu salīdzinājumā ar 2017. gadu. No visiem pakalpojumu sniedzējiem 65 \% nodrošina platjoslas piekḷuves pakalpojumus (SPRK, 2018. g.).

\section{Fiksēto sakaru tirgus attīstības}

Latvijā vēsturiski klātesošs ir Tet (līdz 2019. gada aprīlim zīmols Lattelecom). Operatoram pieder valsts mēroga infrastruktūra, un tas ir lielākais fiksēto platjoslas savienojumu nodrošinātājs. Alternativi fiksētās platjoslas sakaru pakalpojumu nodrošinātāji (kabeḷu operatori un ISP) sāka izvietot savu infrastruktūru pēc liberalizācijas 2003. gadā un ir koncentrējušies optiskās šķiedras izvietošanai, vispirms ieguldot pilsētvides teritorijās un koncentrējoties uz optiskās šḳiedras kabeḷu nodrošināšanu līdz ēkai (FTTB). Kopš tā laika optiskās šḳiedras izvietošana ir izvērsta uz retāk apdzīvotajām teritorijām, kurās ir identificēta biznesa iespēja ieguldījumiem.

Reaǵējot uz to, Tet sāka ieguldīt Optiskās šḳiedras kabel̦u nodrošināšanā līdz galalietotājam (FTTH) 2006. gadā. Pašlaik Tet ir galvenais FTTH pakalpojumu sniedzējs, konkurējot ar alternatīvajiem FTTB pakalpojumu sniedzējiem. 2014. gadā Tet sāka izvietot VDSL2 vektorēšanas tehnoloǵiju, lai uzlabotu tā vara tīkla veiktspēju. Šāda infrastruktūras konkurence ir bijusi galvenais virzītājspēks, kas nosaka optiskās šḳiedras piekḷuves tīklu attīstību Latvijā.

Salīdzinoši bieži fiksēto sakaru tirgū ienāk un iziet l̦oti mazi operatori (Eiropas Komisija, 2019). 2018. gada decembrī Tet pārziṇā bija 56 \% fiksēto platjoslas sakaru abonenti, savukārt Baltcom šis rādītājs bija 13\%, Balticom $10 \%$, bet citiem operatoriem - 22 \%. Šajos 22 \% ir iekḷauti 154 operatori, no kuriem lielākā daḷa ir mazie (3.16. attēls). Tet tirgus daḷa ir pieaugusi salīdzinājumā ar 2010. gadu, kad tā pārziṇā bija 52 \%, bet samazinājusies salīdzinājumā ar 58,8 \% 2015. gada jūlijā. Tomēr tā joprojām ir augstāka nekā vēsturisko operatoru vidējā tirgus daḷa Eiropas Savienībā (40,3%) (Eiropas Komisija, 2018b). Pēdējā laikā "citu operatoru" skaits ir samazinājies, jo notikušas apvienošanās. Tomēr jāatzīmē, ka Latvijai nav noteiktu kritēriju par to, kas ir "mazs operators".

\section{Mobilo sakaru tirgus attistība.}

2020. gada maijā Latvijā bija trīs mobilo sakaru tīkla operatori (MSTO): Latvijas Mobilais Telefons (LMT), Tele2 un Bite Latvija (Bite). Triatel, kas piedāvāja CDMA pakalpojumus, atstāja mobilo sakaru tirgu 2020. gadā. Visi MSTO piedāvā GSM/UMT/LTE pakalpojumus. Latvijā 4G pārklājums aptver gandrīz $100 \%$ mājsaimniecību, un 4G pašlaik tiek piedāvāts paralēli ar 2G un 3G. No 2019. gada vidus operatoriem nav bijis plānu par savu $2 \mathrm{G}$ un $3 \mathrm{G}$ tīklu atslēgšanu tuvākajā nākotnē.

Kopš 2010. gada mobilo sakaru tirgus Latvijāi ir attīstījies un kḷvis mazāk koncentrēts salīdzinājumā ar 2018. gada decembri. Pēc tirgus dal̦as lielākais MSTO kopš 2010. gada ir bijis LMT, kura dal̦a tirgū ir 
samazinājusies no 49 \% līdz 39 \%, pēc tam Tele2 (samazinājusies no 37 \% līdz 34 \%) un Bite (pieaugusi no 12 \% līdz 21 \%) (3.17. attēls). Tomēr Amigo, kura operators bija Zetcom un kas bija vienīgais mobilo sakaru virtuālā tîkla operators (MSVTO) valstī, kā arī 100 \% LMT îpašumā, pārtrauca darbu, visus klientus pārvietojot pie sava vadošā tîkla pakalpojumu sniedzēja LMT, kaut arī tā mobilo platjoslas sakaru abonentu apjoms bija pieaudzis no 2 \% 2010. gadā līdz 6 \% 2018. gadā.

3.16. attēls. Fiksētaās platjoslas tirgus daḷas Latvijā, 2010. un 2018. g.

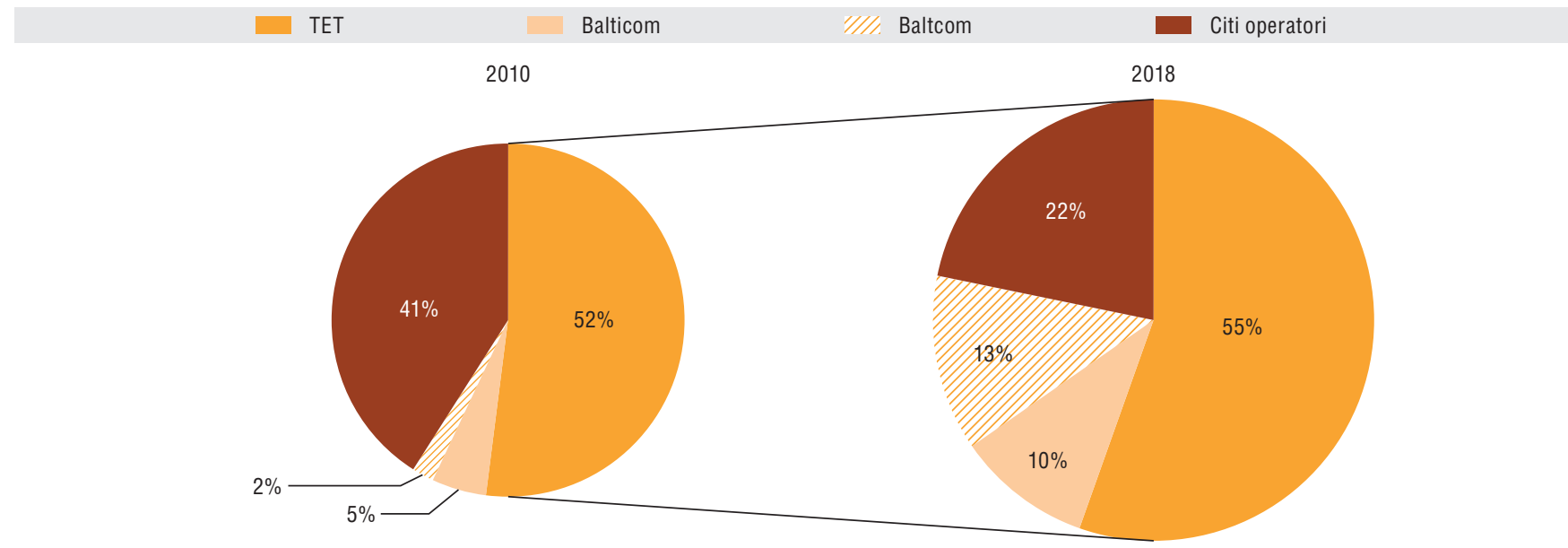

Avots: SPRK

3.17. attēls. Mobilo sakaru platjoslas tirgus daḷa, 2010. un 2018. g.

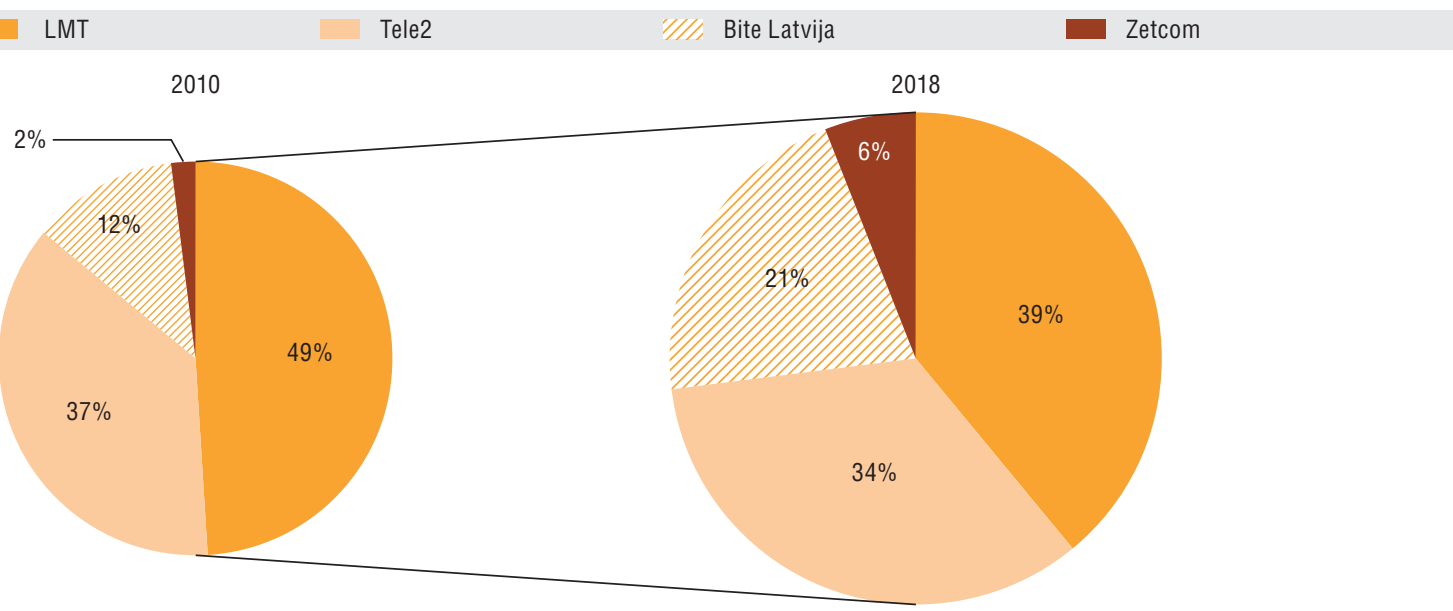

Avots: SPRK (2018a), Elektronisko sakaru nozares: faktos un skaitlos 2018, https://infogram.com/id-es_nozares_raditaji_2018-1hxj48qk0y154vg?live.

Citas pozitīvās norises Latvijas mobilo sakaru tirgū iekḷauj iniciatīvas, kas var samazināt ar tīklu izvēršanu saistītās MSTO izmaksas, piemēram, par tīklu koplietošanu. Tomēr tīklu koplietošana var arī ietekmēt tirgus konkurences dinamiku, tāpēc tā ir stingri jāuzrauga. Piemēram, 2019. gadā Tele2 un Bite parakstīja līgumu par tīklu koplietošanu Latvijā un Lietuvā. Abu operatoru tỉkli veidos kopēju koplietotu tīklu, kas iekḷauj radio tīklu un neiekḷauj tikai specifiskus klientu risinājumus. Partnerība iekḷauj esošo tīklu infrastruktūras koplietošanu, spektra koplietošanu un turpmāko $5 \mathrm{G}$ ieviešanu. Šis kopējais tîkls tiks izvietots pakāpeniski, sākot no 2021. gada, un pilna tīkla pabeigšana tiek plānota līdz 2023. gada decembrim. Katrai pusei būs 50 \% ìpašumtiesību kopuzṇēmumā (Tele2, 2019. gads).

\section{Spektra pieškiršana}

Viens no svarīgākajiem resursiem un mobilo sakaru tirgus priekšnosacījumiem ir spektra pieejamība. Pašlaik Latvijas valsts frekvenču plānā bezvadu platjoslas sakariem ir pieškirtas šādas frekvenču joslas: $450 \mathrm{MHz}, 800 \mathrm{MHz}, 900 \mathrm{MHz}, 1,5 \mathrm{GHz}, 1,8 \mathrm{GHz}, 2 \mathrm{GHz}, 2,3 \mathrm{GHz}, 2,6 \mathrm{GHz}, 3,4 \mathrm{GHz}$ un 3,6 GHz (3.18. attēls). Neraugoties uz spektra piešķīruma progresu, Latvijā pašlaik nav sekundāra spektra tirgus. Papildus labi 
izplānotām spektra izsolēm labi funkcionējoša sekundārā tirgus iespēja varētu uzlabot efektivitāti ši nepietiekamā resursa piešḳiršanā. Kopumā Latvijā kopš 2012. gada ir notikušas piecas spektra izsoles (3.3. tabula).

3.18. attēls. Spektra pieejamība Latvijā, 2019. g.

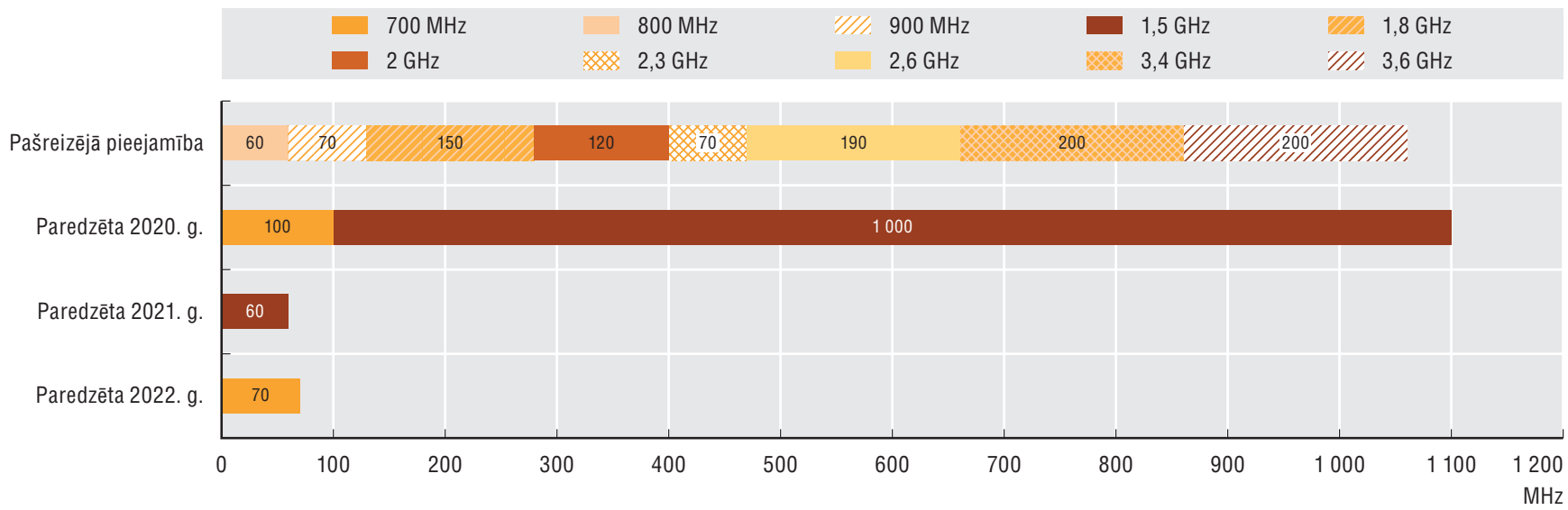

Piezime: Ziņojums 2019. gada decembrī.

Avots: ESAO, pamatojoties uz datiem no SPRK.

3.3. tabula. Latvijā veiktās spektra izsoles

\begin{tabular}{|c|c|c|c|}
\hline Josla & Gads(-i) & $\begin{array}{c}\text { leņēmumi } \\
\text { (miljonos EUR) }\end{array}$ & Izsoles rezultāts \\
\hline $791,0-821,0 \mathrm{MHz}$ un $832,0-862,0 \mathrm{MHz}$ & 2013 & 4,7 & Tele2, LMT un Bite \\
\hline $890,0-903,2 \mathrm{MHz}$ un $935,0-948,2 \mathrm{MHz}$ & 1992 & $\mathrm{~N} / \mathrm{P}$ & LMT \\
\hline $880,2-889,8 \mathrm{MHz}$ un $925,2-934,8 \mathrm{MHz}$ & 2005 & $\mathrm{~N} / \mathrm{P}$ & Bite \\
\hline $904,2-914,0 \mathrm{MHz}$ un $949,2-959,0 \mathrm{MHz}$ & 2002 & $\mathrm{~N} / \mathrm{P}$ & Tele2 \\
\hline $903,3-904,1 \mathrm{MHz}$ un $948,3-949,1 \mathrm{MHz}$ & 2008 & $\mathrm{~N} / \mathrm{P}$ & Tele2 \\
\hline 914-915 MHz un 959-960 MHz & 2010 & $\mathrm{~N} / \mathrm{P}$ & Tele2 \\
\hline $1710,0-1734,8 \mathrm{MHz}$ un $1805,0-1829,8 \mathrm{MHz}$ & 2001 & $\mathrm{~N} / \mathrm{P}$ & LMT \\
\hline $1735,2-1759,8 \mathrm{MHz}$ un $1830,2-1854,8 \mathrm{MHz}$ & 2000 & $\mathrm{~N} / \mathrm{P}$ & Tele2 \\
\hline $1760-1785 \mathrm{MHz}$ un $1855-1880 \mathrm{MHz}$ & 2005 & $\mathrm{~N} / \mathrm{P}$ & Bite \\
\hline $\begin{array}{l}\text { 1920-1940 MHz un } 2110-2130 \mathrm{MHz} ; 1960-1980 \mathrm{MHz} \\
\text { un } 2150-2170 \mathrm{MHz}\end{array}$ & 2002 & $\mathrm{~N} / \mathrm{P}$ & LMT un Tele2 \\
\hline $1940-1960 \mathrm{MHz}$ un $2130-2150 \mathrm{MHz}$ & 2005 & $\mathrm{~N} / \mathrm{P}$ & Bite \\
\hline $2300-2360 \mathrm{MHz}$ & 2012 & 0,316 & LMT un Bite \\
\hline $2500-2570 \mathrm{MHz}$ un $2620-2690 \mathrm{MHz}$ & 2012 & 3,4 & $\begin{array}{l}\text { Četriem sakaru operatoriem tika piešķirtas lietošanas tiesības } \\
\text { no 2014. gada 1. janvāra līdz 2028. gada 31. decembrim }\end{array}$ \\
\hline $2570-2620 \mathrm{MHz}$ & 2013 & 0,284 & LMT \\
\hline $3450-3500 \mathrm{MHz}, 3600-3650 \mathrm{MHz}$ un $3700-3750 \mathrm{MHz}$ & 2002 & $\mathrm{~N} / \mathrm{P}$ & Unistars (2017. gadā iegādājās Bite) \\
\hline $3400-3450 \mathrm{MHz}$ un $3650-3700 \mathrm{MHz}$ & 2017 & 0,5 & LMT \\
\hline $3550-3600 \mathrm{MHz}$ & 2018 & 6,53 & Tele2 \\
\hline
\end{tabular}

Piezīmes: $\mathrm{MHz}=$ Megahercs; N/P = nav pieejams. Pirms SPRK izveidošanas dažādos laika periodos daudzus spektra blokus $900 \mathrm{MHz}, 1,8 \mathrm{GHz}$ un 2 GHz frekvenču joslās iedalīja un piešḳīra Satiksmes ministrija (SM), izsniedzot licenci, izdodot rīkojumu vai pien̦emot lēmumu. Atsevišḳi dati par summām, kas samaksātas par spektra piešķiršanu pirms SPRK izveidošanas, nav pieejami.

Avots: SPRK (2018b), Radiofrekvenču izsoles, www.sprk.gov.lv/content/radiofrekvencu-izsoles (piekḷuve 2020. gada 6. maijā).

3,4-3,8 GHz josla, kas ir piemērota $5 \mathrm{G}$ izvietošanai, ir pieškirta pilnībā. Divi mobilo sakaru operatori (LMT un Tele2) izvietoja pirmās $5 \mathrm{G}$ bāzes stacijas 2019. gada jūlijā 3,4-3,8 GHz joslā. Piešķiršanai atlikušais bezvadu platjoslas pakalpojumu spektrs galvenokārt ir $700 \mathrm{MHz}, 1,4-1,5 \mathrm{GHz}$ un $26 \mathrm{GHz}$ joslās:

- $700 \mathrm{MHz}$ joslu pašlaik TV apraidei (digitālā virszemes televīzija, DVT) izmanto Tet, kura lietošanas tiesību termiṇš beidzas 2021. gada 31. decembrī. 700 MHz joslas izsole ir plānota 2020. gada beigās ar komerciālo izmantošanu no 2022. gada. 
- 2019. gada janvārī 1,4-1,5 GHz joslas (1427-1518 MHz) izmantošana tika piešk̦irta sakaru pakalpojumiem (Eiropas Komisija, 2019. g.). Spektra piešk̦iršana izsolē ir plānota 2010. gada beigās.

- 26 GHz spektra joslas pārdalīšanu ir paredzēts veikt 2020. gadā, un izsole ir paredzēta 2020. gada beigās vai 2021. gada sākumā. Kamēr spektra joslas virs $24 \mathrm{GHz}$ jau tiek izmantotas $5 \mathrm{G}$ testiem, lai realizētu pamatresursu frekvenču piešķiršanu no $24,25 \mathrm{GHz}$ līdz 27,5 GHz ar 5G, joprojām ir nepieciešama koordinācija ar militārajiem spēkiem (Eiropas Komisija, 2019. g.).

- Pastāv plāni par to, lai tiktu nodrošināta $60 \mathrm{MHz}$ pieejamība no 1,5 GHz joslām 2021. gadā un apmēram 80 MHz no 700 MHz joslas 2022. gadā (notiek diskusijas par pieejamo joslu iespējamo paplašināšanu).

2002. gada februārī Latvijas Ministru kabinets apstiprināja “Ceḷvedi piektās paaudzes (5G) publisko mobilo elektronisko sakaru tīklu ieviešanai Latvijā". Dokumentā ir sniegts pārskats par spektra piešk̦iršanu, komerciālo tīklu izvietošanu lielos pilsētu centros un pārklājuma saistības $700 \mathrm{MHz}$ piešk̦īrumam attiecībā uz dzelzceḷiem un ceḷiem.

Jāatzīmē, ka Latvijas nacionālais frekvenču plāns ir tehnoloǵiski neitrāls attiecībā pret mobilo sakaru pakalpojumiem izmantotajām frekvenču joslām. Tā rezultātā operatori var izvēlēties izvietot 5G, izmantojot jau piešḳirtās frekvenču joslas, ja pastāv ierīces, ar kuru palīdzību to var izdarīt. Pirmo 5G testu rezultāti tika parādīti reǵionālās konferences laikā - tas bija pirmais Baltijas jūras reǵiona 5G ekosistēmas forums "5G Techritory", kas notika Rīgā, 2018. gada septembrī (5G Techritory, 2019. g.; Eiropas Komisija, 2019. g.).

Tajā pašā mēnesī Igaunija, Latvija un Lietuva parakstīja Saprašanās memorandu (SM), vienojoties par sadarbību 4G+, 4G ++ un 5G tīkla ieviešanā Via Baltica daḷā, kas aptver Tallinu, Rīgu un Kauṇu (Lietuvā), lai sekmētu inovācijas transporta sistēmās un autonomo transportlīdzekḷu testēšanu (The Baltic Course, 2018). 2019. gada novembrī šis SM, kas tagad iekḷāva arī Poliju, tika izvērsts par kopēju ceḷu karti, lai izveidotu kopēju pieeju esošās infrastruktūras kartēšanai un noteiktu finanšu trūkumus infrastruktūras ieviešanā un kopīgos principus infrastruktūras ieviešanai Via Baltica koridorā.

5G sekmēšanas nolūkā SM pašlaik strādā pie diviem pilotprojektiem, kas attiecas uz $5 \mathrm{G}$ iespējotas pasīvās infrastruktūras ieviešanu Via Baltica koridorā un Rail Baltic maršrutos, kam tiek gaidīti pieejamie līdzekḷi. Tiek paredzēti arī pasākumi, lai samazinātu ieviešanas izmaksas un administratīvo slodzi, atvieglojot režīmu mazo elementu ieviešanā, un atvieglotu piekḷuvi informācijai par finansiālā atbalsta mehānismiem no Eiropas Savienības.

Īpaši svarīgas ir tendences, kas saistītas ar pakalpojumu komplekta piedāvājumu, kā arī audiovizuālā satura piedāvājums caur IP tīkliem, jo komplekti darbojas kā konverǵences līmeṇa rādītājs patērētāju piedāvājumos.

Pašlaik Latvijas pakalpojumu komplektu tirgum ir raksturīgi galvenokārt divkārši piedāvājumi: 96 \% no pārdotajiem komplektiem ir divkārši, un tikai maza daḷa ir trīskārši piedāvājumi (4 \%) (3.19. attēls). Tā kā Latvijā nav vertikāli integrētu dalībnieku, pašlaik nav arī četrkāršu piedāvājumu. Fiksēto sakaru vēsturiskajam dalībniekam Tet nav mobilo sakaru darbības, un valdība (kam pieder 51 \% Tet) 2016. gada aprīlī noraidīja fiksēto sakaru vēsturiskā dalībnieka un mobilo sakaru vēsturiskā dalībnieka (LMT) apvienošanu. Kopš tā laika Telia Group (kam pieder 49 \% no Tet) ir mainījusi savu globālo pārvaldību un apvienojusi savus fiksēto un mobilo sakaru meitasuzṇēmumus Igaunijā, kas varētu ietekmēt turpmākās diskusijas par apvienošanu Latvijā (Eiropas Komisija, 2019. gads; Telecompaper, 2019).

SPRK nav definējis attiecīgu tirgu pakalpojumu komplektiem. Tomēr komplektu veidošanas prakses ietekme uz konkurētspējas dinamiku tiek uztverta kā pozitīva, jo Latvijā pastāv konkurence uz infrastruktūras bāzes, un alternatīvie operatori var atkārtot vēsturiskā dalībnieka Tet piedāvājumus.

Mobilo sakaru operatori konkurē ar fiksēto sakaru vēsturisko operatoru, piedāvājot fiksēto-bezvadu sakaru pakalpojumus, kas iekḷauj televīzijas un interneta pakalpojumu piedāvājumus, izmantojot speciālus 4G maršrutētājus mājās. Tomēr SPRK pētījumā tika secināts, ka mobilo sakaru platjoslu vēl nevar uzskatīt par pilnu aizstājēju fiksēto sakaru platjoslai Latvijā (Eiropas Komisija, 2019. g.). Tomēr neierobežoti mobilās platjoslas pakalpojumi, tostarp speciālie platjoslas pakalpojumi, izmantojot 4G maršrutētājus mājās, var kḷūt par daḷēju aizstājēju nākotnē, turpinot mobilo tīklu uzlabošanu. Pagaidām 
fiksēto un mobilo tīklu konverǵenci var novērot tīklu centrā, kur optiskā šḳiedra tiek ieviesta dziḷāk fiksēto, bet arvien vairāk arī mobilo sakaru tīklos, lai ievērotu digitālās transformācijas augošās prasības. Piemēram, 2017. gadā aptuveni 54 \% mobilo sakaru datplūsmas visā pasaulē tika atslogotas, novirzot uz fiksētajiem tīkliem caur Wi-Fi vai mazām zemas jaudas šūnu bāzes stacijām (CISCO, 2018. gads). Bezvadu tīkli savā ziṇā kḷūst par fiksēto tīklu paplašinājumiem, un, pieaugot mobilo datu datplūsmas pieprasījumam, bezvadu tīkli arvien vairāk balstās uz fiksēto platjoslas sakaru infrastruktūru. Šì tendence turpināsies un padziḷināsies ar 5G tīkliem.

3.19. attēls. Klienti, kuri abonē pakalpojumu komplektus Latvijā, 2018. g.

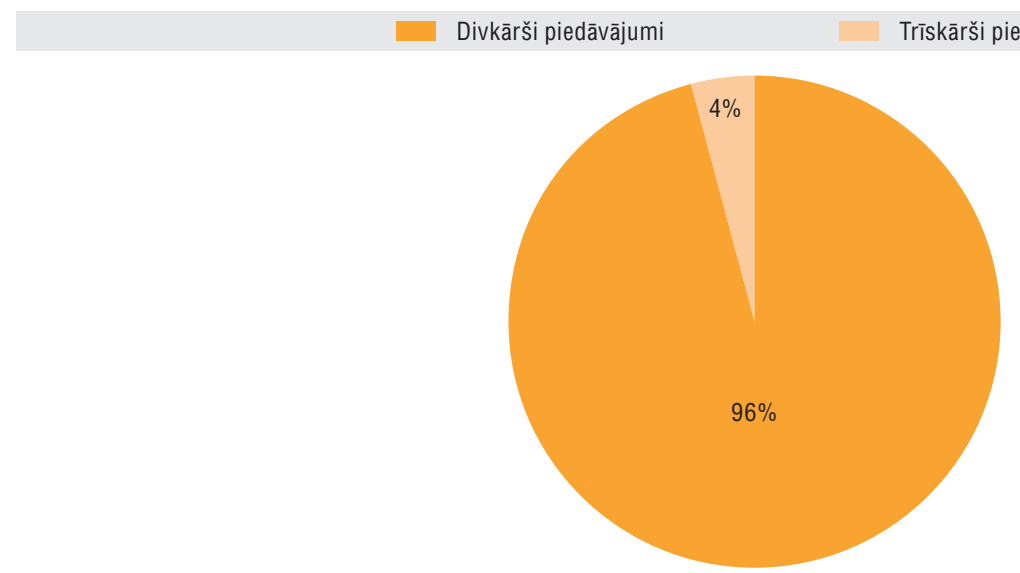

Piezīme. Divkāršs piedāvājums var būt balss + internets, TV + internets vai balss + TV; trīskāršs piedāvājums ir balss + internets + TV Avots: ESAO, pamatojoties uz datiem no SPRK.

Saistībā ar audiovizuālo pakalpojumu nodrošināšanu, izmantojot IP tīklus, Latvijā ir vairāki IPTV piedāvājumi. IPTV pakalpojumu sniedzēji ir pilnvaroti kā sakaru nodrošinātāji un ievēro tādus pašus noteikumus kā operatori, kuri nodrošina tradicionālos maksas televīzijas vai jebkurus citus sakaru pakalpojumus (ESAO, 2019b).

Vēl viena audiovizuālā satura nodrošināšanas IP tīklos kategorija ir over-the-top (OTT) pakalpojumi, kurus var nodrošināt tiešsaistes uzṇēmumi vai sakaru pakalpojumu sniedzēji (piemēram, Shortcut OTT, ko nodrošina Tet). Pašlaik OTT pakalpojumiem nav nepieciešama SPRK ațlauja, un tiem nav jāievēro pakalpojumu kvalitātes (PK) saistības. Tomēr notiek diskusijas par rīcību attiecībā uz šo kategoriju jaunās normativās struktūras transponēšanas kontekstā.

Interesanti, ka arī Latvijas komunikāciju sektorā ir pieredzētas tendences uz konverǵenci ar citiem inženierkomunikāciju un pakalpojumu sektoriem. 2017. gadā pēc elektroenerǵijas nozares liberalizācijas sakaru jomas vēsturiskais dalībnieks Tet ienāca elektrības tirgū kā tālākpārdevējs, piedāvājot komplektus ar sakaru pakalpojumiem. Tet arī pārdod tālruṇus, televizoru komplektus, datorus, dronus un citu aprīkojumu, piedāvā viedās mājas risinājumus un nodrošina datu centrus, mākoṇpakalpojumus, izklaidi, dažādus IT pakalpojumus un citus mārketinga rīkus. Vēsturiskais dalībnieks piedāvā arī e-apmācības risinājumus vecākiem pieaugušajiem.

Visbeidzot mobilo sakaru operators Bite piedāvā arī ceḷojumu apdrošināšanu, apdrošināšanu planšetdatoru un tālruṇu ekrāniem, kā arī antivīrusa aizsardzību. LMT sadarbībā ar Rīgas Tehnisko universitāti izstrādā mākslīgās inteliǵences (MI) risinājumus, lai sniegtu palīdzību, izmantojot dronus, meža ugunsgrēku un pazudušu cilvēku glābšanas darbos.

\section{Regulējuma un politikas attīstība Latvijā}

\section{Institucionālā struktūra un plānojums}

Latvijas sakaru tirgos ir iesaistītas vairākas varas iestādes, un dažām no tām ir regulatīvas funkcijas, savukārt citas ir atbildīgas par politikas formulēšanu (piemēram, platjoslas attīstības politikām). 
Par platjoslas politiku izstrādi atbildīgā varas iestāde ir Satiksmes ministrija. Daži no citiem pienākumiem ir Vides Aizsardzības un Reǵionālās attīstības ministrijas (VARAM) atbildība par valsts frekvenču un numuru plānu attīstību. Sabiedrisko Pakalpojumu Regulēšanas Komisija (SPRK) ir atbildīga par sakaru sektora regulāciju un uzraudzību, un Nacionālā Elektronisko Plašsaziņas Lìdzekḷu Padome (NEPLP) ir atbildīga par audiovizuālā sektora regulāciju un uzraudzību. Konkurences Padome darbojas kā visu sektoru konkurences varas iestāde.

\section{Satiksmes ministrija}

SM ir atbildīga par publiskās politikas ieviešanu transporta un sakaru jomā. Ministrijai ir plašas pilnvaras, tomēr tikai ierobežots personāla skaits ir atbildīgs par darbu ar sakaru jautājumiem. SM sadarbojas ar SPRK jautājumos, kas ir saistīti ar platjoslas politikas plānošanu, nesenām izstrādēm un tendencēm šajā sektorā, frekvenču plānošanu un Eiropas Savienības Direktīvu transponēšanu valstu tiesibu aktos.

\section{Vỉes Aizsardzības un Reǵionālās attīstības ministrija}

Papildus digitālajai valdības un stratēgiijas lomai Vides Aizsardzības un Reǵionālās Attīstības ministrija (VARAM) ir atbildīga par valsts frekvenču un numuru plānu attīstību politikas līmenī. Tomēr spektra un numerācijas pārvaldības tehniskais aspekts ir delegèts uzṇēmumam Latvijas VAS Elektroniskie sakari (VASES), kas pilnībā pieder valstij. VAS tika izveidots SM pakḷautībā 2004. gadā un restrukturizēts VARAM pakḷautībā 2011. gadā pēc Eiropas Komisijas ieteikuma, kurā valstij piederošā operatora LVRTC klātbūtne un spektra pārvaldības tehniskā loma tās pašas ministrijas pakḷautībā tika uzskatīta par problemātisku.

Pastāv divas pastāvīgas darba grupas frekvenču un numerācijas jautājumos, lai nodrošinātu koordināciju starp institūcijām. VAS ir atbildīgs par aptauju veikšanu operatoriem un konsultācijām ar citām institūcijām sadarbībā ar VARAM un SPRK. Turklāt VAS pienākums ir koordinēt frekvenču piešķiršanu saskaṇā ar starptautiskiem līgumiem sadarbībā ar SPRK. VAS iekasē maksu par spektra izmantošanu (ievērojot Eiropas Komisijas direktīvu 2002/20) un izmanto ieṇēmumus ekspluatācijas izmaksu finansēšanai, kas iekḷauj kaitīgo traucējumu uzraudzību.

\section{Sabiedrisko pakalpojumu regulēšanas komisija}

Sabiedrisko pakalpojumu regulēšanas komisija (SPRK) ir 2001. gadā nodibināta neatkarīga daudznozaru regulatīvā iestāde ar regulācijas pienākumiem sakaru pakalpojumu, enerǵētikas, pasta pakalpojumu, atkritumu apsaimniekošanas un ūdens apsaimniekošanas nozarē. Likums par sabiedrisko pakalpojumu regulatoriem ir primārais tiesību akts, kas nosaka to funkcijas. Tā mērḳis ir nodrošināt "iespēju saṇemt nepārtrauktus, drošus un kvalitatīvus sabiedriskos pakalpojumus, kuru tarifi (cenas) atbilst ekonomiski pamatotām izmaksām, kā arī veicināt attīstību un ekonomiski pamatotu konkurenci regulējamās nozarēs" (SPRK, 2019. g.). Saskaṇā ar SPRK salīdzinošo pārskatu, ko veica ESAO (2016. gadā), pašreizējais SPRK daudznozaru uzstādījums ir iezīmīga funkcija, kas l̦auj veikt piemērojamo regulācijas procesu, kurš ir īpaši saistīts ar tarifiem, metodiku noteikšanu un inženierkomunikāciju reǵistrāciju.

Noteikumos par regulējamiem sabiedrisko pakalpojumu veidiem (Latvijas Republika, 2009. gads) ir norādīts, ka radio vai televīzijas programmu izplatīšanas pakalpojumi sabiedriskajos komunikāciju tīklos ir jāregulē, un saskaṇā ar valsts likumdošanu atbildīgā juridiskā persona ir SPRK. Tādējādi SPRK ir atbildīga par apraidi saistībā ar signālu pārraidi un apraides tīkliem, bet ne par plašsaziṇas lỉdzekḷu saturu vai darbībām. Nacionālā elektronisko plašsaziṇas līdzekḷu padome (NEPLP) uzrauga atbilstību elektronisko plašsaziṇas līdzekḷu darbībām. Abu varas iestāžu lomas nepārklājas.

Kā minēts iepriekš, VARAM pilnvaras ietver frekvenču un numerācijas plānošanas pārvaldību, kas tiek veikta ar VAS starpniecību sadarbībā ar SPRK.

\section{Nacionālās elektronisko plašsazinas lìdzekḷ padome}

NEPLP ir neatkarīga autonoma institūcija, kas uzrauga plašsaziṇas līdzekḷu darbības normatīvo aktu ievērošanu Latvijā. Padome ir atbildīga par apraides un atkārtotas pārraides aț̣auju izsniegšanu, maksas televīzijas pakalpojumu sniedzēju pilnvarošanu un audiovizuālās nozares attīstỉbas pārraudzỉbu Latvijā. 


\section{Politikas un regulācijas iniciativuas piekḷ̂uves uzlabošanai}

Šajā sadaḷā ir aplūkotas politikas un regulācijas iniciatīvas, piemēram, tās, kuru mērḳis ir samazināt ieviešanas izmaksas, racionalizēt administratīvās procedūras un uzlabot operatoru piekḷuvi resursiem. Turklāt šeit tiek novērtētas programmas sakaru pakalpojumu piekḷuves un izmantošanas sekmēšanai un ātrdarbīgas fiksētās platjoslas infrastruktūras paplašināšanai lauku un attālās teritorijās.

\section{Piekluves paplašināšana}

Latvijā galvenā programma piekḷuves paplašināšanai lauku un attālās teritorijās ir valsts atbalsta programma "Nākamās paaudzes tīkli lauku teritorijās" (2012.-2020. g.), ko līdzfinansē Eiropas Reǵionālās attīstības fonds (ERAF). Programma tika izveidota sakaru tīklu pieejamỉbas uzlabošanai lauku teritorijās, nodrošinot vidējās jūdzes infrastruktūras ieviešanu teritorijās, kur nevienam pakalpojumu sniedzējam nav infrastruktūras vai nav plānu ātras platjoslas (vismaz $30 \mathrm{Mb} / \mathrm{s}$ ) ieviešanai nākamo trīs gadu laikā. Platjoslas programmas ietvaros valstij piederošais operators Latvijas Valsts Radio un Televizijas Centrs (LVRTC) ir atbildīgs par atvērtas piekḷuves vidējās jūdzes infrastruktūras izveidošanu identificētajās "baltajās zonās", kur mazumtirdzniecības nodrošinātājiem tiek nodrošināta vairumtirdzniecības piekḷve. Platjoslas programmai tika nodrošināta pieejamība 72,7 miljonu kopējam finansējumam.

Programmas plānošanas posma laikā 2011. gadā tika veikta SM pieprasītā analīze, lai novērtētu ieinteresēto pušu apmierinātību ar platjoslas ātrumu to teritoriju pašvaldībās, kurās ir zems iedzīvotāju blīvums, kā arī prognozes par platjoslas tīklu un pakalpojumu pieprasijjuma pieaugumu. Pamatojoties uz šo analīzi, pirms apstiprināšanas Optiskā tīkla uzraudzības komitejā tika publicēts un nodots sabiedriskai apspriešanai balto teritoriju saraksta projekts.

Projekta ieviešana tika iedalīta divos posmos. 2015. gada augustā pabeigtā pirmā posma mērḳis bija izvietot 177 piekḷuves punktus un $1813 \mathrm{~km}$ optiskās škiiedras, sniedzot iespēju operatoriem izveidot savienojumu ar tīklu jebkurā vietā visā maršrutā. LVRTC izpildỉja visus pirmā posma uzdevumus.

2014. gadā tika veikta vēl viena analīze, lai atjauninātu to teritoriju sarakstu, kurām vajadzētu gūt labumu no lauku platjoslas programmas, un noteiktu, kuras teritorijas ir visvairāk ieinteresētie pakalpojumu sniedzēji. Tika konstatēta vēl 221 baltā zona Latvijā. Līdz ar to otrais posms, kas sākās 2015. gadā un ir jāpabeidz līdz 2021. gada decembrim, tika izstrādāts ar uzdevumu ieviest vēl 220 piekḷuves punktus un 2000 km optiskās šķiedras. LVRTC parakstīja līgumus par 40,7 miljonu kopsummu par kopumā 1950,6 km izvietošanu no plānotajiem 2000 km.

No 2019. gada janvāra 1234 km optiskās škiiedras un vidējās jūdzes pakalpojums bija pieejams 73 no 220 piekḷuves punktiem baltajās zonās. Tomēr pakalpojumu sniedzēju, tostarp mobilo tīklu operatoru, interese bija zemāka nekā sākotnēji paredzēts. 2019. gada janvārī LVRTC bija parakstījis nomas līgumus 78 iznomātajām līnijām ar optiskās šḳiedras kopgarumu 1648,3km. Pašlaik tìklu izmanto tikai 12 operatori, un lielākais klients ir fiksēto sakaru vēsturiskais operators Tet. No lauku teritorijās izvietotās optiskās šḳiedras apjoma apmēram $930 \mathrm{~km}$ ir iznomāti Tet, kas nodrošina fiksēto sakaru platjoslas pakalpojumus gala lietotājiem.

Kopumā lauku platjoslas projekts ir pozitīvs solis Latvijas digitālās plaisas likvidēšanas virzienā. Tomēr galvenais izaicinājums ir nepieciešamība pēc no operatoru izveidotās pēdējās jūdzes infrastruktūras. Lai pilnībā izmantotu programmas sniegtos ieguvumus, nākamajā posmā būtu jākoncentrējas pēdējās jūdzes savienojamības labākas nodrošināšanas veidiem. Pieejas var iekḷaut piegādes puses pasākumus, tostarp analīzi, lai noteiktu izvietošanas izmaksu turpmākas samazināšanas veidus un racionalizētu administratīvās procedūras pēdējās jūdzes ieviešanai, kā arī pieprasījuma puses pasākumus, kuru mērkịis ir virzìt fizisko personu, uzñēmumu (it ỉpaši mazo un vidējo uznēmumu) un izglìtības iestāžu platjoslas pieprasījumu, kā pašlaik plānots, izmantojot SM un Izglītības ministrijas partnerību (3.1. ielikums).

Papildus lauku platjoslas programmai Latvija ir izveidojusi universālas pakalpojumu saistības (UPS), kas cilvēkiem ar invaliditāti nodrošina atlaides balss telefonijai un platjoslas pakalpojumiem. 2018. gadā 3790 lietotāji izmantoja UPS atlaižu sniegtās priekšrocības. Šo saistību potenciālie pārskatījumi tiks aplūkoti Eiropas Elektronisko sakaru kodeksa nosacījumu transponēšanai paredzētā Latvijas Elektronisko sakaru likuma pārskatijuma kontekstā. UPS tvērums var mainīties no 2022. gada un iekḷaut 
platjoslas piekḷuves pakalpojumu kvalitātes minimālo līmeni, lai atbalstītu pielietojumus, kuriem ir nepieciešams lielāks ātrums. Tomēr var veikt papildu darbu, lai samazinātu ieviešanas izmaksas operatoriem. Tāpat arī piegādes puses pasākumus var papildināt ar pieprasījuma puses pasākumiem.

\section{1. ielikums. Platjosla Latvijas skolām}

Satiksmes ministrija (SM) plāno piesaistīt papildu resursus (2020.-23. gadā), lai veiktu platjoslas ieviešanu un piekḷuves punktu palielināšanu izglītības iestādēs, tādējādi reaǵējot uz augošo savienojamības pieprasījumu skolās, palīdzētu īstenot Izglītības ministrijas jauno mācību programmu un nodrošinātu tālmācības iespēju.

Latvijas Pašvaldību savienības veiktajā aptaujā konstatēts, ka platjoslas infrastruktūra no programmas "Nākamās paaudzes tīkli lauku teritorijās" ir pieejama apmēram 70 izglītības iestāžu tuvumā. Pēc šiem rezultātiem LVRTC veica sākotnēju novērtējumu un konstatēja, ka pašreizējās lauku programmas ietvaros pēdējās jūdzes savienojamību var ieviest 17 izglītības iestādēs, kuras atrodas baltajās zonās. Pēc tam projekta grozijjumi tika paplašināti, lai tajos iekḷautu 21 piekḷuves punktu izglītības iestādēs. Tomēr pat pēc apstiprināšanas projekts neaptvers visas valsts izglītības iestādes. 2020. gada aprīlī SM sāka iepirkuma procesu, lai noskaidrotu pārējo izglītības iestāžu aktuālās vajadzības.

SPRK cieši sadarbojas ar Konkurences padomi, un abas organizācijas kopīgo savu uzdevumu veikšanai nepieciešamo informāciju. SPRK dod Konkurences padomei iespēju pirms tā pieṇemšanas komentēt visus tirgus analīzes projektus (piemēram, saistībā ar izbeigšanu, vietējo sakaru līniju nošḳiršanu atsaistītas bitu plūsmas piekḷuves vai nomātu līniju kontekstā u.c.), pamatojoties uz ES normatīvo regulējumu. Neviens no SPRK lēmumiem 2018. gadā netika pārsūdzēts.

Latvijā konkurences barjeras ir vēsturiski saistītas ar ienākšanas un tīkla paplašināšanas barjerām, un SPRK tās izmanto kā būtiskus kritērijus operatoru tirgus spēju noteikšanai Latvijā. Barjeras var atšķirties dažādos tirgos (piemēram, balss, platjosla, nomātās līnijas, pabeigšanas pakalpojumu tirgos).

Pēc liberalizācijas barjeras paplašināšanai un konkurencei bija ḷoti augstas, it ìpaši attiecībā uz tīkla ieviešanu. Gadu gaitā konkurences un inovatīvie risinājumi, kā arī spēja pielāgoties strauji mainīgajam sakaru tirgum ir sniegusi mobilo un fiksēto sakaru operatoriem iespēju pārvarēt dažas no šìm barjerām, kā arī ieviest un uzturēt augstas kvalitātes tīklus. SPRK pielietotais tehnoloǵiskās neitralitātes princips un proporcionālu apstākḷu izveide operatoriem ir bijusi izšḳiroša konkurences veicināšanā.

Operatora Bite ienākšana tirgū 2005. gadā palielināja konkurenci mobilo balss sakaru tirgū. Regulējumi pabeigšanas pakalpojumu tarifu un pārnesamības jomās turpināja sekmēt konkurences pieaugumu, bet tas savukārt stimulēja pakalpojumu kvalitātes uzlabošanu un cenu pazemināšanos patērētājiem.

2018. gadā SPRK veica tirgus analīzi un konstatēja, ka mobilos balss sakarus var uzskatīt par fiksēto balss sakaru aizstājēju. N̦emot vērā novērtējumu, ka konkurence balss sakaru tirgū ir bijusi efektīva, mazumtirdzniecības un vairumtirdzniecības balss sakaru tirgi tika liberalizēti (izṇemot pabeigšanas pakalpojumu tarifus). No 2019. gada vidus tikai 3,5 \% no visas balss datplūsmas attiecas uz fiksētajiem balss sakariem. Latvijā joprojām tiek regulēti pabeigšanas pakalpojumu tarifi, ņemot vērā īpatnības vairumtirdzniecības balss zvanu pabeigšanas tirgos, kas ir ḷāvis secināt, ka šajā tirgus segmentā ienākšanas barjeras joprojām ir augstas.

Tomēr problēma, kuru daži nozares dalībnieki ir akcentējuši balss telefonijas kontekstā, attiecas uz atsevišḳu operatoru piedāvājumiem, kas iekḷauj neierobežotus zvanus tikai uz atsevišk̦iem tīkliem. Viens no šādiem piemēriem ir Bite piedāvājums patērētājiem. Dažu tarifu plānu piedāvājums iekḷauj neierobežotus zvanus uz Bite, LMT, Tele2 un Tet tīkliem, bet ne uz mazākiem fiksētajiem tīkliem. Pēc SPRK lēmuma No.. 1/19 2018. gada janvārī ("Regulējumi par paziṇojumu gala lietotājiem, kas attiecas uz augstākas maksas zvaniem”) patērētāji saṇem mutisku paziṇojumu, ja zvana uz numuriem, kurus 
nenodrošina iepriekš minētie četri lielākie Latvijas sakaru pakalpojumu sniedzēji (trīs mobilo sakaru nodrošinātāji un vēsturiskais dalībnieks Tet fiksēto sakaru pakalpojumiem). Šis jautājums var pamatot Latvijas iestāžu detalizētu analīzi attiecībā uz potenciālo konkurences ietekmi uz noteiktiem tīkliem valstī.

Attiecībā uz platjoslas pakalpojumiem SPRK ir konstatējusi, ka mobilās platjoslas pakalpojumus vēl nevar uzskatīt par pilnu aizstājēju fiksētās platjoslas pakalpojumiem Latvijā, vienlaikus atzīstot, ka fiksētās platjoslas operatori zināmā mērā saskaras ar mobilo sakaru operatoru konkurenci. Ir konstatēts, ka vēsturiskajam operatoram Tet ir bijusi būtiska ietekme tirgū (BIT) vairumtirdzniecības platjoslas piekḷuves tirgos kopš 2007. gada. Kaut arī ienākšanas barjeras tiek uzskatītas par augstām, daži alternatīvie operatori ir izvietojuši savas infrastruktūras blīvāk apdzīvotās Latvijas teritorijās. Pēc konkurētspējas apstākḷu analizēšanas, tos salīdzinot ar kritēriju kopumu, SPRK secināja, ka tirgu vēl nevar uzskatīt par efektīvi konkurētspējīgu un šis regulējums joprojām tiek garantēts.

Latvijā joprojām ir salīdzinoši mazs augstas kvalitātes vairumtirdzniecības tirgus, kas aptver nomātās līnijas, virtuālos privātos tīklus un augstas kvalitātes platjoslu ar garantētu joslas platumu, ko izmanto uzṇēmējdarbības klienti. Turklāt nomāto līniju skaits un ieṇēmumi gadu gaitā ir ievērojami samazinājušies. SPRK ir konstatējusi tendenci, kas atspoguḷo pāreju no nomātajām līnijām un VPN (tīkla operatoru ieviestiem un pārvaldītiem) uz interneta savienojumu ar kuru izmanto mākoṇdatošanas mākoṇpakalpojumu vai pašieviestus programmatūras līmeṇa VPN. Esošie konkurences apstākḷi, kuros ir iesaistījies ne tikai Tet, bet arī alternatīvie operatori, un tirgus dinamikas izmaiṇas liecināja par efektīvas konkurences klātbūtni un norādīja, ka regulējums vairs nav nepieciešams. Attiecīgi SPRK ir liberalizējusi vairumtirdzniecības augstas kvalitātes tirgu 2019. gada decembrī.

\section{Vairumtirdzniecības reguläcija un infrastruktūras koplietošana}

Latvijā tiek regulēti pabeigšanas tarifi. Vairumtirdzniecības pabeigšanas tarifu samazinājums ir pozitīvi ietekmējis gala lietotāju cenas, kā arī uzlabojis numuru aglabāšanas pakalpojuma pieejamību. Vēsturiski pabeigšanas tarifi Latvijā ir uzskatīti par pārāk augstiem un par šḳērsli jauniem dalībniekiem. Lai izvairītos no l̦aunprātīgas izmantošanas, operatoru saraksts Latvijā tiek bieži atjaunināts, kā arī tiek regulēti fiksētā savienojuma pabeigšanas tarifi (FSPT) un mobilā savienojuma pabeigšanas tarifi (MSPT) (maksimālais FSPT bija noteikts kā 0,0701 eirocenti/minūtē, bet maksimālais MSPT — 0,8868 eirocenti/ minūtē 2018. gada janvārī) (Eiropas Komisija, 2019. g.).

Latvijā nozīmīgākā attīstība vairumtirdzniecības regulējuma ziṇā ir bijusi asimetriska, pielietota vēsturiskā Tet kabeḷiem un stabiem (izstrādāta situācijai, kurā ir operatori ar būtisku ietekmi vairākos tirgos) un SPRK pilnvarota 2014. gadā. Vēsturiski Tet ir regulēts attiecībā uz mazumtirdzniecības balss sakariem, nomātām līnijām, vairumtirdzniecības balss sakaru izcelsmi, pāreju, vairumtirdzniecības platjoslas piekḷvi un vairumtirdzniecības nomātajām līnijām. Lielākajā dalā šo tirgu ir pakāpeniski ieviesta liberalizācija. Pašlaik Tet tiek regulēts tikai atsaistītas bitu plūsmas piekḷuves kontekstā, iekḷaujot piekḷuvi kabeḷiem un stabiem. Turklāt drīzumā ir paredzēta nomāto līniju vairumtirdzniecības pabeigšanas segmentu liberalizācija.

Kaut arī šie operatoru ar būtisku ietekmi palīglīdzekḷi neiekḷauj piekḷuvi kabel̦iem, SPRK ir pieṇēmusi citus līdzekḷus, piemēram, vietējās abonentlīnijas atsaistīšanu un vairumtirdzniecības bitu plūsmas piekḷvi, lai citi operatori ar ierobežotu pārklājumu varētu izmantot Tet tīklu un konkurēt mazumtirdzniecības līmenī. Turklāt uz Tet attiecas noteikumi, kas iekḷauj diskriminācijas novēršanu, caurskatāmību, cenu kontroli, izmaksu uzskaiti un grāmatvedības nodalīšanu (Eiropas Komisija, 2019. gads).

Pilsētvides zonās, piemēram, Rīgā, konkurences pamatā joprojām ir infrastruktūra, izmantojot gaisa kabel̦us starp jumtiem (Eiropas Komisija, 2019. gads). Tomēr tas parasti neatbilst noteikumiem, kuros tiek prasīta kabeḷu pazemes uzstādīšana, lai piedāvātu drošu, aizsargātu un slēptu vidi sakaru tīkliem. Pilsētvides vadlīnijas un pašvaldību noteikumi visā valstī aizliedz izmantot gaisa kabeḷus vēsturiskās teritorijās. Turklāt, kaut arī nav konstatēta vietējās abonentlīnijas bitplūsmas piekḷves plaša izmantošana (jo operatori blīvi apdzivotās teritorijās paši konkurē ar savām infrastruktūrām), operatoru ar būtisku ietekmi līdzekḷi pazemina barjeras uz platjoslas pakalpojuma piedāvājumu paplašināšanos galvenokārt mazumtirdzniecības līmenī un, kur iespējams, veicina uz pakalpojumiem balstītu konkurenci. 
2017. gadā Eiropas Komisijas platjoslas izmaksu samazināšanas direktīva (BCRD) tika pilnībā transponēta valsts tiesību aktos. Likums par ātrdarbīga elektronisko sakaru tīklu paredz obligātu nosacījumu par piekḷuvi fiziskai infrastruktūrai (piemēram, caurulei, mastam, cauruḷvadam, pārbaudes kamerai, pārbaudes lūkai, kabinetam, ēkai vai ieejai ēkā, antenas uzstādījumam, tornim un stabam) operatoriem, kuri ir pilnvaroti sakaru pakalpojumu sniegšanai, kā arī citiem inženierkomunikāciju pakalpojumu (piemēram, gāzes, elektrības, apkures, transporta un kanalizācijas pakalpojumu) sniedzējiem. Šāda piekḷuve ir jānodrošina ar godīgiem un pamatotiem noteikumiem un nosacijumiem, tostarp cenu, lai izvietotu ātrdarbīgus tīklus. SPRK ir direktīvā paredzētā strīdu izšk̦iršanas padome (SIP).

Kaut arī kartēšanas saistības nepastāv, lai uzlabotu koordināciju un novērstu informācijas trūkumus, sakaru operatori var piekḷūt datu portālam par fiksētu maksu caur Latvijas vienoto klientu apkalpošanas centru (www.latvija.lv). Šajā portālā ir iekḷauta esošā informācija, kuru valdība ir apkopojusi par jebkura tīkla operatora fizisko infrastruktūru (piemēram, atrašanās vietu, maršrutu, tipu, infrastruktūras pašreizējo izmantošanu un kontaktpunktu). Ja trūkst kādas informācijas, piekḷuves meklētāji var pieprasīt datus no infrastruktūras īpašniekiem vai apmeklēt fizisko infrastruktūru. 2017. gada likumā ir paredzēta arī būvdarbu koordinācija, nosakot, ka sakaru pakalpojumu un citi infrastruktūras nodrošinātāji koordinē ātrgaitas tīklu efektīvu izvietošanu.

Lai novērstu dubultu regulāciju, BCRD transponēšanas procesa laikā 2017. gada likuma nosacījumi tika piesaistīti nosacījumiem saskaṇā ar 2014. gada Elektronisko sakaru likumu, kas nosaka simetrisku piekḷuvi. Seši operatori (tostarp Tet) pašlaik nodrošina citu operatoru piekḷuvi savai kabeḷu kanalizācijai. Tomēr operatoriem, kuri potenciāli interesējas par piekḷuvi vēsturiskā dalībnieka infrastruktūrai, realitātē tiek liegta piekḷuve uz kapacitātes nepietiekamības pamata, kas ir saistīts ar vēsturiskā dalībnieka turpmākajām kapacitātes vajadzībām. Turklāt operatoriem ir jāmaksā katru reizi, kad viṇi pieprasa pieejamās kapacitātes novērtēšanu. It īpaši šì un citu iemeslu dēḷ nav izmantoti stabi lauku teritorijās, neraugoties uz acīmredzamu interesi par infrastruktūras koplietošanu.

Attiecībā uz citām inženierkomunikācijām uzṇēmumiem, kas nodrošina enerǵijas (Latvenergo), dzelzceḷa (Latvijas Dzelzcel̦š), ūdens, kanalizācijas un gāzes pakalpojumus, ir arī sakaru vajadzības, ir uzstādīta optiskā šḳiedra un uzlabota infrastruktūra (piemēram, lai atbalstītu vadības sistēmas, viedo mērīšanu, signalizāciju, sliežu cel̦us un drošības pārvaldību).

Pirms BCRD transponēšanas tika apspriesti daži esošie optiskās šḳiedras uzstādī̌̌anas projekti, izmantojot citu inženiertīklu infrastruktūru Latvijā. Tie iekḷauj 1994. gadā izveidoto Latvenergo un Tet savstarpējo sadarbību, kas aptver pazemes optiskās šḳiedras kabeḷa uzstādīšanu un optiskās šķiedras troses (OPGW) kabeḷa tehnoloǵiju augstsprieguma gaisvadu līnijās. Drošības standartu dēl augstsprieguma gaisvadu līnijām ir nepieciešams zibensaizsardzības vads (proti, ekranēti vadi), kas tiek uzstādīti virs strāvas līnijām (lielākoties $110 \mathrm{kV}$ ), kuras vēsturiski tika izgatavotas no tērauda. Tās pakāpeniski ir aizstātas ar OPGW kabel̦iem, kas nodrošina zemējuma un sakaru iespējas, turklāt ir izturīgāki (aptverti ar tērauda un alumīnija vada aisargslāṇiem). Latvenergo un Tet ir kopīgi izvietojuši 1847 km OPGW kabel̦u un pazemes optisko šk̦iedru pēc vienošanās, ka dažas šḳiedru dzīslas tiek piešķirtas Latvenergo, bet citas - Tet pamattīklam.

Lai samazinātu izvietošanas izmaksas (iekḷaujot tās, kas attiecas uz piekḷuves tiesībām), vairāki operatori ir finansējuši iespēju šḳiedru tīklu izvietošanai gar ceḷiem un dzelzceḷiem. 2019. gadā septiṇi Latvijas operatori izmantoja infrastruktūru gar cel̦iem, bet četri — uzṇēmuma Latvijas Dzelzcel̦š infrastruktūru, lai uzstādītu optisko šķiedru kabeli gar dzelzceḷiem, vai izmantoja mobilo sakaru operatoru torṇus, lai uzstādītu bāzes stacijas. Latvijas operatori izmanto arī kopīgu piekḷuvi torṇiem un mastiem. Visi mobilo sakaru tīklu operatori nodrošina piekḷuvi saviem mastiem, un pieci fiksēto sakaru operatori nodrošina piekḷuvi saviem mastiem un torṇiem.

Kaut arī pastāv infrastruktūras koplietošanas gadījumi atvilces izvietošanai, infrastruktūras koplietošana Latvijā joprojām ir ierobežota, it īpaši attiecībā uz citu inženierkomunikāciju infrastruktūras izmantošanu. Ievērojot BCRD norādījumus, 2017. gada likumā par ātrdarbīgu elektronisko sakaru tīklu ir norādīts, ka "Būvniecības ierosinātājs, saṇemot atḷauju būvēt jaunu vai pārbūvēt esošu dzivojamo māju vai nedzìvojamo ēku, nodrošina ātrdarbīgam elektronisko sakaru tīklam atbilstošu iekšējo fizisko infrastruktūru" (Latvija, 2017. g.). Tomēr likums paredz dažus izṇēmumus, it īpaši, ja jau pastāv piemērota infrastruktūra, ja ir objektīvi iemesli piemērotas infrastruktūras nodrošināšanai vai ēkas paredzētajai izmantošanai nav nepieciešama ātrdarbīgu tīklu izmantošana. 
Tomēr noteiktas esošās daudzdzīvokḷu ēkas Latvijā (kur pastāv specifiska, citās Eiropas valstīs reti sastopama īpašumtiesību forma, kurā katram dzīvokḷa ìpašniekam daḷeji pieder ēkas koplietošanas telpas, piemēram, kāpṇu telpa un pagrabs) ir izslēgtas no šìm saistībām ar 2017. gada likumu, pamatojoties uz to, ka šādas saistības pārkāptu konstitucionālās īpašumtiesības. Vēl ir jānovērtē, cik lielā mērā šāda rezidence veido būtisku dalı no ēkām bez ātrdarbīgai platjoslai piemērotas infrastruktūras.

BCRD paredzētie pasākumi ietilpst SM darbības jomā. Izṇēmumi attiecas uz Strīdu izšķiršanas padomi (SIP), kuras funkcijas izpilda SPRK. Saistībā ar direktīvas pielietojumu nav radušās domstarpības.

\section{Patērētāju aizsardzība}

SPRK sadarbojas ar Patērētāju tiesību aizsardzības centru (PTAC), lai aizstāvētu patērētāju tiesības regulētajos sektoros. SPRK pienākumi attiecas uz sakaru pakalpojumu līgumiem, tarifiem un PK. PTAC pilnvaras attiecas uz līguma noteikumu pielietojumu. Līdz 2018. gada novembrim SPRK bija saṇēmusi 45 patērētāju sūdzības par PK (16 \%), tarifiem (16 \%), rēḳiniem (18 \%), līgumu noteikumiem (24 \%) un citiem (27\%) nekompetences gadījumiem un atbildējis uz tām. PTAC ir saṇēmis 93 individuālās sūdzības par sakaru nodrošinātājiem (Eiropas Komisija, 2019. g.).

SPRK uzrauga to, kā operatori ievēro specifiskās kvalitātes prasības, un publicē mobilās platjoslas kvalitātes mērijjumu rezultātus. Tà veic divu veidu interneta kvalitātes mērījumu — seriālos un paraugu mērỉjumus. Seriālie mērījumi tiek veikti specifiskās vietās pilnu diennakti (24 stundas) vismaz vienu nedēḷ. Tie nodrošina pārskatu par mobilā interneta sniegumu dienas periodā un parāda interneta ātruma izmain,as dažādos laikos. Paraugu mērījumi tiek veikti dažādās geoogrāfiskās vietās visā Latvijā un sniedz pārskatu par faktiskajiem mobilā interneta kvalitātes rādītājiem. Šis rīks ir bijis īpaši noderīgs patēēētājiem, lai salīdzinātu visu mobilo operatoru mobilo platjoslas pakalpojumu kvalitāti dažādās g̀eogrāfiskās teritorijās. Turklāt jau vairākus gadus tiešsaistē ir bijis pieejams neatkarīgs tarifu salīdzināšanas rīks (www.gudriem.lv).

Saistībā ar fiksēto platjoslas pakalpojumu reklamēšanas praksi Latvijā maksimālajam (reklamētajam) ātrumam ir jābūt vidējam ātrumam, ko gala lietotājs pastāvīgi iegūst dienas laikā (izṇemot maksimuma stundas), bet minimālajam garantētajam ātrumam jābūt vismaz 20 \% no līgumā norādītā maksimālā ātruma vai maksimālā ātruma diapazona augšējās robežas. Mobilajiem pakalpojumiem minimālajam garantētajam ātrumam jābūt vismaz platjoslas savienojuma ātruma apakšējai robežai (proti, $256 \mathrm{Kbit} / \mathrm{s})$. Turklāt SPRK paredz, ka ISP līgumos iekḷauj maksimālos ātrumus.

SPRK veiktie kvalitātes mērījumi ir noderīgs rīks, lai veicinātu konkurenci un mudinātu uz mobilo tīklu uzlabojumiem, jo rezultāti ir pieejami publiski. Turklāt tie ḷauj operatoriem uzraudzìt savu tīklu sniegumu. Latvijā ir maz patēēētāju sūdzību par PK, to apjoms 2018. gada novembrī bija 7 no 45 patērētāju sūdzībām. Tomēr līdz šim nav veikta specifiska patērētāju apmierinātības aptauja par PK (Eiropas Komisija, 2019).

\section{Tỉkla neitralitāte}

Latvijā tīkla neitralitātes noteikumi tiek ieviesti saskaṇā ar Eiropas Savienības regulu 2015/2120. Atbilstības uzraudzības nolūkos SPRK pieprasa informāciju no ISP, analizē gala lietotāja sūdzības, veic tehniskos pasākumus (pastāvīgi mobilo sakaru tīkliem un tikai sūdzību gadījumos fiksēto sakaru tīkliem) un pārbauda informāciju ISP tīmekḷa lapās.

Nav konstatēti Eiropas Savienības regulas pārkāpumi attiecībā uz tīkla neitralitāti (Eiropas Komisija, 2019. gads). SPRK galvenās jomas, kas attiecas uz tīkla neitralitāti, ir caurskatāmība (līguma informācija), interneta ātrumi, uzraudzības mehānismi (veiktspējas neatbilstības testēšanai) un datplūsmas pārvaldība (iekḷaujot porta bloḳē̌anu).

SPRK ziṇoja, ka 2018. gadā 19 \% ISP ir veikuši datplūsmas pārvaldības pasākumus (piemēram, l̦aunprogrammatūras, l̦aunprātīgu lietotṇu un surogātpasta novēršanai) (Eiropas Komisija, 2019. gads). Viens mobilo sakaru operators (Bite) nodrošina piedāvājumus ar nulles tarifiem. Nulles tarifi attiecas uz tādiem pielietojumiem kā sociālie tīkli, balss, ìsziṇu pakalpojumiun ǵeogrāfiskās navigācijas pakalpojumu lietotnes. Tā kā nav sūdzību par nulles tarifu praksi, kā arī nav plaši pieejami abonenti ar neierobežotu internetu un konkurētspējīgas cenas visu Latvijas mobilo sakaru operatoru vidū, SPRK neuzskatīja Bite piedāvātos nulles tarifa piedāvājumus par kaitīgiem. Turklāt, tā kā Bite ir mazākais 
mobilo sakaru operators Latvijā, tā nulles tarifa piedāvājums tiek uzskatīts par mēǵinājumu piesaistīt jaunus klientus un instrumentu konkurences sekmēšanai.

\section{Politikas ieteilkumi}

Kopumā Latvija nodrošina labu sniegumu attiecībā uz fiksēto un mobilo platjoslas ātrdarbīgo tīklu izvietošanu. Tomēr politikas izstrādē un normatīvajā struktūrā ir dažas vājās vietas, kas var aizkavēt digitālā dalījuma plaisas novēršanu, bezvadu pakalpojumu spektra efektīvu piešķiršanu, IoT pien̦emšanu, konverǵences sekmēšanas mēǵinājumus un jauno tehnoloğiju (piemēram, 5G) sagatavošanu.

- Institūcijas. Latvija būtu noderīga holistiska politika un regulatīva pieeja savienojamỉbai. Jāapsver tāda konvergèta regulatora izveide, kas rīkojas ar sakaru, apraides un plašsaziṇas līdzekḷu pakalpojumiem. Pašlaik šīs funkcijas ir sadalītas starp SPRK un NEPLP. Izstrādēm IP tīklu konverǵencē un potenciālajā konverǵencē starp fiksētajiem un mobilajiem tīkliem ir un būs vērojams tirgus struktūru efektivitātes pieaugums. Konverǵēta regulatīvā struktūra uzlabotu efektīvāku pievēršanos šīm izmaiṇām, ṇemot vērā plašos izaicinājumus un tendences. Kamēr ministriju līmenī šīs lomas pašlaik dala SM un VARAM, institucionālā izstrāde varētu gūt labumu no viena skaidra fokusa punkta izveidošanas. Visbeidzot ierobežojumi personāla nolīgšanai valsts sektorā, ieskaitot ekspertus ar kompetenci sakaru jomā, var traucēt politikas veidošanu un tehnisko zināšanu iegūšanu institūcijās.

- Būvdarbi un piekḷuves tiesības. Pašvaldību teritorijas plānošanu var uzlabot, sekmējot "viena rakuma" politiku, aț̣aujot jaunus torṇus, plānojot jaunus maršrutus optiskās šḳiedras un zemējuma kabeḷiem, saskan,ojot procedūras (piemēram, tīkla objekta reǵistrāciju) un vienkāršojot tīkla izvietošanas administratîvos procesus. Turklāt pašvaldỉbas var īstenot koordināciju savstarpēji un ar SM, lai atbalstītu platformas, kur pakalpojumu sniedzēji var skatìt bāzes staciju izvietošanai pieejamās vietas (piemēram, uz valdības èku jumtiem). Vājās vietas fiksēto un mobilo sakaru tỉkla izvietošanā pašvaldību līmenī kḷūs izteiktākas līdz ar tīkla blīvuma pieaugumu 5G izvietošanas rezultātā. Turklāt, lai uzstādìtu daudzās 5G nepieciešamās antenas, l̦oti svarīga būs piekḷuve infrastruktūrai.

- Infrastruktūras piekḷuve un koplietošana. Būtu jācenšas samazināt informācijas asimetriju, kas attiecas uz pieejamo infrastruktūru, un jānovēro iespējami diskriminējošā prakse, kas attiecas uz piekḷuvi pasīvajai infrastruktūrai, it īpaši uznēemumiem ar nozīmīgu lomu tirgū.

- Konkurence. Neraugoties uz pozitīvo attīstību mobilo sakaru tirgū, raizes par konkurenci joprojām pastāv fiksētās platjoslas tirgū Latvijā, kur viena uzṇēmuma tirgus daḷa ir 56 \%. Jāturpina uzraudzìt šì situācija un jāiekḷauj infrastruktūras koplietošanas saistību ieviešana.

- Pēdējās jūdzes piekḷuve. Savienojamỉbas plaisas aizvēršana izolētās, ekonomiski mazāk pievilcīgās teritorijās joprojām būs galvenais infrastruktūras izaicinājums. Lauku platjoslas programmas nākamajam posmam Latvijā vajadzētu koncentrēties uz pēdējās jūdzes risinājumiem, lai likvidētu savienojamības plaisas. Pasākumi varētu koncentrēties uz turpmāku izvietošanas izmaksu samazināšanu un administratīvo procedūru racionalizēěanu, kā arī uz pieprasījuma puses pasākumu sekmēšanu, lai virzìtu fizisku personu, uzṇēmumu (it īpaši mazo un vidējo) un izglìtības iestāžu pieprasījumu.

- Spektrs. Kaut arī Latvijai ir vērojams progress radiofrekvenču spektra sadalijjuma ziṇā, frekvenču spektram pašlaik nav sekundāra tirgus. Ja tiktu atjaunināts normatīvais regulējums, lai aț̣autu šādus tirgus, varētu efektīvāk izmantot spektru.

- IoT. IoT sola palielināt inovācijas un efektivitāti vairākās nozarēs, piemēram, energètikā vai rūpniecības automatizācijā. Tomēr Latvija atpaliek no M2M un IoT izmantošanā. Kaut arī jauns numurācijas plāns tiek uzskatīts par reakciju uz M2M un IoT vajadzībām, nav plašāka plāna problēmu apzināšanai un šo pakalpojumu sekmēšanai. Turklāt operatori ir izteikuši bažas par pieprasījuma trūkumu no uzṇēmumu un patērētāju puses saistībā ar šiem pakalpojumiem. Latvijai vajadzētu izveidot plašāku IoT plānu, lai apzinātu esošos problēmas, kā arī sekmētu plašāku IoT ekosistēmu un IoT pakalpojumu ieviešanu valstī.

- IPv6. Latvija atpaliek Ipv6 pienূemšanas ziṇā. IPv6 ir svarīgs ne tikai turpmāko interneta attīstību mērogojamības dēḷ, bet arī izšḳirošs no drošỉbas viedokḷa, jo IPv6 var labāk veicināt galšifrēšanu. Šis pēdējais faktors var būt labvēlīgs, piemēram, industriālo IoT pielietojumu drošìbai. Kaut arī Latvija veic pasākumus, lai palielinātu IPv6 pien,emšanu valsts sektorā, ieteicams ieviest rūpīgu IPv6 stratēéiju, lai sekmētu plašu izvietošanu. Tas ir jāveic koordinācijā ar pilsonisko sabiedrību, privāto sektoru un ieinteresētajām tehniskajām personām (kā notika Zviedrijā).

- IPAP. Dažiem interneta plūsmu apmaiṇas punktiem ir tikai ierobežots dalībnieku skaits. It īpaši Latvijas interneta apmaiṇas punkta izstrāde kavē tā turpmākās izaugsmes potenciālu saistībā ar Latvijas prefiksu radītajiem datplūsmas ierobežojumiem. Regulatoram vai ministrijai (VARAM vai SM) būtu 
jāstrādā ar valstī esošajiem IPAP un tīkliem, lai uzlabotu IPAP pārvaldību un veiktspēju, pamatojoties uz labo praksi, un tādējādi palielinātu vietējās datplūsmas apmainas apjomu. Analīze par satiksmes apmain,as stāvokli valstī un esošo IPAP veiktspēja varētu būt šāda pasākuma sākumpunkts.

\section{2. ielikums. Politikas ieteikumi}

Lai nodrošinātu Latvijas sagatavotību gaidāmajām sakaru tehnolog̣iju un tirgus norisēm, valdībai vajadzētu:

- novērtēt ieguvumus, ko sniedz konvergéta regulatora izveide sakaru un apraides pakalpojumiem, it īpaši saistỉbā ar pakalpojumu konverǵences pieaugumu IP tīklos;

- izveidot skaidru ministrijas fokusa punktu sakaru pakalpojumiem, jo pašlaik kompetences ir sadalītas starp Satiksmes ministriju (SM) un Vides Aizsardzỉbas un Reǵionālās attīstỉbas ministriju (VARAM);

- uzlabot teritoriālo plānojumu pašvaldībās, atbalstot "viena rakuma" politikas, piešḳirot atḷaujas jauniem torṇiem un plānojot jaunus optisko šḳiedru kabeḷu maršrutus, kā arī saskaṇojot un vienkāršojot administratīvās procedūras tīkla izvietošanai;

- palielināt koordināciju starp pašvaldībām un SM, lai novērstu šḳēršlı fus fiksēto un mobilo tīklu izvēršanai un sagatavotos $5 \mathrm{G}$ nepieciešamajai tīkla sablīvēšanai;

- samazināt informācijas asimetrijas attiecībā uz pieejamo infrastruktūru un stingri uzraudzīt situāciju attiecībā uz potenciāli diskriminējošu praksi saistībā ar piekḷuvi pasivvai infrastruktūrai;

- uzraudzìt konkurences stāvokli fiksētās platjoslas tirgū un îstenot infrastruktūras koplietošanas saistỉbas kā pēc nepieciešamības;

- iesaistīt vietējās ieinteresētās puses lauku platjoslas programmā, kas attiecas uz pēdējās jūdzes risinājumiem, un sekmēt pieprasījumu ar mērḳtiecīgām iniciatīvām;

- atjaunināt normatīvo regulējumu, lai sekundārā spektra tirgum l̦autu veicināt efektīiāku izmantošanu;

- izstrādāt un ieviest valsts IoT plānu, lai apzinātu problēmas un sekmētu pieprasījumu no uzṇēmumiem un patēēēājiem;

- izstrādāt un ieviest vispusīgu IPv6 stratēǵiju, sadarbojoties ar pilsonisko sabiedrību, privāto sektoru un ieinteresētajām tehniskajām pusēm;

- veikt datplūsmas apmaiņas stāvokḷa analīzi un veicināt neitrālu IPAP izvietošanu, pamatojoties uz labu starptautisko praksi, lai uzlabotu datplūsmas apmain,u un sekmētu labi funkcionējošas interneta ekosistēmas izveidošanu. 


\section{Atsauces}

5G Techritory (2019), 5G Techritory, www.5gtechritory.com/story (piekḷuve 2019. gada 9. novembrī).

Akamai (2020), "IPv6 adoption visualization”, www.akamai.com/uk/en/our-thinking/state-of-the-internet-report/state-of-the-internetipv6adoption-visualization.jsp (piekl̦uve 2020. gada jūnijā).

APNIC (2020), "IPv6 measurement maps", http://stats.labs.apnic.net/ipv6 (piekḷuve 2020. gada jūnijā).

CISCO (2018), Cisco Visual Networking Index: Global Mobile Data Traffic Forecast Update, 2017-2022 White Paper, Cisco Systems, San Jose, CA, www.cisco.com/c/en/us/solutions/collateral/service-provider/visual-networking-index-vni/white-paper-c11-738429.html (piekluve 2019. gada 20. septembrī).

CRCT (2019), Communications Monitoring Report 2019, Kanādas radio-televīzijas un telekomunikāciju komisija, Otavā, https://crtc. gc.ca/eng/publications/reports/policymonitoring/2019/index.htm.

Eiropas Komisija (2019), DESI Report 2019 - Telecommunication Chapter of Latvia, Eiropas Komisija, Brisele, https://ec.europa.eu/ digital-single-market/en/news/2019-desi-report-electronic-communications-markets-overview-member-state-telecom-chapters.

Eiropas Komisija (2018a), Study on Broadband Coverage in Europe 2018, Brisele, https://ec.europa.eu/newsroom/dae/document.cfm?doc_ $i d=62760$.

Eiropas Komisija (2018b), DESI Report 2018 -Telecommunication Chapter of Latvia, Brisele, https://ec.europa.eu/digital-single-market/ en/scoreboard/latvia.

Eiropas Komisija (2016), Connectivity for a Competitive Digital Single Market - Towards a European Gigabit, Brisele, https://ec.europa.eu/ newsroom/dae/document.cfm?doc_id=17182.

Eiropas Komisija (2010), Digital Agenda for Europe, Brisele, https://ec.europa.eu/digital-single-market/en/digital-agenda-europekeypublications.

ESAO (2020a), ESAO telekomunikāciju un interneta statistika (datubāze), https://doi.org/10.1787/data-00170-en (piekḷve 2020. g. 9. jūlijā).

ESAO (2020b), OECD Broadband Portal (datubāze), www.oecd.org/sti/broadband/oecdbroadbandportal.htm (piekḷūts 2020. gada 6. maijā).

ESAO (2019a), Measuring the Digital Transformation: A Roadmap for the Future, OECD Publishing, Parize, https://dx.doi.org/ 10.1787/9789264311992-en.

ESAO (2019b), "The road to 5G networks: Experience to date and future developments", OECD Digital Economy Papers, No. 284, OECD Publishing, Parize, https://dx.doi.org/10.1787/2f880843-en.

ESAO (2018a), "Bridging the rural digital divide”, OECD Digital Economy Papers, No. 265, OECD Publishing, Parīze, https://dx.doi. org/10.1787/852bd3b9-en.

ESAO (2018b), OECD Reviews of Digital Transformation: Going Digital in Sweden, OECD Publishing, Parīze, https://dx.doi. org/10.1787/9789264302259-en.

ESAO (2016), "Driving performance at Latvia's Public Utilities Commission”, The Governance of Regulators, OECD Publishing, Parīze, http://dx.doi.org/10.1787/9789264257962-en.

ESAO (2014), “The Internet in transition: The state of the transition to IPv6 in today's Internet and measures to support the continued use of IPv4", OECD Digital Economy Papers, No. 234, OECD Publishing, Parize, https://dx.doi.org/10.1787/5jz5sq5d7cq2-en.

FCC (2019), 2019 Broadband Deployment Report, Vašingtona, DC, www.fcc.gou/reports-research/reports/broadband-progress-reports/2019broadband-deployment-report.

Google (2020), “Per-country IPv6 adoption”, www.google.com/intl/en/ipv6 (piekḷuve 2020. gada jūnijā).

Latvijas Republika (2017), Law on High-speed Electronic Communications Network, Likumi, Rīga, https://likumi.lv/ta/en/en/id/289933-law-onhigh-speed-electronic-communications-network.

Latvijas Republika (2009), Noteikumi par regulējamiem sabiedrisko pakalpojumu veidiem, Rīga, www.vvc.gov.lv/export/sites/default/docs/ LRTA/MK_Noteikumi/Cab._Reg._No._1227_-_Regarding_Types_of_Regulated_Public_Utilities.doc.

M-Lab (2019), "Worldwide broadband speed league”, www.cable.co.uk/broadband/speed/worldwide-speed-league (piekl̦uve 2020. gada 9. maijā).

Ookla (2019), "Speedtest”, www.speedtest.net/global-index (piekḷuve 2020. gada 9. maijā).

SPRK (2019), Funkcijas, stratēgija, rīcības plāns, Sabiedrisko pakalpojumu regulēšanas komisija, Rīga, www.sprk.gov.lv/en/content/ mission-objective-and-functions (piekl̦uve 2019. gada 12. decembrī). 
SPRK (2018a), Elektronisko sakaru nozares: faktos un skaitl̦os 2018, Sabiedrisko pakalpojumu regulēšanas komisija, Rīga,, https:// infogram.com/id-es_nozares_raditaji_2018-1hxj48qk0y154ug?live.

SPRK (2018b), Radiofrekvenču izsoles [Radio frequency auctions], Public Utilities Commission, Riga, www.sprk.gov.lv/content/ radiofrekvencu-izsoles (piekḷuve 2020. gada 6. maijā).

Steam (2019), "Steam download stats", https://store.steampowered.com/stats/content (piekḷuve 2020. gada 9. maijā).

Tele2 (2019), “Tele2 and Bite sign agreement to share networks in Latvia and Lithuania”, Tele2, https://www.tele2.com/media/ press-releases/2019/tele2-and-bite-sign-agreement-to-share-networks-in-latvia-and-lithuania.

Telecompaper (2019), “Telia to re-assess position in Latvia after cooperation with govt stalls”, Telecompaper, www.telecompaper. com/news/telia-to-re-assess-position-in-latvia-after-cooperation-with-gout-stalls--1309230.

The Baltic Course (2018), Baltics Keen to Test Self-Driving Cars on Via Baltica, The Baltic Course, www.baltic-course.com/eng/good_for_ business/? doc $=143975$.

Weller, D. and B. Woodcock (2013), "Internet traffic exchange: Market developments and policy challenges”, OECD Digital Economy Papers, No. 207, OECD Publishing, Parīze, http://dx.doi.org/10.1787/5k918gpt130q-en.

\section{Piezīmes}

\section{Izraēla}

Statistikas datus par Izraēlu sniedza, un par tiem atbild Izraēlas attiecīgās iestādes. Šo datu izmantošana ESAO neskar Golānas augstieṇu, Austrumjeruzalemes un Izraēlas apmetṇu statusu Rietumkrastā saskaṇā ar starptautisko tiesību noteikumiem.

1. https://docs.google.com/spreadsheets/d/18ztPX_ysWYqEhJlf2SKQQsTNRbkwoxPSfaC6ScEZAG8/edit\#gid=0.

2. Latvijas Universitātes Matemātikas un informātikas institūta Tīkla risinājumu daḷa (NIC) ir augšèjā līmen,a domēna .lv reǵistrs. 



\section{Nodala 4}

\section{DIGITĀLĀS TRANSFORMĀCIJAS ATBALSTİŠANA STARP CILVĒKIEM, UZN̦ĒMUMIEM UN VALDĪBU}


1991. gada 21. augustā Latvijas Republika deklarēja neatkarības atjaunošanu, un tas bija tikai divas nedēḷas pēc tam, kad tiešsaistē tika publicēta pasaulē pirmā tīmekḷa vietne. Kopš tā laika Latvija ir pārvarējusi daudzus izaicinājumus, piemēram, 2008. gada starptautisko finanšu krīzi, un nākotnē ir jauni izaicinājumi, piemēram, darbspējīgā vecuma iedzīvotāju skaita samazināšanās un COVID-19 radīto problēmu novēršana. Šo izaicinājumu risināšanā var palīdzēt produktivitātes paaugstināšana un digitālo tehnolog̣iju lietošanas sekmēšana.

Latvija ir panākusi ievērojamu progresu attiecībā uz interneta lietošanu. Valdība ir vadošais digitālo tehnoloǵiju lietotājs Eiropas valstu vidū, bet privātais sektors atpaliek. Izstrādājot visaptverošu nacionālo digitālo stratēǵiju ar pietiekamu resursu līmeni, Latvija var vēl vairāk palielināt digitālo tehnolog̣iju lietošanu iedzīvotāju vidū, uzṇēmumos un valdībā, kā norādīts iepriekš šajā nodaḷā. 1. sadaḷā aplūkota lietošana iedzìvotāju vidū, šḳērṣ̌ıi lietošanai augstākā līmenī un politikas, lai lietošanu palielinātu (piem., pamata lietošanas prasmju uzlabošana), tostarp COVID-19 pandēmijas laikā. 2. sadaḷā analizēta nelielā digitālo tehnoloǵiju, īpaši e-komercijas, lietošana uzṇēmumos, pašreizējā politika, lai uzlabotu digitālās prasmes darba vietā, un programmas, lai veicinātu digitālo tehnologiiju ieviešanu uzṇēmumos. 3. sadaḷā aplūkotas veiktās darbības, lai palielinātu digitālo tehnolog̣iju lietošanu valdībā, un 4. sadaḷā sniegti secinājumi un apkopotas politikas rekomendācijas.

\section{Digitālo tehnolog̣iju lietošana iedzìvotāju vidū}

\section{Interneta lietošana pa grupām}

Latvijas iedzīvotāju interneta lietošanas intensitāte ir vidēja, kas atbilst tendencei kaimiṇvalstīs ar līdzīgu IKP līmeni (4.1. attēls). Atšķirības ir starp demogrāiskajām grupām (pamatojoties uz vecumu, izglìtību un dzimumu), bet arī tās atbilst situācijai kaimiṇu valstīs (4.2. attēls). Šādu atšķirību sašaurināšana ir būtiska, lai panāktu Informācijas sabiedrības attīstības pamatnostādnēs noteiktos mērķus ( skatīt 7. nodaḷu).

\section{1. attēls. Interneta lietotāji pēc izglìtības līmeṇa ESAO valstīs, 2018. gadā vai gadā, par kuru pēdējo pieejami dati}

Procentuāli no visām personām vecumā no 16 līdz 74 gadiem katrā kategorijā.

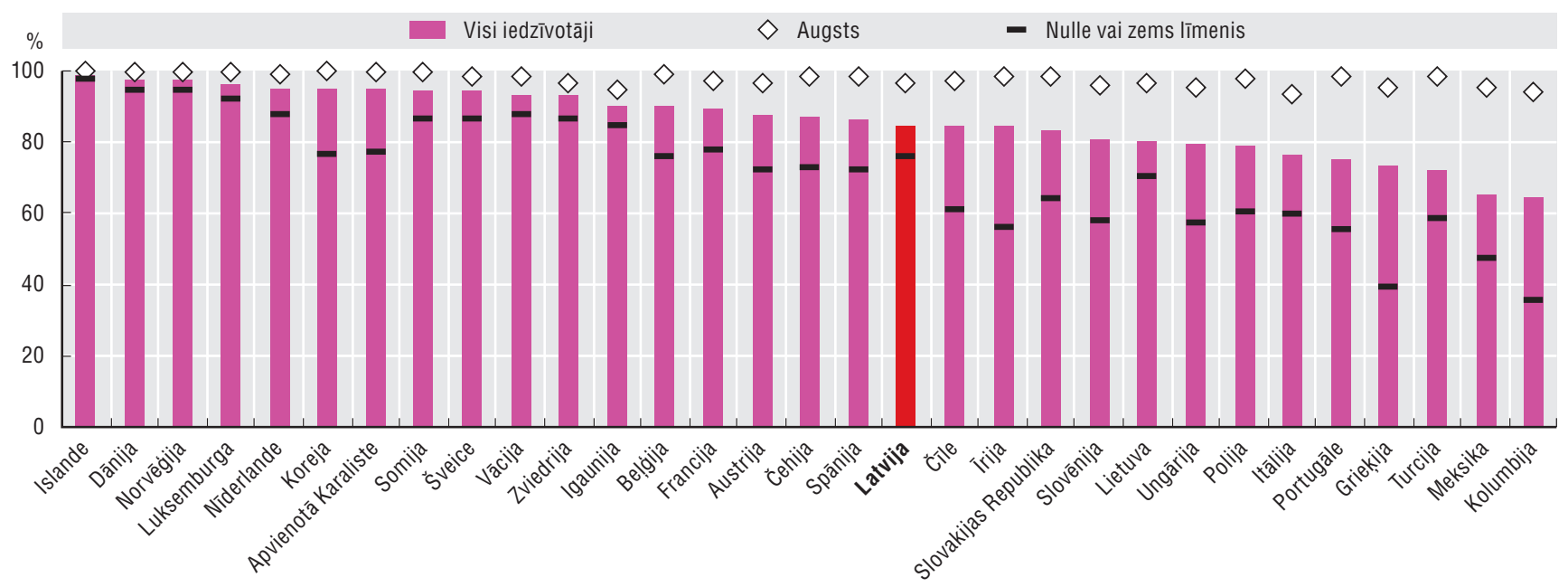

Piezīme: Ja nav norādīts citādi, interneta lietotāji ir noteikti trīs mēnešu atsauces periodam. Attiecībā uz Kolumbiju atsauces periods ir 12 mēneši. Attiecībā uz Savienotajām Valstīm nav konkrēta laika perioda.

Avots: ESAO (2018a), IKT pieejamība un lietošana mājsaimniecī bās un individuāli [ICT Access and Usage by Households and Individuals] (datubāze), http://oe.cd/hhind (skatīts 2020. gada martā).

Taču pēdējo gadu laikā interneta ieviešana ir pakāpeniski palielinājusies (4.3. attēls), iedzīvotāju, kas lieto internetu katru nedēḷu, skaitam pieaugot lēnāk par ES vidējo rādītāju (Eiropas Savienība, 2018a). Šo tendence var daḷeji izskaidrot ar interneta ieviešanas stagnāciju grupās ar zemākiem ienākumiem, jo atšķirības, pamatojoties uz vecumu un izglìtỉbu pakāpeniski sašaurinās (4.4. attēls). 
4.2. attēls. Interneta lietotāji pēc kategorijas ESAO valstīs, 2018. gadā vai gadā, par kuru pēdējo pieejami dati Procentuāli no visiem iedzīvotājiem vecumā no 16 līdz 74 gadiemkatrā kategorijā
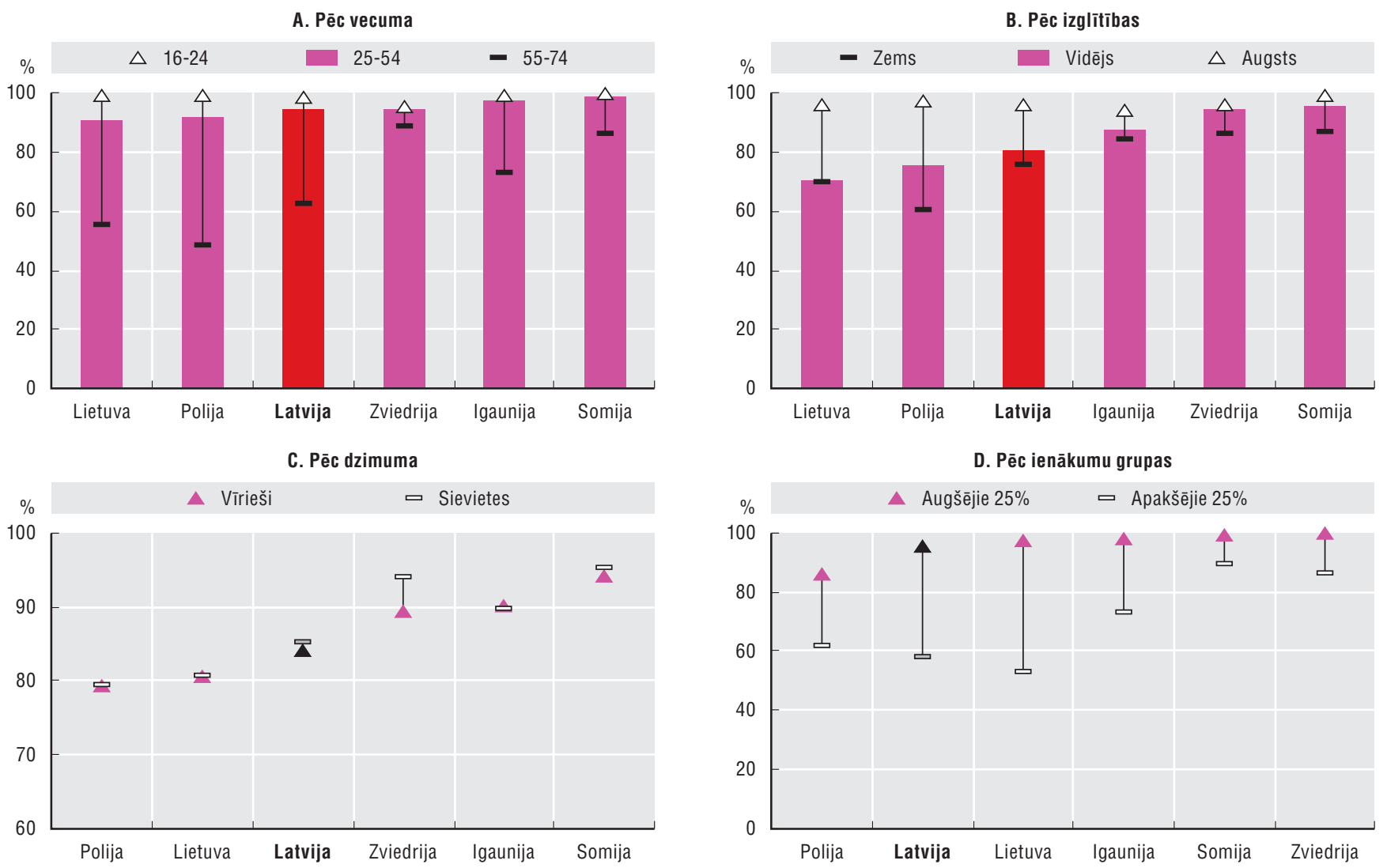

Avots: ESAO (2018a), IKT pieejamība un lietošana mājsaimniecī bās un individuāli [ICT Access and Usage by Households and Individuals] (datubāze), http://oe.cd/hhind (skatīts 2020. gada martā).

4.3. attēls. Interneta lietotāju tendences Latvijā un atlasītajās ESAO valstīs, 2005.-2018.

Procentuāli no visiem iedzīvotājiem vecumā no 16 līdz 74 gadiem

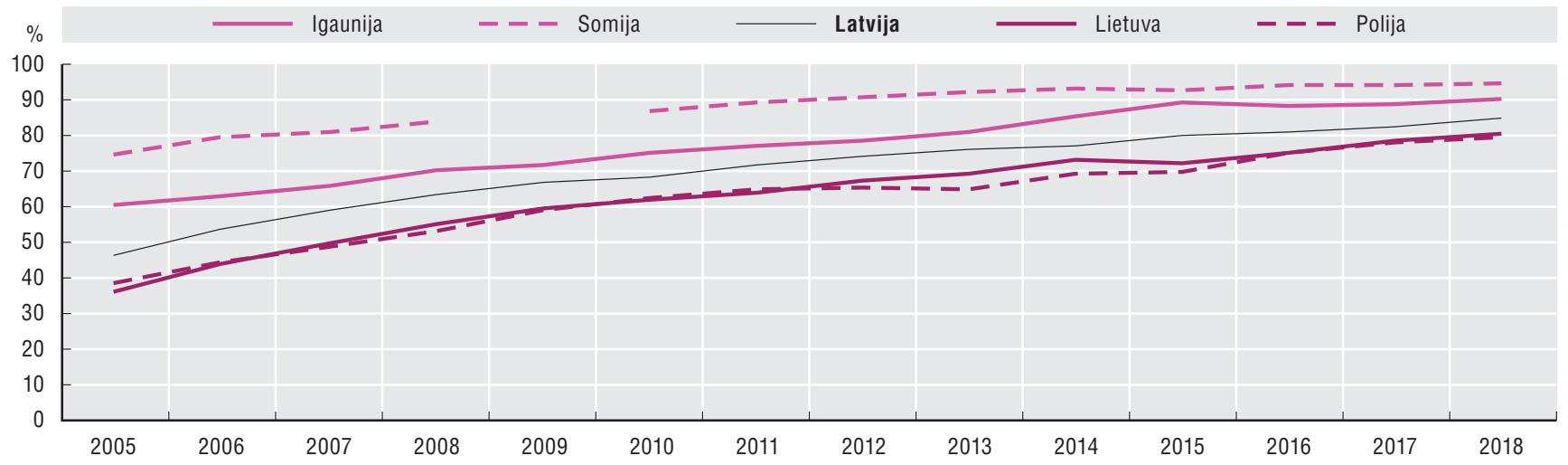

Avots: ESAO (2018a), IKT pieejamība un lietošana mājsaimniecī bās un individuāli [ICT Access and Usage by Households and Individuals] (datubāze), http://oe.cd/hhind (skatīts 2020. gada martā).

Turklāt piektdalai mājsaimniecību nav piekḷuves platjoslas pieslēgumam (4.5. attēls). Daudzas mājsaimniecības norāda, ka pieprasījums pēc piekḷuves internetam mājās ir zems: lai gan izplatītākais iemesls, kāpēc mājās nav piekḷuves internetam, ko norādījušas mājsaimniecības, ir nepieciešamības neesamība, citi faktori ietver arī izmaksas un prasmju trūkumu, īpaši nabadzīgākās mājsaimniecībās. Nabadzīgāko mājsaimniecību norādītā nepieciešamības pēc interneta neesamība var atspoguḷot informētības trūkumu par tā priekšrocībām vai atšķirīgas prioritātes (4.6. attēls). Šis zemais pieslēguma rādītājs attiecas uz mājsaimniecībām gan laukos, gan pilsētās (4.7. attēls). 


\section{DIGITĀLĀS TRANSFORMĀGIJAS ATBALSTİ̌̌ANA}

4.4. attēls. Interneta lietotāju tendences pa kategorijām Latvijā, 2005.-2018.

Procentuāli no visiem iedzīvotājiem vecumā no 16 lìdz 74 gadiem katrā kategorijā
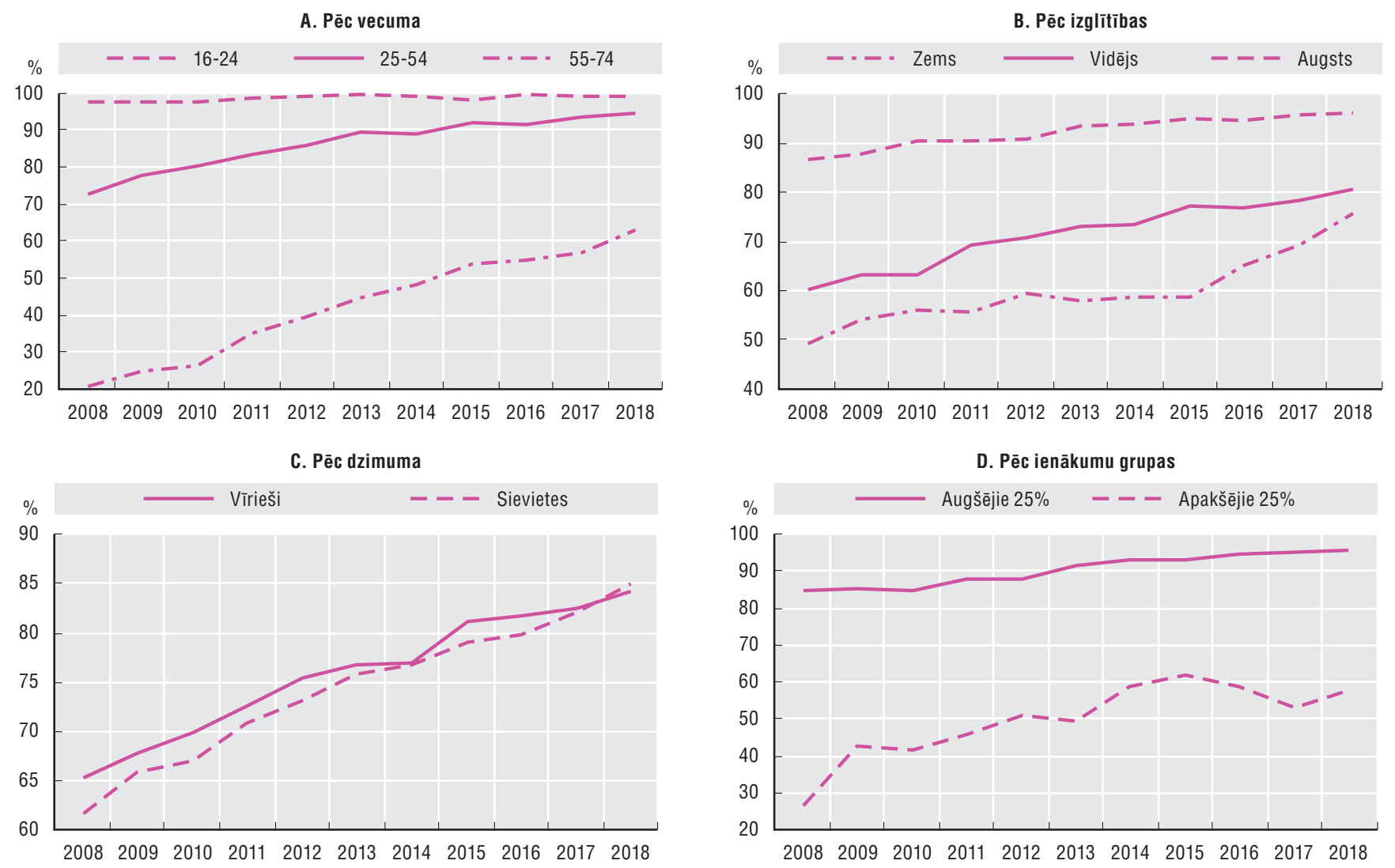

Avots: ESAO (2018a), IKT pieejamība un lietošana mājsaimniecī bās un individuāli [ICT Access and Usage by Households and Individuals] (datubāze), http://oe.cd/hhind (skatīts 2020. gada martā).

\section{5. attēls. Interneta piekḷuve mājās ESAO valstīs, 2018}

Procentuālais mājsaimniecību skaits ar platjoslas piekḷuvi mājās

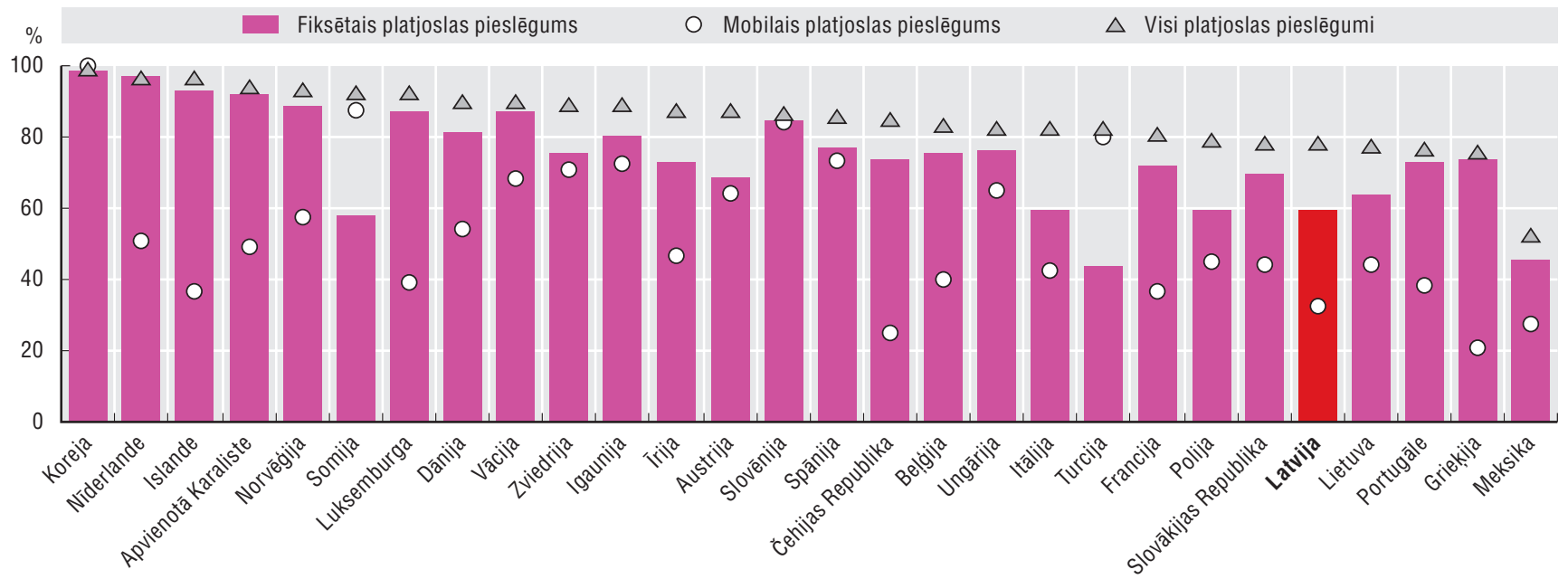

Avots: ESAO (2018a), IKT pieejamība un lietošana mājsaimniecī bās un individuāli [ICT Access and Usage by Households and Individuals] (datubāze), http://oe.cd/hhind (skatīts 2020. gada martā). 
4.6. attēls. Iemesli piekḷuvei internetam mājās neesamībai Latvijā, 2018

Procentuālais daudzums no visām mājsaimniecībām

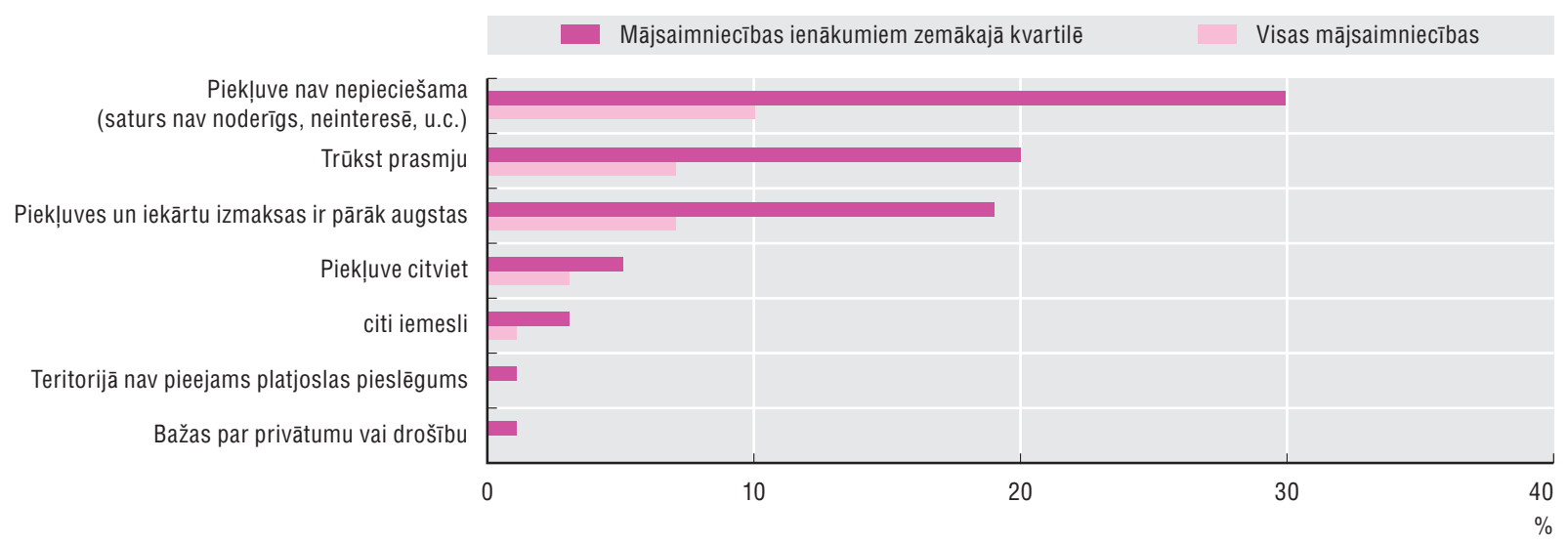

Avots: Eurostat (2020d).

4.7. attēls Lauku unpilsētas plaisa attiecībā uz piekḷuvi platjoslas pakalpojumiem Latvijā un atlasītajās ESAO valstīs, 2018

Procentuālais mājsaimniecību skaits ar platjoslas piekḷuvi mājās

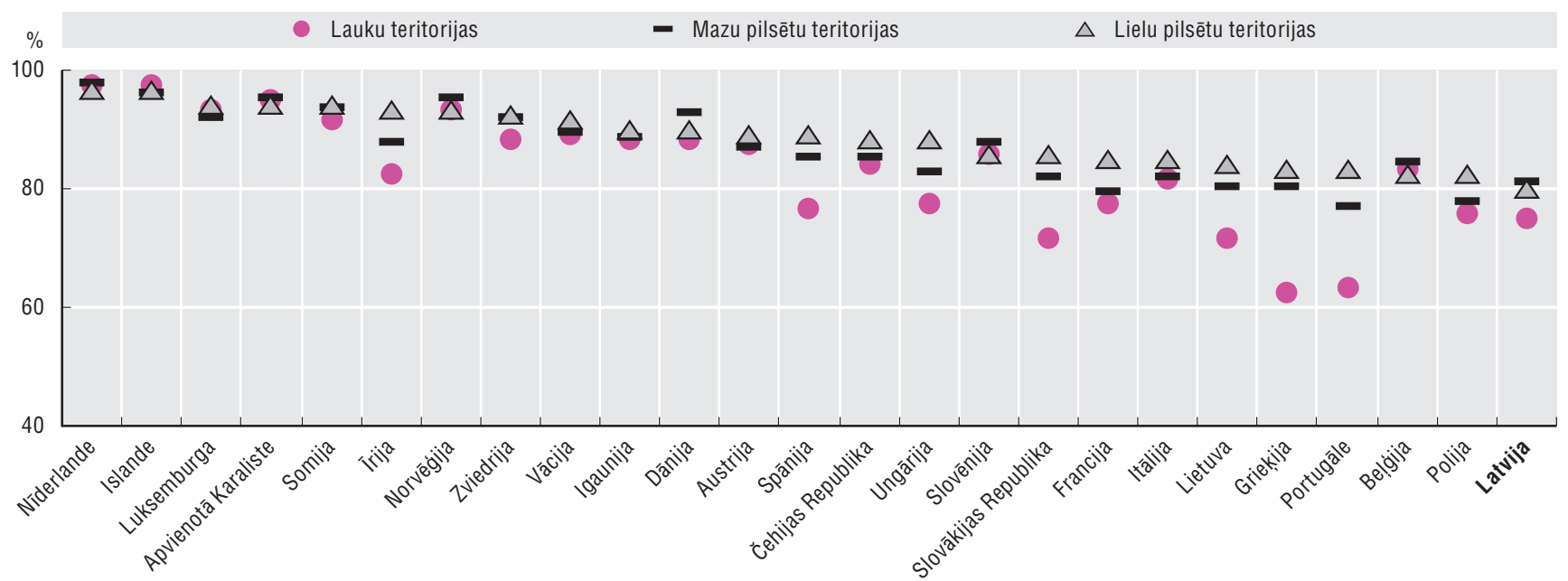

Avots: ESAO (2018a), IKT pieejamība un lietošana mājsaimniecī bās un individuāli [ICT Access and Usage by Households and Individuals] (datubāze), http://oe.cd/hhind (skatīts 2020. gada martā).

\section{Kā iedzivvotāji lieto internetu}

Lai gan ievērojama Latvijas iedzīvotāju daḷa internetu nelieto (skatīt iepriekš), tie, kuri to dara, lieto internetu relatīvi dažādi un komplicēti (ESAO, 2019a). Interneta lietotāju vidū e-banku pakalpojumu lietošanas un kontaktu ar valsts iestādēm līmenis ir augstāks par ESAO vidējo. Taču tiešsaistes kursus ir izmantojuši tikai nedaudzi, un tas atbilst kopējai dalības tendencei izglìtības un apmācības pasākumos (skatīt turpmāk tekstā). Lìdzīgi kā citās ESAO dalībvalstīs atšḳirības starp dzimumiem attiecībā uz interneta lietošanu saglabājas nelielas, sievietēm vairāk nekā vīriešiem lietojot sociālos medijus, kā arī biežāk izmantojot piekḷuvi ar veselību saistītai informācijai (4.8. attēls).

Taču attiecībā uz e-komercijas izmantošanu Latvija atpaliek no citām valstīm ar līdzīgu interneta lietotāju proporcionālo daudzumu. N̦emot vērā augsto piedalīšanās līmeni citās darbībās (piem., e-banku pakalpojumi un kontakti ar valsts iestādēm), šādu zemu iesaistišanās līmeni var izskaidrot ar to, ka nav Latvijas uzṇēmumu ar tiešsaistes tirdzniecību (skatīt nākamo sadaḷu). Pēdējā gada laikā mazāk nekā puse interneta lietotāju ir iepirkušies tiešsaistē, un vēl mazāks skaits ir kaut ko pārdevuši tiešsaistē. Daḷēji iemesls tam ir Latvijas vecāko iedzìvotāju skaits, jo vecuma grupā no 16 līdz 24 gadiem 


\section{DIGITĀLĀS TRANSFORMĀGIJAS ATBALSTİ̌̌ANA}

pirkumu apjoms ir tuvāks ESAO vidējam rādītājam (ESAO, 2018a). Turklāt pirkumi tiešsaistē parasti ir par nelielu summu (4.9. attēls). Latvija jau ir sasniegusi mērḳi, saskaṇā ar kuru 35\% iedzīvotāju iepērkas tiešsaistē līdz 2020. gadam (Informācijas sabiedrības attīstības pamatnostādnes, 6. nodaḷa) (Eurostat, 2020a); tāpēc būtu lietderīgi noteikt ambiciozāku mērkii.

4.8. attēls. Individuālie interneta lietotāji Latvijā, 2017. gadā vai gadā, par kuru pēdējo pieejami dati Procentuālais interneta lietotāju skaits, kas veic katru darbību
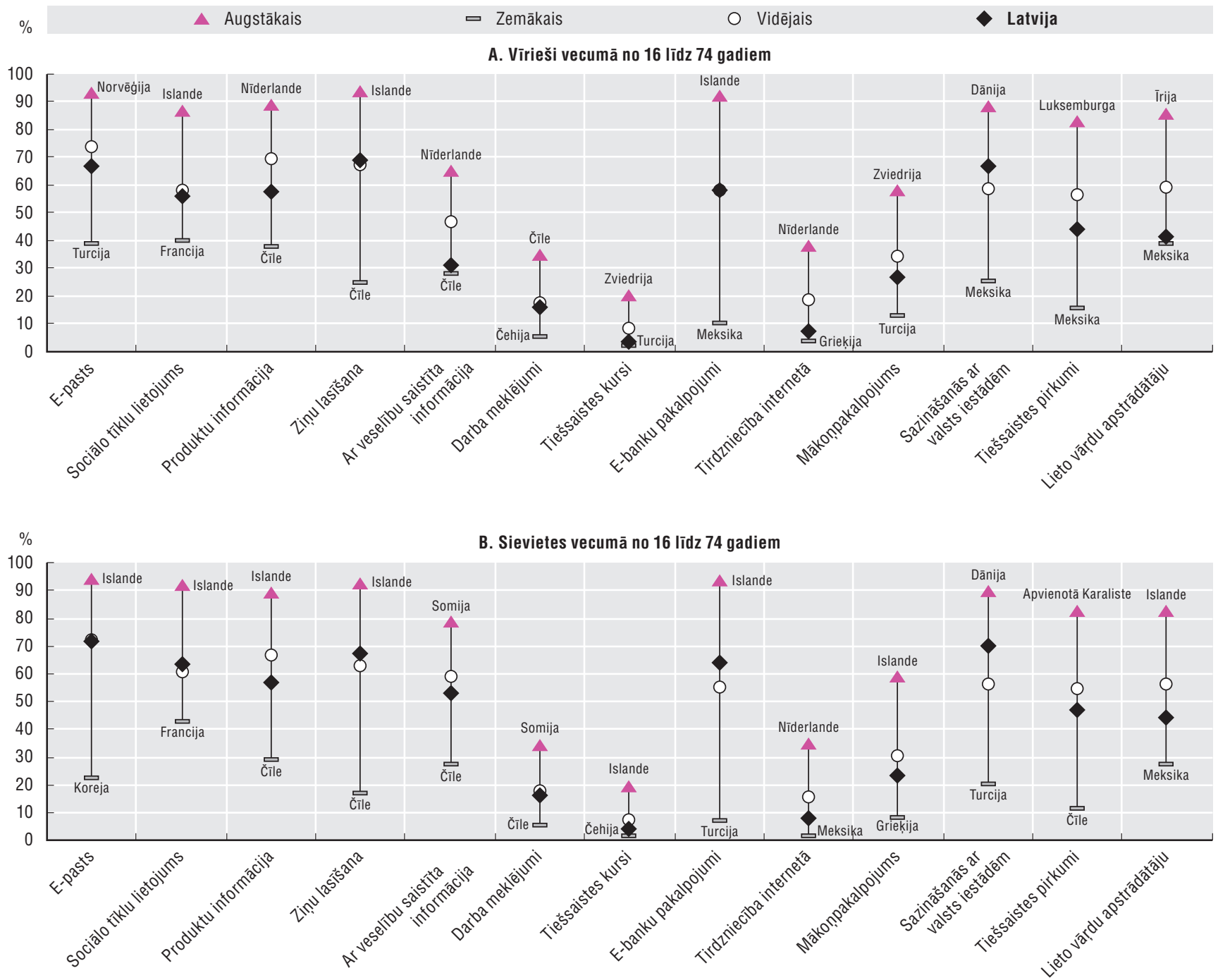

Avots: ESAO (2018a), IKT pieejamība un lietošana mājsaimniecī bās un individuāli [ICT Access and Usage by Households and Individuals] (datubāze), http://oe.cd/hhind (skatīts 2020. gada martā).

\section{IKT lietošanas veicināšana sabiedrībā}

Ir vairākas programmas, lai veicinātu IKT lietošanu sabiedrībā. Tās ir koncentrētas galvenokārt uz to, lai iedzīvotājiem nodrošinātu digitālo tehnoloğiju efektīvas lietošanas prasmes, taču ir mazas pēc mēroga. Kopienā balstītas pieejas pieṇemšana, lai veicinātu digitālo tehnoloǵiju lietošanu, un šìs stratēǵijas apvienošana ar citām stratēǵijām (piem., saistība ar diasporu) varētu palielināt tehnolog̣iju ieviešanu.

Kopš 2010. gada Latvijas valdība ir izvirzījusi mērḳi paaugstināt informētību par IKT iespējām, piedaloties Eiropas Digitālajā nedēḷā (iepriekš E-prasmju nedēḷa), kuras mērḳis ir informēt sabiedrību par ieguvumiem, ko sniedz digitālo prasmju uzlabošana, un apmācību iespējām. 2019. gada Digitālo 
nedēḷu organizēja Latvijas Informācijas un komunikācijas tehnolog̣ijas asociācija (LIKTA) un Vides aizsardzības un reǵionālās attīstības ministrija (VARAM), organizējot vairāk nekā 500 pasākumus 74 pilsētās un apdzìvotās vietās (KISC. 2019a). Turklāt Latvija ir meklējusi iespējas paplašināt pārvaldes e-pakalpojumu lietošanu, izmantojot kampaņu "Mana Latvija.lv Dari Digitali!" (My Latvija.lv Do Digitally!). Tīmekḷa analītikas izmanošana, lai pārbaudītu šãdu programmu ietekmi, varētu palīdzēt Latvijai nodrošināt resursu efektīvu izlietošanu.

\section{9. attēls. Tiešsaistes pirkumi Latvijā un atlasītajās ESAO valstīs, 2018}

Procentuālā visu iedzīvotāju daḷa
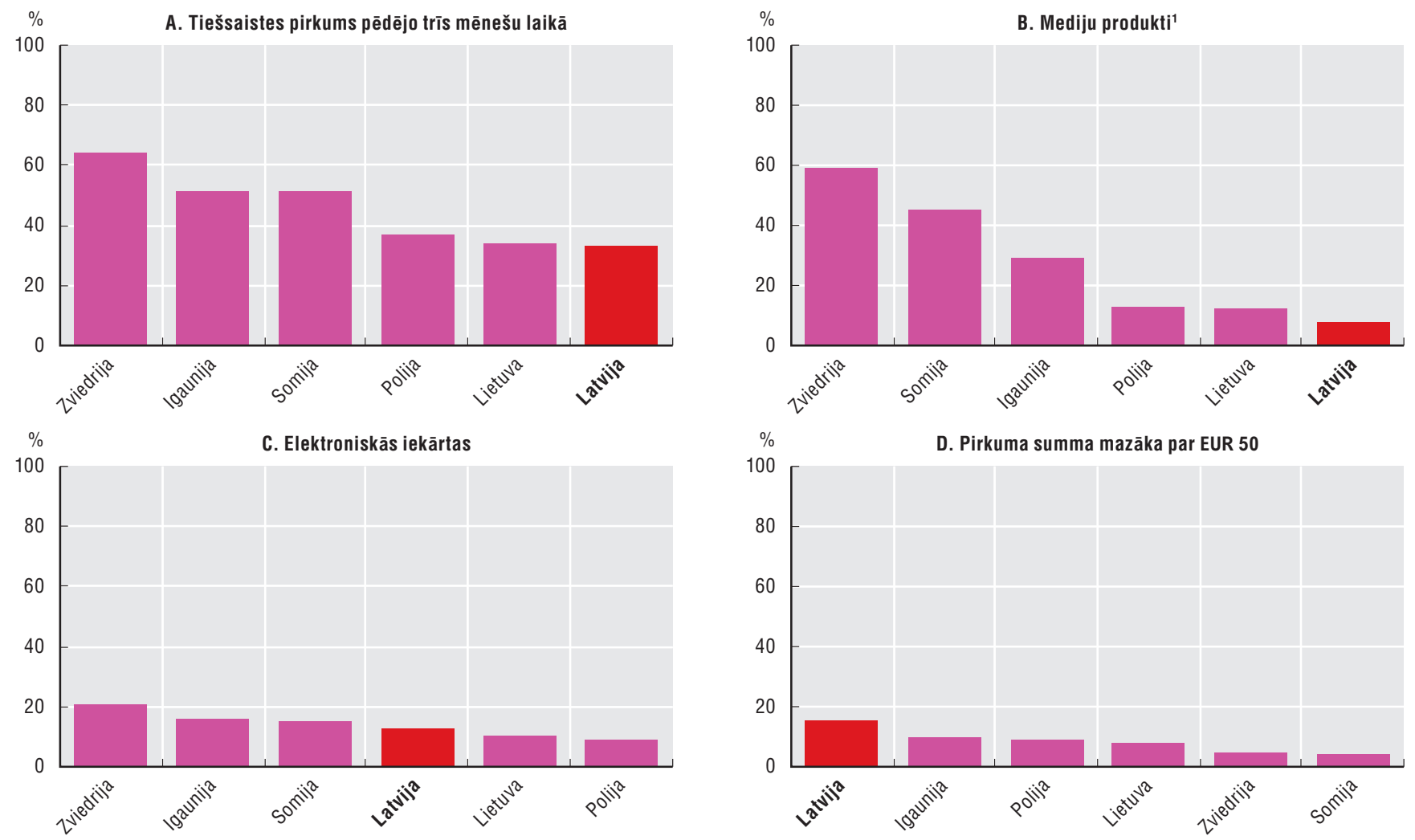

Piezīme: Mediju produkti ietver filmas/mūziku vai grāmatas/žurnālus/e-mācību materiālus vai datoru programmatūru.

Avots: Eurostat (2020c), ICT Usage in Households and by Individuals (database), https://ec.europa.eu/eurostat/cache/metadata/en/isoc_i_esms.htm.

Kultūras ministrija ir centusies paaugstināt interneta efektīvu izmantošanu (atbilstoši kultūras politikas pamatnostādnēm «Radošā Latvija 2014.-2020.»), veicinot tiešsaistes satura latviešu valodā veidošanu. Latvijas Kultūras informācijas sistēmu centrs (KISC) ir izvirzījis mērḳi saglabāt Latvijas kultūras mantojumu, izveidojot laikrakstu un žurnālu un citu materiālu, piemēram, vēsturisku plakātu, atklātṇu un fotogrāfiju, kas šobrīd glabājas Latvijas muzejos, arhīvos un bibliotēkās, digitālos arhīvus (KISC, 2019b). Papildus tam portāls biblioteka.lv nodrošina iespēju piekḷūt vietējam saturam, ko veido publiskās bibliotēkas, bet grāmatu latviešu valodā un tulkojumu izlasei var bez maksas piekḷūt, izmantojot 3td.lv tiešsaistes portālu. KISC nodrošina arī bibliotekāru apmācību. Turklāt valdība ir centusies palielināt uz vietas veidotā satura un satura latviešu valodā apjomu, izstrādājot tulkošanas rīkus, gramatikas korektorus un tiešsaistes terminoloǵijas datubāzes.

Līdzīgi kā daudzās citās valstīs attālinātām mācībām ir bijusi noteicošā loma, lai nodrošinātu izglìīibas turpināšanos Latvijā COVID-19 pandēmijas laikā. Neskatoties uz izaicinājumiem, ko radīja pēkšñā pāreja no klātienes apmācību formas uz e-mācībām, attālinātā apmācība ir krasi paātrinājusi digitālo tehnolog̣iju ieviešanu izglìtībā, radot ietekmi, kas, visticamāk, saglabāsies arī pēc krīzes (skatīt 4.1. ielikums). 


\section{1. ielikums. Attālinātā mācīšanās CovID-19 pandēmijas laikā}

2020. gada 12. martā Latvijas valdība izsludināja ārkārtas stāvokli un slēdza visas skolas, radot problēmu, kā turpināt bērnu izglītošanu Latvijā. Izglītības sistēmas atbildes reakcija bija attālinātās apmācības piedāvājums, izmantojot tradicionālo un digitālo rīku kombināciju.

Izglītības un zinātnes ministrija (IZM) noteica kā prioritātes akadēmisko mācību nepārtrauktību un atbalstu skolotājiem un skolēniem, kam trūkst prasmes tiešsaistes vai neatkarīgu mācību īstenošanai. Valsts izglītības centrs izstrādāja vadlīnijas attālināto mācību īstenošanai, sniedzot tiešsaistes ieteikumus un materiālus vecākiem un skolotājiem. Tika arī izdotas vadlīnijas par skolēnu sekmju vērtēšanu, iekḷaujot ieteikumu nodrošināt skolēniem lielāku elastību savu spēju demonstrēšanai (piem., rakstot vai veidojot video). Turklāt skolām piešḳirta autonomija noteikt prioritārus mācību programmas priekšmetus, ko tās uzskata par piemērotiem (IZM, 2020; www. izm.gou.lv/lv/macibas-attalinati).

Mācību programmas realizācijai ir izmantota dažādu tehnoloǵiju kombinācija. Mācību stundas sākumskolas un vidusskolas skolēniem aptuveni 440 stundu garumā ir pārraidītas bezmaksas televīzijas kanālā, nodrošinot surdotulkojumu bērniem ar dzirdes traucējumiem. Turklāt mācību stundas skolēniem ir pieejamas arī tīmekḷa vietnē Tava klase, bet skolotāji ir izmantojuši tādus rīkus kā Edurio, lai uzdotu pārbaudes darbus un veiktu aptaujas, kā arī plaši izmantotas lietotnes, piemēram, WhatsApp. Arī Latvijas Nacionālais kino centrs ir nodrošinājis Latvijas skolēniem bezmaksas piekḷuvi filmām, kas saistītas ar mācību programmu.

N̦emot vērā pastāvošās digitālās atšḳirības, bija risks, ka atsevišḳi bērni varētu palikt ārpus programmas. Lai risinātu šādu iespējamu problēmu, IZM ir nodrošinājusi digitālās ierīces aptuveni 500 skolēniem (aptuveni 3\% visu skolu audzēkṇu), kuriem nebija piekḷuves šādiem rīkiem. Turklātdažās skolās ir sagatavoti un skolēniem izdalīti drukātu materiālu komplekti.

Lai gan digitālās tehnologijas neaizstāj tradicionālās mācību klases, zināmus ieguvumus tās nodrošina, tostarp padara darbības, piemēram, mājasdarbu pildīšanu, par interaktīvu un efektīvu mācīšanās rīku. Latvijā attālinātā mācǐšanās ir uzraudzìta, izmantojot iknedēlas atskaites, un digitālo tehnoloǵiju izmantošanas sniegtās mācības var ietekmēt to, kā turpmāk tiks nodrošināta izglītība.

\section{Prasmju uzlabošana ir nozīmīga centienu paaugstināt IKT lietošanu daḷa}

Pamata digitālo prasmju trūkums kavē plašāku IKT lietošanu iedzīvotāju vidū, un šādas prasmes Latvijā nav pusei pieaugušo iedzīvotāju (piem., prasme pārvietot vai kopēt datnes starp mapēm) (4.10. attēls). Atšķirības starp dzimumiem šajā jomā ir nelielas, lai gan lielākajai dal̦ai sieviešu (30\%) ir augstākas pamatprasmes nekā vīriešiem (24\%), atšķirībā no citām ES dalībvalstīm (Eurostat, 2019a). Turklāt atšḳirības starp lauku un pilsētu teritorijām ir nelielas.

IKT izglītības un e-prasmju uzlabošana ir Informācijas sabiedrības attīstības pamatnostādṇu uzmanības centrā. Papildus darba devēju pieprasītajai augstāka līmeṇa prasmju apmācībai ir izveidotas programmas lietotāju pamata prasmju uzlabošanai (skatīt nākamo sadaḷu). Valdība ir izstrādājusi vairākas politikas pieaugušo Latvijas iedzīvotāju digitālās pratības veicināšanai, un tās tiek ìstenotas, izmantojot publisko bibliotēku tīklu.

Publiskās bibliotēkas darbojas kā interneta piekḷuves punktu un pamata digitālo prasmju attīstības centri. 2008. gadā KISC saṇēma finansējumu no Bill \& Melinda Gates fonda un Latvijas valdības, lai nodrošinātu Latvijas publiskajām bibliotēkām 4000 datorus programmas "Trešais tēva dēls» ietvaros. Bibliotēkām tika nodrošināti platjoslas pieslēgumi un bezmaksas piekḷuve Wi-Fi. Bibliotēkārus apmācīja, lai viṇi varētu palīdzēt lietotājiem, un tika izstrādāta pamata IT prasmju apmācību programma, kuras mērḳauditorija ir iedzīvotāji ar zemiem ienākumiem un izglītības līmeni, lauku iedzīvotāji un gados vecāki cilvēki, kā arī līdzīga programma tika izstrādāta bērniem (KISC, 2015). Papildus tam ERAF finansēta projekta ietvaros tika izveidoti vairāk nekā 450 publiskas Wi-Fi pieslēgvietas (ko pārvalda 76 pašvaldības) (ir pieejami arī vairāk nekā 4400 bezmaksas Wi-Fi pieslēgvietu, kam netiek saṇemts valsts finansējums). 
4.10. attēls. Pamata vai augstākas par pamata digitālās prasmes ${ }^{1}$ Latvijā un atlasītajās ESAO valstīs, pēc dzimuma, 2017

Personu ar pamata vai augstākām par pamata digitālajām prasmēm procentuālais daudzums

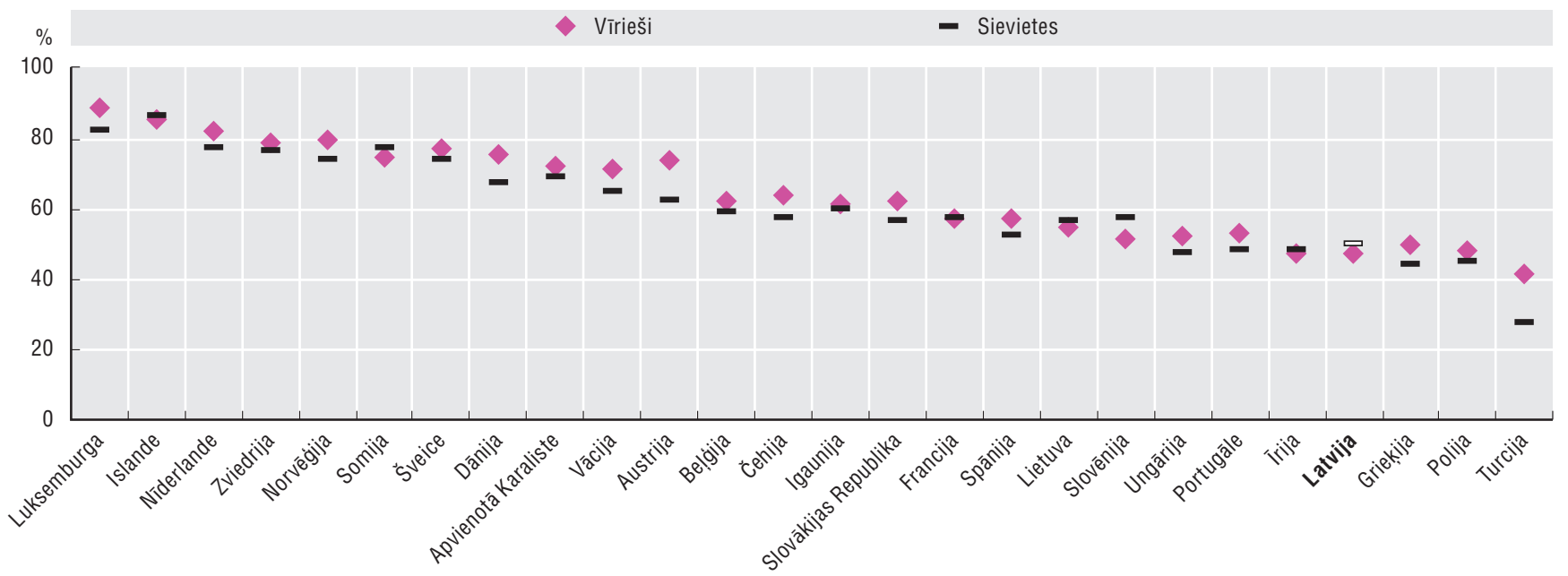

1. Personas ar pamata prasmēm ir veikušas vienu no šīm darbībām: kopējušas vai pārvietojušas datnes vai mapes, saglabājušas datnes glabātuvēs interneta telpā, ieguvušas informāciju no valsts iestāžu/dienestu tīmekḷa vietnēm, atradušas informāciju par precēm vai pakalpojumiem un meklējušas ar veselību saistītu informāciju. "Augstākas par pamata” prasmes nozīmē spēju veikt divas vai vairākas no šīm darbībām.

Avots: Eurostat (2020c), ICT Usage in Households and by Individuals (database), https://ec.europa.eu/eurostat/cache/metadata/en/isoc_i_esms.htm.

\subsection{1. attēls Plaisa starp laukiem un pilsētu attiecībā uz digitālajām prasmēm ${ }^{1}$ Latvijā $^{-}$ un atlasìtajās ESAO valstīs, 2017}

Personu ar pamata vai augstākām par pamata digitālajām prasmēm procentuālais daudzums

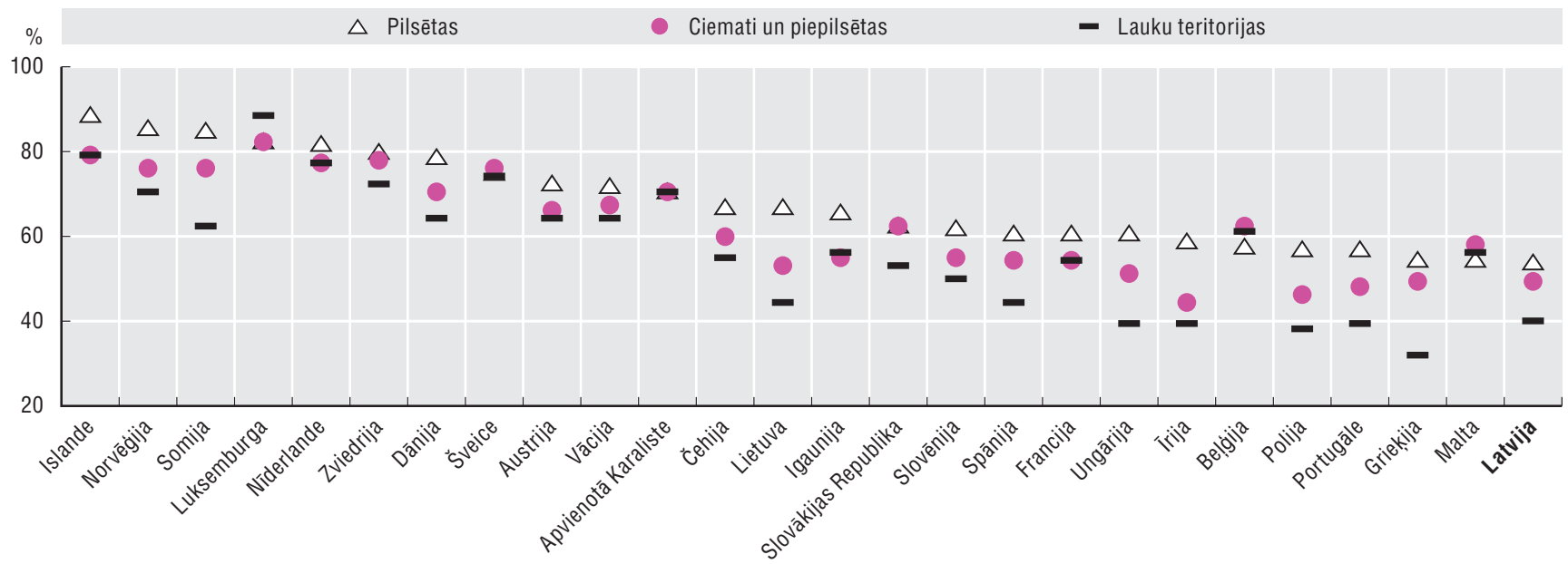

1. Personas ar pamata prasmēm ir veikušas vienu no šīm darbībām: kopējušas vai pārvietojušas datnes vai mapes, saglabājušas datnes glabātuvēs interneta telpā, ieguvušas informāciju no valsts iestāžu/dienestu tīmekḷa vietnēm, atradušas informāciju par precēm vai pakalpojumiem un meklējušas ar veselību saistītu informāciju. "Augstākas par pamata" prasmes nozīmē spēju veikt divas vai vairākas no šīm darbỉbām.

Avots: Eurostat (2020c), ICT Usage in Households and by Individuals (database), https://ec.europa.eu/eurostat/cache/metadata/en/isoc_i_esms.htm.

Trešā tēva dēla programma ir bijusi sekmīga, taču atbildība par iekārtu un pamata IKT apmācības nodrošināšanu ir gūlusies uz pašvaldībām. Turklāt daudzi tiešsaistes apmācību materiāli (pieejami KISC tīmekḷa vietnē) tagad ir novecojuši. Šo materiālu atjaunināšana palīdzētu nodrošināt, ka bibliotēkas arī turpmāk var sniegt palīdzību tiem, kuri vēlas apgūt digitālās pamata prasmes. Turklāt pašvaldībām būtu jānosaka pienākums nodrošināt nepieciešamo iekārtu uzturēšanu un nomaiṇu, paredzot tam līdzekḷus no centralizētajiem avotiem.

Taču, ṇemot vērā Latvijas iedzīvotāju zemo digitālo prasmju līmeni, šim jautājumam būtu jāpievērš lielāka uzmanība. Šobrīd lielākā daḷa resursu digitālo pamata prasmju attīstīšanai ir paredzēti skolas 
vecuma bērniem (skatīt turpmāk). Kolumbijā sekmīga izrādījās iniciatīva, kas paredz saistīt programmas digitālo prasmju attīstī̌šanai bērniem ar vakara programmām bērna vecāku prasmju attīstīšanai, un tā varētu būt noderīga arī Latvijā (ESAO, 2019b).

Latvijā vajadzētu balstīties uz programmas «Trešai tēva dēls» panākumiem, izveidojot kopienā balstītu programmu iedzīvotāju attālākos lauku rajonos un gados vecāku Latvijas iedzīvotāju digitālo prasmju paaugstināšanai. Lai gan pastāv «digitālo ağentu» programma, tajā uzmanība koncentrēta drīzāk uz valsts pārvaldes digitālo pakalpojumu lietošanas veicināšanu, nevis vispārēju lietojumu. Latvijai drīzāk vajadzētu piešḳirt dotācijas partneriem, piemēram, NVO vai vietējām kopienas grupām, lai apmācītu digitālos mentorus izcelt IKT priekšrocības, un šãda pieeja ir bijusi sekmīga Austrālijā un Norvēǵijā (4.1. ielikums). Latvijas vajadzētu pirmām kārtām strādāt ar tām grupām, ko veido cilvēki, kas relatîvi maz lieto IKT (piem., gados vecāki cilvēki), lai atklātu, ar kādām barjerām vini saskaras, un izpētītu veidus, kā digitālo tehnoloǵiju plašāka izmantošana viniem nāktu par labu.. Šìs darbības rezultātus izmantotu, lai izstrādātu apmācību programmu, ko pasniegtu digitālie mentori.

\section{2. ielikums. Austrālija un Norvēgijija izvēlas kopienā balstītas pieejas, lai veicinātu digitālo pratību pieaugušo vidū}

Austrālijas programmas "Be Connected" [Pieslēdzies] mērḳis ir paaugstināt gados vecāko Austrālijas iedzìvotāju digitālo pratību un risināt sociālās problēmas, mazinot vientulības izjūtu un pastiprinot kopienas saites. Sociālo pakalpojumu departaments piešķir dotācijas 2500 vietējiem partneriem (piem., kopienas organizācijām), lai apmācītu digitālos mentorus, kuri tad ìsteno uz kopienu centrēto pieeju pamata prasmju mācīšanā, piemēram, iepirkšanās tiešsaistē, e-pasta nosūtišana un sociālo mediju lietošana.

Norvēǵijā 2017. gada programmas "Digidel" mērḳis bija sekmēt digitālo pratību un iekḷaušanu. Tika izveidotas mērḳa grupas - tās, kas nelieto IKT regulāri (tostarp gadus vecāki cilvēki un imigranti), lai izprastu, ar kādām barjerām šie cilvēki saskaras, un kāds būtu vinuu ieguvums no šo rīku lietošanas. Pēc tam notika apmācības, ko veica vietējās bibliotēkas, NVO un uzṇēmumi.

N̦emot vērā valdības norādīto mērḳi stiprināt saites ar latviešu diasporu, Latvija varētu izmantot digitālās tehnologiijas, lai digitāli kontaktētos ar diasporas loceklịiem (Pārresoru koordinācijas centrs, 2017). Šìs iniciatīvas pirmajā posmā notiktu gados vecāko Latvijas iedzìvotāju apmācība sociālo mediju lietošanai, lai vini varētu uzturēt kontaktus ar saviem radiniekiem ārzemēs. Interneta pamata lietošana var kalpot kā aizsākums augstāka līmen,a lietošanas apgūšanai Latvijas iedzìvotājiem. Iniciatīvas otrajā posmā būtu sociālajos medijos aktīvi jāpopularizē KISC uzturētais digitālais saturs.

\section{Lietošana privātpersonām- secinājumi}

Latvijas pastāvīgo centienu palielināt to iedzīvotāju proporciju, kas efektīvi lieto internetu, rezultātā ir panākts progress, lai gan pamata prasmes vēl joprojām trūkst ievērojamai daḷai. Bibliotēkas un kopienā balstītas programmas var palīdzēt sniegt šiem cilvēkiem trūkstošās digitālās prasmes. Turklāt var labāk izmantot esošos resursus, lai izveidotu virtuālās saiknes ar Latvijas diasporu ārzemēs. Šajā sadaḷā sniegtās rekomendācijas ir apkopotas 4.10. ielikums.

Taču, lai palielinātu patērētāju iesaistīšanos e-komercijā, būs nepieciešams palielināt Latvijas uzṇēmumu, kas efektīvi izmanto digitālās tehnoloğijas, proporciju. Šis jautājums ir analizēts nākamajā sadaḷā.

\section{Digitālo tehnologiju lietošana uzṇēmumos}

Lai paaugstinātu dzīves līmeni, Latvijai ir jāpaaugstina ekonomiskā izaugsme un produktivitāte. Latvijas rūpniecībā ir liels zemo tehnolog̣iju uzṇēmumu îpatsvars un produktivitāte atpaliek no kaimiņos esošajām Baltijas valstīm, ko izraisījusi produktivitātes izaugsmes tempa palēnināšanās pēc finanšu krīzes (Eiropas Komisija, 2018b; ESAO 2019c). Turklāt plašā produktivitātes izplatība starp uzṇēmumiem, īpaši administrācijas un atbalsta sektoros, norāda, ka jaunās tehnoloǵijas izmanto tikai 
nedaudzi modernie uzṇēmumi (ESAO, 2019c). Lielāka digitālo tehnoloǵiju ieviešana, īpaši mazākos uzṇēmumos, var palīdzēt paaugstināt produktivitāti.

\section{Pašreizējais IKT lietojums uzṇēmumos}

IKT lietojuma ziṇā Latvijas uzṇēmumi atpaliek no uzṇēmumiem citās ESAO dalībvalstīs. Lai gan lielākajai daḷai uzṇēmumu ir platjoslas interneta pieslēgums, relatīvi nelielai daḷai (80\%) ir fiksētie pieslēgumi (kas parasti nodrošina lielāku àtrumu), kā rezultātā kopumā pieslēguma àtrums ir viduvējs (4.12. attēls).

\subsection{2. attēls. Uzṇēmumu pieslēgumi fiksētiem platjoslas pakalpojumiem Latvijā un atlasītajās ESAO valstīs, 2018. gadā vai gadā, par kuru pēdējo pieejami dati \\ Uzṇēmumu ar 10 un vairāk nodarbinātiem darbiniekiem procentuālā daḷa}

A. Uzṇēmumu platjoslas pieslēgumi pēc uzṇēmuma lieluma

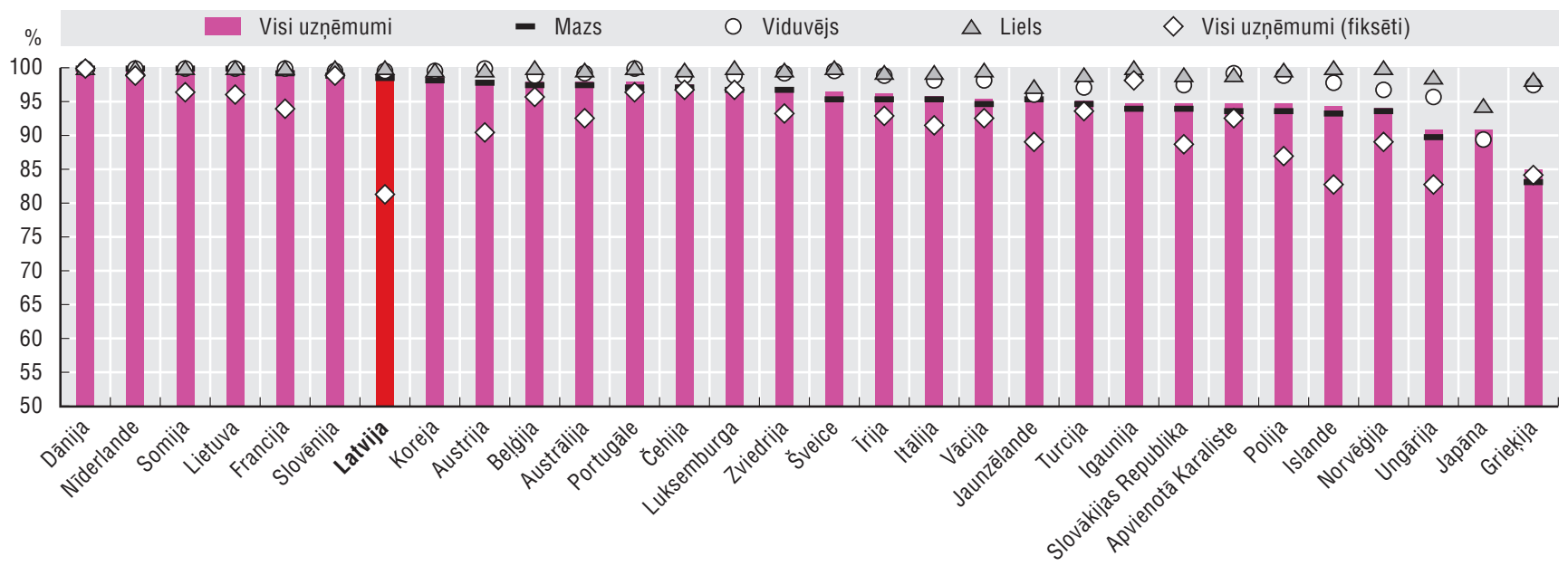

B. Uzṇēmumi ar platjoslas lejupielādes ātrumu vismaz $30 \mathrm{Mbit} / \mathrm{s}$

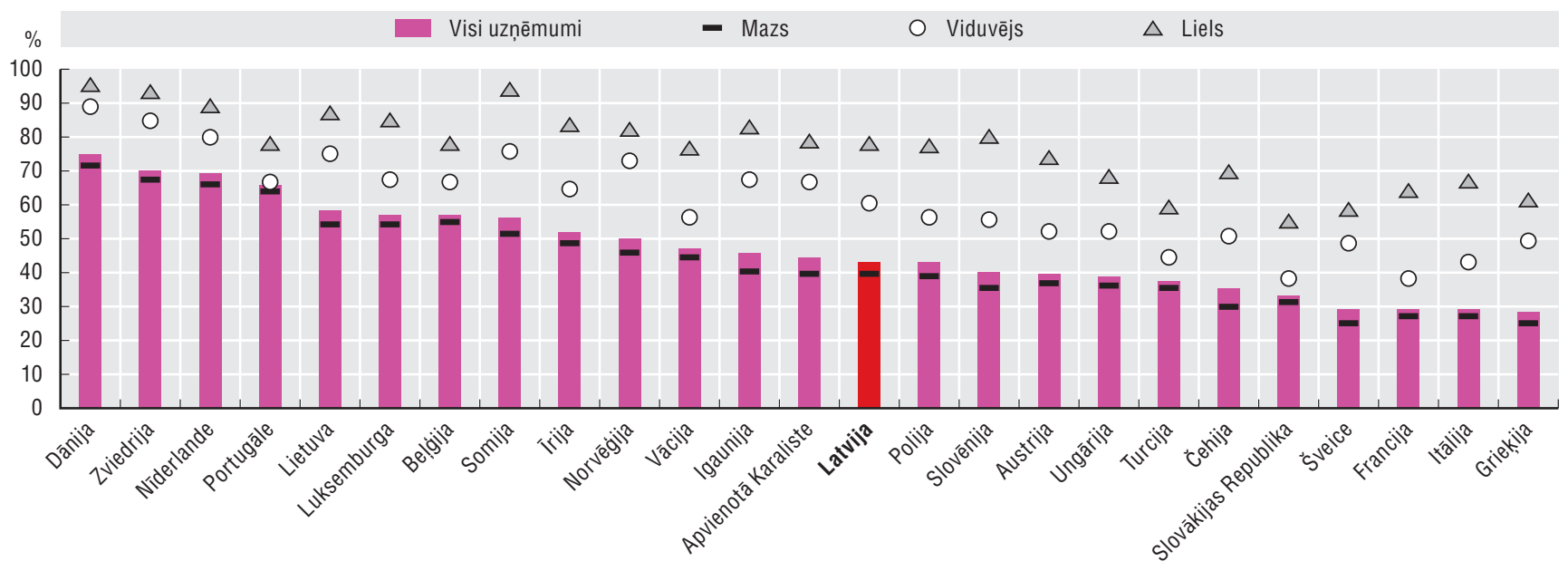

Piezīme: N̦emti vērā tikai uzṇēmumi ar desmit vai vairāk darbiniekiem. Lieluma kategorijas ir definētas šādi: mazie (10-49 darbinieki), vidējie (50-249 darbinieki) un lielie (250 vai vairāk darbinieku). Attiecībā uz Japānu dati attiecas uz uzṇēmumiem ar 100 un vairāk, nevis 10 un vairāk darbiniekiem; vidējos uzṇēmumos ir 100 lìdz 299 darbinieku un lielos uzṇēmumos ir 300 vai vairāk darbinieku.

Fiksēts platjoslas pakalpojums ir vadu vai fiksēts bezvadu platjoslas pieslēgums.

Avots: ESAO (2018a), IKT pieejamība un lietošana uzṇēmumos [ICT Access and Usage by Businesses] (datubāze), http://oe.cd/bus (skatīts 2019. gada martā).

Turklāt, neskatoties uz Latvijas iedzīvotāju vēlmi lietot internetu dažādām darbībām, piemēram, e-banku pakalpojumiem, uzṇēmumu iesaistī̌anās e-komercijā saglabājas zema (4.13. attēls). Latvija atpaliek no ESAO vidējiem rādītājiem attiecībā uz uzṇēmumu, kam ir sava tīmekḷa vietne, skaitu, un lai gan uzṇēmumu, kas veic e-pirkumus, skaits atbilst ESAO vidējam līmenim, uzṇēmumu apgrozijums 


\section{DIGITĀLĀS TRANSFORMĀCIJAS ATBALSTİ̌̌ANA}

no pārdošanas tīmeklī ir viens no zemākajiem ES (4.14. attēls). Šķiet, ka Latvijas uzṇēmumi nesasniegs mērḳi nodrošināt 15\% apgrozījuma no pārdošanas internetā līdz 2020. gadam, kā tas ir noteikts Informācijas sabiedrības attīstības pamatnostādnēs.

4.13. attēls. Interneta lietošana pēc atlasītajās ESAO valstīs, 2018. gadā vai gadā, par kuru pēdējo pieejami dati

Uzñēmumu ar 10 un vairāk nodarbinātiem darbiniekiem procentuālā daḷa

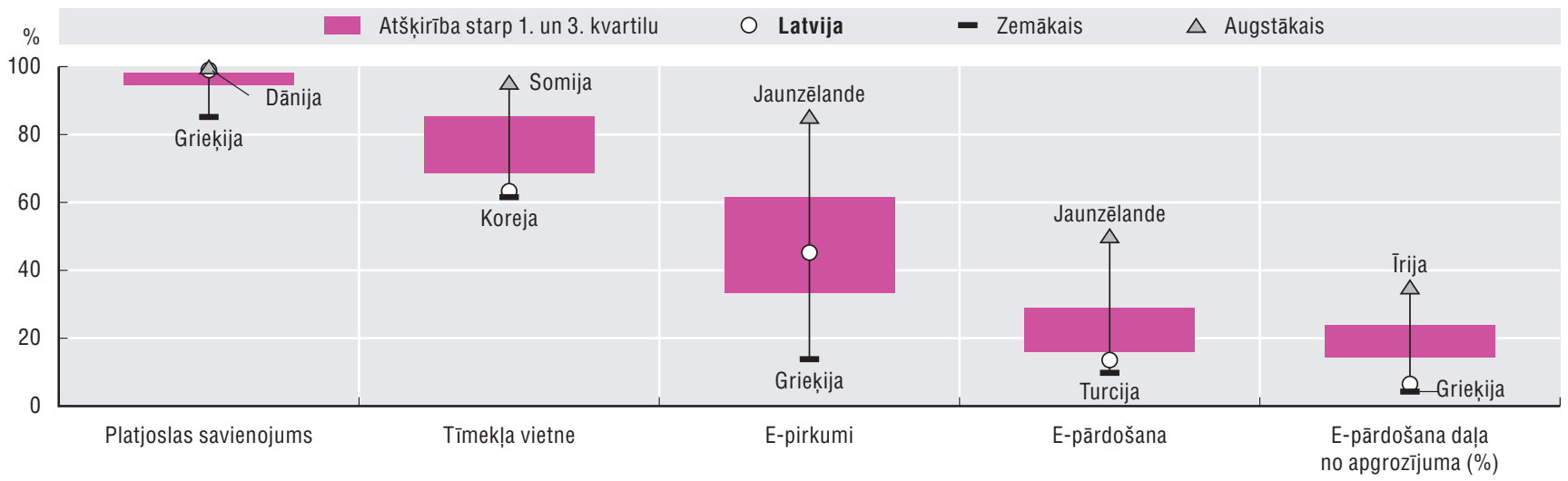

Piezīme: N̦emti vērā tikai uzṇēmumi ar desmit vai vairāk darbiniekiem.

Avots: ESAO (2018a), IKT pieejamība un lietošana uzṇēmumos [ICT Access and Usage by Businesses] (datubāze), http://oe.cd/bus (skatīts 2019. gada martā).

\subsection{4. attēls. Apgrozījums no tirdzniecības internetā Latvijā un atlasītajās ESAO valstīs, 2017}

Kopējā apgrozījuma procentuālā daḷa

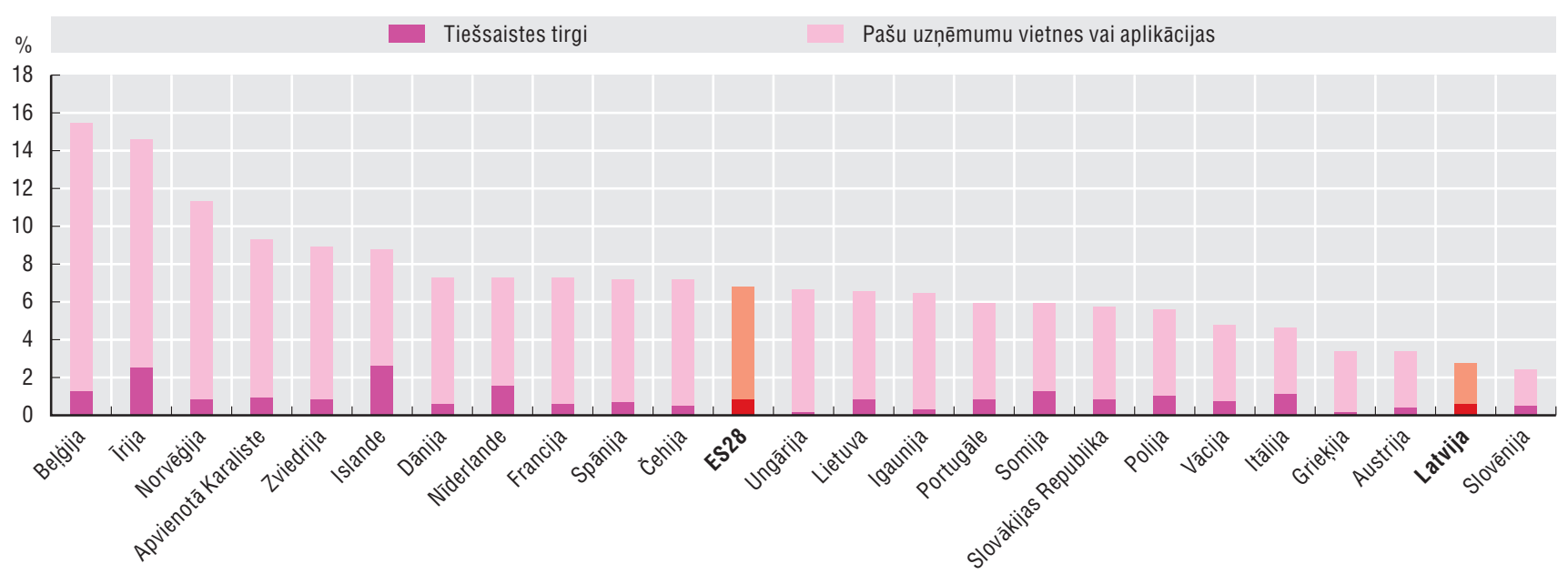

Avots: Eurostat (2019c), E-Commerce Statistics (database), https://ec.europa.eu/eurostat/statistics-explained/index.php/E-commerce_statistics.

Turklāt Latvija atpaliek no ESAO vidējiem rādītājiem vēl vairāk attiecībā uz sarežǵìtāku tehnoloǵiju lietošanu, piemēram, uzṇēmuma resursu plānošanas (ERP) programmatūras, klientu attiecību pārvaldības (CRM) programmatūras un radio frekvenč identificēšanas (RFID) tehnoloǵijas izmantošanas ziṇā. (4.15. attēls) (ESAO, 2018b).

\section{Šķēršli plašākai digitālo tehnoloǵiju lietošanai}

IKT ieviešanu kavē dažādi faktori. To starpā ir lielā mazo uzṇēmumu proporcija, kam parasti ir zemāki IKT ieviešanas rādītāji; tādu darbinieku trūkums, kuriem ir atbilstošas prasmes, lai pilnībā izmantotu IKT priekšrocības; un darbinieku trūkums ar papildu prasmēm, piemēram, nav pārvaldības, kas nepieciešama darba prakses pārveidošanai uzṇēmumos. 


\subsection{5. attēls. Moderno digitālo tehnologiju lietošana atlasītajās ESAO valstīs, 2017. gadā vai gadā, par kuru pēdējo pieejami dati \\ Uzñèmumu ar 10 un vairāk nodarbinātiem darbiniekiem procentuālā daḷa}

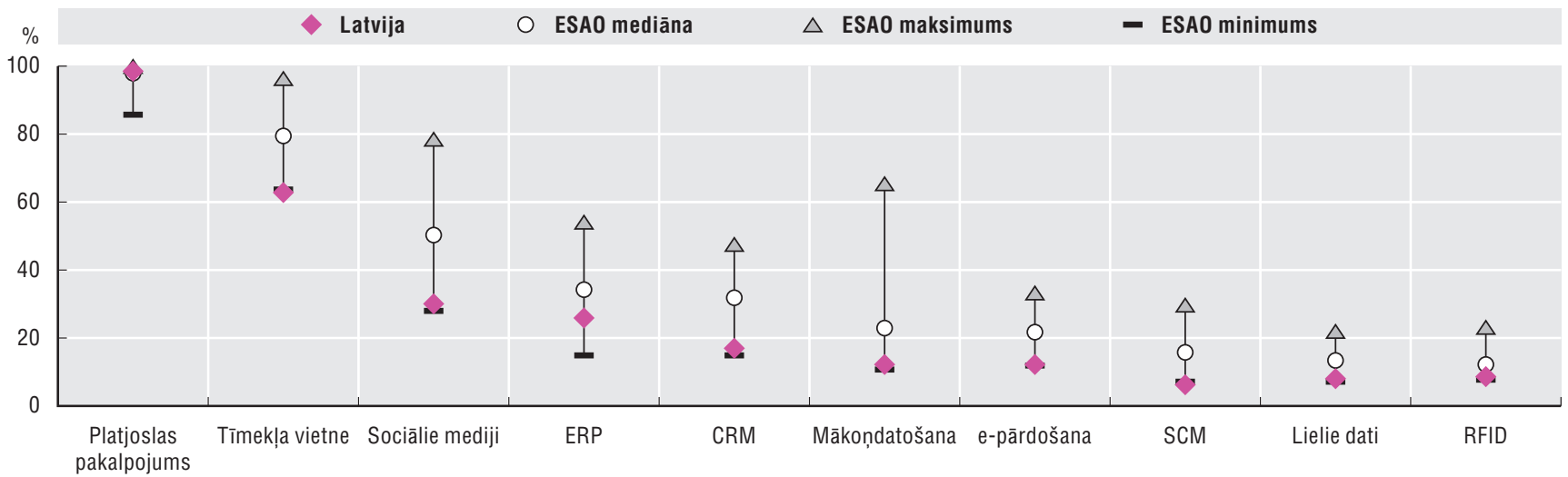

Piezīme: Dati aptver 26 ESAO valstis un atbilst uzṇēmumu daḷai ar desmit vai vairāk darbiniekiem ar platjoslas pieslēgumu (fiksētu vai mobilu), ar tīmekḷa vietni vai mājaslapu, kas ir sociālo mediju, uzṇēmumu resursu plānošanas (ERP) programmatūras, klientu attiecību pārvaldības (CRM) programmatūras, iepirkumu mākoṇdatošanas pakalpojumu lietotāji, pasūtījumu saṇemšana datortīklos, elektroniska informācijas apmain,a ar piegādātājiem un klientiem (SCM), izmantojot radiofrekvenču identifikācijas (RFID) tehnoloǵiju un veicot lielo datu analīzi (2018. gada dati).

Avots: ESAO (2018a), IKT pieejamība un lietošana uzṇēmumos [ICT Access and Usage by Businesses] (datubāze), http://oe.cd/bus; Eurostat (2020c), ICT Usage in Households and by Individuals (database), https://ec.europa.eu/eurostat/cache/metadata/en/isoc_i_esms.htm.

\section{Latvijā ir proporcionāli liela mazu uzņēmumu daḷa}

Latvijā ir liela mikro un mazo uzṇēmumu daḷa, turklāt lielākā daḷa darba vietu ir koncentrētas mazajos uzṇēmumos (4.16. attēls).

\subsection{6. attēls. Nodarbinātība pēc uzṇēmuma lieluma Latvijā un atlasītajās ESAO valstīs, 2016}

Visu nodarbināto personu procentuālā daḷa

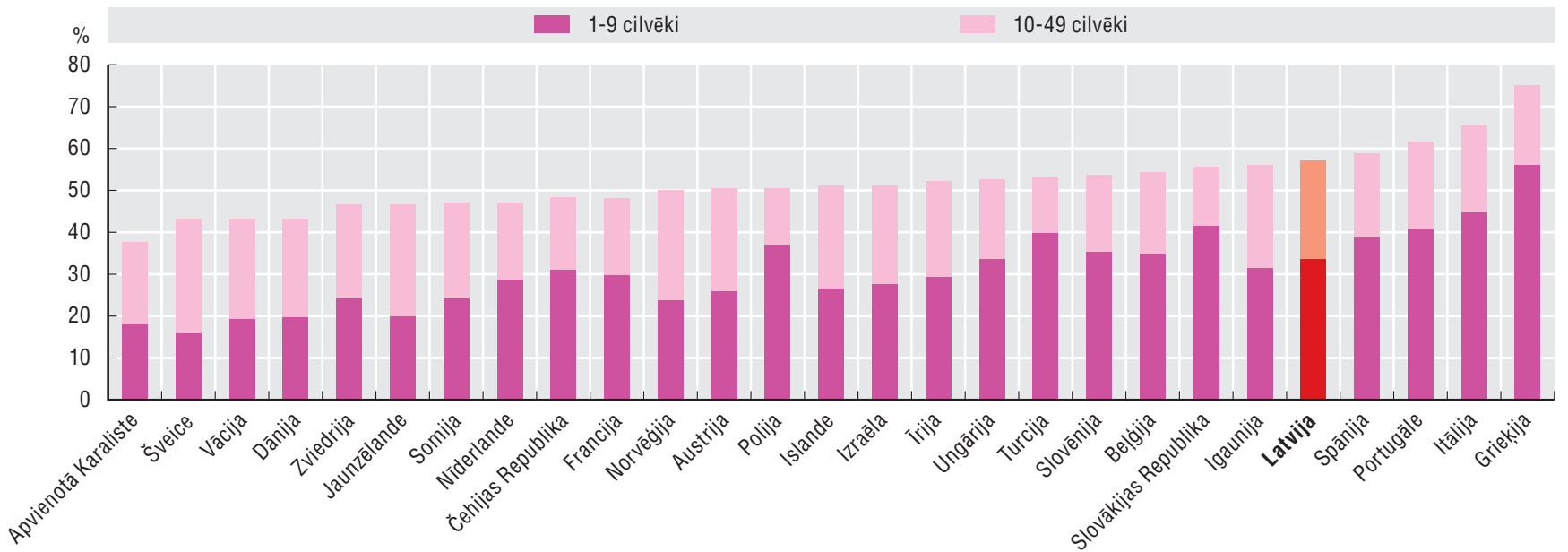

Avots: ESAO (2020), ESAO strukturālo un demogrāfijas uzṇēmumu statistika [OECD Structural and Demographic Business Statistics] (SDBS) (datubāze), https://stats.oecd.org/Index.aspx?DataSetCode=SSIS_BSC_ISIC4 (piekḷuve 2020. gada 9. maijā).

Mazāki uzṇēmumi saskaras ar sk̦ēršliem IKT ieviešanai, tostarp grūtībām piekḷūt finanšu līdzekḷiem, ko ieguldīt IKT. Kopš finanšu krīzes aizdevumi MVU ir saglabājušies zemi (ESAO, 2019d). Turklāt salīdzinoši maz uzṇēmumu daḷu vada profesionāli vadītāji (nevis ǵimenes locekḷi vadošos amatos), un tas var kavēt modernu vadības pieeju pieṇemšanu, kas papildina digitālās tehnoloǵijas, (4.18. attēls) (Andrews, Nicoletti un Timiliotis, 2018; ESAO, 2019c;). Latvijā noteikti trūkst profesionāḷ ar vadības un administratīiām prasmēm (4.19. attēls,turpmāk). Tā rezultātā lielā daḷā mazu uzṇēmumu pēdējo gadu laikā produktivitāte nav uzlabojusies, norādot uz nespēju ieviest jaunas tehnoloğijas (ESAO, 2019c). Latvijas MVU nav vēlējušies ieviest digitālās tehnoloğijas pat pamata lieošanas līmenī, piemēram, sociālo mediju lietojumu (4.17. attēls). 


\subsection{7. attēls. Moderno digitālo tehnologiju izmantošana pēc uzṇēmuma lieluma Latvijā un atlasītajās ESAO valstīs, 2017}

Uznēmumu ar 10 un vairāk nodarbinātiem darbiniekiem procentuālā daḷa
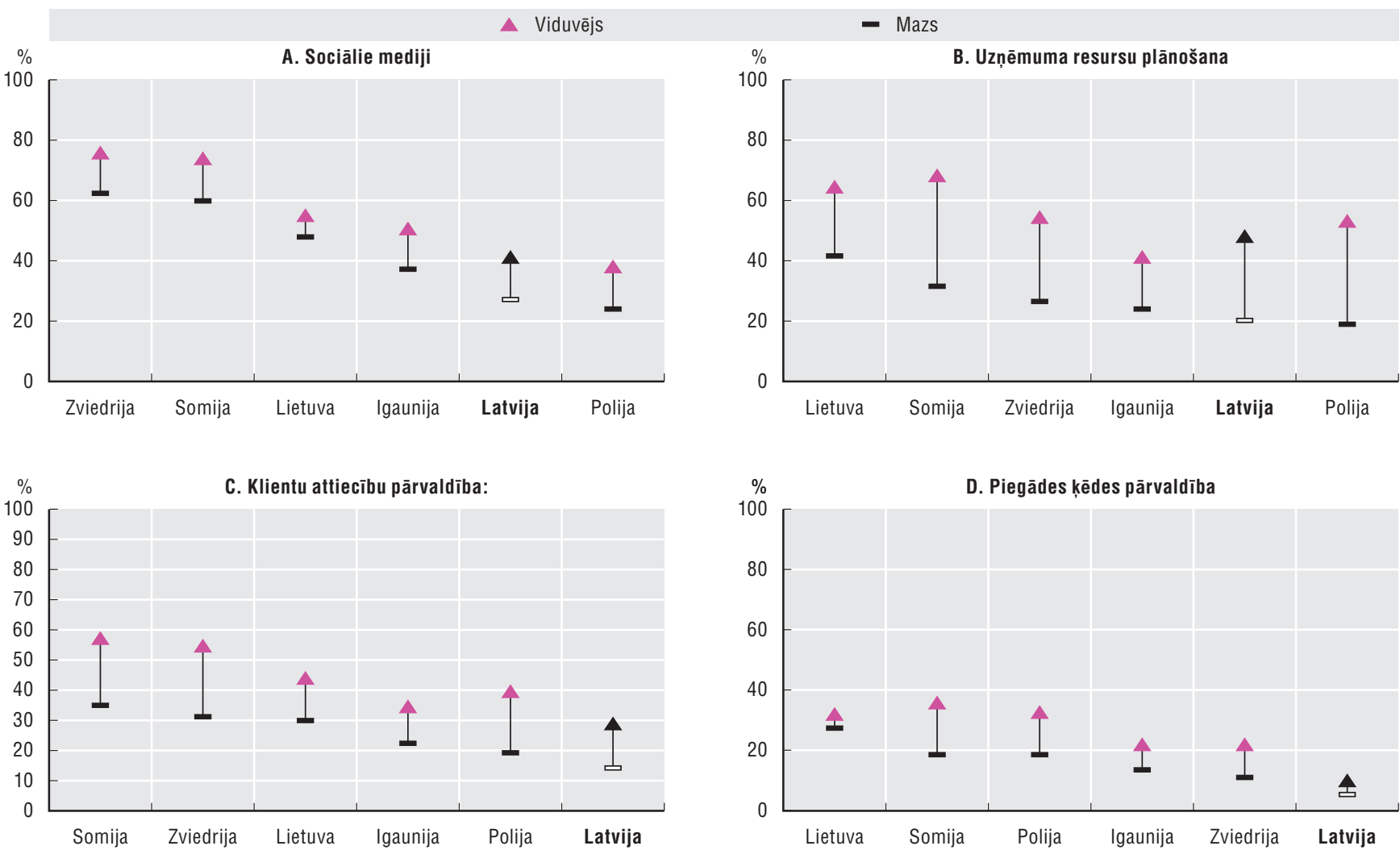

Piezīme: Lieluma kategorijas ir definētas šādi: mazie (10-49 darbinieki) un vidējie (50-249 darbinieki).

Avots: ESAO (2017c), IKT pieejamība un lietošana mājsaimniecī bās un individuāli [ICT Access and Usage by Households and Individuals] (datubāze), http://oe.cd/hhind (skatīts 2020. gada februārī).

\subsection{8. attēls. Paḷaušanās uz profesionālu pārvaldību un atlasītajās ESAO valstīs, 2017.-2018.}

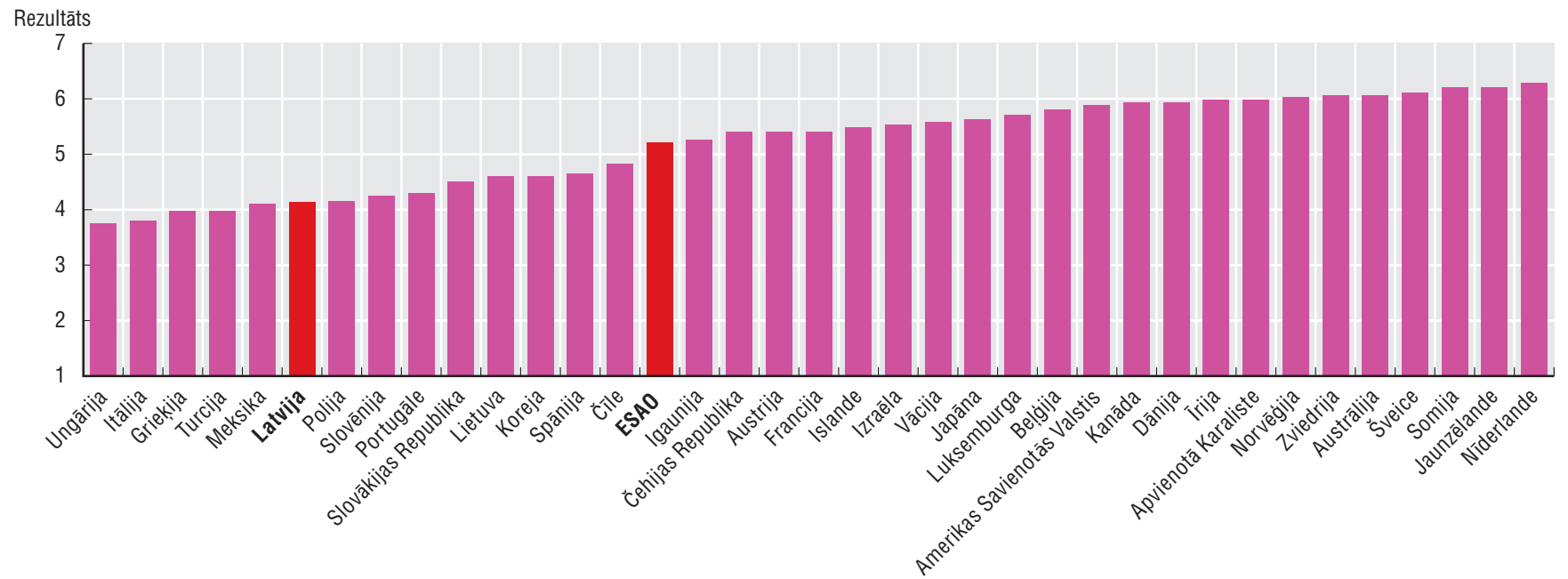

Piezīme: Rezultāts, pamatojoties uz atbildēm uz jautājumu: "Kas jūsu valstī ieṇem augstākos vadības amatus uzṇēmumos? [1 = parasti radinieki vai draugi neatkarīgi no atbilstošām īpašībām; 7 = galvenokārt profesionāli vadītāji, kas izvēlēti pēc atbilstošām īpašībām un kvalifikācijas]”.

Avots: Pasaules ekonomikas forums (2017), Globālā konkurētspējas indeksa vēsturiskā datu kopa 2007.-2017. [The Global Competitiveness Index Historical Dataset 2007-2017], https://tcdata360.worldbank.org/indicators/fin.loc.eqy.mkt?country=BRA\&indicator=525\&viz=line_chart\&years=2007,2017. 
Lielo mazu uzṇēmumu proporciju var daḷēji izskaidrot, pamatojoties uz samazinātā 15\% mikrouzṇēmuma nodokḷa režīmu, kurā ietverts sociālās apdrošināšanas un iedzīvotāju ienākuma nodoklis, tostarp darbiniekiem (ESAO, 2019e). Lai kvalificētos, uzṇēmumā nedrīkst būt nodarbināti vairāk par pieciem cilvēkiem, neviena darbinieka mēneša ienākums nedrīkst pārsniegt 720 EUR (salīdzinājumam ar minimālo algu 430 EUR), un uzṇēmuma apgrozījums nedrīkst pārsniegt 40000 EUR (samazināts no 100000 EUR 2018. gadā) (FM, 2018). Tas nemotivē uzṇēmumus augt, pārsniedzot šos sliekšn,a līmeṇus, un var izraisīt situāciju, ka uzṇēmumi deklarē samazinātus ienākumus (Jacobs et al; 2017).

Latvijā ir arī augsts formalitāšu neievērošanas līmenis, kas var kavēt digitālo tehnoloǵiju ieviešanu. Saskaṇā ar aplēsēm nedeklarētās ekonomikas apmērs Latvijā ir gandrīz 25\% IKP un 10\% darbinieku nav reǵistrēti valsts iestādēs, liela daḷa no viṇiem ir migranti (Sauka un Putniṇš, 2019). Formalitāšu neievērošana var kavēt digitalizāciju, jo neoficiāli uzṇēmumi var vēlēties palikt mazi,, lai izvairītos no atklāšanas, bet samazinātu ienākumu deklarēšana var izraisīt banku nevēlēšanos aizdot naudu (Perry, 2017; ESAO, 2019c).

Latvijā digitālās tehnoloǵijas izmanto, lai mazinātu formalitāšu neievērošanu. Piemēram, tagad būvniecības uzṇēmumiem ir obligāta prasība elektroniski reǵistrēt strādājošo darba laiku un reǵistrēt visas personas, kas ienāk būvlaukumā (piem., izmantojot karti vai mobilo ierīci). Rezultātā iegūtos datus augšupielādē centrālā datubāzē (VEDLUDB), kurai var piekḷūt nodokḷu iestādes (ESAO, 2019c). Turklāt2017. gadā tika ieviests plāns, saskaṇā ar kuru obligāti ir jālieto elektroniskie kases aparāti, un līdz 2019. gada septembrim tika nomainīti 88\% šo ierīču. Valsts ieṇēmumu dienestā IKT tiek izmantotas, lai labāk atlasītu nodokḷu maksātājus nodokḷu auditu veikšanai (ESAO, 2019c). Latvija varētu izmantot šo panākto progresu, izveidojot automātisku algu deklarēšanas sistēmu, līdzīgu Austrālijas "Single Touch Payroll” [Viena pieskāriena algu saraksts] sistēmai. Šajā sistēmā uzṇēmuma algu programmatūra automātiski ziṇo datus Austrālijas nodokḷu iestādēm, tiklīdz darbiniekiem izmaksā algu, samazinot tiesību normu izpildes izmaksas gan uzṇēmumiem, gan iedzìvotājiem, un l̦aujot ātrāk atklāt uzṇēmumus, kas neizpilda nodokḷu un sociālās apdrošināšanas saistības (Austrālijas Nodokḷu iestāde, 2019).

Ir arī mainīti likumi, lai likvidētu šk̦ēršḷus digitālo tehnologiju lietošanai un samazinātu noteikumu ievērošanas izmaksas. Birokrātija ir samazināta attiecībā uz uzṇēmumiem, piemēram, izmantojot vienas pieturas aǵentūras principu uzṇēmumu dibināšanai (ESAO, 2017a). 2015. gadā tika izdarīti grozījumi Elektronisko dokumentu likumā, lai likvidētu pastāvošos ierobežojumus elektronisko parakstu lietošanai (piem., privātiem uzṇēmumiem vai ǵimenes tiesībās), un tagad ir iespējams elektroniski reǵistrēt uzṇēmumus un elektroniski reǵistrēt īpašumu bez notāra starpniecības (ESAO, 2017a). Turklāt no 2019. gada digitālie dokumenti ir jāpieṇem Latvijas Zvērinātu notāru padomes dalībniekiem (piem., finanšu iestādēm), kas vēl vairāk samazinās vajadzību pēc notāra apliecinātiem dokumentiem (Valdani Vicari and Associati, 2019).

\section{Ir nepieciešami plašāki centieni veicināt digitālo tehnoloǵiju lietošanu mazos uzṇēmumos}

Šobrīd Latvija koncentrējas uz digitālo prasmju uzlabošanu (skatīt turpmāk), taču trūkst politiku digitālo tehnoloǵiju lietošanas paplašināšanai mazajos uzṇēmumos, kā arī stratēǵija privātā sektora digitalizācijai. Lai gan pastāv vairākas programmas, piemēram Latvijas IT klastera vadītais X industriju hakatons, to mērogs ir neliels un tās parasti ir iekḷautas inovāciju politikā (skatīt 5. nodaḷu). Daḷēji tās ir sekas tam, ka projektus izvēlas, pamatojoties uz ES finansējuma pieejamību, nevis skaidrām nacionālajām prioritātēm.

Lai veicinātu digitālo transformāciju, Latvijai būtu jāizstrādā stratēgija MVU digitalizācijai, koncentrējoties uz tādu nosacījumu radīšanu, lai MVU vēlētos pieṇemt digitālās tehnoloǵijas un ieguldīt papildu zināšanās balstītos aktīvos un digitālajā drošībā. Šie nosacījumi ietver veicinātājus (piem., infrastruktūra un regulēšanas vide), uzṇēmumu attīstības veicinošos faktorus (piem., finansējuma un prasmju pieejamība) un tehnoloǵiju esamību (piem., digitālās platformas un pakalpojumi, kas sekmē MI un lieto datu lietošanu) (ESAO, 2019f).

Darbsemināru, kuros maziem uzṇēmumiem tiek mācīti vienkārši paṇēmieni, kā iesaistīties e-komercijā (piem., izmantojot tiešsaistes platformas), piedāvājuma paplašināšana varētu palīdzēt palielināt šādu tehnoloǵiju izmantošanu un palīdzēt efektīvākajiem uzṇēmumiem iegūt tirgus daḷu. Turklāt Latvija varētu attīstīt valsts finansētu programmu esošo tehnolog̣iju ieviešanas Latvijas MVU veicināšanai un piedāvāt dotācijas dažādu sektoru uzṇēmumiem. Šāda pieeja darbotos kā pamudinājums konkurentiem 
ieviest efektīvākas tehnolog̣ijas un biznesa praksi. Turklāt varētu piedāvāt nodokḷu atvieglojumus,, lai mudinātu mazos uzṇēmumus investēt IKT.

N̦emot vērā Latvijas MVU izrādīto nevēlēšanos pieṇemt digitālās tehnologiijas, Latvijā vajadzētu izvēlēties nelielu skaitu uzṇēmumu, kas darbotos kā "digitalizācijas čempioni”. Šāda pieeja ir jau izmantota Austrālijā, kur tika izvēlēti 15 mazi uzṇēmumi, kuriem piešḳira intensīvu atbalstu (4.2. ielikums). Par "digitalizācijas čempioniem" varētu izvēlēties sekmīgus Latvijas MVU no nozarēm ar zemu digitālo tehnolog̣iju lietojumu, un tiem varētu piešḳirt atbalstu, pamatojoties uz viṇu priekšlikumu par digitalizāciju. Šādu "digitalizācijas čempionu" panākumi uzskatāmi parādītu digitālo tehnoloǵiju vērtību un iedvesmotu citus uzṇēmumus ieviest tās, lai saglabātu vai palielinātu savu tirgus daḷu.

Nozarēs, kur vairāki uzṇēmumi jau izmanto digitālās tehnolog̣ijas, vairāk atbalsta būtu jāpiešḳir uzṇēmumiem, kas šajā ziṇā atpaliek, lai tie varētu tuvināties vadošajiem uzṇēmumiem. Šo pieeju jau ir îstenojusi Austrija, piedāvājot konsultācijas par modernizācijas iespējām (4.2. ielikums). Nozarēs, kur uzṇēmumi jau saskaras ar konkurenci no augsti digitalizētu uzṇēmumu puses, atpaliekošajiem uzṇēmumiem vajadzētu par šo pakalpojumu maksāt.

\section{3. ielikums. Pieejams plašs atbalsta pasākumu klāsts, lai palīdzētu uzṇēmumiem kḷūt digitāliem}

Valstis piedāvā plašu atbalsta pasākumu klāstu, lai palīdzētu uzn̄ēmumiem ieviest digitalizāciju, sākot ar dotācijām, kas subsidē ieguldījumus digitālajās tehnoloǵijās, līdz apmācībai, lai palīdzētu uzṇēmumiem veikt ieguldījumus, pašiem sedzot izmaksas.

Austrālijas projektā "Small Business Digital Champions" [Mazās uzṇēmējdarbības digitalizācijas čempioni”] atbalstu saņem 100 mazie uzṇēmumi. Projekta kopējais budžets ir 8,9 miljoni AUD, un tajā tiek nodrošināta palīdzība 18500 AUD apmērā, saṇemot papildu atbalstu no partneru uzṇēmumiem. No šiem mazajiem uzn̄ēmumiem 15 tika izvēlēti kā digitalizācijas čempioni un saṇēma mentora palīdzību no pazīstamiem uzṇēmējiem, lai vadītu to digitālās transformācijas procesu. Process tiek dokumentēts un atspoguḷots kā piemērs tiešsaistē. Šo programmu papildina mazo uzṇēmumu konsultāciju dienesta programma "Digitālie risinājumi", kura koncentrējas uz uzṇēmumiemreǵionos. MVU maksā (subsidētu) maksu par digitālo tehnoloǵiju ieviešanu, piemēram, tīmekḷa vietnēm, e-komerciju, sociālajiem medijiem un mazo uzṇēmumu programmatūru. Programmā tiek arī piedāvātas konsultācijas par drošību tiešsaistē un datu privātumu.

Dānijā Dānijas Uzṇēmējdarbības iestāde piešķir dotācijas (ar aptuveno vērtību 1300 EUR) 2000 MVU programmā «SMV:Digital». Dotācijas izmanto privātām konsultācijām, lai palīdzētu MVU atklāt digitālās iespējas, ìpaši koncentrējoties uz e-komerciju, sagatavot uzṇēmējdarbību digitālajai transformācijai un īstenot digitālos risinājumus.

Arī Portugālē ir dotāciju shēma, lai palīdzētu MVU izmantot digitālās tehnoloǵijas tādās jomās, kā e-komercija, tiešsaistes mārketings, tīmekḷa vietṇu izstrāde un lielie dati. Ar dotāciju sedz 75\% attiecināmo izmaksu līdz 7500 EUR projektiem, kuru īstenošanai nepieciešams līdz vienam gadam (Eiropas Investīiju banka, 2019).

Austrija nepiedāvā dotācijas, bet palīdz MVU ìstenot digitalizāciju programmas «KMU Digital» ietvaros. Programmā ir ietverts: 1) tiešsaistes rìks, lai uzṇēmumi varētu novērtēt savu digitālā brieduma līmeni; 2) individuāla konsultācija, lai analizētu, ko un kā var uzlabot; 3) konsultācija, kas vērsta uz uzṇēmuma specifiskajām vajadzībām (tādās jomās, kā e-komercija, IT drošība, datu aizsardzība un iekšējo procesu digitalizācija); un 4) digitālo prasmju apmācību kursi uzṇēmējiem un darbiniekiem.

Čìles inovāciju aǵentūra nesen uzsāka programmu «Digitalizē savu MVU" (Digitaliza tu Pyme), kas nodrošina e-komercijas kursus (78 klātienes mācību stundas), kuros mazo uzṇēmumu īpašnieki var mācīties par digitālo mārketingu, sociālo tīklu lietošanu un elektronisko komerciju. Līdz programmas beigām dalībniekiem ir jāizprot procesi, kas saistīti ar e-komerciju, piemēram, tiešsaistes platformu lietošana.

Avots: Digital Economy Outlook anketa. 


\section{Digitālajai transformācijai nepieciešamās prasmes}

Lai paaugstinātu IKT ieviešanu, Latvijas uzṇēmumiem ir nepieciešami strādājošie, kuriem ir nepieciešamās prasmes, lai efektīvi lietotu digitālās tehnoloǵijas. Tāpēc prasmju uzlabošana ir bijis viens no galvenajiem virzieniem Latvijas pieejā, lai palielinātu digitālo tehnoloǵiju lietošanu uzṇēmumos (Pārresoru koordinācijas centrs. 2017). Uzṇēmumiem ir nepieciešami strādājošie ar pamata datorprasmēm, kā arī IKT speciālisti darbam ar jaunām sistēmām. Turklāt ir nepieciešami darbinieki ar augstākā līmeṇa pratību un skaitḷošanas prasmēm un strādājošie ar augstāko izglītību, lai gūtu peḷnu no jaunām darba metodēm, kas ieviestas ar digitalizāciju. Taču nav vienas stratēǵijas prasmju attīstīšanai; tā vietā pastāv dažādas stratēǵijas, kas paredzētas atšḳirīgiem izglītības līmeṇiem un dažādiem nolūkiem (piem., skolotāju apmācība un kiberdrošības veicināšana) (Eiropas Komisija, 2019a).

Latvijai būs jāpalielina strādājošo skaits ar pamata datorprasmēm un IKT speciālistu skaits, lai atbalstītu digitālo transformāciju. Spēja lietot IKT bija norādīta kā priekšnosacījums vai vēlama prasme vairāk nekā pusē vakanču 2018. gadā, lai gan vairāk nekā pusei iedzīvotāju Latvijā nav pat pamata digitālo prasmju (EURES, 2018) (4.10. attēls). Turklāt trūkst darbinieku, kuri pārzinātu datorus un elektroniku (4.19. attēls). IKT mācību absolventi saṇem ievērojami augstāku atalgojumu, kas liecina par būtisku pieprasījumu pēc viṇu prasmēm (4.20. attēls).

\subsection{9. attēls. Prasmju nepietiekamība Latvijā, 2017}

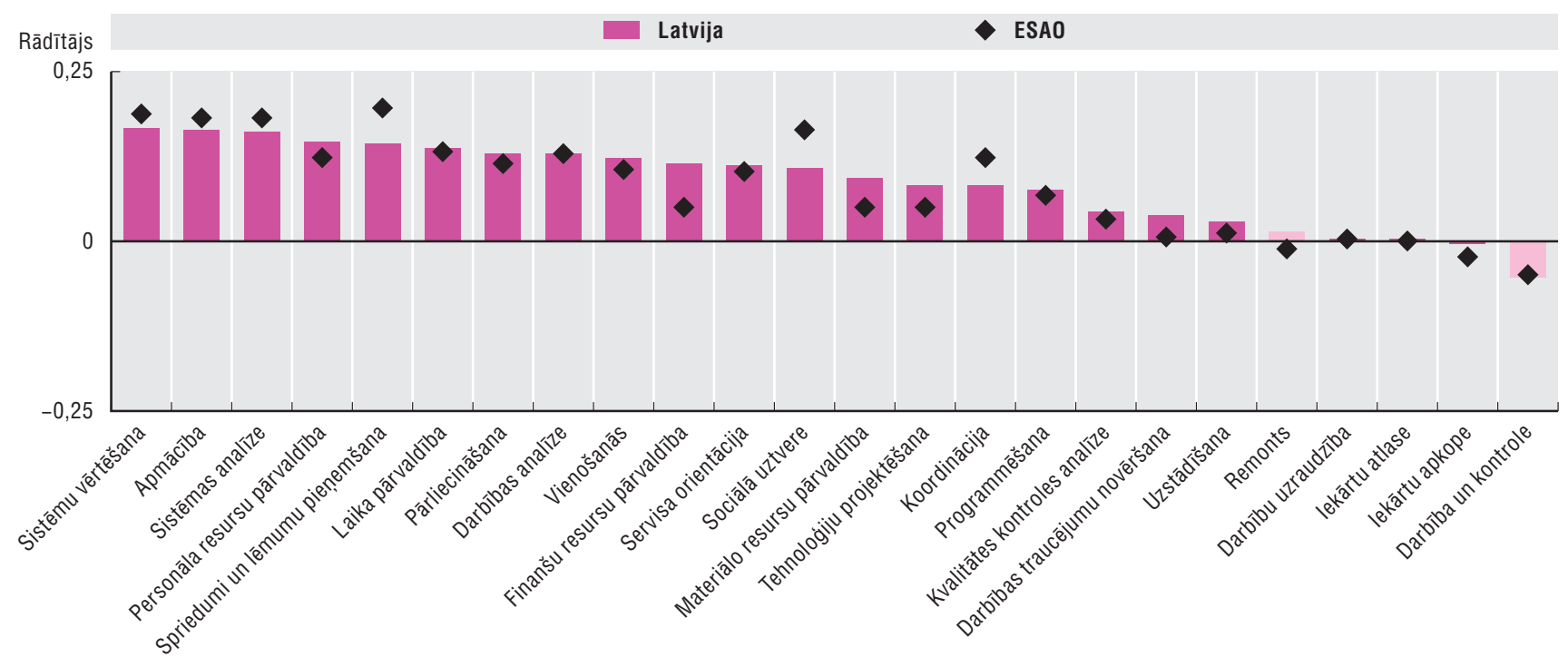

Piezīme: Prasmju nepietiekamība (pozitīvas vērtības) rodas, kad darba devēju meklētās prasmes nav pieejamas potenciālo darbinieku vidū, bet prasmju pārpalikums (negatīvas vērtỉbas) rodas, ja noteiktu prasmju piedāvājums pārsniedz pieprasījumu pēc tām.

Avots: ESAO (2018c), Prasmes darbiem - pārskats par Latvijas valsti [Skills for Jobs - Latvia Country Note], www.oecdskillsforjobsdatabase.org/data/ country_notes/Latvia\%20country\%20note.pdf.

Tomēr nešķiet, ka Latvijas ekonomika būtu gatava nodrošināt darbu 3000 jauniem IKT mācību absolventiem gadā, ko kā mērķi norādījusi EM (2018). Strādātspējīga vecuma absolventu ar IKT kvalifikāciju proporcija ir tikai nedaudz zemāka par ESAO vidējo līmeni (ESAO, 2019g). Turklāt IKT speciālistu sadalījums nav atbilstošs, vairāk nekā puse IKT mācību absolventu strādā jomās, kas nav IKT, un šī proporcija ir līdzīga Somijai un Lietuvai, bet augstāka nekā Zviedrijā, Igaunijā un Dānijā (ESAO, 2018e). Tā dēḷ Latvijā ir viszemākais to darbinieku īpatsvars, kuri strādā ES kā IKT speciālisti, , sieviešu IKT speciālistu īpatsvars samazinās uz pusino 30\% 2008. gadā līdz 14\% 2018. gadā, ko nosaka absolūtā sieviešu IKT speciālistu skaita samazināšanās (kamēr kopējais IKT speciālistu skaits paaugstinājās) (Eurostat, 2019b). Taču tikai 45\% uzṇēmumu, kas publicēja IKT speciālistu vakances, bija grūtības šīs vakances aizpildīt, kas norāda uz vieglākiem nodarbinātības nosacījumiem nekā lielākajā daḷā Eiropas ESAO dalībvalstu (Eurostat, 2020b). Tas norāda, ka galvenais digtitalizācijas trūkuma uzṇēmumos noteicošais faktors ir motivācijas un strādājošo ar pamata datorprasmēm trūkums nevis IKT speciālistu trūkums. 
4.20. attēls. Pieaugušo ar augstāko izglītību ienākumi ESAO pēc studiju jomas, 2017

25-64 gadus vecas personas ar ienākumiem no nodarbinātības (pilnas vai nepilnas slodzes strādājošie); vidējā izglīīiba (visas jomas) = 100 .

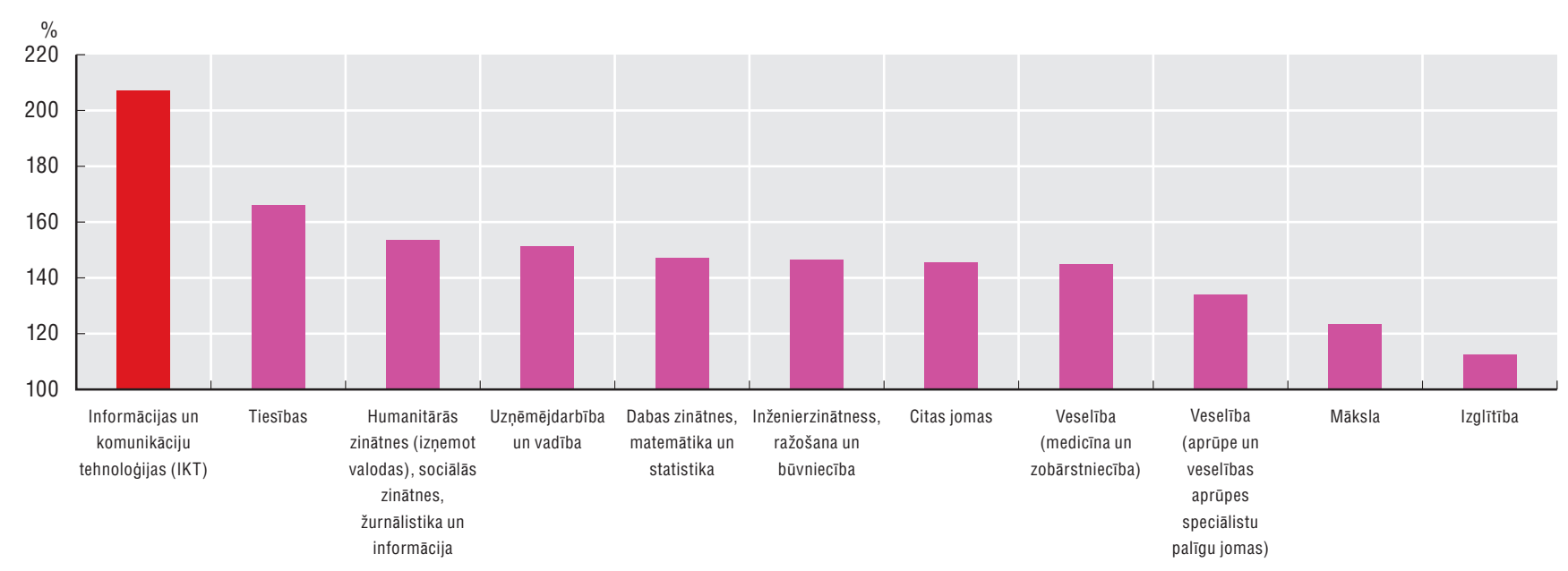

Avots: ESAO (2019g), Education at a Glance: OECD Indicators, https://dx.doi.org/10.1787/f8d7880d-en.

\subsection{1. attēls. Uzṇēmumi, kas sastopas ar grūtībām noalgot IKT speciālistus, Latvijā un atlasītajās ESAO valstīs, 2019}

Procentuāli no visiem uzñēmumiem,kas publicē vakances, kurām nepieciešamas IKT speciālistu prasmes, 2019

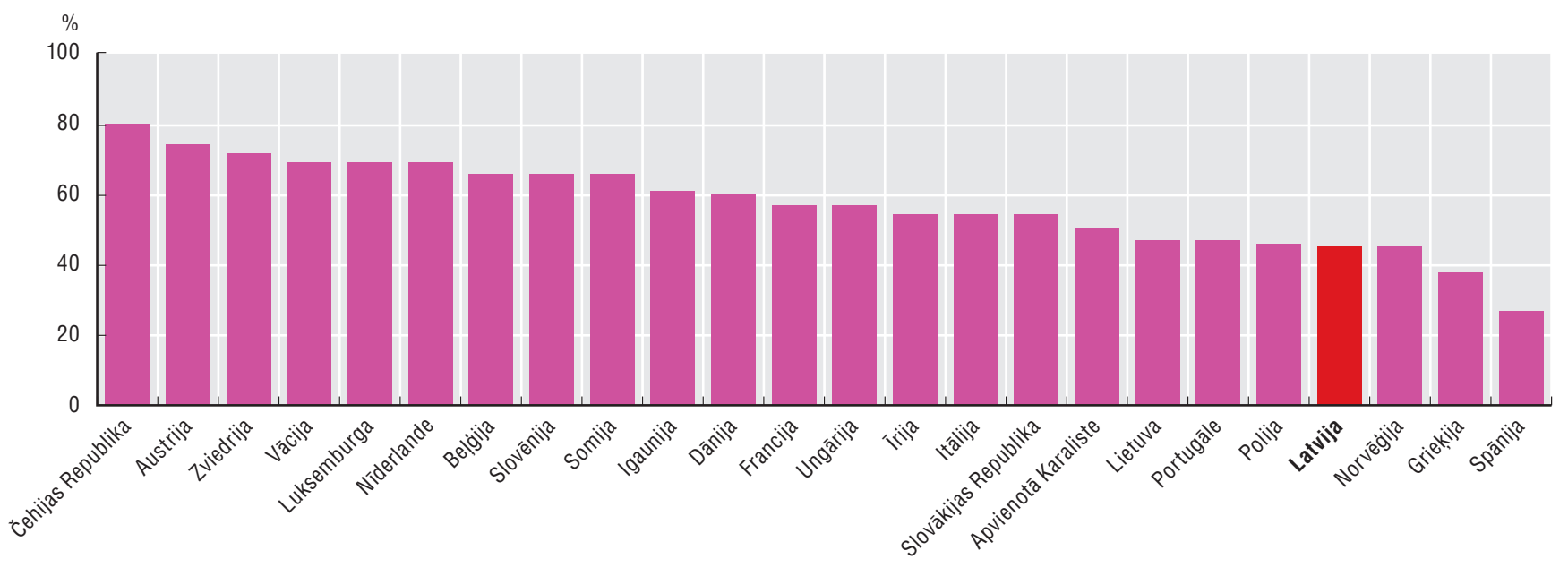

Avots: Eurostat (2020b), Hard-to-fill ICT Vacancies: An Increasing Challenge, https://ec.europa.eu/eurostat/web/products-eurostat-news/-/DDN-20200221-1 (skatīts 2020. gada februāri).

Latvijā trūkst arī vispārīgo prasmju, kas nepieciešamas digitālajai transformācijai (4.3. ielikums). Globālā mērogā lielāks IKT lietojums ir paaugstinājis pieprasījumu pēc vispārīgām un specializētām IKT prasmēm, kā arī papildu prasmēm, piemēram, tiešsaistes mārketings un lielo datu analīze (ESAO, 2016a). Latvija ir sasniegusi daudz, paaugstinot izglītības iegūšanas līmeni, 25-34 gadus vecu iedzivvotāju ar augstāko izglītību proporcijai palielinoties no 25\% 2007. gadā līdz 42\% 2017. gadā, likvidējot plaisu attiecībā pret ESAO vidējo rādītāju. Pieprasījumu pēc absolventiem apliecina viṇu augstākais atalgojums un nodarbinātības iespējas (ESAO, 2018d). Taču, neskatoties uz šiem ieguvumiem, liela daḷa strādājošo atzīst, ka viṇu prasmes ir nepietiekamas darba veikšanai, bet pārmērīgas prasmes nav biežas un saglabājas problēmas ar izglītības kvalitāti, ko apliecina pusaudžu viduvējā lasītprasme un s rēḳināšanas prasme (ESAO, 2019h, 2017a). Turklāt trūkst papildinošo prasmju, piemēram, administrācijas un vadības prasmes (4.19. attēls). Nepietiekama iesaistǐšanās mūžizglītībā un apmācību trūkums darbā apgrūtina Latvijas centienus pielāgoties mainīgajām ekonomikas vajadzībām un uzlabot personu ar zemu izglītības līmeni prasmes. 


\section{4. ielikums. Digitālajai transformācijai ir nepieciešama plaša prasmju kombinācija}

Lai gūtu labumu no digitalizācijas, valstīm un to iedzīvotājiem ir nepieciešams plašs prasmju klāsts, lai gan efektīvi izmantotu internetu, gan nodrošinātu iekḷaušanos darba tirgū, ṇemot vērā tajā notiekošās izmainas. Kognitīvu, sociāli emocionālo un digitālo prasmju nepieciešamība ir tēma, kam pievērsta galvenā uzmanība pārskatā OECD Skills Outlook 2019: Thriving in a Digital World [ESAO prasmju apskats 2019: Panākumu gūšana digitālā pasaulē] (ESAO, 2019a).

Labāka rakstpratība, rēḳināšanas prasme un problēmu risināšanas prasmes kḷūst būtiskas, lai efektīvi lietotu internetu un noteiktu tiešsaistes informācijas ticamību. Turklāt sociāli ekonomiskās prasmes ir nepieciešams palīglīdzeklis vecākiem, kas vēlas palīdzēt bērniem risināt problēmas, piemēram, kiberapcelšanu. No otras puses, prasmju trūkums ir nozīmīgs faktors, kas palīdz izskaidrot, kāpēc daži cilvēki neizmanto internetu mājās.

Mainoties prasmju pieprasījumam, plaša prasmju kombinācija ir nepieciešama arī darba vietā. Tehnolog̣ija attīstās arvien straujāk, radot jaunas darba vietas, bet vienlaickus iznīcinot citas. Parastos zemas kvalifikācijasuzdevumus arvien vairāk izpilda tehnolog̣ijas, taču palielinās pieprasijums pēc darbiniekiem, kas var veikt neparastus, kognitīvus uzdevumus. Tāpēc valstīm ir jānodrošina apmācỉbu politikas, lai palīdzētu darbiniekiem pielāgoties un atrast kvalitatīvas darbavietas. Šādai mūžizglītībai var palīdzēt, uzlabojot piekḷuvi apmācībām un to kvalitāti visos dzives posmos.

\section{Veiktie pasākumi digitālo prasmju uzlabošanai}

Visticamāk, ka prasmju pieprasījums, piemēram, pieprasījums pēc IKT speciālistiem, palielināsies, uzṇēmumiem iesaistoties digitālajā transformācijā. Latvijā ir veikti pasākumi, lai uzlabotu darbaspēka prasmes: Informācijas sabiedrības pamatnostādṇu mērḳis ir uzlabot cilvēku spēju izmantot digitalizācijas sniegtās iespējas; attīstīt cilvēku, uzṇēmēju un valsts sektorā strādājošo prasmes; apmācīt IKT speciālistus ar prasmēm, kas nepieciešamas darba tirgū; un ieviest algoritmus un digitālo pratību skolu mācību programmās. Lai sasniegtu šos mērḳus, Latvija ir reformējusi izglìtības un apmācību sistēmu.

Tā kā nav iespējams precīzi prognozēt, kādas prasmes nākotnē būs nepieciešamas, ir svarīgi, lai Latvijas iedzīvotājiem būtu iespēja atjaunināt savas prasmes visā darba dzīves laikā (pamatojoties uz labu vispārējo izglītību dzìves sākumposmā). Turklāt viṇiem ir jābūt piekḷuvei izglìtības turpināšanai, lai uzturētu un atjauninātu prasmes. Izglìtības un apmācību iestādēm ir jāreagè uz izmaiṇām prasmju pieprasījumā, kā norādīts nesenajā publikācijā OECD Skills Strategy Latvia: Assessment and Recommendations [ESAO Prasmju stratēéija Latvijā: novērtējums un ieteikumi] (ESAO, 2019i).

Latvija pakāpeniski ievieš pārskatīto vispārējās izglītības mācību programmu (no sākumskolas līdz vidusskolai), pārejot no zināšanās bāzētas mācību programmas uz kompetenču mācību programmu, izmantojot ESF finansēto "Kompetenču pieeju izglìtības mācību programmai" projektu (plašāk pazīstams ar nosaukumu "Skola 2030) (IZM, 2020; VISC, 2019). Jaunās mācību programmas mērḳis ir attīstìt digitālo pratību kā caurvijošu prasmi visās mācību jomās, kodēšanas pamatu mācīšanu uzsākot sākumskolā un turpinot vēlāk. Turklāt datormācība tiks apgūta sākumskolā, sākot no 4. klases. Jaunā vispārējās izglìtības mācību programma tiek pakāpeniski īstenota kopš 2019. gada septembra pirmskolās un kopš 2020. gada septembra sākumskolās un vidusskolās (sākot ar 1., 4., 7. un 10. klasi). Mācību programmā ir uzsvērta digitālās un mediju pratības un IKT prasmju attīstǐšanas nozīme skolēniem un IKT kā mācību līdzekḷu izmantošanas veicināšana (ESAO, 2017a).

Papildus tam, vidusskolu audzēkṇi apgūst ar IKT saistītus mācību priekšmetus "Datormācība' un "Dizains un tehnoloǵijas", mācoties arī par datoru algoritmiem, valodām un tīkliem, kā arī attēlu, video un audio apstrādi. Skolēniem ir iespēja turpināt apgūt šos priekšmetus vai mācīties citus priekšmetus, piemēram, kodēšana, digitālais dizains vai robotika, augstākā līmenī.

Digitālā transformācija var radīt arī jaunus izaicinājumus, piemēram, kiberapcelšana, kā minēts iepriekš. Vadošo lomu bērnu aizsardzībā no jauniem digitāliem apdraudējumiem Latvijā ir uzṇēmušās vairākas organizācijas. Piemēram, pastāv tālruṇa līnija bērniem, lai ziṇotu par kiberapcelšanu, bet 
projekts "Supervaroṇi internetā", kas ir Net-Safe Latvija un policijas sadarbība, sekmē bērnu drošību (Burns un Gottschalk, 2019). Lai gan Latvija risina šĩs tēmas jaunajā mācību programmā, pastāv risks, ka, mainoties tehnoloǵijām, ieteikumi novecos. Tāpēc IZM vajadzētu regulāri konsultēties ar plašāku ieinteresēto pušu grupu, piemēram, Latvijas Drošāka interneta centrs, lai san̨emtu ieteikumus par mācību programmas atjaunināšanu.

Lai veicinātu skolēnu interesi par IKT un pārliecinātu viṇus izvēlēties karjeru IKT jomā, Accenture Rīga, Rīgas Tehniskā universitāte un MAK IT ir izveidojušas Start(it) fondu. Fonds sadarbojas ar Latvijas Izglìīibas satura centru, piedāvājot mācību līdzekḷus un mācību materiālus tiešsaistes portālā (Startit. lv), kā arī apmācību skolotājiem. Šos materiālus izmanto vairāk kā 400 skolotāji vairāk nekā 300 skolās, portālam piekḷūst vairāk kā 15000 cilvēku.

Atbilstoša apmācība skolotājiem ir būtiska, lai nodrošinātu mācību programmas reformu sekmīgu ìstenošanu un iepriekšējo iznākumu uzlabošanu. Lìdzīgi kā lielākajā daḷā ESAO valstu, Latvijas skolās, kas izmantoja IKT, bija sliktākie rezultāti lasīšanā, matemātikā un zinātnē, kas atspoguḷo nepieciešamību nodrošināt vairāk apmācību skolotājiem (ESAO, 2019a). Lai gan relatīivi liela daḷa (trīs ceturtdaḷas) skolotāju ir apguvuši apmācību par IKT lietošanu kā daḷu no nesenām profesionālās pilnveides aktivitātēm, tikai puse no viniiem jūtas labi sagatavoti IKT izmantošanai mācišanas procesā. Kaut gan šì tendence atbilst ESAO vidējam rādītājam, ir nepieciešams turpmāks progress snieguma uzlabošanai (ESAO, 2019j).

Sākotnējās skolotāju mācību programmas ir reformētas, lai tās atbilstu notiekošajām izmaiṇām vispārējā izglītības sistēmā. Turklāt ir ieviesta viengadīga apmācību programma tiem, kuriem jau ir augstākās izglītības grāds (piem., STEM priekšmetos). Jaunajā programmā cita starpā ir iekḷauta IKT prasmju attīstišana un moduḷi par IKT izmantošanu mācību procesā un digitālā satura izstrādē. STEM un IKT speciālistu piesaistīšana skolotāja profesijai vidusskolas līmenī var izrādīties sarežğìts uzdevums. Skolotāju algas Latvijā ir zemas, un algu struktūra ir vienota, lai gan skolu vadītājiem ir zināma elastība paaugstināt skolotāja algu skolas kopējā algu budžeta robežās (ESAO, 2019i). Tāpēc var būt nepieciešams skolotājiem ar STEM kvalifikāciju maksāt papildu piemaksu no valsts līdzekḷiem.

\section{Notiek profesionālās izglītības reforma}

Arī profesionālās vidusskolas piedāvā apmācību IKT speciālistiem tādās specialitātēs, kā piemēram, datorprogrammēšana un sistēmtehnik̦is. Profesionālajā izglītībā šobrīd notiek reforma, ieviešot modulāras programmas. Modulāri atjauninājumi l̦auj skolām izvairīties no pilnīgas programmu pārstrādes, vienlaicīgi piedāvājot audzēkṇiem lielāku elastību izvēlēties mācību priekšmetus atbilstoši viṇu interesēm. Papildus tam, visās modulārajās programmās ir iekḷauts obligāts IKT komponents, kuru var integrēt citos moduḷos. Latvija ir arī noteikusi profesionālās kvalifikācijas prasības, lai pielāgotos Eiropas kvalifikāciju satvaram (EKS) (ESAO, 2019k).

Latvijas profesionālās izglītības un apmācības (PIA) sistēmā ir notikusi modernizācija, tai kḷūstot mazāk centralizētai, ar plašāku vietējo darba devēju un PIA skolu sadarbību, bet konsolidācijas rezultātā ir samazinājies PIA iestāžu skaits. Taču PIA saskaras ar izaicinājumiem, piemēram, liels mācības pārtraukušo audzēkṇu skaits, un mācību iestādēm ir grūti piesaistīt talantīgus audzēkṇus. Plašāka karjeras konsultāciju sniegšana vecākiem un skolēniem varētu palīdzēt palielināt skolēnu, kas izvēlas profesionālo izglìtîbu, skaitu. ES finansētā programma "Efektīva PIA skolu pārvaldība" (SO 8.5.3.) būtu jāievieš plaši kā nacionāla programma (ar valsts finansējumu), kas beigsies ES finansējums, jo ar šìs iniciatīvas palīdzību tiek paaugstināti PIA skolu standarti. Pagaidām paaugstināt PIA nozīmīgumu darba tirgū varētu ar līdzfinansējumu Nozaru ekspertu padomēm (NEP) (ESAO, 2019i).

Taču saikni starp PIA skolām un uzṇēmumiem varētu uzlabot. Latvijai vajadzētu palielināt laiku, ko skolēni pavada darbā balstītās mācībās, kas varētu palīdzēt atbalstìt ciešas saiknes starp skolām un darba devējiem un dot iespēju skolām ātri pielāgoties darba devēju prasību izmaiṇām, kas ir īpaši svarīgs jautājums attiecībā uz strauji mainīgajām prasībām IKT speciālistu prasmēm. Vairāki ar IKT saistīti uzṇēmumi Latvijā ir izrādỉjuši vēlēšanos ieṇemt aktīvu lomu Latvijas izglìtības un apmācības sistēmā. Lai gan uzṇēmumi var saṇemt subsīdiju par algām, kas izmaksātas skolēniem, kas piedalās darbā balstītās mācībās, administratīvais slogs ir augsts un subsīdija ir pieejama tikai uzṇēmumiem, kam nav nodokḷu parādu. Tāpēc Latvijā vajadzētu vienkāršot kārtību, lai pieteiktos uz šo atbalstu (ESAO, 2019i). Turklāt nosacījums par darbā balstītiem kursiem skolās būtu jākonsolidē ar tiešām saiknēm ar darba devējiem. 
Varētu arī vēl vairāk pastiprināt darba devēju pārstāvniecību skolu līmenī. Kopš 2016. gada visās profesionālajās skolās koleǵiālajās konsultatìvajās institūcijās, kas nodrošina atbalstu stratēǵiskajai pārvaldībai, ir vietējo darba devēju pārstāvji. Papildus tam, par jauno moduḷu apstiprināšanu ir atbildīgi Profesionālās izglìtỉbas kompetences centri (PIKC) (ESAO, 2019k). Taču, lai gan ar NEP starpniecỉbu darba devējiem ir iespēja piedalīties lēmumu par PIA mācỉbu programmu pien,emšanā, šādas padomes nav l̦oti reprezentatīvas (ESAO, 2019c). Tāpēc Latvija varētu palielināt mācỉbu programmas proporciju, kas tiek noteikta skolas līmenī. Piemēram, Slovēnijā, par 15\% programmas satura lēmumu pieñem skolas sadarbỉbā ar vietējiem uzṇēmumiem (papildus 25\% kursu laika, kas veltīts darbā balstītām mācībām) ESAO, 2017b).

Latvija varētu arī eksperimentēt ar praksi ar IKT saistītās profesijās, kas ir jau citās valstīs izmantota pieeja. Piemēram, Austrija, kur ir labi attīstīta duālās izglìtības sistēma, 2018. gadā ieviesa trīsgadīgu e-komercijas komersantu prakses programmu, lai aizpildītu e-komercijas vadītāju darbavietas uzṇēmumos (WKO, 2018). Galvenajai motivācijai uzṇēmumiem nodrošināt darbā balstìtas mācības (prakses programmās vai sadarbībā ar PIA skolām) vajadzētu būt iespējai iegūt piekḷuvi nepieciešamajām prasmēm nevis finansiāliem stimuliem. Tāpēc Latvijā vajadzētu nodrošināt samazinātu administratīvo slogu iesaistītajiem uzṇēmumiem un augstus apmācību standartus, lai praktikanti varētu strādāt produktīvi. Valdībai un/vai sociālajiem partneriem vajadzētu arī piedāvāt atbalstu vai apmācību iesaistītajiem uzṇēmumiem, lai palīdzētu tiem izstrādāt darba prakses, kas maksimāli palielina mācību iespējas. Papildus tam, valdībai vajadzētu uzraudzìt nodrošināto apmācību, lai nodrošinātu, ka praktikanti gūst labumu no programmas (ESAO, 2018f).

\title{
Augstākās izglītības iestādes nepalielina IKT absolventu skaitu
}

\begin{abstract}
Latvijas augstākās izglītības iestādes (AII) nodrošina gan profesionālo, gan akadēmisko augstāko izglītību un uzṇem studentus, pamatojoties uz valsts centralizēto eksāmenu rezultātiem (ESAO, 2019e). Valsts teritorijā ir izvietots liels skaits AII, pozitīivi ietekmējot terciārās izglìtības sasniegumus (Eiropas Komisija, 2018b). Lìdzās pastāv gan valsts, gan privātās AII, lai gan privātās izglìtỉbas iestādes parasti nepiedāvā STEM kursus (ESAO, 2019k). Absolventu skaits, kas mācās STEM nozarēs, ir nedaudz mazāks par vidējo ESAO rādītāju (22\%) un zemāks nekā citās Baltijas valstīs. Taču tikai 3\% Latvijas augstskolu beidzēju vecumā no 25 līdz 64 gadiem ir studējuši IKT nozarēs, un tas ir mazāk par ESAO vidējo rādītāju (lai gan $5 \%$ doktorantūras absolventu ir IKT jomās, kas ir vairāk par ESAO vidējo rādītāju) (ESAO, 2019g, 2019c).

Latvija ir ieviesusi politikas, lai palielinātu STEM un IKT absolventu skaitu. Valdība ir novirzijusi valsts stipendijas no sociālajām zinātnēm uz STEM ar mērksi nodrošināt 27\% stipendiju finansējuma STEM jomām līdz 2020. gada beigām (ESAO, 2019k, 2019c). Šìs darbības rezultātā ir palielinājies STEM priekšmetus studējošo skaits, jauno absolventu ar grādu IKT jomā proporcijai palielinoties līdz 5\% 2017. gadā (no 4,4\% 2015. gadā), kas ir septītais augstākais rādītājs ES (Eurostat, 2020c). Taču absolūtais absolventu skaits IKT kursos nav palielinājies sakarā ar lielo studentu skaitu, kas pārtrauc mācības (4.22. attēls) (ESAO, 2019k). Turklāt Latvijai nav izdevies atrast piemērotus kandidātus visu piedāvāto STEM stipendiju piešķiršanai, kas daḷeji ir jauniešu iedzīvotāju skaita samazināšanās sekas.
\end{abstract}

\subsection{2. attēls. Kopējais augstākās IKT izglītības absolventu skaits Latvijā, 2013.-2017.}

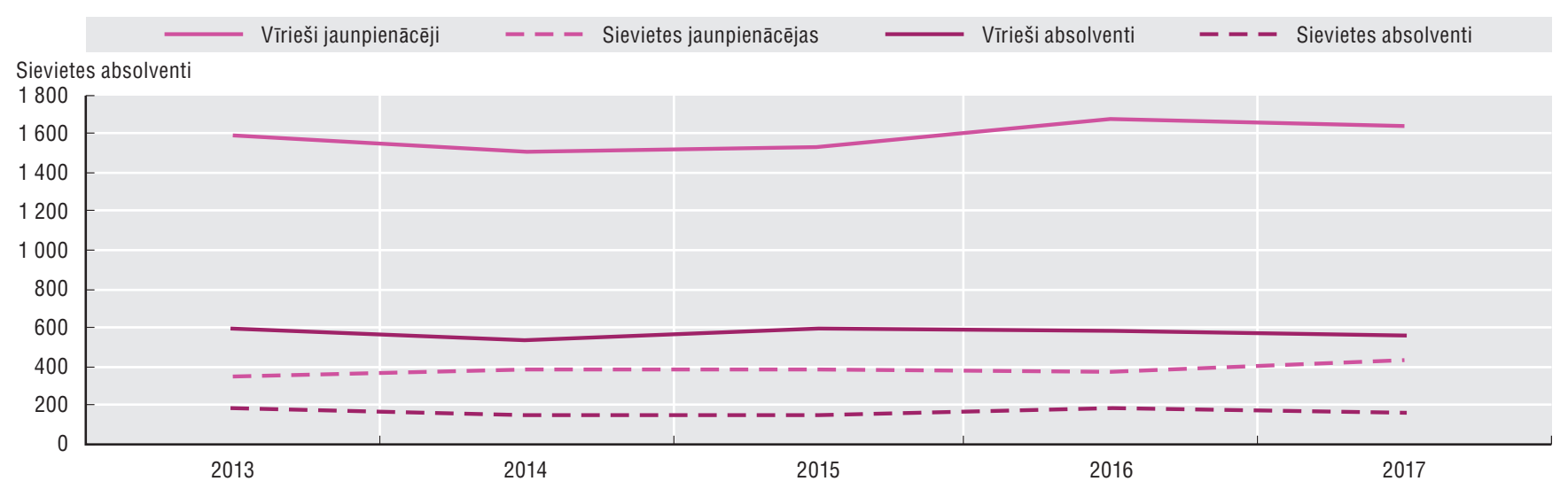

Piezīme: Jaunpienācēji ir pilnīgi jaunpienācēji augstākās izglītības programmās, sākot no īstermiṇa terciārās izglītības līdz doktorantūras līmenim. Avots: Eurostat, Izglītības pārvaldības dati no 2013. gada. 
Latvijas augstākās izglīīibas nozare šobrīd modernizē 300 STEM programmas, tostarp IKT programmas. Aptuveni EUR 70000 tiks tēēēti IKT izmantošanai mācību procesa veicināšanai. Tiks modernizēta arī IKT studiju programmās izmantotā infrastruktūra (tostarp 4 profesionālajām programmām, 13 bakalaura programmām, 13 mağistra programmām un 7 doktorantūras programmām). Valdība vēlas arī samazināt studiju programmu fragmentāciju (OP SO 8.2.1), un 14 AII ìsteno Eiropas Sociālā fonda (ESF) finansētus projektus, lai izstrādātu 5 IKT studiju programmas, tostarp programmas citās valodās nevis tikai latviešu.

Saikṇu starp uzṇēmumiem un AII attīstišana var palīdzēt uzlabot informācijas par pieprasītām prasmēm nodošanu AII. Latvija ir panākusi progresu šādu saišu uzlabošanā, izmantojot programmas inovāciju un pētniecības un attīstības veicināšanai (skatīt 6 . nodaḷu). Turklāt daži uzṇēmumi nodrošina stipendijas un piedāvā prakses iespējas akadēmiskajam personālam un studentiem (Latvijas Finanšu nozares asociācija, 2019). Tomēr kopumā saiknes starp AII un uzṇēmumiem nav plaši izplatītas un universitāšu padomēs nav pārstāvētas ārējās ieinteresētās puses, mazinot to spēju reaǵēt uz pārmaiṇām ekonomikā (ESAO, 2019i) (Eiropas Komisija, 2018b). Esošo saikṇu attīstīšana palīdzēs uzturēt IKT programmu nozīmīgumu. To var panākt, l̦aujot darba devējiem piedalīties kursu izstrādē un motivējot lielāku dalu studentu izvēlēties prakses vietas. Papildus tam, Latvijai vajadzētu ieviest tiesisko sistēmu darbā balstītām mācībām terciārās izglìtības līmenī (ESAO, 2019i).

Turklāt, IKT prasmju nodrošināšanā lielākam skaitam absolventu Latvijā var palīdzēt lielāks atbalsts modulārām programmām, apvienojot IKT moduḷus ar citiem priekšmetiem (piem., uzṇēmējdarbību). Šajā sakarā Rīgas Tehniskā universitāte (RTU) un Rīgas Biznesa skola, un Latvijas Universitāte (LU) sadarbībā ar Latvijas Finanšu nozares asociāciju (nozares institūcija) ir izveidojusi bakalaura studiju programmu "Datorzinības un organizācijas tehnoloǵijas".

Studentu zināšanu par kursa rezultātiem palielināšana var palīdzēt viṇiem izvēlēties piemērotāko kursu un paaugstināt standartus. Lai uzlabotu Latvijas izglīīibas kvalitātes nodrošināšanu, 2018. gadā Augstākās izglītības kvalitātes ağentūra (AIKA) pievienojās Eiropas Augstākās izglìtības kvalitātes nodrošināšanas reǵistram (EQAR) uz piecu gadu periodu (ESAO, 2019l). IKT var izmantot arī studentu zināšanu uzlabošanai par nodarbinātỉbas iespējām. Kopš 2017. gada IZM seko absolventu turpmākajām gaitām, tostarp apkopo datus par absolventu nodarbinātību, darba jomu, algu un informāciju par iestādi un mācību programmu, ko studenti izvēlējušies. Ministrija plāno padarìt šos datus publiski pieejamus (ESAO, 2019i).

Vairākās programmās arī sievietes tiek aicinātas izvēlēties karjeru IKT jomā. 2016. gadā tika dibināta organizācija Riga Tech Girls, lai mudinātu meitenes un sievietes attīstìt digitālās prasmes, palielinātu sieviešu redzamību IKT nozarē un izveidotu IKT nozarē strādājošo sieviešu profesionālo tīklu.

\section{Bezdarbniekiem ir piekḷuve digitālajai apmācībai}

Tradicionāli Latvija ir piedāvājusi ierobežotu sociālo aizsardzību, un tās tēriṇi aktīvām darba tirgus politikām (ADTP) ir bijuši mazāki par vidējo rādītāju (ESAO, 2019k, 2019c). Taču pēdējo gadu laikā valsts ir strādājusi, lai uzlabotu savu apmācību sistēmu bezdarbniekiem, un darba tirgus aktivizēšana ir pārvirzījusies no darba iespēju nodrošināšanas valsts sektorā uz nodarbinātības motivāciju un ilgtermiṇa bezdarbnieku rehabilitāciju (ESAO, 2019k).

Latvijā tiek izmantota apmācību kuponu sistēma, lai nodrošinātu apmācību iespējas darba meklētājiem. Nodarbinātības valsts aǵentūra (NVA) izveido ADTP dalībnieku profilus, pamatojoties uz viṇu pašu sniegto informāciju un interviju ar konsultantu. NVA tīmekḷa vietnē darba meklētājiem, kas meklē apmācību iespējas, tiek sniegta informācija par konkurētspējīgu apmācību nodrošinātājiem (piem., iepriekšējo apmācību dalībnieku skaits, kas atraduši darbu) un darba tirgus prognozēm pa specialitātēm. Tiek nodrošināta gan formālā apmācība, kā rezultātā tiek iegūtas akreditētas prasmes, gan pamata, neformāla apmācỉba. Neformālā apmācỉba parasti ilgst vidēji 42 dienas, bet formālā apmācība 91dienu. Tos, kam trūkst IKT prasmju, kas nepieciešamas sistēmas lietošanai, nosūta uz neformālu IKT apmācību. 2018. gadā programmā piedalījās vairāk kā 18000 cilvēku, no kuriem aptuveni 14000 apguva neformālo apmācību, uzlabojot izredzes atrast darbu (ESAO, 2019k).

Neformāla IT apmācība ir bijusi populāra dalībnieku izvēle, nodrošinot cilvēkiem bez IKT prasmēm 40 stundu apmācību kursu. 2016. gadā visvairāk apmeklētie neformālie kursi bija IT pamati (1400 dalībnieki, kuru skaits 2017. gadā palielinājās līdz 2000), kam sekoja augstākā līmeṇa IT prasmes (1200 dalībnieki). Pretēji tam, laikā no 2012. līdz 2017. gadam tikai aptuveni 1000 cilvēki apguva formālu IKT 
apmācību (salīdzinājumā ar 3600 formālās metinātāju apmācības dalībniekiem) (ESAO, 2019k). NVA nodrošina arī 10 digitālo prasmju uzlabošanas programmas, kas ilgst no 120 lỉdz 150 stundas, kā arī divas profesionālās apmācības IKT programmas. Ir pieejami arī ìstermiṇa kursi gados vecākiem darbiniekiem, un NVA nodrošina e-mācības. NVA rīko ikgadējas tikšanās ar darba devējiem, lai nodrošinātu, ka tās piedāvātie kursi atbilst augošajām darba tirgus vajadzībām.

Latvija piedalās reǵionālajā projektā "Young ICT Women" [Jaunas IKT sievietes] (Nr. 2017-1-094), kura mērḳis ir mācìt digitālās prasmes jaunām sievietēm (vecumā no 15 līdz 29 gadiem), kas saskaras ar izstumšanas risku no darba tirgus. Latvijas darbības koordinē LIKTA (izmantojot finansējumu no Eiropas Ekonomiskās zonas un Norvēǵijas dotāciju fonda jauniešu nodarbinātỉbai), un tas norisināsies no 2018. gada septembra līdz 2021. gada augustam (LIKTA, 2019, 2018). Taču programma ir neliela (ar mērkị iesaistīt 700 sievietes septiṇās valstīs). Turklāt ir grūti saskatìt, kā gūtās mācības varētu nodot NVA.

\section{Varētu vairāk izmantot apkopotos datus}

Latvijas rīcībā ir bagāts datu avots, kas ietver informāciju no NVA, valsts sociālās apdrošināšanas aǵentūras, Iedzīvotāju reǵistra un Sociālās palīdzības datubāzes (ESAO, 2019k). NVA izmanto šo informāciju, lai sagatavotu īstermiṇa darba tirgus prasmju prognozi (bet EM sagatavo vidēja līdz isstermiņa prognozi). Apmācību komisija izmanto šos pārskatus kā pamatu, lai katru gadu noteiktu mācību jomas bezdarbniekiem. Latvijas Digitālajā darba kārtībā un e-pārvaldes stratēgeijā varētu vairāk izmantot tiešsaistes rīkus darba meklētājiem ar zemu bezdarba risku, bet tīmekḷa pārlūkošana varētu palīdzēt atrast vakances, kas nav reǵistrētas NVA. Turklāt datus varētu izmantot, lai labāk uzraudzìtu ADTP ietekmi (ESAO, 2019k).

Lai gan Latvijas Valsts izglìtỉbas informācijas sistēma (VIIS) apkopo datus par izglìtības programmām, iestādēm un personālu, sākot no agrīnās bērnības izglìtības un aprūpes līdz augstākajai izglīiībai, atsevišķi dati (piem., skolu darbinieku raksturojums) atsevišķos gadijumos nav ticami. Turklāt netiek apkopoti dati par neformālo izglìtību un apmācību un profesionālajām kvalifikācijām, ko piešķir iestādes, kas nav valsts iestādes, un nav pieejami elektroniski ieraksti par cilvēku iepriekš iegūtajām kvalifikācijām. Lai šo situāciju uzlabotu, ministrija veic izmaiṇas VIIS, sasaistot to ar augstākās izglītības absolventu datiem un pieaugušo mācību datiem (ESAO, 2019i). VIIS, Bezdarba uzskaites un reǵistrēto vakanču sistēma (BURVIS), kā arī informācijas sistēma ESF projektam "Profesionālās kompetences paaugstināšana" arī varētu tikt uzlabota, izmantojot labākas saites. Turklāt datu saskan,ošanas tehnikas varētu palīdzēt izveidot visaptverošāku ainu, atspogul,ojot mūžizglìtỉbu (ESAO, 2019i).

\section{Uzṇēmumi nodrošina nepietiekamu apmācību darbā}

Latvijas uzṇēmumu investīcijas strādājošo prasmju attīstībā ir relatīvi mazas, īpaši attiecībā uz IKT apmācību. Relatīvi nedaudz uzṇēmumu novērtē nākotnes prasmju vajadzỉbas, un EEZ uzṇēmumi nevēlas investēt apmācībā, jo pastāv risks, ka apmācītie darbinieki pārcelsies uz ārvalstīm, lai saṇemtu augstāku algu (VARAM, 2013). Turklāt, dalība mūžizglītībā ir ḷoti ierobežota un strādājošo ar zema līmeṇa prasmēm iesaistišanās pieaugušo izglītība ir mazāka (ESAO, 2019c, 2017a). Tas ir īpaši izteikti attiecībā uz IKT apmācību nodrošināšanu, kur nepietiekams ir pat lielāku uzṇēmumu sniegums (4.23. attēls).

Latvijā ir divas galvenās ERAF programmas, kas nodrošina atbalstu digitālajai apmācībai uzṇēmumiem: 1.2.2.1. pasākums "Atbalsts nodarbināto apmācibām", kas nodrošina finansējumu desmit nozaru asociācijām IKT speciālistu apmācībai; (pasākuma 1. atlases kārtas ietvaros); un 1.2.2.3. pasākums "Atbalsts IKT un netehnolog̣iskām apmācỉbām, kā arī apmācībām, lai sekmētu investoru piesaisti”, kuras ietvaros tiek ìstenotas ar IKT saistītas apmācỉbas. Šìs programmas īsteno nozaru asociācijas, piemēram, LIKTA. Papildus tam, ESF projekta ar vispārīgāku orientāciju "Pilnveidot nodarbināto personu profesionālo kompetenci" (SO 8.4.1) mērḳis ir cita starpā uzlabot IKT prasmes pieaugušiem strādājošajiem ar zemu prasmju līmeni.

Projekts "IKT profesionāl̨u apmācības inovāciju veicināšanai un nozares attīstībai" (Nr. 1.2.2.1/16/A/003) ir paredzēts, lai uzlabotu IKT speciālistu prasmes un palīdzētu pārvarēt šādu speciālistu trūkumu Latvijā. Projektu realizēja LIKTA un līdz 2019. gada martam par EUR 1,8 miljoniem (ar ES finansējumu EUR 900000 apmērā) tika apmācīti 1630 IKT speciālisti no 77 uzṇēmumiem (esfondi.lv, n.d.)

Lai nodrošinātu IKT apmācību pašnodarbinātiem strādājošajiem un darbiniekiem mikro un mazajos uzṇēmumos vairākos Latvijas reǵionos, LIKTA uzsāka projektu "Mazo un mikro komersantu apmācības inovāciju un digitālo tehnoloǵiju attīstībai Latvijā” (Nr. 1.2.2.3/16/I/002), kas norisinājās no 2016. gada 
decembra līdz 2020. gada decembrim. Tiek veikts uzṇēmumu vērtējums, lai pārliecinātos par to vajadzībām un to darbinieku veicamajiem uzdevumiem, un pēc tam tiek ieteikta piemērota apmācība, kas ietver tādas tēmas, kā piemēram, datu drošība, digitālais mārketings un digitālie klientu apkalpošanas rīki. Dalībnieki, kas apgūst apmācību, saṇem sertifikātu. Mērḳis ir apmācīt 6500 dalībniekus ar kopējām izmaksām EUR 2,7 miljoni (70\% finansē ERAF) (esfondi.lv, 2015).

\subsection{3. attēls. Uzṇēmumi, kas nodrošina IKT apmācības saviem darbiniekiem, Latvijā un atlasītās ESAO valstīs, 2012. un 2018. gads}

Procentuāli no visiem uzṇēmumiem katrā lieluma grupā

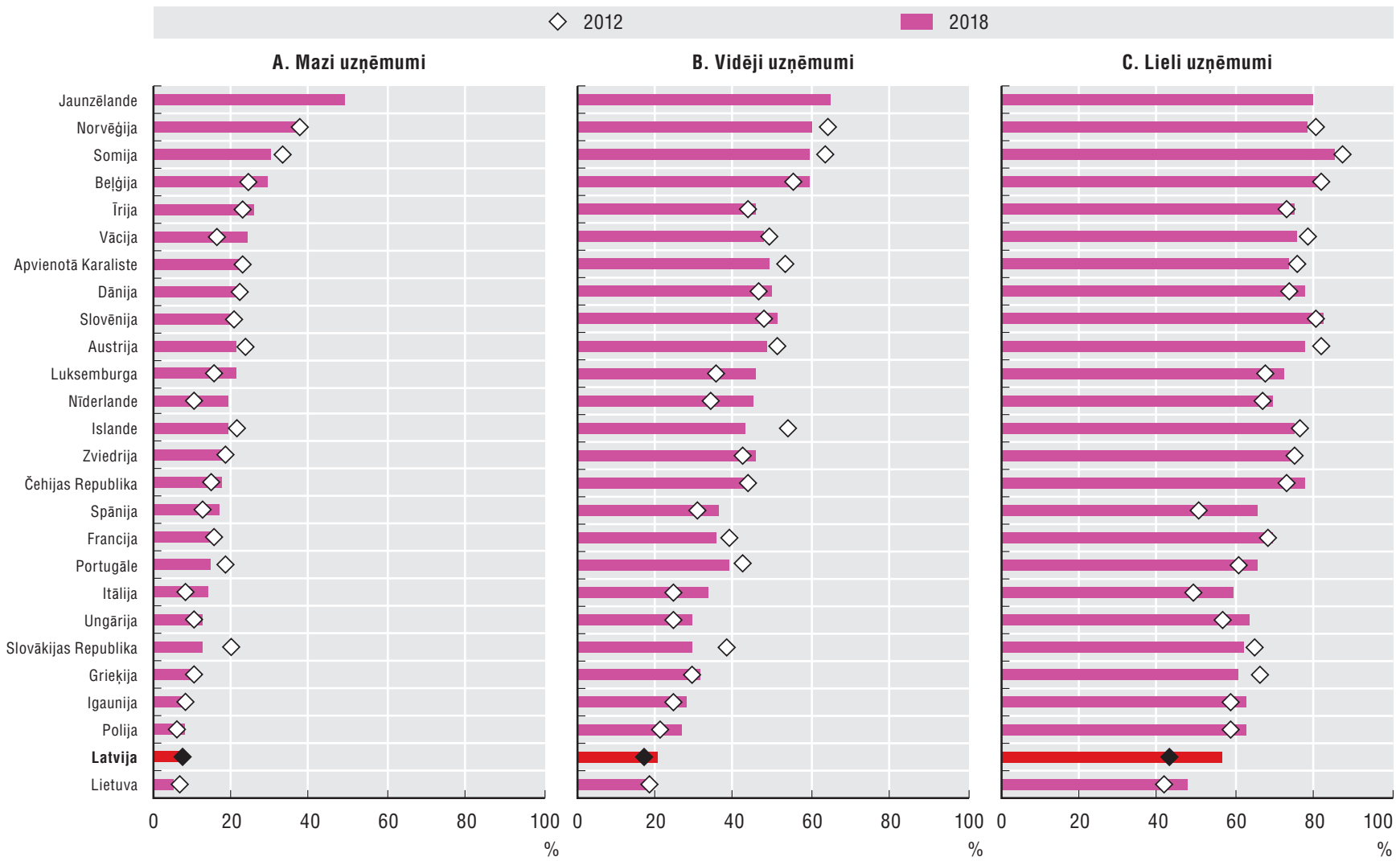

Piezīme: Dati attiecas uz uzṇēmumiem ar 10 vai vairāk darbiniekiem, kas pēdējo 12 mēnešu laikā nodrošināja jebkāda veida apmācỉbu, kas paredzēta darbinieku ar IKT saistīto prasmju attīstībai. Dati par Jaunzēlandi attiecas uz 2016. gadu un dati par Islandi uz 2014. gadu. Dati par vidēja lieluma uzṇēmumiem Portugālē attiecas uz 2017. gadu. Mazos uzṇēmumos ir nodarbināti līdz 49 cilvēki, vidējos uzṇēmumos ir nodarbināti 50 līdz 249 cilvēki, un lielos uzṇēmumos ir nodarbināti 250 un vairāk cilvēku.

Avots: ESAO (2017c), IKT pieejamība un lietošana uzṇēmumos [ICT Access and Usage by Businesses] (datubāze), http://oe.cd/bus.

Papildus tam, Latvijas Tirdzniecỉbas un rūpniecỉbas kamera (LTRK) issteno projektu ar nosaukumu "LTRK netehnoloǵisko apmācību projekts" (Nr. 1.2.2.3/16/I/001), kurā uzmanība koncentrēta uz produktivitātes paaugstināšanu mazajos uzṇēmumos plašā nozaru klāstā. Apmācībā ir iekḷautas jomas, kā piemēram, grāmatvedība un viesnīcu pārvaldība, un var iekḷaut arī IKT lietošanu. Projekta mērḳis ir apmācīt 4700 cilvēkus 285 uznēèmumos līdz 2020. gada beigām (LTRK, 2017), un kopš 2019. gada novembra ir piedalījušies 1850 darbinieki no 199 uzṇēmumiem, kopējām izmaksām sasniedzot EUR 1,7 miljonus (ERAF finansējums EUR 900000 apmērā) (LCCI, 2019).

Darba devēji nevēlas maksāt par savu strādājošo apmācību, jo baidās viṇus pazaudēt, viniiem izvēloties citus uzṇēmumus, līdz ar to Latvijas kopējais sniegums pieaugušo izglītības finansēšanā ir zems (ESAO, 2019m, 2019i). Tāpēc Latvijai vajadzētu izveidot kopīgu apmācību fondu un prasìt darba devējiem maksāt mācību nodevu (kā procentuālu bruto algas daḷu). Uzṇēmumi tad var izmantot šĩ fonda līdzekḷus, lai maksātu par apmācību, kas nav uzṇēmumam specifiska (tostarp mācībām par jaunu digitālo rīku lietošanu), vai atgūt šo nodevu apmācību kuponu formā. Šādas nodevas-dotāciju sistēmas šobrīd darbojas Francijā, Itālijā un Polijā (citu starpā) (ESAO, 2019m). Tā kā darbinieki var saskarties ar 
šḳēršlıiem, lai piedalītos apmācībās, piemēram, finanšu barjeras vai pienākumi gimenē, fonds varētu segt arī daḷu no darbiniekaalgas apmācību periodā (ESAO, 2019n).

\section{5. ielikums. Izmainas izglītības un apmācību sistēmā, sekojot izmaināan ekonomikā}

Latvijas izglìtỉbas un apmācību sistēmas pielāgošana ir būtiski svarīga, lai apmierinātu mainīgās ekonomikas un sabiedrības vajadzības. Paturot to prātā, Latvija izstrādā Nacionālo vidēja termiṇa izglīīibas un prasmju stratēgiju (2021.-2027.). Šì stratēǵija ir OECD Skills Strategy Latvia: Assessment and Recommendations [ESAO Prasmju stratēgija Latvijā: novērtējums un rekomendācijas] (ESAO, 2019i) uzmanības centrā, analizējot visus Latvijas izglìtības un apmācību sistēmas visus posmus, sākot no agrīnas bērnības līdz augstākajai izglìtībai, un turpmāk līdz pieaugušo izglìtībai, koncentrējoties uz studējošo prasmju uzlabošanu, atbalstu mūžizglītỉbai, prasmju nelīdzsvarotības mazināšanu un prasmju sistēmas pārvaldības uzlabošanu.

Pārskatā ir konstatēts, ka Latvijā ir nepieciešams pielāgojams darbaspēks, lai izmantotu digitālās transformācijas piedāvātās iespējas. Augsti kvalificēti pasniedzēji var palīdzēt studentiem iegūt pamata pratību un skaițıšanas prasmes agrīnā dzìves posmā, nodrošinot viniiem iespēju labāk pielāgoties vēlākos dzìves posmos. Latvijai vajadzētu turpināt attīstīt Latvijas novecojošo skolotāju prasmes (t.i. sasaistot skolotāju darba novērtējumu ar pastāvīgu profesionālo attīstỉbu) un vērtēt skolas, lai nodrošinātu atbildību.

Arī mūžizglīîibas kultūras atbalstīšana var palīdzēt pieaugušajiem neatpalikt no ekonomikas izmaiṇām. To var panākt, uzlabojot informētību par iespējām piedalīties mūžizglītībā un mazināt barjeras līdzdalībai, vienlaikus paugstinot nodrošinājumu un kvalitāti. Turklāt Latvijai vajadzētu pakāpeniski atteikties no paḷaušanās uz Eiropas struktūrfondiem pieaugušo izglītỉbas nodrošināšanai un meklēt plašāku finansējuma avota klāstu, un PIA skolās vajadzētu paplašināt pieaugušajiem audzēkṇiem piedāvāto apmācību.

Arī izglītības un apmācību sistēmai pašai ir jāreaǵē uz mainīgajām vajadzībām. Terciārās izglìtības sistēma varētu uzlabot reaǵēšanu, paplašinot sadarbību starp AII un darba devējiem, piemēram, izmantojot darbā balstītu mācīšanos. Turklāt, izglītỉbas un apmācības pārvaldība varētu labāk reaǵēt uz pieprasījuma izmaiṇām, piemēram, veidojot partnerības ar sociālajiem partneriem, lai izstrādātu prasmju politikas.

Darba tirgus reaǵēšanas spēju varētu uzlabot, atvieglojot prasmīgu strādnieku no ārvalstīm iebraukšanu un veicinot mobilitāti Latvijā.

\section{Migrācijas atvieglošana un piekl̦uve ārvalstu IKT darbinieku prasmēm}

Prasmju trūkumu Latvijā pasliktina politikas, kas apgrūtina atgriešanās migrāciju un prasmīgu darbinieku imigrāciju. İpaši stingrās latviešu valodas zināšanas prasības daudzām profesijām var mazināt vēlmi atgriezties latviešiem, kuru laulātais ir ārzemnieks (ESAO, 2016b). Lai gan Latvija kḷūst par populāru galamērḳi ārvalstu studentiem, pēc absolvēšanas šeit paliek tikai nedaudzi no viṇiem, lai gan valdības mērḳis ir palielināt šo proporciju līdz 10\% līdz 2030. gadam (ESAO, 2017a). Turklāt valdība nesen īstenoja rīcību, lai atvieglotu darba tirgus testus attiecībā uz profesijām, kurās trūkst strādājošie (ESAO, 2019c). Minimālā alga, kas ir jāpiedāvā strādājošam ārvalstniekam ir samazināta no 50\% augstākas par vidējo algu līdz 20\% augstākai, un dienu skaits, pēc kurām darbavieta ir jāreǵistrē NVA kā vakance, ir samazināts no 30 līdz 10 dienām. N̦emot vērā augsto pieprasījumu pēc IKT speciālistiem, Latvijai vajadzētu atteikties no darbatirgus testiem attiecỉbā uz tiem, kuri var pierādìt darba pieredzi attiecīgajā jomā vai atbilstošu kvalifikāciju, kā tas tiek darìts Vācijā un Apvienotajā Karalistē (4.5. ielikums). Prasmju trūkuma problēmu palīdzētu risināt arī darba tirgus testu atcelšana tiem cilvēkiem, kuri ir pabeiguši studijas Latvijā (ESAO, 2019c). Visbeidzot, nodokḷa atlaide studentu aizdevumiem varētu būt īpaši pievilcīga tiem, kas studējuši àrvalstīs, un palīdzētu piesaistìt darbiniekus ar ḷoti nepieciešamajām prasmēm.

Arī pašnodarbināto izmantošana nodrošina uzṇēmumiem piekḷuvi plašākam darbaspēka klāstam. Varētu vairāk izmantot tiešsaistes darbu, jo Latvijas situācija ir specifiska tādā ziṇā, ka tiešsaistes darba tirgos ir maza programmatūras un tehnoloǵijas izstrādes uzdevumu proporcija, bet nozīmīgāki ir rakstišanas un tulkošanas darbi (4.24. attēls) (ESAO, 2019a). 


\section{6. ielikums. Vācija un Apvienotā Karaliste izmanto vienkāršotas procedūras IKT speciālistu nodarbināšanai no ārvalstīm}

Vācijas jaunajā Likumā par kvalificētu personu imigrāciju ir vienkāršota migrantu ar noteiktām prasmēm no valstīm ārpus ES, īpaši IKT speciālistu pieņemšana darbā. Strādājošajiem no valstīm ārpus ES, kam ir atbilstoša kvalifikācija un vācu valodas zināšanas, vairs nav nepieciešams darba līgums, lai uzturētos Vācijā, bet viṇi var saṇemt uzturēšanās atḷauju uz sešiem mēnešiem, dodot viṇiem laiku atrast darbu. IKT speciālistiem nav nepieciešami pierādijumi par atbilstošu kvalifikāciju, ja viṇi var pierādīt, ka ir strādājuši attiecīgā amatā vairākus gadus. Turklāt, darba devējiem vairs nav jāpierāda, ka viṇi nav varējuši atrast darbinieku ar šādām zināšanām ES (Zech, 2020).

Arī Apvienotā Karaliste ir vienkāršojusi procedūras IKT speciālistu no ārvalstīm pien,emšanai darbā. Personām, kas piesakās darbā uz vakanci, kas iekḷauta Trūkstošo profesiju sarakstā (kurā ir arī IKT speciālisti), nav jāizpilda prasība par minimālo algu 30000 GBP, tādējādi dodot iespēju atrast darbu attiecīgajā jomā strādājošajiem ar mazāku pieredzi. Tāpat kā Vācijā darba devējiem vairs nav jāveic Rezidentu darba tirgus tests, lai pierādītu, ka viṇi nav varējuši atrast piemērotu darbinieku ES (gov.uk, 2020).

4.24. attēls. Pieṇemšana darbā tiešsaistē pēc nodarbinātības grupas Latvijā un atlasītajās ESAO valstīs, 2018

Visu projektu/uzdevumu, kas publicēti tiešsaistes platformā, procentuālā daḷa pēc darba devēja valsts

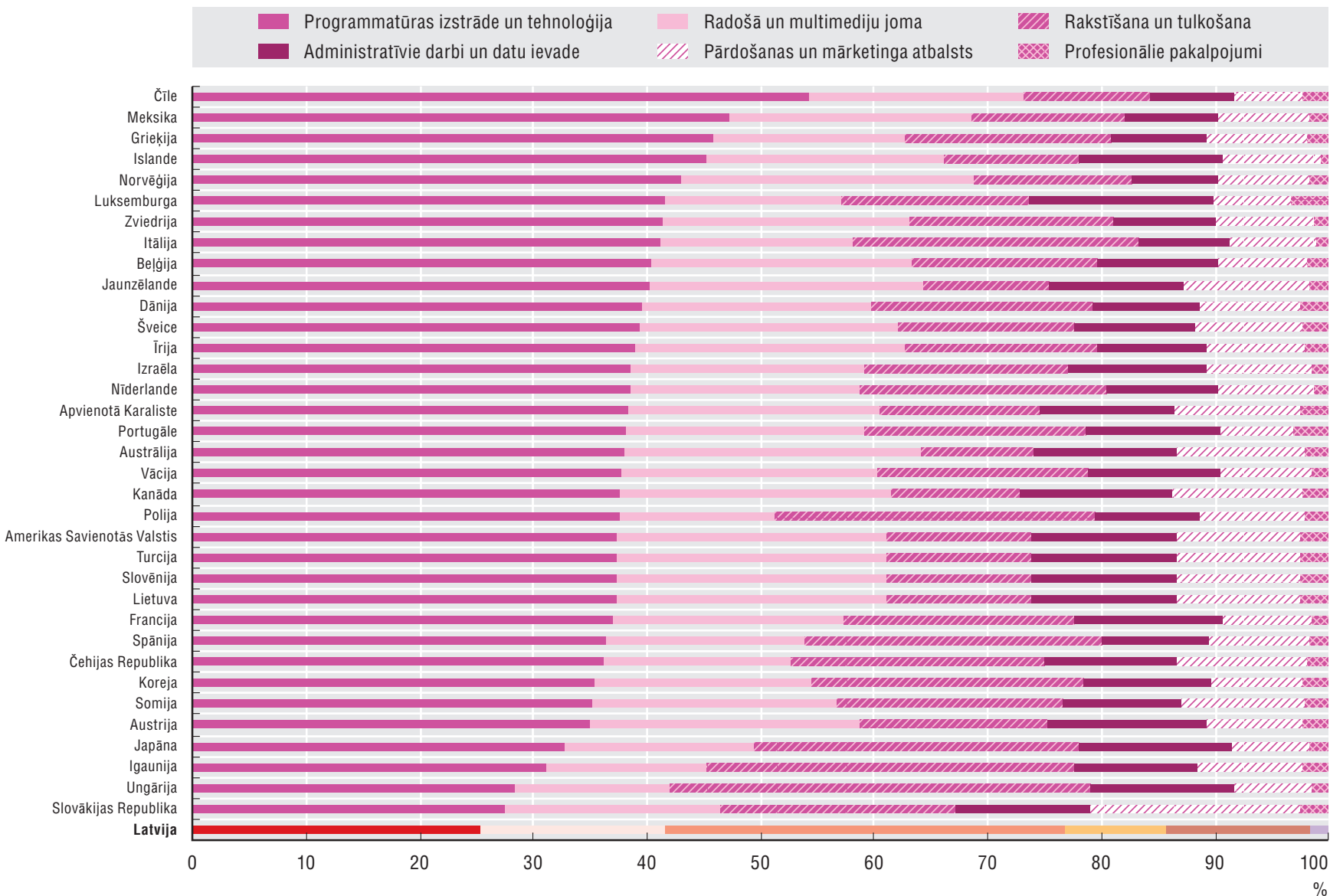

Piezīme: Katrs stabiṇš parāda darba devēja valstu projektu/uzdevumu daḷu, kas publicēta tiešsaistes darba platformās no 2018. gada janvāra līdz jūlijam, pēc projekta/uzdevuma nodarbinātības. Piemēram, no projektiem/uzdevumiem, ko darba devēji, kas atrodas Čīlē, publicējuši tiešsaistē, vairāk nekā 50\% bija saistīti ar programmatūras izstrādi un tehnoloǵijām, un 20\% ar radošo un multimediju nozari. Tiešsaistes darbaspēka indeksā ir ietverti visi projekti un uzdevumi, kas publicēti piecās lielākajās platformās anglu valodā, kas veido vismaz 70\% datu plūsmas uz tiešsaistes darba platformām. Nodarbinātības klasifikācija ir balstīta uz Upwork.com izmantoto.

Avots: Kässi un Lehdonvirta (2018), Online Labour Index: Measuring the Online Gig Economy for Policy and Research, https://mpra.ub.uni-muenchen.de/86627 (piekḷuve 2018. gada 20. jūnijā). 


\section{Lietošana uzṇēmumos - secinājumi}

Latvijas uzṇēmumi ir palielinājuši digitālo tehnoloǵiju izmantošanu, tomēr vēl joprojām atpaliek no citām ESAO dalībvalstīm. Lai gan Latvijas darbaspēka digitālo prasmju uzlabošana būs nepieciešama, lai palīdzētu uzn̄ēmumiem pienemt digitālās tehnoloğijas, šobrīd pietrūkst motivācijas uznēmumiem šādas tehnolog̣ijas īstenot. Šìs nodaḷas rekomendācijas, lai veicinātu digitālo tehnolog̣iju ieviešanu un uzlabotu digitālās prasmes, ir apkopotas 4.10. ielikums.

Lai gan uzṇēmumi ir nozīmīgs digitālo transformāciju veicinošs faktors, arī lietošanai valdībā ir svarīga loma. Tā ir analizēta nākamajā sadaḷā.

\section{Digitālo tehnolog̣iju lietošana valdỉbā}

IKT ieviešana pārvaldē var darboties kā spēcīgs virzošais faktors, sekmējot to ieviešanu uznēemumos un mājsaimniecībās. Latvijā digitālo tehnolog̣iju un datu lietošanas palielināšana pārvaldē ir svarīga Latvijas Informācijas sabiedrības attīstības pamatnostādṇu daḷa. Tiešsaistes pakalpojumu un e-veselības kā klātienes konsultāciju alternatīvas izmantošana var arī palīdzēt Latvijai risināt dažas iproblēmas, ko izraisijjusi COVID-19 pandēmija. Atbilstoši digitālās pārvaldes stratēǵijai Latvija ir spēcīgi pavirzijusies uz priekšu tiešsaistes pakalpojumu un atvērto datu nodrošināšanas ziṇā, kḷūstot par vienu no vadošajām digitālās pārvaldes valstīm ES (Eiropas Komisija, 2019b). Tomēr līdz šim brīdim Latvija ir lielā mērā koncentrējusies uz publisko pakalpojumu efektivitātes paaugstināšanu un vēl ir pilnībā jāizmanto digitālo tehnoloğiju spēja mainīt pakalpojumu uzbūvi un lietot datos politikas veidošanas uzlabošanai.

\section{Pašreizējā IKT lietošanas pārvaldē stratēǵija}

Latvijas digitālās pārvaldības stratēgiija ir izklāstīta Informācijas sabiedrības attīstības pamatnostādnēs, un papildu informācija ir pievienota Publisko pakalpojumu sistēmas uzlabošanas koncepcijā (2015. gada janvāris) un Valsts pārvaldes reformas rīcības plānā 2017.-2020. gadam. Daḷēji stratēǵiju noteica nepieciešamība paaugstināt efektivitāti valsts sektorā budžeta ierobežojumu dēḷ, kas sekoja pēc starptautiskās finanšu krīzes. Informācijas sabiedrības attīstības pamatnostādnes ir koncentrētas galvenokārt uz plāniem uzlabot iekšējos procesus valsts sektorā un nodrošināt pakalpojumus digitāli; lai gan minēta arī IKT izmantošana procesu pārveidošanai (skatīt 4.7. ielikums).

Stratēgija ir saistīta ar "Latvija kā datu virzīta nācija: satvaru, kura mērḳis ir veidot sabiedrību, kas intensīvi lieto valsts un privātajā sektorā generētos datus. Plānu ir apstiprinājusi Informācijas sabiedrības padome, un to veido trīs pīlāri: 1) datu demokrātiskums un pieejamība; 2) datu iespējota iedzīvotāju iesaistǐšana; un 3) datu virzītas inovācijas/novatīvu datu komercializācija.

Vides aizsardzības un reǵionālās attīstības ministrija (VARAM) ir digitālās pārvaldes politikas vadošā ministrija. Valsts reǵionālās attīstības aǵentūra (VRAA) ir daḷa no VARAM un ir atbildīga par centralizēto pakalpojumu darbības (piem., pilsonu portāls Latvija.lv, datu apmainas platforma VISS.gov. lv un e-maksājumi) nodrošināšanu pašvaldībām un valsts aǵentūrām. VARAM uzraug visus digitālās pārvaldības projektus, ko finansē ERAF, nodrošinot to atbilstību valdības IKT arhitektūrai.

Taču Latvija saskaras ar zināmiem izaicinājumiem stratēǵijas īstenošanai, īpaši koordinētas IKT iepirkumu stratēgijas trūkumu, kad ministrijas pieñem pašas savus lēmumus. Lai gan VARAM pēta iespējas, kā uzlabot pakalpojumus iedzīvotājiem (tostarp scenārijus, kas ietver kontaktus ar dažādām aǵentūrām, piemēram, reǵistrējot uzṇēmumu), ministrijai nav pilnvaru pieṇemt saistošus lēmumus. Turklāt, darbiniekiem var nebūt nepieciešamo prasmju, bet citas aǵentūras var neuzskatīt pakalpojumu digitalizāciju par prioritāti. Finansējuma digitālajai pārvaldei konsolidācija vienā ministrijā, piemēram, VARAM, kas ir atbildīga arī par digitālās pārvaldes stratēǵijas izstrādi, varētu palīdzēt nodrošināt saskan,otu valdības digitālās pārvaldes stratēǵijas ieviešanu (skatīt 7. nodaḷu). Alternatīva iespēja uzlabot koordināciju ir koordinācijas mehānismi (piem., pārstāvju komiteja digitalizācijas koordinēšanai) apvienojumā ar politikas svirām (piem., budžeta limiti vai finansēšanas mehānismi).

Turklāt, Latvijā nav kopējas civildienesta apmācību stratēǵijas. IT un digitālo prasmju apmācību šobrīd neuzskata par prioritāti civildienesta ierēdṇiem, lai gan ir pieejama tiešsaistes mācišanās (ESAO, 2019o). Šãdā stratēóijā vajadzētu iekḷaut IKT lietošanas apmācību, kā arī pakalpojumu izstrādi, lai nodrošinātu lietošanas ērtumu pakalpojuma lietotājiem. Turklāt lielāku progresu varētu panākt, 
daloties ar digitalizācijas procesā gūtajām mācībām valsts sektorā, izstrādājot labas pakalpojuma nodrošināšanas prakses rokasgrāmatu. Tas varētu būt pirmais solis, izveidojot civildienesta kultūru digitālās transformācijas veicināšanai. Apvienotajā Karalistē šāda rokasgrāmata jau ir izveidota un ietver 14 punktu pakalpojumu standartu, kam ir jāatbilst sabiedriskajiem pakalpojumiem, tostarp tehniskās prasības un izstrādes standartus, lai nodrošinātu sabiedrības ērtu lietošanu, un veiksmes novērtēšanas veidi, piemēram, tīmekḷa analīze (Government Digital Service, 2019).

\section{7. ielikums. Latvijas Informācijas sabiedrības attīstības pamatnostādnes}

Informācijas sabiedrības attīstības pamatnostādnēs ir iekḷauti divi rīcības virzienu komplekti, kas saistīti ar IKT lietošanas pārvaldē palielināšanu.

Sadaḷā par modernu un efektīvu valsts pārvaldi ir iekḷautas šādas darbības:

- valsts pārvaldes pamatdarbỉbas procesu modernizācija

* pamata procesu transformācija un optimizācija

* pamata darbības procesu digitalizācija

- atbalsta procesu digitalizācija

* sadarbība valsts pārvaldes procesu starpā

- sabiedrības e-līdzdalỉba un e-demokrātija

- vienota valsts pārvaldes datu telpa

- IKT infrastruktūras optimizācija

Sadaḷā par e-pakalpojumiem un digitālo saturu sabiedrībai ir iekḷautas šādas darbības:

- valsts pārvaldes datu un transakciju pakalpojumu atvēršana citiem lietotājiem

- koplietošanas platformu un pakalpojumu attīstỉba publisko pakalpojumu sniegšanai

- oficiālās elektroniskās adreses iedzīvotājiem un uzṇēmējiem ieviešana

- publisko pakalpojumu digitalizācija

- automatizēta elektronisko rēḳinu izsniegšana un pien̦emšana

- kultūras mantojuma digitalizācija un pieejamība

- latviešu valodas lietojumu izplatības veicināšana digitālajā vidē

- e-veselības risinājumi efektīvai, drošai un uz pacientu orientētai veselības aprūpei

Kolumbijā daži no šiem izaicinājumiem ir atrisināti, izmantojot Tiešsaistes pārvaldes izcilības programmu (Programa para la Excelencia en Gobierno Electrónico), kuras mērḳis ir veicināt inovācijas kultūru valsts sektora pārvaldībā. Programmā ir iekḷauti darbsemināri un virtuālie kursi valsts pārvaldes darbiniekiem papildus studentu un pēcstudiju apmācībām. Šāda centralizēta programma var palīdzēt izveidot digitalizācijas ekspertu kopienu un palīdzēt izmantot mācības visā valsts dienestā. Papildus tam, Kolumbija piedāvā Izcilības zīmogu (Sello de Excelencia) tiešsaistes pārvaldes pakalpojumiem un procedūrām, kas atbilst augstam standartam. Tas palīdz uzlabot informētību par sekmīgiem digitalizācijas projektiem valsts sektorā.

\section{Progress pakalpojumu digitalizācijā}

2017. gada jūlijā Latvijas valdība pieņēma jaunus noteikumus (MK noteikumi Nr. 402) par valsts pārvaldes pakalpojumu digitalizāciju. Kur iespējams (un ṇemot vērā izmaksu efektivitāti), valsts iestādēm ir jāsniedz pakalpojums elektroniski, ja pakalpojumu gada laikā pieprasa 5000 reizes vai ja veido vismaz 10\% no šîs iestādes sniegto pakalpojumu apjoma. Turklāt pakalpojums ir digitalizējams, ja tas uzlabo pakalpojuma pieejamību un ērtības klientiem un samazina administratīvo slogu vai pakalpojuma sniegšanas izmaksas. Noteikumos aprakstīta arī izmantojamā pieeja, lai nodrošinātu, ka pakalpojumi ir lietotājam draudzīgi, un pakalpojumu sniedzēji publicē snieguma indikatorus (piem., nepabeigto pakalpojuma lietošanas mēǵinājumu skaits). Pakalpojuma sniedzējiem ir jānodrošina, ka elektroniska piekḷuve pakalpojumam saṇēmējiem ir ātrāka nekā analoga alternatīva vai tās izmaksas ir zemākas. 
Pēdējo gadu laikā Latvija ir digitalizējusi pakalpojumus daudzās nozarēs. Piemēram, NVA izmanto IKT, lai uzlabotu pakalpojumus bezdarbniekiem (skatīt iepriekš), un Valsts Izglītības attīstības aǵentūra tiešsaistē apstrādā iesniegumus par nodarbinātu pieaugušo izglītību. 2018. gadā Latvija uzsāka arī lietotnes "Ceḷo droši" darbību, lai brīdinātu cilvēkus par riskiem ārvalstīs un ieteiktu darbības ārkārtas situācijā (Eiropas Komisija, 2019c). Valsts e-pakalpojumiem var piekḷūt portālā Latvija.lv, kur ir sniegta informācija, konsultāciju iespējas un e-procedūras (piem., veidṇu augšupielāde, pilnībā automatizēti elektroniskie pakalpojumi un tiešsaistes maksājumi) (Eiropas Komisija, 2019c). Sabiedrībai ir pieejami vairāk kā 800 e-pakalpojumi, no kuriem vairāk kā 100 pievienoti 2019. gadā. 2019. gadā pakalpojumu izmantojuši gandrīz 700000 reǵistrēto lietotāju (VRAA, 2019).

2018. gada aprīlī valdība uzsāka kampaṇu Mana Latvija.lv! Dari digitāli!", lai aicinātu iedzīvotājus izmantot pieejamos e-pakalpojumus. Kampaṇā bija iekḷautas apmācības 6000 valsts un pašvaldību ierēdṇiem, bibliotekāriem, skolotājiem, tiesu darbiniekiem, NVO pārstāvjiem un žurnālistiem, lai palīdzētu nodrošināt vispārīgu e-pakalpojumu lietošanu. Turklāt valdība izstrādāja video mācības par pakalpojumu lietošanu un īstenoja informatīvo kampaṇu, izmantojot tradicionālos un tiešsaistes medijus. Laikā no 2017. līdz 2019. gadam cilvēku skaits, kas reǵistrējušies nacionālajā pakalpojumu portālā, pieauga par ceturtdaḷu (lìdz vairāk nekā 1 miljonam), gandrīz divkāršojot lietotāju dalı. Šie rādītāji liecina par sekmīgu kampaṇu, tomēr pieaugumu varētu būt izraisījuši arī citi faktori. Precīzāk sadalīti snieguma indikatori, kuri ir iespējami pateicoties digitālām tehnoloǵijām, varētu palīdzēt noteikt, piemēram, vai tīmekḷa vietṇu apmeklējumu skaits palielinās dienās pēc informācijas kampaṇas. Plašāka šādas tīmekḷa analīzes lietošana varētu palīdzēt nodrošināt visefektīvāko resursu izmantošanu.

Pakalpojumu digitalizāciju veicina elektronisko personas apliecību izveidošana saistībā ar tiesiskā regulējuma attiecībā uz obligātu elektronisko identifikāciju pieṇemšanu. Šajās fiziskajās apliecībās ir iekḷauti biometriskie dati, kurus var nolasīt elektroniski, nodrošinot iespēju identificēt lietotāju un izveidot derīgu elektronisko parakstu. Tās var lietot kā personu apliecinošus un ceḷošanas dokumentus. Lai gan elektroniskās personas apliecības tiek izsniegtas kopš 2012. gada, sākot ar 2023. gadu, elektroniskās personas apliecības kḷūs obligātas (Pilsonības un migrācijas lietu pārvalde, 2020). Turklāt, jaunas lietotnes l̦auj cilvēkiem izmantot viedtālruni, lai apliecinātu e-identitāti un digitāli parakstītu līgumus. Šìs lietotnes izmantošana palielinājās COVID-19 pandēmijas laikā (eParaksts, 2020).

Papildus tam, Latvijas valdība pāriet uz principu “digitāls pēc noklusējuma” saziṇai ar iedzīvotājiem, lai gan tie, kuriem nav piekḷuves internetam, var no šìs iespējas atteikties vai izmantot vietējos vienotos klientu apkalpošanas centrus (skatīt turpmāk). Oficiālas elektroniskās adreses saskaṇā ar Likumu par oficiālajām elektroniskajām adresēm tika ieviestas 2018. gada 1. martā, lai nodrošinātu drošu saziṇu starp valsts iestādēm un iedzīvotājiem. Kopš 2018. gada jūnija visām valsts iestādēm ir elektroniskās adreses (un no šì brīža arī iedzivvotāji var saṇemt elektronisku adresi), un 3000 valsts iestādēm ir pienākums nosūtīt dokumentus tikai elektroniski, atbildot uz sabiedrības pieprasījumiem. No 2020. gada arī uzṇēmumiem būs elektroniskās adreses (Eiropas Komisija, 2019c).

Pakalpojumu izveidošana "tikai tiešsaistes" formā (kā tas ir Valsts zemes atbalsta dienestā), var kalpot kā virzītājspēks, motivējot uzṇēmumus un mājsaimniecības ieviest digitālās tehnolog̣ijas. Latvija ir nodrošinājusi, ka pakalpojumiem, kas ir tikai digitāli, var piekḷūt vienotajos klientu apkalpošanas centros (skatīt turpmāk), tādējādi nodrošinot piekḷuves iespējas tiem, kuri nelieto internetu.

Šo pasākumu rezultātā pakalpojumi ir kḷuvuši lietotājam draudzīgāki. Ir samazinājusies to iedzīvotāju proporcija, ka tikai lejupielādē oficiālās veidnes, un arvien vairāk cilvēku aizpilda veidnes tiešsaistē (4.21. attēls). Turklāt par vidējo lielāka lietotāju proporcija lieto internetu, lai sazinātos ar valsts iestādēm (4.8. attēls, iepriekš).

Uzṇēmējdarbības mijiedarbības digitalizācija ar valsti ir bijusi arī Uzṇēmējdarbības vides attīstības pasākumu plānā 2017.-2020. gadam (Pārresoru koordinācijas centrs, 2017). Dažās nozarēs digitālā komunikācija ir obligāta; piemēram, no 2019. gada visi dokumenti saistībā ar jaunu ēku būvniecību ir jāiesniedz tiešsaistes portālā. Latvijai vajadzētu izveidot motivāciju uzṇēmumiem kontaktēties ar pārvaldes iestādēm tiešsaistē, piešķirot prioritāti uzṇēmumiem, kas izmanto pakalpojumus digitāli (piem., izdodot ațaujas vai veicot maksājumus ātrāk tiem uzṇēmumiem, kas kontaktējas tiešsaistē). Turklāt Latvijai vajadzētu izstrādāt sarakstu ar pakalpojumiem, kas uzṇēmumiem tiek nodrošināti tikai tiešsaistē. 
4.25. attēls Tiešsaistes pakalpojumu lietošanas tendences Eiropas Savienībā, 2010.-2019. gads 16-74 gadus vecu iedzīvotāju procentuālā daḷa

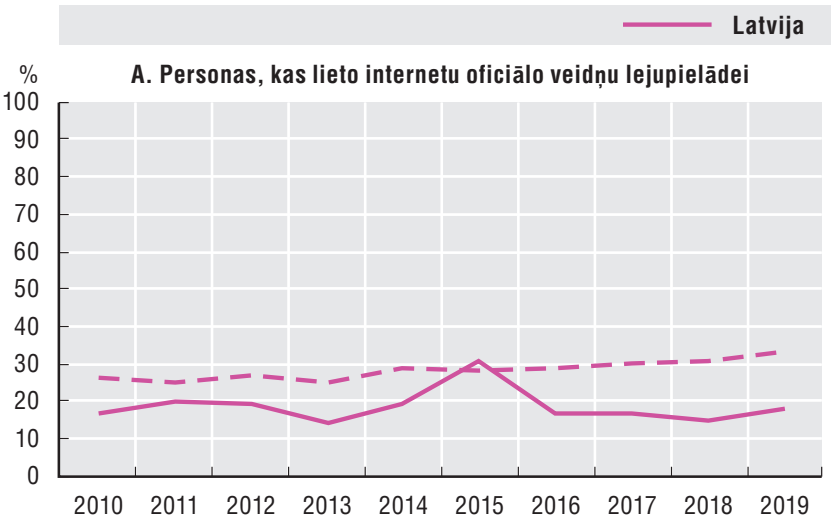

$$
--E S 28
$$

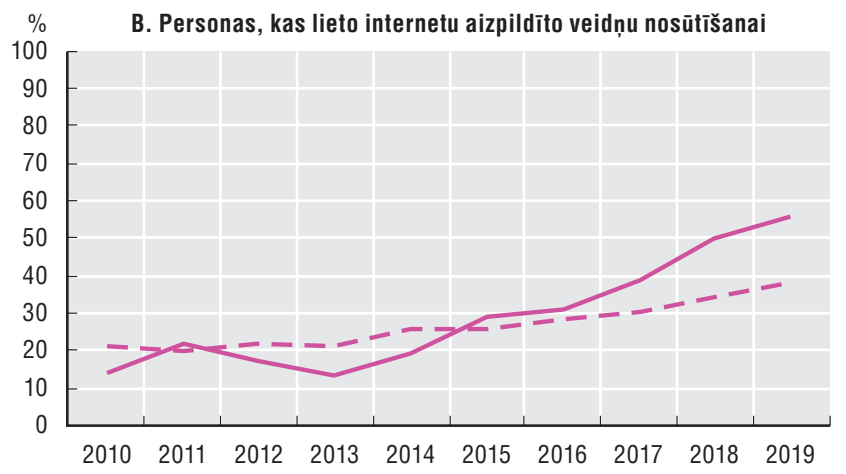

Avots: Eurostat (2020c), Personu e-pārvaldes darbības tīmekḷa vietnēs [ICT Usage in Households and by Individuals] (datubāze), https://ec.europa.eu/ eurostat/cache/metadata/en/isoc_i_esms.htm.

\section{Panākts ievērojams progress veselības aprūpes pakalpojumu digitalizācijā}

Latvijas e-veselības politikas mērkị ir uzlabot veselības aprūpes nodrošināšanas efektivitāti, uzlabojot informācijas koplietošanu un samazinot laiku, ko veselības aprūpes speciālisti tērē birokrātiskām darbībām. E-veselības priekšrocības ir kḷuvušas vēl redzamākas COVID-19 pandēmijas laikā. E-veselības politikas mērḳis ir dot iespēju iedzīvotājiem vieglāk kontrolēt veselības aprūpi; samazināt laiku, kas pacientam jātērē, lai sazinātos ar medicīnas iestādēm; atvieglot veselības aprūpes speciālistiem pacientu ierakstu novērtēšanu, vienlaicīgi mazinot ierakstu dublēšanos; kā arī uzlabot veselības aprūpes datu ticamību un drošību. Saskaṇā ar aplēsēm veselības sistēmas digitāla transformācija varētu dot ieguvumu, kas vienāds ar 8\% veselības aprūpes izdevumu (ESAO, 2019p). Šādi ieguvumi varētu būt lieli sakarā ar Latvijas gados veco iedzìvotāju augsto proporciju un saistīto veselības problēmu pieaugumu.

Kopš 2016. gada pacientiem un veselības aprūpes speciālistiem ir pieejami personiskie veselības ieraksti, tomēr šajā jomā ir daži ierobežojumi (piem., trūkst datu par imunizāciju). Turklāt kopš 2018. gada obligātas ir e-receptes valsts kompensētajiem medikamentiem, kā arī darbnespējas lapas var izdot tikai elektroniski, šo sistēmu sasaistot ar sociālās apdrošināšanas slimības pabalsta izmaksu (Eiropas Komisija, 2018a). Veselības aprūpes speciālisti var elektroniski nosūtīt pacientus pie speciālista vai uz diagnostikas pārbaudēm, sagatavot medicīnas dokumentus un apskatīt citu veselības aprūpes speciālistu sagatavotos dokumentus konsultācijas laikā, bet var arī liegt pacientam apskatīt noteiktu medicīnas informāciju. Pacienti var piešk̦irt vai liegt piekḷuvi savai informācijai, lai gan sākumposma problēmas saistībā ar datu privātumu ir mazinājušas uzticēšanos sistēmai noteiktā Latvijas iedzīvotāju daḷā (Eiropas Komisija, 2019c; Menshikov un Volkova, 2019).

Taču veselības informācijai tiešsaistē piekḷūst relatīvi maza interneta lietotāju daḷ, un īpaši maza ir vīriešu daḷa (4.8. attēls). Turklāt maza ir arī to iedzīvotāju daḷa, kas tiešsaistē piesakās vizītēm (4.26. attēls). Lielāka regulējuma noteiktība attiecībā uz datu privātumu varētu palīdzēt veicināt medicīnas vizǐšu pieteikšanas platformas attīstību, kas varētu būt līdzīga Francijā un Vācijā lietotajai Doctolib platformai un kuras saṇemtā informācija varētu būt noderīga Latvijas novecojošo iedzīvotāju veselības uzraudzībai. Vairāk varētu izmantot arī šobrīd apkopotos datus, piemēram, lai prognozētu gripas epidēmiju un informētu neaizsargātos iedzīvotājus par vakcinācijām.

Lai panāktu lielāku progresu veselības jomā, ir nepieciešama nacionālā digitālā stratēǵija, efektīvāk ir jāimanto iespējas, ko sniedz veselības datu pārvaldība, un lielākas institucionālās un darbības spējas (piem., nodrošinot strādājošajiem un sabiedrībai prasmes, kas nepieciešamas efektīvai jauno sistēmu lietošanai). Gan Somija, gan Čehijas Republika, gan Zviedrija ir panākušas labu progresu, izpildot prasības attiecībā uz veselības sektora digitālo transformāciju (skatīt 4.7. ielikums) (ESAO, 2019p). Latvijai būtu jānodrošina veselības sektora datu un IKT sistēmu sadarbspēja. Turklāt Latvijai būtu jāizveido skaidra politika, lai aizsargātu privātos datus, un tikai ar pacientu piekrišanu jāsasaista dati no dažādiem datu avotiem (skatīt 5. nodaḷ). Pētniecību, kas izmanto veselības datus, ir iespējams veicināt, izveidojot vienas pieturas kontaktpunktu, tiem, kuri vēlas piekḷūt veselības un sociālās aprūpes datiem. 
4.26. attēls. Personas, kas pierakstījās vizìtē pie veselības aprūpes speciālista tiešsaistē, Latvijā un atlasītajās ESAO valstīs, 2012. un 2018. gads

Procentuāli no visiem iedzīvotājiem vecumā no 16 līdz 74 gadiem

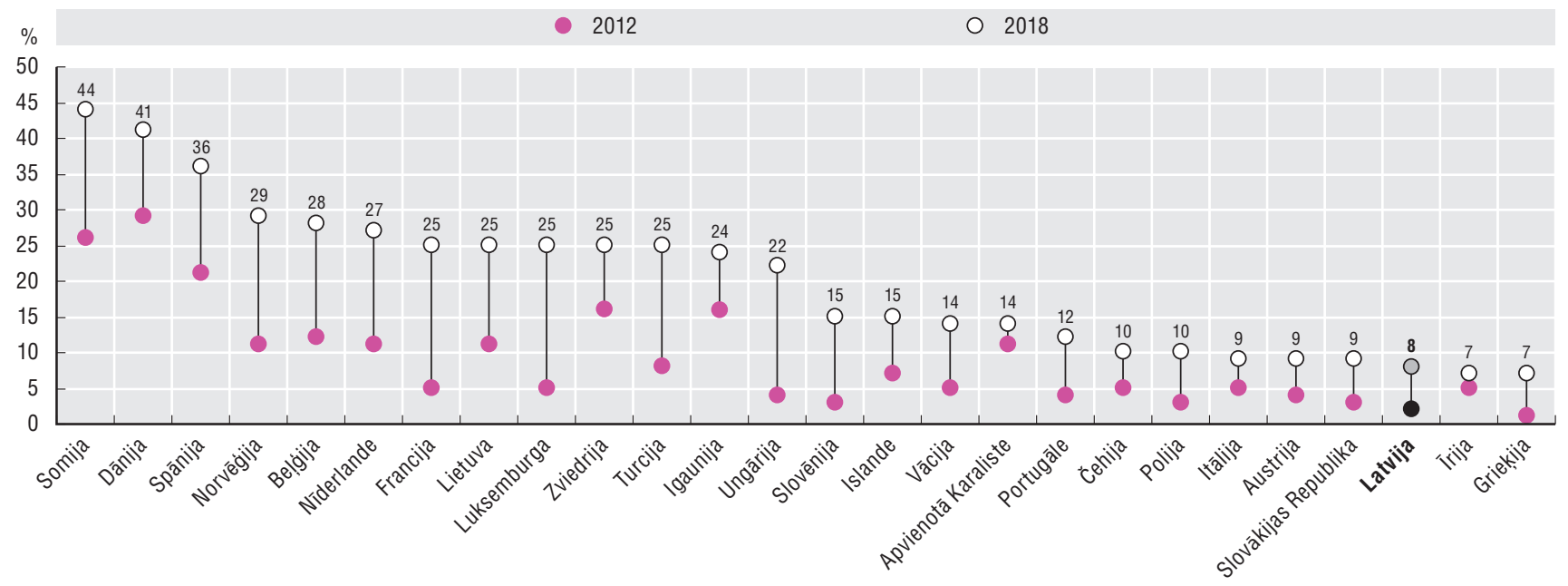

Avots: Eurostat (2020c), Personu e-pārvaldes darbības tīmekḷa vietnēs [ICT Usage in Households and by Individuals] (datubāze), https://ec.europa.eu/ eurostat/cache/metadata/en/isoc_i_esms.htm.

\section{8. ielikums. Nepieciešams noteikt skaidrus noteikumus, lai veicinātu medicinas datu koplietošanu}

ESAO rekomendācijās par veselības datu pārvaldību sniegtas norādes valstīm, kā pārvaldīt ar veselības datiem saistītos riskus un gūt ieguvumus. Tajās ir 12 principi, piemēram, nodrošināt, lai cilvēki būtu informēti par to, kā viṇu dati tiek izmantoti, un pārliecināties, ka tie, kuri apstrādā personas datus, ir apmācīti privātuma un datu drošības jautājumos.

Stratēǵijas veselības datu koplietošanai ir īstenojušas vairākas valstis.

Zviedrijas digitālās stratēǵijas mērḳis ir palielināt datu koplietošanu dažādu valsts iestāžu un iedzīvotāju starpā, vienlaikus saglabājot privātumu un datu drošību, kā arī nodrošinot datu un IKT sistēmu sadarbspēju veselības sistēmas ietvaros. Zviedrijā pacientiem ir piekluve saviem elektroniskajiem veselības ierakstiem, kas cita starpā ietver informāciju par vakcinācijām, analižu rezultātus un norīkojumus.

Somijas sistēmā My Kanta personām ar Somijas personas kodu ir nodrošināta iespēja pieklūt medicīnas ierakstiem, pārvaldīt piekrišanas (datu koplietošanai un orgānu izmantošanai) un redzēt savu datu izmantošanu. Tikai $4 \%$ lietotāju Somijā ir izvēlējušies nepiekrist savu medicīnas datu izmantošanai pētniecības vajadzībām. Turklāt Somija strādā pie vienas pieturas kontaktpunkta izveidošanas tiem, kuri vēlas piekḷūt veselības un sociālās aprūpes datiem pētniecības nolūkā, kas darbosies kā viena iestāde, kas apstiprinās datu izmantošanu (ESAO, 2019p).

Čehijas Republikā tiek izstrādāts Likums par e-veselību un drošu datu koplietošanu veselības aprūpes nodrošinātāju starpā, jo pašreizējie fragmentārie tiesību akti padara neiespējamu e-veselības sistēmas efektīvu pārvaldību. Mērḳis ir izveidot pamata noteikumus, procedūras un standartus, tostarp attiecībā uz drošību veselības nozares digitalizācijai. Turklāt likuma mērk̦is ir definēt noteikumus, kompetenci un tiesības attiecībā uz pacientu iesaistīšanas veselības aprūpes sistēmā palielināšanu.

Digitālo tehnoloǵiju lietošanas palielināšana var palīdzēt Latvijai risināt izaicinājumu, kas saistīts ar iedzīvotāju novecošanos, tostarp pieaugošo spiedienu uz veselības sistēmu, kas pēdējā laikā ir norādījusi uz nepieciešamību nodrošināt veselības aprūpes pakalpojumu, jo īpaši pacientiem, kuriem diagnosticēta saslimšana ar kādu infekcijas slimību, piemēram, ar COVID-19. Tāpēc Latvijai vajadzētu izstrādāt telemedicīnas izmēǵinājuma programmas un ìstenot tās, kas piedāvā skaidrus 
ieguvumus, vienlaikusi veicinot paraugprakses izplatîšanu. Lai gan telemedicīna ir atlauta, vēl nav tiesību aktu, kuros būtu regulēta tās lietošana (atškirīibā no Dānijas, Somijas un Polijas), tostarp, vai pacientam ir jāierodas pie veselības aprūpes speciālista klātienē, kad tiek izrakstīta recepte. Dānija ir guvusi sekmes teleuzraudzībā: pēc randomizēta kontrolēta izmēǵinājuma pacientu ar hronisku obstruktīvo pulmonāro saslimšanu uzraudzība mājās ir kḷuvusi par izplatītu standartu, un vēl citu teleuzraudības programmu izmanto priekšlaikus dzimušiem bērniem. Tiek izmantotas arī video konsultācijas (Oliveira Hashiguchi, 2020). Tā kā nevienlīdzība digitālās pratības ziṇā nozīmē, ka tiem, kuri varētu gūt lielāko labumu no telemedicinnas, ir vismazākās iespējas to izmantot, šādas politikas ir jākombinē ar kopienā balstītām iniciatīvām digitālās pratības uzlabošanai.

Datu un algoritmu izmantošana var būt ìpaši noderīga, lai atbalstītu pacientus ar kompleksām vajadzībām, piemēram, gados vecākus cilvēkus, kurus vienlaikus ārstē ar vairākiem medikamentiem (ESAO, 2019p). Ziemel̦valstu padome (Dānija, Somija, Islande, Norvēgija un Zviedrija) ir izveidojusi Ziemeḷvalstu veselības un labklājības programmu, lai stiprinātu pētniecības sadarbību šajās jomās (ESAO, 2019p). Līdzīgas programmas izveidošana Baltijas valstu starpā varētu palīdzēt apvienot resursus, lai risinātu kopīgus izaicinājumus veselības un labklājỉbas jomā.

\section{IKT izmantošana pakalpojumu uzlabošanai}

Latvija ir gājusi tālāk par esošo procesu digitalizāciju un tagad atrodas sākumposmā, sākot lietot digitālos rīkus, lai mainītu pakalpojumu sniegšanas veidu. Nodokḷu iestāde lieto datus, lai labāk atlasītu nodokḷu maksātājus nodokḷu auditam, bet NVA izmanto digitālos rīkus, lai novērtētu bezdarbnieku vajadzības (skatīt iepriekš). Taču valdība varētu vēl vairāk izmantot datus, kas savākti ar digitalizāciju, lai sniegtu mērḳtiecīgākus un personalizētākus pakalpojumus.

Digitalizācija ir arī devusi iespēju Latvijai mainīt pakalpojumu sniegšanas sabiedrībai veidu. 2011. gadā valsts pieṇēma "vienas pieturas ağentūras" principu attiecībā uz piekḷuvi publiskajiem pakalpojumiem gan klātienē, gan digitāli, un kopš 2014. gada darbojas valsts un pašvaldību vienoto klientu apkalpošanas centru (VPVKAC) tīkls. Šajos centros tiek piedāvāti digitalizēti pakalpojumi no dažādām iestādēm, piemēram, Valsts ienēēmumu dienesta (VID) un NVA, un tie ir pieejami 78 pašvaldību centros. Kopumā ir digitalizēti vairāk nekā 800 sabiedrskie pakalpojumi. Lai gan vienas pieturas aǵentūras principu izveidoja VARAM, par pakalpojumu nodrošināšanu ir atbildīgas atsevišķas aǵentūras. Iedzīvotāji var izmantot "Mazāka sloga" tīmekḷa rīku jeb Futbols lietotni (pieejama tikai latviešu valodā), lai novērtētu pakalpojumus un iesniegtu priekšlikumus par pakalpojumu uzlabojumiem, ko pēc tam vērtē Valsts kanceleja.

Latvijā ir izstrādāti arī e-līdzdalības procesi. 2013. gadā sāka darboties petīiju tīmekḷa vietne (manabalss. lv), kurā jebkurš vismaz 16 gadus vecs Latvijas iedzìvotājs var iesniegt priekšlikumu un elektroniski parakstìt iniciatīvu. Ja par iniciatīvu tiek iesniegti 10000 paraksti, to iekḷauj Saeimas darba kārtībā. 2015. gada decembrī tika pien̨emti noteikumi, atḷaujot iedzīvotājiem iesniegt petīcijas elektroniski (ja iesniegumā ir iekḷauti līdzekḷi elektronisko parakstu verifikācijai) (Eiropas Komisija, 2019c). Taču šo rīku sava viedokḷa izteikšanai valsts amatpersonām izmantoja relatīva neliela iedzīvotāju daḷa, un savu viedokli tiešsaistē izsaka tikai 7\% interneta lietotāju (ESAO, 2019i, 2019q).

Latvija ir arī izmantojusi digitālās tehnologiijas, lai palīdzētu pārvarēt valodas barjeru tiem iedzīvotājiem, kuri nelieto latviešu kā pirmo valodu. Mašīntulkošanas portālā Hugo.lv angliski un krieviski runājošie var piekḷūt informācijai un e-pakalpojumiem latviešu valodā. Latvija plāno šo pakalpojumu papildināt, izveidojot virtuālo asistentu, kas dotu iespēju iedzīvotājiem lietot e-pakalpojumus izvēlētajā valodā. Uzṇēmums Tilde pēta tulkošanas tehnoloǵijas (NIFO, 2018).

Ideju un zināšanu apmaiṇu Latvijas valsts sektorā varētu veicināt ikgadēja darbsemināra izveidošana, kurā piedalītos gan valsts ierēdṇi, gan pētnieki, piemēram, akadēmisko aprindu pārstāvji, kur ministrijas varētu demonstrēt, kā tās lieto datus lēmumu pieṇemšanas uzlabošanai. Turklāt, Latvijai vajadzētu atbalstīt sociālo pētījumu vienības izveidošanu vai nu valsts aǵentūrā, vai kā daḷu no AII, datu analīzei un jaunu pakalpojumu ieteikšanai. Šì vienība varētu būt vai nu ar kompetenci šãdu pētījumu veikšanai iekšienē, vai uzticētu tos kā ārpakalpojumus universitātēm. Šai vienībai būtu jāvar nodrošināt anonimizētu mikro datu pieejamību apstiprinātiem pētniecības projektiem, ko veic ārējas organizācijas (ṇemot vērā bažas par privātuma nodrošināšanu). 
Latvija ir panākusi būtisku progresu pakalpojumu uzlabošanā, tomēr ir nepieciešams papildu darbs, lai attīstītu datu virzītu valsts sektoru. Datu izmantošana var palīdzēt valdībai uzlabot pakalpojumu plānošanu un paredzēt pieprasījuma maksimumu, kā arī uzlabot plānošanu un uzraudzību. Tā var arī palīdzēt paaugstināt sabiedrības uzticēšanos valdībai. Šādām darbībām ir nepieciešama spēcīga vīzija un vadība, saskan,ota ìstenošana, noteikumi un vadlīnijas datu lietošanai, kā arī datu infrastruktūra un arhitektūra (ESAO, 2019r).

\section{9. ielikums. Digitalizācijas veicināšana reǵionos}

Digitalizācijas reǵionos veicināšana ir Ziemeḷvalstu prioritāte un tēma Nordregio ziṇojumā Governing the Digital Transition In Nordic Regions: The Human Element [Digitālās transformācijas pārvaldība Ziemel̦valstu reǵionos: cilvēka elements], kurā konstatēts, ka reǵionālā digitalizācija ir drīzāk cilvēku nevis tehnisks process (Randall un Berlina, 2019).

Helsingborga Zviedrijas dienvidos izceḷas kā sekmīgs digitalizācijas īstenošanas piemērs. Pilsētas mēra Palle Lundberg vadībā tā vietā, lai izstrādātu stratēǵiju pašvaldības darba procesu uzlabošanai, pašvaldība uzsvēra eksperimentēšanu un mācīšanos. Papildus tam, process bija koncentrēts uz iedzìvotāju, nevis IT sistēmu vajadzībām. Tika uzskatīts, ka par digitalizāciju ir atbildīgi visi pašvaldību darbinieki un pilsētas iedzīvotāji.

Pamatojoties uz šo pieeju, pilsēta izstrādāja platformu "Mana Helsingborga" piekḷuvei pakalpojumiem un "Viedā Helsingborga", lai dotu iespēju iedzivotājiem izveidot pakalpojumus. Tika arī izveidota telpa, lai lietotāji varētu aizṇemties jaunās tehnologiijas un eksperimentēt ar tām. Tā rezultātā 2015. gadā Helsingborga saṇēma balvu kā labākā IT pašvaldība Zviedrijā. 2016. gadā pilsēta saṇēma balvu arī kā vadošā e-komercijas pilsēta Zviedrijas dienvidos.

Šajā gadījumā galvenais panākumu faktors bija ilgtermiṇa politiskais atbalsts un vadība, kas veicināja eksperimentēšanu un bija gatava pien,emt neveiksmes, ja tiktu gūta mācība.

\section{Vairāk valdības datu tagad ir publiski pieejami}

Padarot valdības datus publiski pieejamus, uzṇēmumi var gūt iespēju izstrādāt jaunas lietotnes, kurās šādi dati izmantoti, pētnieki var gūt iespējas uzlabot sabiedrisko pakalpojumu sniegšanu un palielināt caurskatāmību, kas savukārt uzlabo uzticēšanos valdībai. Šobrīd uzticēšanās valsts iestādēm ir zemā līmenī, Latvijai ieṇemot vietu zemāk par ESAO vidējo rādītāju attiecībā uz Pasaules bankas Vispasaules pārvaldības rādītājiem (WGI), uzrādot vājus rezultātus attiecībā uz korupcijas kontroli, balsi un atbildību (ESAO, 2019e, 2019k).

Datu atvērtības palielināšana ir bijusi valdības prioritāte, un šajā ziṇā ir panākts ievērojams progress, 2019. gadā valdībai apstiprinot jauno Latvijas atvērto datu stratēǵiju (4.27. attēls). Informācijas sabiedrības vadlīnijās (2014.-2020.) ir ietverta prasība, ka datiem ir jābūt pieejamiem lietošanai un atkārtotai lietošanai, kā daḷa no pieciem valsts informācijas sistēmas kritērijiem. Turklāt Latvija cenšas izpildīt Eiropas Valsts sektora informācijas direktīvu. 2017. gada jūlijā valdība apstiprināja trešo Nacionālo atvērtās pārvaldības rīcības plānu. Tajā ietverti plāni izstrādāt atvērto publisko datu portālu, pētniecības un publikāciju datu bāzi un valsts kapitālsabiedrību datu bāzi. Latvija plāno arī izveidot portālu, kurā būtu pieejami tiesību aktu projekti, modernizēt statistikas portālu un veikt pasākumus birokrātijas mazināšanai (www.mazaksslogs.gov.lv) (Valsts kanceleja, 2017).

2017. gadā tika uzsākta Latvijas atvērto datu portāla darbība, padarot pieejamas vairāk nekā 260 datu kopas. Valsts iestādes publicē datus mašīnlasāmā formātā kopā ar metadatiem saskaṇā ar Ministru kabineta rīkojumu (Eiropas Komisija, 2018a). Par publicētajiem datiem ir atbildīgas iestādes, bet tās sañem atbalstu no VARAM, un portāla darbību nodrošina Valsts reǵionālās attīstības aǵentūra (VRAA) (VARAM aǵentūra). Visi dati ir pieejami arī no Eiropas Datu portāla (Eiropas Komisija, 2019c). Taču centieni padarīt pieejamus vairāk datu ir saskārušies ar grūtībām, jo daži vērtīgākie dati (piem., geotelpiskie adrešu dati) ir aǵentūru ienākumu avots.

Šo centienu rezultātā atvērto datu pieejamība kopš 2014. gada ir būtiski palielinājusies (4.1. tabula). Dati par valdỉbas izdevumiem un ǵeotelpiskie dati (pasta indeksi un kartes) ir kḷuvuši brīvi pieejami, bet dati, 


\section{DIGITĀLĀS TRANSFORMĀGIJAS ATBALSTİ̌̌ANA}

kas iepriekš bija pieejami ierobežotā veidā (piem., transporta kustības saraksti, valdības budžeti, vēlēšanu rezultāti un tiesību akti), tagad ir pieejami mašinnlasāmā formātā ar atvērto licenci. Tas var veicināt lietotṇu un citu digitālo rīku veidošanu atbilstoši Latvijas nolūkam izveidot inovatīvus pakalpojumus privātajā sektorā, izmantojot digitālo publisko pārvaldi. Vēl viens ieguvums no atvērtības var būt arī caurskatāmības un atbildības palielināšana un līdz ar to uzticēšanās valsts iestādēm uzlabošana.

\subsection{7. attēls. Noderīgu atkārtoti izmantojamu datu atvēršanas (OURdata) indekss 2019}

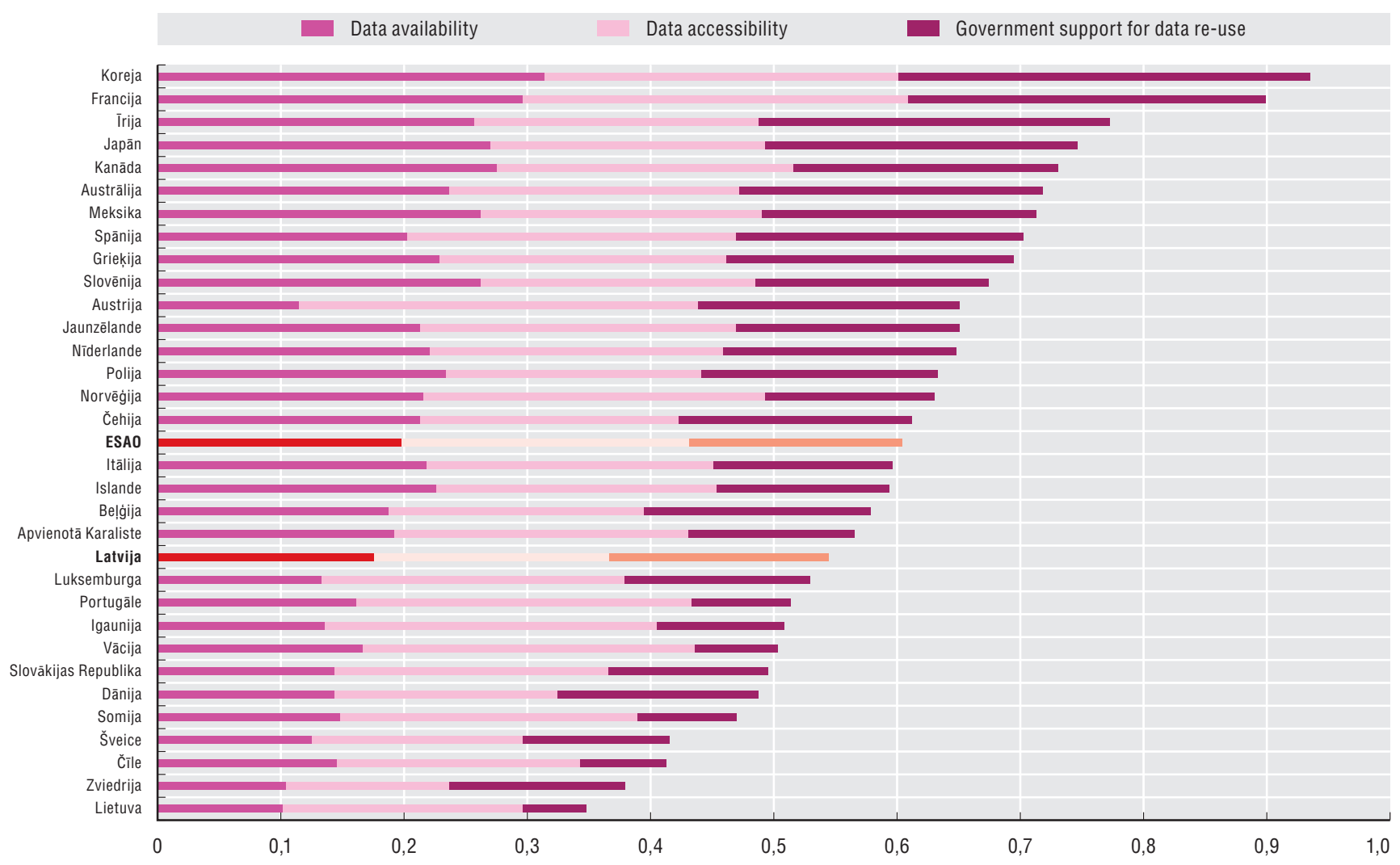

Avots: ESAO (2019o), Valdība issumā 2019 [Government at a Glance 2019], https://dx.doi.org/10.1787/8ccf5c38-en.

\section{1. tabula. Vairāk valdības datu ir kḷuvuši publiski pieejami}

Izmainas valdības datu atklātībā kopš 2014. gada

\begin{tabular}{|c|c|c|c|c|c|c|c|c|}
\hline & Dati pastāv & $\begin{array}{l}\text { Pieejami } \\
\text { digitāli }\end{array}$ & $\begin{array}{c}\text { Pieejami } \\
\text { publiski }\end{array}$ & Bez maksas & $\begin{array}{l}\text { Pieejami } \\
\text { tiešsaistē }\end{array}$ & Mašīnlasāmi & $\begin{array}{l}\text { Pieejami } \\
\text { vairumā }\end{array}$ & $\begin{array}{l}\text { Atvērtā } \\
\text { licence }\end{array}$ \\
\hline Transporta kustības saraksti & $P$ & $P$ & $P$ & $P$ & $P$ & + & + & + \\
\hline Valdības budžets & $P$ & $\mathrm{P}$ & $\mathrm{P}$ & $P$ & $P$ & + & $\mathrm{P}$ & + \\
\hline Valdības tēriņi & $\mathrm{P}$ & $\mathrm{P}$ & + & + & + & + & + & + \\
\hline Vēlēšanu rezultāti & $\mathrm{P}$ & $\mathrm{P}$ & $\mathrm{P}$ & $P$ & $P$ & + & + & + \\
\hline Uzņēmumu reǵistrs & $P$ & $\mathrm{P}$ & $\mathrm{P}$ & $P$ & $P$ & $P$ & $P$ & + \\
\hline Valsts kartes & $\mathrm{P}$ & $\mathrm{P}$ & $P$ & $\mathrm{P}$ & $\mathrm{P}$ & $P$ & + & + \\
\hline Valsts statistiskas dati & $\mathrm{P}$ & $P$ & $P$ & $\mathrm{P}$ & $P$ & $P$ & + & + \\
\hline Tiesību akti ${ }^{1}$ & $\mathrm{P}$ & $\mathrm{P}$ & $P$ & $P$ & $P$ & + & + & + \\
\hline Pasta indeksi & + & + & + & + & + & + & $U$ & + \\
\hline Piesārñojošo vielu emisijas & $P$ & $\mathrm{P}$ & $\mathrm{P}$ & $\mathrm{P}$ & $\mathrm{P}$ & $\mathrm{P}$ & + & $\mathrm{P}$ \\
\hline
\end{tabular}

Piezīme: "P" = apzīmē iepriekš pieejamu 2014. gadā; "+" = apzīmē pēc tam pievienotu; "U” = apzīmē nepieejamību.

Avots: Bojārs un Liepiņš (2014), "The state of open data in Latvia: 2014"; un anketas atbildes. 
Visus atvērtos datus publicē ar atvērtu licenci, un tie ir pieejami bez maksas. Latvija ir îstenojusi īpašus centienus, lai nodrošinātu vērtīgu ǵeotelpisko datu pieejamību. Atvērto datu pieejamība ir daḷeji balstīta uz semināra kampaṇu, ar kuras palīdzību ministrijas un to aǵentūras tika informētas par atvērto datu nozīmīgumu. Šos informētības uzlabošanas centienus 2018. gada septembrī papildināja atvērto datu «hakatons».

Valdībai būtu jādara vairāk, lai veicinātu atvērto datu ekosistēmu Latvijā. Paralēli sociālās izpētes vienībai (skatīt iepriekš) Latvija varētu izveidot balvu fondu, no kura pieškiirt dotācijas un balvas augstākās izglìtības studentiem, kuri lieto atvērtos datus savos darbos, kā arī piešķirt balvas citiem pētniekiem un programmatūras izstrādātājiem, kas izmanto atvērtos publiskos datus, lai risinātu problēmas sabiedrības labā.

\section{Valdības iepirkumu izmantošana digitālās transformācijas veicināšanai}

Valdība varētu vairāk izmantot publiskā iepirkuma noteikumus, lai motivētu MVU ieviest digitālās tehnoloǵijas. Šobrīd publiskais iepirkums veido piekto dal̦u IKP. Latvijas elektronisko iepirkumu sistēmu pārvalda Valsts regiionālās attīstības aǵentūra, un to var izmantot pašvaldības un valsts aǵentūras. 2017. gadā sistēma tika papildināta ar e-sertifikātiem, kas sniedz informāciju par piegādātājiem, lai vienkāršotu procedūras uzṇēmumiem. Kopš 2019. gada janvāra visi konkursu piedāvājumi par summām, kas pārsniedz 10000 EUR, ir jāiesniedz elektroniski (Eiropas Komisija, 2019c). Valsts elektronisko iepirkumu sistēmā tagad tiek izmantotas standarta veidnes, lai tādējādi mazinātu administratīvo slogu uzṇēmumiem. Latvijas e-iepirkumu sistēma ir integrēta arī ar nodokḷu reǵistru (Eiropas Komisija, 2018a) (ESAO 2018g, 2019o). Valdībai būtu jābalstās uz šìs infrastruktūras, nosakot pienākumu iepirkumiem izmantot elektroniskos rēkikinus standarta mašīnlasāmā formātā (kā Norvégijā noteiktais standarts).

Lai gan Latvijā ir zal̦ā publiskā iepirkuma plāns, valdība neizmanto publisko iepirkumu inovācijas atbalstam (Eiropas Komisija, 2018b; ESAO 2019e). Izveidojot tīmekḷa vietni, lai dotu iespēju MVU atrast publiskos līgumus par mazākām summām, piemēram, kā Contracts Finder [Līgumu meklētāja] tīmekḷa vietne Apvienotajā Karalistē, varētu motivēt Latvijas MVU palielināt digitālo tehnoloǵiju izmantošanu. Lìdzīgi, arī Kolumbijā ir izveidot virtuālais veikals (Tienda Virtual) uzṇēmumiem, kas parakstījuši cenu satvara līgumu ar Kolumbijas centrālo iepirkumu aǵentūru. Šajā portālā valdības iestādes (tostarp pašvaldības) var tieši iegādāties bieži pirktas preces no uzṇēmumiem. Līdzīga portāla izveidošana varētu darboties kā motivators mazākiem uzṇēmumiem sākt izmantot e-komerciju.

\section{Lietošana valdībā - secinājums}

Digitālo tehnoloǵiju un datu lietošanas valdībā palielināšana ir svarīga Latvijas Informācijas sabiedrības attīstības pamatnostādṇu daḷ. Tiešsaistes pakalpojumu un e-veselības kā klātienes konsultāciju alternatīvas izmantošana var arī palīdzēt Latvijai risināt dažus no izaicinājumiem, ko izraisījusi COVID-19 pandēmija. Lai gan Latvija ir panākusi nozīmīgu progresu tiešsaistes pakalpojumu sniegšanas un atvērto datu nodrošināšanas ziṇā, digitālo iespēju izmantošanai ir nepieciešams spert turpmākus solus.

\section{Secinājumi un politikas rekomendācijas}

Latvija ir panākusi ievērojamu progresu digitālo tehnologiiju lietošanas ziṇā Lietojums valdībā ir darbojies kā motivators uzṇēmumiem un mājsaimniecībām, un iedzīvotāji ir sākuši lietot internetu, lai kontaktētos ar valsts iestādēm, kā arī daudzas darbības ar uzṇēmumiem tagad notiek tikai tiešsaistē. Taču saglabājas ievērojamas plaisas īpaši attiecībā uz e-komercijas izmantošanu Latvijas uzṇēmumos.

Taču šobrīd Latvijai nav nacionālas stratēgijas interneta lietošanas veicināšanai uzṇēmumos un iedzīvotāju vidū. Turklāt "valdības kopīgas" pieejas neesamība nozìmē, ka netiek izmantotas iespējas, piemēram, nesen digitalizēto kultūras mantojuma resursu izmantošana, lai veidotu saites ar Latvijas diasporu. Latvijā būtu nepieciešama šādas stratēgijas izstrāde, lai izmantotu visas digitālās transformācijas priekšrocības. Šì pārskata rekomendāciju kopsavilkums ir sniegts 4.10. ielikums. 


\subsection{0. ielikums. Rekomendācijas politikas jomā}

\section{Interneta lietošanas palielināšana iedzīvotāju vidū}

- Izmantot tīmekḷa analīzi, lai novērtētu interneta izmantošanas veicināšanas panākumus.

- Modernizēt apmācību resursus, kas tiek nodrošināti Trešā tēva dēla programmā, un apgādāt bibliotēkas ar resursiem no valsts fonda iekārtu uzturēšanai.

- Izveidot kopienā balstītu programmu, kas īpaši paredzēta gados vecākiem Latvijas iedzīvotājiem, lai uzlabotu viṇu digitālās prasmes, kāda jau pastāv Austrālijā un Norvēgijā. Nodrošināt dotācijas partneriem (piem., NVO vai vietējām kopienas grupām) un apmācīt digitālos mentorus.

- Izveidot divvirzienu digitālo diasporas programmu, lai izveidotu saites starp Latvijas iedzìvotājiem un gimeni ārvalstīs un izplatītu digitālos kultūras resursus.

- Saistīt digitālo prasmju mācǐšanu bērniem ar vakara apmācībām vecākiem, kā tas ir darīts Kolumbijā.

\section{Digitālo tehnologiju izmantošanas palielināšana uzṇēmumos}

- Ieviest sistēmu, saskañā ar kuru uzṇēmumu algu programmatūra automātiski iesniedz datus Latvijas nodokḷu iestādēm, veicot samaksu darbiniekiem, kas ir līdzīga Austrālijas Single Touch Payroll [Viena pieskāriena algu] sistēmai.

- Izveidot "digitalizācijas čempionu" programmu, līdzīgu Austrālijas programmai, kur valdība sniedz atbalstu digitālo tehnoloǵiju ieviešanā nelielam skaitam MVU nozarēs, kur ir zems IKT izmantošanas limenis.

- Piedāvāt konsultācijas un vadības padomus uzṇēmumiem, kas atpaliek, nozarēs, kurās ir vairāki digitāli nobrieduši uzṇēmumi, lai tie varētu pietuvināties vadošajiem uzṇēmumiem, kā tas ir darīts Austrālijā un Austrijā.

\section{Skolas mācỉbu programmas reforma}

- Maksāt STEM priekšmetu skolotājiem papildu piemaksu, lai risinātu šādu skolotāju trūkuma problēmu.

- Regulāri konsultēties ar dienestiem un NVI, kas palīdz bērniem ar problēmām saistỉbā ar digitalizāciju, piemēram, Latvijas Drošāka interneta centrs, lai saṇemtu ieteikumus par mācību programmas atjaunināšanu.

- Vairāk izmantot karjeras norādijjumus, lai palielinātu studentu interesi par IKT apmācībām un darba vietām.

- Stiprināt saites starp profesionālajām skolām un uzṇēmumiem, nodarbinot IKT speciālistus un palielinot darbā balstītas apmācības proporciju.

- Vienkāršot procedūras, lai saṇemtu motivācijas atbalstu par darbā balstītas apmācības nodrošināšanu.

\section{Augstākās izglītỉbas reforma}

- Atbalstīt modulāro programmu izstrādi, kas ietver IKT.

- Piešķirt darba devējiem lielākas iespējas, lai ietekmētu universitāšu mācību programmu un palielinātu laiku, ko studenti pavada mācỉbu praksēs.

- Ieviest tiesisko satvaru darbā balstītām mācībām augstākajā izglītībā.

\section{Darbinieku digitālo prasmju uzlabošana}

- Palielināt tiešsaistes rỉku un kursu izmantošanu darba meklētājiem, kuriem ir zems ilgstoša bezdarba risks.

- Saskaņot datus no apmācībām un valsts nodarbinātỉbas aǵentūras datubāzēm, lai uzlabotu aktīvu darba tirgus politikas ietekmes uzraudzibu. 


\subsection{0. ielikums. Rekomendācijas politikas jomā (cont.)}

- Izveidot kopīgu apmācību fondu darbiniekiem, kā tas ir Polijā vai Francijā, ko finansētu darba devēju iemaksas no bruto algām.

- Atcelt darba tirgus testus ārvalstu IKT strādājošajiem ar atbilstošu pieredzi vai kvalifikāciju, kā tas ir Vācijā un Apvienotajā Karalistē, un tiem, kuri ir pabeiguši studijas Latvijā.

- Paplašināt nodokḷu atvieglojumus par augstākās izglītības mācību maksu, lai iekḷautu atskaitijumus par studentu aizdevumiem.

\section{Digitālās pārvaldes izpildījuma uzlabošana}

- Konsolidēt digitālās pārvaldes projektu finansējumu vienā ministrijā, kas nosaka prioritātes saskaṇā ar nacionālo digitālo stratēǵiju.

- Izveidot civildienesta līmeṇa apmācību programmu IKT lietošanai un pakalpojumu izstrādei. To var īstenot (kā Kolumbijā) ar darbsemināriem vai virtuālajiem kursiem valsts pārvaldes darbiniekiem papildus studentu un pēcstudiju apmācībām.

- Izstrādāt labas pakalpojuma nodrošināšanas prakses rokasgrāmatu, kā tas ir darīts Apvienotajā Karalistē, norādot galvenos principus labu tiešsaistes pakalpojumu nodrošināšanas un sekmju vērtēšanas principus.

- Izveidot motivāciju uzṇēmumiem kontaktēties ar pārvaldes iestādēm tiešsaistē, piešḳirot prioritāti uzṇēmumiem, kas izmanto pakalpojumus digitāli (piem., izdodot atḷaujas vai veicot maksājumus ātrāk tiem uzṇēmumiem, kas kontaktējas tiešsaistē).

- Izstrādāt grafiku, saskaṇā ar kuru valsts iestādes sniegs pakalpojumus uzṇēmumiem tikai digitāli.

- Izstrādāt tiesību aktus telemedicinnas regulējumam, kas būtu līdzīgi Likumam par e-veselību un drošu datu apmaiṇu starp veselības aprūpes pakalpojumu sniedzējiem Čehijas Republikā.

- Izveidot vienas pieturas kontaktpunktu, iespējams, sadarbībā ar AII, tiem, kuri vēlas piekḷūt veselības un sociālās aprūpes datiem, saglabājot konfidencialitāti, pētniecības vajadzībām, kā tas ir Somijā. Atbalstīt sociālās izpētes vienības izveidošanu, lai analizētu datus, ko radījuši digitālie dienesti, un rekomendētu jaunus pakalpojumus.

- Izstrādāt izmēǵinājuma programmas telemedicīnai.

- Izveidot balvu fondu augstākā līmeṇa studentiem, kas savos darbos izmanto atvērtos datus, kā arī pētniekiem un programmatūras izstrādātājiem, kas izmanto publiskos datus, lai risinātu sabiedrības problēmas.

- Organizēt ikgadēju darbsemināru, lai dotu iespēju ministrijām demonstrēt, kā tās izmanto datus sabiedrisko pakalpojumu uzlabošanai.

- Izveidot tiešsaistes platformu, lai dotu iespēju maziem uzṇēmumiem pārdot preces ar zemu vērtību centrālajai valdībai un pašvaldībām. 


\section{Atsauces}

Andrews, D., G. Nicoletti and C. Timiliotis (2018), “Digitālo tehnolog̣iju difūzija: jautājums par spējām, motivāciju vai abiem?” [Digital technology diffusion: A matter of capabilities, incentives or both?], OECD Economics Department Working Papers, No. 1476, OECD Publishing, Parīze, https://dx.doi.org/10.1787/7c542c16-en.

Austrālijas nodokḷu iestāde (2019), Viena pieskāriena algas izmaksa [Single Touch Payroll], www.ato.gov.au/Business/Single-Touch-Payroll.

Bojars, U. and R. Liepins (2014), "Atklāto datu statuss Latvijā: 2019" [The state of open data in Latvia: 2014], Baltic Journal of Modern Computing, Vol. 2/3, pp. 160-170.

Burns, T. and F. Gottschalk (eds.) (2019), 21. gadsimta bērnu audzināšana: emocionālā labklājība digitālajā laikmetā [Educating 21st Century Children: Emotional Well-Being in the Digital Age], Educational Research and Innovation, OECD Publishing, Parize, https://dx.doi.org/10.1787/b7f33425-en.

eParaksts (2020), Dubultojies pieteikumu skaits eParaksts mobile san, emšanai [The number of applications for receiving e-Signature mobile has doubled], eParaksts, www.eparaksts.lv/lv/par_mums/Jaunumi/Dubultojies_pieteikumu_skaits_eParaksts_mobile_sanemsanai (piekḷuve 2020. gada jūnjā).

EsFondi.lv (n.d.), IKT profesionāḷ apmācības inovāciju veicināšanai un nozares attīstībai [Training of ICT professionals to promote innovation and industry development], www.esfondi.lv/es-fondu-projektu-mekletajs/project?number=1.2.2.1/16/A/003.

EsFondi.lv (2015), Mazo un mikro komersantu apmācības inovāciju un digitālo tehnoloǵiju attīstībai Latvijā [Training of small and micro entrepreneurs for the development of innovations and digital technologies in Latvia], www.esfondi.lv/es-fondu-projektu-mekletajs/ project?number=1.2.2.3/16/I/002.

EURES (2018), İss pārskats par darba tirgu [Short Overview of the Labour Market], Eiropas Nodarbinātības dienesti, Brisele, https://ec.europa.eu/eures/main.jsp? catId=2776\&countryId=LV\&acro=lmi\&lang=en\&regionId=LV0\&nuts2Code=\%20\&nuts3Code= \&regionName=National\%20Level.

Eiropas Komisija (2019a), Digitālās ekonomikas un sabiedrības indeksa (DESI) valsts ziņojums: Latvija [Digital Economy and Society Index (DESI) Country Report: Latvia], Brisele.

Eiropas Komisija (2019b), E-valdības salīdzinošie kritēriji 2019: Eiropiešu iespēju paplašināšana, izmantojot uzticamus digitālos publiskos pakalpojumus [eGovernment Benchmark 2019: Empowering Europeans through Trusted Digital Public Services], Brisele.

Eiropas Komisija (2019c), Digitālās pārvaldības faktu pārskats 2019: Latvija [Digital Government Factsheet 2019: Latvia], Brisele.

Eiropas Komisija (2018a), E-pārvaldība Latuijā [eGovernment in Latvia], Brisele.

Eiropas Komisija (2018b), Latvijas pētniecības finansēšanas sistēma [The Latvian Research Funding System], Brisele.

Eiropas Investīciju banka (2019), Mazo un vidējo uzṇēmumu digitalizācija Portugālē: digitālo projektu finansēšanas model̦i [The Digitalisation of Small and Medium-sized Enterprises in Portugal: Models for Financing Digital Projects - Summary Report], Luksemburga, www.eib.org/attachments/thematic/digitalisation_of_smes_in_portugal_summary_en.pdf.

EM (2018), Informatīvais ziṇojums pr vidēja termiṇa unilgtermiṇa darba tirgus prognozēm [Informative Report On Medium And Long-Term Labour Market Forecasts], Ekonomikas ministrija, Rīga, www.em.gov.lv/en/economic_development/labor_market/informative_report_ on_medium_and_long_term_labour_market_forecasts.

ESAO (2020), OECD Structural and Demographic Business Statistics (SDBS) (database), OECD, Parīze, https://stats.oecd.org/Index. aspx?DataSetCode=SSIS_BSC_ISIC4 (piekl̦uve 2020. gada 6. maijā).

ESAO (2019a), ESAO prasmju apskats 2019: Panākumu gūšana digitālā pasaulē [OECD Skills Outlook 2019: Thriving in a Digital World], OECD Publishing, Parīze, https://dx.doi.org/10.1787/df80bc12-en.

ESAO (2019b), ESAO digitālās transformācijas apskati: digitalizācija Kolumbijā [OECD Reviews of Digital Transformation: Going Digital in Colombia], OECD Publishing, Parīze, https://dx.doi.org/10.1787/781185b1-en.

ESAO (2019c), ESAO ekonomikas apskati: Latuija 2019 [OECD Economic Surveys: Latvia 2019], OECD Publishing, Parīze, https://dx.doi. org/10.1787/f8c2f493-en.

ESAO (2019d), ESAO apskats par MVU un uznēmējdarbību 2019 [OECD SME and Entrepreneurship Outlook 2019], OECD Publishing, Parīze, https://dx.doi.org/10.1787/34907e9c-en.

ESAO (2019e), Inovācija, lauksaimniecības produktivitāte un ilgtspējaLatuijā [Innovation, Agricultural Productivity and Sustainability in Latvia], ESAO apskati par pārtiku un lauksaimniecību, OECD Publishing, Parīze, https://dx.doi.org/10.1787/9789264312524-en.

ESAO (2019f), ESAO Digitalizācijas MVU globālā iniciatīua [OECD Digital for SMEs Global Initiative], OECD, Parīze, www.oecd.org/ going-digital/sme/resources/D4SME-Brochure.pdf. 
ESAO (2019g), Izglītība ìsumā 2019: ESAO indikatori [Education at a Glance 2019: OECD Indicators], OECD Publishing, Parīze, https://dx.doi.org/10.1787/f8d7880d-en.

ESAO (2019h), PISA 2018 rezultāti (I daḷa): Ko studenti zina un varizdarīt [PISA 2018 Results (Volume I): What Students Know and Can Do], PISA, OECD Publishing, Parīze, https://dx.doi.org/10.1787/5f07c754-en.

ESAO (2019i), ESAO prasmju stratēgija Latvijā: vērtējums unrekomendācijas [OECD Skills Strategy Latvia: Assessment and Recommendations], ESAO prasmju pētījumi, OECD Publishing, Parīze, https://doi.org/10.1787/74fe3bf8-en.

ESAO (2019j), TALIS 2018 rezultāti (I daḷa): Skolotāji unskolu vadītāji kā mūžizglītības audzēkṇi [TALIS 2018 Results (Volume I): Teachers and School Leaders as Lifelong Learners], TALIS, OECD Publishing, Parīze, https://dx.doi.org/10.1787/1d0bc92a-en.

ESAO (2019k) Latvijas aktīuo darba tirgus politiku vērtējums [Evaluating Latvia's Active Labour Market Policies], Cilvēku un darbu savienošana, OECD Publishing, Parīze, https://dx.doi.org/10.1787/6037200a-en.

ESAO (2019l), Izglītības politikas apskats 2019:strādāt kopā, lai palīdzētu skolēniem sasniegt potenciālu [Education Policy Outlook 2019: Working Together to Help Students Achieve their Potential], OECD Publishing, Parīze, https://dx.doi.org/10.1787/2b8ad56e-en.

ESAO (2019m) Pareizās prasmes: nākotnes pieaugušo sagatavošanasmācīšanās sistēmas [Getting Skills Right: Future-Ready Adult Learning Systems], Pareizās prasmes, OECD Publishing, Parīze, https://dx.doi.org/10.1787/9789264311756-en.

ESAO (2019n), ESAO prasmju stratēgija Latvijā: vērtējums un rekomendācijas [OECD Skills Strategy Latvia: Assessment and Recommendations], OECD Skills Studies, OECD Publishing, Parīze, https://dx.doi.org/10.1787/74fe3bf8-en.

ESAO (2019o) Valdība īsumā 2019 [Government at a Glance 2019], OECD Publishing, Parīze, https://dx.doi.org/10.1787/8ccf5c38-en.

ESAO (2019p), Veselība 21. gadsimtā: datu izmantošanaspēcīgākām veselības aprūpes sistēmām [Health in the 21st Century: Putting Data to Work for Stronger Health Systems], ESAO veselības politikas pētījumi, OECD Publishing, Parīze, https://dx.doi.org/10.1787/ e3b23f8e-en.

ESAO (2019q) Digitalizācijas instrumentu komplekts [Going Digital Toolkit], (datubāze), OECD, Parīze, https://goingdigital.oecd.org/en.

ESAO (2019r) Celšs uz datu virzītu valsts sektoru [The Path to Becoming a Data-Driven Public Sector], ESAO digitālās pārvaldības pētījumi, OECD Publishing, Parīze, https://dx.doi.org/10.1787/059814a7-en.

ESAO (2018a), IKT pieejamība un lietošana mājsaimniecībās un individuāli [ICT Access and Usage by Households and Individuals] (datubāze), OECD, Parīze, http://oe.cd/hhind.

ESAO (2018b), Digitalizācija [“Digitalisation”], Īsumā par Latvijas politiku, OECD, Parīze, www.oecd.org/policy-briefs/Latvia-digitalisation.pdf.

ESAO (2018c), Prasmes darbiem - pārskats par Latuijas valsti [Skills for Jobs - Latvia Country Note], OECD, Parīze, www.oecdskills forjobsdatabase.org/data/country_notes/Latvia\%20country\%20note.pdf.

ESAO (2018d), Izglītība īsumā 2018: ESAO indikatori ["Latvia”, in Education at a Glance 2018: OECD Indicators], OECD Publishing, Parize, https://dx.doi.org/10.1787/eag-2018-56-en.

ESAO (2018e), Prasmes darbiem datubāze [Skills for Jobs Database], OECD, Parīze, www.oecdskillsforjobsdatabase.org (piekḷuve 2020. gada martā).

ESAO (2018f), Septini jautājumi par praksēm: profesionālāizglītība un apmācība [Seven Questions about Apprenticeships: Answers from International Experience], OECD Reviews of Vocational Education and Training, OECD Publishing, Parīze, https://dx.doi. org/10.1787/9789264306486-en.

ESAO (2018g), MVU publiskajā iepirkumā: prakse un stratēgijaskopīgiem ieguvumiem [SMEs in Public Procurement: Practices and Strategies for Shared Benefits], ESAO pārskati par valsts pārvaldību, OECD Publishing, Parīze, https://dx.doi.org/10.1787/9789264307476-en.

ESAO (2017a), ESAO ekonomikas apskati: Latvija 2017 [OECD Economic Surveys: Latvia 2017], OECD Publishing, Parize, https://dx.doi. org/10.1787/eco_surveys-lva-2017-en.

ESAO (2017b), ESAO ekonomikas apskati: Slovēnija 2017 [OECD Economic Surveys: Slovenia 2017], OECD Publishing, Parīze, https://dx.doi.org/10.1787/eco_surveys-sun-2017-en.

ESAO (2017c), IKT pieejamība un lietošana uzṇēmumos [ICT Access and Use by Businesses] (datubāze), OECD, Parīze, http://oe.cd/bus.

ESAO (2016a), Jaunas prasmes digitālajaiekonomikai: IKT prasmju pieprasījuma un piedāvājuma darbā vērtējums ["New Skills for the Digital Economy: Measuring the demand and supply of ICT skills at work"], OECD Digital Economy Papers, No. 258, OECD Publishing, Parīze, https://dx.doi.org/10.1787/5jlwnkm2fc9x-en.

ESAO (2016b), ESAO pārskats par darba tirgu un sociālajāmpolitikām: Latuija 2016 [OECD Reviews of Labour Market and Social Policies: Latvia 2016], ESAO pārskati par darba tirgu un sociālajām politikām, OECD Publishing, Parīze, https://dx.doi. org/10.1787/9789264250505-en.

ESAO (2016c), Recommendation of the Council on Health Data Governance, OECD, Parize, https://legalinstruments.oecd.org/en/instruments/ OECD-LEGAL-0433.

Eurostat (2020a), E-komercijas statistika attiecībā uz iedzīvotājiem [E-commerce Statistics for Individuals], Brisele, https://ec.europa.eu/ eurostat/statistics-explained/index.php/E-commerce_statistics_for_individuals\#E-shopping:_biggest_increase_among_young_internet_users (pieklıve 2020. gada jūnijs). 
Eurostat (2020b), Grūti aizpildāmas IKT vakances: pieaugošs izaicinājums [Hard-to-fill ICT Vacancies: An Increasing Challenge], Brisele, https://ec.europa.eu/eurostat/web/products-eurostat-news/-/ DDN-20200221-1 (piekḷuve 2020. gada februārī).

Eurostat (2020c), IKT lietošana mājsaimniecībās un individuāli [ICT Usage in Households and by Individuals] (datubāze), https:// ec.europa.eu/eurostat/cache/metadata/en/isoc_i_esms.htm.

Eurostat (2019a), Iedzīvotāju digitālo prasmju līmenis [Individuals' Level of Digital Skills] (datubāze), https://data.europa.eu/euodp/en/ data/dataset/06Pzf6zY9zRfr8Wg9X5gw.

Eurostat (2019b), IKT speciālistu nodarbinātība [ICT Specialists in Employment], Brisele https://ec.europa.eu/eurostat/statistics-explained/ index.php/ (piekluve 2019. gada oktobrī).

Eurostat (2019c), E-komercijas statistika [E-Commerce Statistics] (datubāze) https://ec.europa.eu/eurostat/statistics-explained/index. php/E-commerce_statistics.

FM (2018), Nodokḷu sistēma Latuijā [Tax System in Latvia], Finanšu ministrija, Rīga, www.fm.gov.lv/en/s/taxes (piekḷuve 2019. gada oktobrī).

gov.uk (2020), Imigrācijas noteikumu K pielikums: trūkstošo profesiju saraksts [Immigration Rules Appendix K: Shortage Occupation List], www.gov.uk/guidance/immigration-rules/immigration-rules-appendix-k-shortage-occupation-list (piekḷve 2020. gada martā).

Government Digital Service (2019), "Pārvaldības pakalpojumu izstrāde un veidošana” [Design and build government services], www. gou.uk/service-toolkit (piekḷuve 2020. gada martā).

IZM (2020), Izglītības mācību programmas un mācīšanās pieejasapraksts [Description of Educational Curriculum and Learning Approach], Izglītības un zinātnes ministrija, Rīga, www.izm.gov.lv/en/highlights/3336-description-of-educational-curriculum-andlearning-approach-2 (piekḷve 2020. gada 11. maijā).

Jacobs, B. et al. (2017), Latvijas nodokḷu apskats [Latvia Tax Review], Pasaules bankas grupa, http://documents1.worldbank.org/curated/ en/587291508511990249/pdf/120580-WP-P158470-PUBLIC-117p-WBLatviareportPOP.pdf.

Kässi, O. un V. Lehdonvirta (2018), Tiešsaistes darbaindekss: Tiešsaistes gid ekonomikas politikai un pētniecībai vērtējums [Online Labour Index: Measuring the Online Gig Economy for Policy and Research], https://mpra.ub.uni-muenchen.de/86627 (piekḷuve 2018.gada 20. jūnijā).

KISC (2019a), Bibliotekāriem piedāvā IT drošības apmācības e-vidē [Librarians are offered IT security training in the e-environment], Kultūras informācijas sistēmu centrs, www.kis.gov.lv/2019/03/bibliotekariem-piedava-it-drosibas-apmacibas-e-vide (piekḷve 2019. gada augustā).

KISC (2019b), Kultūras informācijas sistēmu centrs [Centre for Cultural Information Systems], www.kis.gov.lv.

KISC (2015), Publisko bibliotēku attīstības projekts “Trešais tēva dēls” [Public library development project “Third Father's Son”], Kultūras informācijas sistēmu centrs.

Latvijas Finanšu nozares asociācija (2019), Latvijas Finanšu nozares asociācija atbalsta jauno izcilības programmu, www.financelatvia. eu/en/news/finance-latvia-supports-the-new-program-of-excellence (piekḷuve 2019. gada augustā).

LIKTA (2019), Projekts Women4IT [Project Women4IT], Latvijas Informācijas un komunikācijas tehnoloǵijas asociācija, Rīga, https://likta.lv/en/ project-women4it (piekl̦uve 2019. gada oktobrī).

LIKTA (2018), Young ICT Women, Latvijas Informācijas un komunikācijas tehnoloǵijas asociācija, Rīga, https://likta.lv/en/ young-ict-women (piekl̦uve 2019. gada oktobrī).

LTRK (2019), LTRK turpina īstenot nodarbināto apmācību projektu [LCCI continues to implement the employee training project], Latvijas Tirdzniecības un rūpniecības kamera, Rīga, www.chamber.lv/lv/content/3403.

LTRK (2017), Produktivitātes evolūcija 2 [Productivity Evolution 2], Latvijas Tirdzniecības un rūpniecības kamera, Rīga, www.chamber. lv/en/content/851 (piekḷve 2019. gada oktobrī.).

Menshikov, V. un O. Volkova (2019), Digitalizācija augstākai piekḷuves veselības aprūpes pakalpojumiem drošībai Latvijā "[Digitalization for increased access security to healthcare services in Latvia”], Journal of Security \& Sustainability Issues, Vol. 9/1, 171.-183. lpp.

NIFO (2018), Latviešu valodas automatizētās tulkošanas pakalpojums [Latvian Automated Translation Service], Valsts sadarbspējas satvara novērošanas centrs, https://joinup.ec.europa.eu/ collection/nifo-national-interoperability-framework-observatory/document/ latvian-automated-translation-service.

Oliveira Hashiguchi, T. (2020), Veselībasaprūpes nodrošināšana pacientam: pārskats par telemedicīnas lietošanu ESAO valstīs ["Bringing health care to the patient: An overview of the use of telemedicine in OECD countries"], ESAO veselības darba dokumenti,Nr. 116, OECD Publishing, Parize, https://dx.doi.org/10.1787/8e56ede7-en.

Pārresoru koordinācijas centrs (2017), Nacionālais attīstības plāns 2014.-2020. gadam, Gada un ilgtspējīgas attīstības stratēǵijas Latvijai lìdz 2030. gadam: Ikgadējais ìstenošanas uzraudzības zinojums, [National Development Plan 2014-2020 Annual and Sustainable Development Strategies for Latvia up to 2030: Annual Implementation Monitoring Report], Rìga.

Pasaules ekonomikas forums (2017), The Global Competitiveness Index Historical Dataset 2007-2017, https://tcdata360.worldbank.org/ indicators/fin.loc.eqy.mkt?country=BRA\&indicator=525\&viz=line_chart\&years=2007,2017.

Perry, G. (ed.) (2017), Formalitātes neievērošana, produktivitāte un uzṇēmums [Informality, Productivity, and the Firm], PasaulesBanka, Vašingtona, DC. 
Pilsonības un migrācijas lietu pārvalde (2020), No 2023.gada 1.januāra personas apliecība (eID karte) būs obligāts personuapliecinošs dokuments, Riga, www.pmlp.gov.lv/lv/sakums/jaunumi/aktualitates/2020/02/26/no-2023.gada-1.janv\%C4\%81ra-personasapliec\%C4\%ABba-(eid-karte)-b\%C5\%ABs-oblig\%C4\%81ts-personu-apliecino\%C5\%A1s-dokuments (piekḷuve 2020. gada jūnijā).

Randall, L. un A. Berlina, (2019), Digitālās transformācijaspārvaldība Ziemel̦ualstu reǵionos: cilvēka elements [Governing the Digital Transition In Nordic Regions: The Human Element], Nordregio, Stokholma, http://norden.diva-portal.org/smash/get/diva2:1295022/ FULLTEXT01.pdf.

Sauka, A. un T. Putniņš (2019), Baltijas valstu ēnu ekonomikas indekss 2009.-2018. [Shadow Economy Index for the Baltic Countries 2009-2018], Rīgas Ekonomikas augstskola, www.sseriga.edu/shadow-economy-index-baltic-countries.

Valdani Vicari and Associati (2019), Nacionāloiniciatīuu industrijas digitalizācijai progresa uzraudzība: Valsts zinojums par Latviju [Monitoring Progress in National Initiatives on Digitising Industry: Country Report Latvia], https://ec.europa.eu/information_society/ newsroom/image/document/2019-32/country_report_-_latvia_-_final_2019_0D30BE44-054B-C822-C8DEFA25536D65B0_61211.pdf.

Valsts kanceleja (2017), Valdība apstiprina Latvijas trešo nacionālo atvērtās pārualdības rīcības plānu [The Government Approves Latvia's Third National Action Plan for Open Government Partnership], Rīga, www.mk.gov.lv/en/aktualitates/government-approves-latviasthird-national-action-plan-open-government-partnership.

VARAM (2013), Informācijas sabiedrības attīstības pamatnostādnes 2014.-2020 [Information Society Development Guidelines 2014-2020] (Informatīuā daḷa), Vides aizsardzības un reǵionālās attīstības ministrija, Rīga, www.varam.gou.lv/in_site/tools/download. php?file=files/text/Darb_jomas/elietas//Information_Society_Development_Guidelines_2014_2020.docx.

VISC (2019), Par projektu [About the project], Valsts Izglītības satura centrs, Rīga, www.skola2030.lv/lv/par-projektu (piekḷuve 2020. gada 11. maijā).

VRAA (2019), e-Zinas, e-Ziṇas, Valsts Reǵionālā attīstības aǵentūra, Rīga, www.uraa.gov.lv/uploads/documents/latvijalv10/ vraa_e-zinas_2019_4_cet.pdf.

WKO (2018), Pašreizējā informācija par jaunu praksi kāe-komercijas uzṇēmējam [“Aktuelles zur neuen Ausbildung im Lehrberuf E-Commerce-Kaufmann/-frau"], Wirtschaftskammer Österreich, www.wko.at/branchen/handel/lehrberuf-e-commerce-kaufmann-frau. html (piekḷuve 2020. gada martā).

Zech, T. (2020), “Prasmīgs personāls ir laipni gaidīts” [Skilled personnel welcome], deutschland.de, www.deutschland.de/en/topic/business/ the-skilled-labour-immigration-act-working-in-germany (piekl̦uve 2020. gada martā).

\section{Piezīme}

\section{Izraēla}

Statistikas datus par Izraēlu sniedza, un par tiem atbild Izraēlas attiecīgās iestādes. Šo datu izmantošana ESAO neskar Golānas augstieṇu, Austrumjeruzalemes un Izraēlas apmetṇu statusu Rietumkrastā saskaṇā ar starptautisko tiesỉbu noteikumiem. 



\section{Nodala 5 \\ UZTICAMĪBAS VEICINĀŠANA DIGITĀLAJAI EKONOMIKAI}




\section{Latvijas digitālās drošības politika}

Šajā sadaḷā ir sniegts plašs apraksts par digitālās drošǐbas politiku Latvijā un tās analīze. Pirmajā Latuijas kiberdrošỉbas stratēǵijā, kas aptver 2014.-2018. gada periodu, tika novērtēta digitālā transformācija un iezīmēta pāreja uz stratēǵiskāku un visas valdības pieeju digitālajai drošībai. Otrajā Latuijas kiberdrošības stratēgiijā, kas aptver 2019.-2022. gadu, šis cel̦š tiek turpināts, vairāk akcentējot risku pārvaldību, noturību, sabiedrības informētību un nepieciešamību līdzsvarot digitālo drošỉbu ar atklātỉbu, labklājību un cilvēktiesībām.

Šìs stratēgijijas atspoguḷo virzību Latvijas valdỉbas attieksmē pret digitālās drošības politiku. Tomēr šajos dokumentos vai to ieviešanas procesos vēl nav pilnīgi ieviesti digitālās drošības ekonomiskie un sociālie riski. Faktiski Latvijas ǵeopolitiskā vide ir likusi valdībai galvenokārt balstīties uz nacionālās drošības konceptuālo struktūru, kas koncentrējas uz kritiskām infrastruktūrām un valsts institūcijām. Varētu nostiprināt daudzu ieinteresēto pušu iesaistǐšanos un uz tirgu orientētu politiku, lai pilnībā realizētu digitālās transformācijas potenciālu. Turklāt tas palīdzētu labāk attiecināt digitālās drošības risku uz augstāko vadību organizācijās un uzṇēmumos, it īpaši mazajos un vidējos uzṇēmumos MVU.

\section{Jaunākās tendences}

\section{Uzbrukumi digitālajai drošībai Latvijā}

2018.-2019. gadā plašsaziṇas līdzekḷu uzmanība Latvijā koncentrējās uz politiski motivētu organizāciju uzbrukumiem no valstīm "ar NATO un ES pretēju politisko ideoloǵiju" (CERT.LV, 2018. gads). Kā piemērus var minēt darbības, kuru mērḳis bija Latvijas Saeimas vēlēšanu process. Tomēr rūpīga analīze liecina, ka Latvija tāpat kā daudzas citas valstis cieta no uzbrukumiem ar globālāku tvērumu, piemēram, WannaCry un Mirai ${ }^{1}$ (5.1. attēls). Tomēr šādu uzbrukumu ietekmēto organizāciju skaits Latvijā bija salīdzinoši zems. Digitālās drošības negadījumu galvenie upuri Latvijā bija MVU un pašvaldības (CERT.LV, 2018. gads).

5.1. attēls. Izplatītākie ḷaunprātīgā koda uzbrukumi Latvijā, 2018. gads

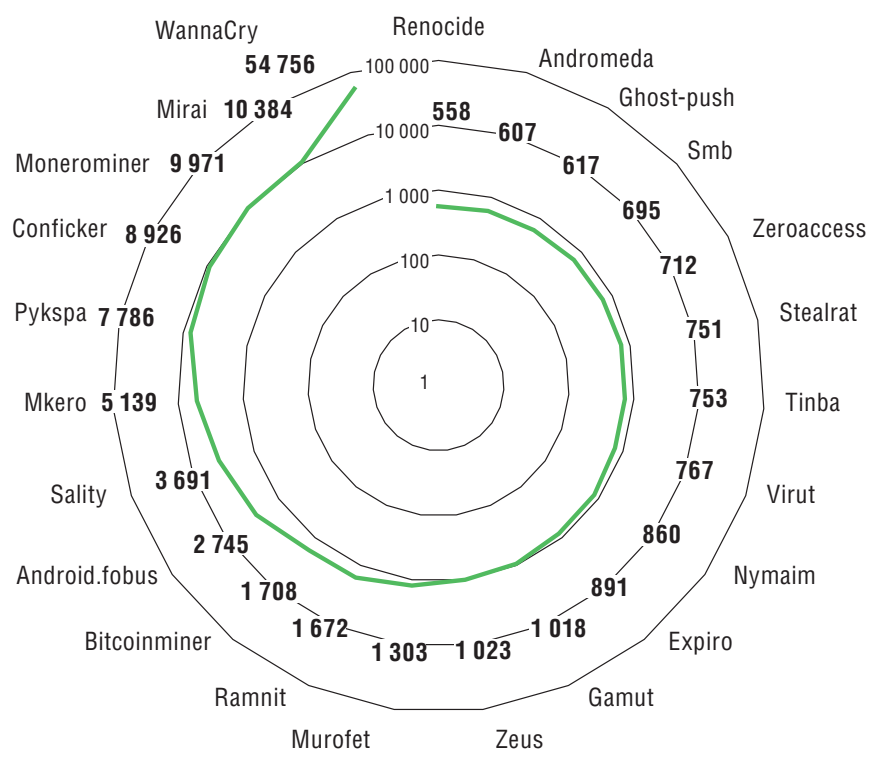

Avots: CERT.LV (2018), CERT.LV Public Performance Report, https://cert.lv/uploads/cert-gada-parskats-2019.pdf.

Jaunāki dati (5.2. attēls) apstiprina, ka pret Latvijas organizācijām mērḳtiecīgi vērstās l̦aunprogrammatūras galvenās formas atbilst šādām formām citās valstīs, un Mirai un WannaCry ir attiecīgi otrā un ceturtā izplatītākā l̦aunprogrammatūra 2020. gada pirmajā ceturksnī. Minr kā izplatītākā ḷaunprātīgā koda dominējošā pozīcija Latvijā šajā periodā ilustrē kriptovalūtu graujošās l̦aunprogrammatūras globālo tendenci. 


\section{2. attēls. Izplatītākie l̦aunprātīgā koda uzbrukumi Latvijā, 2020. gadā (1. cet.)}

L̦aunprātīgā koda apdraudēto unikālo IP adrešu skaits, 2020. g. 1. cet.

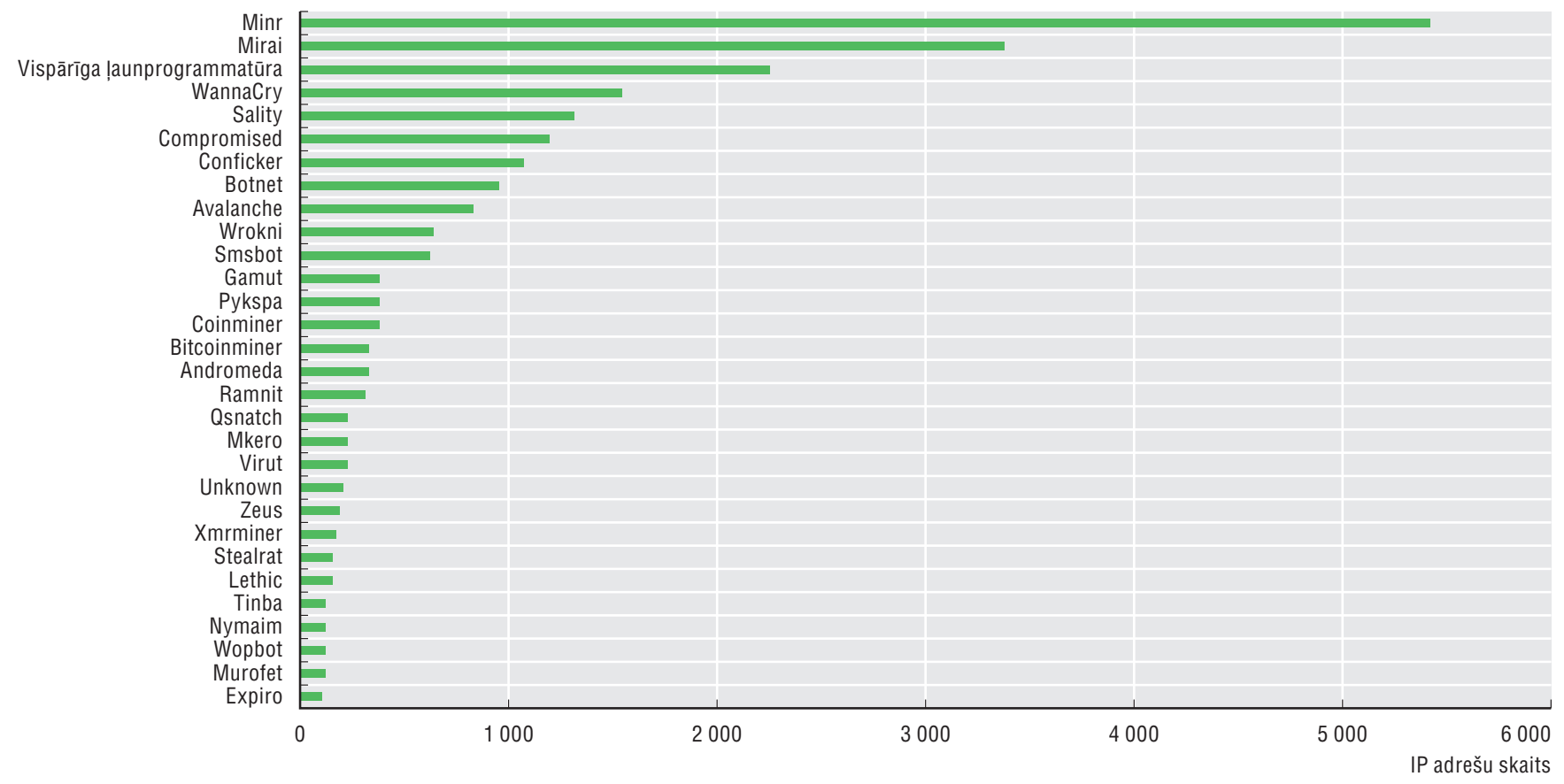

Avots: CERT.LV (2020), CERT.LV reǵistre`tie incidenti no 01.01.2020. l'lldz 31.03.2020, https://cert.lv/lv/2020/04/pieejama-statistika-par-2020-gada-1-ceturksni.

\section{Digitālās drošǐbas politikas suarīgākie datumi Latvijā}

Digitālā drošỉba nav jauna politikas joma Latvijā. Pirms 2012. gada Latvijas pieeja digitālajai drošībai galvenokārt koncentrējās uz tehniskajiem aspektiem un infrastruktūru. Satiksmes ministrija (SM) bija iestāde, kas atbild par digitālās drošības politikas vispārēju koordināciju .

2010. gadā Latvija pieṇēma Informācijas tehnoloǵiju drošǐbas likumu ("IT drošǐbas likumu”), kas stājās spēkā 2011. gadā un kalpo kā digitālās drošǐbas galvenā juridiskā struktūra (skatiet sadaḷu šeit: Tiesiskais regulējums). Tā rezultātā, inter alia, tika izveidota:

- Informācijas tehnoloǵiju drošības incidentu novēršanas institūcija CERT.LV² ir Latvijas Universitātes Matemātikas un informātikas institūta struktūrvienība, kas Informācijas tehnolog̣iju drošības likumā noteiktās tiesības un pienākumus pilda Aizsardzības ministrijas pakḷautībā atbilstoši normatīvajiem aktiem.

- Nacionālā informācijas tehnolog̣iju drošỉbas padome (NITDP) - organizācija, kas tiekas vismaz vienreiz četros mēnešos un sastāv no ministriju un citu digitālās drošības politikā iesaistītu publisku organizāciju pārstāvjiem.

2013. gadā Latvijas Ministru kabinets apstiprināja Informācijas sabiedrības attīstības pamatnostādnes (2014.-2020. g.) (VARAM, 2014. gads), kas kalpo kā nacionālā digitālā stratēgeija. Pamatnostādṇu pieṇemšana atspoguḷoja perspektīvas maiṇu līdz ar atziṇu, ka digitalizācija ietekmē visas sabiedrỉbas daḷas. Digitālās drošỉbas riski ir kḷuvuši par stratēgisku valsts politikas jautājumu, kurā ir nepieciešama daudzu ministriju iesaistī̌anās, izmantojot visu valdības struktūru pieeju.

Šīs izmaiṇas tika apstiprinātas 2014. gadā, pien,emot Latvijas kiberdrošības stratēgiju (2014.-2018. gadam), kurā ir norādīts: "Priekšstatu, ka IKT ir tikai šauras profesionāḷ grupas interešu sfērā, pakāpeniski aizstāj izpratne, ka ar IKT lielākā vai mazākā mērā ir saistīta visa sabiedrība" (AM, 2014. gads). Log̣iski, ka stratēǵijas pirmais mērkịis bija skaidras pārvaldības struktūras izveide digitālajai drošībai Latvijā. Šì jaunā pārvaldības struktūra tika izveidota ap NITDP. Aizsardzības ministrijas (AM) pārṇēma informācijas tehnolog̣iju drošības politikas veidošanas un ìstenošanas koordinēšanu.

2016. gadā AM sadarbībā ar citām ministrijām un NITDP veica stratēgijas îstenošanas vidusposma pārskatu, pēc tam 2019. gadā Latvijas Ministru kabinets apstiprināja ziṇojumu par stratēǵijas ieviešanu, 
kurā ir secināts, ka lielākā daḷa mērḳu ir sasniegti vai atrodas izpildes procesā. Tomēr ziṇojumā tika atzīti arī atsevišḳu mērḳu sasniegšanas šḳēršḷi, it îpaši šie: 1) digitālā drošība ne vienmēr ir lēmumu pieṇēmēju prioritāte; 2) digitālās drošỉbas prasmju trūkums; 3) digitālās drošības finansējuma trūkums.

Pamatojoties uz šiem elementiem, Latvijas Ministru kabinets 2019. gadā apstiprināja otro Latvijas kiberdrošības stratēgiiju (2019.-2022. gadam). Šajā dokumentā, ko AM sagatavoja sadarbībā ar citām ministrijām un NITDP, ir izklāstītas Latvijas digitālās drošības politikas nacionālās prioritātes un noteikti gaidāmie izaicinājumi. Jaunās stratēgijas galvenais mērḳis ir nostiprināt un uzlabot digitālās drošības iespējas, palielinot noturību pret uzbrukumiem un uzlabojot sabiedrības informētību par apdraudējumiem kibertelpā.

Tas atspoguḷo pozitīvu evolūciju Latvijas attieksmē pret digitālo drošǐbu. Divu kiberdrošỉbas stratēǵiju attīstība un AM vadošā loma kopš 2013. gada ir padarījusi digitālo drošību par stratēgisisku prioritāti Latvijā. Tomēr nacionālā drošība ir izvirzịta priekšplānā uz citu aspektu, it îpaši ekonomiskās un sociālās labklājības, rēḳina (skatiet 5.3. attēlu). To ir apstiprinājusi analīze par definīciju kopu (saistītu ar digitālo drošību), kas ir iekḷauta Latvijas politikas dokumentos (skatiet zemāk).

\section{Digitālā drošība un ar to saistītie termini Latvijas politikā}

Latvijas politikas dokumentu pamatā ir jēdzieni "kiberdrošība", "informācijas tehnoloǵiju drošǐba" un "informācijas drošība" (AM, 2014. gads; VARAM, 2014. gads).

Savās 2015. gada Rekomendācijās par digitālās drošības risku pārvaldību ekonomiskās un sociālās labklājības labā, šeit un turpmāk "2015. gada rekomendācijā" (ESAO, 2015. gads) ESAO izmanto terminu "digitālā drošība", nevis "kiberdrošība", "informācijas drošǐba" vai "IT drošība". ESAO definē "digitālo drošību" kā tādu ekonomisko un sociālo risku pārvaldību, kuri izriet no informācijas un komunikācijas tehnolog̣iju (IKT) un datu pieejamības, integritātes un konfidencialitātes (PIK). Šì definīcija atspoguḷo virzību no 2002. gada ESAO Informācijas sistēmu un tīklu drošības pamatnostādnēm ("Drošības pamatnostādnes"), kas galvenokārt koncentrējās uz tehniskajiem aspektiem, nevis uz digitālās drošības risku pārvaldību attiecībā uz ekonomiskajām un sociālajām aktivitātēm, kuru pamatā ir IKT izmantošana.

Tomēr nav vispārpieṇemtas terminoloǵijas, kas aptvertu digitālās drošības dažādās šḳautnes jebkurā kontekstā. Termini dažādās valstīs atšḳiras un atspoguḷo dažādu valstu kultūru un vēsturi: nav "pareizas" vai "nepareizas" terminologijas. 2015. gadā ESAO valstis deva priekšroku terminam "digitāls", nevis "kiber-", jo pēdējais no šiem bieži asociējās ar tādām koncepcijām kā "kiberkarš", "kiberaizsardzība" vai "kiberietekme". Turklāt termins "kiber-" netiek lietots ekonomikas aprindās, kas parasti vairāk izmanto digitālo semantiku: digitālā ekonomika, digitālā transformācija, digitalizācija utt. Vārds "digitāls" sekmē "digitālās drošības" kā ekonomikas jautājuma atzīšanu no politikas veidotāju un uzṇēmumu vadītāju puses. "Informācijas drošība" tika atstāta malā kā tehniskās pārvaldības termins, kas primāri atspoguḷo tehniskās kopienas viedokli (piemēram, ISO/IEC 27000 "Informācijas drošības pārvaldes sistēmas" standartus). Turklāt termins "Informācijas drošība" ir neskaidrs starptautiskajā kontekstā, jo tam ir atškirīgs tvērums tādās valstīs kā K̦īnas Tautas Republikā un Krievijas Federācijā, kuras tajā iekḷauj arī pret dezinformāciju, ietekmi un informācijas manipulācijām vērstu politiku. Dezinformācija, ietekme un kaitīga satura izplatīšana ir svarīgi jautājumi, ko saasina digitālā transformācija. Tie dažkārt var pārklāties ar digitālo drošību, piemēram, ja digitālās drošības uzbrukumus izmanto, lai mainītu datu integritāti, manipulējot ar sabiedrisko viedokli, vai novērstu piekḷuvi valdības pakalpojumiem. Tomēr tie atšķiras no PIK pārkāpumu ekonomisko un sociālo seku pārvaldības, jo ietver atšķirīgus politikas instrumentus un juridiskus apsvērumus saistībā ar runas brīvību un plašsaziṇas līdzekḷu regulējumu.

Papildus semantikai kopienām, kuras pievēršas katrai digitālās drošības dimensijai (skatiet 5.3. attēls), bieži ir atšḳirīgas kultūras un konteksti, un to mērḳi var dažkārt saplūst, pārklāties vai konkurēt atkarībā no konteksta un konkrētā jautājuma. Kriptogrāfijas politika (ESAO, 1998. gads) ir tipisks piemērs par konkurējošiem mērķiem, kad uzṇēmumi, organizācijas un patērētāji sekmē neregulētu kriptogrāfijas izmantošanu, lai veicinātu uzticamību un atbalstītu e-komerciju, digitālās valdības un inovācijas tiešsaistē, kamēr tiesībaizsardzības un informācijas aǵentūras atbalsta regulējumu, kas atvieglo piekḷuvi šifrētajiem datiem, lai cīnītos pret kriminālnoziedzniekiem un terorismu. 


\section{3. attēls. "Kiberdrošības" četras dimensijas}

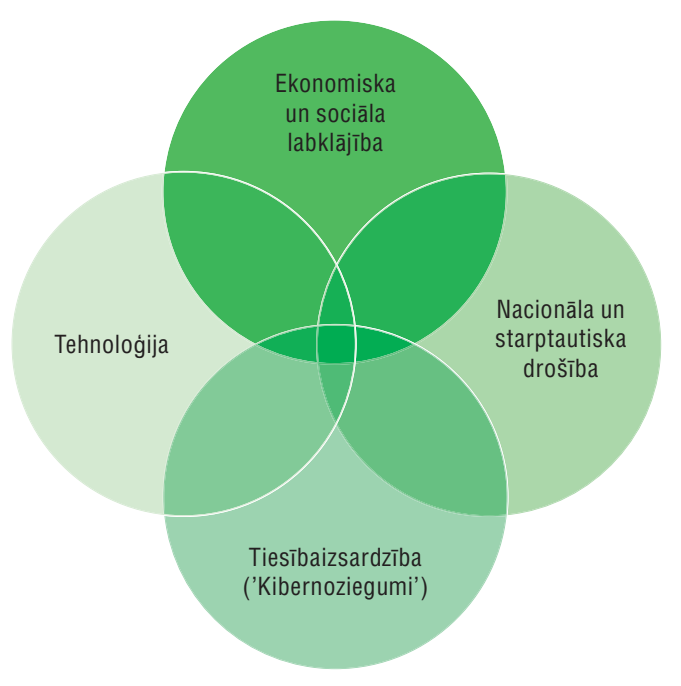

Latvijas politikas dokumentos jēdzieni "kiberdrošība", "IT drošība" un "informācijas drošība" škietami norāda uz kādu no šìm definīcijām (atkarībā no konteksta):

- tehnisko līdzekḷu, piemēram, tỉklu, IKT un datu aizsardzỉba (5.3. attēls aspekts "Tehnoloǵija");

- ar tādas IKT izmantošanas saistīto risku pārvaldība, kas nekoncentrējas uz ekonomiskām un sociālām aktivitātēm, bet tā vietā aizskar jautājumus, kas attiecas uz nacionālo drošību ietekmi uz stratēgijiām demokrātiskās vēlēšanās un kaitīgu saturu (5.3. attēls aspekti "Nacionālā drošība" un “Tiesibaizsardziba").

Piemēram, Latuijas kiberdrošības stratēǵijā (2014-2018) kiberdrošība ir definēta kā "instrumentu, politikas, drošības konceptu un vadlīniju, risku vadības, rīcības, apmācības, pieredzes un tehnoloǵiju kopums, kuru var izmantot elektroniskās vides, tās organizācijas un lietotāju aktīvu aizsardzībai”. Savukārt Latvijas kiberdrošỉbas stratēgija (2019-2022) balstās uz to, ka "Kiberdrošības politikas vīzija ir droša, atvērta, brīva un uzticama kibertelpa, kurā ir garantēta valstij un sabiedrībai būtisku pakalpojumu droša, uzticama un nepārtraukta saņemšana un sniegšana un indivīda cilvēktiesības tiek ievērotas kā fiziskajā, tā virtuālajā vidē". Turklāt šajā dokumentā tiek atzīts, ka "Latvijai ir jāizmanto digitālās vides priekšrocības, lai nodrošinātu ekonomisko un sociālo labklājỉbu, vienlaikus samazinot kiberdrošìbas risku vispārējo līmeni, nevajadzīgi neierobežojot tehnolog̣iju, sakaru un datu plūsmu".

Šìs izmaiņas ir pozitīva attīstība, kur Latvijas valdība šobrīd atzīst, ka digitālā drošība ietekmē citus digitālās ekonomikas aspektus (atvērtību, brīvību), kas liecina, ka ir pamatota uz risku balstīta pieeja un ka ir nepieciešami kompromisi. Stratēǵija atzīst arī kiberfizisko sistēmu parādīšanos, kas virtuālo (jeb "kibertelpas") / fizisko divdalījumu padara mazāk nozīmīgu, jo arvien vairāk ekonomisko un sociālo aktivitāšu "kḷūst digitālas". Kopumā šì semantiskā evolūcija atspoguḷo dziḷākas izmaiṇas veidā, kā Latvija uztver digitālo drošību, atzīstot to kā digitālās transformācijas instrumentu, nevis autonomu elementu.

\section{Pārvaldība}

\section{Digitālās drošības politikas vispārējā pārvaldības struktūra Latvijā}

Kopš 2013. gada AM ir koordinējusi digitālās drošības politikas attīstību un îstenošanu, iesaistot daudzas Latvijas valdības ministrijas. ${ }^{3}$

Lai koordinētu ar informācijas tehnoloǵiju drošǐbu saistītās politikas izstrādi, kā arī attiecīgu uzdevumu un pasākumu plānošanu un īstenošanu, tika izveidota NITDP. NITDP vada AM, parasti valsts sekretāra līmenī. Tā tiekas vismaz vienreiz četros mēnešos un sapulcina pārstāvjus no dažādām institūcijām, tostarp ministrijām un tiesībsargājošajām institūcijām. Citas ieinteresētās puses ir uzaicinātas dalībai uz ad-hoc bāzes, ${ }^{4}$ jo NITDP galvenā funkcija ir koordinēt ar informācijas tehnoloǵiju drošību saistītās politikas izstrādi. 5.4. attēls ir vizuāli attēlota digitālās drošības valdības struktūra Latvijā (2019. g.). 


\section{4. attēls. Digitālās drošības vadības struktūra Latvijā (2019.-2022. g.)}

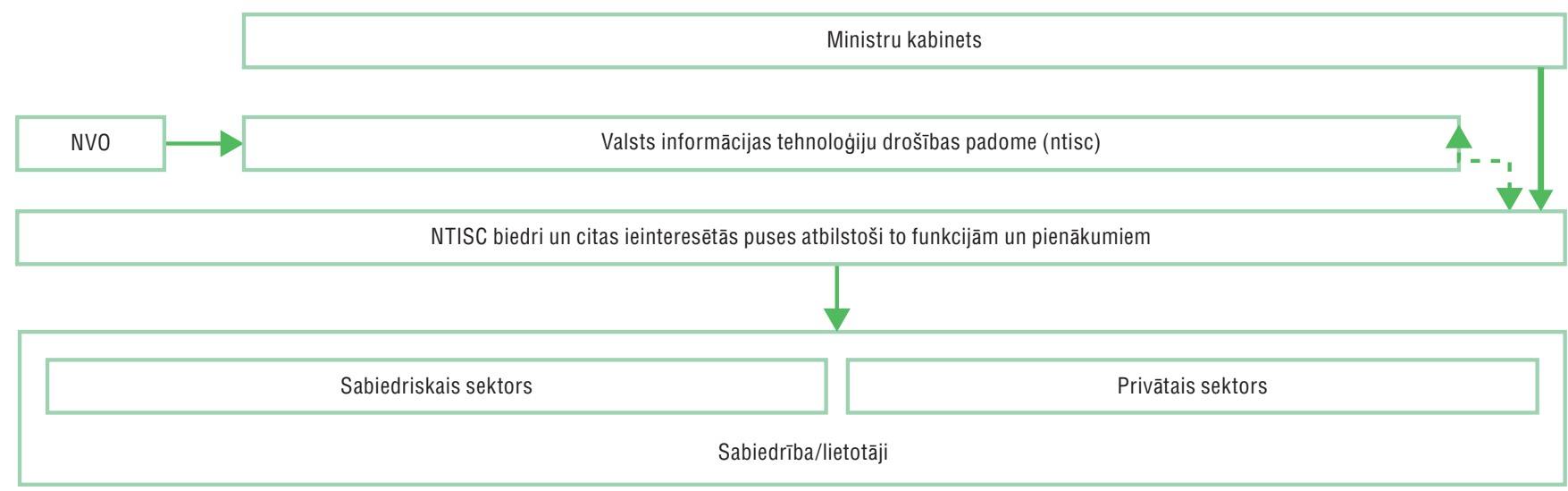

Piezime: NVO = Nevalstiska organizācija.

Avots: AM (2019), Latuijas kiberdrošỉbas stratēǵija (2019.-2022. g.) [Cyber Security Strategy of Latvia (2019-2022)], https://www.mod.gou.lv/sites/mod/files/ document/kiberstrategija.pdf.

NITDP nav piešķirts atsevišķs budžets, un administratīvo atbalstu nodrošina AM. AM Nacionālās kiberdrošības politikas koordinācijas nodaḷa (NKPKN) nodrošina NITDP atbalstu sekretariāta vārdā. Turklāt AM nodrošina Elektroniskās identifikācijas uzraudzības komitejas darbu.

Ārlietu ministrija (ĀM) ko-ordinē ar digitālo drošǐbu saistīto starptautisko sadarbību ar AM iesaistī̌̌anos digitālās drošǐbas jautājumos, kas ir saistīti ar NATO un ES.

Vides aizsardzības un regionālās attīstības ministrija (VARAM) ir atbildīga par valsts informācijas sistēmām un koordinē sabiedrisko pakalpojumu digitalizāciju. Valsts reǵionālās attīstības aǵentūra (VRAA) nodrošina valsts IKT koplietošanas risinājumu darbību un izstrādi, ieskaitot valsts eID un digitālā paraksta platformu, valsts eIDAS vārteju, publisko iepirkumu sistēmu un sabiedrisko pakalpojumu portālu "Latvija.lv", kā arī e-adreses oficiālo risinājumu. Turklāt VARAM vada arī digitālās un informācijas sabiedrības politikas vispārējo attīstību, un VARAM valsts sekretāra vietnieks ir NITDP priekšsēdētāja vietnieks.

Iekšlietu ministrija (IeM) un Valsts policija (VP) ìsteno tiesību aktu ieviešanas politikas, lai apkarotu kibernoziegumus.

CERT.LV nodrošina atbalstu valsts iestādēm, atklājot digitālās drošības incidentus. CERT.LV atbild arī par reaǵēšanu digitālās drošības incidentu gadỉjumā, iekḷaujot krīzes pārvaldību. Tā uzrauga un analizē attīstību digitālās drošības jomā, veido statistiku par incidentiem un reaǵē uz tiem, kā arī koordinē to novēršanu, veic izpēti, organizē izglìtības pasākumus un apmācību, kā arī uzrauga likumā norādīto saistību ieviešanu attiecībā uz Informācijas tehnoloǵiju drošǐbu. Papildus savai primārajai misijai, atbalstīt publiskā sektora institūcijas, CERT.LV atbalsta arī uzṇēmējus un fiziskas personas. CERT.LV budžets pēdējo gadu laikā ir ievērojami pieaudzis no apmēram 120000 EUR 2011. gadā līdz 882000 EUR 2015. gadā un 1328000 EUR 2019. gadā, atspoguḷojot Latvijas valdības apṇemšanos paaugstināt digitālās drošìbas spējas.

Satversmes aizsardzības birojs (SAB), valsts izlūkošanas un drošības aǵentūra uzrauga kritisko infrastruktūru aizsardzību. Turklāt SAB aktīvi iesaistās sadarbības iniciatīvās starp Baltijas valstīm un Amerikas Savienotajām Valstīm, nodrošinot kompetenci un vadību enerğētikas kritiskās infrastruktūras jomā. SAB un CERT.LV strādā kopā, lai pārbaudītu informācijas tehnolog̣iju kritisko infrastruktūru noturību un sniegtu norādes šādu infrastruktūru publiskajiem un privātajiem operatoriem.

Labklājỉbas ministrija (LM) ìsteno sociālo politiku, kā arī politiku bērnu aizsardzībai tiešsaistē.

Valsts akciju sabiedrība Latvijas Valsts radio un televīzijas centrs (LVRTC) ir vienīgais kvalificētu uzticamības pakalpojumu (piemēram, elektronisko parakstu, zīmogu un identifikācijas formu) nodrošinātājs. 
Nacionālie bruṇotie spēki (NBS) un Zemessardzes Kiberaizsardzības vienība (ZS KbrAV) nodrošina atbalstu krī̌̌u gadijjumos. Kaut arī NBS galvenais uzdevums ir militāro informācijas tehnoloǵiju un sakaru sistēmu un tīklu attīstīšana un nostiprināšana, NBS ir būtiska nozīme arī vispārējo kiberaizsardzības spēju uzlabošanā.

\section{Ceḷā uz "visu valdības struktūru" un vairāku ieinteresēto pušu pieeju}

Lai digitālās drošības stratēgijas būtu sekmīgas, nepieciešama efektīva iesaistīšanās ar visiem attiecīgajiem dalībniekiem visā valdībā un plašākā vairāku ieinteresēto pušu kopienā (piemēram, pētnieki, uzṇēmumi un pilsoniskā sabiedrība). Kaut arī daudzaās stratēǵijaās tiek atzìts šīs divvirzienu pieejas svarīgums ("visu valdības struktūru pieejas" koordinācija un "vairāku ieinteresēto pušu" iesaistī̌ana), efektīva ieviešana var izrādīties problemātiska, jo tai ir nepieciešami atbilstoši resursi, uzticamība un reizēm pārmaiṇas kultūrā.

Pašreizējā vadības struktūra Latvijas digitālās drošǐbas politikā, kas aprakstīta iepriekšējā sadaḷā, daḷēji atbilst "visu valdỉbas struktūru" pieejai, un to var raksturot kā "daḷēji centralizētu" (AM, 2014. gads). Šìs struktūras izveide un ieviešana 2012.-2014. gadā iezīmēja pagrieziena punktu Latvijas pieejā: digitālā drošỉba vairs netika uzskatīta tikai par tīkliem atbildīgo institūciju tehnisku problēmu (Satiksmes ministrijai), bet kḷuva par publiskās politikas lietu, kurai ir nepieciešama visu valdības struktūru iesaistīšanās.

Lìdz šim šajā struktūrā Latvijas pieeju ir veidojusi valsts drošības aspektu uzsvēršana, un tas ir palīdzējis digitālās drošỉbas risku pacelt nozīmīga politikas jautājuma līmenī un līdzsvarot resursus valdībā. Piemēram, NITDP vada AM valsts sekretārs, kas savukārt uzrauga CERT.LV.

Kaut arī šì pieeja ir sniegusi nenoliedzamus ieguvumus, tai ir arī daži trūkumi. Ja pieeja digitālajai drošībai veidojas galvenokārt caur nacionālās drošības ietvaru, tas var ierobežot ieinteresēto pušu iespēju pilnībā iesaistīties un identificēt sevi ar digitālās drošības risku, jo nacionālā drošība tiek bieži saistīta ar valsts lietām. Piemēram, industrijas un pilsoniskās sabiedrības ieinteresētās puses parasti tiek aicinātas uz NITDP sanāksmēm uz ad-hoc pamata un nepiedalās stratēǵijas izstrādē un ieviešanā. Kaut arī ieinteresētās puses ir aicinātas piedalīties stratēóijas izstrādes procesā ar publiskiem komentāriem, reālā dalība parasti ir zemā līmenī. Šāda ierobežota iesaistī̌nanās var rasties ilgtermiṇa, uz uzticību balstītas un ilgtspējīgas vairāku ieinteresēto pušu partnerību trūkuma dēḷ, kas ir būtiski jēgpilnas un efektīvas dalības nodrošināšanai (ESAO, 2015. gads). Tas var būt arī nepietiekami koordinētas un strukturētas vairāku ieinteresēto pušu kopienas rezultāts. Uzmanība uz nacionālo drošību var arī ierobežot citu valdības institūciju pieeju digitālajai drošǐbai kā ekonomiskai iespējai (piemēram, pētījumiem, inovācijām, kvalificētai uzṇēmējdarbībai). Ja sadarbība ar ministrijām, kuras ir atbildīgas par ekonomikas attīstību un nozaru koordināciju, un to iesaistī̌anās ir nepietiekama, pastāv arī risks, ka šis ministrijas neattīstīs nepieciešamās tehniskās prasmes un izpratni par saistītajām problēmām, lai piedalītos digitālās drošības stratēgiijas izstrādē un ieviešanā.

Kopsavilkumā var teikt, ka pašreizējā pieeja Latvijā (5.5. attēls) ir strukturēta ap nacionālās drošības ietvaru (NITDP), kas balstās uz spēcīga tehniskā pamata (CERT.LV). Tomēr ekonomiskā un sociālā dimensija ir šķietami mazāk iesaistìta, un politika parasti tiek îstenota caur tehnisku (izmantojot CERT.LV) vai nacionālās drošības objektīvu.

Vairākums valdību ir cīnijušās par atbilstīgas pārvaldības struktūras izveidošanu digitālajai drošībai, jo ir grūti sasniegt pareizo līdzsvaru starp ekonomikas un sociālajiem jautājumiem, nacionālo drošību, tiesībaizsardzību un tehniskajiem aspektiem (5.3. attēls). Nav modeḷa, kas atbilstu visiem gadijjumiem, un pārvaldības struktūras un koordinācijas mehānismi dažādās ESAO valstīs ievērojami atškiriras, atspoguḷojot valstu vēsturi, ǵeopolitisko kontekstu, vadības stilu un briedumu šajā jomā.

Daudzās ESAO valstīs digitālās drošības pārvaldības ietvara veidošanas process bieži sākas ar nacionālo drošỉbu, kibernoziegumu (piemēram, tiesību aktu par kibernoziegumiem pieṇemšanu) vai tehnoloǵisku dimensiju, koncentrējoties uz pieaugošajām tehniskās reakcijas iespējām, piemēram, veidojot Informācijas tehnologiju drošības incidentu novēršanas institūciju (CERT). Pēc tam process pakāpeniski izvēršas, iekḷaujot ekonomisko un sociālo labklājỉbu. Tomēr dažas valstis ir nonākušas pie vienošanās par to, ka uz nacionālo drošību orientētās ağentūras nav vislabākajā pozịcijā, lai izstrādātu un ieviestu ekonomikas un sociālo politiku, to pamatojot ar argumentu, ka tā nav viṇu galvenā misija; šīm aǵentūrām ir bieži vērojams caurskatāmības un vairāku ieinteresēto pušu iesaistīšanās trūkums, kas ir svarīgs, lai veidotu ilgtspējīgas partnerỉbas uz uzticamỉbas pamata. 


\section{5. attēls. Digitālās drošības politika Latvijā}

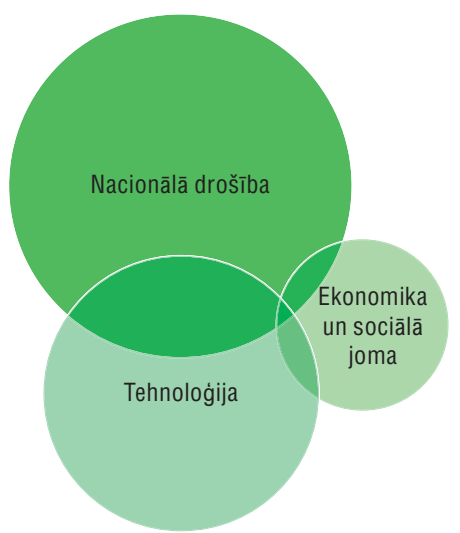

Piezìme: Šajā attēlā ir parādīts līmenis, kādā valdība pievērš uzmanību trim no četriem digitālās drošības struktūras komponentiem (kā redzams 5.3. attēls). Latvijas pašreizējā struktūrā iekḷautā krimināllikuma ìstenošana nav parādīta, jo tā neietilpst šī pārskata ietvaros.

Lai visiem kiberdrošības aspektiem pievērstos nevis fragmentēti, bet holistiski, digitālās drošības stratēóijas ir jāatbalsta augstākajā valdības līmenī (piemēram, valsts va dītājam vai valdỉbas vadītājam) un jāizveido jauni pārvaldības un koordinācijas mehānismi, lai nodrošinātu līdzsvaru starp papildu un reizēm konkurējošiem mērk̦iem dažādās dimensijās (ESAO, 2015. gads). Tomēr katrai valstij ir jāpien,em savai kultūrai un valdības stilam pielāgots pārvaldības modelis.

Piemēram, Austrālijā,Japānā un Apvienotajā Karalistē politikas koordinācija ir uzticēta premjerministram caur Ministru kabineta biroju. Francija ir izveidojusi nacionālo koordinācijas aǵentūru iepriekš pastāvošajā koordinācijas organizācijā, ko pārvalda premjerministrs (ANSSI). Amerikas Savienotās Valstis ir izveidojušas "Kiberdrošības un infrastruktūras drošības aǵentūru" (CISA) Valsts drošības departamentā. Kanādā, Vācijā un Nīderlandē galvenā atbildība par digitālo drošību ir uzticēta esošai ministrijai (attiecīgi Sabiedriskās drošības, Iekšlietu, Drošības un Tieslietu ministrijām). Izraēla ir izveidojusi valsts ağentūru, kas atskaitās tieši premjerministram (INCD).

Dānijā atbildība par digitālās drošības stratēgijas vispārējo koordināciju ir sadalīta starp Digitalizācijas aǵentūru (FM ietvaros) un Kiberdrošības centru (AM). Aǵentūra ir atbildīga par digitālo drošību sabiedriskajā sektorā, kā arī par daudzām uz pilsoniem vērstām iniciatīvām. Centrs konsultē valsts iestādes un privātuzṇēmumus, kas atbalsta kritiskās aktivitātes. Aǵentūra vadīja darba grupu, kura izstrādāja digitālās drošības stratēgeiju.

Igaunijā Ekonomikas lietu ministrija ir atbildīga par digitālās drošības politikas izstrādes un ieviešanas koordinēšanu (5.6. attēls). Arī citas ministrijas (piemēram, Aizsardzības, Izglìtības un pētniecības, Iekšlietu, Tieslietu) ir pilnībā iesaistījušās savā kompetences jomā.

Visos šajos gadījumos pastāv arī dažādas vienošanās par to, kā konkrēti jāveic vairāku ieinteresēto pušu koordinācija un kur ir valdības operacionālais potenciāls. Tas aptver diapazonu no politikas koordinācijas ağentūras (Francija, Izraēla) līdz pievienotajai apakšstruktūrai vai ziṇojumiem ministrijai (Vācija, Nīderlande) vai atsevišķai struktūrai (AK Nacionālais kiberdrošības centrs). Turklāt politikas, kas sekmē kritisko aktivitāšu un infrastruktūras digitālo drošību, rada nepieciešamību iesaistīt nozaru regulatorus (piemēram, telekomunikāciju, veselības, finanšu, transporta un enerǵētikas nozarēs ) , lai nodrošinātu to, ka saistītajā digitālās drošības regulējumā tiek ṇemti vērā esošie tirgus un normatīvie ierobežojumi.

Daudzās ESAO valstīs ir sāktas uz ekonomiku orientētas un vairāku ieinteresēto pušu virzītas iniciatīvas. Valdības ir atbalstījušas nozaru specifiskās partnerības, kuru mērkisis ir informācijas un labākās pieredzes apmaiṇa digitālās drošības izaicinājumu jomā, piemēram, caur Informācijas apmaiṇas un analīzes centriem (ISAC). Kā vēl vienu labu pieredzi var minēt partnerības uzsākšanu ar interneta pakalpojumu sniedzējiem (ISP) un citām ieinteresētajām pusēm, lai atklātu un iztīintu inficētās savienotās ierīces. Piemēram, Nīderlandes valdība ir veikusi darbības, lai uzraudzītu un uzlabotu savienoto ierīču digitālo drošību, ar publiskas-privātas partnerības starpniecību, kas iekḷauj ISP, Ekonomikas lietu ministriju 
un Delftas universitāti. Šīs iniciatīvas mērḳis ir informācijas apmaiṇa starp ražotājiem/pārdevējiem un gala lietotājiem, lai produktu izplatītājus mudinātu apsvērt ietekmēto produktu izṇemšanu no pārdošanas un stimulētu patērētājus uzstādìt drošības atjauninājumus vai deaktivizēt produktus kritiskas ievainojamības atklāšanas gadījumā.

\section{6. attēls. Digitālās drošības pārvaldības struktūra Igaunijā}

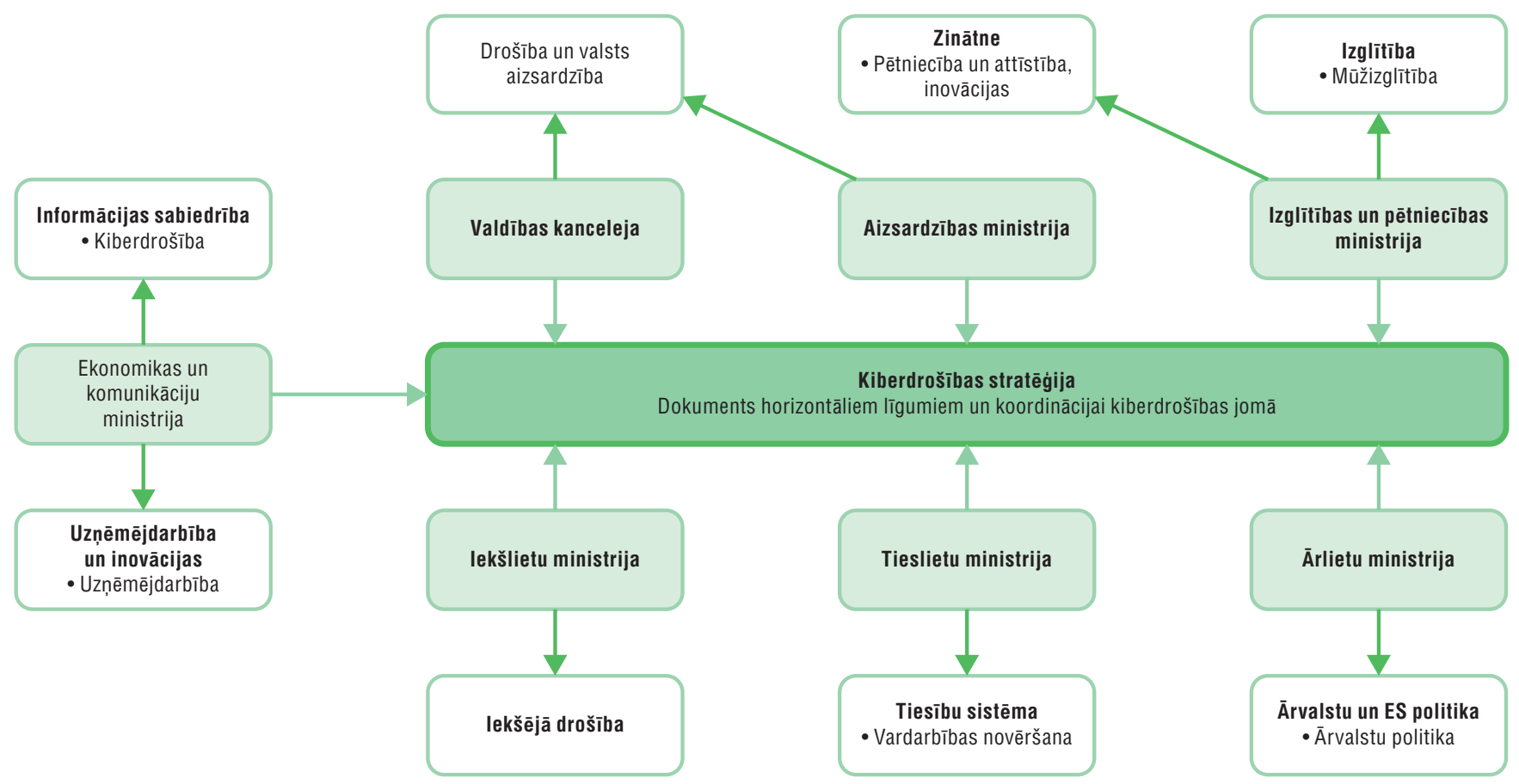

Avots: ELKM (2019), Cyber Security Strategy of Estonia (2019-2022), www.mkm.ee/sites/default/files/kyberturvalisuse_strateegia_2022_eng.pdf.

Latvijā pašreizējā vadības struktūra norāda uz vēlmi veidot sasaisti ar vairāku ieinteresēto pušu kopienu, kaut lai gan varētu uzlabot līdzekḷus to efektīvai līdzdalībai. Lai arī NITDP ir aprakstīta Kiberdrošỉbas stratégijā kā "centrālā nacionālā institūcija valsts un privātā sektora informācijas apmaiṇai un sadarbībai", škiet, ka nevalstiskās ieinteresētās grupas (gan no privātā sektora, gan arī no pilsoniskās sabiedrības) tiek uzaicinātas dalībai tikai ad-hoc gadījumos. Tās nesniedz pilnu ieguldījumu stratēǵijas izstrādē un ieviešanā, kaut arī tiek aicinātas to darīt publisko komentāru. Tas var norādìt uz vairāku ieinteresēto pušu kopienas nepietiekamu strukturizāciju pienācīgai dalībai digitālās drošības politikas veidošanā. Turklāt NITDP tiekas tikai ik reizi četros mēnešos un galvenokārt ir kā kanāls jautājumu pārrunāšanai valdībā, nevis elastīgs un uzṇēmējdarbībai vai pilsoniskajai sabiedrïbai draudzīgs forums. Tas arī daḷēji var izskaidrot, kāpēc uzṇēmumu vadītāji Latvijā ne vienmēr uzskata digitālo drošību par savu prioritāti, jo valdības struktūrā tā galvenokārt ir pasniegta kā nacionālās drošības jautājums.

Visbeidzot dažādos politiku dokumentos NITDP ir raksturota kā "konsultējoša" organizācija, "koordinācijas" platforma, varas iestāde, kas uzrauga kiberdrošības stratēgijas "īstenošanu", un organizācija, kas atbild par digitālās drošības politikas îstenošanas novērtēšanu. Pārvaldības struktūra skaidri neatdala digitālās drošības stratēóijas plānošanas, konsultāciju, īstenošanas un novērtēšanas funkcijas, jo šķiet, ka NITDP AM vadībā veic visas šīs funkcijas. Tas var izraisīt ierobežotu ārējo uzraudzību un vērtīgu atsauksmju trūkumu, kas laika gaitā kavētu stratēgijas uzlabošanu.

\section{Tiesiskais regulejjums}

Digitālās drošības galvenais tiesiskais regulējums ir Informācijas tehnologiju drošības likums, kas tika pien,emts 2010. gadā un kopš tā laika ir vairākkārt grozìts. Likums attiecas uz valsts un pašvaldību institūcijām, informācijas tehnoloǵiju kritiskās infrastruktūras (ITKI) operatoriem, svarīgāko pakalpojumu operatoriem un digitālo pakalpojumu nodrošinātājiem, kā arī elektronisko sakaru nodrošinātājiem. Tajā ir norādītas svarīgākās organizācijas un to pienākumi digitālās drošìbas jomā (piemēram, NITDP un CERT.LV). 
Valsts informācijas sistēmu likums, kas tika pieṇemts 2002. gadā un grozīts 2014. gadā, attiecas uz tīkliem, kurus izmanto un uztur valsts iestādes. Viens no tā nosacỉjumiem ir vienotās procedūras, pēc kurām tiek izveidotas, registrētas, uzturētas, izmantotas, reorganizētas vai atmestas nacionālās informācijas sistēmas, un tas nosaka to digitālās drošības pārvaldību.

Citi svarīgi normatīvie akti:

- Ministru kabineta noteikumi Nr. 422: "Kārtība, kādā tiek nodrošināta informācijas un komunikācijas tehnolog̣iju sistēmu atbilstỉba minimālajām drošības prasībām" (2015. gads, atjaunināti 2017. un 2019. gadā), kuru mērḳis ir saskaṇoti un augstāki drošības līmeṇi IKT sistēmās valsts un pašvaldību iestādēs.

- Ministru kabineta noteikumi Nr. 764: "Valsts informācijas sistēmu vispārējās tehniskās prasības" (2005. gads, jaunākie grozījumi 2009. gadā)

- Ministru kabineta noteikumi Nr. 496: "Kritiskās infrastruktūras, tajā skaitā Eiropas kritiskās infrastruktūras, apzināšanas un drošības pasākumu plānošanas un îstenošanas kārtība" (2010. gads, pèc tam grozīti)

- Ministru kabineta noteikumi Nr. 100: "Informācijas tehnoloǵiju kritiskās infrastruktūras drošības pasākumu plānošanas un īstenošanas kārtība" (2011. gads).

Latvijas institūcijas acìmredzot nav vēl veikušas esošo digitālās drošības jomas likumu un noteikumu un to īstenošanas pilnīgu auditu.

\section{Jaunākās iniciatīvas}

\section{Informācijas sabiedrības attīstības pamatnostādnes (2014.-2020. g.)}

Informācijas sabiedrības attīstības pamatnostādnes (2014.-2020. g.) ir kā Latvijas nacionālā digitālā stratēǵija. To galvenais mērḳis: "nodrošinot iespēju ikvienam izmantot IKT sniegtās iespējas, veidot uz zināšanām balstītu ekonomiku un uzlabot kopējo dzīves kvalitāti, sniedzot ieguldījumu publiskās pārvaldes efektivitātes, valsts konkurētspējas, ekonomiskās izaugsmes paaugstināšanā un darbavietu radišanā". Tomēr pamatnostādnes galvenokārt koncentrējas uz IKT piekḷuves un izmantošanas uzlabojumiem, kā arī e-valdības pakalpojumiem, piemēram, tiešsaistes identitāti un valsts IKT.

Pamatnostādṇu darbības virziens 5.7 ir saistīts ar "Uzticēšanos un drošìbu", bet īpaši (sadaḷā 5.7.1) ar "IKT drošību", konkrēti uzsverot iespēju veidošanu.

Kopumā Pamatnostādnes šķiet ierobežotas attiecībā uz sasaisti ar citiem digitālās drošības politikai nozīmīgiem politikas dokumentiem (piemēram, Kiberdrošības stratēgiju), norādot, ka digitālā drošỉba Latvijā tiek galvenokārt uzskatīta par nacionālās drošības jautājumu. Šì uztvere nav raksturīga tikai Latvijai. Daudzās ESAO valstīs dažādi digitālo stratēǵiju pamatelementi darbojas izkaisīti ar nelielu koordināciju vertikālajos laukos.

\section{Kiberdrošības stratēǵija}

Galvenā digitālās drošības politikas iniciatīva Latvijā ir Latvijas kiberdrošības stratēéija (2019.2022. gadam), kas aizstāj Latvijas kiberdrošības stratēóiju (2014-2018. gadam).

Iepriekšējās stratēǵijas visaptverošais mērḳis bija sasniegt "drošu un uzticamu kibertelpu, kurā ir garantēta valstij un sabiedrībai būtisku pakalpojumu droša, uzticama un nepārtraukta san,emšana". Šì stratēgija attiecās uz valdību, ieskaitot valsts un pašvaldību administrācijas, privāto sektoru un fiziskas personas. Tās pamatā bija četri principi (attīstība, sadarbība, atbildỉba un atvērtība) un pieci prioritāri rīcības virzieni:

- kiberdrošības pārvaldība un resursi;

- tiesiskums kibertelpā un kibernoziedzības mazināšana;

- gatavỉba un rīcībspēja krīzes situācijās;

- sabiedrïbas izpratne, izglìtiba un pētnieciba;

- starptautiskā sadarbība. 
Jaunā stratēǵija (2019.-2022. gadam), šḳiet, nedaudz atšḳiras, atspoguḷojot dažu pēdējo gadu laikā gūtās mācības. Kaut arī tās vīzija sākas tādā pašā veidā (sasniedzamais mērkịis ir "droša, atvērta, brīva un uzticama kibertelpa, kurā ir garantēta valstij un sabiedrībai būtisku pakalpojumu droša, uzticama un nepārtraukta saṇemšana un sniegšana"), tiek ṇemta vērā arī nepieciešamība, ka "indivīda cilvēktiesības tiek ievērotas kā fiziskajā, tā virtuālajā vidē". Tā ir pozitīva attīstība, kas atzīst konkurējošos mērķus, kuri bieži ir dienaskārtībā, izstrādājot digitālās drošības politiku (piemēram, privātums un valsts drošība). Jaunajā stratēǵijā tiek atzīta arī kiberfizisko sistēmu attīstība un nepieciešamība virzīties tālāk par virtuāli-fizisko divdalījumu.

Kas attiecas uz prioritārajiem rīcības virzieniem, tad pēdējie četri būtībā ir tādi paši, izṇemot "rīcībspēja krīzes situācijā", kas ir aizstāta ar šo: "IKT izturētspēja, sabiedrībai kritiski svarīgu IKT un pakalpojumu nodrošināšanas stiprināšana". Pirmais rīcības virziens no "pārvaldỉbas" ir izaudzis līdz šim: "kiberdrošības veicināšana, digitālās drošības risku mazināšana". Tas šḳietami norāda, ka digitālās drošības pārvaldības struktūras veidošanas process Latvijā, kas bija sākotnējās stratēgijas pirmais mērḳis, tagad ir vismaz daḷēji sasniegts, un izaicinājums Latvijas varas iestādēm izmantot šo esošo struktūru, lai visas ieinteresētās puses pilnībā iesaistītu digitālās drošības riska pārvaldībā. Tas ir pozitīvs solis un norāda, ka Latvijas varas iestādes ir atzinušas nepieciešamību iziet ārpus "visu valdības struktūru" pieejas uz "visaptverošas sabiedrības" pieeju, kas it ìpaši iekḷauj ekonomiskajā un sociālajā labklājībā iesaistìtos dalībniekus un kopienas. Šìs izmainas satur arī risku pārvaldības pieejas integrāciju. Faktiski jaunā stratēǵija atzīst, ka IKT "nav absolūti drošas un var tikt pakḷautas uzbrukumiem. Uzbrukuma draudus IKT nevar pilnībā novērst, bet uzbrukuma risku var ievērojami mazināt, lai netraucētu sabiedrỉbas ekonomisko un sociālo attīstību, nenodarītu zaudējumus ekonomikai un gūtu labumu no IKT gan valsts pārvaldē, gan privātajā sektorā".

Tomēr šĩs jaunās Kiberdrošǐbas stratēéijas pozitīvās izmainas joprojām ir jāievieš praksē. Latvijas valdībai viens no izaicinājumiem būs iesaistīt visas attiecīgās ieinteresētās puses iesaistī̌ana un pievērsties digitālās drošības riskiem visā ekonomikā, iesaistot vadošās institūcijas, kuru galvenā auditorija ir vai nu IT komandas (CERT.LV), vai militāristi (AM). Lai gūtu panākumus, var būt nepieciešamas kultūras pārmaiṇas, kā arī dzị̂āka iesaistīšanās un/vai atbalsts no citu institūciju, piemēram, VARAM, Ekonomikas ministrijas (EM) vai premjerministra, puses, kuru darbības joma pēc būtībasir vairāk horizontāla.

\section{Citas iniciatīuas}

Latvijas valdība ir organizējusi citas iniciatīvas digitālās drošības jomā, piemēram, "drošāka interneta dienu", "e-prasmju nedēḷu" un "kiberdrošības mēnesi", kura mērk̦is ir uzlabot informētību un dalīties labajā praksē. Turklāt digitālās drošỉbas krīzes vingrinājumi tiek veikti ar valsts iestādēm CERT.LV un AM vadībā atbilstoši stratēéijai.

CERT.LV ir rādījusi piemēru, publicējot savu ievainojamību atklāšanas politiku. CERT.LV pieṇem ziṇojumus par ievainojamību saviem resursiem, kā arī jebkurai citai organizācijai Latvijā. Pēdējā gadījumā CERT.LV rīkojas kā koordinators iesaistīto pušu starpā (piemēram, starp drošìbas pētniekiem un organizācijām).

CERT.LV nodrošina arī apmācību un informāciju par digitālās drošības riskiem IT profesionāḷiem un sabiedrībai. Piemēram, tas publicē regulāru informāciju par tiešsaistes vīrusiem un apdraudējumiem caur savu IT drošǐbas portālu Esi Drošs. Portālā katra apmeklētāja IP adrese tiek pārbaudīta, salīdzinot ar inficēto IP adrešu datubāzi, un apmeklētāji san̦em informāciju par jebkuru ievainojamību vai infekciju saskaņā ar CERT.LV datiem. CERT.LV ir iesaistīts arī specifisku profesionālo grupu izglītošanā, ieskaitot par IT drošǐbu atbildīgās amatpersonas, darbiniekus, pārvaldniekus, studentus un skolēnus. 2012. gadā CERT.LV sāka iniciatīvu "Atbildīgs interneta pakalpojumu sniedzējs (ISP)", piešḳirot kvalitātes mark̦ējumu ISP, kuri sadarbojas ar komandu. Šãda sadarbỉba iekḷauj incidentu informācijas nodrošināšanu gala lietotājiem, sadarbỉbu ar Latvijas Interneta asociācijas Drošāka interneta centru, lai izṇemtu no interneta nelikumīgu materiālu, un interneta satura filtra nodrošināšanu, ko pēc pieprasījuma var uzstādīt bez maksas. Pašlaik Latvijā ir 13 "atbildīgi ISP", kas aptver aptuveni 77 \% no Latvijas interneta piekḷuves tirgus.

Turklāt CERT.LV organizē izglītỉbas pasākumus, piemēram, "Kiberšahs", un citas zināšanu apmainas aktivitātes. Šie pasākumi piesaista privātā sektora pārstāvjus digitālās drošības vingrinājumiem (piemēram un Locked Shields), kur viṇiem ir jāveic dažādi uzdevumi kopā ar kolēgiem no publiskā sektora. 
Zemessardzes Kiberaizsardzības vienība (ZS KbrAV) apvieno ekspertus, kuri ir ieinteresēti regulāras sadarbības attīstībā digitālās drošības jautājumos, uzlabojot kompetenci un zināšanas valsts un starptautiskā līmenī, kā arī piedaloties un organizējot apmācību digitālās drošības uzbrukumu novēršanai un sniedzot atbalstu sabiedriskajām organizācijām (ja tas ir atbilstoši). ZS KbrAV galvenais mērḳis ir sniegt atbalstu informācijas tehnolog̣iju drošỉbas incidentu reaǵēšanas vienībām, lai novērstu digitālās drošības incidentus un reaǵētu uz tiem, kā arī mazinātu to sekas.

AM sadarbojas ar LIKTA (Latvijas Informācijas un komunikācijas tehnoloǵijas asociācija), kurā ir 160 biedru, lai organizētu, piemēram, gada balvas pasniegšanu par "Labāko kiberdrošības iniciatīvu".

Latvijas Drošǐbas un aizsardzỉbas industriju federācija (DAIF Latvija) pārstāv Latvijas drošǐbas un aizsardzỉbas nozari. Valsts līmenī organizācija aktīvi sadarbojas ar Aizsardzības ministriju, Iekšlietu ministriju, Ārlietu ministriju, Ekonomikas ministriju un Saeimu. DAIF Latvija ir izveidojusi Latvijas Drošibas un aizsardzỉbas klasteri, ko veido mazi un vidēji uzṇēmumi un pētniecỉbas iestādes, ES projekta ietvaros.

\section{Starptautiskā sadarbība}

Latvija ir izveidojusi ciešu trīspusēju sadarbỉbu ar kaimiṇvalstīm Igauniju un Lietuvu. Trīs valstu politị̧i regulāri (vismaz divreiz gadā) tiekas, lai paplašinātu esošo koordināciju, veiktu informācijas apmaiṇu par jaunākajām digitālās drošības tendencēm un — dažos gadījumos - koordinētu kopējo pozīciju par digitālās drošības jautājumiem starptautiskās diskusijās. Praktiskā līmenī CERT.LV sadarbojas ar Lietuvas un Igaunijas CERT komandām, veicot informācijas apmaiṇu par jaunākajiem drošības apdraudējumiem, vīrusiem un citiem riskiem un regulāri tiekoties dažādos forumos. 2015. gadā Igaunijas, Latvijas un Lietuvas Aizsardzības ministrijas oficiāli parakstīja Saprašanās memorandu par sadarbību kiberdrošǐbas jautājumos. Tomēr šḳiet, ka Baltijas valstu Ekonomikas lietu ministrijām, pietrūkst sadarbības digitālās drošības jautājumos, kaut arī Igaunijas Ekonomikas lietu ministrija ir digitālās drošības politikas vispārējais koordinators Igaunijā (5.6).

CERT.LV vadītāja bija Eiropas CSIRT foruma (TF-CSIRT) priekšsēdētāja no 2014. līdz 2019. gadam. Šajā amatā viņa atbalstīja Eiropas CSIRT kopienas izaugsmi un attīstību, sekmēja sadarbību digitālās drošības jomā starp akadēmiskajām institūcijām, valdību un sabiedrisko, kā arī sekmīgi pārstāvēja Eiropas CSIRT kopienu dažādos starptautiskos forumos.

Latvija piedalās vairākos starptautiskos apmācības pasākumos un praktiskos vingrinājumos. Kā piemēru var minēt trīs mācības "Cyber Europe", kuras organizē Eiropas Savienības Kiberdrošības aǵentūras (ENISA).

Latvija iesaistās arī NATO, ES, EDSO un ANO darbā. Tā ir ratificējusi Eiropas Padomes Konvenciju par kibernoziegumiem un tās Papildu protokolu par rasisma un ksenofobijas noziedzīgajiem nodarijjumiem, kas tiek izdarīit datorsistēmās. Turklāt Latvija aktīvi atbalsta dzị̣āku sadarbību starp ZiemeḷvalstīmBaltijas valstīm, Poliju un Amerikas Savienotajām Valstīm.

\section{Secinājumi un politikas ieteikumi}

\section{Latvijai jāturpina balstīties uz 2015. gada ESAO rekomendāciju par digitālās drošības risku pārvaldību ekonomiskai un sociālai labkläjībai}

ESAO 2015. gada rekomendācija par OECD digitālās drošỉbas risku iekḷauj astoṇus principus, kas rezumē "digitālās drošības riska pārvaldības" pieeju (5.1. ielikums), pamatojoties uz izpratni, ka digitālā drošība ir ekonomiska un sociāla prioritāte, kā arī tehnisks vai nacionālās drošības jautājums. Tas nozīmē, ka:

- Digitālās drošības visaptverošs mērķis ir palielināt ekonomisko un sociālo aktivitāšu panākumu iespējamību: digitālajai drošībai ir jābūt labklājības nodrošinātājai, nevis jāaprobežojas ar sevi.

- Organizācijas nevar pilnībā novērst digitālās drošǐbas risku, bet var novērtēt un samazināt riskus līdz pien,emamam līmenim aktuālo ekonomikas un sociālo mērḳu kontekstā.

- Digitālās drošības pasākumi sabiedriskās un privātās organizācijās var negatīvi ietekmēt ekonomiskās un sociālās aktivitātes, kuru aizsardzībai tie ir paredzēti. Lai izvairītos no šīs situācijas, sabiedrisko un privāto organizāciju vadītājiem un lēmumu pieṇēmējiem ir jāintegrē digitālās drošỉbas risku pārvaldỉba savos uzṇēmējdarbības lēmumu pien,emšanas procesos, nevis jāuztic tehniskajiem speciālistiem. 
Organizāciju vadìtājiem un lēmumu pieṇēmējiem ir tandēmā jāpārvalda ekonomiskās iespējas un drošības riski, kas izriet no digitālo tehnoloǵiju izmantošanas.

\section{1. ielikums. ESAO rekomendācijas par digitālās drošības risku pārvaldību ekonomiskai un sociālai labklājībai principi}

\section{Vispārīgie principi}

1. Informētỉba, prasmes un iespēju paplašināšana. Visām ieinteresētajām pusēm ir jāizprot digitālās drošỉbas risks un tā pārvaldības veids.

2. Atbildība:Visām ieinteresētajām pusēm ir jāuzṇemas atbildỉba par digitālās drošǐbas riska pārvaldỉbu.

3. Cilvēktiesības un pamatuērtības. Visām ieinteresētajām pusēm ir jāpārvalda digitālās drošỉbas risks caurskatāmi, kā arī konsekventi ievērojot cilvēktiesības un pamatvērtības.

4. Sadarbība. Visām ieinteresētajām pusēm ir jāsadarbojas, tostarp pāri robežām.

\section{Darbibas principi}

1. Risku novērtējums un apstrādes cikls. Vadītājiem un lēmumu pien,ēmējiem ir jānodrošina digitālās drošības riska izskatǐšana uz pastāvīgas risku izvērtēšanas pamata.

2. Drošības pasākumi. Vadītājiem un lēmumu pieṇēmējiem ir jānodrošina, lai drošǐbas pasākumi būtu piemēroti un atbilstoši riskam.

3. Inovācijas. Vadītājiem un lēmumu pieṇēmējiem ir jānodrošina inovāciju izskatīšana.

4. Gatavība un nepārtrauktība. Vadītājiem un lēmumu pieṇēmējiem ir jānodrošina gatavības un nepārtrauktỉbas plāna pieṇemšana.

Avots: ESAO (2015. g.), Digital Security Risk Management for Economic and Social Prosperity, www.oecd.org/sti/ieconomy/digitalsecurity-risk-management.pdf.

Latvija ir spērusi nozīmīgus soḷus šīs Rekomendācijas īstenošanas virzienā, atzīstot digitālo drošību kā sabiedrības politikas jautājumu, kuram ir nepieciešama vadības kopēja pieeja, Latvijas kiberdrošības stratēgiijā (2014-2018) un Informācijas sabiedrības attīstības pamatnostādnēs. Turklāt Latvijas kiberdrošības stratēǵija (2019.-2022. gadam) atzīst risku pārvaldības pieejas svarīgumu un to, ka ir nepieciešami kompromisi, lai ieviestu efektīvu digitālās drošības stratēǵiju, ṇemot vērā to, ka, lai gan digitālās drošības pasākumu mērk̦is ir sekmēt uzticamību, tie var arī mazināt uzticību. Faktiski šādi pasākumi var būt pretrunā vai tikt uzskatīti pretrunā ar cilvēktiesībām un pamatvērtībām, it īpaši privātumu un vārda brīvību. Digitālā drošība un cilvēktiesības var pastiprināt vai graut viena otru atkarībā no to pārvaldības. Turklāt, kaut arī digitālās drošības pasākumu mērḳis ir aizsargāt ekonomiskās un sociālās aktivitātes, tie var tās arī kavēt, palielinot izmaksas, samazinot veiktspēju un - vissvarīgāk - samazinot digitālās vides atvērtību un dinamismu, kas ir svarīgi, lai realizētu visus digitālās transformācijas ieguvumus.

Latvijas digitālās drošìbas vadības struktūras un iniciatīvu analīze (sadaḷas 0 un 0) akcentēja ESAO rekomendācijas principu lielākās daḷas ievērošanu. Tomēr sadarbības, atbildības un inovācijas principu īstenošana joprojām ir nepilnīga. Ja digitālā drošība tiek galvenokārt uztverta kā tehnisks vai valsts drošības jautājums, tad visticamāk tiks ierobežota riska piederība un mijiedarbība starp uzṇēmumu vadītājiem un lēmumu pieṇēmējiem gan privātajā sektorā, gan pilsoniskajā sabiedrībā, un atbildīgo digitālās drošības institūciju. Turklāt mazāk ticams, ka par nacionālo drošību atbildīgās institūcijas veicinās caurskatāmību un horizontālo sadarbību, kā arī pārvaldīs ar digitālās drošības inovācijām, MVE un jaunajiem uzṇēmumiem saistītās programmas.

Vēl svarīgāk ir tas, ka Latvijas pieeja akcentē tehnoloǵiju, tiesībaizsardzību un nacionālo drošību, bet mazāk uzmanības pievērš ekonomikas un sociālajām dimensijām (5.3. attēls). Kaut arī Latuijas kiberdrošỉbas stratēǵija (2019.-2022. gadam) šķietami labāk integrē cilvēktiesības un pamatvērtības, kā arī risku novērtēšanu un darbu ar tiem, ekonomikas un sociālā perspektīva škiet nepietiekami attīstīta. Tas var ierobežot valdības un organizāciju spēju pienācīgu novērtēt riskus, uzlabot informētību un sniegt iespēju visām ieinteresētajām pusēm uzṇemties pienācīgo atbildības daḷ. It îpaši varētu attīstīt šādas jomas: programmas labākai ekonomisko faktoru stimulēšanai, lai veiktu pienācīgus drošības 
pasākumus (piemēram, sertifikāciju, vairāku ieinteresēto pušu partnerības); nozaru un starpnozaru iniciatīvas digitālās drošỉbas veicināšanai, piemēram, caur informācijas apmaiṇas iniciatīvām (ISAC), kā arī programmas, kas ir saistītas ar digitālās drošìbas inovācijām un sasaista attiecīgās ieinteresētās puses (piemēram, uzṇēmējus, pētniekus, uzṇēmumus un valdības).

Informācijas sabiedrības attīstības pamatnostādnēs (VARAM, 2014. gads) identificētie šḳēršḷi digitālās drošības uzlabošanai Latvijā ir aptuveni tādi paši kā tie, kas tika konstatēti 2016. gada termiṇa vidusposma pārskatā par pirmās Kiberdrošības stratēǵijas ìstenošanu (AM, 2016. gads). Tie iekḷauj cilvēku un finanšu resursu trūkumu institūcijām, kuras ir atbildīgas par digitālo drošību, digitālās drošības prasmju trūkumu Latvijā un ieinteresēto pušu digitālās drošības risku piederības trūkumu, it īpaši augstākajai vadībai, piemēram, lēmumu pieṇēmējiem un uzṇēmumu vadìtājiem. Kamēr digitālā drošība tiek aplūkota un uztverta galvenokārt kā tehnisks un nacionālās drošỉbas jautājums, nevis kā ekonomiskās un sociālās labklājības attīstības faktors, Latvijas varas iestādēm būs grūti palielināt informētību un paplašināt lietotāju un kopienu iespējas. Piemēram, Igaunijā tās kiberstratēgijas pamatprincipi atzìst digitālo drošību kā ekonomiskās izaugsmes veicinātāju un kā pamatvērtības norāda caurskatāmību un atvērtu komunikāciju (Igaunija, 2019. gads).

\section{Latvijai nepieciešams izmantot savas stiprās puses, lai attīstītu digitālās drošības politikas ietvaru}

CERT.LV un AM ir kḷuvuši par digitālās drošības politikas ietvara galvenajiem dalībniekiem. Tomēr citas institūcijas Latvijā vēl nav ieviesušas līdzīgu saistību līmeni attiecībā uz digitālajai drošỉbai atvēlētajiem cilvēkresursiem un finanšu resursiem. Tas varētu liegt šìm institūcijām pilnībā iesaistīties Latvijas digitālās drošības stratēǵijas izstrādē un îstenošanā.

Lai likvidētu šo plaisu, citām Latvijas institūcijām ir jāattīsta savas iespējas un pieejas digitālajai drošībai. CERT.LV un AM var palīdzēt šādas kapacitātes izveidē, piemēram, ar kopīgiem darbsemināriem, kvalifikācijas celšanas semināriem un pagaidu darbinieku apmainu.

\section{Jāuzlabo CERT.LV un NITDP lomas}

Pēdējo gadu laikā CERT.LV ir kḷuvis par uzticamu institūciju, kas spēj atbalstīt privāto sektoru, tostarp Latvijas MVU, drošības incidentu gadỉjumos. Kaut arī NITDP ir raksturota Kiberdrošỉbas stratēǵijā kā "centrālā nacionālā institūcija valsts un privātā sektora informācijas apmaiṇai un sadarbībai", škiet, ka CERT.LV faktiski atrodas vairāku ieinteresēto pušu sadarbības centrā Latvijā. Papildus saiknei ar privāto sektoru CERT.LV ir izveidojis spēcīgas saites ar pilsonisko sabiedrību un tehnisko kopienu, ko parāda tā mijiedarbība ar IT drošības ekspertu grupu un ikgadējā konference "Kiberšahs". CERT.LV ir darbojies arī kā instruments nesenās politikas attīstībā Eiropas Savienības līmenī, kā arī plašākā CERT kopienā, piemēram, attiecībā uz ievainojamības atbildīgu atklāšanu. Tomēr CERT.LV galvenā auditorija joprojām ir IT komandas sabiedriskajās un privātajās organizācijās. Viens no Latvijas paredzamajiem izaicinājumiem ir digitālās drošības risku piederības pāriešana no šìm IT komandām uz administrāciju.

Latvija varētu līdzsvarot CERT.LV panākumus, lai labāk izglītotu un iesaistītu citas ministrijas digitālās drošības stratēǵijas ieviešanā, piemēram, ar personāla kopīgu pasākumu un darbsemināru kopīgu organizēšanu.

Kā norādīts iepriekš, NITDP izveidošana bija svarīgs solis kopīgas valdỉbas pieejas veidošanā attiecībā uz digitālo drošỉbu; tomēr ir konstatēti daži trūkumi. Joprojām nav skaidrības par NITDP lomu: tā ir alternatīvi definēta kā valdības iekšējā koordinācijas organizācija, AM konsultatīvā grupa, iestāde, kas atbild par Kiberdrošības stratēgijas izstrādi, ieviešanu, uzraudzību un novērtēšanu, un vārteja starp valdību un citām ieinteresētajām pusēm. Lai gan NITDP pašreizējais formāts ir sniedzis Latvijai iespēju paaugstināt digitālo drošỉbu līdz svarīgam sabiedrības politikas jautājumam, tas var arī ierobežot tās biedru spēju pilnībā risināt jautājumu par jēgpilnu apmaiṇu un koordināciju. Pastāv risks, ka NITDP var kḷūt par monolītu struktūru, kurā amatpersonas apspriež iniciatīvas, īsti nepievēršoties galvenajiem politikas jautājumiem.

Lai pilnībā līdzsvarotu NITDP potenciālu, var izpētīt dažādus ceḷus:

- palielināt sanāksmju biežumu, piemēram, ar darba līmeṇa sanāksmi kā augsta līmeṇa sanāksmes papildinājumu, koncentrējoties uz pievēršanos galvenajiem politikas jautājumiem un ātrāk nodrošinot rezultātus; 
- labāk veidot sasaisti ar citām ieinteresēto pušu grupām, izmantojot CERT.LV atbalstu; izmantot "foruma" formātu, lai uzṇēmumu vadītāji varētu regulāri, nevis tikai uz "ad-hoc" pamata apspriest problēmas, ar kurām viṇi saskaras digitālās drošības jomā;

- tikties vienreiz vai divreiz gadā premjerministra biroja vadībā. Tas skaidri norādītu, ka digitālā drošība nav tikai valsts drošības jautājums, bet drīzāk tāds, kas attiecas uz ekonomiskajām un sociālajām aktivitātēm.

\section{Latvijai ir jāveic labāka ekonomiskās un sociālās politikas dimensijas integrēšana valdības struktūrā, kas attiecas uz digitālo drošĭbu}

Digitālās drošības politikas ietvaru Latvijā veido spēcīgas tehniskās dimensijas (CERT.LV) kombinācija ar stratēgisko dimensiju (NITDP), tomēr tai trūkst politiskās dimensijas, kas aptver ekonomikas un sociālas perspektīvas. Lai pievērstos šim trūkumam, jāizpēta šīs iespējas:

- palielināt visas valdỉbas iesaistīšanos un koordināciju ar skaidrām pilnvarām un plāniem "horizontālajām" ministrijām (piemēram, EM, VARAM), lai izstrādātu un ieviestu politiku, pamatojoties uz digitālās drošības ekonomiskajām un sociālajām dimensijām (nozaru partnerības, inovācijas, sertifikācija u.c.);

- labāk integrēt Kiberdrošỉbas stratēǵiju ar Informācijas sabiedrības attīstības pamatnostādnēm;

- pastiprināt Kiberdrošỉbas stratēgijas rīcības plānu ar nosakāmiem mērḳiem, kas ir orientēti uz ekonomisko un sociālo labklājību;

- attīstīt trīspusēju sadarbību ar Latvijas kaimiṇvalstīm Igauniju un Lietuvu. Pašlaik šāda sadarbība digitālās drošības politikas jomā pastāv tikai starp CERT.LV un AM. Varētu izveidot jaunu darbības virzienu, kas sasaista par ekonomikas jautājumiem atbildīgās Baltijas valstu ministrijas, lai pārrunātu digitālo drošību no ekonomiskās un sociālās perspektīvas. (Faktiski Ekonomikas lietu ministrija ir atbildīga par digitālās drošības politikas koordinēšanu Igaunijā). Trīs valstu politiḳi varētu regulāri (vismaz divreiz gadā) tikties, lai paplašinātu koordināciju un veiktu informācijas apmaiṇu par saiknēm starp digitālo drošību un ekonomisko un sociālo labklājību.

\section{2. ielikums. Politikas ieteikumi}

Lai pievērstos digitālās drošības izaicinājumiem un iespējām, Latvija var balstīties uz esošajiem stabilajiem pamatiem. Latvijas Informācijas tehnologiju drošības incidentu novēršanas institūcija (CERT.LV) ir starptautiski atzīta par savu tehnisko kompetenci un rādījusi piemēru attiecībā uz koordinētas ievainojamības atklāšanas politikas pieṇemšanu. Latvijas Aizsardzības ministrija (AM) ir arī stingri apṇēmusies atbalstīt digitālo drošību kā stratēǵijas jautājumu, kā tiek norādīts Latvijas kiberdrošỉbas stratēǵijā (2019.-2022. gadam). Vissvarīgākais ir tas, ka Kiberdrošības stratēǵijā digitālā drošība tiek pienācīgi atzīta kā ekonomikas un sociālo risku pārvaldības izaicinājums, nevis vienkārši tehnisks jautājums. Nacionālās IT drošības padomes (NITDP) izveidošana 2011. gadā bija labs pirmais solis, veidojot valdības kopējo pieeju digitālajai drošībai.

Tomēr sabiedrības politikas un pārvaldības ietvars, kas attiecas uz digitālo drošību Latvijā, vēl nepietiekami atspoguḷo šo ekonomikas un sociālo risku pārvaldības pieeju. Turklāt digitālās drošības politikas izstrāde un ieviešana Latvijā joprojām koncentrējas uz nacionālās drošības ietvaru. Tã rezultātā institūcijās un valsts politikā netiek pietiekami pievērsta uzmanība digitālās drošības ekonomiskajai un sociālajai dimensijai (piemēram, prasmes, inovācijas, MVU). Turklāt ieinteresētās puses nav pietiekami konsultētas par digitālās drošības politikas veidošanu. Lai risinātu šīs problēmas, Latvijai jāapsver:

- savas digitālās stratēǵijas atbalstīšana augstākajā valdības līmenī;

- pastiprinot visas valdības pieeju digitālajai drošǐbai, palielinot "horizontālo" (proti, par ekonomikas un reǵionālo attīstību atbildīgo) ministriju iesaistīšanās līmeni digitālās drošības politikas veidošanā un iniciatīvās;

- labāka digitālās drošības stratēǵijas integrēšana ar valsts digitālo stratēǵiju (Informācijas sabiedrības attīstības pamatnostādnes); 


\section{2. ielikums. Politikas ieteikumi (cont.)}

- prasmju pilnveidošanas un darbaspēka apmaiṇas programmu izveidošana starp valsts iestādēm, lai citas ministrijas varētu gūt labumu no CERT.LV un AM pieredzes, kā arī karjeras iespēju veicināšana digitālās drošỉbas jomā;

- atbalsts vairāku ieinteresēto pušu kopienas izveidošanai un vairāku ieinteresēto pušu sadarbības palielināšanai ar ilgtspējīgām partnerībām uz uzticamības pamata (piemēram, NITDP lomas paplašināšana, organizējot “foruma” formāta pasākumus, lai efektīvi iesaistītu kopienu);

- starptautiskās sadarbības palielināšana, it īpaši ar citām Baltijas valstīm, digitālās drošỉbas jomā, lai veicinātu ekonomikas un sociālo labklājību, papildus nacionālās drošības vai IT drošības jomās esošajām programmām.

\section{Uzticamības veidošana ar lielālku privātumu}

(VDAR) Vispārīgā datu aizsardzības regula nodrošina galveno tiesību aktu struktūru personas datu aizsardzībai Latvijā un citās ES valstīs. (FPDAL) Fizisko personu datu apstrādes likums tika pien,emts tādu noteiktu jautājumu regulēšanai, kas attiecas uz VDAR tiešu pielietojumu Latvijā, piemēram, nosakot uzraudzības iestādes statusu unvalsts prasības specifiskās personas datu apstrādes situācijās.

FPDAL pieṇemšanā tika ṇemta vērā VDAR un līdz ar to aptvertas ESAO Pamatnostādnes par privātās dzīves aizsardzību un personas datu pārrobežu plūsmu. Visiem publiskajiem un privātajiem pārziṇiem ir jāievēro FPDAL prasības.

Šajā sadaḷā ir pārskatītas FPDAL galvenās funkcijas un to ieviešana. Likumā tiek ṇemti vērā iespējamie izaicinājumi, kas ir atklāti VDAR kontekstā un uzraudzības iestādes galvenās aktivitātes saskaṇā ar FPDAL un VDAR.

\section{Datu aizsardzības tiesiskais regulējums}

FPDAL kopā ar VDAR un likumu Par fizisko personu datu apstrādi kriminālprocesā un administratīvā pārkāpuma procesā veido pašreizējo tiesisko regulējumu, kas nosaka personas datu apstrādi publiskajam un privātajam sektoram Latvijā. FPDAL ir sadalìts 8. nodalās un satur 37. sadaḷas un 5 pārejas nosacījumus. FPDAL pilnībā stājās spēkā 2018. gada 5. jūlijā, un neilgi pēc tam tika pien,emti Ministru kabineta noteikumi Nr. 478 ar nosaukumu "Datu valsts inspekcijas direktora amata pretendentu atlases un atbrīvošanas no amata noteikumi”, kas stājās spēkā 2019. gada 18. oktobrī.

Vairāki likumi nosaka personas informācijas privātumu un apstrādi dažādās jomās Latvijā. Tie iekḷauj šos:

- Šengenas informācijas sistēmas darbības likums nosaka, kurām institūcijām ir piekḷuve šai sistēmai, un pilnvaro DVI personas datu apstrādes uzraudzībai šajā sistēmā.

- Elektronisko dokumentu likums nosaka elektroniskās komercijas un elektronisko parakstu juridisko statusu, kā arī nosacījumus elektronisko dokumentu glabāšanai un noteikumus par sertifikācijas pakalpojumu sniedzēju un uzticamo sertifikācijas pakalpojumu sniedzēju akreditāciju un uzraudzību.

- Elektronisko sakaru likums pilnvaro Datu valsts inspekciju (DVI) uzraudzīt personas datu aizsardzību elektronisko sakaru sektorā saskaṇā ar FPDAL norādītajām tiesībām.

- Cilvēka genoma izpētes likums nosaka DVI uzraudzības funkcijas attiecībā uz ǵenētikas datiem, iekḷaujot sūdzību izskatīšanu, kas attiecas uz tādu ǵenētisko datu apstrādi, kurus datu subjekti var iesniegt DVI.

- Informācijas tehnoloǵiju drošības likums nosaka darbības, kas jāveic informācijas drošības incidenta gadījumā.

- Pacientu tiesību likums nosaka pacientu tiesības un aizsardzību, iekḷaujot personas datu aizsardzību.

- Latvijas Administrativo pārkāpumu kodekss, kura termiṇš beidzas 2020. gada 1. jūlijā, nosaka sankcijas (un to apjomu), kuras var piemērot personas datu aizsardzības pārkāpumu gadījumos, kā arī šādu sankciju piemērošanas procedūras.

- Administratīuā procesa likums attiecas uz administratīvajām procedūrām institūcijās, ja citi likumi neparedz konkrētus noteikumus. 
- Krimināllikums nosaka kriminālatbildību par personas datu pārkāpumiem. Ja DVI secina, ka lieta var nozīmēt kriminālatbildību, tā var pārsūtīt lietu Valsts policijai.

- Bērnu tiesību aizsardzības likums nosaka aizliegumu izplatīt informāciju par bērniem, piemēram, tas attiecas uz informāciju, kas ir personīgi iegūta no bērniem kā upuriem vai lieciniekiem, vai bērniem, kuri ir izdarījuši likumpārkāpumu.

Atsevišķos noteikumos ir aprakstīti arī personas datu aizsardzības tehniskie un organizatoriskie pasākumi.

MK noteikumos 117/2004 par elektronisko dokumentu izvērtēšanas veidu, uzglabāšanas kārtību un nodošanu valsts arhīvam glabāšanāir norādīts elektronisko dokumentu izvērtēšanas veids, uzglabāšanas kārtība un laika periodi, kad šādi dokumenti tiek nodoti glabāšanā valsts arhīvos. Noteikumi attiecas uz valsts un pašvaldības iestādēm un juridiskajām personām, kurām elektroniskie dokumenti ir jānodod valsts glabāšanai saskaṇā ar normatīvajiem aktiem.

MK noteikumos 473/2005 ir norādītas papildu procedūras, kas attiecas uz elektronisko dokumentu izstrādi, sagatavošanu, uzglabāšanu un apriti valsts un pašvaldību institūcijās, procedūras, kas nosaka elektronisko dokumentu apriti starp valsts un pašvaldību iestādēm vai šìm iestādēm un fiziskām personām, un juridiskām personām.

\section{Institucionālā uzraudzī̉ba}

Datu valsts inspekcija (DVI) tika izveidota 2001. gada 2. janvārī un darbojās saskaṇā ar iepriekšējo Personas datu aizsardzības likumu (nav spēkā kopš 2018. gada 5. jūlija). Tagad DVI darbojas saskaṇā ar FPDAL, VDAR, likumu Par fizisko personu datu apstrādi kriminālprocesā un administratīuā pārkāpuma procesā un 2019. gada 18. oktobra Ministru kabineta noteikumiem Nr. 478.

DVI strādā 25 cilvēki, un tās paziṇotais budžets 2019. gadā bija 640998 EUR. N̦emot vērā tās plašos pienākumus kopš FPDAL un VDAR stāšanās spēkā, ir jāpalielina personāls un resursi. It īpaši DVI nepietiek resursu, lai noalgotu speciālu IT un tehnisko personālu privātuma pārkāpumu izmeklēšanai digitālajā telpā

Turklāt DVI uzrauga Šengenas informācijas sistēmas nacionālo komponentu, pārbaudot, vai personas datu apstrādē netiek pārkāptas datu subjektu tiesības, un pārstāv Latvijas Republiku Šengenas informācijas sistēmas kopīgās uzraudzības iestādē, Eiropola kopīgās uzraudzības iestādē, Eiropola apelācijas komitejā un Muitas informācijas sistēmas kopīgās uzraudzības iestādē, Eiropas Datu aizsardzības padomē un Eiropas Padomes konsultatīvajā komitejā saistībā ar Eiropas Padomes Konvenciju par personu aizsardzību attiecībā uz personas datu automātisko apstrādi (108. konvencija), kā arī pārbauda citas Eiropas Savienības un starptautisko datu aizsardzības iestāžu darbības.

Nākamajās sadaḷās tiek aplūkots līmenis, kādā DVI efektīvi darbojas, ieviešot FPDAL un VDAR, un analizēta pieejamā statistika saistībā ar DVI darbību uzraudzību un novērtēšanu.

\section{Valsts datu inspekcijas (DVI) mērķi un tvērums}

Saskaṇā ar FPDAL DVI mērḳis ir aizsargāt fundamentālās cilvēku tiesības un brīvības datu aizsardzības jomā. DVI veic savas darbības un darbojas uz neatkarīga pamata, n,emot vērā principus par vienlīdzību likuma priekšā, nevainīguma prezumpciju, ticamību un likumību.

DVI specifiskās darbības un uzdevumi (papildus VDAR 57. pantā norādītajiem) ir ietverti FPDAL 4. sadaḷā (5.3. ielikums).

Citi DVI galvenie saistības uzdevumi ar FPDAL un VDAR iekḷauj ikgadējā ziṇojuma izstrādi par tās darbību un funkcijām; ziṇojums tiek iesniegts Saeimai, Ministru kabinetam, Augstākajai Tiesai, Eiropas Komisijai un Eiropas Datu aizsardzības kolēǵijai (līdz 1. martam), kā arī tiek nodrošināta tā pieejamība tās tīmekḷa vietnē (13. sadaḷ).

Tāpat arī FPDAL 5 sadaḷā (papildus VDAR 58. pantā ietvertajām tiesībām) tiek norādīts DVI saraksts ar FPDAL ieviešanas tiesībām un pilnvarām (5.4. ielikums). 


\section{3. ielikums. Latvijas DVI galvenās regulatīvās pilnvaras un darbības saskaṇā ar FPDAL}

1. Uzraudzīt personas datu apstrādes atbilstību likumu un noteikumu prasībām.

2. Veicināt datu aizsardzības efektivitāti.

3. Nodrošināt datu aizsardzības sertifikācijas procedūras.

4. Nodrošināt datu aizsardzības darbinieku kvalifikācijas pārbaudi un uzturēt to datu aizsardzības darbinieku sarakstu, kuri ir nokārtojuši kvalifikācijas eksāmenu.

5. Sniegt ieteikumus Saeimai, Ministru kabinetam, pašvaldībām un citām institūcijām atbilstoši savai kompetencei attiecībā uz likumu un noteikumu grozījumiem, kā arī piedalīties citu institūciju sagatavoto likumprojektu un noteikumu izstrādē un atzinumos.

6. Sniegt atzinumus par valsts pārvaldes iestādēs izveidojamo datu apstrādes sistēmu atbilstību normatīvo aktu prasībām.

7. Sniegt atzinumus valsts akreditācijas iestādei par sertifikācijas iestādes atbilstību Datu aizsardzības regulai.

8. Sadarboties ar ārvalstu uzraudzības iestādēm, kas ir iesaistītas datu aizsardzībā, informācijas atklātībā un piekḷvē, kā arī nevēlamā komerciālā komunikācijā.

9. Nodrošināt, lai informācijas pieprasījumi no datu objekta tiktu pārsūtīti uz Eiropas Tiesiskās sadarbības vienību (Eurojust) un Eiropas Policijas biroju (Eiropolu).

10. Pārstāvēt Latvijas Republiku starptautiskās organizācijās un pasākumos datu aizsardzības jomā.

11. Veikt pētījumus, analīzi, sniegt ieteikumus un viedokḷus, kā arī informēt sabiedrību par savas kompetences jomu aktuālajiem jautājumiem.

12. Veikt citos likumos un noteikumos norādītos uzdevumus.

13. Publicēt informāciju savā tīmekḷa vietnē par Datu aizsardzības regulas pārkāpumiem, ko izdarījušasjuridiskas personas, valsts un privātas iestādes un amatpersonas, kā arī citas valsts iestādes, un to novēršanu.

\section{4. ielikums. DVI tiesības saskaṇā ar FPDAL}

1. Veikt datu apstrādes pārbaudi, ievērojot likumos un noteikumos iekḷautās prasības.

2. Sastādīt ziṇojumus par administratīvajiem pārkāpumiem, izmeklēt administratīvo pārkāpumu lietas un piemērot administratīvās sankcijas par pārkāpumiem.

3. Pieprasīt un saṇemt dokumentus, kopijas un citus materiālus, kas ir nepieciešami pārbaudei, tostarp ierobežotas pieejamībuas informāciju, bez maksas no privātpersonām, valsts pārvaldes institūcijām un amatpersonām.

4. Apmeklēt valsts pārvaldes institūcijas un ražotnes, noliktavas, komerciālas un citas nedzivojamas telpas, kas pieder, ir īpašumā vai ko izmanto juridiskas un fiziskas personas Latvijas teritorijā, lai pārbaudītu pārziṇa darbības atbilstību likumos un noteikumos iekḷautajām prasībām, rīkojoties savas kompetences ietvaros.

5. Atbilstoši savai kompetencei brivi iepazīties ar visu veidu informāciju, kas ir pieejama reǵistros, informācijas sistēmās, datubāzēs un tai piekḷūt (neatkarīgi no informācijas īpašnieka), lai iegūtu pārbaudei nepieciešamo informāciju.

6. Pieprasīt un saṇemt atbilstoši savai kompetencei informāciju, dokumentus un citus tādus materiālus par personām sniegtajiem pakalpojumiem, kas ir nepieciešami pārbaudei.

7. Pieprasīt un saṇemt neatkarīga un objektīva eksperta viedokli pārbaudes ietvaros.

8. Sniegt atbildes angliski, izmeklējot nerezidentu sūdzības sadarbībā ar citām uzraudzības iestādēm.

9. Ierosināt lietas izskatīšanu tiesā par šī Likuma vai Datu regulas pārkāpumiem. 
Saskaṇā ar FPDAL 6. sadaḷas 2. apakšpunktu DVI direktoram ir pienākums izveidot konsultatīvās padomes, kā arī darba grupas jautājumu izvērtēšanai DVI kompetences jomās. Pēc Tieslietu ministrijas (TM) iniciatīvas 2018. gadā tika izveidota Fizisko personu datu aizsardzības konsultatīvā atbalsta padome (DAKP). DAKP mērḳis ir veicināt vispārējās izpratnes un labas pārvaldības principu pielietojumu VDAR ieviešanā, kliedēt mītus un novērst nepareizas interpretācijas ne tikai publiskajā administrācijā, bet arī sabiedrībā kopumā.

Turklāt DAKP ir kā platforma diskusijām jautājumos, kas attiecas uz VDAR un tās piemērošanu, labākās pieredzes un kompetences apmaiṇu, datu aizsardzības sekmēšanu un savstarpēji interesējošu jautājumu pārrunāšanu. Padomi pārvalda TM valsts sekretārs, un tā ietver DVI un lielāko nozaru (piemēram, plašsaziṇas līdzekḷu, veselības aprūpes, labklājības un izglìtības) pārstāvjus.

Latvijas Pašvaldību savienība (LPS) regulāri organizē diskusijas un publicē informāciju par datu aizsardzību. LPS ir sabiedriska organizācija, kas apvieno Latvijas Republikas pašvaldības uz brīvprātības pamata. Saskaṇā ar Likuma par pašvaldībām 96. pantu LPS ir pilnvarota pārstāvēt pašvaldības sarunās ar Ministru kabinetu, jo LPS pārstāv vairāk nekā pusi no visu veidu pašvaldībām. Visas Latvijas pašvaldỉbas (no 9 pilsētām un 110 municipalitātēm) ir LPS dalībnieces. Citas institūcijas var sazināties arī ar TM un DVI. 2019. gada sākumā datu aizsardzības speciālisti no ministrijām un to pakḷautībā esošajām iestādēm sapulcējās, lai pārrunātu aktuālākos jautājumus saistībā ar VDAR ieviešanu, iekḷaujot datu aizsardzību, un veiktu labākās pieredzes un kompetences apmaiṇu.

FPDAL satur piecus pārejas nosacījumus. 5. sadaḷā ir norādīts, ka Ministru kabinetam ir jānovērtē regulējuma efektivitāte attiecībā uz datu aizsardzības darbinieku kvalifikācijas eksāmenu, ko satur FPDAL, un jāiesniedz vērtējums par šì eksāmena atcelšanas iespēju Saeimai lỉdz 2021. gada 30. jūnijam.

\section{Piemērošana}

DVI ir atbildīga par FPDAL, VDAR un citu nacionālo normatīvo kas nosaka privātumu un datu aizsardzỉbu, ieviešanu.

2019. gada 26. augustā DVI piemēroja naudas sodu 7000 EUR apmērā tiešsaistes mazumtirgotājam par VDAR neievērošanu, it îpaši par to, ka netika ievērotas un aizsargātas datu subjektu tiesības uz izdzēšanu un sadarbību ar uzraudzības iestādi. Sankcijas tika piemērotas tādēl, ka mazumtirgotājs neveica savu pārziņa pienākumu par datu subjekta pieprasījuma izpildi, kā arī nenodrošināja DVI pieprasīto informāciju norādītajā laika periodā. Turklāt mazumtirgotājs neievēroja rīkojumu, kuru DVI bija sniegusi saskanāa ar VDAR pantu 58(2)(c) un (g) FPDAL 23. pantu. ${ }^{5}$

Attiecībā uz lēmumiem par soda naudām DVI saṇēma 1236 sūdzības saistībā ar iespējamiem personas datu apstrādes pārkāpumiem. Atbildot uz to, tika veiktas 246 pārbaudes, un 9 gadijumos tika uzlikti naudas sodi.. Administratīvo pārkāpumu lietās piemērotie naudas sodi bija no 300 līdz 150000 EUR. Septin,os gadījumos tika izteikts brīdinājums.

Attiecīgi 2018. un 2017. gadā pieṇemto lēmumu skaits administratīvo pārkāpumu lietās ir parādīts 5.1.

\section{1. tabula. Administratīvo pārkāpumu lietās pieṇemtie lēmumi}

\begin{tabular}{lcccc|cr}
\hline & \multirow{2}{*}{$\begin{array}{c}\text { Pieņemtie lēmumi } \\
\text { (skaits) }\end{array}$} & $\begin{array}{c}\text { Lēmumi par lietas } \\
\text { izbeigšanu (skaits) }\end{array}$ & $\begin{array}{c}\text { Piemērots sods } \\
\text { (skaits) }\end{array}$ & $\begin{array}{c}\text { Piemērotās soda } \\
\text { naudas (skaits) }\end{array}$ & $\begin{array}{c}\text { Brīdinājumu } \\
\text { izteikšana (skaits) }\end{array}$ & $\begin{array}{c}\text { Soda naudu } \\
\text { kopsummas (eiro) }\end{array}$ \\
\hline $\mathbf{2 0 1 7}$ & 151 & 86 & 65 & 35 & 30 & 46593 \\
$\mathbf{2 0 1 8}$ & 97 & 71 & 26 & 12 & 14 & 7 \\
$\mathbf{2 0 1 9}$ & 45 & 29 & 16 & 9 & 10 & 730 \\
\hline
\end{tabular}

Avots: DVI (2020), Activity Report 2019, Data State Inspectorate Republic of Latvia, https://www.dvi.gov.lv/en/wp-content/uploads/2013/01/Annualreport-2019.pdf.

Līdzīgā veidā DVI ziṇo, ka no 20 inspekcijas amatpersonu apstrīdētajiem lēmumiem attiecībā uz administratīvo pārkāpumu 12 tika pārsūdzēti tiesā. Kopumā 2018. gadā tika sāktas 24 tiesvedības. DVI ziṇo, ka tiesā pārsūdzēto lietu skaits 2018. gadā samazinājās, jo apstrīdēto inspekcijas lēmumu, kas tika pārsūdzēti, skaits 2017. gadā samazinājās par 3. 


\section{Tehniskie pasākumi datu aizsardzībai}

FPDAL nesatur nekādus specifiskus nosacijumus vai sadaḷas, kas attiektos uz personas informācijas tehniskiem un organizatoriskiem drošības pasākumiem. VDAR 32. pantā ir noteikti pārziṇu un apstrādātāju pienākumi, kas attiecas uz pienācīgu tehnisko un organizatorisko pasākumu ieviešanu, lai nodrošinātu riskam atbilstošu drošỉbas līmeni.

Latvijas Elektronisko sakaru likuma 68.panta pirmajā daḷā ir ietverts nosacījums par personas datu apstrādes drošību elektronisko sakaru komersantiem kur norādīts, ka minētie pakalpojumu sniedzēji: 1) nodrošina to, ka personas datiem var piekḷūt tikai pilnvarots personāls un tie tiek izmantoti tikai iepriekš norādītajos nolūkos; 2) nodrošina personas datu aizsardzību pret nejaušu vai nelikumīgu iznīcināšanu vai nejaušu zudumu, kā arī neatḷautu vai nelikumīgu glabāšanu, apstrādi, piekḷuvi vai izpaušanu; 3) dokumentē iekšējās procedūras, kas tiek veiktas personas datu aizsardzības pārkāpuma izmeklēšanas un novēršanas nolūkos.

\section{Pazin̄ojums par personas datu pārkāpumu}

VDAR 33. pantā ir noteikts, ka pārzinim ir jāziṇo uzraudzības iestādei par drošības incidentiem vai personas informācijas datu pārkāpumiem bez liekas kavēšanās un ne vēlāk kā 72 stundas pēc uzzināšanas par situāciju, ja datu pārkāpums rada risku indivīdu tiesībām un brīvībām. VDAR 34. pantā ir noteiktas datu pārziṇu pienākums paziṇot datu subjektam par personas informācijas datu pārkāpumiem bez nepamatotas kavēšanās, ja datu pārkāpums varētu izraisīt augstu risku fizisku personu tiesībām un brīvībām.

Darbības, kas jāveic datu pārkāpuma gadījumā, ir noteiktas saskaṇā ar VDAR un likumu Par fizisko personu datu apstrādi kriminālprocesā un administratīuā pārkāpuma procesā. VDAR un Pamatnostādnes, kas attiecas uz personas datu pārkāpuma paziñojumu saskaṇā ar Regulu 2016/679, nosaka pienākumus, kas attiecas uz ziṇošanu par datu pārkāpumiem, datu pārziṇiem un datu apstrādātājiem. ${ }^{6}$

Informācijas tehnoloǵiju drošìbas likums nosaka darbības, kas jāveic informācijas drošības incidentu gadijumos.

Informācijas tehnoloǵiju drošības likuma galvenais mērḳis ir uzlabot informācijas tehnoloǵiju drošību valsts, pašvaldību iestāžu un privātu institūciju starpā. Likums nosaka pienākumus, kas attiecas uz ziṇošanu par drošības incidentiem un darbībām drošības ievainojamības novēršanai. Sadaḷā 6(2) ir atrunāts, ka valsts vai pašvaldības institūcijām vai informācijas tehnoloǵiju kritiskās infrastruktūras īpašniekam ir 90 dienu laikā jāveic visas nepieciešamās darbības, lai novērstu drošības neaizsargātību, un jāinformē kompetentās incidentu reaǵēšanas vienības. Turklāt saskaṇā ar sadaḷu 7(4) Drošỉbas incidentu reaǵēšanas vienībai var tikt atḷauts veikt personas datu apstrādi, kas nav saistīta ar šādu incidentu novēršanu, tikai tad, ja tā sagatavo un nosūta DVI aprakstu par personas datu plānoto apstrādi un aizsardzību. Drošības incidentu reaǵěšanas vienībai ir jāsagatavo un jāiesniedz DVI ziṇojums par iepriekšējā gadā veikto personas datu apstrādi līdz nākamā gada janvāra beigām.

DVI 2019. gada ikgadējā ziṇojumā ir norādīts, ka DVI ir saṇēmusi 1236 sūdzības un pieteikumus saistībā ar personas datu apstrādes iespējamiem pārkāpumiem. Pieteikumus un sūdzības saskaṇā ar VDAR 57. pantu iesniedza gan datu subjekti, gan citas valsts iestādes (visbiežāk tiesībaizsardzības iestādes), kā arī organizācijas un asociācijas. DVI saṇēma 107 ziṇojumus par personas datu pārkāpumiem, un daži no tiem satur vairāku veidu pārkāpumus (5.7. attēls).

\section{Privātuma pārvaldības programmas}

Pārskatāmības princips ir viens no 1980. gada Privātuma pamatnostādṇu astoṇiem sākotnējiem pamatprincipiem. Privātuma pamatnostādṇu 2013. gada pārskatījumā tika iekḷauta jauna sadaḷa "Pārskatāmības ieviešana", kurā tiek akcentēti elementi, kas ir nepieciešami datu pārziṇiem, lai ieviestu pārskatāmības principu, it īpaši ieviešot jēdzienu "privātuma pārvaldības programmas" (PPP). Saskaṇā ar pārskatītajām Pamatnostādnēm PPP ir primārais darba instruments, kas, kā paredzams, palīdzēs praksē īstenot Pamatnostādṇu 2. daḷā ietvertos pamatprincipus. It īpaši pievienotajā sadaḷā ir norādīts, ka datu pārzinim ir jānodrošina atbilstība Pamatnostādnēm attiecībā uz visiem viṇa pārziṇā esošajiem personas datiem, ieviešot savu darbību struktūrai, mērogam, apjomam un sensitivitātei 
pielāgotu PPP, un tas nodrošina pienācīgu aizsardzību, pamatojoties uz privātuma riska novērtējumu un iekḷaujot plānus reaǵēšanai uz jautājumiem un incidentiem. Turklāt datu pārzinim vajadzētu būt gatavam pierādīt sava PPP darbỉbu un, ja nepieciešams, informēt iestādes un datu subjektus, ja ir bijis ievērojams drošības pārkāpums, kas ietekmē personas datus. Eiropā PPP joprojām ir agrīnā attīstības fāzē, un tikai dažas valstis ir pieṇēmušas vispusīgas pamatnostādnes un labāko pieredzi publiskā sektora institūcijām. ${ }^{7}$

\section{7. attēls. Ziṇotie personas datu pārkāpumi Latvijā}

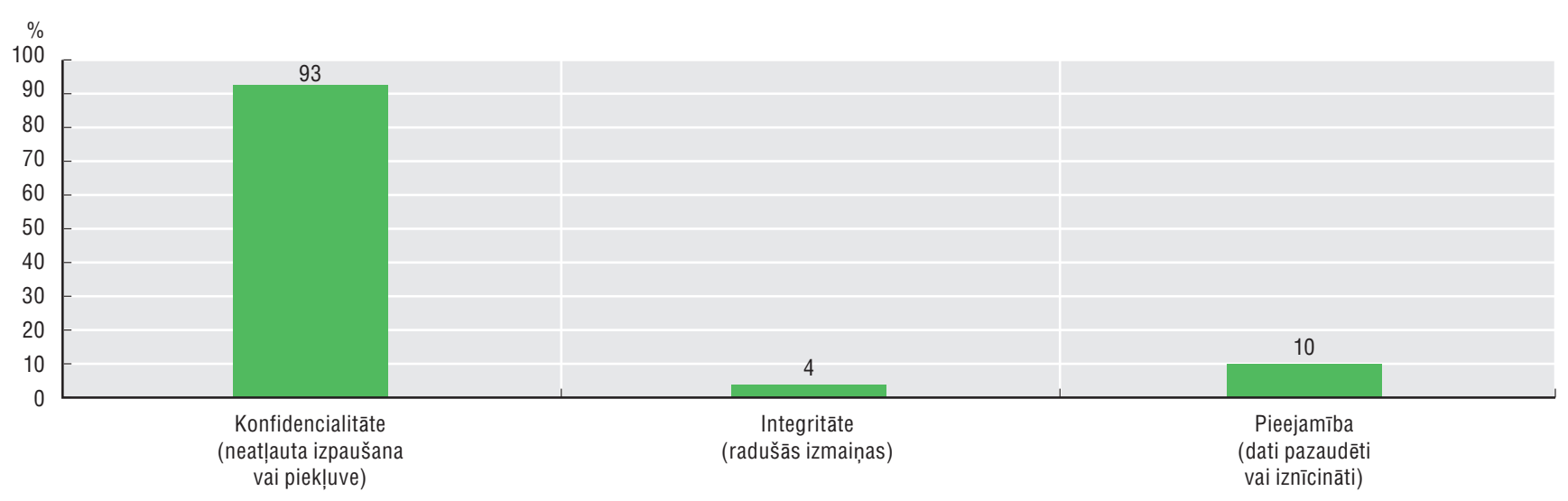

Avots: DVI (2020), Activity Report 2019, https://www.dvi.gov.lv/en/wp-content/uploads/2013/01/Annual-report-2019.pdf.

2018. gada 18. decembrī DVI izstrādāja Sarakstu ar tām apstrādes darbībām, uz kurām attiecas novērtējuma par ietekmi uz datu aizsardzību prasība, saskaṇā arVDAR pantu 35(4). Dokumentā ir saraksts ar piemēriem, kas datu pārziṇiem jānemem vērā, ja datu apstrāde var izraisīt augstu risku fizisku personu tiesībām un brīvībai. Dokumentā ir norādītas 13 dažādas iespējas, kad datu pārziṇiem, kuru iestādes galvenā vieta ir Latvijas teritorija, jāveic datu ietekmes novērtējums.

DVI ir publicējusi arī vairākas rekomendācijas (piemēram, par komerciālo komunikāciju un personas datu apstrādi sociālajos tīklos). DVI cieši sadarbojas ar asociācijām, lai izstrādātu specifiskas vadlīnijas personas datu apstrādei dažādās jomās. ${ }^{8}$

\section{Politikas veidošana}

NVO var piedalīties politikas veidošanā, komentējot likumprojektus, kas ir paziṇoti sabiedrībai, lai saṇemtu komentārus to veidošanas periodā. Konsultēšanās ar NVO notiek pirms katras jaunas iniciatīvas un likumdošanas projekta priekšlikuma, galvenokārt balstoties uz uzaicinājumu no TM, kas vada tiesību aktu projekta izstrādi privātuma jomā. Svarīgās NVO iekḷuj Datu aizsardzības speciālistu asociāciju, Latvijas Informācijas un komunikācijas tehnoloǵijas asociāciju un Latvijas Finanšu nozares asociāciju. Piemēram, MK noteikumi par kredītinformācijas biroju sertifikāciju un uzraudzību tika izstrādāti, konsultējoties ar Latvijas Finanšu nozares asociāciju un Sertificēto personas datu speciālistu asociāciju. Vēl viens piemērs ir DVI ikgadējo rekomendāciju izstrāde koordinācijā ar NVO, iekḷaujot privātos dalībniekus, piemēram, rekomendācija "Personas datu apstrāde tiešsaistes sociālajos tīklos", kas tika izstrādāta pēc dažādu sociālo tīklu pakalpojumu sniedzēju viedokḷu analīzes.

DVI 2018. gada ikgadējā ziṇojumā ir norādīts, ka DVI ir atbalstỉjusi personas datu aizsardzības vadlīniju izstrādi, kas ir attiecināmas uz dažādu nozaru asociācijām. Piemēram, tiek minēts, ka DVI ir iesaistijusies datu aizsardzības vadlīniju izstrādē kopā ar Latvijas Finanšu nozares asociāciju un Latvijas Personāla vadī̌anas asociāciju, kā arī sniegusi atbalstu Latvijas Zvērinātu advokātu padomei, sagatavojot vēl vienu vadliniju komplektu datu aizsardzībai.

\section{Pārrobežu sadarbības īstenošana}

2013. gada ESAO pārskatītajās privātuma vadlīiju IV sadaḷā tiek akcentēta pārrobežu sadarbības nozīme, ìstenojot privātuma likumus un sekmējot savstarpējo juridisko palīdzību privātuma tiesībaizsardzības iestādēm. 
VDAR 61. un 62. pantā ir akcentēts uzraudzības iestāžu pienākums nodrošināt savstarpēju un efektīvu sadarbību, kas attiecas uz konsultācijām, pārbaudēm un izmeklēšanām saistībā ar datu aizsardzību, un noteikti kritēriji, kas ir nepieciešami, lai veiktu kopīgas izmeklēšanas un kopīgus ieviešanas pasākumus pret pārziṇiem un datu apstrādātājiem, kuri attiecīgi atrodas vairāk nekā vienā ES dalībvalstī.

Līdz 2016. gadam DVI sadarbojās ar ārvalstu datu aizsardzības iestādēm (DAI) katrā atsevišḳā gadījumā un regulāri ar citām Baltijas valstīm. Pēc VDAR pien̦emšanas DVI regulāri sadarbojas ar ES dalībvalstu datu aizsardzības iestādēm atbilstoši VDAR.

DVI 2018. gada ikgadējā ziṇojumā ir norādīts, ka 2017. gada 15. jūnijā DVI parakstīja sadarbības memorandu par principa "Vispirms konsultācija" ieviešanu, kas atbalsta koncentrēšanos uz klientu valsts regulatīvajās darbībās. Pielietojot principu "Vispirms konsultācija" DVI ir pamudinājusi pārzini VDAR izklāstīto pienākumu veikšanai 179 gadījumos. Ziṇojumā ir norādīts, ka pārziṇi ir rīkojušies atbilstoši DVI pamudinājumam 25 lietās (78 \%).

Latvija vēl nepiedalās Globālajā privātuma tiesībaizsardzības tīklā (GPEN) un līdzīgos starptautiskos tìklos, kuri īsteno privātuma un datu aizsardzỉbas likumus.

Latvija ir ratificējusi Eiropas Padomes Konvenciju par personu aizsardzību attiecībā uz personu datu automātisko apstrādi (108. konvencija) 2001. gada 30. maijā un tās Papildu protokolu par uzraudzības institūcijām un pārrobežu datu plūsmām 2017. gada 21. novembrī. Latvija ir parakstījusi grozījumu protokolu (Konvencija 108+Konvencija 108) 2018. gada 10. oktobrī, bet nav turpinājusi ar ratifikāciju.

DVI 2018. gada ikgadējā ziņojumā ir norādīts, ka DVI turpina iesaistīties Eiropas Padomes 108. konvencijas konsultatīvās komitejas darbā, piedaloties sanāksmēs, nodrošinot nepieciešamo statistisko informāciju un komentējot sagatavotos darba dokumentus.

\section{Uzraudzība}

DVI izveido ikgadējo ziṇojumu un iesniedz ziṇojuma kopsavilkumu TM. Šajā ziṇojumā ir detalizēti atspogul̦otas DVI galvenās darbības, sniegta informācija par finanšu resursiem un personālu, kā arī informācija par galvenajām problēmām, kas radušās gada laikā. Tajā tiek iezīmētas arī DVI nākamā gada prioritātes. Saskaṇā ar attiecīgajiem MK noteikumiem ikgadèjie ziņojumi un to kopsavilkumi ir pieejami (latviski) DVI tīmekḷa vietnē.

DVI saņemtās sūdzības tiek analizētas katru ceturksni un izskatītas atbilstoši DVI attiecīgā gada plānotajām prioritātēm. Dažos gadījumos sūdzības vairāk tiek analizētas pēc ad - hoc principa, piemēram, ja DVI saṇem vairākas sūdzības par vienu jautājumu ìsā laika periodā.

\section{Izglītība un informētība}

DVI 2018. gada ikgadējā ziṇojumā ir norādīts, ka DVI sadarbībā ar TM ir izstrādājusi informācijas materiālus iedzivotājiem par VDAR pielietojuma apjomu. Tie ir zināmi kā "Mīti un patiesība", kas valsts pilsoṇiem izskaidro viṇu tiesības, kā arī pārziṇu un datu apstrādātāju pienākumus saskaṇā ar VDAR. DVI ir organizējusi 52 lekcijas un seminārus par personas datu aizsardzību un VDAR pielietojumu valsts un privātā sektora pārstāvjiem un apmeklējusi 76 seminārus, konferences, diskusiju sanāksmes un darba grupas, ko organizēja citas institūcijas un uzṇēmèji.

\section{Datu pārvaldības struktūras}

Piekḷuve datiem un to kopīgošana ir izšḳiroši svarīga digitālās ekonomikas inovācijās. Piemēram, piekḷuve datiem var uzlabot publisko pakalpojumu nodrošināšanu un sekmēt jauno valdības un sociālo izaicinājumu identificēšanu.

Atvērto datu politikas pārvaldību koordinē Latvijas valdỉba.

Latvijas Atvērto datu portālu izveidoja Eiropas Reǵionālās attīstības fonds ar Publiskās pārvaldes informācijas un komunikācijas tehnoloǵiju arhitektūras pārvaldības sistēmas (PIKTAPS) atbalstu. ${ }^{9}$ 
Latvija piedalās Atvērtās pārvaldības partnerībā (OGP), un kā minēts Latvijas Atvērto datu portālā, Latvijas Trešais nacionālais atvērtās pārvaldības rīcības plāns ietver darbību, kas veicinātu atvērtību, atbildību, sabiedrības iesaistīšanos un IKT izmantošanu. Šajā plānā ir ieklautas darbības dažādu tiešsaistes pakalpojumu uzlabošanai un ieviešanai. Vienas no 12 saistībām ir publiskos resursos pieejamu publisko datu portāla izstrāde. Tomēr, lai sasniegtu OGP 2017.-2019. gada plāna mērķus, Latvija ir apn,ēmusies iesaistīt sabiedrību datu kopu atlasišanā. Līdz ar to tīmekḷa vietnē ir funkcija, kas lietotājiem ḷauj balsot par datiem, kurus vini vēlas atvērt.

\section{Secinājumi un politikas ieteikumi}

Latvija ir ievērojami progresējusi privātuma un datu aizsardzības tiesību îstenošanā kopš VDAR un FPDAL stāšanās spēkā. DVI ir sākusi proaktīvi îstenot tiesisko regulējumu un uzlikt organizācijām administratīvus sodus par likumos noteikto vispārējo saistību neievērošanu. Tomēr DVI ir jābūt nodrošinātiem cilvēku un finanšu resursiem, kas ir nepieciešami, lai efektīvi veiktu tās uzdevumus, kuri iekḷauj privātuma un datu aizsardzības digitālajā telpā konsultācijas un izmeklēšanas.

ESAO Privātuma pamatnostādṇu 2013. gada pārskatījumā tika ieviesta PPP koncepcija, kas kalpo kā centrālie darbības mehānismi, ar kuru palīdzību organizācijas īsteno privātuma aizsardzību. It īpaši 15(a) (i) sadaḷā ir norādīts, ka datu pārziṇa PPP ir jāievieš ESAO Privātuma pamatnostādnēs "visiem personas datiem, kas ir tā kontrolē". Tiek gaidīta Eiropas Padomes 108. konvencijas konsultatīvās komitejas ceḷveža izstrāde DVI, lai vairāk proaktīvi ieviestu VDAR nosacījumus par privātumu pēc ieceres un par privātumu pēc noklusējuma, kā arī PPP, un tajā ir jānnem vērā EDAK izstrādātās pamatnostādnes, kā arī esošā labākā pieredze ESAO dalībvalstīs.

Attiecībā uz pārskatāmības saistībām DVI ir izstrādājusi sarakstu ar apstrādes darbībām, kurām ir nepieciešami privātuma ietekmes novērtējumi. Tomēr DVI joprojām ir jāizstrādā pamatnostādnes pārskatāmības saistībām, kas ir izklāstītas saskaṇā ar VDAR, piemēram, rīcības kodeksu ievērošana un esošo sertifikācijas shēmu izmantošana, ievērojot attīstību šajā jomā visā ESAO dalībā. Rakstīšanas laikā DVI ir jānosaka arī eksāmeni datu aizsardzības speciālistiem.

Attiecībā uz starptautisko sadarbību DVI ir bijusi diezgan aktīva Eiropas kontekstā, it īpaši attiecībā uz tās dalību Datu aizsardzības kolẹgijā (EDAK) un Eiropas Padomes 108. konvencijas konsultatīvajā komitejā. Tomēr DVI vēl nav pievienojusies Globālajam privātuma aizsardzības tīklam (GPEN), kas varētu sekmēt un uzlabot tās sadarbību ar citām valstīm un reǵioniem.

Speciālo datu kategoriju izmantošanas un apstrādes skaidra nošķiršana no privātuma tiesību aizsardzības paliek īpašs uzdevums, kuram ir jāveltī sevišķa uzmanība MI un IoT attīstības kontekstā. DVI ir tādējādi jānodrošina pastāvīga datu subjektu tiesību īstenošana saskaṇā ar VDAR un nacionālās datu aizsardzības juridisko struktūru. Jātupina izstrādāt turpmākie aizsardzības pasākumi, kas palīdz uzlabot datu subjekta tiesību aizsardzību MI kontekstā, kā arī pārējie IoT uzdevumi. To var sasniegt ar turpmāku iesaistišanos un sadarbībā ar starptautiskiem forumiem datu aizsardzības un privātuma jomā, iekḷaujot ESAO darbu šajās jomās.

\section{5. ielikums. Politikas ieteikumi}

Latvijai veicamās turpmākās darbības, lai uzlabotu privātumu:

- Datu valsts inspekcijas (DVI) nodrošināšana ar cilvēku un finanšu resursiem, kas ir nepieciešami, lai efektīvi veiktu tās uzdevumus, kas iekḷauj privātuma un datu aizsardzības konsultācijas un izmeklēšanas digitālajā telpā;

- veicināt DVI pamatnostādṇu izstrādi, kā pamatu izmantojot esošo labo pieredzi, lai sekmētu pārskatāmību un "privātuma pārvaldības programmas" (PPP);

- mudināt uz DVI un citu valstu, tostarp ārpus ES, savstarpējo sadarbību, piemēram, pievienojoties Globālajam privātuma aizsardzības tīklam (GPEN);

- izveidot pienācīgu MI un IoT pārvaldību, tostarp turpinot iesaistišanos un sadarbību ar starptautiskiem forumiem, piemēram, ESAO. 


\section{Patērētāju aizsardzība}

\section{Politikas struktūra}

Latvijas Patērētāju tiesību aizsardzības likums ${ }^{10}$ un Negodīgas komercprakses aizlieguma likums ${ }^{11}$ satur vispārīgus principus, kas aptver: 1) informācijas izpaušanu; 1) produktu drošību; 3) negodīgu, maldinošu un agresīvu komercpraksi, kas attiecas uz tradicionālajiem un e-komercijas darijjumiem. Saskaṇā ar Eiropas Savienības (ES) Patēê̄ēāju tiesību direktīuu 2011/83/ES Patērētāju tiesību aizsardzības likums 2014. gadā tika grozìts ar Attālinātā darba līgumu regulējumu ${ }^{12}$, kurā tiek identificētas galvenās informācijas izpaušanas prasības pirms līguma noslēgšanas (attiecībā uz uzṇēmumu, produktu un darījumu). Regulējumā ir aptverti arī distances līgumu apstiprināšanas nosacījumi, kas saskaṇā ar 17. pantu ir jānodrošina patērētājiem ar izturīga datu nesēja starpniecību un pamatoti piennemamā laikā pēc līguma noslēgšanas (ne vēlāk kā preču piegādes laikā vai pirms pakalpojuma izpildes). Ar regulējumu tiek ieviestas arī jaunas atteikšanās tiesības patērētājiem, kuri noslēdz distances līgumus (tostarp ar e-komercijas starpniecību).

Papildus iepriekš minētajiem likumiem specifiski e-komercijas nosacijjumi ir iekḷauti Informācijas sabiedrības pakalpojumu likumā, ${ }^{13}$ Elektronisko sakaru likumāa ${ }^{14}$ un iepriekš minētajā Negodīgas komercprakses aizlieguma likumā.

- Informācijas sabiedrības pakalpojumu likumā ir norādīta galvenā informācija, kas pakalpojumu sniedzējiem ir jānodrošina patērētājiem, iekḷaujot pirmslīguma informāciju par uzṇēmumu, produktu un darījumu. Tas aptver arī rīcibas kodeksus, nosacỉjumus par informācijas glabāšanu termināḷa aprīkojumā, prasības par komercsakariem, atbildību, kā arī uzraudzības iestāžu, piemēram, Latvijas Patērētāju aizsardzības centra un DVI, lomu un pienākumiem. ${ }^{15}$ Likuma 4. pantā ir norādīta vispārīga informācija, kas jānodrošina pakalpojumu sniedzējiem. 5. pantā ir izklāstīta informācija, kas pakalpojumu sniedzējam jānodrošina pirms pasūtỉjuma veikšanas. 7. pantā ir norādīta informācija par līguma noteikumiem un rīcības kodeksu, kas jānodrošina pakalpojumu sniedzējam.

- Elektronisko sakaru likums aptver lietotāju, elektronisko sakaru nodrošinātāju, privātu elektronisko sakaru tīklu un valsts administratīvo institūciju, kas ir saistītas ar elektronisko sakaru sektoru, tiesības un saistības. Tas satur arī nosacījumus par elektronisko sakaru pakalpojumiem un ierobežoto resursu lietošanu un administrāciju, iekḷaujot spektra iedališanu un radio frekvenču piešķiršanu. Turklāt likumā ir noteiktas attiecīgo regulatīvo agentūru tiesības un saistības dažādos sektoros saskaṇā ar regulējumu. Tajā ir izklāstītas specifiskās saistības, kas attiecas uz juridiskajām personām un uzṇēmumiem ar ievērojamu ietekmi tirgū, saistības attiecībā uz universāliem pakalpojumiem, datu aizsardzības saistỉbas elektronisko sakaru sektorā un saistỉbas, kas attiecas uz datu saglabāšanu balss telefonijas un publiskās telefonijas nodrošināšanā, kā arī publiskās interneta piekḷuves pakalpojumu nodrošināšanā.

- Negodīgas komercprakses aizlieguma likums aptver arī bērniem paredzētas tiešsaistes reklāmas, maldinošu un negodīgu komercpraksi, kā arī produktu drošìbu.

Papildu prasības, kas nosaka darījumus tiešsaistē un it īpaši reklāmas bērniem, ir norādītas Reklāmas likumā ${ }^{16}$ (5. sadaḷā), kurā ir izklāstìtas soda sankcijas par likuma un sekundārā regulējuma neievērošanu.

Maksājumu pakalpojumus, elektronisko naudu un maksājumu kartes nosaka Maksājumu pakalpojumu un elektroniskās naudas likums, ${ }^{17}$ kurā ir noteiktas maksājumu pakalpojumu sniedzēju un lietotāju, e-naudas izdevēju un turētāju tiesības un pienākumi, kā arī prasības, kas attiecas uz maksājumu pakalpojumu nodrošināšanu e-naudas izsniegšanai, sadalei un atgūšanai, un atbildība par maksājumu iestādēm un e-naudas iestādēm.

Turklāt Latvijā pašlaik notiek process, kura gaitā tiek ieviestas turpmākās politikas par patērētāju aizsardzību, kas saskan ar nesen pien,emtajiem ES regulējumiem, kuri ietver centienus veicināt un uzlabot Eiropas vienoto digitālo tirgu, tostarp ES regulējumu par geobloḳēšanu. ${ }^{18}$ Pēc tam, kad stājās spēkā ES regula ${ }^{19}$ par sadarbību starp valsts varas iestādēm, kuras ir atbildīgas par patērētāju aizsardzības likumu īstenošanu, 2018. gadā tika pien,emts Latvijas Elektronisko sakaru likums, kas valsts Patērētāju tiesību aizsardzības centram (PTAC) nodrošina papildu pilnvaras informācijas pieprasīšanai elektronisko sakaru nodrošinātājiem, un tas attiecas uz informāciju par abonentu vai lietotāju (piemēram, tīmekḷa pārzini). 


\section{ESAO principu ieviešana digitālo patērētāju aizsardzī̄ō}

Šīs sadaḷas mērḳis ir novērtēt pakāpi, kādā Latvijas patērētāju politikas struktūra iemieso digitālo patērētāju aizsardzības vispārīgos principus, saskaṇā ar ESAO Rekomendāciju par patērētāju aizsardzību e-komercijas jomā, kas ir zināma arī kā "E-komercijas rekomendācija" (ESAO, 2016. gads). Rekomendācijas galvenie nosacījumi ir ietverti 5.6. ielikums. Turklāt sadạ̣ā tiek pētīta pakāpe, kādā Latvijas struktūra aptver pašreizējo e-komercijas formu dažādību, iekḷaujot darījumus starp patērētājiem, darījumus ar mobilo ierīču starpniecỉbu un darījumus, kas neietver naudas maksājumu.

\section{6. ielikums. Digitālo patērētāju aizsardzības vispārīgie principi}

- Godīga uzṇēmējdarbības un reklāmu prakse

- Atbilstīga izpaušana

- Efektīvi procesi darījumu apstiprināšanai un maksājumiem

- Produkta drošība e-komercijas piegādes k̦ēdēs

- Jēgpilna piekḷuve efektīviem mehānismiem, lai atrisinātu strīdus

- Patērētāju izglīīiba un informētība

- Varas iestāžu pilnvaras izpētīt un rīkoties iekšzemes līmenī

- Varas iestāžu spēja iesaistīties starptautiskajā politikā un îstenošanas sadarbībā.

Avots: OECD (2016).

E-komercijas rekomendācija tika pārskatīta 2016. gadā, lai aptvertu daudzas jaunas problēmas un attīstỉbas, piemēram, àtru izaugsmi un nemateriālu digitālā satura produktu pienememšanu no patērētāju puses, mainīgu un aktīvāku patērētāju rīcību tiešsaistē, tostarp ar mobilo ierīču starpniecību, plaša tiešsaistes un mobilo maksājumu klāsta parādī̌anos, kā arī pieaugošās raizes par tiešsaistes produktu drošību. Rekomendācijā ir izcelta arī nepieciešamība nodrošināt kompensāciju patērētājiem, kuri ir iesaistīti nemonetāros darījumos, un ietverts aicinājums uzṇēmumiem, lai klientiem tiktu nodrošināta skaidra un skaidri redzama informācija par digitālā satura produktu ierobežojumiem, funkcionalitāti un mijiedarbību un notiktu pievēršanās e-komercijas pakalpojumu privātuma un drošǐbas riskiem, iekḷaujot maksājumu metodes.

\section{Institucionālā uzraudzība}

E-komercijas rekomendācija satur atjauninātus nosacījumus par patērētāju aizsardzības iestādēm (PAI) un nepieciešamību uzlabot savu patēēēāju aizsardzības spēju e-komercijā. Rekomendācijas 2. dạ̣ā tiek akcentēti regulatīvās struktūras ieviešanas principi un valdības tiek aicinātas sadarbībai ar ieinteresētajām pusēm, lai sasniegtu Rekomendācijas mērkii:

- pārskatot un, ja nepieciešams, pieṇemot un pielāgojot likumus, kas aizsargā patērētājus e-komercijā, paturot prātā tehnolog̣ijas neitralitātes principu (53 ii);

- izveidojot un uzturot PAI, kurām ir pilnvaras un iespējas veikt izmeklēšanu un rīkoties, lai patērētājus aizsargātu pret krāpniecisku, maldinošu vai negodīgu komerciālo praksi, kā arī resursi un tehniskā kompetence savu pilnvaru efektīvai izmantošanai (53 iii);

- iedrošinot efektīvu kopīgas regulācijas un pašregulācijas mehānismus pastāvīgu attīstību, kas palīdz uzlabot uzticibu e-komercijai, tostarp atbalstot efektîvus strīdu izškikiršanas mehānismus (53 v).

Latvijā par patērētāju politikas veidošanu, realizēšanu un ieviešanu saistībā ar e-komerciju ir atbildīgas tās pašas varas iestādes, kuras pārzina tradicionālo iepirkšanos. Patērētāju politikas veidošanu vada $\mathrm{EM},{ }^{20}$ it îpaši konkurences, tirdzniecỉbas un patērētāju tiesību daḷa. Nozaru politiku, kas attiecas uz patēēētāju jautājumiem (piemēram, veselības aprūpes pakalpojumi, transports vai telekomunikācijas), koordinē citas ministrijas kopā ar EM. Tā kā patērētāju aizsardzība, tostarp strīdu izšǩiršana, ir cieši saistīta ar civiltiesiskajiem un administratīvajiem likumiem, TM ir iesaistīta arī patērētāju politikas attīstībā. 
Galvenā īstenošanas un ieviešanas iestāde ir PTAC, ${ }^{21}$ kas ir pakḷauta EM. Kaut arī EM ir atbildīga par PTAC pien,emto lēmumu juridiskās atbilstības pārskatī̌sanu, tā nevar iejaukties PTAC lēmumu pien,emšanas procesā vai pārskatīt viedokli, uz kura pamata piennemts lēmums. EM ir tiesības iejaukties un likt PTAC pieñemt lēmumu tikai gadījumos, kad PTAC nerīkojas saskañā ar likumu (nelikumīga bezdarbība). Ministru kabinets pēc EM ieteikuma ieceḷ PTAC direktoru uz piecu gadu termiṇu. Saskaṇā ar Patērētāju tiesību aizsardzības likumu PTAC lēmumus var apelēt tiesā saskaṇā ar Administratìvo procedūru likumā norādītajām procedūrām.

PTAC galvenais uzdevums ir īstenot patērētāju tiesības un intereses. Tās pienākumi iekḷauj atsevišķu patērētāju sūdzību izskatǐšanu, tirgus novērošanu lielākajai dal̦ai nepārtikas produktu un patērētāju likumu un noteikumu īstenošanu. Papildu tiesībaizsardzības iestādes papildina PTAC konkrētās jomās, tostarp DVI, kas ir atbildīga par personas datu aizsardzību, un dažas nozaru specifiskās ministrijas, kurām ir ìpašs budžets un personāls patērētāju aizsardzībai.

PTAC ir plašas regulatīvās pilnvaras (skatiet 5.7. ielikums), tostarp iespēja pieprasīt uzṇēmumiem publicēt attiecīgo informāciju, ja ir pārkāptas patērētāju tiesības, piemēram, nepareizas vai maldinošas produktu informācijas, negodīgas komercprakses vai bīstamu produktu gadījumā.

\section{7. ielikums. PTAC galvenās izpildes pilnvaras}

- Pieprasīt no uzṇēmumiem, valsts, pašvaldības institūcijām un fiziskām vai juridiskām personām visu informāciju, kas PTAC ir nepieciešama, lai izpildītu savas funkcijas.

- Lūgt uzṇēmumiem veikt brīvprātīgas darbības paredzētajā laika periodā, lai nodrošinātu komercprakses atbilstỉbu likuma un regulatīvajām prasībām, piemēram, izbeigtu nelikumīgu komercpraksi.

- Pieprasīt uzṇēmumiem publicēt attiecīgu informāciju, ja ir pārkāptas patērētāju tiesības, piemēram, nepareizas vai maldinošas produktu informācijas, negodīgas komercprakses vai bīstamu produktu gadỉjumā.

- Apmeklēt jebkuru ēku, telpu vai vietu, kur tiek ražotas, glabātas vai tirgotas preces, kas neatbilst patērētāju tiesību aizsardzības politikai un likumam, vai tiek sniegti neatbilstīgi pakalpojumi; apmeklēt jebkuru vietu, kur tiek izmantoti, ražoti, remontēti vai pārdoti mērinstrumenti.

- Pieprasīt un saṇemt tādu preču paraugus, par kurām ir aizdomas, ka tās pārkāpj patērētāju tiesības saskaṇā ar normatīvajos aktos noteiktajām procedūrām, lai veiktu laboratorijas vai citu speciālistu izmeklējumus.

- Pieprasīt preču izṇemšanu no apgrozỉbas vai pārtraukt pakalpojumu sniegšanu neatbilstỉbas ar patērētāju aizsardzības politiku, regulu vai tehnisko standartu gadījumos.

- Pārtraukt izmeklēšanas laikā preču pārdošanu vai pakalpojumu sniegšanu, līdz tiek pien,emts lēmums, pamatojoties uz laboratorijas testēšanas rezultātu vai eksperta viedokli.

- Piemērot administratīvās sankcijas un soda naudas.

PTAC pašlaik ir 107 štata darbinieki, no kuriem vairākums ir iesaistīti patērētāju tiesību îstenošanā un produktu drošības jautājumos, iekḷaujot preču un pakalpojumu uzraudzību, patērētāju tiesību aizsardzību, patērētāju konsultācijas un sūdzības, kā arī pārrobežu jautājumus. Daḷu patērētāju likuma îstenošanas realizē DVI, it īpaši e-komercijas kontekstā. E-komercijas uzraudzību veic PTAC speciālās uzraudzības daḷas ar atbalsta vienību palīdzìbu. 5.2. tabula ir norādīta budžeta un personāla resursu informācija par 2017.-19. gada periodu. ${ }^{22}$

Papildus PTAC informācijas pieprasīšanu un saṇemšanu, kā arī administratīvo sankciju (soda naudu, aizliegumu) piemērošanu var veikt Valsts Veselības inspekcija (par veterināro un farmaceitisko pakalpojumu reklamēšanu) un Nacionālā elektronisko plašsaziṇas līdzekḷu padome (reklāmas). Gadījumos, kas ietver kriminālpārkāpumus (piemēram, saistībā ar surogātpastu), var tikt iesaistīta Valsts policija. 
5.2. tabula. PTAC budžets un personāls, 2017.-19. gads

\begin{tabular}{lcc}
\hline & Budžets (EUR) & Personāls (bez ECC-Net) \\
\hline $\mathbf{2 0 1 7}$ & 2383111 & 96 \\
2018 & 2895983 & 107 \\
$\mathbf{2 0 1 9}$ & 2849981 & 107 \\
\hline
\end{tabular}

Avots: ESAO, pamatojoties uz PTAC datiem.

Pēdējo gadu laikā ir ievērojami pieaudzis PTAC saṇemto patērētāju sūdzību skaits par distances līgumiem. Piemēram, 2017. gadā tika iesniegtas aptuveni 486 sūdzības, to apjomam pieaugot par vairāk nekā 200 \% salīdzinājumā ar 2017. gadu, kad tika iesniegtas 222 sūdzības. PTAC ir izmeklējusi vairākas lietas un pieṇēmusi lēmumus par patērētāju interešu aizsardzību, kā arī publicējusi norādes patērētājiem un brīdinājumus plašsaziṇas līdzekḷos, lai patērētājus informētu par problēmām, kas ir saistītas ar konkrētiem tiešsaistes mazumtirgotājiem un platformām.

5.3. tabula ir norādīti dati par PTAC iesniegtajām patērētāju sūdzībām laikā no 2017. gada līdz 2019. gada jūnijam.

5.3. tabula. PTAC saṇemtās un atrisinātās patērētāju sūdzības laikā, 2017. g. - 2019. g. jūnijs

\begin{tabular}{lcr}
\hline & Saņemtās sūdzības & Atrisinātās sūdzības \\
\hline $\mathbf{2 0 1 7}$ & 3616 & 958 \\
$\mathbf{2 0 1 8}$ & 3604 & 1002 \\
2019. g. (lī̃z 30. jūnijam) & 1940 & 405 \\
\hline
\end{tabular}

Avots: ESAO, pamatojoties uz PTAC datiem.

\section{Piemērošana}

PTAC regulāri apṇemas veikt īstenošanas darbības e-komercijas kontekstā. Papildus regulatīvajām pilnvarām, kas aprakstītas 5.7. ielikums, PTAC var likt tīmekḷa vietnēs bloḳēt nelikumīgu saturu, kas ir kaitīgs bērniem, tostarp no pakalpojumu sniedzējiem, kas ir reǵistrēti ārpus Eiropas Savienības. Daudzos gadījumos PTAC īstenošanas darbības ir saistītas ar negodīgu komerciālo praksi e-komercijā.

Ar kriminālu krāpšanu saistītās sūdzības parasti tiek nosūtītas Valsts policijai, lai tā veiktu attiecīgu izmeklēšanu un pārbaudes ar kriminālprocesuālu darbību palīdzību. Dažas no sūdzībām attiecās uz tiešsaistes mazumtirgotājiem, kuri nepiegādāja produktus vai neizmaksāja kompensāciju patērētājiem. 5.4. tabula ir norādīti dati par sūdzībām, kas saṇemtas no 2017. gada līdz 2019. gada jūnijam.

5.4. tabula. Ar e-komerciju saistītās sūdzības, 2017. g. - 2019. g. jūnijs

\begin{tabular}{|c|c|c|c|}
\hline & lesaistītie uzņēmumi & Saņemtās patērētāju sūdzības & Lēmums \\
\hline 2017 & 6 tiešsaistes mazumtirgotāji & 196 & Nodots Valsts policijai \\
\hline 2018 & 3 tiešsaistes mazumtirgotāji & 252 & Nodots Valsts policijai \\
\hline 2019. g. (līdz 30. jūnijam) & 1 izklaides pasākums & 105 & Nodots Valsts policijai \\
\hline
\end{tabular}

Avots: ESAO, pamatojoties uz PTAC datiem.

Negodīga komercprakse tiek uzskatīta par kolektīvo patērētāju interešu pārkāpumu un to īsteno ar kolektīvām patērētāju darbībām (izmantojot administratīvo tiesvedību). Atsevišķas patērētāju sūdzības nevar atrisināt ar šādu kolektīvu rīcību, tomēr PTAC ir kompetents iejaukties un pārtraukt šìs komercdarbības, pārkāpjot patērētāju tiesību aktus. To var izdarīt pēc brīvprātības principa ar brīvprātīgu pārkāpumu pārtraukšanu vai apṇemšanos, vai pieṇemot administratīvus lēmumus. Uzṇēmumu apṇemšanās un PTAC administratīvos lēmumus var izmantot kā pierādījumus patērētāji, kuri meklē kompensāciju tiesā vai iesaistās alternatīvā strīdu atrisināšanā. Tomēr ne visas patērētāju sūdzības izraisa kolektīvas darbības (piemēram, viena kolektīvā lieta var saturēt vairākas patērētāju sūdzības, patērētāja sūdzība par pārkāpumu var netikt uzturēta vai kolektīvā lieta var būt ierosināta pirms patērētāja sūdzības). ${ }^{23}$ 
Kaut arī nav pieejama specifiska statistika par negodīgu praksi e-komercijā, 5.5. tabula ir norādītas sūdzību darbības saistībā ar dažādu veidu komercpraksi, no kurām dažas ir saistītas ar e-komerciju.

5.5. tabula. Oficiālās patērētāju sūdzības par negodīgu komercpraksi laikā 2017. g. - 2019. g. jūnijs

\begin{tabular}{lc}
\hline & Sūdzības \\
\hline 2017 & 204 \\
2018 & 279 \\
2019. g. (lídz 30. jūnijam) & 197 \\
\hline
\end{tabular}

Avots: ESAO, pamatojoties uz PTAC datiem.

Pagaidām nav pieejama arī specifiska oficiālā statistika par nelikumīgu praksi e-komercijā. 5.6. tabula ir redzama iekšējā lietu izskatišanas informācija ("Uzraugs"), kas tiek glabāta PTAC iekšējā datubāzes sistēmā.

5.6. tabula. Nelikumīgas e-komercijas prakses, 2017. g. - 2019. g. jūnijs

\begin{tabular}{|c|c|c|c|c|c|}
\hline & $\begin{array}{c}\text { Sāktās } \\
\text { administratīiās } \\
\text { lietas (saistībā ar } \\
\text { tiešsaisti) }\end{array}$ & $\begin{array}{l}\text { PTAC aicinājumi uz } \\
\text { brīvprātīgu pārtraukšanu } \\
\text { (saistībā ar tiešsaisti) }\end{array}$ & $\begin{array}{c}\text { Saņemtās rakstveida } \\
\text { apņemšanās (saistībā ar } \\
\text { tiešsaisti) }\end{array}$ & $\begin{array}{c}\text { Pieņemtie administratīvie } \\
\text { lēmumi (saistībāa ar } \\
\text { tiešsaisti) }\end{array}$ & $\begin{array}{c}\text { Piemērotie sodi, } \\
\text { EUR } \\
\text { (saistībā ar } \\
\text { tiešsaisti) }\end{array}$ \\
\hline 2017 & 99 & 50 & 8 & 12 & 85000 \\
\hline 2018 & 177 & 149 & 1 & 18 & 194900 \\
\hline 2019. g. (līdz jūnijam) & 71 & 39 & 2 & 6 & 52570 \\
\hline
\end{tabular}

Piezīme: PTAC $=$ Patērētāju tiesību aizsardzības centrs.

Avots: ESAO, pamatojoties uz PTAC datiem.

\section{Uzraudzība un novērtēšana}

Patērētāju aizsardzības īstenošana e-komercijas kontekstā ir novērtēta ziṇojumā, ko PTAC katru gadu iesniedz EM. ${ }^{24}$ PTAC 2018. gada ikgadējā ziṇojumā ${ }^{25}$ tika iekḷauti vairāki interesanti ieskati, statistika un informācija par e-komercijas jomā veiktajām īstenošanas darbībām. Piemēram, attiecībā uz godīgu cenu noteikšanas praksi un distances līguma noteikumiem no tiešsaistes mazumtirgotājiem ziṇojumā ir norādīts, ka "tika pārbaudīti 25 no populārākajiem interneta veikaliem un ierosinātas 25 administratīvās lietas", kam sekoja pārkāpuma brīvprātīga pārtraukšana.

Vēl viens noderīgs uzraudzības instruments ir interneta pārbaude, ${ }^{26}$ ko organizē Eiropas Komisija un Starptautiskais patērētāju tiesību aizsardzības un īstenošanas tīkls (ICPEN) kā līdzekli ES patērētāju aizsardzības likuma realizēšanai. Pārbaudes ir veiktas dažādās jomās, iekḷaujot digitālos produktus, tiešsaistes lidsabiedrību biḷešu pārdošanu un bērniem paredzētas tiešsaistes spēles. Rezultāti sniedz noderīgu informāciju par patērētāju aizsardzības tiesību aktu iespējamiem pārkāpumiem un palīdz Latvijai novērtēt jautājuma nopietnību, kā arī patērētāju politikas ieviešanas efektivitāti valstī.

\section{Izglītība un informētība}

PTAC regulāri informē patēētājus par veidiem, kā droši iepirkties tiešsaistē, gan reaǵējot uz žurnālistu jautājumiem, gan arī caur sociālo tīklu kanāliem. PTAC uztur tīmekḷ vietni, ${ }^{27}$ lai patērētājus informētu par iespējamiem riskiem, kas ir saistìti ar maldinošu un krāpniecisku komercpraksi, ko ìsteno specifiski tiešsaistes veikali un platformas.

Turklāt PTAC ir izstrādājis kontrolsarakstu ${ }^{28}$ ar ieteikumiem un noderīgu informāciju patērētājiem, kad vin,i pien,em lēmumu par to, vai iepirkties tiešsaistes veikalā.

Turklāt PTAC ir izplatīijis informāciju (video, gif, infografiku), ko nodrošina Eiropas Patērētāju centru tīkls (ECC-Net) par abonēšanas lamatām un iepirkšanos tiešsaistē. 2018. gadā PTAC sadarbojās ar Patentu biroju kampaṇā par viltotām precēm. 
2019. gadā PTAC piedalijjās valdības institūciju atvērto durvju dienā. ${ }^{29}$ Augstskolas studenti apmeklēja PTAC un piedalījās dažādās aktivitātēs, ieguva informāciju par drošu iepirkšanos tiešsaistē un nedrošu preču atpazī̌anu, kā arī uzzināja par patērētāju tiesībām ne tikai Latvijā, bet arī ES.

PTAC ir ḷoti aktīvi atbalstījis patērētāju tiesības sociālajos tīklos. 2019. gada Valentīna dienā tas uzsāka kampaṇu par to, kā izvēlēties interneta iepazišanās tīmekḷ vietni. ${ }^{30}$ Turklāt PTAC regulāri internetā (savā tīmekḷa vietnē) publicē informāciju par patērētāju tiesību aizsardzību.

Papildus patērētāju izglītošanai PTAC ir iesaistījies patērētāju tiesību veicināšanā attiecībā uz e-komercijas darbībās iesaistītajiem uznēmumiem. It îpaši PTAC ir izlaidis nesaistošas vadlīnijas, lai uzṇēmumiem palīdzētu interpretēt likumdošanas aktus, it îpaši koncentrējoties uz elektronisko sakaru pakalpojumu tirgiem, līgumu noteikumiem un nosacijumiem e-komercijā, grupu pirkumiem, kā arī paziṇojumu un rīcības procedūrām, lai panāktu brīvprātīgu pārkāpumu pārtraukšanu tīmekḷa vietnēs.

2015. gada septembrī PTAC publicēja paketi Vadlīnijas godīgas komercprakses ìstenošanai bērniem paredzēto tiešsaistes spēḷ jomā. ${ }^{31}$ Iestāde sadarbojās ar Eiropas Komisiju un Dāniju attiecībā uz pirkumiem lietotnēs, koncentrējoties uz bērnu spēlu mobilajām lietotnēm, un rezultāti tika iekḷauti Vadlīnijās.

Arī nacionālās NVO aktīvi iesaistās patērētāju aizsardzības veicināšanā e-komercijas kontekstā. Piemēram, Latvijas Interneta asociācija ${ }^{32}$ organizē iniciatīvas, lai uzlabotu informētību par interneta drošību, tostarp e-komercijas kontekstā. LIKTA ${ }^{33}$ sadarbībā ar EM ir organizējusi vairākas aktivitātes, tostarp seminārus par e-komerciju un e-pakalpojumiem, organizējusi e-komercijas informācijas dienu un izveidojusi e-komercijas balvu labākajam e-komercijas pārdevējam. Turklāt NVO ir svarīga loma ar negodīgu komercpraksi saistìto tiesību aktu īstenošanā e-komercijas kontekstā, regulāri informējot PTAC par iespējamiem pārkāpumiem.

Turklāt LIKTA veicina e-prasmes, kā arī informētību tiešsaistes drošības jautājumos. Vairāk nekā 180000 cilvēku visā Latvijā ir piedalījušies tās apmācības iniciatīvā Latvija@Pasaule kopš 2005. gada, kas piedāvā apmācību un sertifikāciju, un ir izstrādājuši dažādus apmācỉbu projektus e-prasmēm un iekḷaujošai apmācībai.

\section{Domstarpību izškiršana un tiesību atjaunošana.}

Latvijas politikas mērķis strīdu izšķiršanā un tiesiskajā aizsardzībā (DRR) ir sniegt patērētājiem iespēju izmantot savas tiesības, noslēdzot līgumus ar ražotājiem, tirgotājiem vai pakalpojumu sniedzējiem un nodrošināt patērētājiem piekḷuvi godīgai un efektīvai $D R R$, rīkojoties individuāli vai kolektīvi gan Latvijā, gan arī saistītās pārrobežu domstarpībās.

Domstarpības, ko nevar atrisināt uzṇēmuma un patērētāja starpā, tiek izskatītas civiltiesās vai strīdu alternatīvās izškirišanas (SAI) struktūrās. SAI galvenās institūcijas ir PTAC un Sabiedrisko pakalpojumu regulēšanas komisijas (SPRK), kā arī privātas SAI organizācijas.

PTAC iekḷauj nacionālu SAI kontaktpunktu un uztur SAI institūciju sarakstu, kā arī Patērētāju sūdzību komiteju (PSK).

PSK tika izveidota līdz ar jaunākajiem Patērētāju tiesību aizsardzības likuma grozījumiem saskaṇā ar ES direktīvu 2013/11/ES par alternatīvu strīdu izšķiršanu patērētāju strīdos. PSK rīkosies pēc PTAC pilnvarām un atrisinās patērētāju un tirgotāju (uzṇēmumu) savstarpējos strīdus. PSK veidos trīs vai vairāk komitejas biedri, pēc vienlīdzības principiem pārstāvot ekspertus no patērētāju un tirgotāju NVO ar vienu neatkarīgu pārstāvi.

Latvijas Patēerētāju ārpustiesas strīdu risināšanas likums ${ }^{34}$ ir bijis spēkā kopš 2015. gada jūlija. Likumā ir izklāstīti noteikumi ārpustiesas strīdu risināšanas organizācijām, kas nodrošina, ka patērētāji var publicēt un aizsargāt savas likumīgās tiesības, iesniedzot sūdzības pret uzṇēmumiem un vienlaikus piedāvājot neatkarīgas, objektīvas, caurskatāmas, efektīvas, ātras un godīgas ārpustiesas strīdu izšķiršanas procedūras. Likums attiecas uz SAI juridiskajām personām un procedūrām iekšzemes un pārrobežu strīdu izšķiršanā attiecībā uz līgumsaistībām. Turklāt likumā ir norādīti konkrēti noteikumi un atbildība (pienākumi) SAI juridiskajām personām un piemērotas procedūras, iekḷaujot struktūru SAI juridisko personu savstarpējai sadarbībai, kā arī sadarbībai starp SAI un citām institūcijām. Likums 
neattiecas uz procedūrām pie strīdu izšḳiršanas organizācijām, kad par strīdu izšḳiršanu atbildīgās fiziskās personas nodarbina vai atalgo tikai atsevišḳ tirgotājs; uz procedūrām patēēētāju sūdzību izskatī̌̌anas sistēmās, ko izmanto tirgotājs; uz tiešām pārrunām patērētāja un tirgotāja starpā; uz procedūrām, kuras tirgotājs ir sācis pret patērētāju; uz tirgotāju savstarpējiem strīdiem; uz strīdiem saistībā ar veselības aprūpes pakalpojumiem, kurus veselības aprūpes speciālisti sniedz pacientiem, lai novērtētu, uzturētu vai atjaunotu viṇu veselības stāvokli, iekḷaujot medicīnas produktu un medicinas ierīču izrakstīšanu, izsniegšanu un nodrošināšanu; uz strīdiem par tālākizglītības vai augstākās izglìīibas publiskiem pakalpojumu sniedzējiem; uz strīdiem saistībā ar rīcību vai nolaidību no zvērināto notāru vai tiesas izpildītāju puses.

Ministru kabineta noteikumi 631/200835 regulē procedūras patērētāju prasījumu iesniegšanai par līguma noteikumiem neatbilstošu preci vai pakalpojumu.

Eiropas Parlamenta un Padomes Regulā (EK) 861/200736 ir noteikta Eiropas mazo prasījumu procedūra, kas ir paredzēta izmaksu samazināšanai, kā arī tiesvedības vienkāršošanai un paātrināšanai saistībā ar mazajiem prasījumiem pārrobežu lietās. Latvijā prasījumus par nelielām summām var iesniegt saskaņā ar Latvijas Civilprocesa kodeksu, ${ }^{37}$ kas paredz vienkāršotu procesu attiecībā uz prasībām, kuru summa ir mazāka par 2100 EUR.

\section{İstenošana un piemērošana}

$\mathrm{EM}^{38}$ ir svarīga loma Latvijas DRR politikas īstenošanā, cieši sadarbojoties ar citām ministrijām un iestādēm, piemēram, Valsts Veselības inspekciju, Valsts Pārtikas un veterināro dienestu un SPRK, kā arī NVO.

Saskaṇā ar noteikumiem par strīdu izšķiršanas procedūrām, kas ir ietverti Patērētāju tiesību aizsardzības likumā (26. sadaḷā), patērētājiem ir vispirms jāiesniedz prasība uzṇēmumam, lai meklētu tiešu izlīgumu. PTAC un citas institūcijas sniedz konsultācijas patērētājiem par viṇu tiesībām īpašās situācijās un attiecīgām darbībām, lai pieprasītu atlī̉zību. Konsultācijas var organizēt pa tālruni, e-pastu un klātienē PTAC telpās. Aptuveni 40-45 \% no sākotnējām prasībām var atrisināt ar šãdu samierināšanās procedūru palīdzību. Ja tiešās sarunās nevar panākt risinājumu, patērētājiem ir vairākas citas iespējas.

Ja patēēētājs iesniedz prasību PTAC un uzṇēmumā nevar panākt risinājumu, var sākt strīdu izšḳiršanas procedūru saskaṇā ar Ministru kabineta 613. regulējumu, kuru ievērojot, PTAC sasaistās tieši ar uzṇēmumu, lai panāktu risinājumu. Tas var iekḷaut administratīvu procedūru un saistošu lēmumu. Šādas administratīvas procedūras, ko veic valsts institūcijas, neparedz nekādas izmaksas patērētājiem, un atbildīgās institūcijas pienākums tiesā (ja lēmums tiek pārsūdzēts tiesā) ir ievākt nepieciešamo informāciju un pierādījumus strīdu atrisināšanai.

Vairākas nozares Latvijā nodrošina savus strīdu izšķiršanas mehānismus. PSK, kas darbojas PTAC pārvaldībā un iekḷauj privātā sektora pārstāvību, ir izveidojis alternatīvu strīdu izšḳiršanas organizāciju.

Sistemātiski tiek ievāktas patērētāju sūdzības, un tās tiek izskatītas pēc produkta kategorijas un patērētāju aizsardzības jautājuma. Turklāt PTAC, citas valdības ağentūras un NVO veic uzraudzības darbības, lai regulāri analizētu tirgus tendences. PTAC organizē dažādas informētības kampaṇas, tostarp sadarbībā ar valsts uzṇēmumiem un NVO, lai palīdzētu patērētājiem ar DRR.

Patērētāju tiesību aizsardzības likumā (22. un 23. sadaḷā) ir norādītas nevalstisko patērētāju organizāciju tiesības aizstāvēt patēēētāju intereses un piedalīties lēmumu pieṇemšanā. Turklāt saskaṇā ar Ministru kabineta noteikumiem Nr. 300 Ministru kabineta kārtības rullis ${ }^{39}$ nevalstiskajām ieinteresētajām pusēm ir jābūt iesaistītām likumprojektu un politikas plānošanas dokumentu sastādīšanā. Patērētāju NVO ir arī tiesības izmeklēt patērētāju sūdzības, palīdzēt patēēēājiem tiesvedībāun pārstāvēt patērētāju intereses valsts tiesās. NVO darbs tiek uztverts kā svarīgs avots informācijai par attīstību patērētāju tirgos, iekḷaujot patēēētāju tiesību potenciālus vai faktiskus pārkāpumus. 5.7. tabula ir parādīta statistika par patēerētāju iekšzemes un pārrobežu strīdiem.

Iepriekš minētā informācija norāda, ka Latvijas datu ievākšanas un analīzes sistēma pēdējo gadu laikā ir uzlabojusies, un PTAC tagad var nodalīt iekšzemes krāpšanas un pārrobežu lietas. 
5.7. tabula. Iekšzemes un pārrobežu patērētāju strīdi

\begin{tabular}{|c|c|c|c|c|c|c|}
\hline & \multicolumn{3}{|c|}{ lekšzemes lietas } & \multicolumn{3}{|c|}{ Pārrobežu lietas ECC-Net } \\
\hline & Strīidi & $\begin{array}{c}\text { Tiesību } \\
\text { atjaunošana }{ }^{1}\end{array}$ & Atrisinātās ${ }^{2}$ & Strīdi & $\begin{array}{c}\text { Tiesību } \\
\text { atjaunošana1 }\end{array}$ & Atrisinātās ${ }^{2}$ \\
\hline 2017 & 1929 & - & 595 & 634 & - & 285 \\
\hline 2018 & 1976 & - & 707 & 489 & - & 203 \\
\hline 2019. gads (līdz 30. jūnijam) & 1132 & - & 203 & 235 & - & 172 \\
\hline
\end{tabular}

1. "Atrisināta" nozīmē to, ka ir panākta pušu savstarpējā vienošanās (tomēr ne obligāti tiesību atjaunošana).

2. PTAC nav pieejama informācija par tiesību atjaunošanu.

Avots: PTAC.

\section{Likumu piemērošana attiecībā uz surogātpastu}

Latvijas politikas mērḳis attiecībā uz surogātpastu ir veicināt godīgu komercpraksi un nodrošināt personas datu apstrādes noteikumu ievērošanu komerciālās komunikācijas kontekstā. Komerciālā komunikācija ieklauj automātiskus zvanus, e-pastu un faksu, kas tiek nosūtīts fiziskām personām bez viṇu tiešas piekrišanas. Personas datu apstrādes noteikumi aptver kontaktinformāciju, kuru var ievākt pakalpojumus sniedzējs, it ippaši iekḷaujot gadījumus, kad šāda apstrāde tiek veikta nolūkos, kas nav komercdarījums, kura nolūkā dati tika ievākti.

\section{Tiesiskais regulējums}

Vispārīgās prasības par informāciju, kas ražotājiem vai pakalpojumu sniedzējiem (uzṇēmumiem) ir jāsniedz patērētājiem, ir noteiktas Patēēêtāju tiesību aizsardzības likumā. Negodīgas komercprakses aizlieguma likums regulē komercprakses, kas ir maldinošas, agresīvas vai nekompetentas profesionālās uzcìtības zin̄ā. Personas datu apstrādes likums nodrošina personas datu aizsardzỉbas principus un regulējumu, it īpaši attiecībā uz nevēlamu komerciālu ziṇojumu vai surogātpasta sūtǐšnu, ko var uzskatīt par pārkāpumu. Informācijas tehnologiju drošỉbas likuma ${ }^{40}$ galvenais mērḳis ir uzlabot informācijas tehnoloǵiju drošǐbu. Likumā ir norādītas svarīgākās prasības, lai garantētu ar šādu tehnolog̣iju starpniecību nodrošināto svarīgo pakalpojumu sanemšanu. Ar to tiek izveidota arī Latvijas Informācijas tehnoloǵiju drošỉbas incidentu reaǵěšanas vienība (CERT.LV) ${ }^{41}$ - institūcija, kuras pilnvaras ieklauj valsts un pašvaldību varas iestāžu informācijas tehnoloğiju drošības uzraudzību un pārvaldību, kas var iekḷaut surogātpasta apkarošanu.

Vairāk detalizēti noteikumi par personas datu aizsardzību un nevēlamas komerciālās komunikācijas aizliegumiem ir ietverti Informācijas sabiedrības pakalpojumu likumā. Ar šo likumu tiek aizliegta automatizēta komerciālā komunikācija, ja tās adresāts nav sniedzis iepriekšēju, brīvu un skaidri formulētu piekrišanu, turklāt šādā komunikācijā ir jāiekḷauj iespēja, ka adresāts var to noraidīt. Šìs juridiskās saistības attiecas arī uz automātiskām zvanu sistēmām, kas darbojas bez cilvēka iejaukšanās, iekḷaujot e-pastu un faksu. Turklāt likumā ir norādīti nosacījumi, ar kuriem pakalpojumu sniedzējs, kurš ir ieguvis elektroniskā pasta adreses no patērētājiem komerciālo darījumu kontekstā, var šādas adreses izmantot citai komerciālai komunikācijai. Tie iekḷauj šos apstākḷus: 1) komerciālā komunikācija attiecas uz līdzīgiem pakalpojumu sniedzēja produktiem vai pakalpojumiem; 2) klients nav iebildis pret turpmāko e-pasta ziṇojumu saṇemšanu; 3) klientam ir sniegta skaidra, noteikta bezmaksas iespēja noraidīt turpmākos e-pasta ziṇojumus.

\section{Izpildes pilnuaras}

Divas galvenās institūcijas, kuru pienākumi un pilnvaras ir saistītas ar surogātpastu, ir DVI un PTAC. Abas iestādes var pieprasīt un saṇemt informāciju, ìstenot likumīgos pienākumus un piemērot administratīvās sankcijas (soda naudas un aizliegumus). Turklāt Latvijas Valsts policija ${ }^{42}$ (Iekšlietu ministrija) var iesaistīties, ja surogātpasta lietas ir saistītas ar kriminālpārkāpumiem, un CERT.LV var iejaukties, ja lietas ietekmē informācijas sistēmu un tīklu drošību. Ar patēēētāju aizsardzību saistītie uzṇēmumi un NVO sekmē uz surogātpastu attiecināmo tiesību aktu îstenošanu, tostarp informējot atbildīgo uzraudzības iestādi par iespējamiem pārkāpumiem. 
Ja kāda uzraudzības iestāde konstatē likumpārkāpumu, tai ir tiesības: 1) pieprasīt visu informāciju, kas ir nepieciešama lietas apstākḷu noskaidrošanai; 2) likt pakalpojumu sniedzējam pārtraukt likuma pārkāpšanu un norādīt laika periodu, kurā uzṇēmumam ir jānodrošina atbilstība likumam.

Lai izvairītos no interešu konflikta, PTAC darbības strīdu novēršanā tiek nodalītas no izpildes darbībām. Strīdu izšḳiršanu veic patērētāju konsultāciju un sūdzību daḷa, un tiesībaizsardzību realizē patērētāju tiesību aizsardzības dạ̦a.

\section{Pārrobežu sadarbība}

Latvijas tiesībaizsardzības iestādes surogātpasta jautājumos sadarbojas ar ārvalstu (galvenokārt Eiropas) tiesībaizsardzības iestādēm surogātpasta jautājumos. It īpaši saskaṇā ar Informācijas sabiedrības pakalpojumu likumu PTAC sadarbojas ar iestādēm no Eiropas Ekonomikas zonas (EEZ) valstīm. Turklāt DVI piedalās ES dalībvalstu valsts iestāžu sadarbības tīklā saskaņā ar EK regulu 2006/200443 par sadarbību starp valstu iestādēm, kas atbildīgas par tiesību aktu ìstenošanu patērētāju tiesību aizsardzības jomā. Šì sadarbība it īpaši ir saistīta ar surogātpasta lietām, kas ietver Personas datu aizsardzības likuma pārkāpumus.

Nav pietiekamas informācijas vai pierādījumu par pakāpi, kādā PTAC un DVI vērtē Latvijas surogātpasta politiku un ir veikušas atbilstīgus pasākumus un uzlabojumus, piemēram, uzlabotu sadarbību ar ārvalstu tiesībaizsardzības iestādēm ārpus EEZ.

PTAC nav konkrētas informācijas vai statistikas par surogātpastu vai saistītiem jautājumiem un tiesībaizsardzības darbībām. Datus par surogātpastu ievāc CERT.LV. Sadarbība starp ag̉entūrām, lai veiktu saistītās informācijas apmaiṇu un analizētu šādus datus, varētu palīdzēt risināt patērētāju problēmas šajā jomā.

\section{Divpusēja palīdzība un pārrobežu sadarbība}

Pārrobežu krāpšanas gadījumi galvenokārt tiek izskatīti, PTAC piedaloties vairākos Eiropas un starptautiskajos tīklos, kas uzlabo informācijas apmainu un sadarbību tiesībaizsardzības jomā. PTAC ir dal̦a no Eiropas Tiesībaizsardzības ağentūru sadarbības tīkla, kas tika izveidots saskaṇā ar Patērētāju tiesību aizsardzības likuma regulu un tiek izmantots, lai risinātu kolektīuāa patērētāju lietas. Latvija ir dalïbniece arī EEK tīklā (ECC-Net), ${ }^{44}$ kas aptver visu Eiropu un palīdz atrisināt atsevišķus pārrobežu strīdus ES. Četras PTAC ieceltas personas pašlaik strādā EKK tīklā. Labāko praksi un izpildes mehānismus izplata arī Eiropas Komisija un ES Padomes darba grupas..

Turklāt PTAC ir ICPEN dalībniece un piedalās ES un ICPEN pārbaudēs, lai novērstu pārrobežu pārkāpumus dažādās jomās, piemēram, saistībā ar tūrismu un pirkumiem lietotnēs. PTAC iesaistās arī Krāpšanas novēršanas mēnesī, ko koordinē ICPEN.

Latvijas ir parakstijusi vairākus divpusējus līgumus par pārrobežu krāpšanas apkarošanu. It īpaši PTAC ir parakstījis sadarbības līgumus ar Lietuvas un Igaunijas patērētāju aizsardzības un tirgus uzraudzības iestādēm. Kopīgas sanāksmes tiek noturētas vismaz vienreiz gadā, lai pārrunātu darba rezultātus un kopējās lietas, kā arī veiktu labākās pieredzes apmainuu. 2011. gada septembrī PTAC parakstīja arī Kopīgā nodoma deklarāciju ar Izraēlas Rūpniecības, tirdzniecības un darba ministriju (MoITAL), lai sadarbotos saistībā ar tirgus uzraudzību un tiesībaizsardzību nepārtikas patērētāju produktu drošības jomā.

Latvijas patērētāji, kas ir saskārušies ar krāpšanu, kas saistīta ar citā valstī bāzētu uzṇēmumu, var iesniegt sūdzību PTAC. Ja Latvijā tiek konstatēta ES pārrobežu pārkāpuma lieta, tad PTAC rīkojas saskaņā ar Regulu par sadarbību patērētāju tiesību aizsardzības jomā, nosūtot informācijas un/vai tiesībaizsardzības pieprasījumus citām ES tiesībaizsardzības aǵentūrām. Ja pārkāpumu ir izdarījis uzṇēmums, kas darbojas ārpus ES, tad PTAC var izmantot ICPEN sadarbības mehānismu. Patērētāji var arī iesniegt sūdzības e-patērētāju tīmekḷ vietnê, ${ }^{45}$ kas ir globāla sistēma sadarbībai pārrobežu lietās, kurās PTAC piedalās.

\section{Noslēgums un politikas ieteikumi}

Lodziṇā 5.6 ir Latvijai piedāvāti ieteikumi, lai uzlabotu tās pierādījumu bāzi patērētāju politikas lēmumu pien,emšanai un patērētāju aizsardzību ES un ārpus tās. 


\subsection{Ielikums. ESAO ieteikumi Latvijai par patērētāju aizsardzības uzlabošanu}

Latvijai ir jāapsver:

- e-komercijai specifisku patērētāju sūdzību datu izstrāde, lai labāku saprastu ar e-komercijas darījumiem saistīto patērētāju problēmu raksturu un mērogu (saskaṇā ar ESAO E-komercijas rekomendācijas 53. sadalıu);

- patērētāju informētības uzlabošana ar e-komerciju saistītos jautājumos un viṇu digitālās kompetences uzlabošana ar informētības programmām, paturot prātā dažādu grupu īpašās pamatvajadzības, piemēram, vecumu, ienākumus un lasītprasmi (saskaṇā ar ESAO e-komercijas rekomendācijas 50.-51. sadal̦u);

- valsts strīdu izškiršanas un kompensācijas sistēmas efektivitātes novērtēšana, piemēram, izpētot patēerētāju lietojumu un apmierinātību, kā arī neatrisinātu strīdu gadījumus;

- pārrobežu strīdu ārpus ES pierādijjumu bāzes uzlabošana, kā arī pārrobežu sadarbība tiesībaizsardzības jomā ES un ārpus tās. 


\section{Atsauces}

AM (2020), Publiskais pārskats par CERT.LV uzdevumu izpildi: 2020. gada 1. ceturksnis [CERT.LV Quarterly Public Review], Aizsardzības ministrija, Rīga, https://cert.lv/uploads/parskati/CERT-LV_Q1_2020_pub.pdf.

AM (2019), Kiberdrošì bas stratēgija 2019.-2022. gadam [Cyber Security Strategy 2019-2022], Aizsardzỉbas ministrija, Rīga, https://www. mod.gou.lu/sites/mod/files/document/kiberstrategija.pdf.

AM (2016), Pārskats par kiberdrošì bas stratēgijas 2014-2018 īstenošanu vidusposmā [Mid-term Review of the Implementation of the 2014-2018 Cyber Strategy], Aizsardzỉbas ministrija, Rìga.

AM (2014), Latuijas kiberdrošì bas stratēgija (2014-2018) [Cyber Security Strategy of Latvia (2014-2018)], Aizsardzības ministrija, Rīga, www.mod.gou.lv/sites/mod/files/document/Kiberdrosibas_strategija\%20EN\%20\%281\%29.pdf.

CERT.LV (2020), CERT.LV registrētie incidenti no 01.01.2020. līdz 31.03.2020 (Incidents registered with CERT.LV from 01.01.2020. until 31.03.2020), https://cert.lv/lv/2020/04/pieejama-statistika-par-2020-gada-1-ceturksni.

CERT.LV (2018), CERT.LV Public Performance Report, Aizsardzỉbas ministrija, Rīga, https://cert.lv/uploads/cert-gada-parskats-2019.pdf.

DVI (2020), 2019. gada darbī bas ziṇojums [Activity Report 2019], Latvijas Republikas Datu valsts inspekcija, Rīga, https://www.dvi. gou.lv/en/wp-content/uploads/2013/01/Annual-report-2019.pdf.

ELKM (Igaunija) (2019), Cyber Security Strategy, Ekonomikas lietu un komunikāciju ministrija, Tallina, www.mkm.ee/sites/default/ files/kyberturvalisuse_strateegia_2022_eng.pdf.

ESAO (2016), Consumer Protection in E-commerce: OECD Recommendation, OECD Publishing, Parīze, www.oecd.org/sti/consumer/ ECommerce-Recommendation-2016.pdf.

ESAO (2015), Digital Security Risk Management for Economic and Social Prosperity, OECD Publishing, Parīze, www.oecd.org/sti/ieconomy/ digital-securityrisk-management.pdf.

ESAO (2012), Cybersecurity Policy Making at a Turning Point: Analysing a New Generation of National Cybersecurity Strategies for the Internet Economy, ESAO, Parize, www.oecd.org/sti/ieconomy/cybersecurity\%20policy\%20making.pdf.

ESAO (2002), Recommendation of the Council Concerning Guidelines for the Security of Information Systems and Networks - Towards a Culture of Security, ESAO, Parize, https://legalinstruments.oecd.org/en/instruments/OECD-LEGAL-0312.

ESAO (1998), Cryptography Policy: The Guidelines and the Issues: The OECD Cryptography Policy Guidelines and the Report on Background and Issues of Cryptography Policy, OECD Publishing, Parīze, https://dx.doi.org/10.1787/9789264162426-en.

VARAM (2014), Informācijas sabiedrības attīstības pamatnostādnes 2014-2020 [Information Society Development Guidelines 2014-2020], Vides aizsardzība un reǵionālās attīstības ministrija, Rīga www.varam.gov.lv/eng/darbibas_veidi/e_gov/?doc=13317.

\section{Piezīmes}

\section{Izraēla}

Statistikas datus par Izraēlu sniedza, un par tiem atbild Izraēlas attiecīgās iestādes. Šo datu izmantošana ESAO neskar Golānas augstieṇu, Austrumjeruzalemes un Izraēlas apmeț̣u statusu Rietumkrastā saskaṇā ar starptautisko tiesību noteikumiem.

1. WannaCry ir l̦aunprātīga programmatūra, kas ir izraisījusi ievērojamu kaitējumu organizācijām. Mirai inficē datorus ar robottīklu, kas pēc tam veic izkliedētā pakalpojumu atteikuma (DDoS) uzbrukumus.

2. Pirmā Datordrošības incidentu reaǵěšanas vienība (CSIRT) Latvijā tika izveidota 2006. gadā un 2011. gadā kḷuva par CERT.LV;

3. Digitālās drošības politika Latvijā aptver daudzas jomas, iekḷaujot kiberkaru (AM), kibernoziegumus (IeM), telekomunikācijas (SM), finanšu sistēmu digitālo drošību (FM) un privātuma aspektus (TM). 
4. Izṇemot Latvijas Banku, kurai NITDP ir pastāvīgs pārstāvis.

5. Skatiet Eiropas Datu aizsardzības padomes jaunumu sadal̦u, kas ir pieejama šeit: https://edpb.europa.eu/news/ national-news/2019/data-state-inspectorate-latvia-imposes-financial-penalty-7000-euros-against_en. DSI preses izlaidums ir pieejams šeit: www.dvi.gov.lv/lv/zinas/datu-valsts-inspekcija-piemero-7000-eiro-lielu-naudas-sodu-internetveikalampar-personas-datu-apstrades-parkapumiem.

6. Papildinformācija, kas attiecas uz ziṇošanu par datu pārkāpumiem un paziṇojumu formātu, ir pieejama DVI tīmekḷa vietnē: www.dvi.gov.lv/lv/personas-datu-apstrades-aizsardzibas-parkapuma-pazinojuma-iesniegsana.

7. Daži saistītie piemēri ir Labākās pieredzes cel̦vedis par privātuma programmu (PPP) pārvaldību (Practice Guide on Privacy Management Programs (PMP)), kuru ir izstrādājis Honkongas Privātuma biroja Personas datu komisārs, akcentējot privātajam un publiskajam sektoram piemērojamo privātuma pārvaldības programmu prasības, kas ir pieejamas šeit: www.pcpd.org.hk/pmp/pmp.html. Līdzīgā veidā Singapūras Personas datu aizsardzības komisārs ir publicējis Ceḷvedi datu aizsardzības pārvaldības programmas izstrādei, kas tika pārskatīts 2019. gada jūlijā un kura mērḳis ir palīdzība 2012. gada personas datu aizsardzības akta atbilstības nodrošināšanā; pieejams šeit: http://bit.do/fp4. Arī Vadlinijas privātuma pārualdības programmas ieviešanai, lai nodrošinātu privātuma pārskatāmību Manitobas publiskajā sektorā (Guidelines for Implementing a Privacy Management Program for Privacy Accountability in Manitoba's Public Sector) tika sastādītas saskaṇā ar dokumentu Pārskatāmības tiesību iegūšana ar privātuma pārvaldības programmu (Getting Accountability Right with a Privacy Management Program), kuru kopīgi publicēja Kanādas Privātuma biroja komisārs un Albertas un Britu Kolumbijas Informācijas un privātuma biroju komisāri; pieejams šeit: www.ombudsman. mb.ca/uploads/document/files/privacy-management-program-guidelines-en.pdf. Meksikas Datu aizsardzības aǵentūra (INAI) 2018. gada augustā izstrādāja komplektu Vadlinijas datu aizsardzības pārvaldības programmām (Guidelines for Data Protection Management Programs), kas bija paredzēts publiskā sektora juridiskajām personām un satur norādes, pasākumus un rekomendācijas, lai ievērotu saistības, kas izklāstītas Vispārīgajā likumā par personas datu aizsardzību publiskā sektora juridiskajām personām (General Law on Protection of Personal Data for Public Sector Entities) un Vispārīgajās vadlīnijās par personas datu aizsardzību publiskā sektora juridiskajām personām (General Guidelines on Personal Data Protection for the Public Sector). Dokuments spāṇu valodā ir pieejams šeit: http://inicio.inai.org.mx/ SitePages/Documentos-de-Interes.aspx? $a=m 4$

8. DVI rekomendācijas un vadlīnijas ir pieejamas šeit: www.dvi.gov.lv/en/legal-acts/recommendations-and-guidelines.

9. data.gov.lv mērḳis ir apkopot un laist apgrozībā valdības iestāžu un organizāciju ievāktos datus vienuviet publiskai izmantošanai, pamatojoties uz to, ka šie dati ir vērtīgi inovāciju attīstībai. Pieejams šeit: https://data. gov.lu.

10. 1999. gada 18. marta Patērētāju tiesību aizsardzības likumu skatiet šeit: https://likumi.lv/ta/en/id/23309-consumerrights-protection-law.

11. 2007. gada 22. novembra Negodigas komercprakses aizlieguma likumu skatiet šeit: https://likumi.lv/ta/en/en/ id/167759-unfair-commercial-practices-prohibition-law.

12. 2014. gada 20. maija regulējumu Nr. 255 Noteikumi par distances līgumu skatiet šeit: https://likumi.lv/ta/en/en/ id/266462-regulations-regarding-distance-contracts.

13. 2004. gada 4. novembra Informācijas sabiedrības pakalpojumu likumu skatiet šeit: https://likumi.lv/ta/en/en/ id/96619-law-on-information-society-services.

14. 2004. gada 28. oktobra Elektronisko sakaru likumu skatiet šeit: https://likumi.lv/ta/en/id/96611-electroniccommunications-law.

15. Pieejams šeit: www.dvi.gov.lv/en.

16. 1999. gada 20. decembra Reklāmas likumu skatiet šeit: https://likumi.lv/ta/en/en/id/163-advertising-law.

17. Maksājumu pakalpojumu un elektroniskās naudas likumu skatiet šeit: www.fktk.lv/texts_files/0_Law_Payment_Services_ Electronic_Money.pdf.

18. Eiropas Parlamenta un Padomes regulu (ES) 2018/302, ar ko novērš nepamatotu ǵeogrāfisko blokēšanu un citus diskriminācijas veidus iekšèjā tirgū klientu valstspiederības, dzīvesvietas vai uzṇēmējdarbības veikšanas vietas dēl, skatiet šeit: https:// eur-lex.europa.eu/legal-content/EN/TXT/?uri=CELEX\%3A32018R0302.

19. Eiropas Parlamenta un Padomes Regula (ES) 2017/2394 (2017. gada 12. decembris) par sadarbību starp valstu iestādēm, kas atbild par tiesību aktu izpildi patērētāju tiesību aizsardzības jomā,un ar ko atcel, Regulu (EK) Nr. 2006/2004, skatiet šeit: https://eur-lex.europa.eu/legal-content/EN/TXT/?uri=celex\%3A32017R2394.

20. Papildinformācija ir pieejama šeit: www.em.gov.lv/en.

21. Papildinformācija par PTAC ir pieejama šeit: www.ptac.gov.lv/en/content/about-crpc.

22. Pieejams šeit: http://ptac.gou.lv/sites/default/files/01_tame_ptac_2018_01.pdf. 


\section{UZTICAMĪBAS VEICINĀŠANA DIGITĀLAJAI EKONOMIKAI}

\section{Atsauces un Piezimes}

23. Saṇemtās rakstveida apṇemšanās ir publicētas PTAC tīmekḷa vietnē šeit: http://ptac.gou.lv/lv/table/rakstveida-apnemsanas. PTAC pien,emtie administrativie lēmumi ir publicēti PTAC tīmekḷa vietnē šeit: http://ptac.gov.lv/lv/table/ptac-l-mumi.

24. Pieejams šeit: www.em.gou.lv/en.

25. Pieejams šeit: http://ptac.gov.lv/sites/default/files/gada-parskats-2018.pdf.

26. Pieejams šeit: https://ec.europa.eu/info/live-work-travel-eu/consumers/enforcement-consumer-protection/sweeps_en.

27. Pieejams šeit: www.ptac.gov.lv/lv/content/aizdomigo-interneta-vietnu-saraksts.

28. Pieejams šeit: www.ptac.gou.lv/lv/content/k-izv-l-ties-dro-u-i-veikalu.

29. Papildinformācija ir pieejama šeit: www.facebook.com/ptacgoulv/posts/1164183977095012.

30. Papildinformācija ir pieejama šeit: www.facebook.com/ptacgoulv/photos/a.274069902773095/1111458369034240/?typ $e=3$ \& theater.

31. Pieejams šeit: http://ptac.gov.lv/sites/default/files/docs/nr_19_vadlinijas_tiessaistes_speles_0.pdf.

32. Papildinformāciju skatiet šeit: www.lia.lv.

33. Papildinformācija ir pieejama šeit: https://likta.lv/en/home-en.

34. 2015. gada 18. jūnija Patērētāju ārpustiesas strīdu risinātāju likumu skatiet šeit: https://likumi.lv/ta/en/id/275063-law-onout-of-court-consumer-dispute-resolution-bodies.

35. Pieejams šeit: www.vvc.gov.lv/export/sites/default/docs/LRTA/MK_Noteikumi/Cab._Reg._No._631_-_Consumer_Claims.doc.

36. Pieejams šeit: http://eur-lex.europa.eu/legal-content/EN/TXT/PDF/?uri=CELEX:32007R0861\&qid=1408967394914\&from=LV.

37. Pieejams šeit: https://likumi.lv/ta/en/id/50500-civil-procedure-law.

38. Pieejams šeit: www.em.gov.lv/en.

39. Pieejams šeit: https://likumi.lv/ta/en/id/190612-rules-of-procedures-of-the-cabinet-of-ministers.

40. 2010. gada 10. novembra Informācijas tehnoloǵiju drošỉbas likumu skatiet šeit: www.dvi.gou.lv/en/legal-acts/law-onthe-security-of-information-technologies.

41. Pieejams šeit: https://cert.lv/en.

42. Pieejams šeit: www.vp.gov.lv.

43. Pieejams šeit: https://eur-lex.europa.eu/legal-content/en/ALL/?uri=CELEX\%3A32004R2006.

44. Papildinformācija ir pieejama šeit: www.ecclatvia.lv.

45. Pieejams šeit: www.econsumer.gov. 


\section{Nodala 6}

\section{EKONOMIKAS UN SABIEDRĪBAS DIGITĀLĀS PĀRVEIDES IESPËJU IZMANTOŠANA}




\section{Digitālo inovāciju šlzērṣ̦̌u novēršana}

Kopš tūkstošgades sākuma Latvija ir guvusi ievērojamu ekonomisko progresu. Valsts ekonomika aug ātrāk nekā citās ES un ESAO dalībvalstīs. Taču produktivitāte joprojām ir ievērojami zemāka nekā citās ESAO valstīs, un darbspējas vecuma iedzīvotāju skaita samazināšanās ierobežo turpmākās izaugsmes iespējas. Digitālās inovācijas ir būtiski svarīga, lai palielinātu produktivitāti un paaugstinātu dzīves līmeni. Tāpēc Latvijas valdība ir veikusi pasākumus, lai palielinātu pētniecību un izstrādi, kā arī inovācijas, kas pašlaik ir zemā līmenī. Taču koordinētāka pieeja pētniecības un inovācijas politikas ìstenošanai, kurā IKT tiktu uzskatītas par transversālu tehnoloǵiju, varētu palīdzēt Latvijai uzlabot savus vājos inovāciju rādītājus.

\section{Inovācijas un pētniecības situācija Latuijā}

Latvija saskaras ar vairākiem sarežǵijumiem, kas var kavēt ekonomikas izaugsmi nākotnē. Iedzīvotāju novecošanās un augsta emigrācijas līmeṇa dēḷ darbspējas vecuma iedzìvotāju daḷa samazinās. Lai gan nelielais vietējais tirgus padara uz eksportu vērstu izaugsmi par nepieciešamību, tomēr Latvija krietni atpaliek no Eiropas ražošanas centriem. Inovāciju veicināšana var palīdzēt Latvijai šos šḳēršḷus pārvarēt. Inovācijas var uzlabot produktivitāti, kas pašlaik ir zemā līmenī, tādējādi veicinot izaugsmi, neskatoties uz iedzīvotāju skaita samazināšanos, un palielināt algas, kas var palīdzēt noturēt darbiniekus (6.1. attēls). Jo īpaši digitālās inovācijas var l̦aut pārvarēt attāluma problēmas un palīdzēt Latvijai palielināt eksporta apjomu.

\section{1. attēls. Produktivitātes atšḳirības atlasītajās ESAO valstīs, 2017. gads}

IKP procentuālās atškirīibas par nostrādātu stundu salīdzinājumā ar 17 bagātākajām ESAO valstīm

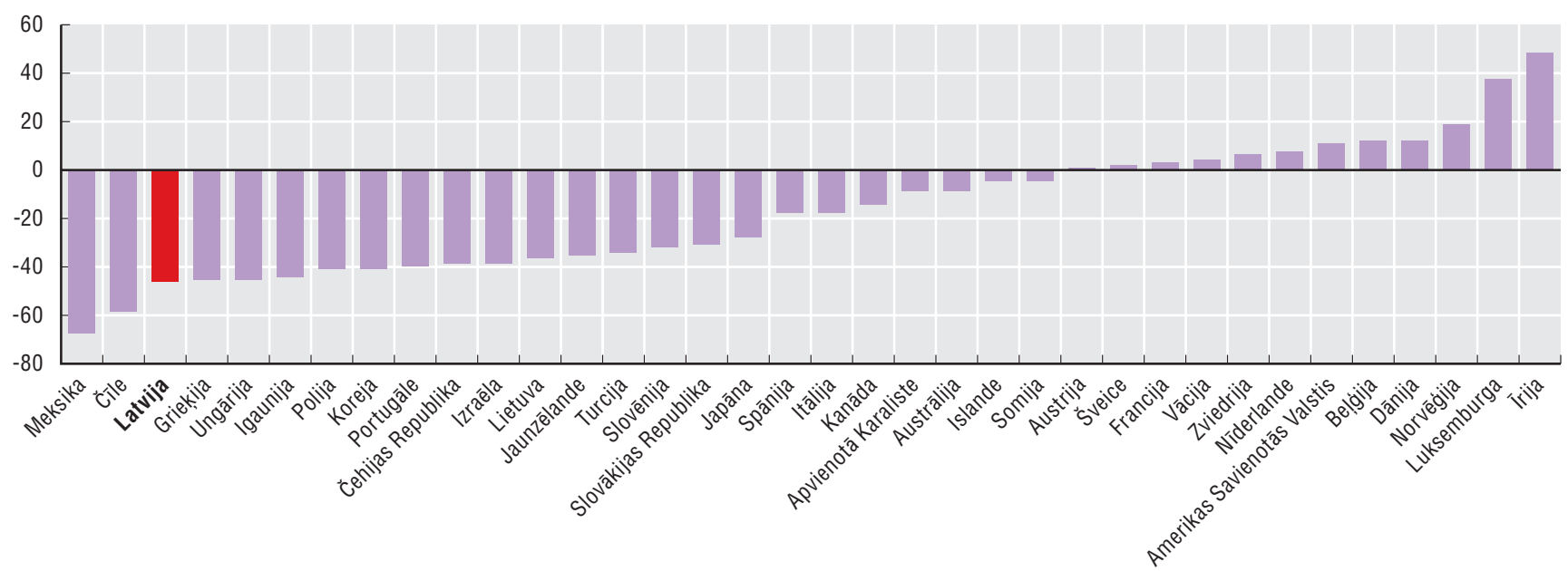

Piezīme: Salīdzinājumā ar svērto vidējo rādītāju, izmantojot iedzīvotāju blīvumu 17 ESAO valstīs ar augstāko IKP uz vienu iedzīvotāju 2016. gadā, pamatojoties uz 2016. gada pirktspējas paritāti (PPP). Darba produktivitāte tiek noteikta kā IKP par nostrādātu stundu.

Avots: ESAO (2019a), OECD Economic Surveys: Latvia 2019, https://dx.doi.org/10.1787/f8c2f493-en.

Pašlaik inovācijām ir salīdzinoši neliela nozīme Latvijas ekonomikā. Pētniecība un izstrāde ir īpaši zemā līmenī, pat salīdzinot ar valstīm, kurām ir līdzīgs IKP uz vienu iedzìvotāju. Turklāt pētniecībā un izstrādē gandrīz ceturto daḷu finansē Eiropas Savienība (6.2. attēls). Latvijā uzṇēmumu izdevumi pētniecībai un izstrādei arī veido vienu no zemākajām IKP daḷām salīdzinājumā ar citām ESAO valstìm.

Latvijai ir arī vāji rezultāti attiecībā uz citiem inovācijas pasākumiem (Eiropas Komisija, 2018a). Valstī ir viena no zemākajām inovatīvu mazo un vidējo uzṇēmumu (MVU) daḷām E S (6.3. attēls). Turklāt Latvijas uzṇēmumu inovācija lielā mērā ir vērsta uz esošo tehnoloǵiju pārṇemšanu, nevis uz jaunu inovāciju veidošanu, kas savukārt radītu intelektuālo īpašumu. Tādējādi patenta pieteikumu skaits uz vienu iedzīvotāju Latvijā ir starp zemākajiem Eiropā (Lauma Muižniece, 2017) (6.4. attēls). Latvijas inovāciju plaisu apliecina tās eksporta specializācija produktos ar zemu pievienoto vērtību un augstu resursu patērēšanas līmeni (ESAO, 2017a). Šos vājos rezultātus daḷēji var skaidrot ar mikrouzṇēmumu 
un mazo uzṇēmumu lielo proporciju (sk. 4. nodal̦u), kuri parasti ir mazāk inovatīvi, un ar ārvalstu tiešo ieguldījumu (ĀTI) apmēru, kas ir zem ES vidējā rādītāja, ĀTI lielākoties tiekot novirzītiem uz nozarēm, kas parasti neveic ieguldījumus pētniecībā un izstrādē (Eiropas Komisija, 2018a; ESAO, 2020a).

\section{2. attēls. Uzṇēmumu izdevumi pētniecỉbai un izstrādei Latvijā un atlasītajās ESAO valstīs, 2018. gads}

\section{Kā procentuālā dala no IKP}

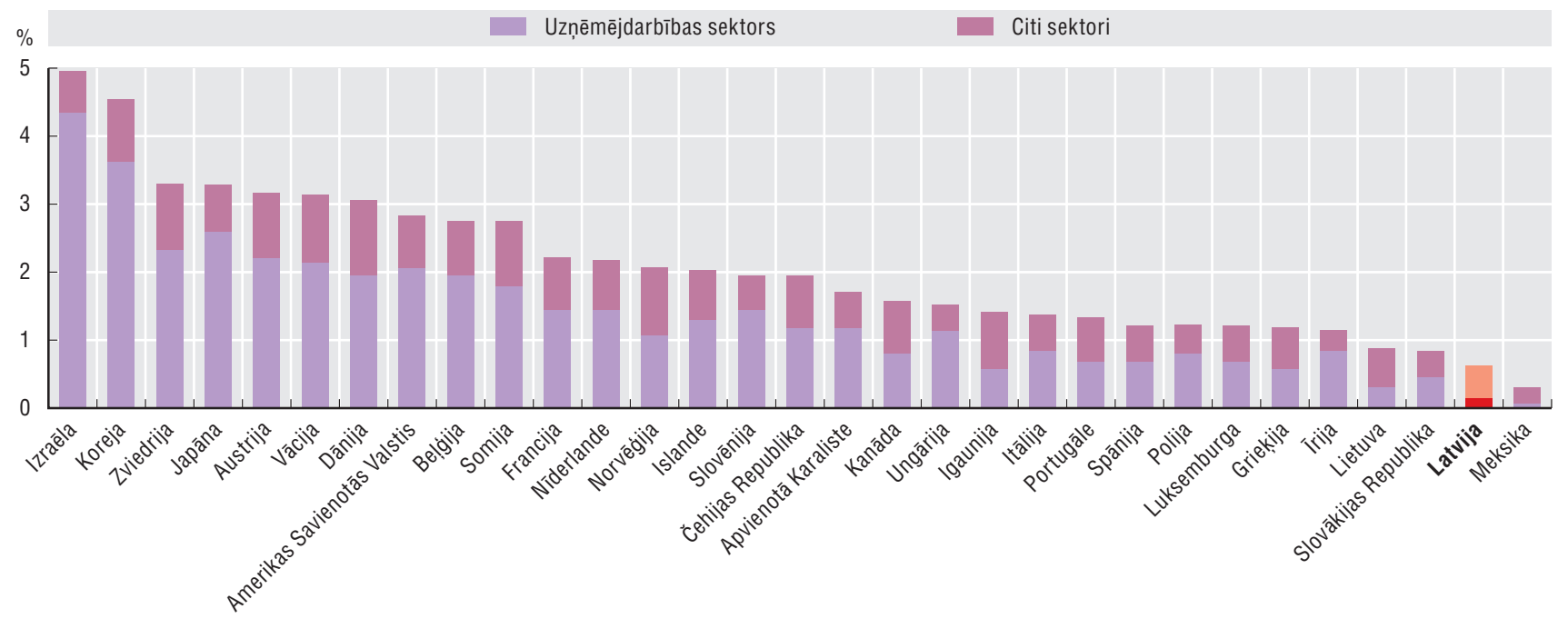

Avots: ESAO (2020b), galvenie zinātnes un tehnologiiju rādītāji [Main Science and Technology Indicators] (datubāze), www.oecd.org/sti/msti.htm.

\section{3. attēls. Inovatīvi $M U^{1}$ Latvijā un atlasītajās ESAO valstīs, 2014.-2016. gads}

Procentuāli no visiem MVU

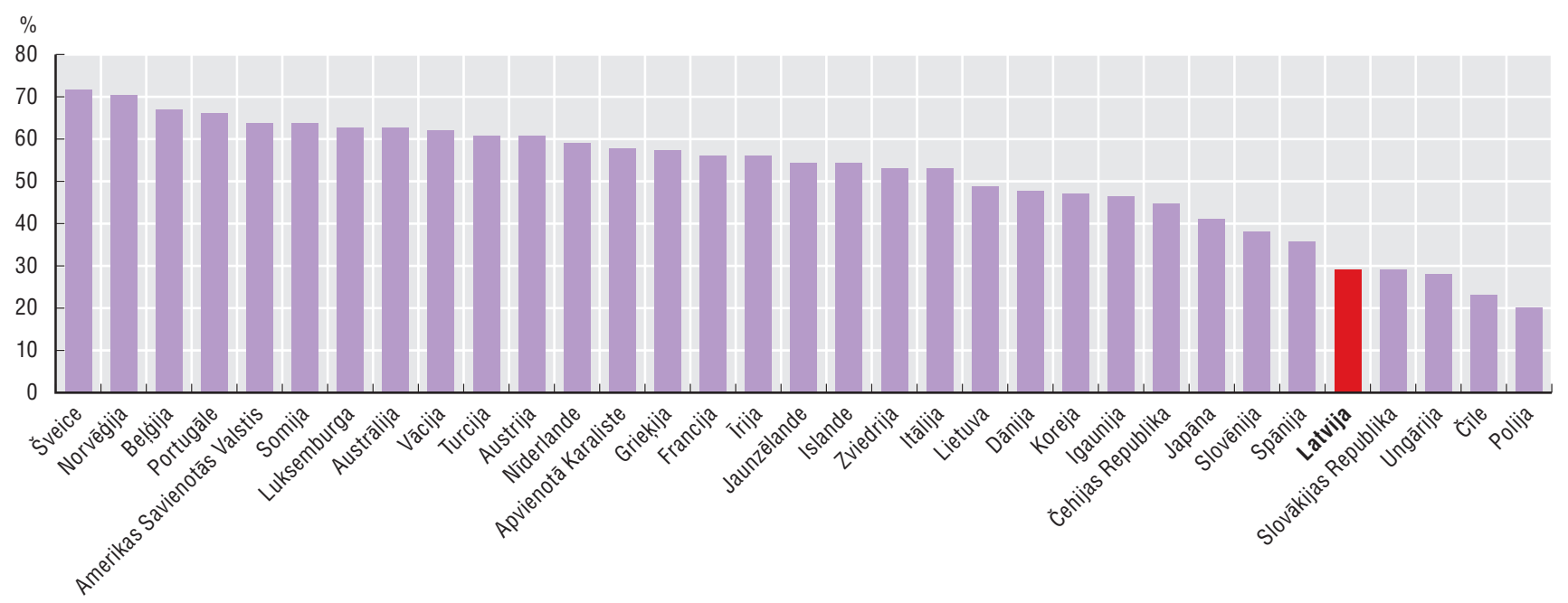

1. Inovatīi MVU ir tie, kuri rada produktu, procesa, mārketinga vai organizatoriskas inovācijas.

Avots: ESAO, pamatojoties uz 2019. gada, ESAO apsekojumu par valstu inovācijas statistiku un Eurostat, Kopienas inovācijas apsekojumu (CIS-2016), http:// oe.cd/inno-stats (piekḷuve 2020. gada 20. janvārī).

Uzṇēmumu vājos inovācijas rezultātus papildina vāji pētniecības rezultāti augstākās izglìtības nozarē. Augstākās izglìtības ieguve vecuma grupā no 25 līdz 34 gadiem Latvijā atbilst ES vidējam rādītājam, taču pētnieku un doktora grāda ieguvēju skaits ir îpaši zems (6.5. attēls) (ESAO, 2019b). Turklāt, lai gan IKT speciālistu daḷa starp visiem doktora grāda ieguvējiem ir līdzīga kā citās Eiropas valstīs, pēdējo gadu laikā tajā ir manāmas samazināšanās pazīmes (6.6. attēls) (Eurostat, 2019). 


\section{4. attēls. Patentu pieteikumi Eiropas Patentu birojam, 2017. gads}

Uz miljonu iedzīvotäju

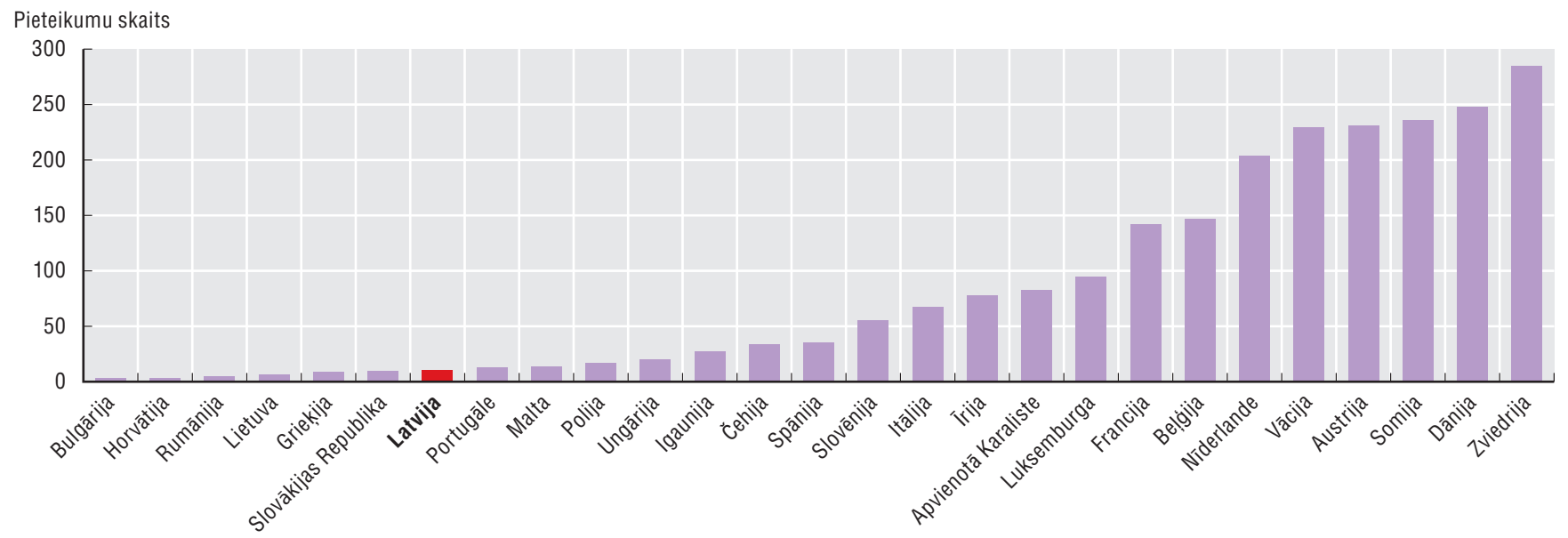

Avots: Eurostat (2020c), Patent Applications to the EPO by Priority Year (datubāze), https://appsso.eurostat.ec.europa.eu/nui/show.do?dataset=pat_ep_ ntot\&lang=en (piekḷve 2020. gada 6. maijā).

\section{5. attēls. Pētnieki un jaunie doktora grāda ieguvēji Latvijā un atlasītajās ESAO valstīs, 2018. gads}

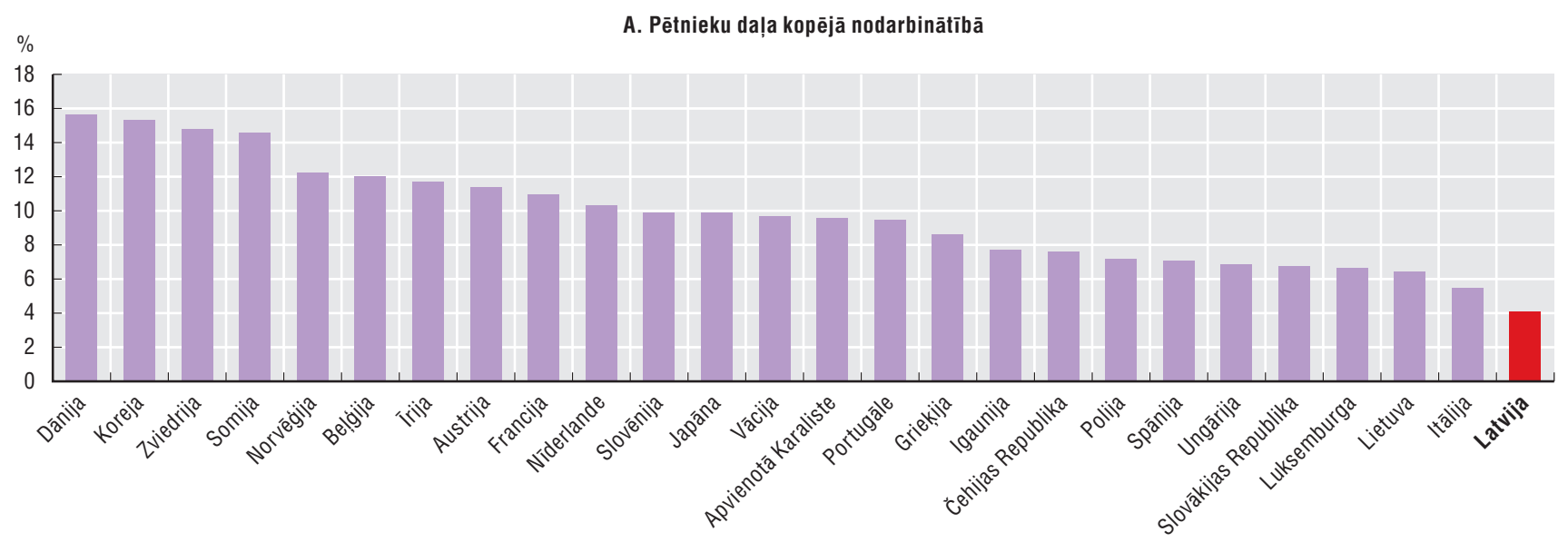

\section{B. Jaunie doktora grāda ieguvēji}

Procentuāli no iedzīvotājiem 25-34 gadu vecumā, 2018. gads

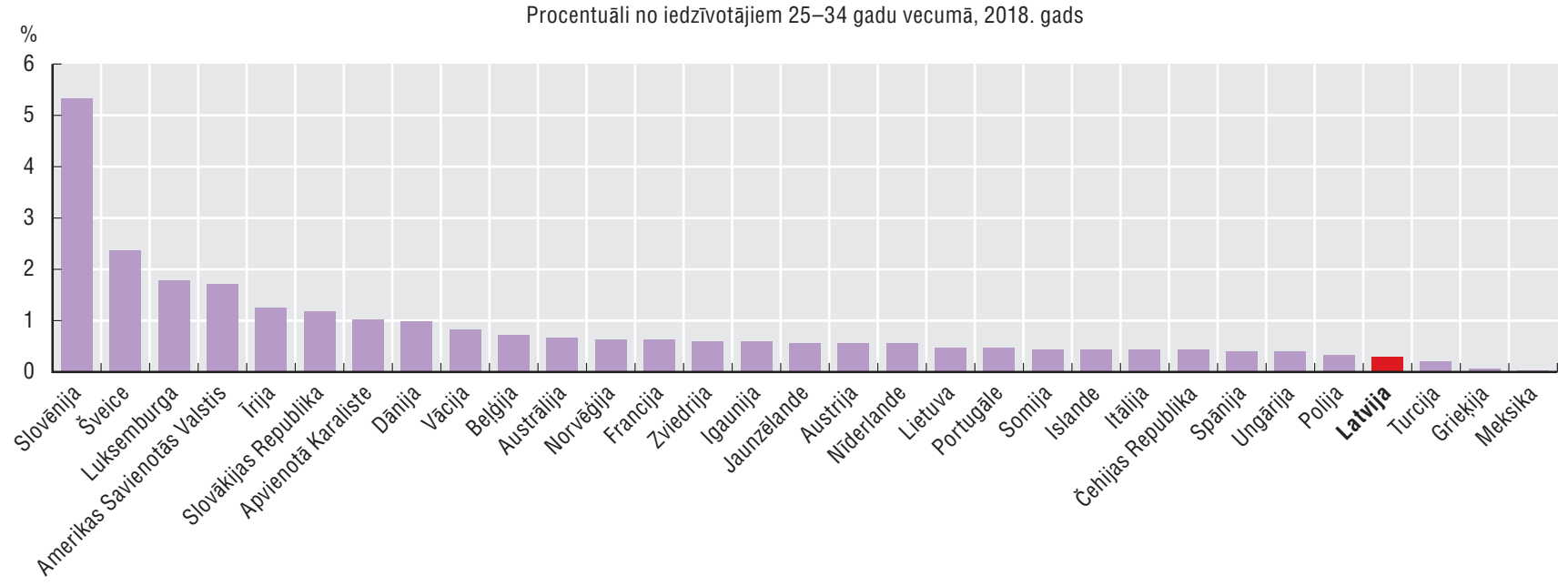

Avots: ESAO (2020b), Galvenie zinātnes un tehnoloǵiju rādītāji [Main Science and Technology Indicators] (datubāze), www.oecd.org/sti/msti.htm; ESAO (2019c), Pārskats par izglītī bu [Education at a Glance], https://dx.doi.org/10.1787/f8d7880d-en. 
6.6. attēls. Doktora grāda ieguvēji IKT jomā Latvijā un atlasītajās ESAO valstīs, 2013.-2017. gads

Procentuāli no visiem doktora grāda ieguvējiem

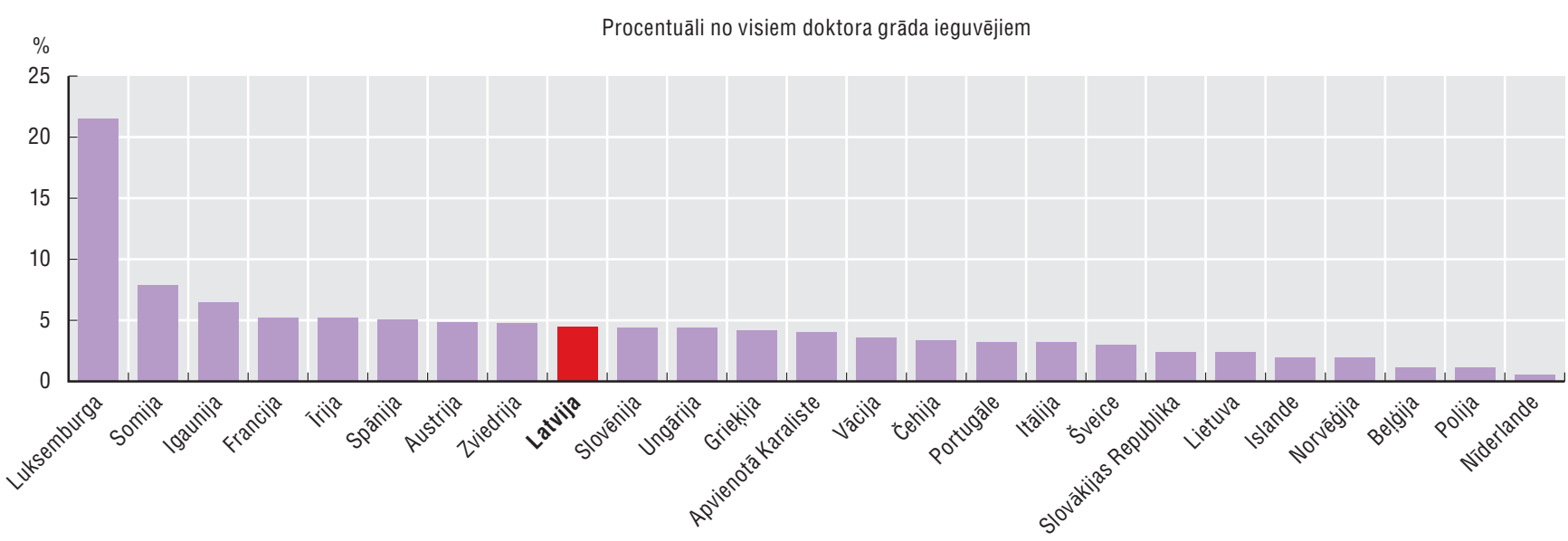

Avots: Eurostat (2019), Administratīie dati par izglītību, sākot no 2013. gada. [Education Administrative Data from 2013 Onwards] (datubāze), https:// ec.europa.eu/eurostat/cache/metadata/en/educ_uoe_enr_esms.htm.

Turklāt pētniecības kvalitāte ir zema salīdzinājumā ar citām ES valstīm (ESAO, 2019a). Latvijas publikācijas IKT jomā ir nepietiekami pārstāvētas starp tiem 10 \%, kas tiek citētas visbiežāk (6.7. attēls), un starptautiskās sadarbības līmenis ir zems (6.8. attēls).

\section{7. attēls. Tie 10 \% zinātnisko publikāciju, kas datorzinātnē tiek citētas visbiežāk atsevišķās ESAO valstīs, 2018. gads}

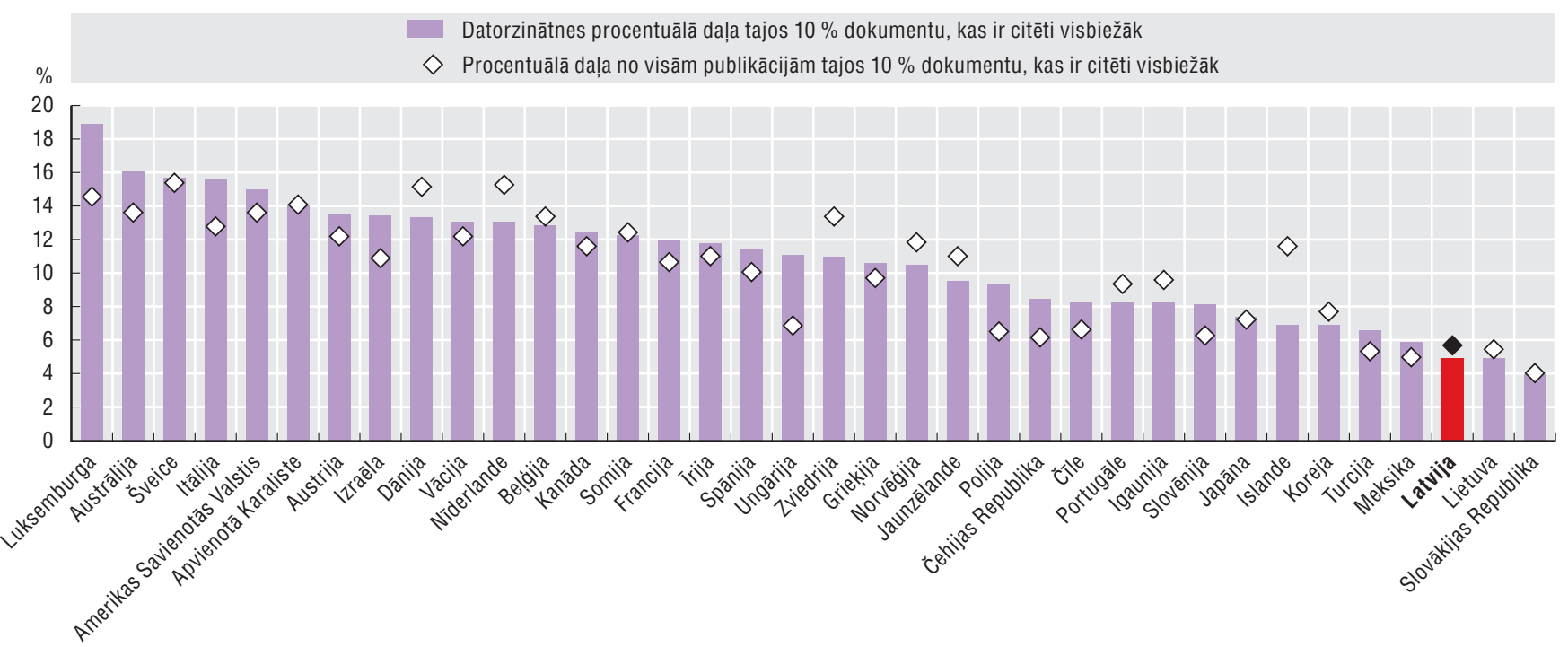

Piezīme: Valsts tiek noteikta pēc tās iestādes atrašanās vietas, kurai ir piesaistīts vadošais autors.

Avots: ESAO aprēḳini, pamatojoties uz Scopus Custom Data, Elsevier, versija: 5.2019.

\section{Inovāciju politika}

Latvijas vidējā termiṇa plāni attiecībā uz inovāciju un uzṇēmējdarbības politiku ir noteikti divos pamatnostādṇu kopumos - Zinātnes, tehnoloǵiju attīstības un inovācijas pamatnostādnēs 2014.-2020. gadam (ZTAI) un Nacionālās industriālās politikas pamatnostādnēs 2014.-2020.gadam. Minētās pamatnostādnes ir balstītas uz ilgtermiṇa redzējumu un ievirzi, kas paredzēta Stratēgijā "Latvija 2030", kurā noteikti vidējā termiṇa mērķi, nepieciešamo resursu līmenis un nodokḷu iniciatīvas, lai šos mērķus labāk sasniegtu, kā arī rādītāju kopums progresa pārraudzībai. Abas minētās pamatnostādnes atbilst Nacionālajam attīstības plānam un stratēgijas "Eiropa 2020" mērḳiem. Taču Latvijā nav īpašas politikas digitālo inovācijus veicināšanai, un pamatnostādnēs IKT nav minēta kā būtiska transversāla tehnolog̣ija ekonomikas modernizēšanai. Turklāt digitālās tehnoloǵijas nav iekḷautas Nacionālajā attīstības plānā 2021.-2027. gadam kā būtisks attīstības elements (Pārresoru koordinācijas centrs, 2019). 


\section{8. attēls. No starptautiskās sadarbības izrietošās zinātniskās publikācijas atlasītajās ESAO valstīs, 2018. gads}

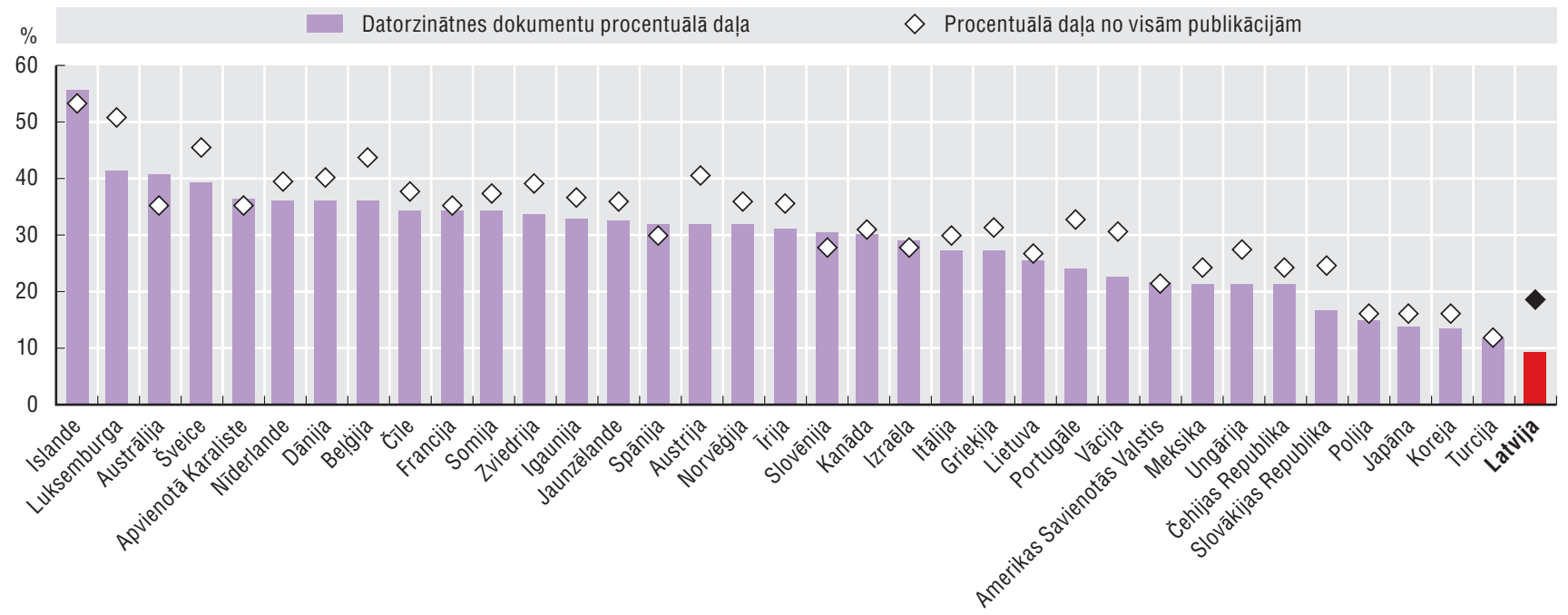

Piezīme: Valsts tiek noteikta pēc tās iestādes atrašanās vietas, kurai ir piesaistīts vadošais autors.

Avots: ESAO aprēkinini, pamatojoties uz Scopus Custom Data, Elsevier, versija: 5.2019.

ZTAI pamatnostādnes ir balstītas uz Latvijas Viedās specializācijas stratēgiju (pazīstama arī ar nosaukumu RIS3), kas vērsta uz vairākām jomām ar augstu pievienoto vērtību (sk. zemāk), taču tajā nav noteikumu attiecībā uz pakalpojumu jomu (6.1. ielikums). Atškirīibā no iepriekšējām pamatnostādnēm uzṇēmumu un pētniecības iestāžu (piem., universitāšu) pētniecības un izstrādes darbības tagad ir sasaistītas vienotā plānošanas sistēmā. Izglītỉbas un zinātnes ministrija (IZM), kas nosaka politiku augstākās izglītības un pētniecības jomā, vadỉja pamatnostādṇu izstrādi, kurā savu ieguldijumu sniedza arī Ekonomikas ministrija (EM), dažādi pētniecības institūti un Latvijas Informācijas un komunikācijas tehnoloǵijas asociācija (LIKTA) (Latvijas valdība, 2013).

ZTAI pamatnostādnēs un Viedās specializācijas stratēǵijā ir atzīta IKT jomas spēja sekmēt Latvijas ekonomikas pārveidi. Turklāt mūsdienīgas IKT sistēmas izstrāde publiskajā un privātajā sektorā ir minēta kā viena no septiṇām izaugsmes prioritātēm. Taču IT joma nav iekḷauta kā atsevišḳs prioritārais virziens zinātnē (Pārresoru koordinācijas centrs, 2017).

Ekonomikas ministrija ir izstrādājusi Nacionālās industriālās politikas (NIP) pamatnostādnes 2014.2020.gadam. Šis pamatnostādṇu kopums lielā mērā ir saistīts ar ražošanu un atgādina par ES mērķuzdevumu palielināt Latvijas izdevumus pētniecībai un izstrādei līdz 1,5 \% no IKP, kas, visticamāk, netiks sasniegts. Tajās uzsvērts, ka ir svarīgi uzlabot sadarbību inovāciju jomā starp pētniecības iestādēm un uznēemumiem (Eiropas Komisija, 2012a), taču nekas nav minēts par digitālajām tehnologiijām (atšķirībā no Zviedrijas, 6.2 ielikums), kaut arī tiek spriests, cik svarīgi ir modernizēt Latvijas ekonomiku.

Turklāt, neskatoties uz ciešo saikni starp digitālo inovāciju un digitālo pakalpojumu sniegšanu, salīdzinoši maz uzmanības ir pievērsts digitālo pakalpojumu vai pakalpojumu inovācijas attīstībai. Ir radušies jauni uzṇēmējdarbības model̦i, piemēram, līdzbiedru izmitināšana (kā Airbnb gadījumā), un ir parādỉjušās jaunas iespējas uzṇēmējdarbībai, izmantojot internetu. Turklāt digitalizācija izpludina robežu starp precēm un pakalpojumiem, piemēram, ja rūpniecības precēs tiek iestrādāti sensori, kuru pārraudzība pēc tam var būt pakalpojums. (ESAO, 2019d).

Latvijai būtu jārīkojas, lai veicinātu digitālos pakalpojumus, sekojot vairāku citu ESAO valstu piemēram. Piemēram, Austrijā ar Viedo un digitālo pakalpojumu iniciatīvu tiek piedāvāts finansējums ar tehnolog̣ijām nesaistītām inovācijām, lai veicinātu pētniecību un izstrādi pakalpojumu jomā un mudinātu tradicionālo nozaru uzṇēmumus sniegt pakalpojumus (piem., iekḷaujot produktos sensorus un sniedzot pārraudzības pakalpojumus Ceturtās rūpnieciskās revolūcijas ietvaros). Mazi uzṇēmumi var izmantot subsīdijas apmērā līdz 45 \%, kas nav jāatmaksā (FFG, 2015; ESAO, 2020c). Savukārt Nīderlandes Uzṇēmumu aǵentūra ražošanas nozarē strādājošajiem MVU piedāvā dizaina pakalpojumu vaučerus 
vērtībā līdz 3000 EUR ar nosacījumu, ka arī tiem pašiem ir jāiegulda vismaz 1000 EUR. Vaučerus var izmantot konsultācijām, lai veicinātu sadarbību starp radošajām nozarēm un ražošanu (ESAO, 2019d; RVO, 2018).

\section{1. ielikums. Zinātnes, tehnoloǵiju attīstības un inovācijas pamatnostādṇu īstenošana}

ZTAI pamatnostādṇu īstenošanā ir četras darbības jomas. Tām ir konkrēti saistītie uzdevumi, piemēram, nodokḷu pasākumi vai inovāciju vaučeru ieviešana, kā parādīts zemāk.

- ZTI jomas konkurētspējas palielināšana:

* attīstīt jomas cilvēkresursu kapitālu;

* attīstīt izcilību pētniecībā;

* samazināt ZTAI resursu sadrumstalotību;

* atbalstīt zinātnes starptautiskošanu un starptautisko sadarbību.

- Zinātnes, tehnoloǵiju un inovāciju sasaistī̌ana ar sociālās un ekonomiskās attīstības vajadzībām:

* veidot zināšanu bāzi un koncentrēt pētniecību uz sabiedrības attīstībai svarīgiem virzieniem;

* veicināt nozares ministriju un pašvaldību pasūtījumus;

* integrēt izglītību, zinātnes attīstību, tehnoloǵiju, inovācijas un uzṇēmējdarbību;

* stiprināt inovāciju un zināšanu apgūšanas spēju uzṇēmumos.

- Efektīvas pārvaldības nodrošināšana ZTI nozarē:

* uzlabot koordināciju;

* palielināt ieguldījumu efektivitāti;

* palielināt valsts budžeta finansējumu ZTAI;

* aprēk̦ināt un piešķirt institucionālo vai bāzes finansējumu saskaṇā ar politikas uzstādījumiem;

* pakāpeniski palielināt iepirkuma procedūrās piešḳirtā pētniecības un izstrādes finansējuma limeni;

* radīt jaunus finanšu instrumentus, kas piemēroti ZTAI politikas mērḳiem un uzdevumiem;

* atbalstīt pētniecību augstākajā izglītībā (ieguldījumi augstākajā izglītībā);

* izstrādāt sistēmu politikas īstenošanai, pārraudzībai un ietekmes novērtēšanai.

- Sabiedrības informētības uzlabošana un zinātnes un inovāciju veicināšana.

\section{2. ielikums. Zviedrijas inovāciju stratēgija}

Zviedrijas inovāciju stratēǵija 2017.-2020. gadam ir noteikta tās pētniecības likumprojektā "Zināšanas sadarbībā - sabiedrības problēmu risināšanai un labākai konkurētspējai" (Kunskap i samverkan -för samhällets utmaningar och stärkt konkurrenskraft). Likumprojekts tika izstrādāts, lai nodrošinātu Zviedrijas kḷūšanu par vienu no pasaulē vadošajām valstīm pētniecības un inovāciju jomā (ESAO, 2018c; Zviedrijas Izglītības un pētniecības ministrija, 2019).

Šì stratēgija uzsver Zviedrijas plašā IKT sektora nozīmīgumu un digitālo tehnoloǵiju spēju darboties kā inovāciju veicinātājam citās jomās. Stratēǵija ietver:

- ieguldījumus digitālās pētniecības infrastruktūrā (piem., Zviedrijas Universitātes datortīklā), lai veicinātu datu ziṇā intensīvu pētniecību;

- dotācijas uz datiem balstītai pētniecībai;

- atvērtās piekḷuves veicināšanu pētniecības datiem, piemēram, izmantojot personas kodus, lai pieslēgtos dažādiem publiskajiem reǵistriem un veicinātu pētniecību medicīnas un sociālo zinātṇu jomā. 
Latvijas inovāciju stratēgijā arī trūkst uzsvara uz lietotṇu un programmatūras veidošanu, lai risinātu dažas no sociālajām un ekonomiskajām problēmām valstī. Piemēram, Kolumbijas 2014.-2018. gada plānā "Digitāla dzīve cilvēkiem" (Vive Digital para la Gente) bija iekḷauts mērḳis padarìt Kolumbiju par vienu no pasaulē vadošajām valstīm tādu lietotṇu izstrādē, kas palīdz sabiedrības nabadzịgākajiem cilvēkiem. Šis mērḳis palīdzēja izstrādāt lauksaimniecības lietotni (Farmapp) labākai kaitēkḷu apkarošanai, kas ir arī eksportēta (ESAO, 2019e). Savukārt Apvienotā Karaliste ir izveidojusi Sociālo tehnoloǵiju paātrināšanas centru, kas ir palīdzējis labdarības organizācijām izstrādāt lietotnes savu mērḳu sasniegšanai.

\section{Pētniecības un izstrādes veicināšana}

Lielāko daḷu Latvijas valdības finansējuma pētniecībai saṇem augstākās izglītības iestādes, savukārt uzñēmumi - gandrīz neko (Eiropas Komisija, 2018a) (6.9. attēls). Lai gan Latvija savulaik sniedza dāsnas nodokḷu atlaides pētniecībai un izstrādei, 2018. gadā šì prakse tika atcelta, veicot uzṇēmumu ienākuma nodokḷa reformu, kuras rezultātā ar nodokli tika aplikts tikai sadalītais ienākums (piem., dividenžu izmaksa). Atbalsts uzṇēmumu pētniecībai un izstrādei pašlaik lielākoties tiek sniegts kā tiešais finansējums un kā nodokḷu atvieglojumi par pētniecības un izstrādes darbinieku pieṇemšanu (sk. zemāk) atškirīibā no lielākās daḷas ESAO valstu (6.3. ielikums) (ESAO, 2019q, 2018a).

\section{9. attēls. Valdības finansējums un nodokḷu atbalsts uzṇēmumu pētniecībai un izstrādei Latvijā un atlasītajās ESAO valstīs, 2017. gads}

Kā procentuālā daḷa no IKP

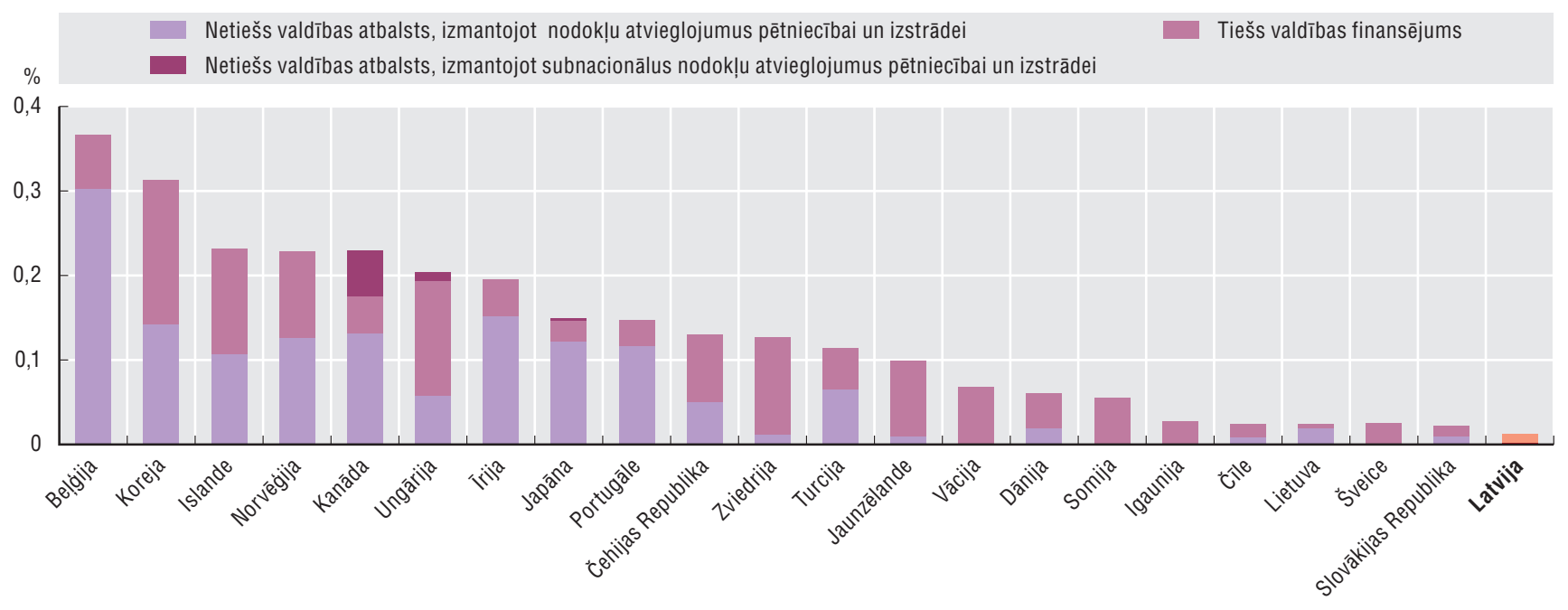

Avots: ESAO (2019f), Pētniecības un izstrādes nodokḷ stimuli (datubāze), www.oecd.org/sti/rd-tax-stats.htm.

\section{Augstākās izglītības iestādes sanem zema līmeña finansējumu pētniecībai}

Latvijas augstāko izglītības iestāžu sektorā finansējuma līmenis ir zems un plaši izkliedēts. Valsts pētniecības finansējums ir 73 miljoni EUR, no kuriem pusi nodrošina ES. Tikai neliela daḷa no šî finansējuma tiek piešķirta uz konkurences pamata, lielākā daḷa tiek piešķirta, lai finansētu iestāžu pamatfunkcijas (sk. zemāk) (Eiropas Komisija, 2018a; ESAO, 2019a). Turklāt finanšu resursi pētniecībai ir sadrumstaloti starp 21valsts sektora pētniecības iestādi (tostarp universitātēs izvietotajām) un zinātniskajām iestādēm, kas saṇem valsts un ERAF finansējumu (Eiropas Komisija, 2018a). Latvijā ir arī vairāk augstākās izglītības iestāžu nekā Igaunijā vai Lietuvā, taču Latvijas Universitāte (LU) un Rīgas Tehniskā universitāte (RTU) nodrošina vairāk nekā 40 \% no pētniekiem un akadēmiskā personāla augstākās izglìtības iestāžu sektorā (Eiropas Komisija, 2018a). Tāpēc Latvijai būtu jāturpina koncentrēt pētniecības finansējumu mazākā skaitā iestāžu, lai varētu veidot iestādes ar dziḷāku pieredzi.

Nepietiekamo finansējumu papildina tas, ka nav efektīvas karjeras struktūras pētniekiem, un tas var apgrūtināt prasmīgu pētnieku noturēšanu un pētniecỉbas spējas veidošanu. Turklāt daudzi universitāšu pētnieki tuvojas pensijas vecumam (Eiropas Komisija, 2018a). Pieṇemšanu darbā apgrūtina latviešu valodas prasības, jo valsts universitātēm ir jāpiedāvā kursi latviešu valodā un akadēmiḳiem tā ir brìvi 
jāpārvalda (lai gan pastāv izṇēmums attiecībā uz vieslektoriem, ar kuriem ir noslēgts līgums uz mazāk par diviem gadiem) (Pasaules Banka, 2018b). Turklāt valdība veido ārvalstīs esošo Latvijas pētnieku datubāzi, lai censtos pārvarēt grūtības saistībā ar nolīgšanu un sekmētu sadarbību pētniecībā un mācǐšanā (ESAO, 2019a).

\section{3. ielikums. Dažādas pieejas, kas izmantotas pētniecības un izstrādes veicināšanai}

Valdības var palīdzēt atbalstīt pētniecību un izstrādi tieši (piem., piešḳirot dotācijas vai pērkot pētniecības un izstrādes pakalpojumus) vai netieši, izmantojot nodokḷu stimulus, piemēram, preferenciālu nodoḳ̣u režīmu pētniecības un izstrādes izdevumiem vai ienākumiem. ESAO valstīs gandrīz 70 \% no visa atbalsta pētniecībai un izstrādei veido netiešie pasākumi (Appelt un citi, 2016).

Tiešā atbalsta priekšrocība ir tāda, ka to var īpaši paredzēt jomām, kas sniedz vislielākos sociālos ieguvumus, taču dotāciju administrēšana un projektu atlase var izmaksāt dārgi. Tiešo atbalstu uzskata par vispiemērotāko pētniecībai, kas radīs sabiedriskus labumus, un riskantākiem pasākumiem, piemēram, uzṇēmumu darbības izvēršanas atbalstam. Uz tirgu balstīto pasākumu, piemēram, nodokḷu atvieglojumu priekšrocība ir tā, ka tie nav atkarīgi no valdības amatpersonu lēmumiem, tāpēc tos ir vienkāršāk pārvaldīt un tie biežāk atbilst starptautiskās tirdzniecības noteikumiem. Nodokḷu atvieglojumi ir lietderīgi, lai stimulētu pētniecības un izstrādes palielināšanos, jo īpaši uzṇēmumos, kuros tā jau tiek veikta. Taču tie nav efektīvi, lai virzītu pētniecību uz jomām, kas sniedz lielākus sociālos ieguvumus, un ir piemērotāki tādas pētniecības veicināšanai, kas izraisīs komercializāciju. Aizdevumi ir piemēroti uz izkliedēšanu vērstai pētniecībai un izstrādei, kurā ir vajadzīgi arī kapitālizdevumi.

Nodokḷu stimulus var aprēḳināt, vai nu pamatojoties uz pētniecības un izstrādes izdevumiem, vai uz ienākumiem, kas no tās gūti. Uz izdevumiem balstīti stimuli ietver nodokḷu atvieglojumus, atbrīvojumus un atlaides, kas samazina nodokḷa bāzes apmēru. Parasti šādos gadījumos ir paredzēts, ka uzṇēmumam ir pietiekami lielas nodokḷu saistības (lai gan nodokḷu kredīti var būt atmaksājami). Alternatīva pieeja (kas tiek izmantota Latvijā) ir samazināt citas pētniecības un izstrādes izmaksas, piemēram, algu nodokḷus pētniecības darbiniekiem. Tie darbojas kā iepriekšēja subsīdija un ir piemērotāki riskantākai pētniecībai, ko dažos gadījumos veic nesen dibināti uzṇēmumi, kuri biežāk strādā ar zaudējumiem vai ir pakḷauti finansiāliem ierobežojumiem. Visbeidzot, vēl viena alternatīva pieeja ir noteikt preferenciālu režīmu no pētniecības un izstrādes gūtajiem ienākumiem (piem., autoratlīdzībām par patentiem). Taču sasaistīt ienākumus ar pētniecības un izstrādes darbībām var būt sarežǵitāk (Appelt un citi, 2016; ESAO, 2019q).

Latvija arī ievieš jaunus darbā pieṇemšanas kritērijus profesoriem, kuriem būs vajadzīgs minimālais akadēmisku publikāciju skaits, lai palielinātu aktīvo pētnieku skaitu augstākajās izglītības iestādēs (Eiropas Komisija, 2018a). Taču augstākās izglītības iestādes nepiedāvā pastāvīgu amatu un līgumi ir spēkā sešus gadus, kas var apgrūtināt talantīgu pētnieku piesaisti (ESAO, 2016). Latvijas valdība plāno atvieglot darbinieku pieņemšanu, apvienojot pētnieku un akadēmiskā personāla karjeras struktūras. Lai sekmētu lietišķos pētījumus un inovāciju (piem., prototipu un patentu izstrādi), pētnieku spēja piesaistīt ārēju finansējumu būtu jāiekḷauj kā kritērijs paaugstināšanai amatā.

\section{Augstākās izglītības iestāžu finansējumā ir veỉktas reformas, lai veicinātu orientāciju uz pētniecību}

Lai palielinātu uzsvaru uz pētniecību augstākās izglītības iestādēs, valdība ir ieviesusi jaunu finansējuma modeli (Eiropas Komisija, 2018a). Tagad finansējumam augstākās izglītības iestādēs ir trīs pīlāri: pamatfinansējums, kas ir atkarīgs no mācību vidējām izmaksām uz vienu studentu; ar rezultātiem saistīts finansējums, kas ir saistīts ar ne vairāk kā pirms pieciem gadiem absolvējušo pētnieku skaitu, piesaistīto starptautiskās pētniecības finansējuma apmēru, ar pētniecības un izstrādes līgumiem piesaistītā finansējuma apmēru, no vietējām pašvaldībām piesaistītā finansējuma apmēru, kā arī ar radošiem un mākslas projektiem piesaistītā finansējuma apmēru; un uz inovācijām vērsts finansējums, ko gandrīz pilnībā sniedz ES inovācijas projekti (sk. zemāk) (Pasaules Banka, 2018a). 2015. gadā 60 \% finansējuma tika veltīti pamatfinansējumam, 20\% — ar rezultātiem saistītam finansējumam un 20\% — uz inovācijām vērstam finansējumam (ESAO, 2019g). Taču 2018. gadā 90\% finansējuma tika veltīti pamatdarbību segšanai un uz inovāciju vērstām darbībām tika piešḳirti tikai 2 \%. 


\section{Finansējums pētniecībai ir vērsts uz zinātni, nevis uz tirgu.}

Latvija pētniecību lielākoties atbalsta ar dotācijām, un tai ir divas sistēmas pētniecības un inovācijas līdzekḷu administrēěanai atkarībā no tā, vai avots ir Latvijas valdība vai Eiropas Reǵionālās attīstības fonds (ERAF). 2017. gadā katrs no abiem avotiem sniedza aptuveni līdzvērtīgu finansējuma apmēru. Valsts programmas mēdz būt mazākas savā mērogā, taču tās darbojas ilgāku laiku, savukārt par struktūrfondu programmām var apgalvot pretējo (t.i., tās ir plašākas, taču darbojas issākā laika posmā) (Eiropas Komisija, 2018a).

Latvijas valdības finansējumu pētniecībai administrē IZM un tās aǵentūras (izṇemot Zemkopības ministrijas pētniecības programmas), IZM arī izstrādā valsts finansējuma programmas. Valsts izglìtības attīstības ağentūra (VIAA) administrē finansējumu, ko sniedz starptautiskie avoti, piemēram, ERAF līdzfinansētas pēcdoktorantūras pētniecības programmas, starptautiskās sadarbības programmas pētniecībā un izstrādē, kā arī Eiropas Ekonomikas zonas un Norvēgijas finansētas programmas. Savukārt Studiju un zinātnes administrācija (SZA) administrē fundamentālo un lietišḳo pētījumu programmas, studiju aizdevumus un pētniecības programmas, kas ir IZM kompetences jomā. Latvijas Zinātnes padome rīko valsts finansēto programmu starptautisku salīdzinošo izvērtēšanu (Eiropas Komisija, 2018a). Turklāt Latvijas Zinātṇu akadēmija piešḳir nelielas stipendijas vadošajiem augsta lìmeña zinātniekiem.

ES finansētas pētniecības un izstrādes, kā arī inovāciju programmas, tostarp projektus pētniecības infrastruktūras modernizēšanai, administrē Centrālā finanšu un līgumu ağentūra (CFLA), kura administrē visus 4,4 miljardus EUR, kas Latvijai no ES līdzekḷiem ir pieejami periodā no 2014. līdz 2020. gadam, un ir Finanšu ministrijas (FM) paklautībā. CFLA nozīme ir pieaugusi kopš 2014. gada, kad tā kḷuva par vienīgo sadarbības iestādi ES kohēzijas fondu jomā. CFLA atlasa projektus un veic to finansiālo un zinātnisko administrēšanu (CFLA, 2020). Tāpat kā VIAA, arī CFLA atlasa pētniekus, izmantojot Eiropas Komisijas datubāzi programmai "Apvārsnis 2020" vai citas līdzvērtīgas starptautisko zinātnisko pētnieku datubāzes. Taču CFLA funkcijas neietver atbalsta sniegšanu projektu vadìtājiem viṇu projektu īstenošanā (ko parasti dara inovācijas aǵentūras, piemēram, Latvijas Investīciju un attīstības aǵentūra) (CFLA, 2019; Eiropas Komisija, 2018a).

CFLA sniegts ieguvums ir vienota kontaktpunkta izveide, lai pieteiktos ES līdzeklịem. Taču divkāršās sistēmas dēḷ īstenošanas aǵentūras atbild Finanšu ministrijai, nevis nozares ministrijām, kas ir atbildīgas par nozaru politiku. Tas arī liek aǵentūrām sacensties ar CFLA izvēlētajiem projektu vērtētājiem. Sākot ar 2020. gada jūliju, jauna Latvijas Zinātnes padome pārṇems visas ar zinātnes politikas isstenošanu saistītās funkcijas no pašreizējas Latvijas Zinātnes padomes, VIAA un SZA (IZM, 2020). Tam vajadzētu palīdzēt uzlabot programmu efektivitāti inovāciju atbalstam.

\section{Stimuli sadarbībai ar uzn,ēmumiem ir vāji, un IKT projekti saṇem nelielu finansējuma daḷ}

Stimuli augstākās izglīīibas iestāžu sadarbībai ar nozari ir bijuši vāji, taču tikai daži MVU sadarbojas ar pētniecības iestādēm (Eiropas Komisija, 2018a) (6.10. attēls). Jaunais, uz rezultātu orientētais finansējuma pīlārs augstākās izglìtības iestādēm šos stimulus ir mainījis, pieškikirot vairāk finansējuma augstākās izglìtības iestādēm, kas sadarbojas ar uzṇēmumiem (ESAO, 2019a). Turklāt ERAF finansētās lietišķo pētijjumu programmas, Kompetenču centru programma un Tehnologiiju pārneses programma (zemāk) ir palīdzējušas stiprināt saites. Augstākās izglīīibas iestāžu finansējuma daḷas, kas ir atkarīga no sadarbības ar uzṇēmumiem, vēl lielāka palielināšana varētu palīdzēt palielināt augstākās izglītības iestādēs veiktās pētniecības orientāciju uz tirgu.

Turklāt tikai neliela daḷa no ES finansējuma pētniecībai Latvijā tiek novirzìta ar IKT saistītiem projektiem. Lietišk̦o pētījumu ERAF finansējuma plūsmas, ko administrē CFLA, mērḳis ir palielināt Latvijas iestāžu pētniecības spējas. Taču no 74 pētniecības projektiem, kas tika veikti 2019. gada beigās, tikai divi bija IKT jomā un sañēma finansējumu 750000 EUR apmērā (t.i., 1,9 \% no kopējā programmas finansējuma) (EsFondi.lv, 2020a, 2020b). Pēcdoktorantūras pētniecības programmā, ko administrē VIAA, 2019. gada beigās bija 194 projekti (gandrīz 25 miljonu EUR apmērā), no kuriem tikai viens IKT jomā ar aptuveni 100000 EUR finansējumu (t.i., 0.4 \% no kopējā programmas finansējuma). Lielākas pētniecības finansējuma dal̦as piešķiršanai ar IKT saistītiem projektiem būtu jābūt vienai no Latvijas prioritātēm, lai sekmētu inovācijas spējas šajā nozarē. 


\subsection{0. attēls. MVU, kas inovācijas darbībās sadarbojas ar augstākās izglītỉbas vai valdības iestādēm atlasītajās} ESAO valstīs, 2014.-2016. gads

Procentuāli no visiem inovativajiem uznēmumiem ${ }^{1}$

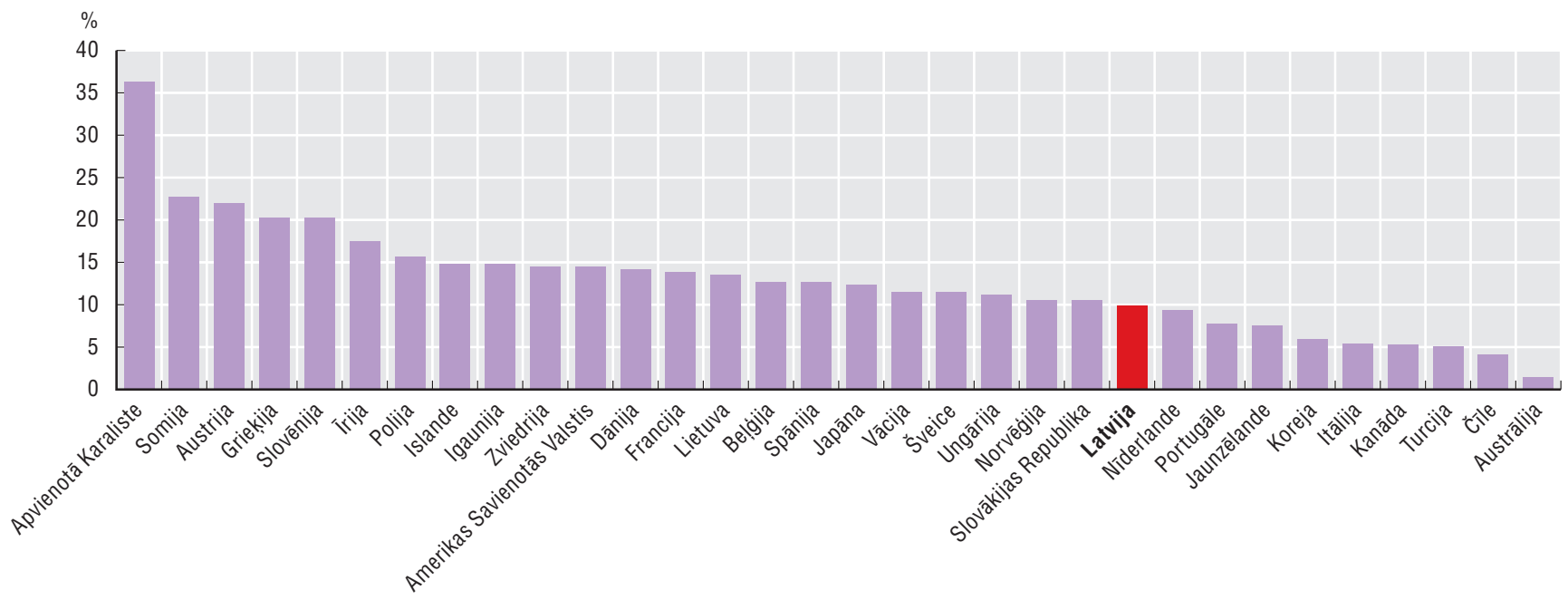

1. Inovatīvi MVU ir tie, kuri rada produktu, procesa, mārketinga vai organizatoriskas inovācijas.

Avots: ESAO, pamatojoties uz 2019. gada, ESAO apsekojumu par valstu inovācijas statistiku; un Eurostat (2016), Kopienas inovācijas apsekojumu (2016), http://oe.cd/inno-stats (piekḷuve 2020. gada 20. janvārī).

\section{Vairāk finansējuma būtu jāpiešķir, pamatojoties uz konkurenci un plašas ietekmes kritērijiem.}

Latvijai būtu jāuzlabo pētniecības kvalitāte, palielinot konkurencē pieškirtā finansējuma daḷu. Uz konkurenci balstīts projektu finansējumus var nodrošināt, ka projekti sasniedz minimālo kvalitātes līmeni un sniedz pētniekiem iespēju pārbaudìt savas idejas starp kolēéiem, lai gan pastāv dažas liecības, ka tā rezultātā var tikt atlasīti īstermiṇa projekti ar zemu risku, vienlaikus palielinot administratīvo slogu pētniekiem un apgrūtinot ilgtermiṇa plānošanu. Starp ESAO dalībvalstīm ir lielas atšḳirības attiecībā uz konkurencē pieškirtā pētniecības finansējuma daḷu, kas parasti ir apmērā no 25 \% līdz 50 \% (ESAO, 2018b). Tomēr Latvijai būtu jāpalielina konkurences procesā pieškirtā pētniecības finansējuma daḷa. Nošķirot daḷu jaunāko pētnieku, varētu labāk pārvarēt grūtỉbas finanšu piesaistîšanā nepietiekamas pieredzes dēḷ.

Latvija lielākoties sniedz ex ante finansējumu, nevis atlīdzina par veiksmīgu pētniecību un inovāciju ex post (ESAO, 2019g). Ja CFLA finansētiem projektiem ir negatīvs ex post novērtējums, izdevumi ir jāatmaksā, lai gan tas līdz šim vēl nav noticis (FM, 2020). Daḷai pētniecības finansējuma vajadzētu būt balstītam uz pētījumu rezultātiem Piemēram, İrijas Zinātnes fonds neizmanto tikai bibliometriskās atsauces un ir ieviesis pētniecības ietekmes novērtējumus, ar kuriem pētniecības komercializācijas un attīstības eksperti novērtē pētījuma ietekmi es post. Turklāt daudziem projektiem starptautiski eksperti veic starpposma pārskatišanu, lai novērtētu progresu attiecībā pret sākotnējo priekšlikumu (ESAO, 2018b).

\section{Inovāciju veicināšana uznèemumos}

Latvijas uzṇēmumos inovācija nav īpaši nozīmīga. (sk. iepriekš). Taču Latvija veic darbības, lai palielinātu inovācijās iesaistīto uzṇēmumu skaitu ar reǵionālām un ERAF finansētām programmām. Tomēr, tā kā nacionālajos plānošanas dokumentos trūkst skaidrības par IKT lomu, programmu mērḳi savstarpēji pārklājas un reizēm nav saskanīgi.

Latvijas Investīciju un attīstības aǵentūrai (LIAA) ir nozīmīga loma uzṇēmēju atbalsta programmu pārvaldībā. LIAA ir galvenā valsts inovāciju aǵentūra un daḷa no Ekonomikas ministrijas. Tā pārvalda no ES struktūrfondiem finansētās inovāciju programmas, piemēram, Tehnoloğiju pārneses programmu, Inovāciju motivācijas programmu un Biznesa inkubatoru programmu (lai gan CFLA administrē finansējumu). LIAA galvenais uzdevums ir atbalstīt ārvalstu tiešos ieguldījumus (ĀTI), lai gan ĀTI lielākoties plūst uz nozarēm, kas nemēdz ieguldīt pētniecībā un izstrādē (Eiropas Komisija, 2018a). 
Latvija ir centusies palielināt sabiedrības informētību par inovāciju sniegtajiem ieguvumiem un ir veikusi pasākumus, lai mudinātu tos, kuriem ir inovatīvas idejas, virzīt tās uz komercializāciju. Piemēram, Inovāciju motivācijas programmas mērḳis ir palielināt visas sabiedrības informētību par inovācijas nozīmīgumu un sekmēt uzṇēmējdarbību. Programma saṇem ERAF finansējumu (0,5 miljoni EUR 2018. gadā), taču to vada Ekonomikas ministrija un LIAA. Līdzšinējās darbības ir ietvērušas diskusijas uzṇēmējdarbības ideju radīšanai, sadarbības tīklu izveidi, vadības inovāciju apmācības tirgotājiem (piem., nedēḷu ilgu "mini MBA" kursu inovācijā un līderībā) un konkursus, piemēram, Ideju kausu par inovatīvām uzṇēmējdarbības idejām (Pārresoru koordinācijas centrs, 2017; LIAA, 2019a).

\section{Ir programmas, kas pārklājas, lai saistītu uzṇēmumus ar augstākās izglītības iestādēm un pētniecības institütiem}

Pastāv vairākas programmas inovāciju veicināšanai, izplatot pieredzi Latvijas uzṇēmumos. Taču šādās programmās digitālās tehnolog̣ijas netiek uztvertas kā galvenie inovāciju veicinātāji. Ir būtiski svarīgi šajās programmās noteikt spēcīgu digitālo fokusu, lai Latvijas uzṇēmumi izmantotu inovāciju iespējas, ko sniedz digitalizācija.

Latvija 2010. gadā uzsāka LIAA pārvaldīto Kompetences centru programmu, lai palielinātu uzṇēmumu konkurētspēju un inovāciju. Šo centru mērḳis ir veicināt lietišḳos pētījumus un progresīvas inovācijas nozarēs, kas atbilst Viedās specializācijas stratēǵijai (sk. zemāk), un tādējādi palīdz izstrādāt jaunus produktus un tehnoloǵijas, sekmējot sadarbību starp pētniecības sektoru un rūpniecību. Taču šajā ziṇā centri pārklājas ar Tehnoloǵiju pārneses programmu (augstāk). Lai gan kompetences centri saṇem dotācijas no ERAF, tie lielākoties pieder privātajam sektoram, un vismaz ceturtā daḷa no to finansējuma ir jāparedz eksperimentālai izstrādei. Līdz 2018. gada beigām gandrīz 150 uzṇēmumiem tika sniegts atbalsts, lai radītu vai uzlabotu 174 produktus, radot gandrīz 500 darbvietu, pētniecībā iesaistot 175 maǵistrantūras un doktorantūras studentus un publicējot vairāk nekā 200 akadēmisku rakstu.

IT kompetences centrs sāka darbību 2011. gada aprīlī un galvenokārt ir vērsts uz dabīgās valodas tehnologiju un biznesa procesu analīzes tehnoloǵijām, izmantojot iepriekš veiktus pētījumus, par ko ir publikācijas akadēmiskajos žurnālos. Centrs laika posmā no 2014. līdz 2020. gadam saṇēma ERAF finansējumu 7,8 miljonu EUR apmērā un papildus arī privātu finansējumu 5,2 miljonu EUR apmērā. Laika posmā no 2019. gada aprīḷa līdz 2021. gada decembrim tiek ìstenoti 20 pētniecības projekti nolūkā palīdzēt 20 uzṇēmumiem izstrādāt jaunus produktus (Esfondi.lv, 2020c). Tā kā ERAF finansējums 2021. gadā beigsies, būs vajadzīgi alternatīvi resursi. Privātā līdzfinansējuma daḷas palielināšana varētu palīdzēt nodrošināt, ka stimuli ir vērsti uz komerciālu inovāciju radīšanu, nevis uz akadēmisku pētniecību.

Turpretī Tehnolog̣iju pārneses programmas mērḳis ir veicināt inovācijas MVU, izplatot pētniecības iestādes tehnoloǵijas un zināšanas (nevis iesaistoties jaunās inovācijās) un veicinot pētījumu komercializāciju. Programmu administrē LIAA, taču tā saṇem finansējumu no ERAF. 'Tehnoloǵiju skauti”, kuri strādā LIAA, palīdz uzṇēmējiem atrast potenciālās pētniecības organizācijas.

Tehnoloǵiju pārneses programma galvenokārt sniedz atbalstu tiem MVU, kas jau kādu laiku darbojas, piedāvājot inovāciju vaučerus, taču tā arī palīdz finansēt apmeklējumus ar potenciāliem investoriem un jaunuzṇēmumudalību gadatirgos, kā arī palīdz pētniecības institūtiem komercializēt savus pētījumus. Inovāciju vaučeri ir pieejami jebkuram uzṇēmumam, kurš izstrādā jaunus produktus vai tehnoloǵiju Viedās specializācijas stratēǵijā minētajās nozarēs. Vaučeriem tiek sniegts 85 \% līdzfinansējums apmērā līdz 25000 EUR, un tos var izmantot priekšizpētei, eksperimentālajai izstrādei, prototipu veidošanai, rūpnieciskajam dizainam, intelektuālā īpašuma nostiprināšanai, kā arī pārbaudēm un sertifikācijai (LIAA, 2019b, 2019c). Pētniecības organizācijām ir arī pieejams atbalsts apmērā līdz 300000 EUR priekšizpētei un komerciālo stratēǵiju veidošanai. Lìdz 2018. gada beigām programmā tika iztērēti 2,7 miljoni EUR un izstrādāti 36 jauni produkti un tehnolog̣ijas, 48 uzṇēmumi saṇēma dotācijas jaunu produktu laišanai tirgū (piem., apmeklējot potenciālos investorus un izstādes), 15 pētniecības organizāciju projekti saṇēma finansējumu komercializācijai. Projekts tiks turpināts līdz 2022. gada beigām (Esfondi.lv, 2000d). 


\section{Latvija ir centusies sekmēt inovāciju, paplašinot sadarb̄̄bu starp uzṇēmumiem}

Tehnoloǵiju izplatīšanu var veicināt, paplašinot sadarbību starp inovatīviem uzṇēmumiem un starptautiskajiem uzṇēmumiem - šādas pieejas Latvijā trūkst. Klasteru programmas mērkis ir palielināt MVU eksporta konkurētspēju, palielinot sadarbību starp vienas nozares uzṇēmumiem. Programma atbalsta 14 klasterus, kā noteikts Viedās specializācijas stratēgijā (EM, 2018a). Latvijas IT klastera locekḷi ir gan uzṇēmumi, gan augstākās izglîtības iestādes, un tie sniedz pakalpojumus, lai palīdzētu eksporta jomā, piemēram, sniedzot uzṇēmumiem informāciju par starptautiskiem tỉklošanās pasākumiem un tirgus izpēti. Taču šādi pasākumi pārklājas ar LIAA darbu eksporta veicināšanai. Turklāt IT klasteris rīko pasākumus, lai veicinātu digitalizāciju citās jomās, sākot no darbsemināriem individuāliem uzṇēmumiem ar mērḳi uzsvērt digitalizācijas sniegtos ieguvumus līdz plašākiem tīklošanās pasākumiem. Šḳiet, ka šādas darbības veic arī IKT nozares asociācija LIKTA.

Latvijas IT klasteris ir arī viens no trim digitālo inovāciju centriem, kas jau darbojas, ceturtais tiek veidots Rīgā. Šādu centru mērkịis ir palielināt sadarbību starp sektoriem. Otrais digitālo inovāciju centrs - Ventspils Augsto tehnoloǵiju parks (VATP) (kas atrodas Ventspilì, gandrīz $200 \mathrm{~km}$ no Rìgas) ir vērsts uz aparatūras izstrādi, piemēram, viedajiem materiāliem, tehnologiiju un inženieriju ražošanas sektorā, un sniedz pakalpojumus, lai palīdzētu uzṇēmumiem to digitalizācijas centienos. Trešais Elektronikas un datorzinātṇu institūts (EDI) ir valsts pētniecības institūts, kas dibināts 1960. gadā un izstrādā programmatūru (piem., signālu un attēlu apstrādei) un integrēto aparatūru (piem., bezvadu sensorus un valkājamās iekārtas) (Eiropas Komisija, 2018b). Vēl viens Digitālo inovāciju centrs - TechHub Riga - atradīsies Rīgā. Taču dažādu centru pastāvēšana potenciāli var ierobežot nepieciešamās pieredzes veidošanos. Tāpēc Latvijai būtu jāapsver finansējuma koncentrēšana mazākā skaitā organizāciju.

Latvijas IT klastera darbošanās gan Klasteru programmā, gan digitālo inovāciju centros var izraisīt konfliktējošus mērķus, no vienas puses, radot īpašo zināšanu nepieciešamo apjomu, un, no otras puses, šādas zināšanas izkliedējot. N̦emot vērā pārklāšanos starp IT klasteri, LIKTA, LIAA un IT kompetences centru, Latvijas valdībai būtu jāpārskata šo organizāciju darbības, jāizvērtē to relatīvās priekšrocības un trūkumi un skaidri jānosaka to attiecīgās funkcijas, pamatojoties uz šādu novērtējumu. Turklāt šādām programmām būtu jābūt vērstām uz digitalizācijas veicināšanu uzṇēmumos, nevis uz inovāciju IT nozarē.

Šādu pārklāšanos zināmā mērā izraisa Nacionālās industriālās politikas pamatnostādnes, kurās digitālās tehnolog̣ijas nav atzītas kā viens no galvenajiem transversālajiem inovācijas veicinātājiem, un nepastāv nekāds nošķīrums starp esošo tehnoloǵiju pien,emšanu un jaunu inovāciju veicināšanu. Digitālās inovācijas nostādīšana Zinātnes, tehnoloǵiju attīstības un inovācijas pamatnostādṇu un Nacionālās industriālās politikas pamatnostādṇu centrā Latvijai ḷaus noteikt skaidras prioritātes savām programmām, samazināt pārklāšanos un palielināt efektivitāti.

\section{Intelektuālā îpašuma un regulatīvo sistēmu pielāgošana varētu veicināt digitālas inovācijas}

Ir arī veikti pasākumi, lai uzlabotu intelektuālā īpašuma aizsardzību, kas var palīdzēt attīstīt jaunas inovācijas. Latvijas intelektuālā īpašuma politika ir sadrumstalota starp Tieslietu ministriju (TM), Kultūras ministriju (KM) un Zemkopỉbas ministriju (ZM), un par autortiesībām, patentiem un preču zīmēm atbild dažādas ağentūras (Pārresoru koordinācijas centrs, 2017). Tas var būt īpaši problemātiski digitālo inovāciju jomā, kas bieži aptver vairākus intelektuālā ìpašuma mehānismus (BeckermanRodau, 2011). Latvija situāciju ir uzlabojusi, izveidojot Intelektuālā îpašuma padomi, kas ir padomdevēja struktūra, un vienotu Intelektuālā īpašuma informācijas centru, lai sniegtu informāciju un konsultāciju pakalpojumus attiecībā uz dažādiem intelektuālā ìpašuma veidiem (Latvijas Republikas Patentu valde, 2019). Latvijas Patentu valde piedāvā meklēšanas ziṇojumus, kas var palīdzēt samazināt izmaksas tiem, kuri piesakās Eiropas patentam. Turklāt Patentu valde (LRPV) un LIAA uzlabo uzṇēmumu informētību par intelektuālā īpašuma nozīmīgumu, rīkojot tādus pasākumus kā semināri un tirdzniecības izstādes. Intelektuālā īpašuma moduḷi tiks arī iekḷauti augstākās izglìtības kursos par grafisko dizainu un tehniskajiem priekšmetiem.

Intelektuālā īpašuma stratēǵijas izveide kā dažās Ziemelvalstīs, kuras to ir veikušas, varētu palīdzēt Latvijai palielināt investīcijas intelektuālajā ìpašumā. Piemēram, Somija 2009. gadā publicēja savu pirmo intelektuālā īpašuma tiesỉbu stratēéiju (pašlaik tiek pārskatìta), lai pārvarētu tādas problēmas kā nepietiekamas MVU zināšanas par potenciālām intelektuālā īpašuma tiesībām, spēju trūkums slēgt 
līgumus, lai pārvērstu savu intelektuālo īpašumu kapitālā, un nespēja pārraudzìt, vai viṇu intelektuālā ìpašuma tiesības netiek pārkāptas (ESAO, 2011). Šì stratēǵija iekḷāva darbības labākai intelektuālā ipašuma aizsardzỉbas efektivitātei tiesu sistēmā, izveidojot īpašus tiesu un nodokḷu stimulus pētniecībai un izstrādei (Takalo, 2013).

Visbeidzot, jauniem digitālajiem uzṇēmumiem var būt sarežǵiti orientēties regulējumā (sk. zemāk). Atbildot uz to, Dānija ir izveidojusi vienotu kontaktpunktu (Nye Forretningsmodeller) regulatīviem pieprasījumiem par jauniem uzṇēmējdarbības modeliem, kurus var ietekmēt jauns regulējums, ko pārvalda dažādas valsts iestādes. Šì aǵentūra arī analizē jaunu uzṇēmumu prasības un veidus, kādos regulējums tiek ìstenots kaimiņvalstīs, lai veidotu jaunus risinājumus regulatīvajām problēmām (Nye Forretningsmodeller, 2019).

\section{Jaunuzņēmumu veicināšana}

Latvija ir arī izvērsusi savus centienus atbalstīt jaunuzṇēmumus visos to darbības cikla posmos. Latvijā ir reg̣istrēti 400 jaunuzṇēmumi, kas lielākoties darbojas Rīgā, lai gan šì pilsēta ir raksturota kā jaunuzṇēmumu kopiena, nevis kā jaunuzṇēmumu ekosistēma (Eiropas Komisija, 2018a; LIAA, 2019d). 2018. gadā darbību uzsāka StartupLatvia.EU — portāls, kurā norādīti visi jaunuzṇēmumiem piedāvātie pakalpojumi. Turklāt labvēlīgas vides radišana inovācijai un jaunuzṇēmumiem tika padarīta par centrālu principu Latvijas inovācijas politikā. Ekonomikas ministrija arī îsteno Uzṇēmējdarbības vides pilnveidošanas pasākumu plānu (ESAO, 2019g). Pēdējo gadu laikā Latvija ir veikusi vēl citus pasākumus, piemēram, atvieglojusi piekḷuvi finansējumam un reformējusi ar nodokḷiem saistītos tiesību aktus, kas var sniegt ìpašus ieguvumus digitālā ziṇā inovatîviem uzṇēmumiem (sk. zemāk).

Biznesa inkubatoru programma, kas darbojas no 2016. līdz 2023. gadam, piedāvā apmācības un mentoringu vēlākos inovācijas procesa posmos (ESAO, 2019h). Inkubatori atrodas visā Latvijā, tostarp Radošo industriju inkubators Rīgā (LIAA, 2019e). Latvijā pavisam ir 15 LIAA inkubatori (no tiem divi atrodas Rīgā), kas piedāvā apmācības, mentoringu un dotācijas ne ilgāk kā uz četriem gadiem. Inkubatori piedāvā apmācības digitālo rīku izmantošanā, un daži no inkubētajiem uzṇēmumiem tagad tirgo digitālus produktus (piem., VRDEV izstrādātā virtuālā un paplašinātā realitāte). Taču šādu inkubatoru mērķis ir sekmēt uzṇēmējdarbību Latvijā, nevis izstrādāt digitālās tehnolog̣ijas (LIAA, 2019f). Tāpēc Latvijai būtu jāpārorientē viena centra darbs uz digitālajiem jaunuzṇēmumiem.

Visbeidzot, 2019. gadā IZM apstiprināja piecas augstākās izglīitibas iestādes, lai tās pieškirirtu stipendijas studentiem ERAF finansēto inovāciju grantu studentiem programmas ietvaros. Šìs programmas mērḳis ir veidot studentu uzṇēmējdarbības un inovācijas prasmes ar apmācību produktu izstrādē un komercializācijā un ar biznesa inkubatoru izveidi studentiem (EsFondi.lv, 2020e; RTU, 2019). Kopējais finansējums 14,25 miljonu EUR apmērā tika apstiprināts, ceturto daḷu no tā nodrošināja privātais sektors.

\section{Nesen ir veikti pasākumi, lai atvieglotu piekl̦uvi finansējumam}

Uzṇēmumi saskaras ar šḳēršliem piekḷuvē finansējumam, kas var apgrūtināt inovācijas. Gandrīz puse uzṇēmumu ziṇo, ka finansējums ir šķērslis investīcijām (6.11. attēls). Aizdevumi MVU kopš finanšu krīzes joprojām ir zemi, un mazāki uzṇēmumi gandrīz visu savu finansējumu iegūst no kapitāla un nebanku ìstermiṇa saistībām, piemēram, tirdzniecības kredīta. Tā rezultātā valdība ir veikusi pasākumus, lai palielinātu finansējumu.

ALTUM ir vienīgā attīstības finanšu aǵentūra Latvijā. Tā tika izveidota 2013. gadā, apvienojot Latvijas Garantiju ağentūru, Latvijas Hipotēku un zemes banku un Lauku attīstības fondu (ESAO(OECD), 2019i). Tā pieder Zemkopības, Ekonomikas un Finanšu ministrijai (Eiropas Komisija, 2018a). ALTUM isteno valsts atbalsta programmas, piemēram, mikrofinansējumu, kredīta garantijas un aizdevumus jaunuzṇēmumiem, dažus no tiem finansē ES (Pārresoru koordinācijas centrs, 2017; ESAO(OECD), 2019a). Aǵentūra 2016. gadā uzsāka mikroaizdevumus jaunuzṇēmumiem, pēc tam 2017. gadā ieviešot arî aizdevumu garantijas (ESAO, 2019h).

Latvijā darbojas četri akcelerācijas fondi, no kuriem visi ir apliecinājuši ievērojamu interesi par digitālo inovāciju. Trim akcelerācijas fondiem, no kuriem divi finansē digitālo tehnoloǵiju izstrādi, 2018. gadā tika piešķirti 15 miljoni EUR (ar finansējumu, ko nodrošina ERAF, taču administrē ALTUM). Overkill 
Ventures fokusējas uz jaunuzṇēmumiem, kas piedāvā programmatūru uzṇēmumu darījumiem ar uzṇēmumiem, savukārt BuildIT fokusējas uz aparatūru un lietu internetu (LIAA, 2019d). 2019. gadā pirmie 18 jaunuzṇēmumi izvirzìjās nākamajā posmā pēc akcelerācijas (Altum, 2019).

\subsection{1. attēls. Uzṇēmumi, kas apgalvo, ka finansējuma pieejamība ir būtisks šḳērslis ilgtermiṇa investīcijām,} 2018. gads

Procentuāli no visiem uznēmumiem

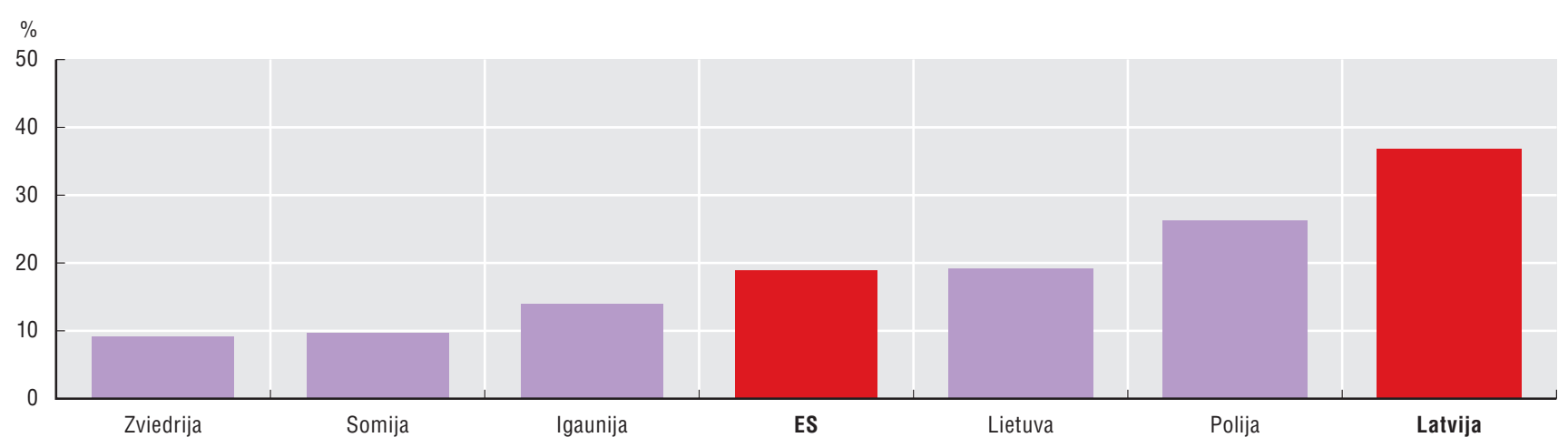

Avots: Eiropas Investīciju banka, EIB 2019. gada apsekojums par investīcijām.

Turklāt 2018. gadā tika uzsākti septiṇi jauni riska kapitāla fondi (ar ES atbalstu) (ESAO, 2019h). Lielāka valsts finansējuma dēḷ riska kapitāla fondi ir paplašinājušies, lai gan riska kapitāla tirgus joprojām ir neliels, jo trūkst labu iespēju investīcijām (ESAO, 2019a). Baltijas Inovāciju fonds (BIF) ir daḷa no Eiropas Inovāciju fonda (EIF) un apvieno finansējumu no trijām Baltijas valstu valdībām (ESAO, 2019g).

\section{Vides uzlabošana jaunuzñèmumiem}

Latvija ir arī veikusi pasākumus, lai atvieglotu migrāciju tiem, kuri strādā jaunuzṇēmumos vai ir tādus dibinājuši, kā arī lai aizsargātu intelektuālā īpašuma tiesības.

2017. gada maijā tika ieviesta īpaša vīzu programma jaunuzṇēmumu dibinātājiem. Latvija jaunuzṇēmumu dibinātājiem, kuri nav no ES, taču par bāzes vietu ir izvēlējušies Latviju, sniedz termiṇuzturēšanās atḷaujas (tā dēvētās jaunuzṇēmumu vīzas) uz laiku lìdz trīs gadiem. Katram jaunuzṇēmumam var būt līdz pieciem dibinātājiem, kuri var izmantot uzturēšanās aț̣auju. Atḷaujas saṇēmēji nedrīkst būt darbinieki vai valdes locekḷi citā Latvijas uzṇēmumā, un viṇiem 12 mēnešu laikā ir jāpiesaista investīcijas vismaz 30000 EUR apmērā no riska kapitāla fonda vai 15000 EUR apmērā no akceleratora vai biznesa eṇgel̦a (LIAA, 2019g).

2017. gadā arī stājās spēkā Jaunuzṇēmumu darbības atbalsta likums, kas tiesīgajiem uzṇēmumiem sniedz divas iespējas, kā samazināt izmaksas, ko rada kvalificēta pētniecības un izstrādes personāla, tostarp IKT speciālistu pieṇemšana darbā. Pirmā iespēja ḷauj uzṇēmumiem veikt valsts sociālās apdrošināšanas iemaksu par noteiktu summu 302 EUR mēnesī par katru darbinieku neatkarīgi no izmaksātās algas kā alternatīvu kopējai valsts obligātajai sociālās apdrošināšanas iemaksu 35 \% likmei. Šì iespēja ir piemērotāka uzṇēmumiem, kuru darbinieki saṇem vismaz divreiz vairāk par minimālo algu. Turklāt jaunuzṇēmumu darbinieki ir atbrīvoti no iedzīvotāju ienākuma nodokḷa par savu algu. Uzṇēmēji alternatīvi var arī izvēlēties 45 \% atlaidi darbaspēka izmaksām par augsti kvalificētiem darbiniekiem, kuriem ir maǵistra vai doktora grāds (informāciju tehnoloǵijā, dabaszinātnēs, matemātikā, inženierijā un tehnoloǵijā, ražošanā un apstrādē vai dizainā) vai vismaz trīs gadu darba pieredze saistītā jomā. Atbilstošie uzṇēmumi šìs priekšrocības sākotnēji var izmantot vienu gadu un to turpināt ne ilgāk kā piecus gadus (Magnetic Latvia, 2019).

Kopējais finansējums palīdzībai saskaṇā ar Jaunuzṇēmumu likumu ir noteikts apmērā līdz 1,6 miljoniem EUR un ir pieejams, izmantojot ERAF un valsts resursus (LIAA projekts Nr. 1.2.1.2/16/I/001) (LIAA, 2019d). Tomēr nav skaidrs, vai nedaudzajiem Latvijas IKT speciālistiem ir izdevīgāk strādāt jaunuzṇēmumos, vai senāk izveidotos uzṇēmumos. Turklāt Latvijā trūkst citu uz tirgu balstītu stimulu pētniecības un attīstības veicināšanai. Tāpēc Latvijai būtu jāapsver iespēja padarīt nodoḳ̣u stimulus pētniecības un attīstības darbiniekiem jaunuzṇēmumos mazāk dāsnus, taču pieejamus visiem uzṇēmumiem. 


\section{Secinājums un politikas ieteikumi}

Latvijas centienos palielināt inovāciju pastāv ievērojama pārklāšanās. Daḷeji to izraisa tas, ka digitālās tehnoloǵijas nav iekḷautas kā transversāls inovāciju veicinātājs dažādos sektoros. LIAA, kompetences centru, klasteru un inovāciju centru darba pārklāšanās var kavēt institucionālo kompetences attīstību vienā organizācijā. Turklāt projekti šḳietami ir izvēlēti pēc to spējas piesaistīt ES finansējumu, nevis pamatojoties uz skaidru valsts prioritāšu kopumu. Tā kā ES programmas mēdz būt īstermiṇa, tas vēl vairāk kavē institucionālo spēju veidošanu, lai atbalstītu inovatīvus uzṇēmumus. Tāpēc jaunas inovācijas stratēǵijas radīšana, kuras pamatā ir digitalizācija, var palīdzēt Latvijai samazināt šādu darba pārklāšanos. Galvenie ieteikumi ir sniegti 6.4. izcēlumā.

\section{4. ielikums. Politikas ieteikumi}

\section{Pētniecỉbas veicināšana}

- Pārskatīt Zinātnes, tehnoloǵiju attīstības un inovācijas pamatnostādnes un Nacionālās industriālās politikas pamatnostādnes nākamajam plānošanas periodam un:

* lielu uzmanību pievērst digitalizācijai kā galvenajam inovāciju un izaugsmes transversālu veicinātājam;

* veicināt digitālo pakalpojumu inovāciju;

* sekmēt digitālās inovācijas, lai risinātu Latvijas sabiedriskās un ekonomiskās problēmas.

- Palielināt valsts atbalstu uzṇēmumdarbības izpētei un attīstībai un dažādot tā sastāvu, lai plašāk izmantotu nodokḷu atvieglojumus pētniecības un attīstības izdevumiem.

- Palielināt augstākās izglītības iestāžu darbinieku stimulus iesaistīties lietišḳajos pētījumos un inovācijās, amatā paaugstināšanas kritērijos iekḷaujot viṇu spēju piesaistīt privāto finansējumu.

- Piešķirt lielāku pētniecības finansējuma dal̦u ar IKT saistītiem projektiem (tostarp starpdisciplināriem projektiem), kas pašlaik ir nepietiekami finansēti.

- Paaugstināt pētniecības kvalitāti, palielinot to finansējuma daḷu, kas piešḳirta konkurences procesos.

- Ieviest ex post novērtējuma sistēmu pētniecības projektiem, kas līdzinās Īrijas Zinātnes fonda izmantotajai.

\section{Inovāciju veicināšana uzṇēmumos}

- Palielināt kompetenču centru privātā līdzfinansējuma daḷu, lai nodrošinātu to orientāciju uz komerciālām inovācijām.

- Pārskatīt IT klastera, LIKTA, LIAA un IT kompetences centra darbību, lai izvērtētu to relatīvās stiprās un vājās puses un skaidri noteiktu to attiecīgās funkcijas, pamatojoties uz šādu novērtējumu.

- Skaidri noteikt IT klastera uzdevumu veicināt digitalizāciju uzṇēmumos, lai novērstu pārklāšanos ar citām programmām.

- Izstrādāt intelektuālā īpašuma tiesību stratēǵiju, pamatojoties uz Somijas veiksmīgo piemēru, un izveidot īpašu tiesu visiem ar intelektuālo īpašumu saistītajiem jautājumiem.

- Vairot uzṇēmējdarbības stimulus ieguldījumiem pētniecībā un attīstỉbā, padarot nodokḷu stimulus pētniecības un attīstības darbiniekiem jaunuzṇēmumos mazāk dāsnus, taču pieejamus visiem uzṇēmumiem.

\section{Latvijas Viedās specializācijas stratēğịja.}

Latvijas valdība 2013. gadā pieṇēma Viedās specializācijas stratēǵiju (RIS3), kas ir nacionāla mēroga pētniecības un inovāciju stratēǵija un nosaka valsts prioritātes uz zināšanām balstītai strukturālai pārveidošanai. RIS3 ir daḷa no ES kohēzijas politikas laikposmam no 2014. līdz 2020. gadam un priekšnosacījums finansiāla atbalsta saṇemšanai no ES Reǵionālās attīstības fonda (ERAF). ${ }^{1}$ Jo īpaši RIS3 lielā mērā nosaka ERAF līdzekḷu sadalījumu dažādās jomās. ES uzskata digitalizācijas programmu par būtisku instrumentu RIS3 ìstenošanai. 
Latvijas Viedās specializācijas stratēǵijā ir noteikti trīs virzieni ekonomikas pārveidošanai: 1) pārmainas tradicionālo ekonomikas jomu ražošanas un eksporta struktūrā; 2) turpmākās izaugsmes jomas, kurā pastāv vai var rasties produkti un pakalpojumi ar augstu pievienoto vērtību; 3) jomas ar ievērojamu horizontālo ietekmi, kas sekmē valsts ekonomikas pārveidi. Stratēgiijā arī ir noteiktas vairākas galvenās prioritātes, tostarp efektīvāka izejvielu izmantošana, jaunu materiālu radīšana, ar tehnoloǵijām nesaistītu inovāciju plašāka lietošana, modernas IKT sistēmas izstrāde privātajā un valsts sektorā, kā arī spēcīgāka zināšanu bāze un cilvēkkapitāls jomās, kurās Latvijai ir salīdzinoša priekšrocība, kas ir nozìmīga pārveides procesā (IZM, 2013a).

Valdība noteica piecas viedās specializācijas jomas atbilstoši trīs virzieniem. Zināšanietilpīga bioekonomika ir stratēgisiska joma tradicionālo nozaru pārveidošanai. Biomedicinna, medicīnas tehnologijas un biotehnoloǵijas un Viedie materiāli, tehnoloǵijas un inženiersistēmas ir jomas ar augstu pievienoto vērtību un augstu izaugsmes potenciālu. Informācijas un komunikāciju tehnoloǵijas un Viedā enerǵétika ir horizontāli strukturālas pārveides veicinātāji visās ekonomikas nozarēs.

Katrā no specializācijas jomām tika uzsvērtas vairākas konkurētspējas nišas (6.1. tabula). 6.2. tabula sniedz kopsavilkumu par pieejamo fondu sadalījumu dažādās viedās specializācijas jomās un finansēšanas mehānismiem 2014.-2018. gadā.

\section{1. tabula. Latvijas viedās specializācijas jomas}

\begin{tabular}{|c|c|c|}
\hline $\begin{array}{l}\text { Specializācijas joma } \\
\text { (RIS3) }\end{array}$ & lespējamās specializācijas nišas (2014. gadā) & Saistītās nozares (NACE 2. red.) \\
\hline $\begin{array}{l}\text { Zināšanietilpīga } \\
\text { bioekonomika }\end{array}$ & $\begin{array}{l}\text { Ilgtspējīga un produktīva mežu audzēšana mainīgos } \\
\text { klimata apstāklıs; Koksnes biomasas pilnīga } \\
\text { izmantošana ksīmiskajai pārstrādei un enerǵijai; } \\
\text { Inovatīvas augu un dzīvnieku selekcijas tehnoloǵijas, } \\
\text { kas samazina risku; Inovatīvu nišas produktu ar augstu } \\
\text { pievienoto vērtību veidošana no koksnes, tradicionālām } \\
\text { un nekonvencionālām lauksaimniecības augu un } \\
\text { dzīvnieku izejvielām; Tehnoloǵiskie risinājumi augu un } \\
\text { dzīvnieku selekcijas izmantošanai un blakusproduktu } \\
\text { apstrādei; Pārtikas nekaitīgums }\end{array}$ & $\begin{array}{l}\text { A - Lauksaimniecība, mežsaimniecība un zivsaimniecī̄ba: A.01 - Augkopība un } \\
\text { lopkopība, medniecība un saistītas palīgdarbības; A.02 - Mežsaimniecība un } \\
\text { mežizstrāde; A.03 - Zivsaimniecība } \\
\text { C - Apstrādes rūpniecība: C.10 - Pārtikas produktu ražošana; C.11 - Dzērienu } \\
\text { ražošana; C.16 - Koksnes, koka un korķa izstrādājumu ražošana, izņemot mēbeles; } \\
\text { salmu un pīto izstrādājumu ražošana; C.17 - Papīra un papīra izstrādājumu } \\
\text { ražošana; C.20 - Ķ̄̄misko vielu un k̦īmisko produktu ražošana; C.23 - Nemetālisko } \\
\text { minerālu izstrāaājumu ražošana; C.27 - Elektrisko iekārtu ražošana; C.28 - Citur } \\
\text { neklasificētu iekārtu, mehānismu un darba mašīnu ražošana } \\
\text { M - Profesionālie, zinātniskie un tehniskie pakalpojumi M.74 - Citi profesionālie, } \\
\text { zinātniskie un tehniskie pakalpojumi }\end{array}$ \\
\hline $\begin{array}{l}\text { Biomedicīna, } \\
\text { medicīnas } \\
\text { tehnoloǵijas un } \\
\text { biotehnoloǵijas }\end{array}$ & $\begin{array}{l}\text { Ķīmiskas un biotehnoloǵiskas metodes farmaceitisku } \\
\text { un bioaktīvu vielu ražošanai; Cilvēku un veterināro zāḷu } \\
\text { izstrāde un pētniecība; Molekulārā un individualizētā } \\
\text { ārstēšana un diagnostikas metodes, šūnu tehnoloǵija; } \\
\text { Funkcionālā pārtika, terapeitiskā kosmētika un } \\
\text { bioaktīvas dabīgās vielas }\end{array}$ & $\begin{array}{l}\text { C - Apstrādes rūpniecība: C.10 - Pārtikas produktu ražošana; C.20 - K̦īmisko vielu } \\
\text { un ķ̄imisko produktu ražošana; C.21 - Farmaceitisko pamatvielu un farmaceitisko } \\
\text { preparātu ražošana; C.26 - Datoru, elektronisko un optisko iekārtu ražošana; } \\
\text { C.26.6 Apstarošanas, elektromedicīnisko un elektroterapijas iekārtu ražošana; } \\
\text { C.32.50 Medicīnas un zobārstniecības instrumentu un piederumu ražošana } \\
\text { Q - darbības cilvēku veselības aizsardzībai }\end{array}$ \\
\hline $\begin{array}{l}\text { Viedie materiāli, } \\
\text { tehnoloǵijas un } \\
\text { inženierzinātnes }\end{array}$ & $\begin{array}{l}\text { Implantātu materiāli, kompozītmateriāli, plānslānni un } \\
\text { pārklājumi, aprīkojums, mehānismi un darba iekārtas, } \\
\text { stiklšķiedras produkti un viedi materiāli uz stikla bāzes }\end{array}$ & $\begin{array}{l}\text { C - Apstrādes rūpniecība: C.20 - Ķīmisko vielu un ķ̄imisko produktu ražošana; } \\
\text { C.23 - Nemetālisko minerālu izstrādājumu ražošana; C.25 - Gatavo } \\
\text { metālizstrādājumu ražošana, izņemot mašīnas un iekārtas; C.28 - Citur neklasificētu } \\
\text { iekārtu, mehānismu un darba mašīnu ražošana, C.32 - Cita veida ražošana }\end{array}$ \\
\hline $\begin{array}{l}\text { Informācijas un } \\
\text { komunikāciju } \\
\text { tehnoloǵijas }\end{array}$ & $\begin{array}{l}\text { Inovatīva zināšanu pārvaldī̄a, sistēmu modelēšana un } \\
\text { programmatūras izstrādes metodes un rīki; Inovatīiva } \\
\text { IKT aparatūras (aparatūra) un programmatūras } \\
\text { (programmatūra) izmantošana nozarēs; Kiberfizikas } \\
\text { sistēmas, valodu tehnoloǵijas un semantiskais tīkls; } \\
\text { Lielapjoma datu un zināšanu infrastruktūra; Informācijas } \\
\text { drošība un kvantu datori; Datorsistēmu testēšanas metodes }\end{array}$ & $\begin{array}{l}\text { J - Informācijas un komunikācijas pakalpojumi: J.61 - Telekomunikācija; } \\
\text { J.62 - Datorprogrammēšana, konsultēšana un saistītas darbības; J.63.1 - Datu } \\
\text { apstrāde, uzturēšana un ar to saistītās darbības; interneta portālu darbība; } \\
\text { J.58.2 - Datorprogrammatūras tiražěšana; C.26.1 - Elektronisko komponentu un } \\
\text { plašu ražošana; C.26.2. Datoru un perifēro iekārtu ražošana; C.26.3. Sakaru iekārtu } \\
\text { ražošana; C.26.4. Sadzīves elektronisko iekārtu ražošana; C.26.8. Magnētisko un } \\
\text { optisko datu nesēju ražošana }\end{array}$ \\
\hline Viedā enerǵija & $\begin{array}{l}\text { Viedtīklu un pieprasījuma-piegādes sistēmu, viedo ēku, } \\
\text { sadzīves tehnikas un māju automatizācijas sistēmu } \\
\text { izstrāde; Nākamās paaudzes tehnoloǵiju izstrāde } \\
\text { atjaunojamo energoresursu enerǵijjai; Energoefektivitātes } \\
\text { paaugstināšana - ēku konstrukcijas energoefektivitāte, } \\
\text { dzīvojamo zonu infrastruktūras elementu } \\
\text { energoefektivitāte; Ilgtspējīga enerǵija transportam - } \\
\text { jaunas tehnoloǵijas, to īstenošanas paātrināšana, } \\
\text { elektromobilitāte }\end{array}$ & $\begin{array}{l}\text { C - Apstrādes rūpniecība: C.27 - Elektrisko iekārtu ražošana; C.28 - Citur } \\
\text { neklasificētu iekārtu, mehānismu un darba maš̄̄nu ražošana; C.29 - Automobiļu, } \\
\text { piekabju un puspiekabju ražošana } \\
\text { D - Elektroenerǵija, gāzes apgāde, siltumapgāde un gaisa kondicionēšana: } \\
\text { D.35 - Elektroenerğijia, gāzes apgāde, siltumapgāde un gaisa kondicionēšana: } \\
\text { F- Būvniecība: F.41 - Ėku būvniecība; F.43 - Specializētie būvdarbi } \\
\text { J - Informācijas un komunikācijas pakalpojumi: J.62 - Datorprogrammēšana, } \\
\text { konsultēšana un saistītas darbības }\end{array}$ \\
\hline
\end{tabular}

Piezime: IKT = Informācijas un komunikācijas tehnolog̣ijas.

Avots: Eiropas Komisija (2018c), "Latvia - S3 Priorities as Encoded in the "Eye@RIS3” Tool”, https://s3platform.jrc.ec.europa.eu/regions/LV/tags/LV (piekliuve 2019. gada 30. septembrī) 
6.2. tabula. Finansējuma instrumenti viedajai specializācijai 2014.-2018. gads

EUR

\begin{tabular}{|c|c|c|c|c|c|c|c|c|}
\hline \multirow{3}{*}{ Avots } & & & \multicolumn{2}{|c|}{$\begin{array}{l}\text { Izglîtīibas un zinātnes ministrijas } \\
\text { finansējuma instrumenti }\end{array}$} & \multirow{3}{*}{$\begin{array}{c}\begin{array}{c}\text { ES Pētniecības } \\
\text { un inovācijas } \\
\text { programma }\end{array} \\
\text { Apvārsnis } 2020\end{array}$} & \multirow{2}{*}{\multicolumn{2}{|c|}{$\begin{array}{c}\begin{array}{c}\text { Ekonomikas ministrijas } \\
\text { finansējuma instrumenti }\end{array} \\
\text { ESI fondi (piem., ERAF, ESF) }\end{array}$}} & \multirow[b]{3}{*}{ Kopā } \\
\hline & \multicolumn{2}{|c|}{ Valsts valdība } & \multicolumn{2}{|c|}{ ESI fondi (piem., ERAF, ESF) } & & & & \\
\hline & ERA-NET & $\begin{array}{c}\text { Fundamentālo } \\
\text { un lietišsco } \\
\text { pētījumu } \\
\text { programma }\end{array}$ & $\begin{array}{l}\text { Pēcdoktoran- } \\
\text { tūras } \\
\text { pētniecība }\end{array}$ & $\begin{array}{l}\text { Praktiskās } \\
\text { ievirzes } \\
\text { pētniecība }\end{array}$ & & $\begin{array}{l}\text { Pētniecības } \\
\text { rezultātu } \\
\text { komerciali- } \\
\text { zācija } \\
\end{array}$ & $\begin{array}{l}\text { Kompetenču- } \\
\text { centri }\end{array}$ & \\
\hline Bioekono-mika & .. & 3003297 & 3255695 & 3349101 & 4456544 & 778245 & 9752819 & 24595701 \\
\hline Biomedicīna & 2539607 & 4996572 & 6155076 & 19683916 & 2329968 & 2302933 & 7871315 & 45879387 \\
\hline Viedā enerǵija & .. & 5378043 & \multicolumn{2}{|c|}{$12404929^{1}$} & 12419688 & \multicolumn{2}{|c|}{$4050008^{1}$} & 34252668 \\
\hline Viedie materiāli & .. & 8012905 & 5352240 & 15722087 & 2994482 & 3713511 & 16399223 & 52194448 \\
\hline IKT & .. & 3494203 & 3813470 & 5238442 & 7511618 & 2095685 & 10780921 & 32934339 \\
\hline Kopā & 2539607 & 24885020 & \multicolumn{2}{|c|}{74974956} & 29712299 & \multicolumn{2}{|c|}{57744660} & 189856543 \\
\hline
\end{tabular}

1. Šis skaitlis attiecas uz kopējiem ESIF līdzekliem.

Piezīme: .. = nav pieejams; $\mathrm{IKT}=$ Informācijas un komunikācijas tehnolog̣ijas.

Avots: ESAO, pamatojoties uz IZM datiem.

\section{3. tabula. Viedā specializācija: Kompetenču centri un klasteri}

\begin{tabular}{|c|c|c|}
\hline Specializācijas joma (RIS3) & Kompetenču centri & Klasteri (ieviesti 2017. gadā) \\
\hline Zināšanietilpīga bioekonomika & $\begin{array}{l}\text { Latvijas pārtikas kompetences centrs (LPKC), Meža nozares } \\
\text { kompetences centrs (MNKC) }\end{array}$ & $\begin{array}{l}\text { Pārtikas produktu kvalitātes klasteris, Latvijas Koka } \\
\text { būvniecības klasteris, CLEANTECH Latvia (starpnozaru), } \\
\text { Viedās pilsētas klasteris (starpnozaru) }\end{array}$ \\
\hline $\begin{array}{l}\text { Biomedicīna, medicīnas } \\
\text { tehnoloǵijas un biotehnoloğijas }\end{array}$ & $\begin{array}{l}\text { Farmācijas, biomedicīnas un medicīnas tehnoloǵiju Kompetences centrs } \\
\text { (FBMTKC) }\end{array}$ & Latvijas Dzīvības zinātņu nozares attīstības klasteris \\
\hline $\begin{array}{l}\text { Viedie materiāli, tehnoloǵijas un } \\
\text { inženierzinātnes }\end{array}$ & $\begin{array}{l}\text { Transporta mašĩnbūves kompetences centrs (TMKC), Viedo materiālu un } \\
\text { tehnoloǵiju kompetences centrs (VMTKC) }\end{array}$ & $\begin{array}{l}\text { Metālapstrādes klasteris, Zalo un viedo tehnoloǵiju klasteris } \\
\text { (starpnozaru), Drukas un mediju tehnoloğiju klasteris }\end{array}$ \\
\hline $\begin{array}{l}\text { Informācijas un komunikāciju } \\
\text { tehnoloǵijas }\end{array}$ & IT kompetences centrs (ITKC), LEO Pētījumu centrs (LEO) & Informācijas tehnoloǵiju klasteris \\
\hline Viedā enerǵija & Viedās inženierijas, transporta enerǵētikas kompetences centrs (VITEKC) & Latvijas elektronikas un elektrotehnikas nozares klasteris \\
\hline
\end{tabular}

Avots: ESAO, pamatojoties uz IZM datiem (2018), Informative Report: Monitoring of Smart Specialization Strategy, https://s3platform.jrc.ec.europa.eu/ documents/20182/0/RIS3_progress+report_LV_2018.pdf/940176c6-b886-4213-9f18-75c20251bfb9.

Pēc viedās specializācijas jomu atlases 2013. gada jūnijā un jūlijā notika vairākkārtējas diskusijas ar uzṇēmējiem, uzṇēmumu apvienībām un akadēmiḳiem. Sākotnējā novērtējumā tika konstatēts, ka plašs produktu klāsts un prasmīgs darbaspēks jau pastāv mežsaimniecības un kokapstrādes, lauksaimniecības un pārtikas nozarēs, kā arī metālapstrādē un mašīnbūvē. Augsts eksporta potenciāls tika konstatēts kokapstrādē, pārtikas rūpniecībā, metāla un tā izstrādājumu ražošanā un ḳimiskajā rūpniecībā, kā arī informācijas un komunikāciju pakalpojumos. Arī veselības aprūpes pakalpojumu eksports, kaut arī tobrīd neliels, tika uzskatīts par daudzsološu. Ievērojamas patentēšanas darbības tika konstatētas virsmu tehnoloǵiju un pārklājumu, materiālu, dzinēju, turbīnu sūkṇu, nanozinātṇu, audiovizuālo tehnolog̣iju, veselības, farmācijas, k̦īmijas un koksnes k̦îmijas, kā arī atsevišşāa IT jomās un pārvaldības metodēs. Visbeidzot, novērtējumā uzsvērta pētniecỉbas specializācija materiālzinātnē, biotehnoloǵijā, IKT, enerǵētikā un transporta tehnolog̣ijā (IZM, 2013a).

Viedās specializācijas jomu atlasē Latvija ir diezgan liela uzmanība tiek pievērsta ražošanai. Pakalpojumi ir atsevišķi ṇemti vērā tikai kā IT pakalpojumi IKT specializācijas jomā. Ar labklājỉbu vai sociālo inovāciju saistīti pakalpojumi nav ṇemti vērā. Tas atšḳiras no daudzām ES valstīm, tostarp Dānijas un Igaunijas, kuras ir īpaši iekḷāvušas veselỉbas aprūpes pakalpojumus vai sociālo darbu kā viedās specializācijas jomas, un liek Latvijas Viedās specializācijas stratēǵijai šḳist diezgan vienpusīgai (Eiropas Komisija, 2012b).

Katru viedās specializācijas jomu atbalsta vairāki kompetences centri un klasteri (6.3 tabula). Kompetences centri ir komerciālas struktūras, ko dibinājuši uznēmumi un pētniecības organizācijas, kas pārvalda un finansē pētniecības un izstrādes darbības ar potenciālu komerciālo vērtību. Tiem ir nozīmīga loma apmaiṇas potenciāla uzlabošanā starp uzṇēmumiem un pētniecības organizācijām. 
Klasteri ir dalībnieku organizācijas konkrētās ekonomikas jomās, kuru mērḳis ir ar tīmekḷa starpniecību radīt dalībniekiem pozitīvu ārējo efektu. Inovācijas sistēmu kontekstā klasteri parasti ietver triju veidu dalībniekus (trīskāršā spirāle), proti, privātās, akadēmiskās un valsts struktūras (piem., universitātes un pētniecības iestādes). Klasteri un klasteru politika tiek uzskatīti par dažiem no galvenajiem pamatelementiem RIS3 izstrādē un īstenošanā (Eiropas Komisija, 2013).

Valdība 2018. gadā veica sākotnējo novērtējumu par Viedās specializācijas stratēǵijas īstenošanu un secināja, ka Latvijas konkurences priekšrocība joprojām lielā mērā ir balstīta uz zemām darbaspēka izmaksām un dabas resursiem. Investīcijas pētniecībā un izstrādē, kas izteiktas kā procentuālā daḷa no IKP, laikā no 2010. līdz 2016. gadam nedaudz samazinājās, savukārt darba produktivitāte ražošanā nedaudz pieauga, tomēr nesasniedza gaidīto. Turklāt Latvija Eiropas inovāciju indeksā pārgāja no pieticīgu uz vidēju rezultātu grupu, lai gan tas lielākoties ir saistīts ar ES atbalstu iepriekšējā finansējuma periodā (2007.-2013. gadā). Novērtējumā tika ziṇots par pozitīvām izmaiṇām attiecībā uz zinātniskajām publikācijām, gados jaunu pieaugušo (vecumā no 30 līdz 34 gadiem) sasniegumiem izglītībā, pētniecības sadrumstalotību un augsto tehnoloǵiju preču eksportu (IZM, 2018). Taču novērtējumā netika skatīti konkrētu specializācijas jomu vai pētniecības nozaru rezultāti.

Lai labāk izvērtētu investēto līdzekḷu efektivitāti, 2016. gadā tika ieviesta RIS3 monitoringa sistēma. Rezultāti tiks izmantoti, lai veidotu nākamo Viedās specializācijas stratēgiju (2021.-2027. gadam), kurā galvenā uzmanība tiks pārvirzīta no vāji saistītām produktu nišām (6.1. tabula) uz mazāku ekosistēmu klāstu, kam ir salīdzinošo priekšrocību potenciāls. Nozīmīga atšḳirība ir tā, ka jaunajā pieejā labāk ir ṇemta vērā dažādu ekosistēmas dalībnieku būtiski svarīgā loma, kā arī augšupējas un lejupējas darbības (t.i., vērtību k̦ēde).

Pašlaik Latvijas valdība ir konstatējusi trīs ekosistēmas attīstībai — biomedicīnu, viedos materiālus un viedās pilsētas. ${ }^{2}$ No tiem viedā pilsēta ir vienīgā ekosistēma, kas pašlaik nav īpaši saistīta ne ar vienu no esošajām specializācijas jomām. Taču pastāv ievērojama pārklāšanās starp viedās pilsētas koncepciju un viedās enerǵijas specializācijas jomām (tostarp mobilitāti), kā arī biomedicīnas specializācijas jomām (tostarp attālināto veselības aprūpes pārraudzību). Skaidru saikṇu uzturēšana ar esošajām viedās specializācijas jomām var būt būtiski svarīga, lai nodrošinātu nepārtrauktību. Tā kā Latvijas definīcijā viedās pilsētas koncepcijai ir īpaši uzsvērti pasākumi, kas l̦auj laikus prognozēt un novērst potenciālas problēmas, piemēram, energoresursu trūkumu, siltumenerǵijas zudumus vai kanalizācijas noplūdes, turpmākajās sadaḷās, kurās sniegts novērtējums un ieteikumi dažādām viedās specializācijas jomām, viedo pilsētu ekosistēma ir skatīta viedās enerǵijas jomas ietvaros. Visaptverošus politikas ieteikumus, kas izriet no turpmākajām sadaḷām, var īsumā raksturot, kā minēts zemāk.

Pirmkārt, valsts atbalsts viedajai specializācijai būtu vairāk jānovirza uz ekosistēmām ar augstu izaugsmes potenciālu, ṇemot vērā visu vērtības k̦ēdi no pētniecības līdz komercializācijai. Agrāk Viedās specializācijas stratēǵija sniedza atbalstu pārāk daudzām atsevišḳām produktu nišām, nenosakot prioritātes. Tā rezultātā līdzekḷi ir sadalīti pārāk maz. Jaunā ekosistēmas pieeja var palīdzēt uzlabot mērḳa noteikšanu, un turpmākajās iedaḷās sniegtas dažas norādes uz iespējamo potenciālu.

Otrkārt, Latvijai būtu labāk jāizmanto IKT viedās specializācijas joma kā inovācijas veicinātājs citās specializācijas jomās. Tā kā digitālās tehnolog̣ijas rada pozitīvu plašāku ietekmi visās saimnieciskajās darbībās, IKT izdevumu daḷa viedās specializācijas kopējos izdevumos (6.2. tabula) būtu ievērojami jāpalielina.

\section{5. ielikums. Viedā specializācija: Visaptveroši ieteikumi}

- Koncentrēt viedās specializācijas finansējumu uz ekosistēmām ar augstu potenciālu.

- Palielināt RIS3 finansējuma dal̦u, kas veltīta IKT un mērḳa lietojumiem ar augstu nozīmīgumu citās viedās specializācijas jomās.

- PapildinātViedās specializācijas stratēǵiju ar pasākumiem, lai paplašinātu un izplatītu inovāciju, jo īpaši sekmējot digitālo tehnologiju izvēršanu.

Treškārt, lai gan inovāciju sekmēšana ir Viedās specializācijas stratēgijas pamatā, esošo tehnoloǵiju izplatības veicināšana ir nozīmīga papildinoša stratēǵija. Konkrēti, universālu tehnoloǵiju, piemēram, 
IKT plašāka izplatî̌sana ir būtiski svarīga, jo tā lauj vairāk uzṇēmumiem ieviest inovācijas (ESAO, 2019j). Tas ir jo îpaši svarīgi pakalpojumu uzṇēmumiem, kuriem būtu jāpiešḳir lielāka loma Latvijas Viedās specializācijas stratēgijā.

\title{
Latvijas bioekonomikas stratēǵija.
}

Bioekeonomika ietver atjaunojamu izejvielu izmantošanu, lai ražotu preces un sniegtu pakalpojumus. Tā aptver dažādas nozares un darbības, tostarp k̦īmiskās vielas, pārtiku, lauksaimniecību, piena ražošanu, mežsaimniecību, celulozi un papīru, atkritumu apsaimniekošanu un citas. Attiecīgi apzīmējums "bioekonomika" ne vienmēr norāda uz īpašu intensitāti tehnoloǵiju ziṇā. Tradicionālā mežsaimniecība ir daḷa no bioekonomikas tādā pašā mērā kā ǵenētiska manipulācija ar biomasu un sintētiskā biolog̣ija. Latvijas Viedās specializācijas stratēgijā (RIS3) zinātnesietilpīga bioekonomika ir saistīta ar dažām tradicionālākām nozarēm, tostarp lauksaimniecību un mežsaimniecību, kā arī ar saistītām ražošanas nozarēm, piemēram, pārtiku un koksnes produktiem. Šì specializācijas joma arī ietver dažas zinātnesietilpīgas darbỉbas, piemēram, koksnes ḳīmisko pārstrādi vai atjaunojamo enerǵiju no bioresursiem. Šajās nozarēs RIS3 uzsver produktu telpas paplašināšanu un pakāpenisku uzlabošanu, tiecoties uz produktiem ar augstāku pievienoto vērtību.

\section{Salīdzinošās priekšrocības bioekonomikā ir balstītas uz resursu pārpiln̄ību, nevis uz inovāciju}

2017. gadā lauksaimniecība, mežsaimniecìba un zivsaimniecība, kā arī ar pārtiku un koksnes produktiem saistītā ražošanaveidoja gandrīz 9 \% no Latvijas kopējās pievienotās vērtỉbas. Tādējādi bioekonomikas nozares tradicionāli ir nozīmīga ekonomikas daḷa. Bioekonomikas nozīmīgums ir īpaši izteikts ražošanas nozarē, kurā no koksnes un korḳa izgatavoti produkti (izn,emot mēbeles, taču ietverot salmu un pìtos materiālus), kā arī pārtika un dzērieni veido 43 \% no kopējās pievienotās vērtības (6.12. attēls). Koksnes un saistīto ražošanas darbību ìpatsvars laika gaitā ir nedaudz pieaudzis - no 21,6 \% 2010. gadā līdz 22,1 \% 2017. gadā, taču pārtikas nozarei tas ir ievērojami samazinājies no 20,9 \% līdz 16,4 \%.

\subsection{2. attēls. Bioekonomikas pienesums ražošanas pievienotajā vērtībā, 2010. un 2017. gads}

\author{
Procentuālā dala no ražošanas kopējās pievienotās vērtības
}

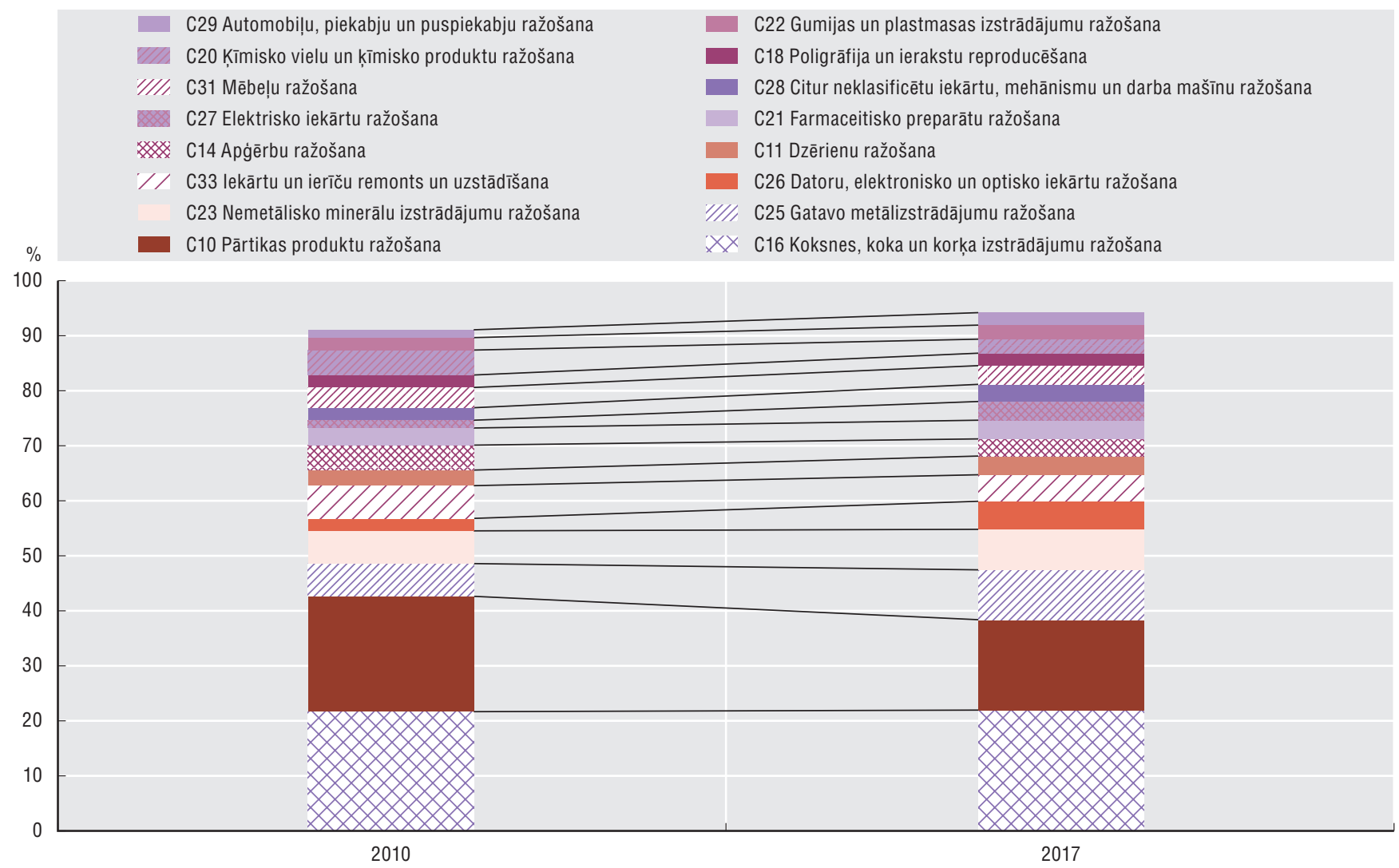

Avots: CSP (2020a), IKG10_060 Total gross value added by kind of activity (NACE 2. red), https://data1.csb.gov.lv/pxweb/en/ekfin/ekfin_ikp_IKP_ikgad. 
Latvijai ir ievērojamas redzamās salīdzinošās priekšrocības tradicionālās bioekonomikas nozarēs. ${ }^{3}$ 2015. gadā koksnes un koksnes produktu daḷa Latvijas kopējā eksportā bija 14 reizes lielāka nekā attiecīgā daḷa pasaules eksportā. Tas attiecas gan uz koksnes un koksnes produktu tiešo eksportu, gan arī uz koksnes produktu, kas integrēti kā starpprodukti citos produktos, netiešo eksportu (6.13. attēls). Turklāt salīdzinājumā ar 2005. gadu redzamā salīdzinošā priekšrocība ar laiku ir kḷuvusi lielāka, kas norāda uz pieaugošu specializāciju. Arī redzamās salīdzinošās priekšrocības lauksaimniecībā, mežsaimniecībā un zivsaimniecībā ir ievērojamas, nozares daḷai kopējā eksportā 2015. gadā esot vairāk nekā 2,8 reizes augstākai nekā citās valstīs.

Taču, lai gan Latvija joprojām eksportē vairāk pārtikas produktu nekā citas valstis, un darba produktivitāte ir pastāvīgi augusi, pārtikas eksportu smagi skāra Krievijas embargo, kas sākās 2014. gadā (EM, 2018b).

\subsection{3. attēls. Latvijas redzamā salīdzinošā priekšrocība, 2005. un 2015. gads}

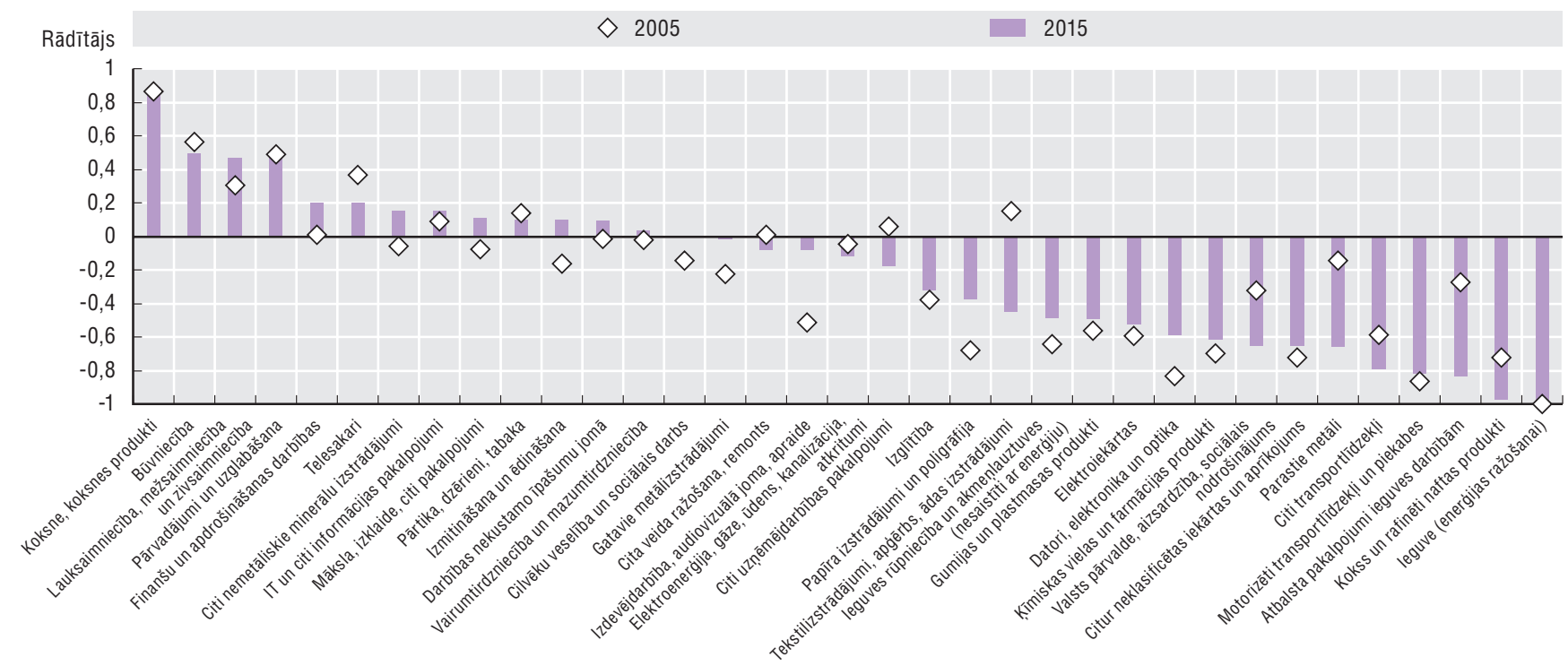

Piezīme: Eksporta redzamā salīdzinošā priekšrocība (RSP) attiecībā uz pievienoto vērtību. Pievienotās vērtības aprēḳinā ṇemti vērā globālo vērtības ḳēžu savienojumi. Attiecīgi, eksports konkrētā nozarē tiek ṇemts vērā neatkarīgi no tā, vai tas ir tiešais eksports vai arī ietverts lejupējo nozaru eksportā. Vairāk informācijas sk. Miroudot un Cadestin (2017). Attēlā redzamā RSP ir standartizēta līdz [-1;1]. Lai iegūtu tekstā minētās oriğinālās RSP vērtības, ir jāizmanto formula ( $\mathrm{x}+1) /(1-\mathrm{x})$.

Avots: ESAO (2020d), OECD Statistics on Trade in Value Added (datubāze), https://dx.doi.org/10.1787/data-00648-en (piekḷuve 2020. gada 27. februārī).

Latvijas tradicionālās bioekonomikas eksportu lielākoties veido produkti ar zemu pievienoto vērtību. Pārtikas nozarē eksportu ar augstu pievienoto vērtību apslāpē pārstrādes jaudas trūkums un nepietiekama efektivitāte vērtību k̦ēdē (ESAO, 2019g). Piemēram, Latvijas pārtikas pārstrādes nozare pašlaik ietver mazāk lielo uzṇēmumu un vairāk mazo uzṇēmumu nekā pirms 10 gadiem, un liela daḷa no arvien augošas biologiiskās produkcijas tiek pārdota tradicionālajiem pārstrādes uzṇēmumiem (piem., vairāk nekā puse no bioloǵiskā piena un olām un viena trešā daḷa gaḷas un graudaugu). Mežsaimniecības vērtības k̦ēdē ievērojamu daḷ eksporta joprojām nosaka tādi produkti kā zāǵmateriāli, malka, nemizota koksne vai kokogles, savukārt produkti, kas vērtības ķēdē atrodas augstāk, tostarp mēbeles vai papīrs, joprojām ir ierobežotā apjomā. Taču laika gaitā ir ievērojami pieaudzis tādu vērtības k̦ēdē augstāk esošu produktu kā koksnes plātṇu un koka māju eksports, kas liecina, ka eksporta vērtība ir palielinājusies salīdzinājumā ar kopējo koksnes produkciju (6.14. attēls). ${ }^{4}$

Attiecībā uz pētniecību un izstrādi Latvijas bioekonomika ievērojami atpaliek no citām ESAO valstīm. Latvijas uzṇēmumu pētniecības un izstrādes izdevumi kā daḷa no pievienotās vērtības 2015. gadā bija 0,13 \% pārtikas ražošanā un 0,12 \% koka izstrādājumu rūpniecībā, savukārt ESAO vidējie rādītāji bija attiecīgi 1,76 \% un 0,81 \% (6.15. attēls). Šk̦iet, tas apstiprina pieṇēmumu, ka izlaide un eksporta izaugsme minētajās nozarēs ir balstītas uz dabas resursu pārpilnību, nevis uz inovācijām un produktivitāti. 


\subsection{4. attēls. Mežsaimniecības produktu pievienotā vērtība Latvijā un atlasītajās ESAO valstīs}

Koksne un koksnes izstrādājumi (HS4401-07), piem.,
zāğmateriāli, malka
Korḳis un korḳa izstrādājumi (HS45)
VIII, Celuloze vai citi škiedraini celulozes materiāili;
pārstrādāts papīrs u.c. (HS47)
Drukātas grāmatas un citi poligrāfijas izstrādājumi (HS49
Saliekamās būvkonstrukcijas (HS9406)

\section{A. Eksporta struktūra}

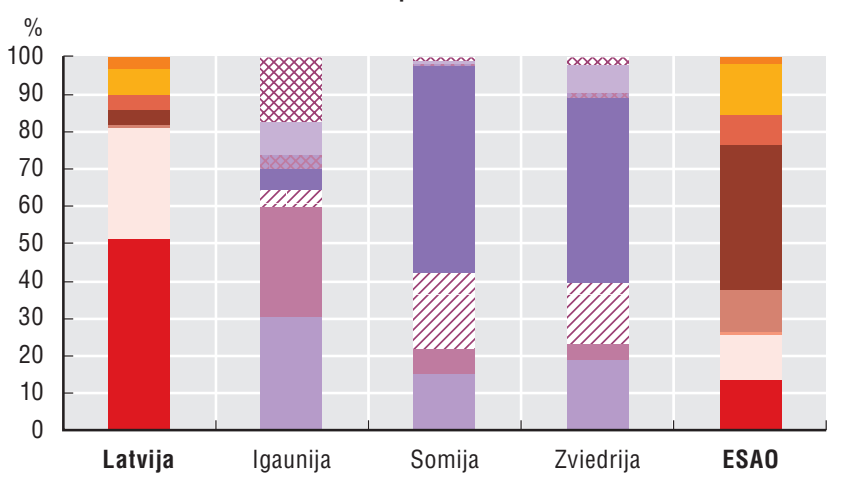

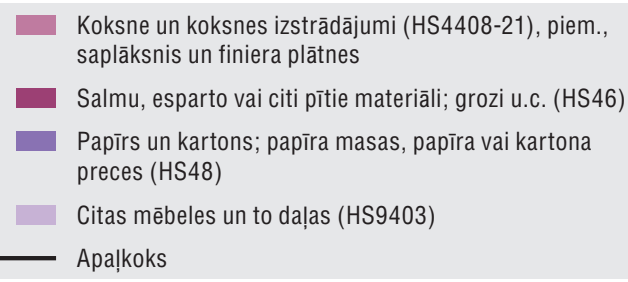

Koksne un koksnes izstrādājumi (HS4408-21), piem., saplāksnis un finiera plātnes

Salmu, esparto vai citi pītie materiāli; grozi u.c. (HS46)

Papīrs un kartons; papīra masas, papīra vai kartona preces (HS48)

Citas mēbeles un to daḷas (HS9403)

Apaḷkoks

\section{B. Eksporta vērtīiba}

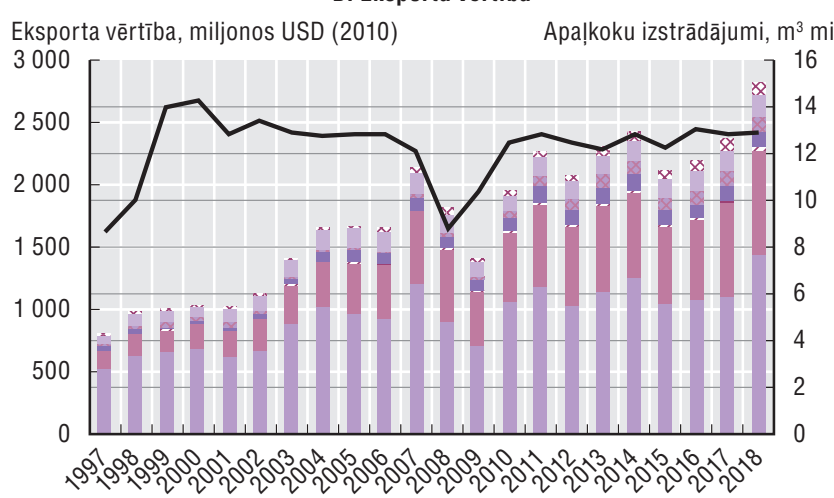

Piezīme: Eksporta vērtỉbas (pašreizējos USD) B shēmā ir deflētas, izmantojot ASV patēriṇa cenu indeksu (2010).

Avots: WITS/UN Comtrade (2020), UNSD Commodity Trade (datubāze), http://wits.worldbank.org (informācija skatīta 2020. gada 4. februārī); FAO (2020), Forestry Production and Trade (datubāze), www.fao.org/faostat/en/\#data/FO/visualize (piekḷuve 2020. gada 20. maijā).

\subsection{5. attēls. Pētniecības un izstrādes izdevumi pa nozarēm Latvijā salīdzinājumā ar ESAO valstīm, 2015. gads}

Procentuālā daḷa no pievienotās vērtības katrā nozarē

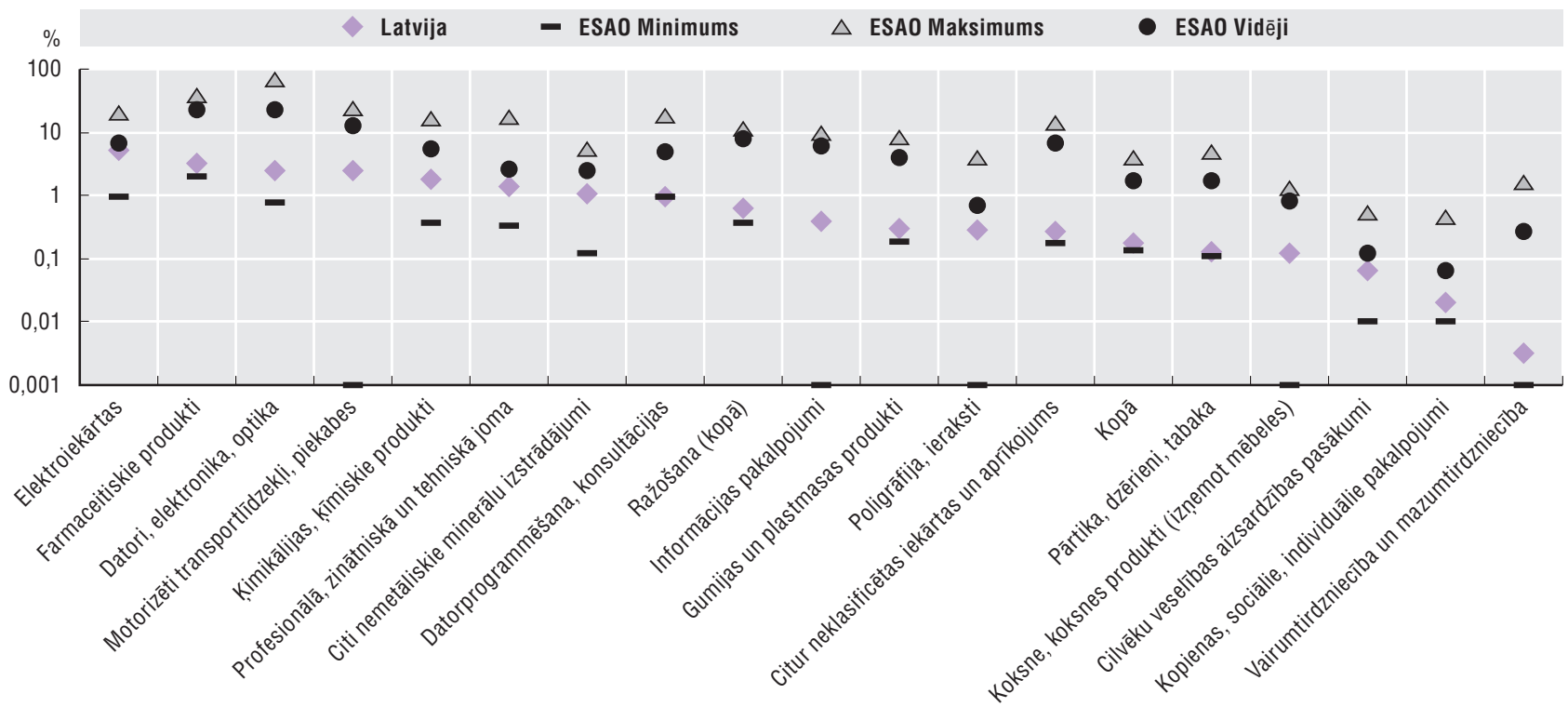

Piezīme: Logaritmiskā skala. Vidējie rādītāji ir svērti, izmantojot pievienoto vērtību pirktspējas paritātē (IKP). 2014. gada dati par Čīli, Igauniju, Ungāriju, Japānu, Lietuvu, Portugāli un ASV. 2016. gada dati par Franciju.

Avots: ESAO (2020e), "Research and development statistics: Business enterprise R-D expenditure by industry - ISIC Rev. 4", https://dx.doi.org/10.1787/ data-00668-en (piekḷuve 2020. gada 13. martā); ESAO (2020f), STAN: OECD Structural Analysis Statistics (datubāze), https://dx.doi.org/10.1787/data-00649en (piekluve 2020. gada 24. februārī). 
Valdība ir pastiprinājusi pētniecību bioekonomikā, taču tehnoloǵiju pārnese uz mazākiem uzṇēmumiem joprojām ir väja

Pēdējās desmitgades laikā valdība ir veikusi ievērojamu darbu, lai veicinātu inovācijas tradicionālajās bioekonomikas nozarēs. Laika posmā no 2010. līdz 2015. gadam valdības izdevumi pētniecībai un izstrādei lauksaimniecỉbas un veterinārajā zinātnē palielinājās gandrīz par 5 miljoniem EUR (t.i., no $25 \%$ līdz 30 \% no valdỉbas izdevumiem pētniecībai un izstrādei dabaszinātnēs un inženierzinātnēs) (6.16. attēls). Taču valdības izdevumu palielinājums (piem.,valsts pētniecības iestādēm) neietvēra papildu finansējumu augstākās izglìtības iestādēm. Tas potenciāli varētu nelabvēlīgi ietekmēt zinātnisko talantu pieejamību nākotnē. ${ }^{5}$

\subsection{6. attēls. Latvijas pētniecības un izstrādes izdevumi dabaszinātnēs un inženierzinātnēs katrā nozarē}

Kā kopējo pētniecības un izstrādes izdevumu procentuālā daḷa dabaszinātnēs un inženierzinātnēs katrā nozarē

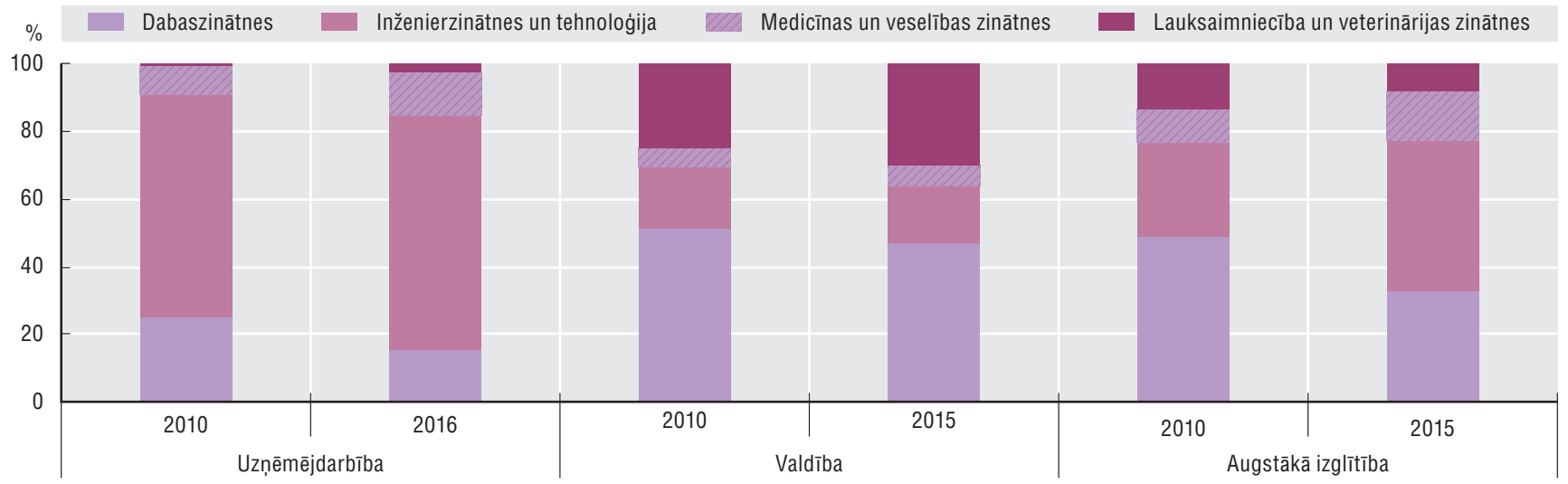

Avots: ESAO (2020g), "Research and development statistics: Gross domestic expenditure on R-D by sector of performance and source of funds", https://dx.doi.org/10.1787/data-00189-en (piekḷuve 2020. gada 26. februārī).

Valdība ir arī veikusi darbības, lai uzlabotu koordināciju starp pētniecības iestādēm. 2014. gadā 14 zinātniskās institūcijas lauksaimniecības, pārtikas, mežsaimniecības un ar tām saistītajās nozarēs, tostarp kokapstrādē un koksnes k̦īmijā, izveidoja Bioekonomikas pētniecības stratēgisko apvienību. Pēc konsolidācijas procesa 2015. gadā šo apvienību pašlaik veido astoṇasinstitūcijas. Tās ir: Latvijas Lauksaimniecības universitāte (LLU); trīs neatkarīgas iestādes, kas darbojas LLU uzraudzībā, proti, Dārzkopības institūts, Agroresursu un ekonomikas institūts un Latvijas Augu aizsardzības pētniecības centrs; Pārtikas drošības, dzīvnieku veselības un vides zinātniskais institūts "BIOR"; Latvijas Valsts mežzinātnes institūts "Silava"; Latvijas Valsts koksnes k̦īmijas institūts; kā arī Meža un koksnes produktu pētniecības un attīstības institūts (MeKA).

Laika gaitā apvienībā ir ievērojami palielinājies pētniecības darbinieku skaits, no 242 darbiniekiem 2013. gadā sasniedzot 359 darbiniekus 2016. gadā (ZM, 2018). Citēto publikāciju daḷa lauksaimniecības un pārtikas zinātnes jomā visās Latvijas publikācijās ievērojami pieauga no 11 \% 2007.-2012. gadā līdz 16 \% 2013.-2016. gadā (ESAO, 2019g). Taču ienēemumi no intelektuālā īpašuma tiesību pārneses vai citiem pētniecības pakalpojumiem, kas sniegti trešām personām, 2015. un 2016. gadā samazinājās no 4,7 miljoniem EUR līdz 4,2 miljoniem EUR, kas ir zemāk par 2013. gada līmeni. Tas liecina, ka Latvijai ir iespējas uzlabot zināšanu pārnesi no valsts finansētiem pētijumiem uz komerciāliem pielietojumiem. Tas, ka ir būtiski svarīgi, lai būtu vairāk zināšanu pārneses mehānismu, ir īpaši atzìts Latvijas Bioekonomikas stratēgiijā 2030. gadam, ko valdība publiskoja 2018. gadā. Konkrēti, stratēǵijā uzsvērts, ka lēna un sadrumstalota zināšanu pārnese ir galvenais šk̦ērslis pievienotās vērtības palielināšanai ražošanā (ZM, 2018).

Nozīmīgs solis ceḷā uz labāku sadarbību starp zinātniskajām iestādēm un uzṇēmumiem bija kompetences centru izveide dažādās pētniecības jomās. Līdz 2018. gada beigām vienu no astoṇiem kompetences centriem bija izmantojuši 149 uzṇēmumi, no kuriem 31 atbalstīja Latvijas pārtikas nozares kompetences centrs, savukārt 13 - Meža nozares kompetences centrs. Privāto investīciju, kas papildina valsts atbalstu pētniecības un izstrādes projektiem, kopējais apjoms bija 1,9 miljoni EUR pārtikas nozarē un 2,3 miljoni EUR meža nozarē. Taču ražošanas nozarē ieinteresētās personas ir norādijjušas, 
ka kompetences centru ierobežotās spējas rada sarežğijumus potenciāliem jauniem projektiem. Vēl jo svarīgāk, projektu augstā pētniecības intensitāte padara programmu nepiemērotu MVU.

Valdībai būtu jāstiprina mehānismi lietišk̦o pētījumu rezultātu komercializācijai, kas ir labāk piemēroti MVU, piemēram, Tehnolog̣iju pārneses programma. Instrumenti pētniecības komercializācijas veicināšanai saṇēma tikai 3,2 \% no kopējiem izdevumiem viedās specializācijas jomā (6.2. tabula). Turklāt Tehnoloǵiju pārneses programmai ir tikai viens kontaktpunkts bioekonomikas jomā, un tas atrodas Latvijas Lauksaimniecības universitātē (LLU). Flandrijas Tehnoloğiju pārneses biroji —piecu flāmu universitāšu kopīga iniciatīva - sniedz labu piemēru, kā dažādas universitātes un pētniecības institūti var sadarboties, lai tiešsaistē nodrošinātu piekḷuvi visām pieejamajām zināšanām un tehnologiijām dažādās institūcijās (6.6. ielikums).

\section{6. ielikums. Flandrijas Tehnologiju pārneses biroji (TPB)}

Flandrijas TPB ir kopīga iniciatīva, kurā iesaistītas piecas flāmu universitātes: G̣entes Universitāte, Antverpenes Universitāte, Lēvenas Katoḷu universitāte, Vrije Universiteit Brussel un Haseltas Universitāte. Minēto universitāšu tehnolog̣iju pārneses biroji ir atbildīgi par zināšanu un tehnologiju pārnesi no universitātēm un saistītajām universitāšu koledžām uz privātajiem un publiskajiem partneriem. Tas ietver kontaktu izveidi ar ražošanas nozari, juridiskā atbalsta sniegšanu saistībā ar līgumiem, izglītỉbas aktivitāšu veicināšanu iesaistîšanās nolūkā, intelektuālā ìpašuma aizsardzību, kā arī atbalstu jaunuzṇēmumiem un meitasuzṇēmumiem.

Kopīgā iniciatīva nodrošina vienotu kontaktpunktu (www.ttoflanders.be) ražošanas nozarēm, kurām vajadzīgas pētniecības īpašās zināšanas un licencēšanas iespējas, lai labāk izmantotu pieejamās zināšanas un tehnoloǵijas. Tā sekmē sadarbỉbu starp pieciem dažādajiem tehnoloǵiju pārneses birojiem un stiprina to darbību, izstrādājot kopīgus līdzekḷus un daloties paraugpraksē. Iesaistītās universitātes un universitāšu koledžas cer, ka iniciatīva palīdzēs flāmu tehnoloǵiju pārneses birojiem kḷūt par efektīvāku dalībnieku Eiropas un starptautiskajā inovāciju jomā.

Flandrijas tehnolog̣iju pārneses biroji piedāvā tehnolog̣ijas tādās jomās kā pārtika un lauksaimniecỉba, veselība, materiāli un k̦īmija, IKT un elektronika, kā arī tīrās tehnolog̣ijas un enerǵija, un nodrošina saites ar attiecīgajiem ekspertīzes centriem. Tīmekḷa vietne ir pieejama ang̣̣u valodā un novirza klientu jautājumus attiecīgajai personai vai pētniecības centram. Paredzētie budžeta izdevumi gadā ir apmērā no 1 līdz 5 miljoniem EUR.

Avots: ESAO (2019k), Benchmarking Higher Education System Performance, Higher Education, https://dx.doi.org/10.1787/ be5514d7-en; Eiropas Komisija/ESAO (2020), STIP Compass: International Database on Science, Technology and Innovation Policy (STIP), 20.03.2020. izdevums, https://stip.oecd.org.

\section{Latvijai būtu jāpievēršas mežsaimniecības produktiem ar augstu pievienoto vērtību un jāizmanto sinergija ar materiālzinātni}

Kokapstrādes nozares rādītāji pēdējo gadu laikā vairākos aspektos, tostarp attiecībā uz pievienotās vērtības līmeni, redzamo salīdzinošo priekšrocību un pētniecības un izstrādes izvedumiem privātajā sektorā, ir pārsnieguši pārtikas nozares rādītājus. Apvienojumā ar absolūto priekšrocību, ko sniedz plašas mežu platības, tas norāda uz augstu konkurētspējīgas ekosistēmas potenciālu Latvijas kokapstrādes nozarē.

Lai saglabātu konkurētspēju starptautiskajos tirgos, Latvijas mežsaimniecības nozarei ir jāvirzās augšup globālajā vērtību k̦ēdē. Samazinoties papīra izmantošanai pasaulē, augot konkurencei no tropu un subtropu reǵioniem, kā arī palielinoties automatizācijai vērtību k̦ēdē, tradicionālajiem koksnes izstrādājumu ražotājiem Latvijā, Somijā un Zviedrijā būs arvien grūtāk konkurēt bez inovācijām (ESAO, 2017b).

Latvijā ir vērojamas pozitīvas dinamikas pazīmes jomās, kurās materiālzinātne un jaunas tehnoloǵijas tiek izmantotas, lai pārveidotu izejmateriālus eksportējamos produktos. Piemēram, nesenā pētniecības sadarbībā, ko pasūtīja Meža nozares kompetences centrs, Latvijas Valsts koksnes k̦īmijas institūts un akciju sabiedrība "Latvijas Finieris", kas ražo bērza saplākšn,a produktus, izstrādāja jaunu metodi betulīna — vielas, kas veido bērza tāss balto krāsu, - i iegūšanai rūpnieciskā mērogā. Nerafinēts betulīns 
ir paredzēts kosmētikas tirgum, un procesa blakusproduktus var izmantot formaldehīda aizstāšanai kā līmi koka kompozītmateriāliem vai kā minerālmēslus.

Betulīns, kas ir pazīstams ar tā labvēlīgo ietekmi uz veselību, ir piemērs potenciālām sineróijām ne tikai viedo materiālu specializācijas jomā, bet arī biomedicīnas ekosistēmā. Piemēram, Rīgas Tehniskā universitāte (RTU) un Rīgas Stradiṇa universitāte (RSU) kopš 2016. gada sadarbojas, lai no betulīna iegūtu bioaktīvu kīmisku savienojumu ar antikancerogēnām ìpašỉbām. RTU un LLU pēta betulīna papildu lietojumus rafinētā veidā, tostarp tā izmantošanu medicīniskajā kosmētikā, lai uzlabotu ādas reǵenerāciju, vai kā pārtikas piedevu, lai paildzinātu piena un galas produktu uzglabāšanas laiku (Vaivare, 2018a). Lai gan pašlaik nav zināms, cik pieprasīti šie produkti būs tirgū, Latvija, visticamāk, iegūs no zināšanām, kas gūtas šajos dažādajos projektos.

\section{Latvijas Bioekonomikas stratēǵijā būtu vairāk jākoncentrējas uz digitālo jomu}

Latvijas Bioekonomikas stratēgijā 2030. gadam nav vērsta uzmanība uz digitālo jomu, kaut gan visa ekosistēma - no izejmateriālu ieguves līdz pārtikas un koksnes produktu ražošanai - ir gatava digitalizācijai. Lai gan pašlaik nav plānota plāna stratēéijas atjaunināšanai, apdomāt, kā vislabāk pārvaldīt digitalizāciju lauksaimniecībā, mežsaimniecībā un pārtikas nozarē, kḷus arvien svarīgāk. Vispirms Latvijai būtu jānovērtē digitalizācija bioekonomikā, sākot ar analīzi par piekḷuvi pamata digitālajām tehnolog̣ijām un to izmantošanu, kā arī par attīstītākiem rỉkiem, kuru izmantošanaraksturīga arlauksaimniecībai, mežsaimniecỉbai un pārtikas ražošanai. Nesenā pieredze pārtikas ražošanas nozarē liecina, ka digitālā gatavība joprojām ir zema un nozares uznēemumi saskaras ar ievērojamām grūtībām pat elementāru digitālās pārvaldības rīku izmantošanā (Pārtikas produktu kvalitātes klasteris, 2019).

Ar vairākām nesenām iniciatīvām tiek mēǵināts šīs nepilnības pārvarēt. Piemēram, Latvijas IT klasteris un Pārtikas produktu kvalitātes klasteris veido dalu no DIGICLUSTERS - ES sponsorētas Eiropas Klasteru kopdarbības programmas, kuras mērḳis ir uzlabot MVU konkurētspēju lauksaimniecības pārtikas iepakojuma nozarē. Latvija arī piedalās SmartAgriHubs -ES pamatprogrammas "Apvārsnis 2020" instrumentā 20 miljonu EUR apmērā, kas sekmē digitālu risinājumu izstrādi un ieviešanu lauku saimniecībās visā Eiropā. Projektā, kas tiek īstenots no 2018. līdz 2022. gadam, paredzēts izveidot inovāciju portālu un katalogu lauksaimniekiem un lauksaimniecības uzṇēmumiem, lai kartētu esošās digitālās tehnolog̣ijas un veicinātu labāko prakšu apmainu starp tīkla dalībniekiem (piem., jaunuzṇēmumiem, MVU, uzṇēmumiem un pakalpojumu sniedzējiem, tehnoloğiju ekspertiem u.c.).

LIKTA īsteno projektu "Mazo un mikro komersantu apmācības inovāciju un digitālo tehnoloǵiju attīstībai Latvijā" (projekts Nr. 1.2.2.3/16/I/002) Ekonomikas ministrijas vadībā. Iniciatīva, kuru kopīgi finansē ES (2 001937 EUR) un privātais sektors (762 600 EUR), sniedz apmācības trijās jomās: digitālajās tehnoloǵijās (piem., mākoṇpakalpojumos vai drošības jautājumos), uzṇēmuma iekšējo procesu digitalizācijā (piem., finanšu pārvaldībā un mārketingā) un digitālajos rīkos ražošanai un pakalpojumu izstrādei (piem., klientu attiecību pārvaldībā). Projekta mērḳis ir līdz 2020. gada decembrim sasniegt 6200 vadītāju un darbinieku.

Taču nav īpašu apmācību kursu, kas tiktu piedāvāti attiecībā uz digitālajiem rīkiem bioekonomikā. Lauksaimniecības nozarē Latvijas Lauku konsultāciju un izglītības centrs (LLKC) piedāvā vairākus kursus lauku uzṇēmējiem ar savas attālināto mācību platformas (LLKC Tālmācība) starpniecību. Taču neviens no kursiem pašlaik nav vērsts uz digitālo jomu. Valdībai būtu jāizmanto LLKC, lai sniegtu specializētākas apmācības par digitālo tehnologiiju, piemēram, precīzās lauksaimniecības vai dronu, izmantošanu lauksaimniecībā. Piemēram, Nacionālais lauku māceklības dienests (SENAR) Brazīlijā kopš 2016. gada piedāvā bezmaksas kursus par dronu izmantošanu lauksaimniecībā, tostarp par regulējumu (SENAR, 2016).

\section{Valdībai būtu jāveicina atvērto datu politika, lai uzlabotu digitalizāciju lauksaimniecības pārtikas nozarē}

Valdība arī varētu vairāk izmantot esošās informācijas sistēmas, lai izplatītu īpašus lietojumus un datu rīkus starp lauksaimniekiem un citiem lauku uzṇēmējiem, kā arī zivsaimniecībā. Divas sistēmas, kas šajā ziṇā šķiet īpaši daudzsološas, ir Lauku atbalsta dienesta Elektroniskās pieteikšanās sistēma (EPS) un Latvijas Zivsaimniecības integrētā kontroles un informācijas sistēma (LZIKIS).

EPS tika izstrādāta 2007. gadā, lai vienkāršotu pieteikšanās procesu ES un valsts atbalstam. Laika gaitā tika pievienotas papildu funkcijas, un 2016. gadā sistēmas izmantošana kḷuva obligāta. EPS pašlaik 
nodrošina sasaisti arī ar citu aǵentūru pakalpojumiem, un piekḷuve ǵeotelpiskajiem datiem tiek nodrošināta ar WMS (Web Map Service) un WFS (Web Feature Service). 2015. gadā programma saṇēma ANO Publisko pakalpojumu balvu kategorijā "Publisko pakalpojumu pieejamības veicināšana informācijas laikmetā" un 2017. gadā arī uzvarēja Pasaules informācijas sabiedrības samita (WSIS) konkursā e-lauksaimniecības jomā. LZIKIS darbību nodrošina Zemkopības ministrija, un tajā ir savienotas vairākas datubāzes un datu rīki. Kopš 2018. gada jūnija sistēma arī ietver produktu izsekojamības moduli, kas izseko zvejas produktus no izkraušanas līdz mazumtirdzniecībai un eksportam. Pašlaik tā sniedz informāciju vairākām valsts aǵentūrām, tostarp zivsaimniecības un pārtikas drošības kontroles aǵentūrām un muitai, kā arī privātā sektora tirgus dalībniekiem, tostarp zvejniekiem, vairumtirgotājiem un patērētājiem.

Privātā sektora iespēja brīvi piekḷūt EPS un LZIKIS pieejamajiem atlasītajiem datiem, kā arī izstrādāt un papildināt pievienotās vērtības pakalpojumus, varētu arī palīdzēt Latvijai piesaistīt inovatīvu pakalpojumu sniedzējus. Piemēram, 2014. gadā Francijas kooperatīvs InVivo ieguva vairākuma tiesības lauksaimniecības programmatūras nodrošinātājā SMAG, lai izstrādātu lauku saimniecību pārvaldības lietotnes, pamatojoties uz tā locekḷu sniegtajiem datiem.

Tiešsaistes platformu veicināšana bioekonomikā var radīt ieguvumus arī citās jomās kā, piemēram, atvērtās programmatūras platformas FIspace gadījumā. FIspace, ko ar ES finansējuma atbalstu izveidoja universitāšu un uzṇēmumu konsorciji), sekmē lauksaimniecības un pārtikas piegādes k̦ēdes datu kopīgošanu, lai uzlabotu uzṇēmumu savstarpējo sadarbību (Paunov un Planes-Satorra, 2019). Brazīlijā tiešsaistes platforma Uller sniedz lauksaimniecības iekārtu koplietošanas risinājumu un ir interesants piemērs tam, kā digitālās tehnolog̣ijas var palīdzēt pārvarēt finansiālos ierobežojumus, ar ko saskaras lauksaimnieciskie ražotāji. Pieteikumi uz labāku politiku ieviešanu arī ir dzīvotspējīgi (6.7. ielikums).

\section{7. ielikums. Izaugsmes potenciāls: lielie dati labākai lauksaimniecības un mežsaimniecỉbas politikai}

Nesenās digitālās inovācijas sniedz iespējas izveidot labāku politiku lauksaimniecības nozarē, palīdzot pārvarēt informācijas nepietiekamību un asimetriju, samazināt ar politiku saistītās darījumu izmaksas un l,aut cilvēkiem ar dažādām vēlmēm un stimuliem kopā strādāt labāk (ESAO, 2019r).

Latvijā pētniecības projekts "Zemes izmantošanas optimizācijas iespēju novērtējums Latvijas klimata politikas kontekstā" ir palielinājis izredzes, ka politika tiks labāk pielāgota mērḳim. Latvijas Lauksaimniecības universitātes (LLU) pētnieki apkopoja telpiskos datus no dažādiem avotiem, lai izveidotu detalizētas kartes (lauku un nogabalu līmenī) gan par zemes izmantošanu lauksaimniecībai, gan mežsaimniecībai Latvijā. Dati ietver plašu informāciju, tostarp par augsnes veidu, lauku saimniecības lielumu vai meliorācijas statusu (lauksaimniecības gadījumā) un par sugām, vecuma grupu vai teritorijas kvalitāti (mežsaimniecības gadījumā). Katra zemes gabala īpašās iezīmes var sasaistīt ar datiem par ekonomikas (piem., peḷn,a), sociālajiem (piem., darbaspēks), klimata (piem., siltumnīcefekta gāzu emisijas) vai bioloǵiskās daudzveidības (piem., putnu dzīvotṇu kvalitāte) pasākumiem, lai labāk izprastu un potenciāli prognozētu rezultātu attiecības. Pētījuma mērḳis bija optimizēt lauksaimniecības un mežu zemes snieguma novērtējumu izmantošanu, un tas varētu palīdzēt politikas veidotājiem izstrādāt saskanīgāku politiku saistībā ar zemes izmantošanu, tostarp finanšu stimulus, kas vienlaikus skar dažādus politikas mērḳus (piem., vides un sociālo).

Valsts akciju sabiedrība "Latvijas valsts meži” (LVM), kas administrē Latvijas valstij piederošos mežus, ir sniegusi finansiālu atbalstu pētniecībai un jau izmanto rīku peḷnas palielināšanai, vienlaikus saglabājot mežu apdzīvojamību. Taču papildu izmantošanas veidi šķiet dzīvotspējīgi, piemēram, lai uzlabotu citu politikas pasākumu pielāgošanu mērķim (piem., samazināt siltumnīcefekta gāzu emisijas). LVM ar savas informātikas nodaḷas starpniecību ir sasnieguši diezgan labus panākumus inovatīvu programmatūras risinājumu izstrādē. Piemēram, LVM GEO sniedz elastīgu piekḷuvi ǵeotelpiskajai informācijai, izmantojot personālo datoru, pārlūku vai mobilās lietotnes (tiešsaistē un bezsaistē). Datubāzē zemes un mežsaimniecības dati ir integrēti citos datu avotos, tostarp meliorācijas kadastra, valsts ceḷu pakalpojumu un Dabas aizsardzības pārvaldes sistēmās. Platforma, kas sākotnēji tika izstrādāta iekšējai lietošanai, tagad ir pieejama arī citiem uzṇēmumiem un organizācijām, tās modulārā struktūra ḷauj izmantot vairākus atsevišḳus risinājumus un integrāciju citās īpašnieksistēmās. 
Latvijas valdībai būtu arī jāpaātrina telpisko datu digitalizācija, ietverot Valsts augu aizsardzības dienesta augu, agroḳimiskos un augsnes datus. Saistībā ar Latvijas saprašanās memorandu "Datos balstīta nācija", Informācijas sabiedrības attīstības padome piekrita padarīt pieejamu ierobežotu skaitu geotelpisko datu kopumu bezmaksas lietošanai. Taču uzñēmējdarbības modelis datu kopīgošanai būtu jāpārdomā (Ozols, 2018). Nozīmīgs šḳērslis plašākai publisko datu izplatīšanai ir tas, ka dažām valsts iestādēm (piem., Valsts zemes dienestam) ievērojamu budžeta daḷu veido datu sniegšana. Austrālijas Produktivitātes komisija 2017. gadā publicēja detalizētu ziṇojumu, kurā analizēti ieguvumi un izmaksas saistībā ar dažādām datu kopīgošanas iespējām starp valsts struktūrām, indivīdiem un privāto sektoru, kas varētu kalpot kā norādījumi, tostarp attiecībā uz regulatīvajām pieejām un principiem, lai risinātu datu īpašniekus interesējošos jautājumus un veicinātu uzticību datu kopīgošanas iniciatīvām (Produktivitātes komisija, 2017). Attiecībā uz finansējuma atbalstu publiskā sektora datu atklāšanai, ziṇojumā aplūkotas vairākas iespējas, tostarp jaunu prioritāšu noteikšana esošajiem aǵentūru budžetiem, iezīmēts papildu finansējums valdībā vai atlīdzības sistēma, ar kuru aǵentūrām tiek atlīdzināts par publiskotajiem datiem, kas izraisa sabiedriski nozīmīgus pētniecības iznākumus. Ziṇojumā arī ieteikts aǵentūrām sniegt gada pārskatus par to datu kopumu proporciju, kas ir padarīti publiski pieejami, kopīgoti un nav pieejami izplatī̌nanai. Tajā ierosināts, ka centrāls birojs (Nacionālais datu uzraugs) varētu uzṇemties kopējo atbildību par datu pārvaldības politikas ìstenošanu un akreditēt citas struktūras savienojumu uzlabošanai starp dažādām datu kopām. ESAO drīzumā sniegs papildu piemērus un labākās prakses, ipaši vēršot uzmanību uz datu pārvaldības regulatīvajiem aspektiem lauksaimniecībā, kas varētu būt informatīvi diskusijai Latvijā.

Piekḷuve telpiskajiem datiem ir arī svarīga attālinātās novērošanas sistēmu plašākai ieviešanai un izmantošanai, tostarp attiecībā uz Latvijas plānoto izmēǵinājuma projektu tehnoloǵiski uzlabotiem uguns novērošanas torniem un droniem. Dronu gadījumā daudzus lietojuma veidus lauksaimniecībā un mežsaimniecībā kavē pašreizējais regulējums, kurā ir aizliegta dronu izmantošana ārpus redzamības zonas (tālāk par 500 m) (MK noteikumi Nr. 737). Jaunais ES regulējums, kas stājās spēkā 2019. gada jūlijā, drīzumā varētu atḷaut elastīgāku izmantošanu, taču tas būs pilnībā piemērojams tikai pēc divu gadu pārejas perioda. Jaunajā regulējumā aprakstīta kategorija "īpašam" lietojumam, atcelot ierobežojumus attiecībā uz tiešo redzamību, masu vai darbības augstumu. Lielākā daḷa lietojuma veidu lauksaimniecībā varētu atbilst īpašajai kategorijai. Latvijas valdībai būtu jāsekmē jaunā regulējuma drīza pielāgošana. Pozitīvs signāls šajā ziṇā bija drona lidojums, ko Latvijas Ministru prezidents un Latvijas Mobilā telefona (LMT) prezidents veica ārpus tiešās redzamības zonas, izmantojot mobilo tīklu, lai apliecinātu 5G ekosistēmas potenciālu.

\section{8. ielikums. Politikas ieteikumi: Bioekonomika}

- Stiprināt Meža nozares kompetences centra spēju un uzlabot zināšanu pārnesi uz mazākiem uzṇēmumiem, izvēršot Tehnologiiju pārneses programmu un izveidojot vienotu digitālu piekḷuves punktu.

- Sekmēt publisko atbalstu pētniecībai par produktiem, kas mežsaimniecības vērtību k̦ēdē atrodas augstu, un izmantot sinerǵijas ar viedajiem materiāliem vai citām viedās specializācijas jomām.

- Novērtēt digitālo tehnoloǵiju izplatišanos lauksaimniecības pārtikas k̦ēdē un izmantot esošās digitālās platformas, piemēram, Elektroniskās pieteikšanās sistēmu (EPS), starp lauku uzṇēmējiem un lauksaimniekiem izplatot attīstītus lietojuma veidus un datu rīkus. Aicināt privātā sektora pakalpojumu sniedzējus nodrošināt atbilstošus pievienotās vērtības pakalpojumus publiskajās platformās.

- Izmantot Latvijas Lauku konsultāciju un izglītibas centru (LLKC), lai sniegtu specializētas apmācības par digitālo lauksaimniecību.

- Sekmēt atvērto datu politiku un nodrošināt viegli pieejamu informāciju, izmantojot attiecīgo normatīvo vidi (piem., tīmekḷa vietni). 


\section{Biomediciniskā pētniecība un inovācija veselības jomā}

Biomedicinna kā viedās specializācijas joma aptver medicīnas tehnoloǵijas un veido saiknes, piemēram, ar k̦īmijas un farmācijas nozarēm, elektrisko un optisko preču ražotājiem, kā arī ar medicīnas un zobārstniecības instrumentu ražotājiem un ar aktivitātēm veselības aizsardzības jomā.

\section{Škiet, ka Latvija zaudē priekšrocības farmācijas preču un medicīnas tehnoloǵiju jomā}

Laika posmā no 1945. līdz 1991. gadam Latvija kḷuva par vienu no galvenajiem jaunu zāḷu un medicīnas produktu ražotājiem bijušajā Padomju Savienībā (LIAA, 2019h). Šo panākumu veicināšanā nozīmīga loma bija valsts pētniecības institūtiem, piemēram, 1957. gadā dibinātajam Organiskās sintēzes institūtam un tādiem lieliem farmācijas produktu ražotājiem kā Grindeks (1946) un Olainfarm (1972).

2017. gadā farmācijas nozare joprojām veidoja 3,3 \% no ražošanas kopējās pievienotās vērtības, nedaudz vairāk nekā 2010. gadā, kad tie bija 3,0 \% (6.12. attēls). Taču tajā pašā laika posmā farmācijas produktu daḷa ražošanas kopējā eksportā samazinājās no 4,6 \% līdz 2,9 \% (6.17. attēls). Turklāt plašāka kopējā nozare, kas ietver arī k̦īmijas jomas, 2015. gadā neuzrādīja nekādu salīdzinošo priekšrocību (6.13. attēls).

\subsection{7. attēls. Latvijas eksports augsto tehnologiju un vidēji augsto tehnologiju produktu jomā, 2010. un 2018. gads}

Procentuālā daḷa no kopējā ražošanas eksporta

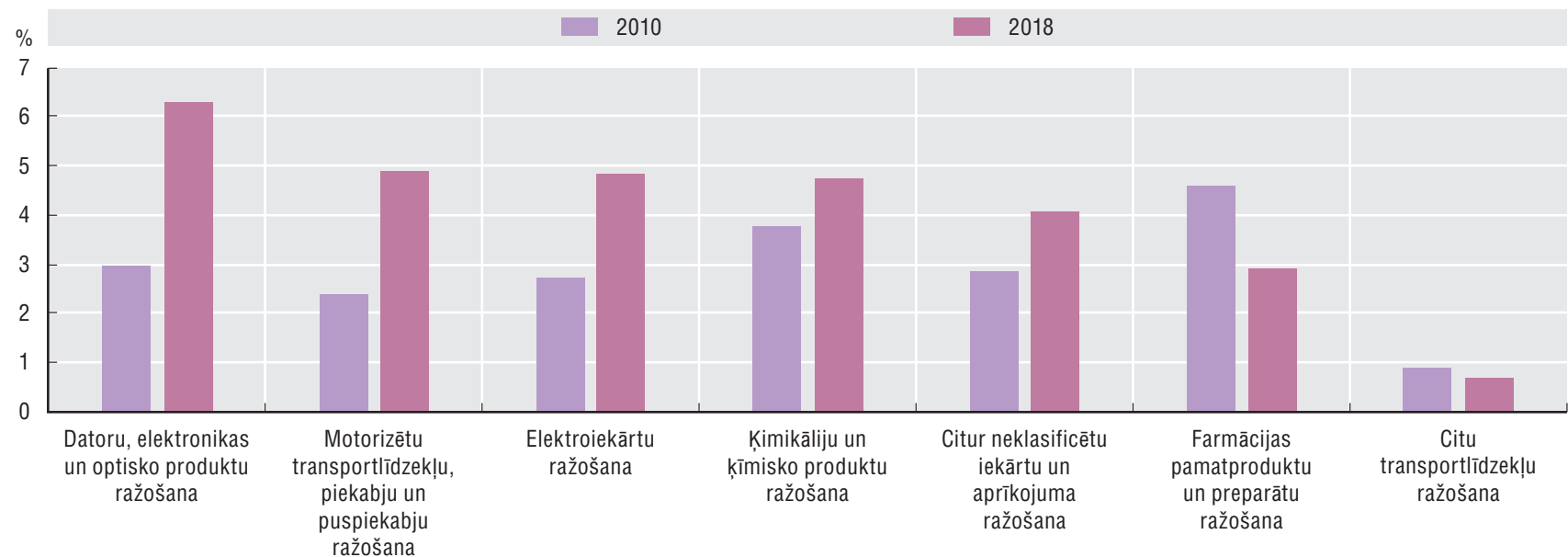

Piezīme: Šajā attēlā parādīta augsto tehnoloǵiju un vidēji augsto tehnolog̣iju produktu daḷa kopējā ražošanas eksportā. Augsto tehnolog̣iju produkti ietver datoru, elektroniskos un optiskos izstrādājumus, kā arī kīmiskos pamatproduktus un kīmiskos preparātus. Klasifikācija balstīta uz GalindoRueda un Verger (2016).

Avots: CSP (2020b), Exports and imports by commodity section and by economic activity (NACE Rev.2) of the importer (thsd euro) - ATG015, www.csb.gov.lv/en/ statistics/statistics-by-theme/foreign-trade/ft-nace-bec/tables/atg015/exports-and-imports-commodity-section-and.

Vairāki rādītāji liecina par inovāciju vājināšanos nozarē. Latvijas pētniecība un izstrāde farmācijas nozarē 2015. gadā veidoja tikai 3,3 \% no pievienotās vērtỉbas atškirībā no ESAO vidējā rādītāja, kas bija 23,4 \% (6.15. attēls). Patentu skaits farmācijas produktu un medicīnas tehnoloǵiju jomā attiecībā pret visiem Latvijas patentiem samazinājās no aptuveni 32 \% 2007.-2011. gadā līdz 19 \% 2012.-2016. gadā. 6

No 2014. līdz 2018. gadam Latvijas zinātnisko publikāciju daḷa farmācijas produktu un farmakoloǵijas jomā starp tiem 10 \% publikāciju, kas citētas visbiežāk, bija 8,5 \% salīdzinājumā ar (definīcijas) vidējo rādītāju pasaulē, kas bija 10 \%. Pētniecības izcilība (t.i., vairāk nekā 10 \% starp biežāk citētajām publikācijām) tika sasniegta noteiktās apakšjomās, piemēram, toksikoloǵijā (14 \% starp 10 \% biežāk citēto) un zāḷu atklāšanā (12,5\%) (6.18 attēls).

N̦emot vērā citas nozares, kas saistītas ar viedās specializācijas jomu, piemēram, medicīnu, imunoloǵiju, bioḳīmiju vai géenētiku, var konstatēt pētniecības izcilību tādās jomās kā plaušu un elpošanas sistēmas medicīna (22,2 \% starp 10 \% biežāk citēto), gastroenteroloǵija (17,2 \%) un molekulārā medicīna (16\%). Taču Latvija nav specializējusies nevienā no šìm jomām, kas nozīmē, ka attiecīgās apakšjomas ieguldỉjums visās Latvijas publikācijās joprojām ir zemāks par šìs jomas dalı visās (pasaules) publikācijās. 


\subsection{8. attēls. Latvijas publikācijas tajos $10 \%$ dokumentu, kas citēti visbiežāk}

Vidēji 2014.-2018. gadā

Relatīvās specializācijas indekss

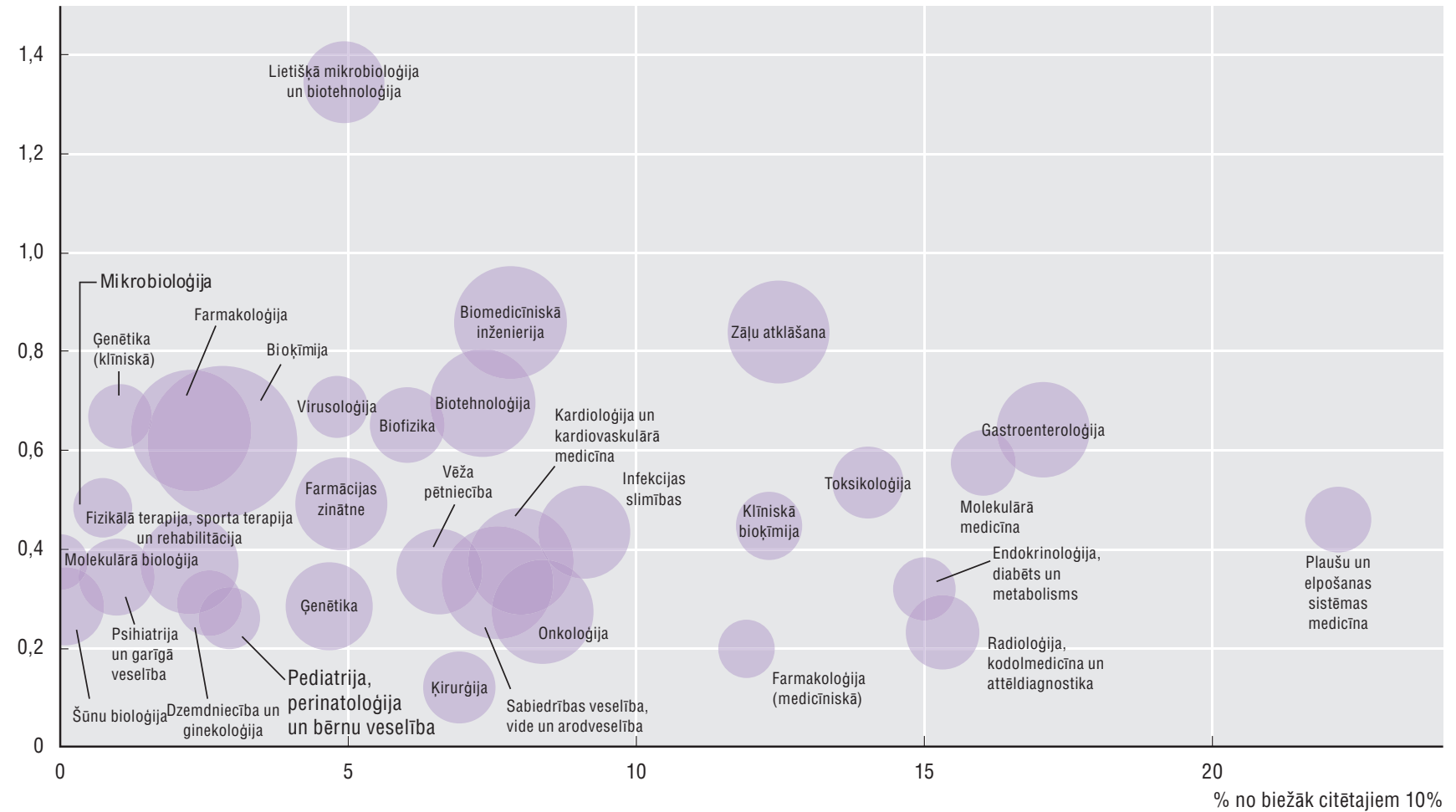

Piezīme: Publikāciju procentuālā daḷa tajos 10 \% dokumentu, kas citēti visbiežāk, ir izcilības rādītājs. Tas norāda uz kādas vienỉbas zinātniskā snieguma apmēru (procentuāli), kas iekḷauts 10 \% biežāk citēto dokumentu grupā attiecīgajā zinātniskajā jomā. Vidējais rādītājs pasaulē attiecīgajā periodā ir 10 \%. Relatīvās specializācijas indekss novērtē relatīvo specializāciju. Šo indeksu aprēkinina, dalot visus valsts A dokumentus kādā jomā ar valsts A kopējo izlaidi visās jomās. Šo proporciju pēc tam dala ar attiecīgo proporciju pasaulē. Vidējais rādītājs pasaulē ir 1. Ir noteikts slieksnis, un indekss ir aprēḳināts tikai valstīm, kurām ir vismaz 50 dokumentu.

Avots: ESAO aprēḳini, pamatojoties uz Scopus Custom Data, Elsevier, versija: 5.2019.

Lietišḳā mikrobiologiija un biotehnoloǵija ir vienīgās ar viedās specializācijas jomu saistītās nozares, kurās Latvija apliecina specializāciju. Taču izcilu publikāciju daḷa joprojām ir zema $(4,9$ \% starp 10 \% biežāk citēto). Turklāt, lai gan Latvijas patentu pieteikumu skaits biotehnolog̣ijā ir palielinājies no 0,2 2007.-2011. gadā līdz 2,1 2012.-2016. gadā, tas ir pārāk mazs, lai veidotu tendenci.

\section{Valdībai būtu jāveicina inovācijas izplatīšana sabiedrības veselības aprūpes sistēmā, vienlaikus stiprinot pētniecības prasmes}

Medicīnas un veselības zinātṇu daḷa kopējos pētniecības un izstrādes izdevumos dabaszinātṇu un inženierzinību jomā laika posmā no 2010. līdz 2016. gadam pieauga no 8,4 \% lỉdz 12,1 \%, palielinoties attiecīgi no 8,1 miljona EUR līdz 11,7 miljoniem EUR. Par lielāko pieaugumu neapšaubāmi ir atbildīgas augstākās izglīīibas iestādes, kas palielināja izdevumus no 3,6 miljoniem EUR līdz 6,8 miljoniem EUR. Salīdzinājumā ar citām dabaszinātṇu un inženierzinātṇu jomām izdevumi medicīnas un veselības zinātnēs kḷuva nozīmīgāki arī uzṇēmējdarbības sektorā un valdībā (6.16. attēls). Taču absolūtā izteiksmē abu dalībnieku izdevumi saglabājās diezgan stabili (attiecīgi 3,2 miljoni EUR un, visticamāk, mazāk par 2 miljoniem EUR). ${ }^{7}$

Laikā no 2014. līdz 2018. gadam biofarmācija un biotehnoloǵijas, kā arī translācijas medicīna veidoja attiecīgi 40\% un 25 \% no līdzekḷiem 46 miljonu EUR apmērā, kas piešḳirti saskaṇā ar viedās specializācijas sistēmu. Liela dạ̣a līdzekḷu biofarmācijai un biotehnologiijām tika novirzīti ar Farmācijas, biomedicīnas un medicīnas tehnoloǵiju Kompetences centra (FBMTKC) starpniecību, un apakšjoma tajos veidoja aptuveni 95 \% no kopējiem izdevumiem jeb aptuveni 7,5 miljonus EUR. Translācijas medicīna, kas tiecas labāk savienot laboratorijas, slimnīcas un pacientus, saṇēma vairāk nekā $62 \%$ no viedās specializācijas jomai iedalìtā "Apvārsnis 2020" finansējuma. 
Divas no lielākajām "Apvārsnis 2020" dotācijām, ko Latvija saṇēma, ne tikai apliecina valsts neseno ieguldījumu šajā jomā, bet arī uzsver attiecības ar digitālajām tehnoloǵijām, starptautiskās sadarbības būtiski svarīgo lomu un potenciālos pētniecības komercializācijas veidus. Latvijas Universitāte saṇēma gandrīz 1,6 miljonus EUR ES iemaksās, kas sadalītas starp trīs kopīgiem Izraēlas Tehnoloǵiju institūta vadītiem projektiem (EK, 2017). Pirmais no tiem — viedtālrunis slimības konstatēšanai no izelpas (SNIFFPHONE) tika īstenots no 2015. gada līdz 2019. gada februārim. Tā ietvaros heterogēnas mikrotehnoloǵijas un nanotehnoloǵijas tika integrētas viedierīcē, kas savienota ar mobilo tālruni un analizē slimības pazīmes izelpā. Pēc tam dati tiek pārsūtīti uz mākoṇa platformu, lai tos novērtētu, un pozitīva testa rezultāta gadījumā saṇēmējam (piem., speciālistam) tiek nosūtīts klīniskais ziṇojums. SNIFFPHONE 2018. gadā saṇēma Eiropas Komisijas balvu par inovāciju. Otrs projekts A-Patch jeb autonoms plāksteris infekcijas slimību noteikšanai reāllaikā l̦auj pielietot gaistošu organisku savienojumu zinātni ādas datu analīzē. Tehnoloǵijā izmantota valkājama ierīce, kas aprīkota ar inteliǵentiem hibrīdsensoriem. Trešais projekts — VOGAS — tiek īstenots līdz 2021. gada decembrim, un tā mērḳis ir izstrādāt jaunu elpas analīzes ierīci, ko izmantot kā neinvazīvu kuṇǵa vēža skrīninga rīku.

Regulāra iesaistīšanās nozīmīgos starptautiskos pētniecības projektos norāda, ka Latvija ir sevi apliecinājusi kā uzticamu partneri attiecībā uz medicīnisku inovāciju testēšanu. Latvijas valdībai šie panākumi būtu jāizmanto, oficiāli integrējot nozares partnerības un ierīču testēšanu sabiedrības veselības aprūpes sistēmā. Piemēram, Nacionālais veselības dienests (NHS) Apvienotajā Karalistē 2016. gadā ieviesa programmu, kas l̦auj testēt jaunas digitālas ierīces un jaunus veselības aprūpes pakalpojumu veidus konkrētās slimnīcās un konkrētām pacientu grupām. Veiksmīgas inovācijas pēc tam var izmantot visā veselības aprūpes sistēmā. Ir arī pieejamas vairākas mācību rokasgrāmatas, piemēram, par to, kā izveidot datu kopīgošanas un informācijas pārvaldības mehānismus, un tās varētu palīdzēt Latvijai izveidot līdzīgu sistēmu (Paunov un Planes-Satorra, 2019).

Latvijai būtu vēl vairāk jāsekmē ar reālo dzīvi saistītu veselības aprūpes datu praktiska izmantošana, lai sniegtu informāciju biomedicinas pētījumiem un novērtēšanai. "Mācīties spējīga veselības aprūpes sistēma", kas balstīta uz elektroniskām pacientu medicīniskajām kartēm un citiem parasti vāktiem datiem, ir l̦oti daudzsološa, lai padarītu medicīnisko pētniecību, tostarp attiecībā uz farmācijas produktiem, efektīvāku un lietderīgāku (piem., Eichler un citi, 2019; ESAO, 2019p). Taču Latvija starp citām ESAO valstīm izcel̦as ar to, ka tai nav valsts standartu attiecībā uz klīnisko terminoloǵiju elektroniskos klīniskajos reǵistros un trūkst valsts plāna vai politikas, lai iegūtu datus no elektroniskām klīnisko reǵistru sistēmām (piem., lai atvieglotu klīniskās pārbaudes vai droši novērotu pacientu). Pašlaik arī nav nekāda procesa, lai novērtētu pacientu elektronisko medicīnisko karšu izmantojamību datu kopas izveidei, un veselības aprūpes dati lielākoties netiek izmantoti pētniecībā (Oderkirk, 2017).

Neṇemot vērā inovācijas medicīnā, ievērojama dinamika ir manāma arī uz genomiku balstītas precīzijas medicīnas un biotehnoloǵijas jomā. Pastāvīgi digitālo tehnoloǵiju uzlabojumi, tostarp attiecībā uz datu glabāšanas un algoritmu spēju, ir ievērojami palielinājuši gēnu sekvencēšanas iespējamību. Šis progress ir atjaunojis interesi par genoma datu analīzi un medicīniskajā pētniecībā pārvirzījis fokusu uz lielajiem datiem un mākslīgo intelektu (ESAO, 2020c).

Pirmā fiziskā biobanka Latvijā — Valsts iedzīvotāju genoma datubāze (VIGDB) — tika izveidota 2006. gadā, pamatojoties uz 2004. gada Cilvēka genoma izpētes likumu (Rovìte un citi, 2018). Kopš tā laika investīcijas Latvijas genomikā ir uzsākuši vairāki lieli starptautiskie uzṇēmumi, tostarp Kīnas genoma sekvencēšanas uzṇēmums BGI, Microsoft un Roche. Piemēram, 2017. gada septembrī Microsoft Latvijas Universitātē (LU) izveidoja Microsoft inovāciju centru (LUMIC), kas ir pirmais šāda veida Microsoft inovāciju centrs Baltijā un Austrumeiropā. LUMIC galvenā darbības joma ir gados jaunu IT profesionāḷ izglītošana un mākonī izvietoti risinājumi starpnozaru IT projektiem, kuros iesaistīti studenti, zinātnieki, nozares pārstāvji un valdība. Uz genomiku balstīta vēža pētniecība ir viens no pirmajiem lielo datu pielietojuma veidiem, kurā izmantota jaunā infrastruktūra. Projektu atbalsta LIAA iniciativva "Atbalsts pētniecības rezultātu komercializācijai" (Vaivare, 2018b).

Virzība uz digitālu genomiku Latvijā daḷēji ir spēcīgas politiskās apṇemšanās rezultāts. 2017. gadā Latvija parakstīja saprašanās memorandu ar Ķīnas genoma sekvencēšanas uzṇēmumu BGI, lai atbalstītu Latvijas-Biolake-BGI dzīvības zinātṇu un tehnolog̣iju centra izveidi. 2019. gada novembrī BGI grupas apakšuzṇēmums MGI, kas ražo DNS sekvencēšanas instrumentus, atklāja K̦īnas un Eiropas Dzīvības zinātṇu inovāciju centru, kā arī pētniecības un izstrādes un ražošanas struktūru Rīgā. Tajā pašā dienā 
BGI Research un MGI Latvijā paziṇoja par projektu "10 miljonu šūnu transkripcija” (scT10M) — sadarbību ar zinātniekiem visā pasaulē, lai sekvencētu un analizētu 10 miljonus šūnu nolūkā izveidot visaptverošu atsevišķu šūnu transkripcijas karti, kurā dalīties ar zinātnisko kopienu (MGI, 2019).

2019. gada maijā ekonomikas ministrs un labklājības ministre kopīgi atklāja konferenci par precīzijas medicīnu, vēršot nepārprotamu uzmanību uz lielo datu analīzi un IKT veselības jomā. Konferencē arī aplūkota nacionālā precīzijas medicīnas sistēma tādās valstīs kā Zviedrija, iespējamo precīzijas medicīnas pētījumu sistēmu Latvijā un ētikas problēmas, izmantojot lielosdatus medicīnā. Ekonomikas ministrija pašlaik kopīgi ar attiecīgajām ieinteresētajām valsts sektora, nozares un akadēmiskās vides personām izstrādā kopīgu biomedicīnas ekosistēmas stratēǵiju 2021.-2027. gada plānošanas periodam.

Lai izmantotu šo dinamiku, Latvijai būtu jāstiprina pētniecība ǵenētikā (tostarp klīniskajā) un veselības informātikā. Pašreizējais publikāciju skaits (2014.-2018. g.) neliecina par pētniecības specializāciju šajās jomās, un tikai neliels skaits publikāciju ir starp $10 \%$ visbiežāk citēto. Lai gūtu izcilību šajās jomās, ir vajadzīgas veidošanas un piesaistīšanas prasmes, un LUMIC inovāciju centrs šajā ziṇā var būt būtiski svarīgs veicinātājs. LU — daḷēji sadarbībā ar Rīgas Stradiṇa universitāti (RSU) — arī piedāvā doktorantūras skolu translācijas medicinā. Taču Datorikas fakultāte pašlaik nav iekḷauta programmā, un LU nepiedāvā nekādu specializāciju veselības informātikā. Turklāt, lai gan RSU ir izveidojusi bioinformātikas pētniecības grupu, maǵistra programma, kas pašlaik tiek piedāvāta biomedicīnas jomā, ir pieejama tikai latviešu valodā, būtiski ierobežojot ārvalstu talantu piesaistīšanu. Lai sekmētu biomedicinas ekosistēmu un izmantotu lielu starptautisko uzṇēmumu investīcijas, Latvijai būtu vēl vairāk jāuzlabo akadēmisko kursu piedāvājums jomās, kurās medicīnas zinātnes pārklājas ar datorzinātnēm.

\section{Latvijai būtu jāpaplašina inovācijas politikas mērogs attiecībā uz biomedicīnas ekosistēmu}

Latvijai būtu jākoncentrē vairāk resursu digitālās veselības jomā, lai atbalstītu privātā sektora inovāciju komercializāciju veselības jomā. Laika posmā no 2014. līdz 2018. gadam tikai 2,5 \% no visiem viedās specializācijas izdevumiem tika veltīti biomedicīnai pētniecības rezultātu komercializācijai (IZM, 2020). Turklāt finansējums, kas tiek novirzìts ar kompetences centru starpniecību, galvenokārt ir vērsts uz farmācijas produktiem, kosmētiku un uzturu. Lai gan privātā sektora risinājumi e-veselībai, jo īpaši programmatūra, tiek veicināti ar Rīgas IT Demo centra (ko 2012. gadā izveidoja Latvijas IT klasteris) starpniecību, centra galvenais mērk̦is šḳiet vietējais tirgus. To, ka par Latvijas veselības aprūpes risinājumiem var būt arī starptautiska interese, apliecina jaunuzṇēmums Anatomy Next. Uzṇēmums izstrādāja programmatūras kā pakalpojuma risinājumu, izmantojot papildināto realitāti un interaktīvus 3D anatomiskos model̦us, lai uzlabotu medicīnas studentu telpisko izpratni par cilvēka anatomiju. Šis risinājums 2017. gadā ieguva Zviedrijas Tirdzniecības un ieguldijjumu padomes gada balvu par tehnoloǵiskajām inovācijām un saṇēma 50000 EUR finansējumu no programmas "Apvārsnis 2020" MVU instrumenta.

Lai sekmētu vairāk tādu inovatīvu uzṇēmumu kā Anatomy Next, valdība arī varētu sniegt lielāku atbalstu MVU un jaunuzṇēmumiem, kuri piesakās "Apvārsnis 2020" finansējumam. Lai gan šķiet, ka zināms atbalsts ir pieejams agrīnajiem procesa posmiem, daudzi jaunuzṇēmumi paḷaujas uz dārgiem ārvalstu konsultāciju uzṇēmumiem, lai pārvaldītu lietojumprogrammu vēlākos posmos. Lai veicinātu izcilības papildu nišu konstatēšanu un strauji reaǵētu uz jaunām tirgus iespējām (piem., vakcīnām, diagnostiku vai medicīnas tehnoloǵijām Covid-19 krīzes kontekstā), atbalstu nevajadzētu ierobežot tikai ar noteiktām jomām. Tomēr uzṇēmumu, kas darbojas noteiktāsnozarēs, piemēram, veselības informātikā, mērḳauditorija varētu būt klasteru iniciatīvas.

Valdībai kā daḷa no biomedicinnas ekosistēmas būtu vairāk jāṇem vērā blakusnozares. Piemēram, potenciālo viedās specializācijas jomu sākotnējās novērtēšanas laikā tika atzīts būtisks eksporta potenciāls attiecībā uz veselības aprūpes pakalpojumiem (IZM, 2013b). Tādējādi laika posmā no 2005. līdz 2015. gadam Latvija tuvojās redzamās salīdzinošās priekšrocības veidošanai ar cilvēku veselību saistītu darbību eksportā (6.13. attēls), un, lai gan nozares uzṇēmumi pētniecībai un izstrādei veltīja tikai 0,07 \% no kopējās pievienotās vērtỉbas, atškirìiba no ESAO vidējā rādītāja $(0,13 \%)$ bija zemāka nekā daudzās citās nozarēs (6.15. attēls). 
Testu platformas nodrošināšana veselības aprūpes inovācijām, kā minēts iepriekš, varētu būt daudzsološs veids, lai Latvija ne tikai uzlabotu savas valsts veselības aprūpes sistēmas vidējo kvalitāti (ESAO(OECD), 2019a), bet arī gūtu starptautisku atzinību kā inovatīvs veselības aprūpes pakalpojumu sniedzējs. Piemēram, Latvija varētu paplašināt savu līdzdalību ProVaHealth tỉklā. ProVaHealth ir viens no 39 apstiprinātajiem Interreg projektiem Baltijas jūras reǵionā, un tā mērkisis ir padarīt reǵionu par vienotu testa vietu jaunu veselības aprūpes produktu un pakalpojumu izstrādei. Pašlaik Latvijas dalība ir ierobežota tikai ar labjutības jomu, un vieniggais dalībnieks ir Latvijas kūrortpilsētu asociācija. Taču projektā varētu iesaistîties arī citi uzṇēmumi, pētniecības institūti un universitātes, lai izmantotu projekta "dzīvās" laboratorijas, kas nodrošina reālās dzīves apstākḷus inovatīvu veselības aprūpes pakalpojumu testēšanai.

Varētu arī radīt sinerǵijas attiecībā uz valsts e-veselības iniciatīvu, ar kuru kopš 2018. gada valsts e-veselības portāla izmantošana ir obligāta recepšu un slimības lapu izrakstīšanas pakalpojumiem. Neskatoties uz ievērojamo progresu, veselības trešā posma - sistēmas paplašināšanas — uzsākšana norit salīdzinoši lēni (VM, 2019). Lai uzlabotu iedzīvotāju veselību un samazinātu ievērojamās atšķirības, kas joprojām pastāv attiecībā uz piekḷuvi valsts veselības aprūpes sistēmai un tās rezultātiem, valdībai būtu jāvirza e-veselības programma, tostarp attiecībā uz veselības datiem (sk. iepriekš) un telemedicīnu. Tādas jomas kā profilakse, primārā aprūpe, aprūpe mājās vai uz kopienu balstīti pakalpojumi šķiet ipaši daudzsološas jomas pielietojuma veidiem, kas varētu samazināt pašreizējo lielo paḷaušanos uz ārstēšanu slimnīcā (ESAO, 2019l).

\section{9. ielikums. Politikas ieteikumi: Biomedicina}

- Pilnveidot pētniecỉbas izcilību translācijas medicīnā, veidojot nozares partnerỉbas un platformas jaunu medicīnas ierī̌cu testēšanai valsts veselības aprūpes sistēmā.

- Izmantot privātās investīcijas digitālās pētniecības infrastruktūrā, stiprinot akadēmiskos rezultātus veselības informātikas un genomikas jomā.

- Palielināt izdevumus digitālās veselības jomā un digitālu veselỉbas aprūpes produktu, tostarp programmatūras, komercializācijā. Atbalstīt jaunuzṇēmumus un MVU pieteikumos "Apvārsnis 2020" finansējumam, lai veicinātu izcilības klasterus.

- Izmantot valsts e-veselības iniciatīvas un esošās sadarbības ar citām valstīm (piem., ProVaHealth), lai testētu un veicinātu inovatīvus veselības aprūpes pakalpojumus un uzlabotu valsts veselības aprūpes sistēmas kvalitāti.

\section{Inovācijas politikas mērķu uzlabošana.}

Jaunu un uzlabotu materiālu atklāšanas un izstrādes līmeņa paaugstināšana ir būtiski svarīga, lai uzlabotu produktu izstrādi un veicinātu masveida pielāgošanu, pamatojoties uz jaunām tehnolog̣ijām, piem., 3D druku. Materiālu atklāšanas un izstrādes paātrināšanu ir padarījis iespējamu progress dažādās jomās, tostarp datu analītikā, zinātnisko instrumentu iespējās, augstas veiktspējas datorikā un prognozējošās skaiț̣ošanas metodēs, kas izmantotas attiecībā uz materiālu struktūru un īpašībām (ESAO, 2017b).Viedie materiāli Latvijas RIS3 tiek uzskatīti par galveno pētniecības specializācijas jomu.

Papildus jauniem materiāliem, piemēram, implantātu materiāliem, kompozītmateriāliem, stikla šḳiedrai un stikla materiāliem vai plānslāṇiem un pārklājumiem viedās specializācijas joma aptver arī plašu klāstu ražošanas darbỉbu, kas saistītas ar tehnoloǵijām un inženierzinātnēm. Tās cita starpā ietver aprikkojumu un kontroles sistēmas ražošanas darbībām, medicīnisko inženieriju un biotehnoloǵiju. Šādas atškirīgas darbības ir atspoguḷotas vairākās ražošanas nozarēs, piemēram, rūpnieciski ražotu metāla izstrādājumu, nemetālisko minerālu izstrādājumu, mehānismu un ḳimiskās produkcijas nozarēs.

\section{Viedo materiālu un inženierijas jomā var paḷauties uz stabilu pētniecības vidi un veiksmīgiem rezultātiem.} nozarē

Daudzas no minētajām nozarēm pēdējo gadu laikā ir kḷuvušas nozīmīgākas. Rūpnieciski ražotu metāla produktu, piemēram, ar inženieriju un pārklājumiem saistīto, pienesums ražošanas kopējā pievienotajā vērtībā pieauga no 6 \% 2010. gadā līdz 9 \% 2017. gadā. Tajā pašā laika periodā citu nemetālisko minerālu 
izstrādājumu, tostarp stikla šḳiedras materiālu pienesums palielinājās no 6 \% līdz 7,4 \%. Gumijas un plastmasas izstrādājumi, kas Latvijas stratēgijā nav iekḷauti attiecīgajās viedo materiālu nozarēs, taču ir saistīti ar jauniem iepakojuma materiāliem, piemēram, bioplastmasu un kompozītmateriāliem, arī palielinājās no 2,2 \% līdz 2,5 \%. Citur neklasificētu ar tehnoloǵiju un inženieriju saistītu iekārtu un mehānismu pienesums palielinājās no 2,2 \% līdz 3,3 \%. Taču k̦īmiskās produkcijas pienesums ievērojami samazinājās no 4,5 \% līdz 2,5 \% (6.12. attēls).

Arī eksporta rādītāji pēdējo gadu laikā ir būtiski uzlabojušies. Ar automobiḷiem, elektriskajām iekārtām vai mehānismiem saistītas ražošanas darbības ievērojami veicinājušas vidēji augsto un augsto tehnologiju preču īpatsvaru eksportā (6.17. attēls). Lai gan 2015. gadā Latvijai šajās nozarēs nebija redzamas salīdzinošās priekšrocības, laikā no 2010. līdz 2015. gadam tā izveidoja redzamo salīdzinošo priekšrocību nemetālisko minerālu izstrādājumu jomā un gandrīz ieguva redzamo salīdzinošo priekšrocību rūpnieciski ražotu metāla produktu jomā (6.13. attēls).

Uzṇēmumu pētniecība un izstrāde kā daḷa no pievienotās vērtības nemetālisko minerālu izstrādājumu jomā (1,1 \%) bija zemāka par ESAO vidējo līmeni (2,5 \%). Taču atšk̦irība no ESAO vidējā līmeṇa gan absolūtā, gan relatīvā izteiksmē bija ievērojami zemāka nekā lielākajā daḷā pārējo ražošanas nozaru. Investīcijas pētniecībā arī bija salīdzinoši augstas elektrisko iekārtu jomā (5,3 \% salīdzinājumā ar 6,8 \%). Atšķirības no ESAO vidējā rādītāja pētniecības un izstrādes intensitātē bija lielākas citās ražošanas nozarēs, tostarp k̦īmisko vielu (1,8 \% salīdzinājumā ar ESAO vidējo rādītāju 5,4 \%), gumijas un plastmasas (0,3 \% salīdzinājumā ar 4,1 \%) un iekārtu un mehānismu jomā (0,3 \% salīdzinājumā ar 6,8\%) (6.15. attēls).

Pētniecības un izstrādes darbības viedo materiālu un inženierijas jomā atspoguḷojās arī vairākos patentu pieteikumos, kas laika posmā no 2012. līdz 2016. gadam iesniegti (citu) īpašu iekārtu, virsmu tehnoloǵiju un pārklājumu, elektroiekārtu, aparātu un enerǵijas, metalurǵijas materiālu un k̦īmiskās inženierijas jomā. Patentu pieteikumu skaits (ietverot proporcionālo attiecību) minētajās jomās palielinājās no 10,0 (9 \% no visiem Latvijas pieteikumiem) 2007.-2011. gadā līdz 26,1 (20 \%) 2012.-2016. gadā.

Zinātniskās publikācijas apstiprina Latvijas spēcīgo specializāciju inženierijā un materiālu zinībās. Lai gan Latvijas publikāciju skaits 2014.-2018. gadā visaugstākais bija elektriskās un elektroniskās inženierijas jomā, izteiktākā specializācija attiecībā pret citām valstīm tika konstatēta automobiḷu inženierijas, rūpnieciskās un ražošanas inženierijas, kā arī biomateriālu jomā. Turklāt Latvija nodrošināja vairāk nekā 10 \% (vidējais rādītājs pasaulē) tajos 10 \% publikāciju, kas visbiežāk citētas materiālu mehānikas, metālu un sakausējumu, kā arī mašīnbūves jomā (6.19. attēls).

\section{Valdības atbalstam materiālzinātnei jābūt labāk ievirzìtam, un tas būtu jāpapildina ar vispārējā atbalsta. mehānismiem inovatīiem uzñēmumiem}

Pētniecību viedo materiālu specializācijas jomā ir veicinājis ievērojams valsts finansējums, izmantojot Viedās specializācijas stratēgiju. Šì joma saṇēma vislielāko līdzekḷu daḷu salīdzinājumā ar pārējām specializācijas jomām, iegūstot finansējumu vairāk nekā 52 miljonu EUR apmērā (27,5 \%) (6.2. tabula).

Taču finansējums tika pārāk sīki sadalīts starp daudzām pētniecības jomām. Labākajos gadījumos (piem., tādās jomās kā plānslāṇi un pārklājumi vai kompozītmateriāli un polimēri) tika piešḳirti vairāki miljoni EUR, lai atbalstītu dažādas gatavības pakāpes no tehnoloǵiskās pamatizpētes (TRL 1) līdz demonstrācijām attiecīgā vidē (TRL 6). Taču citās pētniecības jomās, piemēram, medicīniskajāinženierijā vai implantātu materiālu jomā, tika piešk̦irti tikai attiecīgi 340000 un 600000 EUR, koncentrējoties uz noteiktām tehnoloǵiskās gatavības pakāpēm.

Lai uzlabotu izdevumu efektivitāti, Latvijai būtu jākoncentrē finansējums mazākam skaitam atlasītu ekosistēmu, kas l̦auj veidot ciešas saiknes starp materiālu atklāšanu un produktu izstrādi. Visaptverošas materiālu inovācijas ekosistēmas veidošana, iesaistot pētniecības universitātes un ražotājus, ir būtiski svarīga, lai samazinātu laika nobīdi starp minētajiem posmiem. Digitālās tehnoloǵijas, tostarp skaitḷošanas materiālzinātne un "digitālie dvīṇi", šajā ziṇā ir būtiski veicinošie faktori, jo tās var palīdzēt savienot dažādos posmus materiālu ražošanas aprites ciklā (ESAO, 2017c). Piemēram, integrēta skaitḷošanas materiālu inženierija (ICME) izmanto datu zinātni, datormodelēšanu un simulāciju, lai efektīvāk sasaistītu materiālu izstrādi ar īpašību sertifikāciju un produktu izvēršanu. Latvijas Universitātes Magnētisku mīkstu materiālu laboratorija sadarbībā ar Eksperimentālās fizikas institūtu SAS (Slovākija), Cordouan Technologies un LCPO (Francija) pašlaik ir iesaistīta ICME projektā, 
pētot magnētisko stīgu īpašības un pielietojumus tādās jomās kā enerǵētika, tekstilijas un medicīna. Projektu finansē M-ERA.NET (sk. zemāk).

\subsection{9. attēls. Latvijas publikācijas tajos 10 \% dokumentu, kas visbiežāk citēti materiālzinātnēs un inženierzinātnēs}

Vidēji 2014.-2018. gadā

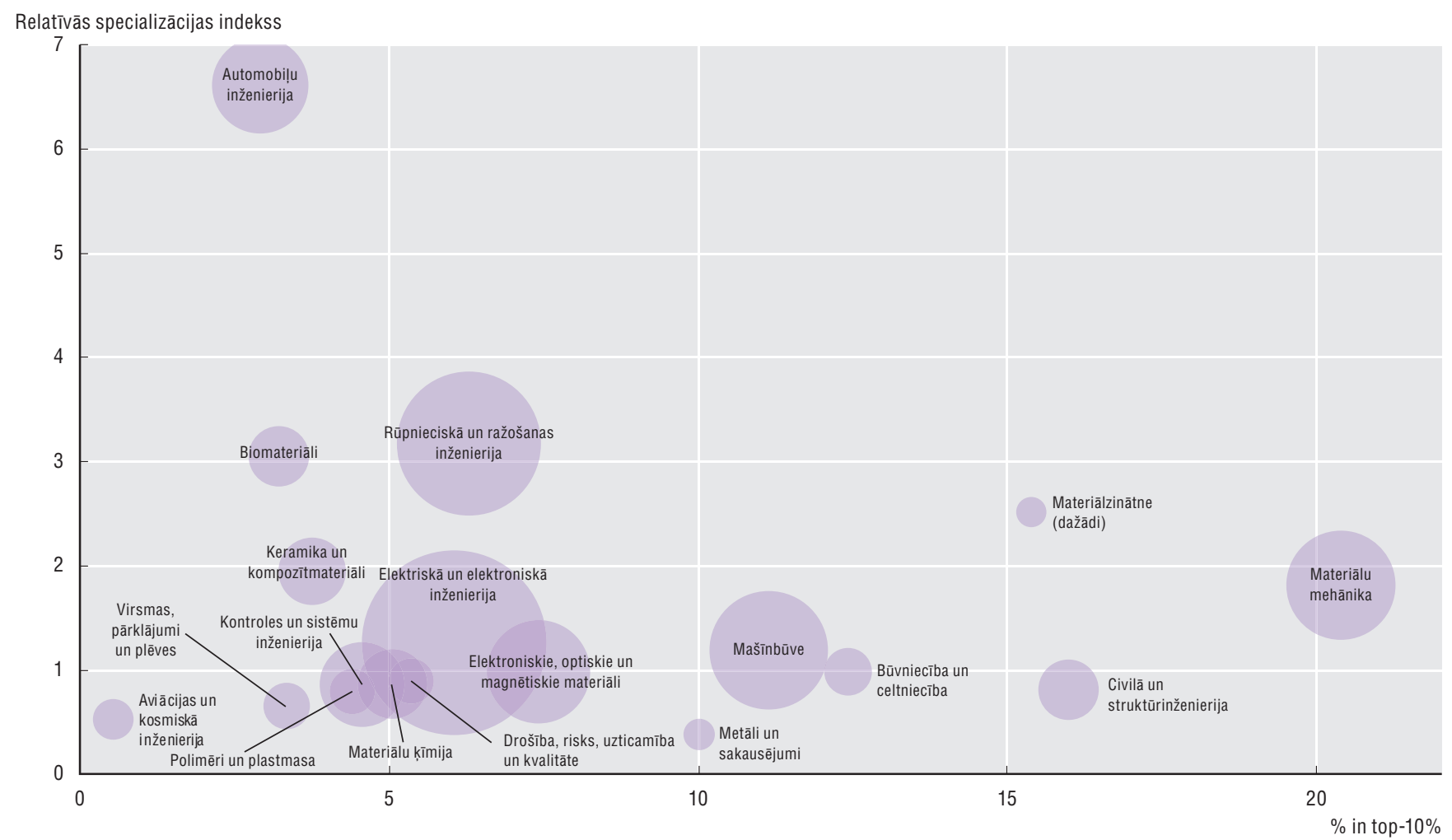

Piezīme: Figūru lielums atbilst publikāciju skaitam, kas ir diapazonā no 7 (materiāli — dažādi) līdz 281 (elektriskā un elektroniskā inženierija). Norādīts kopējais publikāciju skaits no 2014. līdz 2018. gadam. Vairāk informācijas sk. 6.18. attēlā.

Avots: ESAO aprēḳini, pamatojoties uz Scopus Custom Data, Elsevier, versija: 5.2019.

Labs piemērs spēcīgākām saiknēm starp pētniecību un ražotājiem ir Viedo materiālu pētījumu un tehnologiiju pārneses ekselences centrs (CAMART ${ }^{2}$ ). CAMART ${ }^{2}$, kas dibināts 2001. gadā, vada Latvijas Universitātes Cietvielu fizikas institūts (CFI) sadarbībā ar diviem zviedru partneriem - KTH Karalisko tehnologiiju institūtu un Acreo Swedish ICT. Centrs saṇem finansējumu no programmas "Apvārsnis 2020" (15 miljoni EUR) un ESI fondiem (16,3 miljoni EUR). 2018. gadā CAMART izveidoja jaunu platformu "Materize", lai sekmētu jaunu materiālu un tehnoloǵiju pārnesi uz komerciāliem produktiem. "Materize" sniedz pakalpojumus no koncepcijas apliecināšanas laboratorijas apstākḷıs līdz prototipu veidošanai un mazapjoma ražošanai partneru nodrošinātās rūpnieciskās testa platformās.

Latvijai būtu jācenšas aktīvi veicināt saiknes starp materiālu atklāšanu un produktu izstrādi, padarot finansējumu pieejamu dažādiem tehnoloǵiju gatavības līmeṇiem (TRL 1-6) izvēlētā materiālu ekosistēmā no tehnologíiskās pamatizpētes līdz tehnoloǵiju demonstrēšanai un pētniecības rezultātu komercializācijai. Baltijas Biomateriālu ekselences centrs (BBEC) ir piemērs ekosistēmai, kurā šāda pieeja jau tiek izmantota. Latvija varētu arī koncentrēt eksporta atbalstu uz uzṇēmumiem, kas iepriekš ir guvuši labumu no publiski finansētas pētniecības un izstrādes (piem., ar kompetences centru starpniecību).

Pētniecības jomās ar mazāk attīstītām inovācijas ekosistēmām Latvijai būtu jākoncentrējas uz vispārīgākiem atbalsta mehānismiem, kas var palīdzēt uzlabot saiknes starp uzṇēmumiem un valsts pētniecības institūtiem vai universitātēm. Konkrēti, Latvijai būtu jāstiprina sava Tehnoloğiju pārneses 
programma un jāsekmē inkubatori universitātēs. Šḳiet, ka pašlaik arī nav visaptverošas stratēg̣ijas sadarbības veicināšanai starp jaunuzṇēmumiem un pētniecības iestādēm, jo daudzi jaunuzṇēmumi ziṇo par grūtībām piemērotu pētniecības partneru atrašanā (EM, 2018c). Izveidojot tīmekḷa vietni startuplatvia.eu, Latvijas valdība nesen ieviesa centralizētu vienoto kontaktpunktu jaunuzṇemumiem. Taču noderīga informācija par tehnologiju pārneses birojiem un iespējām pētniecības sadarbībai pašlaik nav pieejama.

Latvijas valdībai būtu arī jāsniedz lielāks atbalsts uz izcilību balstītiem uzaicinājumiem iesniegt inovāciju priekšlikumus kā, piemēram, programmā "Apvārsnis 2020". Ar savu valsts kontaktpunktu starpniecību (piem., VIAA) valdība varētu nodrošināt īpašus mācību seminārus pieteikumu iesniedzējiem (piem., sadarbībā ar universitātēm, klasteru iniciatīvām vai kompetences centriem) vai aktīvāku pieeju inovatīvām ieinteresētajām personām privātajā sektorā. Tiešām, sadarbība, kurā iesaistītas vairākas iestādes, tostarp VIAA un IZM, kā arī ārējie eksperti, ir palīdzējusi ievērojami palielināt Latvijas pētniecības priekšlikumu panākumus M-ERA.NET — ES finansētā tīklā, kas ik gadu publicē uzaicinājumus iesniegt priekšlikumus transnacionāliem pētniecības un izstrādes projektiem materiālzinātnēs. Konkrēti, to priekšlikumu procentuālā daḷa, kas tika pieṇemti finansējumam, palielinājās no 5 \% 2012.-2014. gadā līdz gandrīz 20 \% 2017.-2018. gadā.

\section{Latvijai būtu jāsekmē progresīuu ražošanas tehnologiiju ieviešana lejupējās nozarēs}

Latvijas valdībai būtu jāsekmē digitālu ražošanas tehnoloǵiju plašāka ieviešana lejupējās nozarēs. Piemēram, Latvijas ražošanas uzṇēmumi atpaliek 3D drukas izmantošanā (6.20. attēls).

\subsection{0. attēls. 3D printeru izmantošana ražošanai uzṇēmumos Latvijā un atlasītajās ESAO valstīs, 2018. gads}

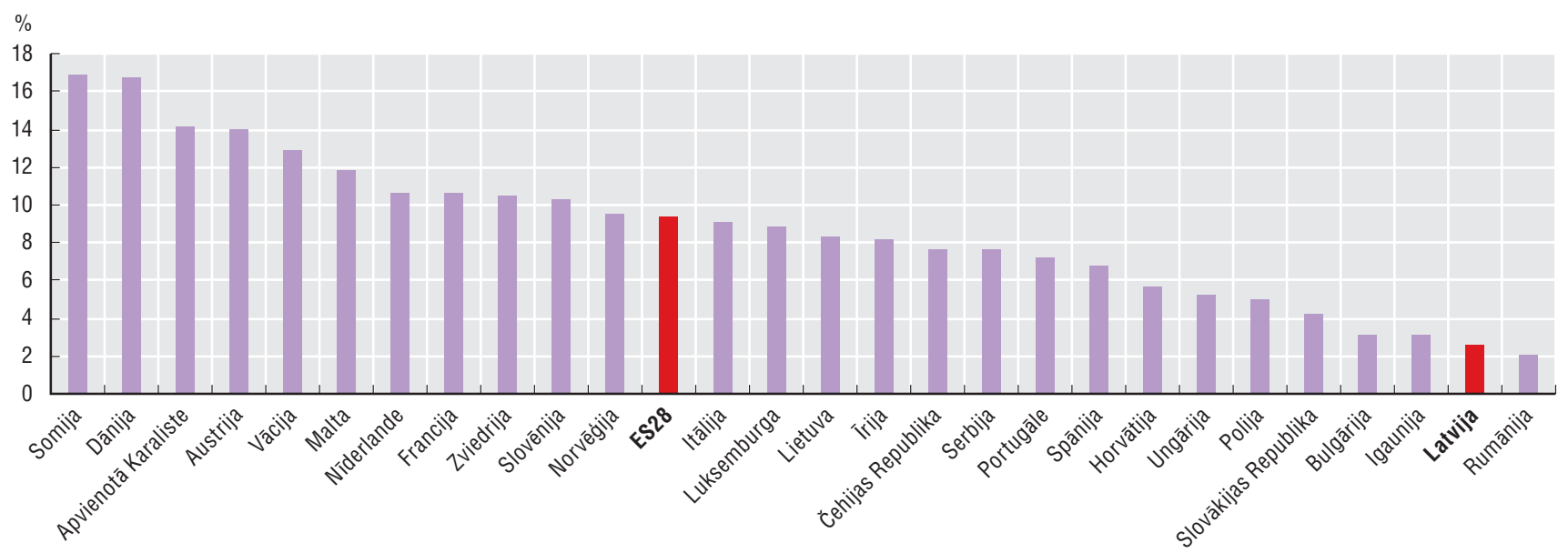

Avots: Eurostat (2020a), ICT Usage in Enterprises - E-business (isoc_eb) (database), https://ec.europa.eu/eurostat/web/digital-economy-and-society/data/ database.

Latvijas ieinteresētās personas sāk aktīvi veicināt digitālās ražošanas tehnologiju ieviešanu galvenajās ražošanas nozarēs. 2016. gadā Mašīnbūves un metālapstrādes rūpniecības asociācija (MASOC) uzsāka valsts mēroga sadarbības programmu "Stiprinot metālapstrādes darbiniekus gudrām nākotnes rūpnīcām” (4CHANGE). Projekts, ko līdzfinansēja ES programma Erasmus+, norisinājās līdz 2019. gada novembrim. Tā budžets bija aptuveni 1,2 miljoni EUR, un projekta mērḳis bija uzlabot profesionālās izglītības un apmācības (PIA) programmas, īpašu uzmanību vēršot uz ciparvadības (CNC) iekārtām. Taču 2018. gadā aptuveni puse no mašīnbūves un metālapstrādes rūpniecības uzṇēmumiem joprojām sevi uzskatīja par digitālā ziṇā neintensīviem (Grīnfelds, 2018).

Lai veicinātu līdzīgus projektus un tos paplašinātu citās nozarēs, valdība kopā ar vairākiem kompetences centriem un Vācijas-Baltijas Tirdzniecības kameru (AHK) nesen parakstīja sadarbības memorandu par platformas Industrija 4.0 izstrādi un īstenošanu (6.10. ielikums). 


\subsection{0. ielikums. Platforma Industrija 4.0}

Lai palielinātu digitālo tehnoloǵiju izmantošanu ražošanas nozarē, Latvija izstrādā Industrijas 4.0 īstenošanas pasākumu kopumu, kura mērk̦is ir uzlabot saiknes starp Latvijas ražošanas uzṇēmumiem un uzṇēmumiem, kas izstrādā viedās tehnoloǵijas. 2019. gada februārī Ekonomikas ministrija, Vides aizsardzības un reǵionālās attīstības ministrija, astoṇi kompetences centri un Vācijas-Baltijas Tirdzniecības kamera (AHK), kas ietver tādus uzṇēmumus kā SAP un Bosch, parakstīja sadarbības memorandu par platformas Industrija 4.0 izstrādi un īstenošanu. Platformas industrija 4.0 mērḳis jo īpaši ir stiprināt sadarbību un koordināciju starp ieinteresētajām personām, konsultējot Latvijas uzṇēmumus par jaunām tehnoloǵijām ražošanas nozarē un veidojot politiku digitālo tehnoloǵiju veicināšanai. Ekonomikas ministrija pašlaik izstrādā stratēǵiju memoranda istenošanai.

Valdības mērḳis ir izmantot digitālo inovāciju centrus (DIC) kā fizisku platformu platformas Industrija 4.0 īstenošanai. Šādi centri darbotos kā vienots kontaktpunkts, kurā uzṇēmumi, jo īpaši MVU, kā arī valsts sektora organizācijas varētu piekḷūt pakalpojumiem saistībā ar testēšanu, investoru piesaisti, prasmēm un apmācību, tīklu veidošanu un inovācijas ekosistēmu. Kā ziṇo valdība, platforma Industrija 4.0 tiks oficiāli izveidota, izmantojot programmu "Digitālā Eiropa" (2021.-2027. g.), kurā ierosināts padarīt pieejamus 9,2 miljardus EUR tādām jomām kā superdatošana, mākslīgais intelekts un Eiropas digitālo inovāciju centru tīkla izveide un stiprināšana.

Lai îstenotu Latvijas platformu Industrija 4.0, kas pašlaik vēl ir plānošanas posmā, Latvijai būtu jāapsver dažas citās valstīs izmantotas pieejas digitālo rīku izplatīšanās veicināšanai, jo īpaši starp MVU. Piemēram, MVU 4.0 kompetences centri Vācijā piedāvā jaunu tehnolog̣iju demonstrācijas un rūpnieciskos pielietojuma veidus MVU. Šādas demonstrācijas bieži tiek veiktas universitātēs un ir īpaši pielāgotas konkrētām nozarēm. Dānijā programma MADE rīko tādu rūpniecības līderu apmeklējumus, kuri vēlas dalīties savā pieredzē ar topošiem jaunākajiem risinājumiem (Paunov un Planes-Satorra, 2019). Latvija varētu apsvērt arī citas iespējas, ne tikai digitālo inovāciju centrus (no kuriem pašlaik darbojas tikai trīs), lai veicinātu jaunu tehnologiju izmantošanu MVU. Piemēram, Latvijas klasteri, kas potenciāli sadarbojas ar klasteriem citās valstīs, varētu rīkot MVU apmeklējumus pie vietējiem vai starptautiskiem rūpniecības līderiem. Turklāt kompetences centri varētu piedāvāt MVU ìpašas attiecīgu jauno tehnoloǵiju demonstrācijas.

Programma Brasil Mais Productivo ir vēl viens piemērs, kas varētu palīdzēt Latvijā sekmēt Industriju 4.0. Programma piedāvā īpašus konsultāciju pakalpojumus, lai palīdzētu radīt procesa inovāciju mazos un vidējos ražošanas uzṇēmumos. Programma ietver aptuveni 120 stundu tehnisko apmācību par taupīgo (lean) ražošanu, energoefektivitātes praksēm un ražošanas procesa digitalizāciju. Koncentrēšanās uz konsultācijām ierobežo programmas izmaksas. Turklāt uzṇēmumiem ir jāsedz daḷa izmaksu, un tas palīdz nodrošināt aktīvu līdzdalību. İpaša kredīta shēma palīdz uzṇēmējiem ar ierobežotiem līdzekḷiem pārvarēt programmas finansiālo slogu. Trūkstot institucionālai struktūrai, kas sniegtu šādus konsultāciju pakalpojumus visos Latvijas reǵionos, specializētus kursus par taupīgo ražošanu un progresīvu tehnoloǵiju izmantošanu varētu arī iekḷaut LIAA piedāvātajos uzṇēmumu apmācības kursos Inovāciju motivācijas programmas ietvaros.

\section{Viedās enerǵijas tehnoloǵijas un viedās pillsētas risinājumi}

Latvijas Viedās specializācijas stratēǵijā vieda enerǵija un IKT ir uztvertas kā nozares ar ievērojamu horizontālo ietekmi uz pārveidošanu citās ražošanas nozarēs. Jo īpaši viedās enerǵijas specializācijas joma uzsver uzlabotas energoefektivitātes un tīru tehnoloǵiju lomu labākai produktivitātei un vides ilgtspējai dažādās ekonomikas nozarēs (IZM, 2015).

\section{Vieda enerǵija Latvijā ir izteikti dinamiska, taču energotaupības tehnoloǵiju izplatība joprojām ir zema}

Nozares, kas ražo viedās enerǵijas tehnoloǵijas, aug. Jo īpaši elektrisko iekārtu dal̦a kopējā ražošanā pieauga no 1,5 \% 2010. gadā līdz 3,3 \% 2017. gadā, savukārt iekārtu un mehānismu pienesums palielinājās no 2,2 \% līdz 3,3 \%. Arī citas saistītas nozares, piemēram, motorizētu transportlīdzekḷu un piekabju ražošana, kḷuva nozīmīgākas (no 1,5 \% līdz 2,5 \%) (6.12. attēls). 


\subsection{1. ielikums. Politikas ieteikumi: Viedie materiāli un inženierzinātnes}

- Vērst Viedās specializācijas stratēgijas finansējumu uz mazāku skaitu atlasītu ekosistēmu, kas l̦auj veidot ciešākas saiknes starp materiālu atklāšanu un pielietojumu. Atbalstīt inovācijas atlasītās ekosistēmās visā inovācijas ciklā no agrīnā posma izpētes līdz mārketingam un starptautiskošanai.

- Atbalstīt izcilību citās pētniecības jomās, izmantojot plašākus inovācijas atbalsta mehānismus, tostarp tehnoloǵiju pārneses programmas, universitātes inkubatorus un apmācību "Apvārsnis 2020" izmantošanai (piem., ar VIAA starpniecỉbu).

- Pabeigt un îstenot Industrija 4.0 ìstenošanas pasākumu kopumu, lai veicinātu digitālo attīstību ražošanas uzṇēmumos, jo īpaši MVU. Izmantot klasterus un kompetences centrus, lai izplatītu zināšanas par progresīviem ražošanas risinājumiem un veicinātu konsultāciju pakalpojumus un apmācỉbu (piem., ar LIAA starpniecību).

Visas trīs nozares arī būtiski veicināja augsto un vidēji augsto tehnoloǵiju preču dal̦as pieaugumu ražošanas kopējā eksportā (6.17. attēls). Taču nevienā no tām Latvija neuzrādijja salīdzinošu priekšrocìbu (6.13. attēls).

Tomēr uzṇēmumu pētniecība un izstrāde elektrisko iekārtu jomā bija daudz augstāka nekā jebkurā citā ražošanas nozarē (5,3 \%) un bija diezgan tuvu ESAO vidējam rādītājam (6,8 \%) (6.15. attēls). Lìdzīgi arī patentu skaits elektrisko iekārtu un aparātu, transporta un vides tehnoloǵiju jomā no 2007. līdz 2016. gadam palielinājās. ${ }^{8}$

Enerǵija un vides zinātnes ir starp veiksmīgākajām pētniecības jomām Latvijā. Saskaṇā ar Eiropas ekoinovāciju indeksu 2018. gadā akadēmiskā izlaide ekoinovāciju jomā Latvijā bija lielāka nekā jebkurā citā ES valstī. Publikācijas saistītās pētniecības jomās tika publicētas relatīvi biežāk nekā citās valstīs (t.i., salīdzinājumā ar vidējo rādītāju pasaulē), arī bieži citēto dokumentu dal̦a bija augstāka. Konkrēti, laikā no 2014. lìdz 2018. gadam aptuveni 17,3 \% Latvijas publikāciju enerǵijas jomā bija starp tiem 10 \% pasaules publikāciju, kas citētas visbiežāk (6.21. attēls). Vides zinātnēs pētniecības rezultāti visaugstākie bija vides inženierijas un ūdens zinātnes un tehnoloǵiju jomās, kurās 17 \% no Latvijas publikācijām bija starp 10 \% biežāk citēto pasaulē. Publikācijas citās saistītās inženierijas jomās, piemēram, civilajā un struktūrinženierijā (16 \%) vai būvniecībā un celtniecībā (13 \%), arī bieži bija starp 10 \% biežāk citēto.

Laikā no 1990. līdz 2016. gadam Latvija vairāk nekā divkāršoja enerǵijas ražošanu no 1,2 miljoniem tonnu naftas ekvivalenta (Mtoe) līdz 2,5 Mtoe. Tajā pašā laikā neto enerǵijas imports samazinājās no 7,5 līdz 2,2 Mtoe, kas norāda uz ievērojami mazāku atkarību no ārējiem piegādātājiem (IEA, 2019a). Biodegviela un atkritumi ir kḷuvuši par galvenajiem energoapgādes avotiem - 2018. gadā Latvijai bija trešā augstākā atjaunojamo energoresursu enerǵijas daḷa enerǵijas bruto galapatēriṇā (40,3 \%) no visām ES dalībvalstīm, atpaliekot tikai no Somijas (41,2 \%) un Zviedrijas (54,6\%) (Eurostat, 2020b).

Taču, lai gan Latvija ir ceḷā uz sava 2020. gada energoefektivitātes mērḳa sasniegšanu, enerğijas patēriņ̌s pieaug, jo to veicina transporta un mājokḷu nozares. Turklāt enerǵijas ražošana no biomasas joprojām ir l’oti neefektīva un - apvienojumā ar augošu transportu pilsētā un zemu energoefektivitāti mājokḷos apdraud Latvijas 2030. gada energoefektivitātes mērḳu sasniegšanu (Eiropas Komisija, 2020; ESAO, 2019a). Valstij arī joprojām ir jāuzlabo ilgtspēja atkritumu apsaimniekošanā, jo reciklēšanas līmenis pašvaldībās vēl arvien ir zems. Turklāt Latvijā ir vienas no augstākajām rūpnieciskās elektroenerğijas cenām pasaulē (6.22. attēls), ko daudzi uzṇēmumi uzskata par ievērojamu šḳērsli konkurētspējai (piem., Grīnfelds, 2018).

\section{Inovatīuu tīro tehnoloǵiju komercializācijai ir vajadzīgs spēcīgāks politiskais atbalsts}

Ar aptuveni 34 miljonu EUR finansējumu 2014.-2018. gadā viedā enerǵija veidoja mazāk nekā piekto dalı no kopējā atbalsta viedajai specializācijai. Lielākā daḷa pētniecības un izstrādes finansējuma tika investēta tehnoloǵiju un risinājumu izstrādē, lai uzlabotu èku un rūpniecības energoefektivitāti (30 \%) un enerǵijas pārvaldību, tostarp viedos tīklus (29\%). Alternatīvās degvielas, tostarp elektromobilitāte, saṇēma 22 \%. Vairāk nekā viena trešā daḷa no kopējā pētniecības un izstrādes finansējuma viedajai 
enerǵijai tika sniegta, izmantojot programmu "Apvārsnis 2020" (36 \%), kas ir ievērojami augstāka daḷa nekā visās pārējās RIS3 jomās, kurās "Apvārsnis 2020" daḷa bija no 5 \% (biomedicīna) līdz 23 \% (IKT) (6.2. tabula).

\subsection{1. attēls. Latvijas publikācijas tajos $10 \%$ dokumentu, kas citēti visbiežāk viedās energètikas jomā} Vidēji 2014.-2018. gadā

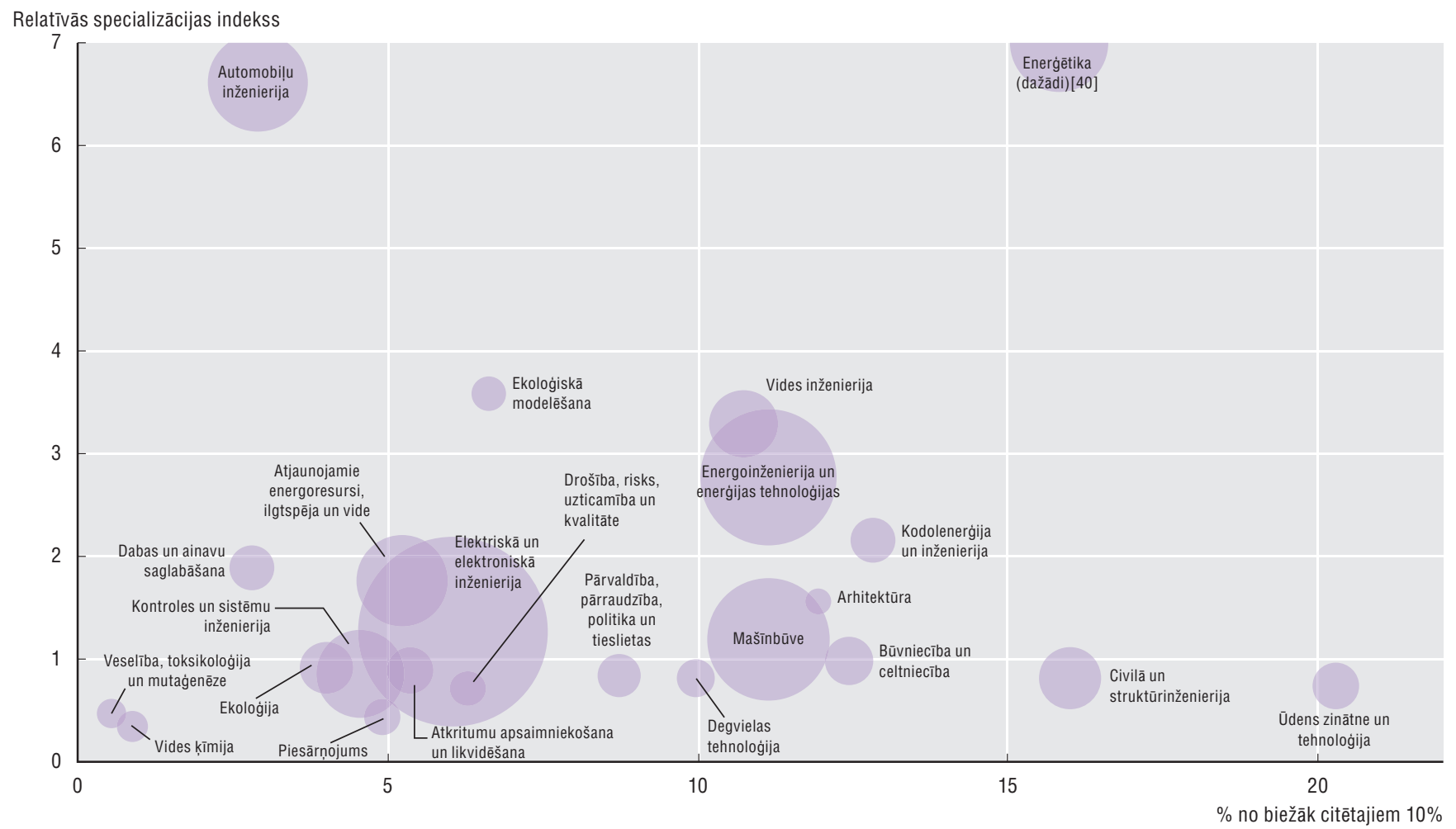

Piezīmes: Figūru lielums atbilst publikāciju skaitam, kas ir diapazonā no 5 (arhitektūra) līdz 281 (elektriskā un elektroniskā inženierija). Norādīts kopējais publikāciju skaits no 2014. līdz 2018. gadam. Vairāk informācijas sk. 6.18. attēlā.

Avots: ESAO aprēkini, pamatojoties uz Scopus Custom Data, Elsevier, versija: 5.2019.

\subsection{2. attēls. Rūpnieciskās elektroenerǵijas cenas Latvijā un atlasītajās ESAO valstīs, 2017. gads}

USD/MWh, izmantojot pirktspējas paritāti

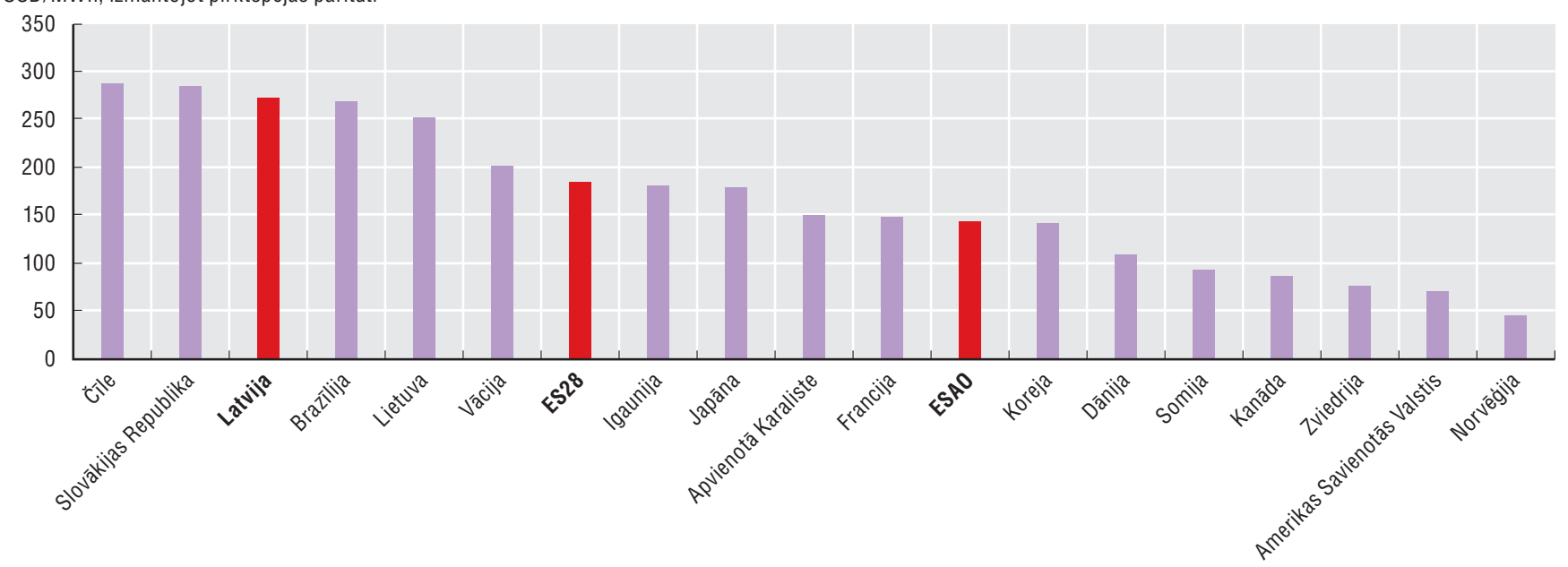

Piezime: $\mathrm{MWh}=$ megawatt-hour.

Avots: IEA (2019b), World Energy Prices, http://data.iea.org/payment/products/121-world-energy-prices-2019-edition.aspx. 
Lielākie projekti, kas tika finansēti ar šo shēmu, ir SUNShINE un SUNShINE Accelerate, no kuriem katrs saṇem ES maksājumus gandrīz 1,3 miljonu apmērā. Projekti ir paredzēti dzīvojamo ēku renovācijai, un tos koordinē Rīgas Tehniskā universitāte. Lai gan tie veicina energoefektivitāti Latvijas mājokḷos un sekmē pieprasījumu pēc energopakalpojumiem, nav nekādu nosacījumu attiecībā uz projektos izmantotajām tehnoloǵijām, un tas nozīmē, ka ietekme uz inovāciju joprojām ir nenoteikta.

Jo īpaši digitālā inovācija var būt l̦oti nozīmīgs energotaupības veicinātājs. Saskaṇā ar Starptautisko Enerǵētikas aǵentūru (IEA) digitālo tehnoloǵiju, piemēram, viedo termostatu un viedā ēku apgaismojuma, izmantošanai ir potenciāls līdz 2040. gadam globāli ietaupīt aptuveni 65 PWh enerğijas, kas ir līdzvērtīgi kopējam enerǵijas galapatēriṇam valstīs, kas nav ESAO dalībvalstis, 2015. gadā (IEA, 2017). Līdzīgi arī digitālo tehnoloǵiju izmantošana transportā (piem., elektrisko transportlīdzekḷu vieda uzlādēšana, kopīga un automatizēta mobilitāte) un rūpniecībā (piem., aditīvā ražošana, "digitālie dvīṇi") varētu padarìt iespējamus ievērojamus enerǵijas ietaupījumus un emisiju samazinājumus. Tāpēc Latvijai būtu īpaši jāsekmē viedās enerǵijas inovācijas, tostarp digitālo tehnoloǵiju izmantošana ēkās, transportā un rūpniecībā, lai veicinātu enerǵijas un izmaksu ietaupijumus.

Divi “Apvārsnis 2020" projekti, kas uzsver veiksmīgu pētniecisko darbību šajā ziṇā, ir MORE-CONNECT un RealValue. MORE-CONNECT koncentrējās uz moduḷu, saliekamo renovācijas elementu projektēšanu un izmēǵināšanu, kas sazinās, izmantojot bezvadu sensorus un vadības elementus veiktspējas diagnostikai un kontrolei. Projekts tika īstenots sadarbībā starp RTU (330 450 EUR), Latvijas Koka būvniecības klasteri (56 875 EUR) un Zemgales tehnologiisko centru (78 925 EUR), kā arī 15 citiem dalībniekiem no septiṇām valstīm un tika pabeigts 2019. gada maijā. RealValue apliecināja viedās elektriskās termoakumulācijas potenciālu esošo elektriskās termoakumulācijas sildītāju un ūdenstvertṇu aizstāšanā. Projektā piedalījās RTU (632 318 EUR), kā arī 11 partneri no Somijas, Vācijas, İrijas un Apvienotās Karalistes. Tas tika pabeigts 2018. gada maijā. Viedās elektriskās termoakumulācijas ierīces kopā ar viedajiem spraudṇiem, sensoriem un viedajiem mērītājiem tika uzstādītas 1250 mājokḷos Vācijā, Īrijā un Latvijā. Vārteja savieno ierīces ar optimizācijas programmu mākonī, kas izveido saites ar elektrotīklu katrā valstī, lai aprēḳinātu un ìstenotu optimizētus uzlādes grafikus. RTU arī piedalījās energosistēmas modelēšanas uzdevumā, kas palīdzēja apliecināt tehniskās un komerciālās izmantošanas potenciālu miljonos mājokḷu attiecīgajos ES reǵionos.

Viedās enerǵētikas inovācijas izplatās arī privātajā sektorā, kurā ir radušies vairāki jaunuzṇēmumi ar specializāciju digitālajās tehnologijāas. Piemēram, 2016. gadā dibinātais Citintelly ir izstrādājis daudzfunkcionālu centrālās vadības mākoṇsistēmu (CMS) ielu apgaismošanai, tostarp sensorus un vadības ierīces, un līdz šim ir īstenojis projektus Izraēlā, Latvijā un Maltā. Savukārt Route4Gas izstrādā programmatūras risinājumus labākai gāzes maršrutēšanai Eiropas dabasgāzes tirgū. Turklāt Marine Digital — viens no pirmajiem starptautiskajiem jaunuzṇēmumiem, kas uzsāka darbību Latvijā valsts jaunuzṇēmumu vīzu programmas ietvaros, (sk. 6.1. iedaḷu) - piedāvā automatizētu ostu un kravu termināḷ pārvaldības sistēmu.

Lai atbalstītu jaunuzṇēmumu dinamiku un privātā sektora inovācijas, valdībai būtu jāpalielina finansējums pētniecības komercializācijai un kompetenču centriem.Viedā enerğija îr viedās specializācijas joma ar vismazākajiem izdevumiem attiecīgajās jomās, par ko ir atbildīga Ekonomikas ministrija. Kopā tās veido tikai 12 \% no kopējiem izdevumiem (4 miljoni EUR) viedās enerǵijas specializācijas jomā salīdzinājumā ar 22 \% biomedicīnā un aptuveni 39-43 \% citās jomās (10-20 miljoni EUR) (6.2. tabula).

Latvijai būtu īpaši jāvērš uzmanība uz ekoinovācijām, lai labāk izmantotu sinerǵiju starp viedo specializāciju un pasākumiem, kas atbalsta tīrāku ražošanu, atkritumu rašanās novēršanu vai bioenerğiju (ESAO, 2019m). Lai gan ekoinovācijas aptver vairākas viedās specializācijas jomas, tostarp viedo enerǵiju, bioekonomiku un viedos materiālus, pašlaik tā nav nevienas jomas uzmanības centrā. Attiecīgi ar vidi saistītie inovatori ir pārstāvēti četros dažādos klasteros: Latvijas elektronikas un elektrotehnikas nozares klasterī, CLEANTECH klasterī, Zaḷo un viedo tehnoloǵiju klasterī un Viedās pilsētas klasterī. Ieinteresēto personu intervijas ar klastera pārstāvjiem šḳietami apstiprina, ka daži uzṇēmumi minētajos klasteros ir saskārušies ar ievērojamām grūtībām piemērotu atbalsta mehānismu atrašanā viedās specializācijas sistēmas ietvaros. 
Valdība varētu, piemēram, aizstāt vai atjaunot inovāciju programmu zaḷās rūpniecības jomā, kas sniedza pirmsinkubācijas un inkubācijas pakalpojumus jaunuzṇēmumiem, kuri iesaistās vides tehnologiiju izstrādē un komercializācijā. Iniciatīvu, kas sākās 2014. gadā, vadīja Ekonomikas ministrija Norvēgijas finanšu instrumenta programmas ietvaros. 2017. gada aprīlī 152 komandas bija sanēemušas pirmsinkubācijas konsultācijas, ko sniedza specializēts zaḷo tehnoloǵiju inkubators, un 23 projektu isstenotāji izmantoja līdzfinansējumu, kura kopējais apmērs bija 2,4 miljoni EUR (IZM, 2018). Finansējuma trūkuma dēl šì programma Latvijā pašlaik nedarbojas.

\section{Viedā energiija un vides tehnoloǵijas var gūt ievērojamu labumu no viedās pilsētas iniciatīuām.}

Daudzsološa koncepcija, kas digitalizācijas kontekstā rada ievērojamu potenciālu viedās enerǵijas specializācijas jomā, ir viedās pilsētas. Viedās pilsētas ir cieši saistītas ar jaunu digitālu tehnolog̣iju rašanos tādās jomās kā energoefektīvas èkas, viedie tīkli, viedi mobilitātes risinājumi un ilgtspējīgi atkritumu un ūdens apsaimniekošanas risinājumi.

Piemēram, Rīgas pilsētas ilgtspējīgas enerǵētikas rīcības plāns viedai pilsētai 2014.-2020.gadam (IERP), ar ko Rīgas pilsēta apṇēmās samazināt $\mathrm{CO}_{2}$ emisijas vismaz par 20 \%, ir balstīts uz energoefektivitātes pieaugumu par $20 \%$ un atjaunojamo energoresursu daḷas kopējā patērētajā enerǵijā pieaugumu par 20 \%. Inovatīvu IKT integrēšana enerǵijas un transporta sistēmās ir viens no galvenajiem programmas elementiem. IERP tika izstrādāts ES Septītās pamatprogrammas "Energoefektivitātes stratēgiskie instrumenti pilsētu attīstības plānošanai” (STEP-Up) ietvaros sadarbībā ar pašvaldībām Beḷgijā, Zviedrijā un Apvienotajā Karalistē.

Viens no programmā paredzētajiem pasākumiem ir pilsētas apgaismojuma sistēmas uzlabošana, izmantojot programmējamas LED lampas. Taču kopš programmas uzsākšanas 2012. gadā progress ir bijis diezgan lēns, un ielu LED apgaismojuma viedā kontrole pašlaik darbojas tikai nedaudzās apkaimēs. Tas ietver Māras dỉka teritoriju, ko Latvijas jaunuzṇēmums Citintelly 2017. gadā aprīkoja ar viedā apgaismojuma tehnolog̣iju. 2019. gadā tika parakstīta vienošanās vairāk nekā 4,7 miljonu EUR vērtībā par trīs jauniem projektiem, lai veicinātu viedā apgaismojuma risinājumu ìstenošanu Rīgā. Projekti ietver tālvadības sistēmas ar radaru klātbūtnes konstatēšanai, lai kontrolētu apgaismojumu un satiksmi.

Papildu investīcijas ir vajadzīgas arī transporta sistēmā. Lielākā daḷa ar transportu saistīto investīciju iepriekš galvenokārt bija paredzētas autoceḷu tīklam, un automašīnas joprojām veido lielāko daḷu pasažieru pārvadājumu Latvijā. Pašlaik nav nevienas integrētas sabiedriskā transporta sistēmas, kas savienotu Rīgu ar tuvējām pašvaldībām, un tas nozīmē, ka tādi pakalpojumi kā maršrutu plānošana, cenu noteikšana un biḷešu tirgošana ir sadalīti starp vairākiem pakalpojumu sniedzējiem un pašvaldībām (ESAO, 2019m). Izstrādājot integrētu sabiedriskā transporta sistēmu ar tādu metropoles transporta iestādi, piemēram, kā Madridē, Prāgā vai Varšavā, cel̦ošana varētu būt vienkāršāka un pieejamāka, kā arī ḷautu digitāli integrēt biḷešu tirgošanas un maršrutu plānošanas sistēmas. Alternatīvu kopīgās un aktīvas mobilitātes risinājumu, piemēram, velosipēdu, elektromobiḷu vai skrejriteṇu izmantošanas veicināšana, varētu vēl vairāk motivēt pasažierus atstāt automašīnu mājās un padarīt transportu iekḷaujošāku un ilgtspējīgāku.

No mazākām pašvaldībām Jelgavas pilsēta viena no pirmajām pieṇēma viedās pilsētas redzējumu. Kopš 2016. gada būtiski svarīgo infrastruktūru pilsētā pārrauga Pašvaldības operatīvās informācijas centrs (POIC), kas ietver satiksmes plūsmas datu pārraudzību reāllaikā, satiksmes optimizāciju, izmantojot viedo satiksmes apgaismojumu, un automatizētu meteoroloǵisko staciju un plūdu aizsargbarjeru uzraudzību, kā arī viedus enerǵijas pārvaldības risinājumus centralizētai siltumapgādei. Iedzīvotājiem arī tika izsniegtas e-kartes (tuvā lauka sakaru tehnoloǵija), kuras var izmantot, lai samaksātu par sabiedrisko transportu un sañemtu sociālos pabalstus. Financial Times investīciju pētniecības nodaḷa 2017. gadā iekḷāva Jelgavu 6. vietā starp Eiropas mazajām pilsētām kategorijā "savienojamība" (Strods, 2017).

Kopš viedās pilsētas tika atzītas par būtisku vērtību k̦ēdi Viedās specializācijas stratēǵijas pārskatītajai versijai, viedo pilsētu ideja Latvijā kḷūst populārāka. Ekonomikas ministrija pašlaik nosaka detalizētus vērtību k̦ēdes elementus, apspriežoties ar valsts, privātajām un akadēmiskajām ieinteresētajām personām, kā arī koordinācijā ar Satiksmes un Vides aizsardzības un reǵionālās attīstības ministrijām. 
Ekonomikas ministrijas pārstāvji un citas ieinteresētās personas ir arī iesaistījušas starptautiskos kolēǵus, lai uzzinātu vairāk par viedās pilsētas koncepcijas īstenošanu tādās valstīs kā Nīderlande vai Smart City Expo kongresā Barselonā.

Viena no dinamikas pieauguma pazīmēm ir iniciatīva VEFRESH — atvērta inovāciju kustība, ko 2019. gadā uzsāka tehnologiju uzṇēmumi, nekustamo īpašumu attīstītāji un Rīgas pašvaldība. Kustības mērḳis ir pārveidot VEF apkaimi Rīgā, kurā atrodas liela daḷa Latvijas IT uzṇēmumu un kas veido vairāk nekā 40 \% no valsts IT eksporta, par testa platformu viedās pilsētas risinājumiem. Valsts valdībai var būt veicinoša loma inovatīvu risinājumu izpildes, spēju veidošanas un izvēršanas atbalstīšanā viedo pilsētu kontekstā (ESAO, 2020i), un tā ar Ekonomikas ministrijas un Rīgas Domes parakstītu saprašanās memorandu ir paudusi tiešu atbalstu viedās pilsētas attīstībai VEF apkaimē.

Arī Cēsu pilsēta ir sākusi veidot digitālu stratēǵiju un rīko seminārus un nodarbības uzṇēmējiem par dažādiem datu rīkiem, tostarp mākslīgo intelektu. Cēsu novada pašvaldība ir saṇēmusi atbalstu no privātā sektora iniciatīvas "Valsts\#196", kas piedāvā platformu dialogam starp pašvaldībām un tehnolog̣isko risinājumu sniedzējiem. Viens no iniciatīvas līdzdibinātājiem ir Latvijas IT klasteris.

Latvijai būtu vairāk jāintegrē viedās pilsētas koncepcija valsts un reǵionālās attīstības stratēǵijās, lai izmantotu papildināmību un uzlabotu koordināciju ar citām politikas jomām, kuru mērḳis ir paaugstināt dzīves kvalitāti un investīciju iespējas visā valstī, tostarp mazajās pašvaldībās. Viedās pilsētas risinājumu nacionālā satvara esamība ir svarīga, jo tas var sniegt iespējas un palīdzēt vietējām pašvaldībām konstatēt savas galvenās vajadzības un iespējas. Kanādas valdība, citu starpā, aktīvi veicina viedās pilsētas risinājumus mazākās pašvaldībās, izmantojot viedo pilsētu konkursu (Smart Cities Challenge). Šīs sacensības, kas ir pieejamas visām pašvaldībām, reǵionālajām valdībām un pamatiedzīvotājiem, mudina dalībniekus pieṇemt inovatīvas tehnoloǵijas, lai uzlabotu savu iedzīvotāju dzīvi. Tiks atlasītas četras iniciatīvas, kuras saṇems federālo finansējumu. Nozīmīga prasība ir tā, ka projektiem jābūt pielāgojamiem mērogā un atkārtojamiem.

Arvien vairāk labu prakšu pasaulē varētu sniegt iedvesmu viedās pilsētas politikai Latvijā. Piemēram, Somijas Sešu pilsētu stratēgija (6Aika), kas uzsākta 2014. gadā, ietver atklātas inovāciju platformas izstrādi, kurā ieinteresētās personas sešās lielākajās pilsētās var dalīties ar viediem risinājumiem. Iesaistītās ieinteresētās personas var brīvi eksperimentēt ar inovatīviem risinājumiem visās sešās pilsētās. Francijāvalsts investīciju banka ir izveidojusi īpašu fondu (Ville de Demain), lai sniegtu finansiālu atbalstu jaunuzṇēmumiem, kas piedāvā viedās pilsētas risinājumus. Papildus finansiālam atbalstam Japāna piešķir regulatīvus atbrīvojumus pilsētām, kuras ir gatavas īstenot viedās pilsētas projektus. Šie un citi piemēri ir apspriesti dokumentos (ESAO, 2020i; 2019n), kuros analizēti viedās pilsētas iniciatīvu eksperimenti, pieṇemšana un izplatība visā pasaulē desmitgades laikā (6.12. ielikums).

Latvijai būtu plašāk un stratēgiskāk jāizmanto publiskais iepirkums, lai veicinātu inovācijas reǵionu un pašvaldību starpā. ${ }^{9}$ ESAO satvarā, lai veicinātu publiskā iepirkuma stratēǵisku izmantošanu inovācijām, ir apspriestas vairāki darbības virzieni, kas varētu Latvijai palīdzēt centienos stiprināt iepirkumus inovāciju jomā (ESAO, 2017d). Būtiski svarīga būs arī finansiālo un regulatīvo šḳēršḷ likvidēšana MVU dalībai publiskā iepirkuma pieteikumu iesniegšanā (sk. 4. nodaḷ). Daudzas valstis ir izstrādājušas integrētus iepirkuma plānus ar skaidri noteiktiem mērḳuzdevumiem inovatīviem projektiem pašvaldību līmenī. Piemēram, Zviedrijā dažas pašvaldības ir iekḷāvušas inovācijas mērḳuzdevumus iepirkuma procedūrās, savukārt VINNOVA — Zviedrijas inovāciju aǵentūra — sniedz atbalstu līgumslēdzējām iestādēm, kuras vēlas iegādāties inovāciju, piedāvājot tām finansēšanas iespējas (ESAO, 2017d). Latvijas Finanšu ministrija pašlaik analizē iespējas plašāk izmantot valsts un privātā sektora partnerības, kas ir veiksmīgi izmantotas citās valstīs, lai finansētu viedās pilsētas projektus (Deloitte, 2018).

Latvijai būtu arī jāveido "regulatīvās smilškastes", lai palīdzētu pārvarēt ar viedās pilsētas iniciatīvām saistītos regulatīvos sarežgijumus un nenoteiktību. Šajā ziṇā interesantu modeli piedāvā Lielbritānijas Gāzes un elektroenerǵijas tirgu birojs (Ofgem). Ofgem ir izveidojis vienotu kontaktpunktu enerǵētikas nozarē, sniedzot uzṇēmumiem operatīvas konsultācijas par enerǵētikas regulējumu. Ja regulatīvie šķēršḷi nel̦auj tirgū laist tādu produktu vai pakalpojumu, kas sniegtu ieguvumu patērētājiem, var izveidot "regulatīvo smilškasti", lai atḷautu izmēǵinājumu (Paunov un Planes-Satorra, 2019). 


\subsection{2. ielikums. Digitalizācijas pienesuma palielināšana nākotnes viedajās pilsētās}

Digitalizācija rada iespējas īpašām inovācijām pilsētvides dizainā, politikas veidošanā un infrastruktūrā. Pilsētas šo potenciālu jau izmanto, bieži vien ciešā sadarbībā ar privāto sektoru. Pašvaldības izmanto datus un digitālās tehnoloǵijas, lai palīdzētu risināt klimata pārmaiṇas, sekmētu iekḷaujošu izaugsmi vai uzlabotu administratīvos procesus, meklējot efektivitāti, samazinot birokrātiju vai iesaistot iedzīvotājus. Arī ar nozarēm saistītas tehnoloǵijas ir veicinājušas jaunas sociālās iniciatīvas, darbības klimata pārmaiṇu mazināšanai un apzaḷumošanas attīstību pilsētās.

Meklēšana, izmantojot Google Trends pakalpojumu, liecina, ka kopš 2013. gada pasaulē ir būtiski pieaugusi interese par viedām pilsētām, kā rezultātā īpašības vārds "viedas" kḷūst par vispopulārāko saistībā ar pilsētām, pārsniedzot tādus citus kā "ilgtspējīgas", "veselīgas”, "dzìvojamas", "zaḷas" un "noturīgas". Arī viedās pilsētas koncepcija pati par sevi attīstās un joprojām tiek apspriesta. Uzsverot būtiski svarīgo nozīmi iedzìvotāju labjutībā, ESAO ir definējusi viedās pilsētas kā “iniciatīvas vai pieejas, kas efektīvi izmanto digitalizāciju, lai uzlabotu iedzīvotāju labjutību un sniegtu efektīvākus, ilgtspējīgus un iekḷaujošus pilsētvides pakalpojumus un apstākḷus vairāku ieinteresēto personu sadarbības procesā" (OECD, 2020i). Šajā definīcijā, kā arī nesenajās ESAO diskusijās īpaši ir uzsvērta:

- vajadzība izstrādāt, īstenot un pārraudzīt viedu pilsētu politiku, lai nodrošinātu, ka strauja jaunu tehnoloǵiju izplatīšanās uzlabo visu cilvēku labjutību;

- veicinošā loma, ko valstu valdības varētu uzn,emties un kas tām būtu jāuzṇemas, lai atbalstītu inovatīvu risinājumu radīšanu, spēju veidošanu un plašāku izvēršanu;

- visaptveroša, daudznozaru un elastīga satvara, kas palīdz virzìt novērtēšanas programmu un ir saskaṇota ar vietējām un valsts stratēgiskajām prioritātēm, kā arī ietver efektivitātes, lietderīguma un ilgtspējas aspektus, būtiski svarīgā loma;

- vajadzība pēc holistiskas un gudras pārvaldības, kas reizēm liek mainīt regulējumu, nevis to vienkārši samazināt, izmanto publisko iepirkumu un pielieto uzṇēmumu un līgumu modeḷus, kas spēj strauji pielāgoties mainīgai pilsētvidei.

Iedzīvotāju galvenā loma ne tikai kā viedās pilsētas politikas adresātiem, bet arī kā tās dalībniekiem nozīmē politikas pārveidošanu visā politikas ciklā. Taču politikas veidotājiem joprojām bieži trūkst skaidras izpratnes par sarežgījumiem, riskiem un kompromisiem saistībā ar digitālo inovāciju pilsētās. Digitalizācija tiešām var vai nu uzlabot sabiedriskās politikas reakciju uz citām transformējošām megatendencēm, piemēram, globalizāciju, demogrāfijas pārmaiṇām un klimata pārmaiņām, vai arī pastiprināt to destabilizējošo ietekmi. Bez integrētas, daudznozaru un visu valdības iestāžu perspektīvas digitālās inovācijas var apvērst tiesisko un regulatīvo satvaru, kas nodrošina ar pieṇemamu cenu saistītos mērķus, patērētāju aizsardzību, nodokḷu piemērošanu, darba līgumus un godīgu konkurenci. Tās var arī apdraudēt iedzìvotāju datus, privātumu un drošību, tādējādi radot kompromisus starp datu atklāšanu un priekšstatu par viedas pilsētas pakalpojumu ietekmi.

Lai nodrošinātu, ka digitalizācija nepalielina sociālo nevienlīdzību un neveicina iedzivotāju plašāku neapmierinātību un vēršanos pret valsts iestādēm, publiskās un privātās darbības ir jānovērtē attiecībā uz to vērtību sabiedrībai un viedās pilsētas risinājumiem būtu jābūt labi savienotiem ar iekḷaujošas izaugsmes mērḳiem. Investīcijas cilvēkresursos, piemēram, ar mūžizglītību, un plašāki centieni nodrošināt, ka cilvēkiem ir prasmes, kas viṇiem nākotnē būs vajadzīgas darbā, tostarp digitālā pratība, ir jāīsteno visās pilsētās un reǵionos un būtu jāuzskata par ieguldījumu, nevis par izmaksām.

Avots: ESAO (2020i; 2019n).

\section{Sinerǵiju uzlabošana RIS3 jomās}

Kā minēts iepriekš, Latuijas Viedās specializācijas stratēǵijā viedā enerǵija un IKT tiek uzskatītas par nozarēm ar ievērojamu horizontālo ietekmi uz pārmaiṇām citās ražošanas nozarēs (IZM, 2015). Šajā sadaḷā aplūkotas IKT preces un pakalpojumi, tostarp saistītās ražošanas nozares, piemēram, plaša patēriṇa elektronika. 


\subsection{3. ielikums. Politikas ieteikumi: Viedā enerğija}

- Vērst uzmanību uz ekoinovāciju, paplašinot viedās enerǵijas specializācijas jomu, lai iekḷautu vides tehnologiijas (piem., atkritumu un ūdens resursu apsaimniekošanai).

- Pārdalīt viedās specializācijas līdzekḷus pētniecības komercializācijai un kompetenču centriem.

- Atjaunot inovāciju programmu zaḷās rūpniecības jomā, nodrošinot pietiekamu resursu līmeni.

- Integrēt viedās pilsētas koncepciju reǵionālās attīstības politikā, lai veicinātu ekoinovāciju un palielinātu dzìves kvalitāti un investīciju iespējas visos reǵionos.

- Veicināt viedās pilsētas risinājumus ar finansiālu atbalstu inovatīvām pašvaldībām, atklātām inovācijas platformām, gudru iepirkumu un "regulativvajām smilškastēm".

\section{IKT preces un pakalpojumi veido arvien lielāku dal̦u Latvijas eksportā, taču pētniecības potenciāls joprojām ir zems}

IKT pakalpojumu daḷa kopējā uzṇēmumu pakalpojumu eksportā laika posmā no 2010. līdz 2015. gadam ievērojami palielinājās, pieaugot no 3,6 \% līdz 6 \%. Lai gan IKT pakalpojumu eksporta intensitāte kaimiṇvalstī Igaunijā bija augstāka (8,3 \%), Latvija pārspēja gan Dāniju (5,3 \%), gan Norvēǵiju (5,7 \%) (6.23. attēls). Laikā no 2010. līdz 2015. gadam Latvija arī vēl vairāk uzlaboja redzamo salīdzinošo priekšrocību IT un citu informācijas pakalpojumu eksportā ar pievienoto vērtību (6.14. attēls). Taču pētniecības un izstrādes izdevumi kā daḷa no kopējās pievienotās vērtības $(0,5 \% 2015$. gadā) IKT pakalpojumiem joprojām bija ievērojami zemāka par ESAO vidējo rādītāju (4,8 \%).

6.23. attēls. IKT pakalpojumu ${ }^{1}$ eksports no Latvijas un atlasītajās ESAO valstīs, 2010.-2015. gads

Procentuāli no visa eksporta uznēmējdarbības sektorā²

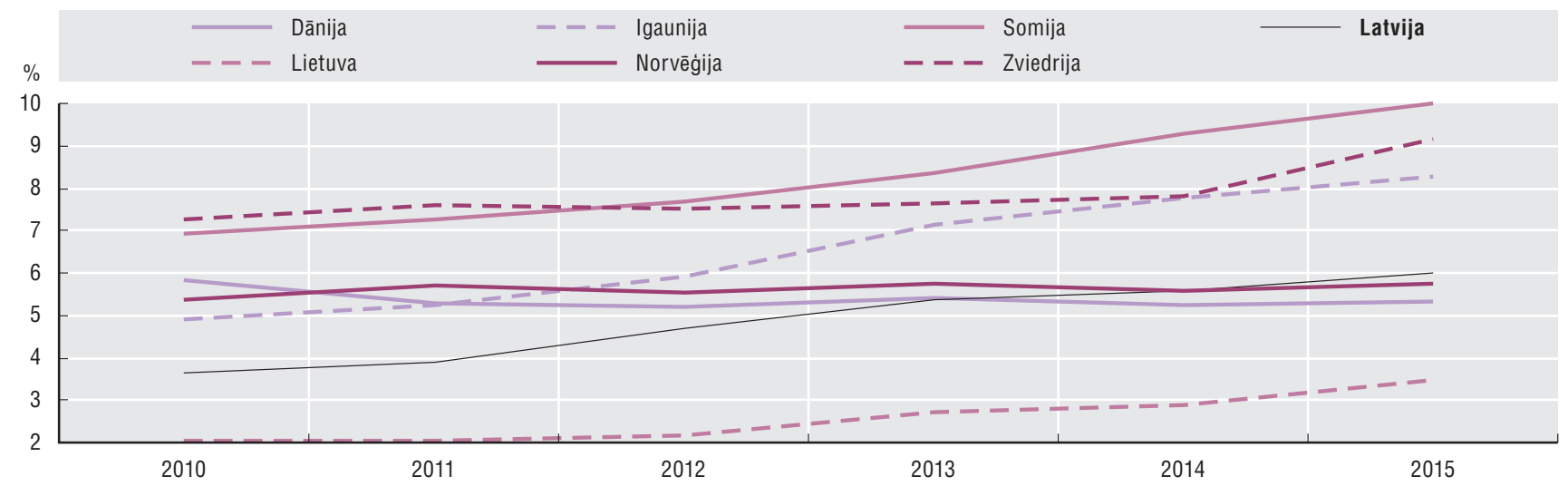

1. IKT pakalpojumi ir saistīti ar D62-D63 (ISIC, 4. red.), IT un citiem informācijas pakalpojumiem.

2. Uzṇēmējdarbības sektora pakalpojumi (D45-D82) neietver nekustamo īpašumu.

Avots: ESAO (2020f), "STAN Industry ISIC Rev. 4", https://dx.doi.org/10.1787/data-00649-en (piekḷuve 2020. gada 24. februārī).

Arī IKT un elektronikas preču nozare pēdējos gados ir strauji augusi. No 2010. līdz 2017. gadam datoru, elektronisko un optisko iekārtu daḷa ražošanas kopējā pievienotajā vērtībā vairāk nekā divkāršojās — no 2,2 \% līdz 4,9 \% (6.12. attēls). Līdzīgs pieaugums ir vērojams arī ražošanas eksporta jomā, kurā sektora daḷas kopējā vērtība no 2010. līdz 2018. gadam pieauga no 3 \% līdz 6,3 \% (6.17. attēls).

Liels eksporta pieaugums tika konstatēts tādās produktu kategorijās kā pārraides aparāti (radio, tālruṇi un TV), monitori un projektori, mikrofoni un iespiedshēmas. Minētie produkti kopā veidoja vairāk nekā trīs ceturtdaḷas no IKT preču kopējā eksporta 2018. gadā. ${ }^{10}$ Taču, neskatoties uz progresu kopš 2010. gada, Latvija 2015. gadā neieguva redzamu salīdzinošo priekšrocību šajā sektorā kopumā (6.13. attēls). Turklāt pētniecības un izstrādes izdevumi datoru, elektronisko un optisko iekārtu produktiem kā daḷa no pievienotās vērtības (2,5\%) arī bija ievērojami zemāki par ESAO vidējiem (23,7 \%) (6.15. attēls). 
Taču patentu pieteikumi liecina par augošu pētniecỉbas aktivitāti jomās, kas saistītas ar audiovizuālajām tehnoloǵijām un datortehnoloǵiju. Šādas patentu kategorijas 2012.-2016. gadā kopā veidoja 8,9 \% no visiem pieteikumiem, pieaugot no 1,9 \% 2007.-2011. gadā. Pieteikumu skaits saistītās jomās (piem., telesakari, sakaru pamatprocesi, pusvadītāji un digitālie sakari) samazinājās (no 5,4 \% līdz 2,4 \%). ${ }^{11}$

\subsection{4. attēls. Latvijas publikācijas tajos 10 \% dokumentu, kas visbiežāk citēti datorzinātnē, elektroniskajā inženierijā un saistītās jomās}

Vidēji 2014.-2018. gadā

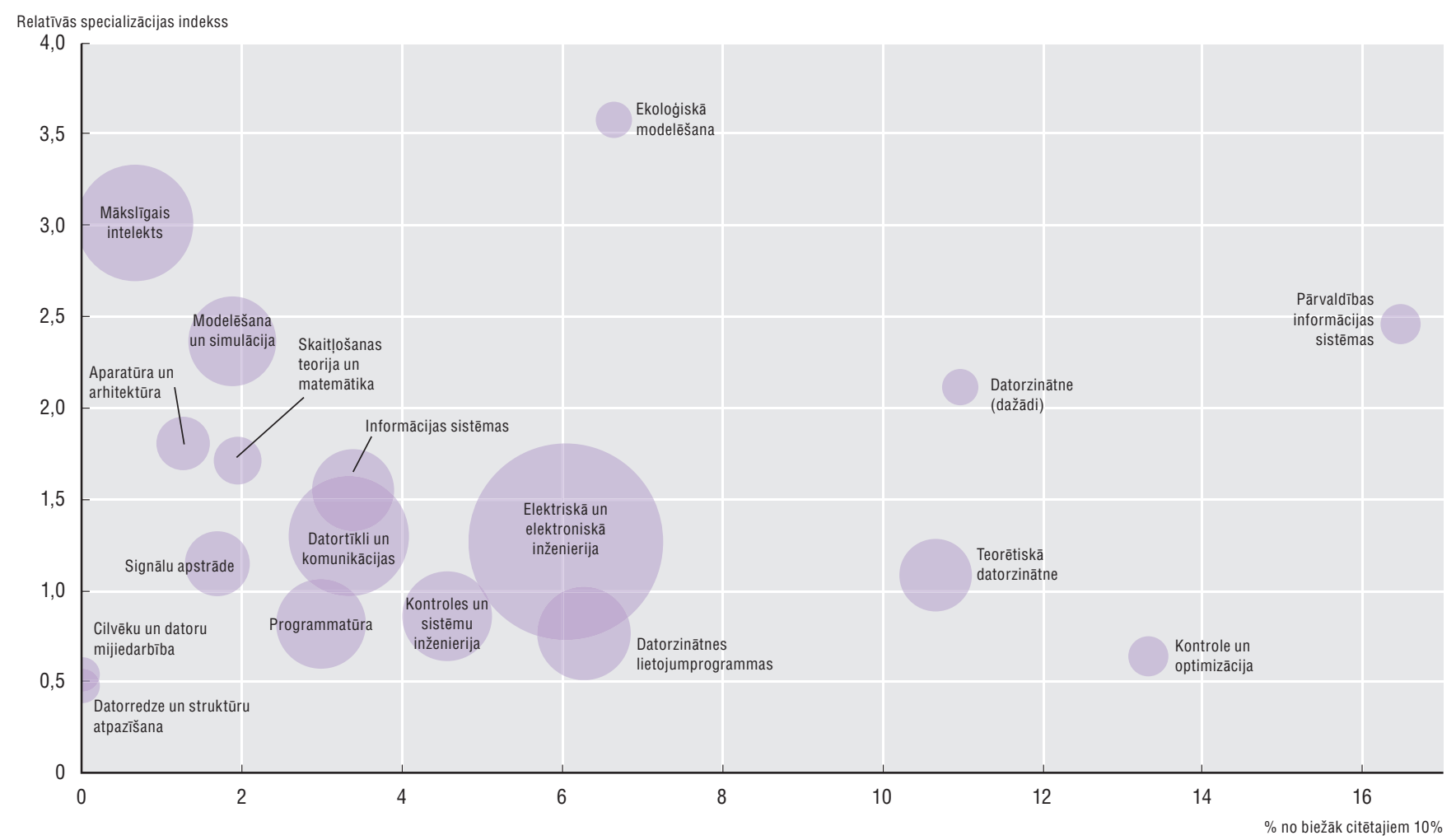

Piezīme: Jomas, kurās laika posmā no 2014. līdz 2018. gadam ir mazāk par piecām publikācijām, nav ieklautas. Publikāciju skaits (proporcionāli) ir diapazonā no 8,8 (cilvēku un datoru mijiedarbība) līdz 281 (elektriskā un elektroniskā inženierija). Vairāk informācijas sk. 6.18. attēlā.

Avots: ESAO aprēḳini, pamatojoties uz Scopus Custom Data, Elsevier, versija: 5.2019.

Biežāk citēto zinātnisko publikāciju daḷa lielākajā daḷā informātikas un elektroniskās inženierijas jomu joprojām bija zem 10 \%, kas ir vidējais rādītājs pasaules valstīs (6.24. attēls). Izṇēmums bija neliels skaits daudz citētu publikāciju teorētiskajā datorzinātnē (piem., kvantu skaitḷıšanā un pārvaldības informācijas sistēmās). Pastāv izteikta specializācija mākslīgā intelekta jomā, kurā no 2014. līdz 2018. gadam bija aptuveni 100 publikāciju. Taču atsauču ziṇā tikai 0,7 \% no tām bija starp tiem 10 \%, kas citētas visbiežāk. Kā minēts iepriekš, daudz publikāciju bija elektroniskās inženierijas jomā, taču tikai 6 \% bija starp tiem $10 \%$ dokumentu, kas citēti visbiežāk, tā nesasniedzot vidējo rādītāju pasaulē (10\% pēc definīcijas).

Šie konstatējumi liecina, ka pastāv iespējas vēl vairāk stiprināt pētniecības spēju un specializāciju — gan vispārīgās nozarēs, piemēram, tādās kā mākslīgais intelekts, gan nozarēs ar skaidru pielietojumu citās viedās specializācijas jomās, piemēram, veselības informātikā vai ekolog̣iskajā modelēšanā.

\section{Valdības atbalsts ir nepietiekami vērsts uz viedās specializācijas jomām}

IKT viedās specializācijas joma veidoja aptuveni 17,4 \% no finansējuma, ko sniedz saskaṇā ar Viedās specializācijas stratēéiju pieejamie instrumenti (6.2. tabula). Tā kā tiek uzskatīts, ka šajā jomā pastāv ievērojama starpnozaru ietekme kā, piemēram, viedās enerǵijas jomā, kas saṇēma 27,5 \% no kopējā finansējuma, piešḳirto resursu zemā daḷa ir pārsteidzoša. Programmas, kas sekmē pētniecības komercializāciju, un IKT kompetences centri veidoja salīdzinoši lielāku dalı no attiecīgajā jomā 
pieejamajiem līdzekḷiem, savukārt finansējums fundamentālajiem un lietišḳajiem pētījumiem, pēcdoktorantūras pētniecībai vai praktiskajai pētniecībai bija salīdzinoši zems. Tādējādi, lai gan IKT pētniecība agrīnajos posmos (TRL 1-3) 2014.-2018. gadā saṇēma tikai 12,5 miljonus EUR, finansējums viedajiem materiāliem sasniedza 29,1 miljonu EUR un biomedicīnai - 33,4 miljonus (6.2. tabula).

Finansējums arī tika sadrumstalots, aptverot daudzas nozares. Aptuveni 32 \% no kopējiem pieejamajiem IKT līdzekḷiem tika sadalīti starp IKT precēm, tostarp viedajiem sensoriem un lietu internetu (11,1\%), robotiku un datorredzi $(4,6 \%)$ un plašu elektronikas preču klāstu $(16,3 \%)$ no viedajiem ekrāniem, pusvadītājiem un mikroshēmām līdz viedajām automašīnām, 3D printeriem, audioiekārtām un precīzijas instrumentiem (6.4. tabula). Vairāk īpaši paredzēto lìdzekḷu tika veltīti datorlingvistikai un mašīntulkošanai (14,5 \%). Atlikusī daḷa tika sadalīta starp dažādām pētniecības jomām, tostarp, izglītības tehnolog̣ijām, kvantu pētniecību, kosmosa tehnologiijām, uzṇēmējdarbības procesu pārvaldību, lielajiem datiem un kiberdrošǐbu. Tà rezultātā konkrētas jomas, kas ir īpaši nozīmīgas viedās specializācijas vērtību k̦ēdēm, saṇēma ierobežotu finansējumu. Piemēram, medicīnas informātika un bioinformātika tika skatītas kopā ar citiem lielo datu lietojuma veidiem, kas visi kopā saṇēma tikai 8,6\% no pieejamajiem līdzekḷiem.

6.4. tabula. Atbalsts IKT neatbilst citu viedās specializācijas jomu vajadzībām Lìdzekl̦i viedajai specializācijai IKT jomā, 2014.-2018. g.

\begin{tabular}{|c|c|c|c|c|c|c|}
\hline \multirow{4}{*}{ Pētniecības jomas } & \multicolumn{3}{|c|}{$\begin{array}{l}\text { Izglītības un zinātnes ministrijas finansējuma } \\
\text { instrumenti }\end{array}$} & \multirow{2}{*}{$\begin{array}{c}\begin{array}{c}\text { ES Pētniecības } \\
\text { un inovācijas } \\
\text { programma }\end{array} \\
\text { "Apvārsnis } \\
\text { 2020" }\end{array}$} & \multicolumn{2}{|c|}{$\begin{array}{l}\text { Ekonomikas ministrijas finansējuma } \\
\text { instrumenti }\end{array}$} \\
\hline & $\begin{array}{l}\text { Valsts/valdības } \\
\text { finansējums }\end{array}$ & $\begin{array}{c}\text { ES fondi } \\
\text { (piem., ESI } \\
\text { fondi, ERAF) }\end{array}$ & $\begin{array}{c}\text { ES fondi } \\
\text { (piem., ESI } \\
\text { fondi, ERAF) }\end{array}$ & & $\begin{array}{c}\text { ES fondi } \\
\text { (piem., ESI fondi, } \\
\text { ERAF) }\end{array}$ & $\begin{array}{c}\text { ES fondi } \\
\text { (piem., ESI } \\
\text { fondi, ERAF) }\end{array}$ \\
\hline & $\begin{array}{c}\text { Fundamentālo } \\
\text { un lietiškso } \\
\text { pētijumu } \\
\text { programma }\end{array}$ & $\begin{array}{l}\text { Pēcdoktoran- } \\
\text { tūras } \\
\text { pētniecība } \\
\text { (1.1.1.2.) }\end{array}$ & $\begin{array}{l}\text { Praktiskā } \\
\text { pētniecība } \\
\text { (1.1.1.1.) }\end{array}$ & $\begin{array}{l}\text { "Apvārsnis } \\
\text { 2020" }\end{array}$ & $\begin{array}{l}\text { Pētniecības } \\
\text { rezultātu } \\
\text { komercializācija } \\
\text { (1.2.1.2.) }\end{array}$ & $\begin{array}{l}\text { Kompetenču } \\
\text { centri } \\
\text { (1.2.1.1.) }\end{array}$ \\
\hline & TRL 1-2 & TRL 1-2 & TRL 2-3 & TRL 4-8 & TRL 3-5 & TRL 4-6 \\
\hline Datorlingvistika & 495446 & 133806 & 1338661 & 1375750 & $x$ & 1419752 \\
\hline Algoritmi & 698910 & 802836 & 921276 & $\mathrm{x}$ & 23572 & 1134227 \\
\hline Mašīnmācīšanās & 699874 & 267612 & $x$ & 17339 & $x$ & 830155 \\
\hline Izglīīibas tehnoloǵijas un digitalizācija & 200000 & 401418 & 1837020 & $x$ & $x$ & $x$ \\
\hline Uznēmējdarbības procesu pārvaldības sistēmas & $\mathrm{x}$ & $\mathrm{x}$ & $\mathrm{x}$ & 533663 & $\mathrm{x}$ & 1647396 \\
\hline Elektronika & $x$ & $x$ & 517036 & 1064329 & $x$ & 3778490 \\
\hline Viedie sensori un lietu internets & 300000 & 1070448 & $x$ & 1553216 & 730743 & $x$ \\
\hline Robotika & 300000 & 267612 & $x$ & 550560 & 332936 & 62500 \\
\hline Lielie dati & $x$ & 401418 & $x$ & 1669115 & 681584 & $x$ \\
\hline Datu glabāšana, pārnešana un sistēmas & $x$ & 401418 & $x$ & 246561 & $x$ & 1835455 \\
\hline Kosmosa tehnoloǵijas un tālzondēšana & 799973 & 66903 & 624449 & 100000 & 326850 & $x$ \\
\hline Sabiedrības drošība un kiberdrošība & $x$ & $x$ & $x$ & 401085 & $x$ & 72946 \\
\hline Kopā & 3494203 & 3813470 & 5238442 & 7511618 & 2095685 & 10780921 \\
\hline
\end{tabular}

Piezīme: $\mathrm{x}=$ nav piemērojams. Datorlingvistika ietver pētniecỉbu mašīntulkošanas jomā. Algoritmi ietver kvantu pētniecību. Robotika ietver datorredzes pētniecību. Lielie dati ietver medicīnas informātikas /bioinformātikas pētniecỉbu. Elektronika ietver pētniecību vairākās jomās, tostarp viedos ekrānus, pusvadītājus, mikroshēmas, viedās automašīnas, 3D printerus, kā arī audio un precīzijas ierīces.

Avots: ESAO, pamatojoties uz IZM datiem.

Tādējādi pašreizējā finansēšanas struktūra nepietiekami atbalsta lietišḳās IKT pētniecības nozīmi kā būtiskam citu specializācijas jomu veicinātājam. Konkrēti, mērḳtiecīgāks finansējums varētu palīdzēt atbalstīt jaunas ekosistēmas citās viedās specializācijas jomās, tostarp specializēto pētniecību integrētajā skaitḷošanas materiālu inženierijā (ICME), vides modelēšanā, bioinformātikā vai veselības informātikā. Modulāru programmu sekmēšana (sk. 4. nodal̦u) un spēcīgāka inženieru un IKT speciālistu iesaistīšana lietišķo institūtu, piemēram, LU Genomikas un bioinformātikas laboratorijas vai RTU Materiālzinātnes un lietišķās k̦īmijas fakultātes, pētniecības projektos šajā ziṇā varētu palīdzēt. Turklāt būtu jāizmanto arī jaunradītā infrastruktūra, piemēram, Microsoft inovāciju centrs (LUMIC), lai sekmētu jaunas viedās 
specializācijas ekosistēmas. Šo pieeju atbalstītu arī starptautisku pētnieku uzaicināšana uz Latviju, tostarp konferencēm, piemēram, uz 15. Starptautisko lauksaimniecības informātikas un komunikāciju konferenci (Rīga, 2021).

\section{IT nozarē ir vajadzīgs plaša mēroga politikas atbalsts}

Atsevišķi izcilības klasteri Latvijas IKT nozarē ir piesaistījuši ievērojamu finansējumu no programmas "Apvārsnis 2020". Pašlaik 36 parakstītās dotācijas saṇem "Apvārsnis 2020" finansējumu gandrīz 7,9 miljonu EUR apmērā. IKT projekti Latvijā bija trešā nozīmīgākā "Apvārsnis 2020" finansējuma joma pēc pārtikas un enerǵētikas. Vairāki projekti ir radušies datorlingvistikas un mašīntulkošanas jomā. Tie ietver projektu SUMMA (Scalable Understanding of Multilingual Media), kas sanēma iemaksas 1,2 miljonu EUR apmērā, tā kḷūstot par lielāko “Apvārsnis 2020" projektu IKT jomā. Projekts tika īstenots no 2016. līdz 2019. gadam, un tajā piedalījās Latvijas nacionālā informācijas aǵentūra (LETA), kā arī pētniecības iestādes četrās citās Eiropas valstīs.

Kopā ar 12 citiem uzṇēmumiem un pētniecības iestādēm LETA arī bija viens no pirmajiem IT kompetences centra (ITKC) programmas, kuras viena no galvenajām darbības jomām ir valodu tehnoloǵijas, dibinātājiem 2010. gadā. Arī SIA “Tilde” — vēl viens ITKC līdzdibinātājs — bija iesaistīts vairākos "Apvārsnis 2020" mašīntulkošanas projektos. Divi nesenākie projekti, kas koordinēti Francijā un Vācijā, attiecīgi saṇēma 935000 EUR finansējumu līdz 2021. gadam. Tildes mašīntulkošanas tehnoloğija, kas specializējas Baltijas valstu valodās, ir pārspējusi tādu ievērojamu dalībnieku kā Google un Microsoft risinājumus lietuviešu, igauṇu un latviešu valodas tulkojumos (LSM, 2019). Tehnologija ir brīvi pieejama visās trijās Baltijas valstu valodās, kā arī arābu, angḷu, somu, poḷu un krievu valodā.

Arī citi veiksmīgi dziḷo tehnoloǵiju uzṇēmumi ir guvuši labumu no Kompetences centru programmas. Piemēram, uzṇēmums Squalio kā daḷa no ITKC izstrādāja dziḷo tehnoloǵiju risinājumu transportlīdzekḷu reǵistrācijas numura atpazī̌anai, un to izmantoja fotoradaros izmēǵinājuma projektā ar Latvijas Ceḷu satiksmes drošības direkciju (CSDD). Saskaṇā ar CSDD risinājums jau ir samazinājis autoavāriju skaitu un ir labs piemērs tam, kā gudru iepirkumu var izmantot tehnoloǵisko inovāciju veicināšanai. Vēl viens piemērs — Tilde 2017. gadā saṇēma tiesības slēgt līgumu ar Eiropas Komisijas G3 direktorātu par rīku un resursu nodrošināšanu automatizētai tulkošanai un valodu apstrādes pakalpojumiem.

Latvijas dziḷās tehnoloǵijas nākotnē, visticamāk, attīstīsies vēl vairāk, tādiem uzṇēmumiem kā Tilde vai Sualio radot informētību par konkrētām tehnoloǵiju nišām. Turklāt Latvijas IT klasteris nesen piesaistīja papildu līdzekḷus no "Apvārsnis 2020" programmai, kas l̦autu palìdzēt dziḷo tehnoloǵiju jaunuzṇēmumiem uzlabot produktus un pārdot efektīvāk (STARTUP3). Taču, lai gan "Apvārsnis 2020" vai kompetenču centri var palīdzēt attīstīt ìpašas tehnoloǵiju nišas, tie ir jāpapildina ar visaptverošākiem politikas pasākumiem inovāciju atbalstam.

Valstis ir ieviesušas vairākus pasākumus, lai atbalstītu IKT nozaru izaugsmi, tostarp aizdevumus, eksporta vai inovāciju subsīdijas, apmācības un īpašus inkubatorus un akceleratorus IKT jomā (ESAO, 2019o). Arī pasākumiem digitālo tehnoloǵiju ieviešanas veicināšanai (sk. 4. nodaḷu) ir svarīga nozìme pieprasījuma radīšanā pēc vietējiem risinājumiem. Latvijai būtu jāapsver stratēǵijas, kā atvieglot pieprasījumu pēc prasmēm un uzlabot produktivitāti nozarē. Papildus izglītības sistēmas pielāgošanai šādas stratēǵijas varētu ietvert pasākumus IKT speciālistu piesaistī̌̌anai no ārvalstīm. Beḷgijā īpašs nodokḷu režīms ārvalstu amatpersonām un speciālistiem kopš 1983. gada ir sniedzis pagaidu ieguvumus ārvalstniekiem ar īpašām prasmēm. Vācijā valdība ar vadošajiem uzṇēmumiem nesen vienojās par plānu, lai atvieglotu ārvalstu darbinieku iekḷūšanu valstī. No tā izrietošajā saprašanās memorandā paredzēts atbalsts Vācijas birokrātijā, palīdzība mājokḷa meklējumos un ātrāks vīzu piešḳiršanas process.

Regulatīvo pielāgojumu izstrāde un īstenošana būs ārkārtīgi svarīga konkrētās nozarēs. Piemēram, IKT uzṇēmumi, kas izstrādā finanšu tehnolog̣iju risinājumus, visticamāk, gūs ievērojamus ieguvumus no "regulatīvās smilškastes" vides radīšanas vai no jauna regulējuma straujas un konsekventas īstenošanas. Piemēram, Latvijas Alternatīvo finanšu pakalpojumu asociācija, kas pārstāv vairākus Latvijas finanšu tehnologiju uzṇēmumus, ir apvienojusi spēkus ar asociācijām Dānijā, Polijā un Spānijā, lai paustu bažas par arvien lielākajām grūtībām saistībā ar nelieliem aizdevumiem pāri robežām. Koalīcija, kas pārstāv aptuveni 100 digitālo aizdevēju, apgalvo, ka esošo ES noteikumu, piemēram, Patēriṇa kredītu direktīvas, ìstenošana dažādās dalībvalstīs ievērojami atšḳiras un neḷauj tirgū ienākt ārvalstu konkurentiem. Uz to reaǵējot, Eiropas Komisija pašlaik izvērtē vajadzību pārskatīt Patēriṇa kredītu direktīvu. Šajā un 
citos līdzīgos gadījumos Latvijas valdībai vajadzētu sekmēt notiekošo dialogu ar nozares pārstāvjiem un - ES regulējuma gadijjumā - ar citām valstīm, lai noteiktu, kā regulējumu var īstenot, neradot nevajadzīgas grūtības.

\subsection{4. ielikums. Politikas ieteikumi: IKT}

- Pārdalīt viedās specializācijas finansējumu IKT specializācijas jomai, lai labāk ṇemtu vērā pozitīvo papildu ietekmi, ko IKT rada ekonomikā, tostarp citās viedās specializācijas jomās.

- Koncentrēt finansējumu atlasītās izcilības nišās (piem., mašīntulkošanā, audio tehnolog̣ijās), kā arī pētniecības jomās, kas papildina citas viedās specializācijas jomas (piem., veselības informātikā).

- Papildināt īpašos instrumentus ar plašāku atbalstu IKT inovācijai un pien̦emšanai un apsvērt īpašu nodokḷu režīmu ieviešanu vai pārcelšanās atbalstu, lai piesaistītu ārvalstu IKT speciālistus.

- Sekmēt dialogu ar nozares pārstāvjiem, lai nodrošinātu, ka jauns regulējums tiek ìstenots, neradot nevajadzīgas grūtības. 


\section{Atsauces}

ALTUM (2019), "The first 18 startups financed by the ALTUM accelerator programs graduate most promising teams will qualify for 250 thousand euro investment”, www.altum.lv/en/news/veiksmigi-nosledzies-pirmais-posms-altum-akceleratoru-programmadaudzsolosakie-jaunuznemumi-pretende-uz-250-tukstosu-eiro-ieguldijumu (piekḷuve 2020. gada martā).

Appelt, S. un citi (2016), "R\&D tax incentives: Evidence on design, incidence and impacts", OECD Science, Technology and Industry Policy Papers, No. 32, OECD Publishing, Parīze, https://dx.doi.org/10.1787/5jlr8fldqk7j-en.

Beckerman-Rodau, A. (2011), "The problem with intellectual property rights: Subject matter expansion", Yale Journal of Law and Technology, 13/1 sēj., 36.-89. lpp.

CFLA (2020), "History", Centrālā finanšu un līgumu aǵentūra, Rīga, www.cfla.gov.lv/en/about-us/history (informācija skatīta 2020. gada 20. Maijā).

CFLA (2019), "General information" Centrālā finanšu un līgumu aǵentūra, Rīga, www.cfla.gou.lv/en/eu-funds-2014-2020/generalinformation (piekḷve 2020. gada 20. maijā).

CSP (2020a), IKG10_060 Total Gross Value Added by Kind of Activity (NACE 2. red) (datubāze), Latvijas Centrālā statistikas pārvalde, Riga, https://data1.csb.gov.lv/pxweb/en/ekfin/ekfin_ikp_IKP_ikgad.

CSP (2020b), Exports and Imports by Commodity Section and by Economic Activity (NACE Rev.2) of the Importer (thsd euro) - ATG015 (datubāze), Latvijas Centrālā statistikas pārvalde, RīgaRīga, www.csb.gov.lv/en/statistics/statistics-by-theme/foreign-trade/ft-nace-bec/ tables/atg015/exports-and-imports-commodity-section-and.

Deloitte (2018), Using Public-Private Partnerships to Advance Smart Cities. 2. dala: Funding and Financing Smart Cities Series, Deloitte Center for Government Insights, Nujorka, NY, www2.deloitte.com/content/dam/Deloitte/global/Documents/Public-Sector/gx-ps-public-privatepartnerships-smart-cities-funding-finance.pdf.

Eichler, H-G. un citi (2019), "Data rich, information poor: Can we use electronic health records to create a learning healthcare system for pharmaceuticals?” Clinical Pharmacology and Therapeutics, 105/4 sēj., 912.-922. lpp., doi:10.1002/cpt.1226.

Eiropas Komisija (2020), 2020.gada zinojums par Latviju, Komisijas dienestu darba dokuments, Brisele, https://eur-lex.europa.eu/ legal-content/EN/TXT/?qid=1584543810241\&uri=CELEX\%3A52020SC0513.

Eiropas Komisija (2018a), The Latvian Research Funding System, Brisele, https://op.europa.eu/en/publication-detail/-/publication/ f631a55b-bbba-11e8-99ee-01aa75ed71a1.

Eiropas Komisija (2018b), "Digital Innovation Hubs - Smart Specialisation Platforms", Brisele, https://s3platform.jrc.ec.europa.eu/ digital-innovation-hubs-tool/-/dih/13295/view (piekḷve 2020. gada februārī).

Eiropas Komisija (2018c), "Latvia - S3 Priorities as Encoded in the "Eye@RIS3” Tool”, Pārdomātas specializācijas platforma, Versija:1.0.47, Brisele, https://s3platform.jrc.ec.europa.eu/regions/LV/tags/LV (piekḷuve 2019. gada 30. septembrī).

Eiropas Komisija (2017), Latvian Research Funding System Background Report: Horizon 2020 Policy Support Facility, European Commission, Brisele, http://dx.doi.org/10.2777/4162.

Eiropas Komisija (2013), The Role of Clusters in Smart Specialisation Strategies, Eiropas Komisija, Pētniecības un inovācijas ǵenerāldirektorāts, Brisele, https://ec.europa.eu/research/evaluations/pdf/archive/other_reports_studies_and_documents/clusters_smart_ spec2013.pdf.

Eiropas Komisija (2012a), Latvia: National Industrial Policy Guidelines for 2014-2020. Digital Transformation Monitor, Eiropas Komisija, Brisele, https://ec.europa.eu/growth/tools-databases/dem/monitor/sites/default/files/DTM_Latvia_vf.pdf.

Eiropas Komisija (2012b), Guide to Research and Innovation Strategies for Smart Specialisation (RIS 3), Reǵionālā politika, Eiropas Komisija, Brisele, http://s3platform.jrc.ec.europa.eu/documents/20182/84453/RIS3+Guide.pdf/fceb8c58-73a9-4863-8107- 752aef77e7b4.

Eiropas Komisija/ESAO (2020), STIP Compass: International Database on Science, Technology and Innovation Policy (STIP), Eiropas Komisija, Brisele/ESAO, Parize, https://stip.oecd.org.

EM (2018a), “Clusters”, Ekonomikas ministrija, Rīga, www.em.gov.lv/en/sectoral_policy/industrial_policy/clusters.

EM (2018b), Economic Development of Latvia, Ekonomikas ministrija, Rīga, www.em.gov.lv/files/tautsaimniecibas_attistiba/leap/ leap_2018-en.pdf.

EM (2018c), "Assessment of Latvian Start-Up Ecosystem, Description of the Current Situation and Recommendations for Further Improvements", Ekonomikas ministrija, Rīga.

ESAO (sagatavošanā), Regulatory Aspects of Data Governance for the Digital Transformation of Agriculture, OECD Publishing, Parīze.

ESAO (2020a), FDI Stocks (rādītājs), OECD Publishing, Parīze, https://dx.doi.org/10.1787/80eca1f9-en (piekḷuve 2020. gada 28. februārī). 
ESAO (2020b), Main Science and Technology Indicators (datubāze), OECD, Parīze, www.oecd.org/sti/msti.htm (piekḷuve 2020. gada 28. februārī).

ESAO (2020c), The Digitalisation of Science, Technology and Innovation: Key Developments and Policies, OECD Publishing, Paris, https://dx.doi.org/10.1787/b9e4a2c0-en.

ESAO (2020d), "Trade in value added", OECD Statistics on Trade in Value Added (datubāze), ESAO, Parīze, https://dx.doi.org/10.1787/ data-00648-en (piekḷuve 2020. gada 27. februārī).

ESAO (2020e), "Research and development statistics: Business enterprise R-D expenditure by industry - ISIC Rev. 4", OECD Science, Technology and R\&D Statistics (datubāze), OECD, Parīze, https://dx.doi.org/10.1787/data-00668-en (piekḷve 2020. gada 13. martā).

ESAO (2020f), “STAN Industry ISIC Rev. 4”, STAN: OECD Structural Analysis Statistics (datubāze), https://dx.doi.org/10.1787/data-00649-en (piekḷve 2020. gada 24. februārī).

ESAO (2020g), "Research and development statistics: Gross domestic expenditure on R-D by sector of performance and source of funds", OECD Science, Technology and R\&D Statistics (datubāze), ESAO, Parīze, https://dx.doi.org/10.1787/data-00189-en (piekḷuve 2020. gada 26. februārī).

ESAO (2020h), "Patents by main technology and by International Patent Classification (IPC)", OECD Patent Statistics (datubāze), OECD, Parīze, https://dx.doi.org/10.1787/data-00508-en (piekl̦uve 2020. gada 17. martā).

ESAO (2020i), Smart Cities and Inclusive Growth, OECD, Parīze, www.oecd.org/cfe/cities/OECD_Policy_Paper_Smart_Cities_and_Inclusive_ Growth.pdf.

ESAO (2019a), OECD Economic Surveys: Latvia 2019, OECD Publishing, Parīze, https://dx.doi.org/10.1787/f8c2f493-en.

ESAO (2019b), Business Innovation Statistics and Indicators (datubāze), OECD, Parīze, http://oe.cd/inno-stats.

ESAO (2019c), Education at a Glance 2019: OECD Indicators, OECD Publishing, Parīze, https://dx.doi.org/10.1787/f8d7880d-en.

ESAO (2019d), Digital Innovation: Seizing Policy Opportunities, OECD Publishing, Parīze, https://dx.doi.org/10.1787/a298dc87-en.

ESAO (2019e), OECD Reviews of Digital Transformation: Going Digital in Colombia, OECD Publishing, Parīze, https://dx.doi.org/ 10.1787/781185b1-en.

ESAO (2019f), R\&D Tax Incentives (datubāze),), OECD, Parīze, www.oecd.org/sti/rd-tax-stats.htm.

ESAO (2019g), Innovation, Agricultural Productivity and Sustainability in Latvia, OECD Food and Agricultural Reviews, OECD Publishing, Parīze, https://dx.doi.org/10.1787/9789264312524-en.

ESAO (2019h), OECD SME and Entrepreneurship Outlook 2019, OECD Publishing, Parīze, https://dx.doi.org/10.1787/34907e9c-en.

ESAO (2019i), “Country Snapshots: Latvia”, in Financing SMEs and Entrepreneurs 2019: An OECD Scoreboard, OECD Publishing, Rīga, https://doi.org/10.1787/fin_sme_ent-2019-en.

ESAO (2019j), Regions in Industrial Transition: Policies for People and Places, OECD Publishing, Parīze, https://dx.doi.org/10.1787/c76ec2a1-en.

ESAO (2019k), Benchmarking Higher Education System Performance, Higher Education, OECD Publishing, Parīze, https://dx.doi.org/10.1787/ be5514d7-en.

ESAO (2019l), Latvia: Country Health Profile 2019, State of Health in the EU, OECD Publishing, Parīze/Eiropas veselības sistēmu un politikas novērošanas centrs, Brisele, https://dx.doi.org/10.1787/b9e65517-en.

ESAO (2019m), OECD Environmental Performance Reviews: Latvia 2019, OECD Environmental Performance Reviews, OECD Publishing, Parize, https://dx.doi.org/10.1787/2cb03cdd-en.

ESAO (2019n), Enhancing the Contribution of Digitalisation to the Smart Cities of the Future, OECD Publishing, Parize, www.oecd.org/cfe/ regional-policy/Smart-Cities-FINAL.pdf.

ESAO (2019o), "ICT investments in OECD countries and partner economies: Trends, policies and evaluation", OECD Digital Economy Papers, No. 280, OECD Publishing, Parīze, https://doi.org/10.1787/bcb82cff-en.

ESAO (2019p), "Harnessing data to manage biomedical technologies", krājumā Health in the 21st Century: Putting Data to Work for Stronger Health Systems, OECD Publishing, Parīze, https://dx.doi.org/10.1787/1df03c3b-en.

ESAO (2019q), "Innovation support in the enterprise sector", OECD Science, Technology and Industry Policy Papers, OECD Publishing, Parīze, https://doi.org/10.1787/4ffb2cbc-en.

ESAO (2019r), Digital Opportunities for Better Agricultural Policies, OECD Publishing, Parīze, https://doi.org/10.1787/571a0812-en.

ESAO (2018a), "R\&D tax incentives: Latvia, 2017”, OECD, Parīze, www.oecd.org/sti/rd-tax-stats-latvia.pdf.

ESAO (2018b), "Effective operation of competitive research funding systems", OECD Science, Technology and Industry Policy Papers, Nr. 57, OECD Publishing, Parīze, https://dx.doi.org/10.1787/2ae8c0dc-en.

ESAO (2018c), OECD Reviews of Digital Transformation: Going Digital in Sweden, OECD Publishing, Parīze, https://dx.doi. org/10.1787/9789264302259-en.

ESAO (2017a), OECD Economic Surveys: Latvia 2017, OECD Publishing, Parīze, https://dx.doi.org/10.1787/eco_surveys-lva-2017-en. 
ESAO (2017b), OECD Territorial Reviews: Northern Sparsely Populated Areas, OECD Territorial Reviews, OECD Publishing, Parīze, https://dx.doi.org/10.1787/9789264268234-en.

ESAO (2017c), The Next Production Revolution: Implications for Governments and Business, OECD Publishing, Parīze, https://dx.doi. org/10.1787/9789264271036-en.

ESAO (2017d), Public Procurement for Innovation: Good Practices and Strategies, OECD Public Governance Reviews, OECD Publishing, Parīze, https://dx.doi.org/10.1787/9789264265820-en.

ESAO (2016), Education in Latvia, Reviews of National Policies for Education, OECD Publishing, Parīze, https://dx.doi.org/10.1787/ 9789264250628-en.

ESAO (2011), "Nordic countries: Matching exceptional design and creativity with progressive policy", in Intellectual Assets and Innovation: The SME Dimension, OECD Publishing, Parīze, https://dx.doi.org/10.1787/9789264118263-6-en.

EsFondi.lv (2020a), "Informācijas sistēmu modelēšanas principu piemērošana strukturētai un mērk̦tiecīgai kompetenču pārvaldībai" [Application of information systems modeling principles to structured and purposeful competence management], www.esfondi. lu/es-fondu-projektu-mekletajs/project?number=1.1.1.1\%2F16\%2FA\%2F252 (piekḷuve 2020. gada martā).

EsFondi.lv (2020b), "Neironu tīkli fleksīvo dabisko valodu apstrādei" [Neural networks for processing flexible natural languages], www.esfondi.lv/es-fondu-projektu-mekletajs/project?number=1.1.1.1\%2F16\%2FA\%2F215 (piekluve 2020. gada martā).

EsFondi.lv (2020c), "Informācijas un komunikācijas tehnoloǵiju kompetences centrs" [Information and Communication Technology Competence Centre], www.esfondi.lv/es-fondu-projektu-mekletajs/project?number=1.2.1.1/18/A/003 (piekḷuve 2020. gada maijā).

EsFondi.lv (2020d), “Tehnologiju pārneses programma” [Technology transfer programme], www.esfondi.lv/es-fondu-projektu-mekletajs/ project?number=1.2.1.2\%2F16\%2FI\%2F001 (piekḷuve 2020. gada maijā).

EsFondi.lv (2020e), "RTU inovāciju granti studentiem” [RTU innovation grants for students], http://www.esfondi.lv/es-fondu-projektumekletajs/ project?number=1.1.1.3/18/A/001 (piekḷve 2020. gada maijā).

Eurostat (2020a), ICT Usage in Enterprises -E-business (isoc_eb) (datubāze), https://ec.europa.eu/eurostat/web/digital-economy-and-society/ data/database.

Eurostat (2020b), "Renewable Energy Statistics", Eurostat Statistics Explained, https://ec.europa.eu/eurostat/statistics-explained/index. php?title=Renewable_energy_statistics\#Share_of_renewable_energy_almost_doubled_between_2004_and_2018 (piekluve 2020.gada10. jūnijā).

Eurostat (2020c), Patent Applications to the EPO by Priority Year (database), https://appsso.eurostat.ec.europa.eu/nui/show.do?dataset=pat_ ep_ntot\&lang=en (piekḷuis 2020. gada 6. maijā).

Eurostat (2019), Education Administrative Data from 2013 Onwards (datubāze), https://ec.europa.eu/eurostat/cache/metadata/en/educ_ uoe_enr_esms.htm.

Eurostat (2016), Community Innovation Survey (CIS-2016) (datubāze), https://ec.europa.eu/eurostat/web/microdata/community-innovationsurvey.

FAO (2020), Forestry Production and Trade (datubāze), www.fao.org/faostat/en/\#data/FO/visualize (piekḷuvis 2020. gada 20. maijā).

FFG (2015), Service Innovations - Funding Guidelines, Austrijas Pētniecības veicināšanas aǵentūra, Vīne, www.ffg.at/en/programme/ service-innovations (piekḷve 2020. gada martā).

FM (2020), Vadlīnijas par finanšu korekciju piemērošanu, ziṇošanu par Eiropas Savienī bas fondu ieviešanā konstatētajām neatbilstī bām, neatbilstoši veikto izdevumu atgūšanu 2014.-2020.gada plānošanas period [Guidelines on the application of financial corrections, reporting on discrepancies identified in the implementation of European Union funds, recovery of irregularly incurred expenditure in the 2014-2020 programming period], Finanšu ministrija, Rìga, www.esfondi.lv/upload/Vadlinijas/vadlinijas_10022020. zip., Ministry of Finance, Rìga, www.esfondi.lv/upload/Vadlinijas/vadlinijas_10022020.zip.

Galindo-Rueda, F. un F. Verger (2016), “OECD taxonomy of economic activities based on R\&D intensity”, OECD Science, Technology and Industry Working Papers, Nr. 2016/4, OECD Publishing, Parīze, https://dx.doi.org/10.1787/5jlv73sq9p8r-en.

Grinfelds, T. (2018), "Industry trends and challenges in Latvia”, presentation for Digital Transformation of the Engineering Industries in the Baltic Sea region - Conference in the framework of "Tech Industry 2018", https://veca.likta.lv/EN/Documents/ TomsGrinfelds-MASOC.pdf (piekḷuve 2019. gada 3. oktobrī).

IEA (2019a), World Energy Balances (datubāze), Starptautiskā Enerǵētikas aǵentūra, Parīze, www.iea.org/statistics/?country=LVA\&isISO=true.

IEA (2019b), World Energy Prices, Starptautiskā Enerǵētikas aǵentūra, Parīze, http://data.iea.org/payment/products/121-world-energyprices- 2019-edition.aspx.

IEA (2017), Digitalisation and Energy, Starptautiskā Enerǵētikas aǵentūra, Parīze, www.iea.org/reports/digitalisation-and-energy.

IZM (2020a), "Latvijā tiek veidota vienota un spēcīga zinātnes politikas ieviešanas iestāde" [A unified and strong science policy implementation institution is being established in Latvia], Izglītības un zinātnes ministrija, Rīga, www.izm.gou.lu/lv/ aktualitates/4002-latvija-tiek-veidota-vienota-un-speciga-zinatnes-politikas-ieviesanas-iestade (skatīts 2020. gada 14. maijā).

IZM (2020b), RIS3 Info on Investments in RIS3 by Instrument (2014-2018), Izglītības un zinātnes ministrija, Rīga. 
IZM (2018), Informative Report: Monitoring of Smart Specialization Strategy, Izglīiibas un zinātnes ministrija, Rīga, https://s3platform.jrc. ec.europa.eu/documents/20182/0/RIS3_progress+report_LV_2018.pdf/940176c6-b886-4213-9f18-75c20251bfb9.

IZM (2015), Analytical Description of the Ecosystem of Smart Specialization Area "Smart Energetics”, Izglītibas un zinātnes ministrija, Rìga, https://cfla.gov.lv/userfiles/files/1111_Ecosystem\%20-\%20Smart\%20energetics.docx.

IZM (2013a), About the development of Smart Specialisation Strategy, Izglītības un zinātnes ministrija, Rīga, www.izm.gov.lv/images/ zinatne/RIS3_ENG/The_Informative_Report_Development_of_RIS3.pdf.

IZM (2013b), Assessment of Export Potential of Economic Sectors, 2. papildinājums informatīvajam zinojumam "On the Development of Smart Growth Strategy and Determination of Specialisation”, Izglìtības un zinātnes ministrija, Rīga, www.riseba.lv/sites/ default/files/inline-files/Appendix_2_Assessment_of_Export_Potential_of_Economic_Sectors.pdf.

Latvijas Republikas Patentu valde (2019), “Intellectual Property Information Centre”, Rīga, http://www.lrpv.gov.lv/en/patent-andtechnology-library/patent-and-technology-library (piekluve 2019. gada oktobrī).

Latvijas valdība (2013), Guidelines for Science, Technology Development, and Innovation 2014-2020, Rīga, https://s3platform.jrc.ec.europa.eu/ documents/20182/227021/Guidelines+for+Science+Technology+and+Innovation+2014-2020.pdf/d96566cd-e61b-471b-9f80-4d06236037b4 .

Lauma Muizniece, A. (2017), "Supporting university technology transfer-struggles and barriers in Latvia”, Ekonomska misao i praksa, 26/1. sēj., 321.-342. lpp.

LIAA (2019a), "Inovāciju motivācijas programma” [Innovation motivation programme], Latvijas Investīciju un attīstības aǵentūra, Rìga, www.liaa.gov.lv/lv/fondi/2014-2020/inovaciju-motivacijas-programma.

LIAA (2019b), "Innovation Voucher Program: Financial boost for empowering innovation”, Latvijas Investīciju un attīstības aǵentūra, Rìga, https://startuplatvia.eu/innovation-voucher.

LIAA (2019c), “Inovāciju vaučeru atbalsta pakalpojumi” [Innovation voucher support services], Latvijas Investīciju un attīstības aǵentūra, Rīga, www.liaa.gov.lv/lv/fondi/2014-2020/inovaciju-vauceru-atbalsta-pakalpojumi.

LIAA (2019d), "Start-up ecosystem”, Latvijas Investīciju un attīstỉbas aǵentūra, Rīga, www.liaa.gov.lv/en/invest-latvia/ start-up-ecosystem (skatīts 2019. gada oktobrī).

LIAA (2019e), "Incentives for R\&D”, Latvijas Investīciju un attīstības aǵentūra, Rīga, www.liaa.gov.lv/en/invest-latvia/investor-businessguide/incentives-investors/incentives-rd (skatīts 2019. gada oktobrī)

LIAA (2019f), "Magnetic Latvia business incubators", Latvijas Investīciju un attīstības aǵentūra, Rīga, https://startuplatvia.eu/ magnetic-latvia-business-incubators (skatīts 2019. gada oktobrī).

LIAA (2019g), "Startup visa application process”, Latvijas Investīciju un attīstības aǵentūra, Rīga, https://startuplatvia.eu/files/resources/ editor/LV\%20Startup\%20Visa\%20Application\%20Process\%202019.10.09.pdf.

LIAA (2019h), "Life sciences”, Latvijas Investīciju un attīstỉbas aǵentūra, RīgaRīga, www.liaa.gov.lv/en/invest-latvia/sectors-and-industries/ life-sciences (skatīts 2019. gada 5. decembrī).

LSM (2019), "Latvia's Tilde beats Internet giants in machine translation battle", LSM.lv, https://eng.lsm.lv/article/society/education/ latvias-tilde-beats-internet-giants-in-machine-translation-battle.a327904 (skatīts 2019. gada 18. oktobrī).

Magnetic Latvia (2019), "Startup law benefits”, https://startuplatvia.eu/startup-law-benefits.

MGI (2019), "BGI Group and European Partners launch project to sequence and analyze 10 million cells", MGI News Center, https:// en.mgitech.cn/news/108 (skatīts 2020. gada 17. februārī).

MoH (2019), "Veselības ministre uz laiku apturējusi e-veselības trešās kārtas uzsākšanu”, [Minister of Health Temporarily Suspended the Launch of the Third Round of e-Health], Ministry of Health, Rīga, www.um.gov.lv/lv/aktualitates/preses_relizes/5946_veselibas_ ministre_uz_laiku_apturejusi_eveselibas_tresas_kar (piekḷuve 2019. gada 14. oktobrī).

Miroudot, S. and C. Cadestin (2017), "Services in global value chains: Trade patterns and gains from specialisation", OECD Trade Policy Papers, No. 208, OECD Publishing, Parīze, https://dx.doi.org/10.1787/06420077-en.

Nye Forretningsmodeller (2019), “One Stop Shop for new business models”, Kopenhāgena, https://nyeforretningsmodeller.dk/english (piekḷuve 2020. gada februārī).

Oderkirk, J. (2017), "Readiness of electronic health record systems to contribute to national health information and research", OECD Health Working Papers, No. 99, OECD Publishing, Parize, https://dx.doi.org/10.1787/9e296bf3-en.

Ozols, G. (2018), “Cooperation on data driven nation development in Latvia”, Joinup, Brisele, https://joinup.ec.europa.eu/collection/ egovernment/document/cooperation-data-driven-nation-development-latvia (informācija skatīta 2019. gada 22. augustā).

Pārresoru koordinācijas centrs (2019), National Development Plan of Latvia for 2021-2027, pirmās versijas kopsavilkums, Rīga.

Pārresoru koordinācijas centrs (2017), National Development Plan 2014-2020 Annual and Sustainable Development Strategies For Latvia Up To 2030. Annual Implementation Monitoring Report, Rīga.

Pārtikas produktu kvalitātes klasteris (2019), "Digitalisation is at the base of growth - new digitalisation workshops are launched, specifically designed for the food industry”, PPKK.lv, www.ppkk.lv/en/international-activities (piekliuve 2019. gada 2. oktobrī). 
Paunov, C. un S. Planes-Satorra (2019), "How are digital technologies changing innovation?: Evidence from agriculture, the automotive industry and retail”, OECD Science, Technology and Industry Policy Papers, Nr. 74, OECD Publishing, Parīze, https://dx.doi.org/10.1787/67bbcafe-en.

Pasaules Banka (2018a), Focus on Performance - World Bank Support to Higher Education in Latvia, Volume 2: Internal Funding and Governance, Pasaules Banka, Vašingtona.

Pasaules Banka (2018b), Focus on Performance - World Bank Support to Higher Education in Latvia, Volume 3: Academic Careers, Pasaules Banka, Vašingtona.

Produktivitātes komisija (2017), Data Availability and Use, Produktivitātes komisijas izmeklēšanas ziṇojums Nr. 82, Austrālijas valdỉba, Kanbera, www.pc.gov.au/inquiries/completed/data-access/report/data-access.pdf.

Rovite, V. un citi. (2018), “Genome Database of the Latvian Population (LGDB): Design, goals, and primary results”, Journal of Epidemiology, Vol. 28/8, pp. 353-360, http://dx.doi.org/10.2188/jea.je20170079.

RTU (2019), “RTU Innovation Grants for Students”, rtu.lv, www.rtu.lv/en/university/rtu-projects/open?project_number=3912 (piekluve 2020. gada 13. maijā).

RVO (2018), Service Design Vouchers, Agency, N. (ed.), www.rvo.nl/subsidies-regelingen/service-design-vouchers (piekḷve 2020. gada martā).

SENAR (2016), "SENAR-MT Lança Treinamento Sobre Operação de Drones na Agropecuária” [SENAR-MT uzsāk apmācības dronu izmantošanā Agropecuári], Agro de Precisão.

Strods, J. (2017), "Smart city solutions for small city", Jelgavas Pilsētas domes prezentācija, www.norden.lv/Uploads/2017/09/ 11/1505122734_.pdf (piekḷuve 2020. gada 23. februārī).

Takalo, T. (2013), "Rationales and instruments for public innovation policies”, Bank of Finland Research Discussion Papers, Vol. 1/2013, http://dx.doi.org/10.2139/ssrn.2217502.

Vaivare, L (2018a), "Miracle tree”, Innovation, 3. sēj. (vasara), Magnetic Latvia, https://startuplatvia.eu/sites/default/files/resurs_file/ InnovationMag3_2018_0.pdf (piekḷuve 2019. gada 10. oktobrī).

Vaivare, L. (2018b), "Life with a plastic bag on your head", Innovation, 5. sēj (rudens/ziema), Magnetic Latvia, https://startuplatuia. eu/files/resources/resource_file/innovation_journal.pdf (piekluve 2019. gada 15. oktobrī).

WITS/UN Comtrade (2020), UNSD Commodity Trade (datubāze), http://wits.worldbank.org (piekḷuve 2020. gada 4. februārī).

ZM (2018), Latvian Bioeconomy Strategy 2030 - Informative Report, Zemkopỉbas ministrija, Rīga, www.zm.gov.lv/public/files/CMS_Static_ Page_Doc/00/00/01/46/58/E2758-LatvianBioeconomyStrategy2030.pdf.

Zviedrijas Izglītības un pētniecības ministrija (2019), Swedish National Roadmap for the European Research Area 2019-2020, Stokholma, www.government.se/4adab0/contentassets/514bde7beb4d423ea7b7b1f2c50f470f/swedish-national-roadmap-for-era-2019-2020.pdf.

\section{Piezīmes}

\section{Izraēla}

Statistikas datus par Izraēlu sniedza, un par tiem atbild Izraēlas attiecīgās iestādes. Šo datu izmantošana ESAO neskar Golānas augstieṇu, Austrumjeruzalemes un Izraēlas apmetṇu statusu Rietumkrastā saskaṇā ar starptautisko tiesību noteikumiem.

1. ERAF ir viens no pieciem Eiropas strukturālajiem un investīciju fondiem (ESI fondi). Pārējie fondi ir Eiropas Sociālais fonds (ESF), Kohēzijas fonds, Eiropas Lauksaimniecības fonds lauku attīstībai (ELFLA) un Eiropas Jūrlietu un zivsaimniecības fonds (EJZF).

2. ESAO definē viedās pilsētas kā "iniciatīvas vai pieejas, kas efektīvi izmanto digitalizāciju, lai uzlabotu iedzīvotāju labjutībuun sniegtu efektīvākus, ilgtspējīgus un iekḷaujošus pilsētvides pakalpojumus un apstākḷus vairāku ieinteresēto personu sadarbības procesā" (OECD, 2020i). Latvijas Vides aizsardzības un reǵionālās attīstības ministrijas viedās pilsētas definīcija ir atrodama tajā pašā dokumentā. 
3. Redzamā salīdzinošā priekšrocība (ar pievienoto vērtību) tiek definēta kā pievienotās vērtības dalı noteiktā valsts eksporta nozarē, kas dalīta ar pievienotās vērtības daḷu tajā pašā nozarē pasaules eksportā. Pasaulē bez jebkādiem tirdzniecības kropḷojumiem redzamā salīdzinošā priekšrocība būtu labs pamats tam, ko ekonomisti definē kā salīdzinošo priekšrocību. Valstij ir salīdzinoša priekšrocība kādā nozarē, ja šì daḷa ir lielāka par 1 (piem., ja pievienotā vērtība konkrētajā nozarē valstij veido lielāku daḷu salīdzinājumā ar vidējo rādītāju pasaulē) (sk. Miroudot un Cadestin, 2017).

4. Eksporta vērtības izmaiṇas laika gaitā pilnībā neatspoguḷo īpašās cenu izmaiṇas eksporta produktu klāstā. Skaitḷos nav ṇemtas vērā iespējamas izmaiṇas koksnes k̦īmijā un jauni biomateriāli (sk. zemāk).

5. Pētniecības un izstrādes izdevumi bioekonomikai rodas arī tādās jomās kā inženierzinātnes un tehnolog̣ijas, piemēram, saistībā ar procesu inovācijām vai jaunām iekārtām.

6. Aprēḳinu pamatā ir ESAO (2020h), un tajos ṇemti vērā patentu pieteikumi, kas iesniegti saskaṇā ar Nolīgumu par sadarbību patentu jomā (Patentu kooperācijas līgums), kā noteicošās iezīmes izmantojot prioritāros datus un izgudrotāja dzìvesvietas valsti. Skaita pamatā ir saraksts ar katram patenta dokumentam pieškirtajiem Starptautiskā patentu klasifikācijas kodiem, izmantojot daḷskaițus.

7. Konfidencialitātes apsvērumu dēl precīzi valdības sektora dati par 2016. gadu nav pieejami.

8. ESAO aprēķini, pamatojoties uz ESAO (2020h).

9. Publiskā iepirkuma stratēégiskā izmantošana inovācijām ir definēta kā jebkāda veida publiskā iepirkuma prakse (pirmskomerciāla vai komerciāla), kas ir paredzēta, lai stimulētu inovācijas, izmantojot pētniecību un izstrādi, un inovatīvu produktu un pakalpojumu izplatǐšanos tirgū (ESAO, 2017d).

10. ESAO aprēḳini, pamatojoties uz WITS/UN Comtrade (2020), UNSD Commodity Trade (datubāze), http://wits.worldbank. org (informācija skatīta 2020. gada 4. februārī)

11. ESAO aprēḳini, pamatojoties uz ESAO (2020h). 



\section{Nodala 7 \\ DIGITĀLĀS TRANSFORMĀCIJAS POLITIKAS: REKOMENDĀCIJAS VALDĪBAS KOPĒJAI PIEEJAI}




\section{Digitalizācija Latvijā: Integrētas politikas satvars}

Šā Pārskata iepriekšējās nodaḷās ir analizēti pēdējie notikumi vairākās politikas jomās saistībā ar digitalizāciju Latvijā. Analīzes rezultāts ir veiktspējas novērtējums un politikas rekomendāciju kopums katrai jomai. Šajā iedal̦ā šĩs rekomendācijas ir aplūkotas un kartētas digitalizācijas integrētās politikas satvara, kas aprakstīts 1. nodaḷā un apkopots 7.1. attēls, kontekstā.

Galvenie analizētie satvara komponenti ir piekḷuve, lietošana, uzticēšanās un inovācijas. Tos kā prioritātes ir noteikušas Latvijas iestādes. Pēc iestāžu pieprasījuma Pārskatā izmantots arī stratēgiskais nākotnes skatījums, lai analizētu galvenās nenoteiktības, kas saistītas ar digitālās transformācijas nākotni un potenciālajām sekām Latvijai.

\section{1. attēls. Digitalizācijas integrētās politikas satvars}

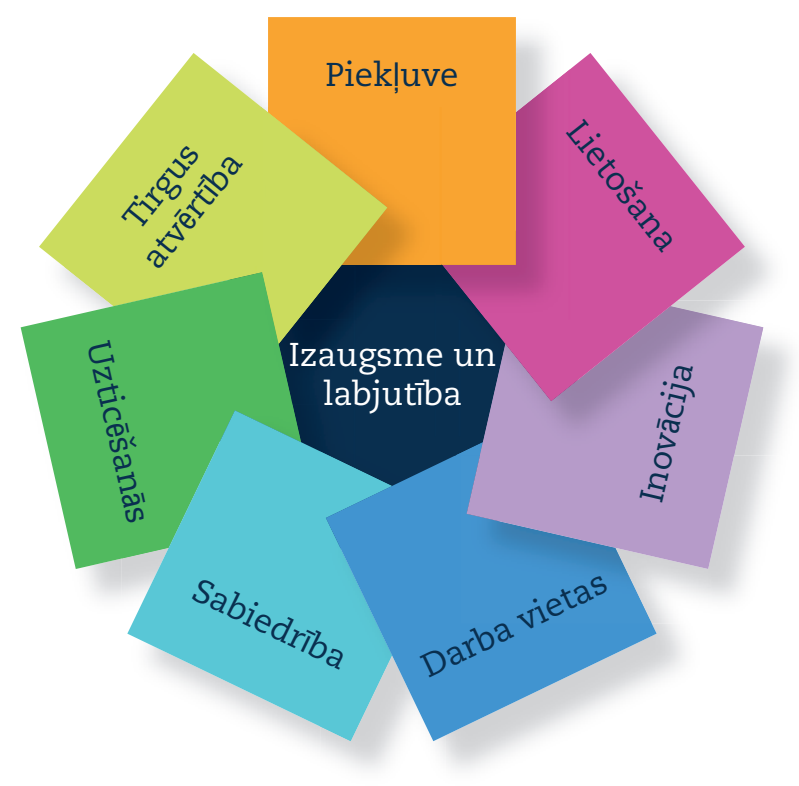

Avots: ESAO (2019), Going Digital: Shaping Policies, Improving Lives, https://doi.org/10.1787/9789264312012-en.

\section{Stratēgisks skatijums}

Digitālā transformācija virza straujas bezprecedenta globāla mēroga pārmaiṇas. Strauju pārmaiṇu un augstas nenoteiktības laikā stratēgiskā nākotnes skatỉjuma mērḳis ir palīdzēt lēmumu pieṇēmējiem Latvijā labāk paredzēt destruktīvas pārmaiṇas, noteikt būtiski svarīgās nenoteiktības, izstrādāt inovatīvas jaunas stratēgijas un politiku un veikt esošo plānu un prakses stresa testēšanu.

Stratēgiskā nākotnes skatījumā sākumā analizēts trīs scenāriju kopums. Pirmajā scenārijā apsvērta pasaule, kurā aktīvie pilsoṇi ṇēmuši digitalizāciju savās rokās un izveidojuši visaptverošu spēcīgu tiešsaistes kopienu "trešo pīlāru", kas nodrošina pretsvaru valstīm un tirgiem. Otrajā scenārijā raksturota pasaule, kurā valdības izveidojušas digitālās platformas, kas kḷūst par to ekonomiku mugurkaulu, veicinot apmaiṇu starp valstīm, kas lieto vienu un to pašu sistēmu, bet veidojot barjeras ar tām, kas to nelieto. Trešajā scenārijā aplūkota nākotne, kurā daudznacionālas digitālas konglomerātu korporācijas var apkalpot savus lietotājus tik labi, ka daudzas no lomām, kas tradicionāli pieder valstij, piemēram, izglìīibu un labklājību, var labāk piedāvāt nevalstiskas organizācijas.

Šie scenāriji palīdz noteikt dažas galvenās darbības stratēgiijas Latvijā, kas iedalās četrās galvenajās kategorijās:

- Novērtēt un stiprināt Latvijas stratēgiskās partnerỉbas digitālai transformācijai.

- Noteikt viedas pieejas izglīỉibai un prasmēm, lai veidotu adaptīvākus un kritiskākus Latvijas iedzīvotājus.

- Noteikt ceḷus virzībā uz iekḷaujošu digitālu Latviju, ko veido cilvēki cilvēkiem.

- Veidoot kapacitāti, lai gūtu labumu no piekḷuves personas datiem un to lietošanas, vienlaikus aizsargājot digitālo drošìbu un privātumu. 


\section{Piekḷuves un pārklājuma uzlabošana}

Latvijas panāktie rezultāti attiecībā uz fiksēto un mobilo platjoslas ātrdarbīgo tīklu izmantošanu ir labi. 2019. gada jūnijā mobilo platjoslas pakalpojumu abonentu skaits bija 127 uz 100 iedzīvotājiem, kas ir viens no augstākajiem rādītājiem ESAO valstīs. Optiskās šḳiedras savienojumi veido 70\% no visiem fiksētajiem platjoslas pieslēgumiem, kas ir ceturtais augstākais rādītājs ESAO aiz Korejas, Japānas un Lietuvas. Fiksēto un mobilo platjoslas pakalpojumu pieslēgumu cenas ir būtiski zemākas par ESAO vidējām.

Neskatoties uz šiem sasniegumiem, saglabājas pārklājuma atšķirības starp pilsētu un lauku teritorijām, ìpaši salīdzinot Rīgu ar pārējiem reǵioniem. Pastāv arī bažas par konkurenci fiksēto platjoslas pakalpojumu tirgū, kur pašreizējā tirgus dalībnieka daḷa ir 56\%.

Turpmāk norādītās rekomendētās pārmaiṇas politikas konstrukcijā un regulēšanas satvarā var palīdzēt sagatavot Latviju turpmākajai komunikāciju tehnolog̣iju un tirgus attīstībai:

- Novērtēt ieguvumus, ko sniedz konverǵenta regulatora izveidošana gan telekomunikāciju, gan pārraides pakalpojumiem, īpaši saistỉbā ar pakalpojumu konverǵences paaugstināšanu IP tỉklos.

- Izveidot skaidru ministrijas līmeña kontaktpunktu komunikāciju pakalpojumiem. Kompetences šobrīd ir sadalītas starp Satiksmes ministriju (SM) un Vides aizsardzības un reǵionālās attīstības ministriju (VARAM).

- Uzlabot teritoriālo plānošanu pašvaldībās, popularizējot «dig-once» politikas, piešķirot atḷauju jaunu torṇu būvniecībai un plānojot jaunus optiskās šḳiedras un kabeḷu maršrutus, kā arī harmonizējot un vienkāršojot administratīvās procedūras tīklu izvietošanai.

- Paaugstināt koordināciju pašvaldỉbu un SM starpā, lai novērstu sastrēgumvietas fiksēto un mobilo tīklu izvietošanā un sagatavotos tīkla blīvuma palielināšanai atbilstoši $5 \mathrm{G}$ tehnoloǵijas izvietošanai.

- Mazināt informācijas asimetrijas par pieejamo infrastruktūru un stingri uzraudzīt potenciālās diskriminējošās prakses attiecībā uz piekḷuvi pasīvajai infrastruktūrai.

- Uzraudzìt konkurenci fiksēto platjoslas pakalpojumu tirgū un atbilstoši apstākḷiem ieviest infrastruktūras koplietošanas pienākumus.

- Sadarboties ar vietējām ieinteresētajām pusēm saistỉbā ar pēdējās jūdzes risinājumiem kā daḷu no lauku teritoriju platjoslas pakalpojumu programmām un veicināt pieprasījumu, izmantojot mērḳtiecīgas iniciativas.

- Atjaunināt regulēšanas struktūru, lai atḷautu sekundārā spektra tirgus attīstỉbu, veicinot efektīvāku lietošanu.

- Izstrādāt un īstenot nacionālo Lietu interneta (IOT) plānu, lai noteiktu izaicinājumus un sekmētu pieprasījumu no uzṇēmumiem un patērētājiem.

- Izstrādāt un īstenot visaptverošu IPv6 stratēǵiju, koordinējot to ar pilsonisko sabiedrỉbu, privāto sektoru un tehniskajām ieinteresētajām pusēm.

- Veikt datu plūsmas apmaiṇas stāvokḷa analīzi un sekmēt neitrālu IXP izvietošanu, pamatojoties uz labas starptautiskās prakses paraugiem.

\section{Efektīuas digitālo tehnologiju lietošanas veicināšana}

Pēdējo gadu laikā Latvija ir panākusi ievērojamu progresu interneta lietošanā, valdībai kḷūstot par vadošo digitālo tehnolog̣iju lietotāju Eiropā. Taču Latvijas iedzīvotāji vēl joprojām ir viduvēji interneta lietotāji, bet uzṇēmumi atpaliek no citiem uzṇēmumiem ESAO valstīs. Lielā daḷā mazo uzṇēmumu digitālo tehnolog̣iju ieviešanu kavē prasmju trūkums. Latvijā ir arī zemākais IKT speciālistu, īpaši sieviešu nodarbinātības rādītājs ES. Tāpēc valstī būtu jāīsteno saskan,otu pasākumu komplekss, lai sekmētu efektīvu digitālo tehnoloǵiju lietošanu sabiedrībā, uzṇēmumos un valdībā.

\section{Digitālo prasmju uzlabošana}

- Modernizēt apmācību resursus, kas tiek nodrošināti Trešā tēva dēla programmā, un apgādāt bibliotēkas ar pietiekamiem resursiem IKT iekārtu uzturēšanai.

- Izveidot kopienā bāzētu IKT apmācību programmu grupām ar zemu digitālo tehnoloǵiju izmantošanas lìmeni, līdzīgi kā tas tiek darīts Austrālijā un Norvēǵijā. 
- Atbalstīt modulāro programmu, kas ietver IKT, izstrādi augstākajā izglīīibā.

- Paaugstināt darba devēju iesaistî̌anos universitāšu mācību programmu izstrādē un ieviest tiesisko struktūru darbā bāzētām apmācībām augstākajā izglīiībā.

- Stiprināt saiknes starp profesionālajām skolām un uzṇēmumiem, kas nodarbina IKT speciālistus, un vienkāršot procedūru, lai pieškirirtu uzṇēmumiem atbalstu apmācībām darba vietā.

- Ieviest apmācību kuponus darbiniekiem, finansējot tos no darba devēju iemaksām no bruto algām, kā to dara Francijā un Polijā.

- Noteikt atbrīvojumu no darba tirgus testiem ārvalstu IKT speciālistiem ar pierādītu pieredzi vai tiem, kuri pabeiguši studijas Latvijā, kā tas notiek Vācijā un Apvienotajā Karalistē.

\section{Digitālo tehnoloǵiju izmantošanas palielināšana uzṇēmumos}

- Izveidot digitālo čempionu programmu, kas līdzīga Austrālijas programmai, kur valdība sniedz atbalstu nelielam skaitam MVU nozarēs, kur ir zems IKT izmantošanas limenis.

- Nodrošināt konsultatīvos pakalpojumus un pārvaldības padomus, lai palīdzētu uzṇēmumiem pietuvoties augsti digitalizētu uzṇēmumu līmenim, kā tas jau ir darīts Austrālijā un Austrijā.

- Ieviest sistēmu, kas l̦auj uzṇēmumu algu programmatūrai automātiski iesniegt datus nodokḷu iestādēm, kas ir līdzīga Austrālijas Single Touch Payroll [Viena pieskāriena algu] sistēmai.

\section{Digitālās pārualdības atbalstīšana}

- Konsolidēt finansējumu digitālajai pārvaldỉbai vienā ministrijā, kas tad var noteikt prioritātes atbilstoši nacionālajai stratēgijai.

- Izveidot pilsoniskās sabiedrības mēroga programmu par IKT lietošanu un e-pārvaldes pakalpojumu izstrādi, kā arī izstrādāt labās prakses piemēru rokasgrāmatu, kas līdzīga tai, ko izmanto Apvienotajā Karalistē.

- Ieviest motivāciju uzṇēmumiem kontaktēties ar valdības iestādēm tiešsaistē (piem., izdot ațaujas vai maksājumus ātrāk nekā klātienē). Izveidot grafiku, saskaṇā ar kuru notiktu atteikšanās no izvēlētiem e-pārvaldības pakalpojumiem klātienē.

- Izstrādāt jaunus noteikumus, procedūras un standartus par telemedicīnas lietošanu, līdzīgus Likumam par e-veselību un drošu datu apmainu Čehijas Republikā.

- Izveidot vienas pieturas kontaktpunktu tiem, kuri vēlas piekḷūt veselības un sociālās aprūpes datiem pētniecībai, kā tas ir Somijā.

- Atbalstīt atvērtu datu ekosistēmu, piešķirot apbalvojumus augstākā līmeṇa studentiem un pētniekiem, kas izmanto atvērtos datus, lai risinātu sabiedrỉbas problēmas.

\section{Uzticības palielināšana digitālajā vidē}

\section{Digitālās drošības atbalstī̌šana}

Latvijā ir izveidoti stabili pamati, balstoties uz kuriem risināt digitālās drošības izaicinājumus un iespējas. Latvijas Informācijas tehnologiiju drošǐbas incidentu novēršanas institūcija (CERT.LV) ir starptautiski atzīta, pateicoties tās tehniskajām zināšanām un ievainojamības atklāšanas politikām. Arī Latvijas Aizsardzības ministrija (AM) ir stingri apṇēmusies veicināt digitālo drošību kā stratēọisku jautājumu, ko pierāda nesen pienemtā Kiberdrošības stratēgija (2019.-2022.). Latvijas Nacionālās IT drošības padomes (NITDP) izveidošana 2011. gadā ir vēl viens solis, lai attīstìtu valdības lìmeṇa pieeju digitālajai drošībai.

Taču digitālās drošības politika Latvijā vēl joprojām ir šauri koncentrēta uz nacionālās drošības aspektiem, pievēršot nepietiekamu uzmanību digitālās drošības ekonomiskajai un sociālajai dimensijai.

Lai risinātu šos jautājumus, Latvijai vajadzētu:

- Veicināt digitālās drošības stratēéiju augstākajā valdības līmenī.

- Paaugstināt ministriju iesaistī̌̌nonos, piešķirot transversālu mandātu (piem., tām, kas atbildīgas par ekonomikas un reǵionu attīstību) digitālās drošỉbas iniciatīvās. 
- Labāk integrēt digitālās drošības stratēǵiju ar Informācijas sabiedrības attīstības pamatnostādnēm.

- Veicināt prasmju paaugstināšanu un darbaspēka kopīgas izmantošanas programmas starp valsts iestādēm.

- Pastiprināt vairāku ieinteresēto pušu sadarbību digitālās drošības politikas izstrādē, izmantojot uz uzticēšanos balstītas partnerības.

- Pastiprināt starptautisko sadarbību digitālās drošības jomā ekonomikas un sabiedrības labklājības labā, īpaši ar citām Baltijas valstīm.

\section{Privātuma paaugstināšana}

Kopš ES Vispārīgās datu aizsardzības regulas (VDAR) un Fizisko personu datu apstrādes likuma (FPDAL) pien,emšanas 2018. gadā Latvijā ir sasniegts būtisks progress, nodrošinot personu privātuma un datu aizsardzības tiesības. Datu valsts inspekcija (DVI) ir sākusi gan proaktīvu juridisko sistēmu ieviešanas nodrošināšanu, gan piemērojusi administratīvos sodus uzṇēmumiem par vispārīgo pienākumu, kas noteikti abos tiesību aktos, neievērošanu.

Lai uzlabotu privātumu, Latvijai būtu jāveic šādas darbības:

- Nodrošināt DVI cilvēku un finanšu resursus, kas nepieciešami, lai efektīvi izpildītu tās uzdevumus, tostarp konsultējot un izmeklējot privātumu un datu aizsardzību digitālajā telpā.

- Izstrādāt DVI norādījumus par privātumu un privātuma pārvaldības programmām (PPP), pamatojoties uz pastāvošo labo starptautisko praksi.

- Veicināt sadarbību starp DVI un citām valstīm, tostarp ārpus ES, piemēram, pievienojoties Globālajam privātuma aizsardzības tīklam (GPEN).

- Izveidot atbilstošu mākslīgā intelekta (MI) un IoT datu pārvaldību, tostarp ar turpmāku līdzdalību un sadarbību ar starptautiskajiem forumiem, piemēram, ESAO.

\section{Patērētāju aizsardzības uzlabošana tiešsaistē}

Latvijas patērētāju politikas satvarā ir iekḷauti vispārīgie principi digitālo patēēēāju aizsardzībai, kas ir atbilstoši ESAO rekomendācijām par patērētāju aizsardzību e-komercijā (ESAO, 2016). Taču valdība varētu rīkoties, lai uzlabotu savu pierādījumu bāzi patēētāju politikas lēmumu pieṇemšanai un paaugstinātu patērētāju aizsardzību ES un ārpus tā, veicot šādas darbības:

- Apkopot un analizēt patēēēāju sūdzību datus, kas attiecas uz e-komerciju, lai labāk izprastu patērētāju problēmu, kas saistìtas ar e-komercijas transakcijām, raksturu un mērogu.

- Uzlabot patēēētāju informētỉbu par jautājumiem, kas saistīi ar e-komerciju, koncentrējoties uz dažādu grupu speciālajām vajadzībām atbilstoši to vecumam, ienākumiem un pratības līmenim.

- Novērtēt strīdu izšķiršanas un pārsūdzības sistēmas efektivitāti, izpētot patērētāju lietojumu un apmierinātību un analizējot neatrisinātās strīda situācijas.

- Uzlabot pierādījumu bāzi par pārrobežu strīdiem ārpus ES un uzlabot sadarbību pārrobežu lēmumu izpildē ES un ārpus ES.

\section{Digitālo inovāciju atraisīšana}

Kopš tūkstošgades sākuma Latvijā ir panākts ievērojams ekonomiskais progress. Ekonomikas izaugsme ir bijusi straujāka nekā jebkurā citā ES un ESAO valstī. Latvijas Nacionālā Viedās specializācijas stratēǵijas pētniecībai un inovācijai (RIS3) mērḳis ir veicināt ekonomikas strukturālo transformāciju, virzoties uz zināšanās balstītām aktivitātēm. Taču produktivitāte saglabājas būtiski zemāka nekā citās ESAO valstīs, bet darbspējīgā vecuma iedzìvotāju skaita samazināšanās ierobežo turpmākas izaugsmes potenciālu. Tāpēc inovācija ir atslēga produktivitātes un dzìves līmeṇa paaugstināšanai Latvijā.

Lai palielinātu pētniecību un attīstību (P\&A) un atbalstītu inovācijas uzṇēmējdarbībā, Latvijai vajadzētu:

- Koncentrēt uzmanību uz digitalizāciju kā galveno transversālo līdzekli inovāciju un izaugsmes nodrošināšanai.

- Veicināt digitālo pakalpojumu inovāciju.

- Veicināt digitālo inovāciju, lai risinātu Latvijas sabiedriskās un ekonomiskās problēmas. 
- Paaugstināt valsts atbalstu uzṇēmumu P\&A un diversificēt tās saturu, virzoties uz lielāku nodokḷu atlaižu izmantošanu P\&A izdevumiem.

- Piešk̦irt lielāku pētniecības finansējuma daḷu ar IKT saistītiem projektiem, kam šobrīd ir nepietiekams finansējums.

- Palielināt RIS3 finansējuma dal̦u, kas paredzēta IKT, un virzīt būtiskus pielietojumus izmantošanai citās viedās specializācijas jomās.

- Uzlabot pētniecības kvalitāti, paaugstinot finansējuma daḷu, ko piešķir konkurences procesā.

- Ieviest ex post pētniecības projektu novērtēšanas sistēmu, līdzīgu Zinātnes fondam İrijā.

- Palielināt kompetenču centru privātā līdzfinansējuma proporcionālo daḷu, lai nodrošinātu, ka tie ir vērsti uz komerciālām inovācijām.

- Novērtēt IT klastera, LIKTA, LIDA un IT Kompetences centra darbību un skaidri noteikt to attiecīgās lomas, pamatojoties uz šo novērtējumu.

- Izstrādāt Intelektuālā īpašuma (IP) tiesību stratēǵiju, balstoties uz veiksmīgo Somijas piemēru, un izveidot specializētu tiesu visu IP jautājumu risināšanai.

- Paaugstināt uzṇēmējdarbības motivāciju ieguldīt P\&A, padarot esošās nodokḷu priekšrocības $P \& A$ personālam jaunuzṇēmumos mazākas pēc apjoma, taču pieejamas visiem uzṇēmumiem.

\section{Kopīgas valdības līmeṇa pieejas digitālās transformācijas politikas izveide}

Digitālā transformācija kompleksi un savstarpēji skar dažādas ekonomikas un sabiedrības daḷas, apgrūtinot kompromisu starp valsts politikas mērḳiem. Lai gūtu labumu no digitālās transformācijas un risinātu tās radītos izaicinājumus, ir nepieciešama koordinācija visās politikas jomās, kas noteiktas Digitalizācijas integrētās politikas satvarā (7.1. attēls). Nepieciešams apsvērt arī transversālās politikas jautājumus (piem., prasmes, digitālo valdību un datu pārvaldību), kas attiecas uz vairākām satvara politikas dimensijām (ESAO, 2019). Tāpēc iepriekš norādītās politikas rekomendācijas (7.1. iedaḷa) ir nepieciešams koordinēt, izmantojot kopīgu valdības līmeṇa pieeju.

Koordinācija ietver plaša personu loka iesaistīšanos dažādās valdības daḷās un līmeṇos, kā arī nevalstisko ieinteresēto pušu un starptautisko partneru līdzdalību. Taču kopīga valdības līmeṇa pieeja var izrādīties izaicinājums. Piemēram, augstas transakciju izmaksas, varas un informācijas asimetrija un atšḳirīgas pārvaldības pieejas dažādos valdības līmeṇos var apgrūtināt koordināciju un sarunas.

Vienlaikus labi izplānota pārvaldība ir efektīvas koordinācijas pamats. Taču nav pieejas, kas būtu piemērota visam. Dažādas pieejas var atspoguḷot, piemēram, pārmaiṇas valsts iestādēs, valdības organizāciju vai administratīvo kultūru un kapacitāti. Turklāt pārvaldības organizācija laika gaitā pilnveidojas, piemēram, sekojot izmaiṇām valdībā, tehnoloǵijas progresam un iesaistīto personu, kas virza digitālo transformāciju, sastāva izmaiṇām.

Šajā iedaḷā ir analizēts pašreizējais digitālās transformācijas koordinācijas mehānisms Latvijā un sniegtas rekomendācijas, lai palīdzētu nodrošināt saskaṇotu un vienotu visas valdības pieeju digitālās transformācijas politikām.

\section{Latvijas ilgtspējas stratēgija 2030}

Latvijā ir hierarhijas politikas plānošanas stratēgija ar ilgtermiṇa (līdz 25 gadiem), vidēja termiṇa (līdz septiṇiem gadiem) un īstermiṇa (lìdz trim gadiem) perspektīvām (7.2. attēls). Ilgtspējīgas attīstības stratēgija ir augstākā valsts līmeṇa ilgtermiṇa plānošanas dokuments. Tajā ir noteiktas galvenās valdības un sabiedrības prioritātes, lai panāktu lìdzsvarotu un ilgtspējīgu attīstību.

Pašreizējā Ilgtspējīgas attīstības stratēǵijā Latuija 2030 ir iekḷautas 7 attīstības prioritātes, 7 stratēg̣iskie indikatori, 11 mērḳi, 11 attīstības virzieni, 42 rīcības jomas un 27 snieguma indikatori (SAEIMA, 2010).

Plānā Latvija 2030 digitalizācija aplūkota saistībā ar nacionālās attīstības prioritātēm. Kultūras telpas attīstības (1. prioritāte) kontekstā digitālās tehnoloǵijas ir aplūkotas kā iespēja uzlabot piekḷuvi kultūrai, saglabāt Latvijas valodas un kultūras mantojumu un stiprināt nacionālo identitāti. Ilgtspējīgas attīstības stratēǵijā bibliotēkām piešḳirta vietējo kompetences centru loma ar uzdevumu nodrošināt mūžizglītību un informāciju, lai atbalstītu ilgtermiṇa investīcijas cilvēkkapitālā (2. prioritāte). 


\section{2. attēls. Latvijas nacionālais attīstības plāns}

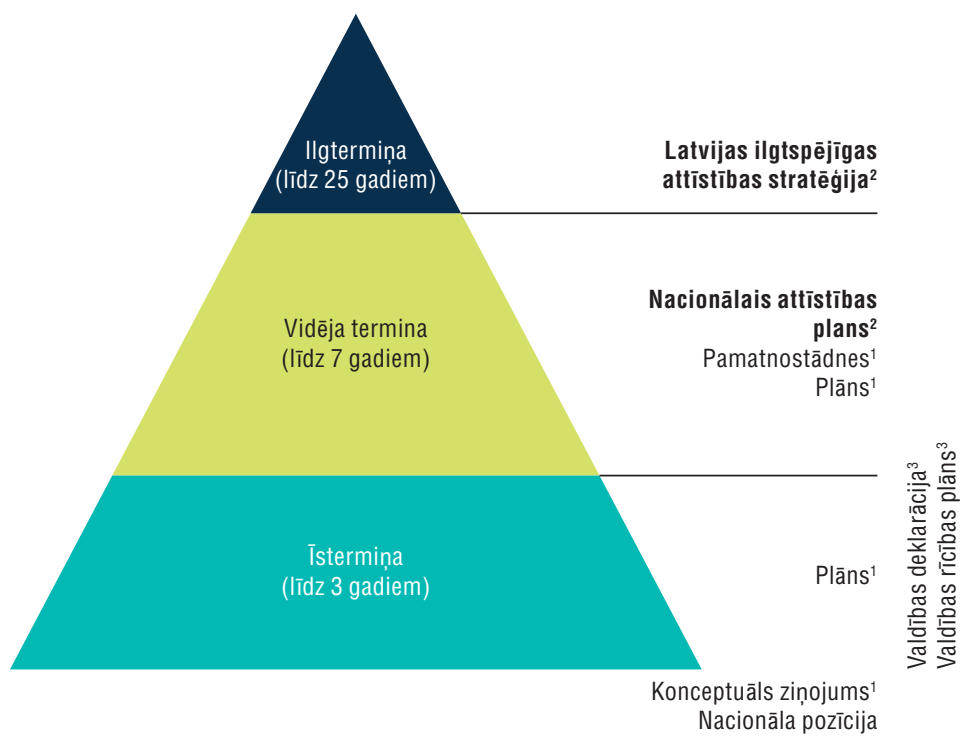

1. Politikas plānošanas dokuments

2. Teritorijas attīstības plānošanas dokuments

3. Politisko vadliniju dokuments

Avots: CSCC (2020), Latuijas Nacionālais attīstības plāns 2014.-2020, https://www.pkc.gov.lv/index.php/en/national-developmentplanning/.

Tiek arī sagaidīts, ka digitalizācija veicinās izglīīibas paradigmas maiṇu (3. prioritāte), uzlabojot piekḷuvi sociālo pakalpojumu tīkliem, skolu, bibliotēku un izglīīibas materiālu digitalizāciju, kā arī e-mācības.

Atvērtām zināšanām un zinātnei, izmantojot virtuālos biznesa inkubatorus, digitālos tīklus un platformas, ir potenciāls veicināt inovatīvu un ekoefektīvu ekonomiku (4. prioritāte). Paredzams, ka digitālā licencēšana atvieglos piekḷuvi intelektuālajam īpašumam un samazinās licencēšanas izmaksas. Pāreja no transporta izmantošanas uz teledarbu un attālināto mācišanos samazinātu arī enerǵijas patēriṇu un gāzu emisijas.

Digitālās tehnolog̣ijas un platformas var palīdzēt izveidot dabiskos aktīvus kā nākotnes kapitālu (5. prioritāte), kā arī iedzīvināt jaunu praksi, lai mazinātu cilvēka darbības ietekmi uz ekolog̣iju. Ātrdarbīgu platjoslas tīklu izmantošana padarītu digitālos pakalpojumus pieejamus lauku teritorijās un attālinātos rajonos, tādējādi veicinot reǵionālo attīstību (6. prioritāte).

Visbeidzot, digitalizāciju uzskata par līdzekli valdības inovācijas un sabiedrības līdzdalības stiprināšanai (7. prioritāte). E-pārvalde var potenciāli efektīvāk nodrošināt labākus pakalpojumus, bet sociālie tīkli un interneta platformas var darboties kā publiski forumi, kur iedzīvotāji dalās ar viedokḷiem un sadarbojas, lai risinātu sociālās problēmas.

Plānā Latuija 2030 ir noteikti arī 27 indikatori, lai mērītu progresu 7 attīstības prioritātēs. Taču tikai viens indikators (t.i. e-pārvaldes lietošana sabiedrībā) ir tieši saistīts ar digitālo transformāciju.

Augsta līmeṇa politikas dokumentā plānā Latvija 2030 nav precīzi aprakstītas konkrētas darbības; tās ir izstrādātas un precīzi aprakstītas nacionālajos plānos un nozaru pamatnostādnēs.

\section{Nacionālais attīstības plāns 2014.-2020. gadam}

Nacionālais attīstības plāns (NAP), kas ir Latvijas galvenais vidēja termiṇa plānošanas dokuments, ir galvenais Ilgtspējīgas attīstības stratēǵijas îstenošanas rīks. NAP ir noteikti vidēja termiņa mērḳi, prioritātes un veiktspējas indikatori, darbības jomas, iznākumi un atbildīgās institūcijas septiṇu gadu periodam. Plānu ìsteno ar nozaru un teritoriju attīstības politiku palīdzību (reǵionu, vietējās pašvaldības), tostarp ar centrālās valdības un vietējo pašvaldību plānošanas investīciju programmām, ES politikas instrumentiem un citiem finanšu avotiem. 
NAP 2014.-2020. ir noteikti 12 stratēǵiskie mērḳi trīs prioritātēs: 1) tautsaimniecības izaugsme; 2) cilvēku drošība; un 3) reǵionu izaugsme (CSCC, 2012). Kā norādīts iepriekš, vairākās NAP paredzētajās darbībās stratēgisko mērķu sasniegšanai tiek izmantota digitālā transformācija.

Lai sasniegtu stratēǵisko mērḳi "Augstražìga un eksportspējīga ražošana un starptautiski konkurētspējīgi pakalpojumi”, NAP ir paredzēta uzṇēmēju apmācība par ražošanas procesiem produktivitātes paaugstināšanai un pārvaldības metodēm, un biznesa modeḷiem, tostarp tiem, ko nodrošina digitālās tehnologijas.

Darbības, lai sasniegtu stratēǵisko mērḳi "Pakalpojumu pieejamība līdzvēertīgāku darba iespēju un dzìves apstākḷu radišanai”, ietver uzlabotu piekḷuvi ātrdarbīgiemun īpaši ātrdarbīgiemdatu pārraides tīkliem visā Latvijā, vispārīgu iedzīvotāju e-prasmju uzlabošanu un uzlabotu piekḷuvi e-pārvaldes pakalpojumiem, kā arī digitālā satura, produktu un pakalpojumu attīstību.

Lai sasniegtu stratēgisko mērḳi "Kompetenču attīstība", NAP ir paredzēta inovatīvu satura un aktivitāšu formu ieviešana pamata un vidējās izglìtības līmenī, lai veicinātu radošas un uzṇēmējdarbības prasmes digitālā mācību vidē.

Administratīvā sloga samazināšana uzṇēmējiem, tostarp izmantojot digitālās tehnoloǵijas, un vienas pieturas tiešsaistes platformas izveidošana e-pārvaldes pakalpojumu sniegšanai uzṇēmumiem veido daḷu no darbībām, lai sasniegtu stratēǵisko mērḳi izveidot "izcilu uzṇēmējdarbības vidi”.

Visbeidzot, stratēgiskā mērḳa "Attīstīta pētniecība, inovācija un augstākā izglìtỉba" sasniegšana ir balstīta uz augstākās izglìtības, zinātnes un privātā sektora sadarbības platformas attīstǐšanu Baltijas valstu starpā izvēlētās jomās, tostarp viedo tehnoloǵiju un inženierzinātṇu jomā. NAP ir paredzētas citas darbības, lai atbalstītu pētniecỉbas un tehnologiiju pārnesi, bet nav īpašas atsauces uz digitālajām tehnolog̣ijām.

NAP ir īpaša atsauce uz indikatoru kopumu, lai novērtētu progresu. Lai gan vairākos indikatoros, iespējams, ir ietverts digitālais komponents (piem., P\&A, augsto tehnologiju eksports un prasmes), tikai divos ir iekḷauta tieša saite ar digitālo transformāciju: 1) mājsaimniecỉbu ar piekḷuvi internetam proporcija, un 2) iedzīvotāju, kas lieto internetu saziṇai ar valsts un vietējo pašvaldību iestādēm, proporcija. 2020. gada mērḳi attiecỉbā uz abiem indikatoriem, t.i. attiecīgi 80\% un 50\%, ir sasniegti (4. nodalala).

NAP 2021.-2027. gadam Ministru kabinets apstiprināja 2020. gada 25. februārī. NAP 2021.-2027. gadam ir noteikti trīs stratēǵiskie mērḳi - vienādas iespējas, produktivitāte un ienākumi, un sociālā uzticēšanās sešām prioritārām jomām: 1) spēcīgas ǵimenes, veseli un aktīvi cilvēki; 2) zināšanas un prasmes personiskajai un valsts izaugsmei; 3) biznesa konkurētspēja un materiālā labklājība; 4) kvalitatīvi dzìves apstākḷi un teritoriālā attīstība; 5) kultūra un sports aktīvai un piepildītai dzìvei; un 6) vienota, droša un atvērta sabiedrỉba.

NAP 2021.-2027. gadam ir iekḷauti vairāki pasākumi digitālo iespēju izmantošanai:

- digitālo un jauno tehnolog̣iju prasmju stiprināšana sadarbībā ar uzṇēmumiem

- digitālo tehnolog̣iju izmantošanas veicināšana uzṇēmējdarbībā

- digitālo risinājumu izplatības sekmēšana informācijas apmainai saimnieciskās darbības veicēju, valsts un vietējo iestāžu starpā

- principa "digitalizācija vispirms" ieviešana uz lietotāju orientētiem, atvērtiem sabiedriskajiem pakalpojumiem

- IKT infrastruktūras uzlabošana valsts pārvaldei, pašvaldībām un izglìtības iestādēm

- valsts un pašvaldību infrastruktūras fiziskās un digitālās pieejamības paplašināšana

- Viedās specializācijas stratēǵiju veicināšana piecās jomās, tostarp IKT

- kultūras mantojuma, sporta tradīciju un vērtību saglabāšana un nodošana nākotnes paaudzēm, tostarp, izmantojot IKT.

\section{Informācijas sabiedrības attīstības pamatnostādnes 2014.-2020. gadam}

Informācijas sabiedrības attīstības pamatnostādnēs (INFSO) 2014.-2020. gadam, kas ir nākamais dokuments Latvijas plānošanas sistēmas hierarhijā, ir noteikta digitālā stratēéija (Ministru kabinets, 2013a). Pamatnostādnes funkcionē kā vidēja termiṇa attīstības plāns, un tās izstrādāja darba grupa, 
kuras darbu koordinēja Vides aizsardzības un reǵionālās attīstības ministrija (VARAM) un kuras sastāvā bija pārstāvji no 12 ministrijām (Lauksaimniecības, Kultūras, Aizsardzības, Ekonomikas, Izglītības, Finanšu, Ārlietu, Veselïbas, Iekšlietu, Tieslietu, Satiksmes un Labklājības), Valsts kancelejas, IKT nozares asociācijām, Latvijas UNESCO nacionālās komisijas un Latvijas Tirdzniecības palātas.

ISAP 2014.-2020. gadam mērḳis ir "nodrošināt iespēju ikvienam izmantot IKT sniegtās iespējas, veidot uz zināšanām balstītu ekonomiku un uzlabot kopējo dzīves kvalitāti, sniedzot ieguldijjumu valsts konkurētspējai, un ekonomiskās izaugsmes paaugstināšanā un darbavietu radīšanā" (Ministru kabinets, 2013a).

Ekonomiskā izaugsme un darbavietu radīšana ir stratēgijas pamatā un nosaka katra no septiṇiem darbības virzieniem, kas noteikti pamatnostādnēs: 1) IKT izglītība un prasmes; 2) plaši pieejama piekḷuve internetam; 3) moderna un efektīva valsts pārvalde; 4) e-pakalpojumi un digitālais saturs sabiedrībai; 5) pārrobežu sadarbība Digitālajam vienotajam tirgum; 6) IKT pētniecība un inovācija; un 7) uzticēšanās un drošìiba.

Vadlīnijās īpaša uzmanība pievērsta atvērto datu principu kā sabiedrisko pakalpojumu efektivitātes uzlabošanas rīka izmantošanai valsts pārvaldē. E-prasmju uzlabošanai un interneta piekḷuves un ātruma uzlabošanai arī ir būtiska loma kā e-komercijas un e-uzṇēmējdarbības veicinošiem faktoriem. Digitālo rīku izmantošana, lai mazinātu administratīvo slogu un uzlabotu valsts pārvaldes efektivitāti, ir nozīmīga arī ISAP 2014.-2020. gadam ar mērḳi samazināt administratīvās izmaksas uzṇēmumiem, ipaši MVU.

Katrs rīcības virziens ir izteikts ar vairākiem pasākumiem, kā parādīts 7.1. tabula.

\section{1. tabula. Informācijas sabiedrības attīstības pamatnostādnes 2014.-2020. gadam}

\begin{tabular}{|c|c|c|c|}
\hline \multirow{2}{*}{$\begin{array}{l}\text { Darbības virziens } \\
\text { Galvenie pasākumi }\end{array}$} & \multicolumn{3}{|c|}{ IKT izglītībā un e-prasmes } \\
\hline & Atbildīgā iestāde & lesaistītās iestādes & Plānotie izdevumi (LVL) \\
\hline 1.1. Darbinieku un uzņēmēju e-prasmju uzlabošana & VARAM & Vietējās pārvaldes, visas ministrijas & 4035294 \\
\hline 1.2. Darbinieku apmācība sadarbībā ar uzņēmumiem & EM & LIAA & $15000000^{1}$ \\
\hline 1.3. E-prasmju apmācība bezdarbniekiem un darba meklētājiem & LM & $\begin{array}{l}\text { EM, IZM, vietējās pārvaldes, NVA, } \\
\text { sociālie partneri }\end{array}$ & 10000000 \\
\hline 1.4. E-prasmju apmācība pieaugušajiem & LM & EM, IZM, sociālie partneri & 1900000 \\
\hline 1.5. Digitālo mācību grāmatu bibliotēka & IZM & $\begin{array}{l}\text { KM, VARAM, pašvaldības, VISC, } \\
\text { sociālie partneri }\end{array}$ & 694118 \\
\hline $\begin{array}{l}\text { 1.6. Integrētās izglītības mācību programmas izstrāde, ietverot algoritmisku } \\
\text { domāšanu un informācijas pratību }\end{array}$ & IZM & $\begin{array}{l}\text { SECC, KM, VARAM, pašvaldības, } \\
\text { sociālie partneri }\end{array}$ & $1058824^{1}$ \\
\hline 1.7. Digitālie mācību materiāli vispārējai izglītībai & IZM & $\begin{array}{l}\text { KM, VARAM, pašvaldības, sociālie } \\
\text { partneri }\end{array}$ & 2966667 \\
\hline 1.8. Dabaszinātņu kabinetu aprīkojums skolās, tostarp programmatūra & IZM & Pašvaldības & $18000000^{1}$ \\
\hline 1.9. Metodoloǵisks atbalsts IKT & IZM & Pašvaldības un valsts skolas & 10000000 \\
\hline 1.10. Ergonomiski iekārtojumi un IKT risinājumi reǵionālajās vidusskolās & IZM & Pašvaldības & 57400000 \\
\hline 1.11. Skolotāju kvalifikācijas paaugstināšana, tostarp IKT & IZM & SECC, pašvaldības & $6000000^{1}$ \\
\hline 1.12. Skolotāju prasmju, tostarp IKT prasmju, uzlabošana & IZM & $\begin{array}{l}\text { Pašvaldības, LM, KM, EM, LM, sociālie } \\
\text { partneri }\end{array}$ & 3507100 \\
\hline 1.13. Pārvald̄̄bas uzlabošana mazajās lauku skolās, tostarp ar IKT iegādi & IZM & Pašvaldības & 11764706 \\
\hline 1.14. Nākamās paaudzes tīkla attīstība lauku reǵionos & SM & Valsts Radio un televīzijas centrs & 65000000 \\
\hline 1.15. Platjoslas pakalpojums savienojuma pēdējai jūdzei & SM & Telekomunikāciju uzņēmumi & 36000000 \\
\hline 1.16. Esošo elektronisko komunikāciju tīklu novērtēšana & SM &.. & SM parastais budžets \\
\hline 1.17. Esošās elektronisko sakaru tīklu infrastruktūras kartēšana & SM & .. & 2400000 \\
\hline 3.1. IKT centralizēto platformu izstrāde valsts pārvaldei & VARAM & Visas ministrijas & 25035294 \\
\hline 3.2. Valsts pārvaldes pakalpojumu digitalizācija & VARAM & Visas ministrijas, vietējās pārvaldes & 76258824 \\
\hline $\begin{array}{l}\text { 3.3. Valsts pārvaldes cilvēkresursu pārvaldības sistēmas ieviešana, kas } \\
\text { balstīta uz e-pārvaldes principiem }\end{array}$ & VAS & $\begin{array}{l}\text { Valsts administrācijas skola, visas } \\
\text { ministrijas }\end{array}$ & $6670600^{1}$ \\
\hline
\end{tabular}


7.1. tabula. Informācijas sabiedrības attīstības pamatnostādnes 2014.-2020. gadam (cont.)

\begin{tabular}{|c|c|c|c|}
\hline \multirow{2}{*}{$\begin{array}{l}\text { Darbības virziens } \\
\text { Galvenie pasākumi }\end{array}$} & \multicolumn{3}{|c|}{ IKT izglītībā un e-prasmes } \\
\hline & Atbildīgā iestāde & lesaistîtās iestādes & Plānotie izdevumi (LVL) \\
\hline 3.4. E-izsoļu ieviešana & TM & TA, IAP & 1 miljons \\
\hline $\begin{array}{l}\text { 3.5. Vienotas IT platformas patentu, preču zīmju un dizainparaugu izstrāde } \\
\text { reǵistrācijai }\end{array}$ & $\mathrm{TM}$ & Patentu birojs & 800000 \\
\hline 3.6. Darba tirgus prognozēšanas sistēmas ieviešana & LM & EM, IZM, LM, sociālie partneri & 764706 \\
\hline 3.7. Hospitalizēto pacientu veselības aprūpes iestāžu efektivitātes uzlabošana & VM & Vietējās pašvaldības,, sociālie partneri & 3000000 \\
\hline 3.8. Invaliditātes ekspertīzes pakalpojumu kvalitātes uzlabošana & LM & VM, pašvaldības, sociālie partneri & 505882 \\
\hline 3.9. Tiešsaistes psiholoǵiskās konsultācijas bērniem stresa situācijās & LM & VBTAI & 120000 \\
\hline 3.10. Sadarbība ar pilsonisko sabiedrību saistībā ar tīmekla 2.0 risinājumiem & VAS & Visas ministrijas, sociālie partneri & 300000 \\
\hline 3.11. Pētniecības un publikāciju datu bāzes izstrāde & PKC & .. & 11800 \\
\hline 3.12. Integrētās klimata pārmaingu un gaisa kvalitātes datu bāzes izstrāde & VARAM & FEI, LVĢMC, LLU, Silava & Budžetā \\
\hline 3.13. Klimata pārmaiņu mazināšanas politikas novērtējums & VARAM & FEI, LVĢMC, LLU, Silava & Budžetā \\
\hline 3.14. Klimata pārmaiņu portāla izstrāde & VARAM & .. & Budžetā \\
\hline 3.15. Informācijas sistēmas izstrāde plūdu riska teritorijām & VARAM & .. & Budžetā \\
\hline 3.16. E-pakalpojumi un sistēmas, kas saistītas ar tiesību aktiem & TM & TA (LR), DVI, IAP, UR, VTEB, VZD, & 7000000 \\
\hline 3.17. Kultūras mantojuma digitalizācija & KM & KISC, LNB, KM & 11764706 \\
\hline $\begin{array}{l}\text { 3.18. Bibliotēkas, arhīva un muzeja informācijas sistēmas atjaunināšana } \\
\text { saskaņā ar ES Direktīvu 2013/37/ES }\end{array}$ & KM & KISC, LNB, KM & 1750000 \\
\hline 3.19.Digitālā kultūras mantojuma kompetences tīkla izstrāde un uzturēšana & $\mathrm{KM}$ & KISC, LNB, KM & 3000000 \\
\hline 3.20. Mašīntulkošanas sistēmas uzlabošana & KM & KISC & 4000000 \\
\hline 3.21. IKT pārvaldības sistēmas izstrādei centrālajai pārvaldei & VARAM & VRAA & 1487022 \\
\hline 6.1. Atbalsts lietišķajai P\&A komerciālai lietošanai & IZM & $\begin{array}{l}\text { LM, KM, EM, VARAM, VM, reǵistrētās } \\
\text { pētniecības institūcijas }\end{array}$ & $3250000^{1}$ \\
\hline 6.2. Atbalsts jaunajiem produktiem un tehnoloǵijām & EM & LIAA & $124000000^{1}$ \\
\hline 7.1. Latvijas centralizētas IKT drošības un prevencijas platformas izstrāde & CERT.LV/AM & Valsts pārvaldes iestādes & 515530 \\
\hline 7.2. Elektroniska ziņošana par nelegālu un kaitīgu saturu internetā & CERT.LV/AM & LIA & 184200 \\
\hline 7.3. Sabiedrības informētības par IKT drošību uzlabošana & VARAM & CERT.LV, AM & 4035294 \\
\hline $\begin{array}{l}\text { 7.4. Sabiedrības informētības uzlabošana par riskiem un apdraudējumiem } \\
\text { internetā }\end{array}$ & VARAM & CERT. LV/AM, LM, VBTAI & 208200 \\
\hline $\begin{array}{l}\text { 7.5. Palīdzības līnija bērniem un jauniešiem, kas saskārušies ar kaitīgu saturu } \\
\text { internetā }\end{array}$ & LM & VBTAI & 220200 \\
\hline 7.6. Sabiedrības informētības uzlabošana par personas datu drošību & $\mathrm{TM}$ & CERT.LV, DVI, VARAM & 53400 \\
\hline $\begin{array}{l}\text { 7.7. Valsts pārvaldes iestāžu informēšana par nepieciešamību nodrošināt } \\
\text { personas datu apstrādes drošīibu interneta vidē }\end{array}$ & TM & CERT.LV, DVI, VARAM & 12000 \\
\hline 7.8. Darbību ar personas datiem augsta līmeņa aizsardzības nodrošināšana & DVI & .. & 629778 \\
\hline 7.9. 112 zvanu platformas modernizācija & IM & VARAM & 8800000 \\
\hline
\end{tabular}

1. Tikai dal̦a izdevumu attiecas uz INFSO 2014-2020 pasākumiem.

Piezīme: .. = nav pieejams. 2014. gada 1. janvārī LVL (Latvijas lats) nomainīja eiro, 1 LVL = EUR 1,42288. Tikai daži no izdevumiem, kas apzīmēti ar “*”, attiecas uz ISAP 2014.-2020. pasākumiem. TA: Tiesu administrācija; CERT.LV: Latvijas Informācijas tehnolog̣iju drošības incidentu novēršanas institūcija; KISC: Kultūras informācijas sistēmu centrs: PKC: Pārresoru koordinācijas centrs; DVI: Datu valsts inspekcija; IAP: Iekšējā audita padome; FEI: Fizikālās energētikas institūts; LVG̣MC: Latvijas Vides, ǵeoloǵijas un meteoroloǵijas centrs; LIA: Latvijas Interneta asociācija; LIAA: Latvijas Investīciju un attīstības ağentūra; LNB: Latvijas Nacionālā bibliotēka; VZD: Valsts Zemes dienests; LLU: Latvijas Lauksaimniecības universitāte; LM: Lauksaimniecības ministrija; KM: Kultūras ministrija; AM: Aizsardzibas ministrija; EM: Ekonomikas ministrija; IZM: Izglīīibas un zinātnes ministrija; VARAM: Vides aizsardzỉbas un reǵionālās attīstības ministrija; VM: Veselības ministrija; IM: Iekšlietu ministrija; TM: Tieslietu ministrija; SM: Satiksmes ministrija; LM: Labklājības ministrija; VISC: Valsts izglìtības satura centrs; UR: Latvijas Republikas Uzṇēmumu registrs; VK: Valsts kontrole; VTEB: Valsts tiesu ekspertǐ̌u birojs; Silava: Valsts meža pētniecības institūts; VBTAI: Valsts bērnu tiesību aizsardzības inspekcija; VZD: Valsts Zemes dienests; VRAA: Valsts reǵionālās attīstības aǵentūra.

Avots: Ministru kabinets (2013a), Informācijas sabiedrības attīstības pamatnostādnes 2014.-2020. - Informatīuā daḷa, Rīkojums Nr. 486, 14. oktobrī, www.varam.gov.lv/in_site/tools/download.php?file=files/text/Darb_jomas/elietas//Information_Society_Development_Guidelines_2014_2020.docx.

Pamatnostādṇu īstenošanas starpposma novērtējums tika veikts 2019. gada oktobrī (VARAM, 2019). Galīgo vērtējumu VARAM iesniegs Ministru kabinetam 2021. gada jūlijā.

ISAP starpposma vērtējumā secināts, ka digitālajai transformācijai nozīmīgākie aspekti ir cilvēkkapitāls un inovācija kopā ar digitālo risinājumu savstarpējo savietojamību. Lai gūtu ieguvumu, ir vēl vairāk 
jāuzlabo sinerǵijas starp valsts pārvaldi un privāto sektoru, uzlabojot esošo institucionālo struktūru un attīstot jaunu struktūru, kas reaǵē uz digitalizācijas radītajiem izaicinājumiem.

Šobrīd ir spēkā vairāki citi ar attīstību saistīti dokumenti, kuros bieži uzmanība pievērsta e-pārvaldes pakalpojumu uzlabošanai. To vidū ir Valsts informācijas un komunikācijas tehnoloǵiju pārvaldỉbas organizatoriskais modelis (Ministru kabinets, 2013b), Valsts pārvaldes informācijas sistēmu konceptuālā arhitektūra (Ministru kabinets, 2015), un informatīvie ziņojumi par mākoṇdatošanas pakalpojumu izmantošanu valsts pārvaldē (Ministru kabinets, 2018) un Latvijas Atvērto datu stratēǵija (Ministru kabinets, 2019) (4. nodaḷa), kā arī informatīvais ziṇojums par mākslīgā intelekta risinājumu attīstỉbu (Ministru kabinets, 2020a) un publisko pakalpojumu transformācijas rīcibas plānu (Ministru kabinets, 2020b).

Citos dokumentos, piemēram, Nākamās paaudzes platjoslas elektronisku sakaru tīklu attīstības koncepcijā 2013.-2020. gadam un Elektronisko komunikāciju politikas plānā 2018.-2020. gadam lielāka uzmanība koncentrēta uz IKT piekḷuvi un infrastruktūru (3. nodaḷa).

Papildu dokumenti ietver Intelektuālā īpašuma tiesību aizsardzỉbas un nodrošināšanas pamatnostādnes 2015.-2020. gadam un Latvijas kiberdrošības stratēǵiju 2014.-2018. gadam. Latvijas kiberdrošības stratēgijas pamatnostādnes (2019-2022) tika apstiprinātas 2019. gada septembrī (5. nodaḷa).

Latvijai šobrīd nav vispārējas stratēgeijas par uzṇēmējdarbības digitalizāciju. Taču ir Viedās specializācijas stratēǵija, kas ir saistīta ar Zinātnes, tehnolog̣iskās attīstības un inovācijas pamatnostādnēm 2014.2020. gadam (STDI) un Valsts industriālās politikas (NPI) pamatnostādnēm 2014.-2020. gadam. Pēdējā no dokumentiem mērḳis ir veicināt nozares modernizāciju (EK, 2018b). NPI pamatnostādnes tika publicētas 2012. gadā un citu starpā viens no to mērḳiem ir salāgot darbaspēka piedāvājumu un izglìtību ar ekonomikas attīstības vajadzībām un sekmēt atklātu, radošu un inovatīvu vidi (6. nodaḷa).

\section{Skaidri budžeta piešķ̄irumi digitālajai stratēgijai}

ISAP 2014.-2020. gadam ir iekḷauta informācija par izdevumiem, kas nepieciešami ìstenošanai (7.1. tabula), bet nav paredzēti nekādi budžeta piešķīrumi. Tāpēc Pamatnostādnes ir jāisteno ar katras ministrijas parasto budžetu. Tādējādi ministrijām tiek piešķirtas būtiskas pilnvaras attiecībā uz resursiem, kas tiek izmantoti pasākumiem, kas paredzēti Pamatnostādnēs, un to faktiskai îstenošanai.

Turklāt, speciāla budžeta ISAP 2014.-2020. gadam neesamība apgrūtina faktiskā resursu piešķīuma novērtējumu ex post. Šìs grūtības ir ilustrētas ISAP progresa vērtējumā, kas veikts 2019. gadā, kurā nav iekḷauta informācija par faktiskajiem atbildīgo ministriju izdevumiem Pamatnostādnēs paredzētajiem pasākumiem.

Grūti nosakāms, kādi resursi ir piešḳirti Pamatnostādṇu īstenošanai centrālajā valdības budžetā. Piemēram, atbilstoši ISAP 2014.-2020. gadam Ekonomikas ministrijai (EM) būtu jāpiešḳir daḷa no 2014.2020. gada budžeta darbinieku apmācībai (EUR 21,4 milj.) un jānodrošina atbalsts jauniem produktiem un tehnoloǵijām (EUR 176,4 milj.) saistībā ar digitālo tehnoloǵiju pien,emšanu un prasmēm. EM budžetā šie pasākumi ir iekḷauti galvenokārt pie Eiropas Reǵionālās attīstības fonda (ERAF) finansējuma, kur kopējais budžets 2018.-2020. gadam ir mazāks par EUR 50 miljoniem. Turklāt nav norādīts faktiskais resursu daudzums, kas pieškirts politikai digitālo tehnoloǵiju ieviešanai.

Tāpat arī EUR 57,4 miljoni būtu jāparedz pasākumam "Ergonomiski iekārtojumi un IKT risinājumi reg̣ionālajās vidusskolās"; kas ir viens no lielākajiem plānotajiem izdevumiem Pamatnostādnēs. Lai gan vietējām pārvaldēm tika uzdota 44 projektu īstenošana šĩ pasākuma ietvaros, šķiet, ka izdevumi IKT risinājumiem (EUR 23 miljoni) ir būtiski mazāki par ISAP 2014.-2020. gadam plānotajiem.

Šḳiet, ka Latvijā izstrādāto nozaru pamatnostādṇu lielais skaits veido šḳērsli, lai nodrošinātu skaidru politikas iniciatīvu un budžeta piešķīrumu saskan,ošanu. Lai gan šajās pamatnostādnēs ir atbalstīta ministriju un aǵentūru sadarbība konkrētās politikas jomās, to daudzskaitlīgums noved pie pasākumu pārklāšanās vairākās pamatnostādnēs.

Turklāt, lai gan par katrām no vadlīnijām atbilstošās ministrijas ir atbildīgas par to īstenošanu, škiet, ka nozaru ministriju atbildība ir mazāka, mazinot to motivāciju ìstenot pamatnostādnes (ESAO, 2018). Tas palīdz izskaidrot, kāpēc Latvija ir panākusi labāku progresu pasākumos, kas saistīti ar e-pārvaldi, jo VARAM ir atbildīga gan par ISAP 2014-2020. gadam, gan e-pārvaldes politiku. 
Šîs problēmas ir atzītas dokumentā Latvija 2030: "Ir izveidots liels skaits - vairāki simti - attīstības plānošanas dokumentu. Attīstības plānošanas sistēma ir vāji saistīta ar budžeta procesu, un tai trūkst vidēja termiṇa un ilgtermiņa novērtējuma. Spēcīga nozaru perspektīva politiku veidošanā un īstenošanā ir vēl viens sarežǵijumu avots." Ilgtspējīgas attīstības stratēǵija bija paredzēta kā vienots dokuments, kas kopā ar pārvaldes model̦a izmaiṇām risinātu šìs problēmas. Taču formāla Ilgtspējīgas attīstības stratēǵijā un atsevišķ ki NAP noteikto mērķu ievērošana, pastāvīga spriedze nozaru pamatnostādṇu starpā saglabājas kā nopietns šḳērslis politikas veidošanai Latvijā.

\section{Spēcīgāks koordinācijas mehānisms valdības ietvaros}

Lai palielinātu valdības apṇemšanos īstenot digitālo darba kārtību, šḳiet, ir nepieciešami trīs soḷi. Pirmais no tiem ir virzīt digitālās transformācijas politiku kā prioritāru politikas darba kārtībā. Tas nozīmē, ka digitālās transformācijas mērḳiem būtu jābūt nozīmīgākai lomai Ilgtspējīgas attīstības stratēgijā un Nacionālās attīstības plānos. Kā norādìts iepriekš, šajos dokumentos ir paredzēta digitālās transformācijas politika, bet nav sniegta pietiekami precīza informācija par tās raksturu un mērogu. Lai gan laikposmam no 2021. līdz 2027. gadam tiek izstrādāts jauns NAP ar iespēju stiprināt digitālās transformācijas politikas lomu, Ilgtspējīgas attīstības stratēǵija darbosies līdz 2030. gadam. Tāpēc valdībai vajadzētu izpētīt iespēju pārskatīt stratēǵiju ar mērḳi paredzēt spēcīgāku un skaidrāku apṇemšanos ìstenot digitālās transformācijas politiku.

Otrais solis ir noteikt skaidrus budžeta piešķīrumus Informācijas sabiedrības attīstības pamatnostādnēm nākamajam plānošanas periodam. Lai gan šḳiet piemēroti uzticēt šo pamatnostādṇu īstenošanu katrai ministrijai, kam būs labāka informācija par nozarēm tās kompetencē, ir nepieciešams noteikt skaidrākus budžeta piešķīrumus un skaidrākas izdevumu saistības ministrijas līmenī. Tas palielinātu caurskatāmību saistībā ar Pamatnostādṇu mērḳiem, kalpotu kā spēcīgs signāls, apstiprinot valdības apṇemšanos, un stiprinātu pasākumu politisko ticamību. Lielāka caurskatāmība atvieglotu arì Pamatnostādṇu īstenošanu.

Noslēgumā, ir svarīgi izveidot institucionālus mehānismus, lai koordinētu digitālās transformācijas politiku valdības lìmenī. Informācijas sabiedrības attīstības pamatnostādṇu vadība, izstrāde un pārvaldība ir sadalīta starp vairākām ministrijām, tostarp VARAM, EM, SM un IZM. Formālas, kopīgas valdības līmeña pieejas trūkums kavē Latvijas digitālās transformācijas darba kārtības kopējo efektivitāti.

ISAP 2014.-2020. gadam progresa novērtējumā nonākts pie līdzīga secinājuma, aicinot veikt līdzsvarotu digitalizācijas politikas integrāciju nozaru politikās, piešķirot pietiekamus līdzekḷus koordinācijai, atbilstošu finansējumu, lai sasniegtu noteiktos mērķus un ambiciozos, taču sasniedzamos indikatorus.

ESAO valstīs tiek izmantoti dažādi nacionālo digitālo stratēǵiju pārvaldības modeḷi (7.2. tabula). Daži no tiem ir balstīti uz īpašu ministriju vai iestādi; citos paredzēta nacionālās digitālās stratēgijas koordinācija kāda ministra vai iestādes portfelī. Nelielā skaitā valstu par koordināciju ir atbildīgas vairākas ministrijas, vai tā notiek augstākajā valdības līmenī (t.i. Premjerministra birojs, prezidentūra vai kanceleja).

7.2. tabula. Nacionālo digitālo stratēgiju pārvaldība ESAO valstīs

Valstu skaits

\begin{tabular}{lcccc}
\hline Atbildīgā iestāde & Koordinācija & Īstenošana & Uzraudzība & Vērtēšana \\
\hline Premjerministra birojs, prezidentūra vai kanceleja & 5 & 0 & 3 & 4 \\
\hline İpaša ministrija vai iestāde šim nolūkam & 12 & 8 & 12 & 10 \\
Ministrija vai iestāde, kas nav paredzēta tikai šim nolūkam & 14 & 4 & 12 & 8 \\
\hline Vairākas ministrijas vai iestādes & 6 & 24 & 8 \\
\hline
\end{tabular}

Piezīme: Dati ir balstīti uz 33 valstu atbildēm uz aptaujas jautājumiem. Katras atbildības summa var pārsniegt valstu skaitu (33), ja atbildība noteikta vairāk nekā vienai iestādei.

Avots: ESAO (2019b), Going Digital: Shaping Policies, Improving Lives, https://doi.org/10.1787/9789264312012-en.

Lai gan iepriekš minētajiem modeḷiem piemīt gan stiprās, gan vājās puses, ir būtiski, lai iestādei, kas atbildīga par digitālās stratēgijas koordināciju ir gan pietiekama politiskā ietekme, gan atbilstoši resursi sava mandāta izpildei. 
Šḳiet, ka premjerministra biedrs ir piemērots kandidāts digitālās transformācijas politiku Latvijā koordinatora lomai. Premjerministra biedrs, ko iecel Ministru kabinets, ir atbildīgs par valdības Nacionālās attīstības plānu un tās saskaṇotību ar Ilgtspējīgas attīstības stratēgiju, kā arī budžeta procesu. Pildot amata pienākumus, šì persona var palīdzēt nodrošināt, ka digitālās transformācijas politikai tiek piešḳirta augsta līmeṇa prioritāte politikas darba kārtībā.

Digitālās ekonomikas stratēǵijas koordinācijā atbalstu varētu sniegt Pārresoru koordinācijas centrs (PKC). PKC ir vadošā iestāde attiecībā uz nacionālās attīstības plānošanu un koordināciju Latvijā. Atrodoties premjerministra tiešā pakḷautībā, PKC atbild par Ilgtspējīgas attīstības stratēgijas un Nacionālā attīstības plāna izstrādi un uzraudzību. Tas veic arī analìtiskos uzdevumus, ko uzdevis premjerministrs un Premjerministra birojs, tostarp sniedz palīdzību valdības deklarācijas un rīcības plāna sagatavošanā.

Kā Latvijas digitālās ekonomikas stratēǵijas koordinatoram premjerministra biedram vajadzētu būt arī viṇa pārvaldībā esošam budžetam, ko izmantot, lai finansētu politikas atbilstoši valdības noteiktajiem mērḳiem, ko īsteno saskaņoti ar divām vai vairākām iestādēm: ministrijām, ag̉entūrām vai vietējām pārvaldēm. Lai gan nozaru ministri saglabātu atbildību un budžeta piešķīumus digitālās transformācijas politikas īstenošanai attiecīgajā nozarē, šāds budžets sniegtu motivāciju iestāžu sadarbībai. Piemēram, premjerministra biedrs varētu piešḳirt papildu līdzekḷus (t.i. zināma veida koordinācijas prēmiju) politikām, kas īstenotas vairāku ministriju koordinētā darbībā.

Šādi budžeta piešḳīumi parasti būtu atbilstošas dotācijas formā (t.i. dotācija, kas ir jāizmanto konkrētam nolūkam un kura pieškiršanas nosacījums ir papildu resursi no saṇēmējām iestādēm).

Budžetam nebūtu nepieciešami papildu resursi, bet piešḳīumu, kas šobrīd piešķirti digitalizācijas politikām dažādās valdības centrālā budžeta sadaḷās, pārdale. Kā norādīts iepriekš, šì koordinācijas mehānisma izveidošanas priekšnosacījums ir skaidrāka budžeta sadale.

\section{1. ielikums. Politikas rekomendācijas valsts pārvaldes kopējai pieejai}

Lai palīdzētu nodrošināt saskaņotu un koordinētu visas valsts pārvaldes pieeju digitālās transformācijas politikām Latvijā, pārvaldei vajadzētu:

- Virzīt digitālās transformācijas politiku kā prioritāru politikas darba kārtỉbā

- Noteikt skaidrus budžeta pieškīrumus Informācijas sabiedrības attīstỉbas pamatnostādnēm

- Institucionalizēt digitālās transformācijas politiku koordinācijas mehānismu (piem., piešḳirot koordinatora funkcijas premjerministra biedram). 


\section{DIGITĀLĀS TRANSFORMĀCIJAS POLITIKAS}

\section{Atsauces un Piezimes}

\section{Atsauces}

ESAO (2019) Digitalizācija: Politikas veidošana, dzīves uzlabošana [Going Digital: Shaping Policies, Improving Lives], OECD Publishing, Parīe, https://doi.org/10.1787/9789264312012-en.

ESAO (2018), Uznēmumu piekl̦uve tiesiskumam un iekḷaujoša izaugsme Latvijā [Access to Justice for Business and Inclusive Growth in Latvia], OECD Publishing, Parize, https://doi.org/10.1787/9789264303416-en.

ESAO (2016), Patērētāju aizsardzība e-komercijā: ESAO rekomendācijas [Consumer Protection in E-commerce: OECD Recommendation], OECD, Parize, www.oecd.org/sti/consumer/ECommerce- Recommendation-2016.pdf.

Ministru kabinets (2020a), Informatīvais ziṇojums "Par mākslīgā intelekta risinājumu attīstību", Rīga, http://tap.mk.gov.lv/ doc/2020_02/IZ_MI\%5b1\%5d.2.docx.

Ministru kabinets (2020b), Sabiedrisko pakalpojumu transformācijas rīcības plāns, Rīga.

Ministru kabinets (2019), Latvijas atvērto datu stratēǵija, [Latvia's Open Data Strategy], 20. augusts, Rīga, http://polsis.mk.gou.lv/ documents/6533.

Ministru kabinets (2018), Informatīuais ziņojums “Mākoṇdatošanas pakalpojumu izmantošana valsts pārvaldē” [Using Cloud Computing Services in Public Administration], 20. februāris, Rīga, http://polsis.mk.gov.lv/documents/6140.

Ministru kabinets (2015), Valsts pārvaldes informācijas sistēmu konceptuālā infrastruktūra [Conceptual Architecture of Public Administration Information Systems], 10. marts, Rīga.

Ministru kabinets (2013a), Informācijas sabiedrības attīstības pamatnostādnes 2014.-2020. - Informatīvā daḷa, [Information Society Development Guidelines 2014-2020 - Informative Part], Rīkojums Nr. 486, 14. oktobrī, Rīga, www.varam.gov.lv/in_site/tools/ download.php?file=files/text/Darb_jomas/elietas//Information_Society_Development_Guidelines_2014_2020.docx.

Ministru kabinets (2013b), Valsts informācijas un komunikācijas tehnologiiju pārvaldības organizatoriskais modelis [Concept of the Organisational Model of Public ICT Management], Rīkojums Nr. 57, Rīga, 15. janvāris, www.varam.gov.lv/in_site/tools/download. php?file=files/text/Darb_jomas/elietas//E2269_Organisational_Model_for_the_Management_of_Public_Infor_and_Com_Techn.doc.

PKC (2012), Latvijas Nacionālais attīstības plāns, Pārresoru koordinācijas centrs [National Development Plan of Latvia 2014-2020, Cross-Sectoral Coordination Centre], Rīga, www.pkc.gov.lv/images/ NAP2020\%20dokumenti/NDP2020_English_Final.pdf.

SAEIMA (2010), Latvijas ilgtspējīgas attīstības stratēgija līdz 2030. gadam, [Sustainable Development Strategy of Latvia until 2030], Rīga, www.varam.gou.lv/in_site/tools/download.php?file=files/text/dokumenti/pol_doc//LIAS_2030_parluks_en.pdf.

VARAM (2019), Informācijas sabiedrības attīstības pamatnostādṇu 2014.-2020. gadam 2. starpposma vērtējums [2nd Interim Evaluation of the Information Society Development Guidelines 2014-2020, Vides aizsardzības un reǵionālās attīstības ministrija, Rīga, http://polsis.mk.gou.lv/api/file/file7299860066764117769.pdf. 


\section{Attēli}

Nodal̦a 1 LATVIJA DIGITĀLAJĀ TRANSFORMĀCIJĀ: IESPĒJAS UN IZAICINĀJUMI

1.1. Darbaspēka produktivitāte Latvijā un atlasītajās ESAO valstīs, 2000.-2019. gads

1.2. Uzṇēmējdarbības pētniecỉba un attīstība informācijas nozarēs Latvijā un atlasītajās ESAO valstīs, 2016

1.3. Nodarbinātie IKT speciālisti Eiropas Savienībā, 2018 .

1.4. Personas, kuras dzīvo nabadzīgās mājsaimniecībās Latvijā un ESAO valstīs, 2017.

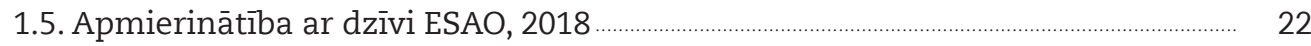

1.6. Digitalizācijas integrētās politikas satvars …....................................................................... 24

\section{Nodaḷa 3 INFRASTRUKTŪRAS LATVIJAS DIGITĀLAJAI EKONOMIKAI}

3.1. Mobilās platjoslas abonenti uz 100 iedzìvotājiem pēc ESAO valstīs, 2019. gada jūnijs.

3.2. Fiksētās platjoslas abonenti uz 100 iedzìvotājiem pēc ESAO valstīs, 2019. gada jūnijs

3.3. Optiskās šḳiedras savienojumu procentuālā daḷa kopējā fiksētajā platjoslā ESAO valstīs, 2015. gada 2. ceturksnis - 2019. gada 2. ceturksnis

3.4. Fiksētās platjoslas abonenti Latvijā pēc tehnolog̣ijas, 2015. gada - 2019. gada 2. ceturksnis

3.5. Fiksētās platjoslas abonenti Rīgā un ārpus tās pēc tehnoloǵijas, 2018. gads .... 58

3.6. Fiksēto platjoslas savienojumu pieredzētie lejupielādes caurmēra ātrumi ESAO valstīs, 2019. gada jūlijs.

3.7. Fiksētās platjoslas abonenti uz 100 iedzìvotājiem ESAO valstīs, pēc ātruma lìmeniem, 2019. gada jūnijs

3.8. Procentuālie rādìtāji par mājsaimniecībām kopumā un lauku teritorijām ar fiksēto platjoslas pārklājumu vismaz $30 \mathrm{Mb} / \mathrm{s}$ ESAO valstīs, 2018. gada jūnijs .

3.9. Mājsaimniecỉbu ar LTE mobilo pārklājumu procentuālais rādītājs kopumā un lauku, 2018. gada jūnijs

3.10. Fiksēto sakaru platjoslas cenu tendences Latvijā un ESAO valstīs, 2013. gada jūnijs - 2019. gada decembris

3.11. Mobilo sakaru platjoslas cenu tendences Latvijā un ESAO valstīs, 2013. gada maijs - 2019. gada novembris

3.12. Mobilo datu lietojums uz mobilo sakaru platjoslas abonentu atsevišḳās ESAO valstīs, 2016.-2018 gads

3.13. M2M/integrētie šūnu mobilo sakaru abonenti atsevišķās ESAO valstīs, 2019. gada jūnijs

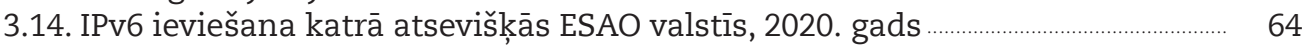

3.15. Sakaru ieñēmumu un ieguldỉjumu tendences Latvijāa , 2010-18 ............................. 64

3.16. Fiksētaās platjoslas tirgus daḷas Latvijā, 2010. un 2018. g........................................ 66

3.17. Mobilo sakaru platjoslas tirgus dala, 2010. un 2018. g. ..................................... 66

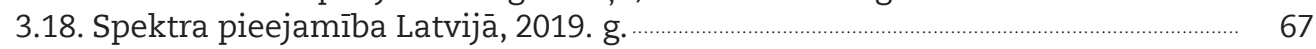

3.19. Klienti, kuri abonē pakalpojumu komplektus Latvijā, 2018. g. ……………........ 69

\section{Nodaḷa 4 DIGITĀLĀS TRANSFORMĀCIJAS ATBALSTİ̌̌ANA STARP CILVĒKIEM, UZN̦ĒMUMIEM UN VALDĪBU}

4.1. Interneta lietotāji pēc izglìiības līmeṇa ESAO valstīs, 2018. gadā vai gadā, par kuru pēdējo pieejami dati.

4.2. Interneta lietotāji pēc kategorijas ESAO valstīs, 2018. gadā vai gadā, par kuru pēdējo pieejami dati.

4.3. Interneta lietotāju tendences Latvijā un atlasītajās ESAO valstīs, 2005.-2018.... 
4.4. Interneta lietotāju tendences pa kategorijām Latvijā, 2005.-2018.

4.5. Interneta piekḷuve mājās ESAO valstīs, 2018 .................................................... 84

4.6. Iemesli piekḷuvei internetam mājās neesamībai Latvijā, 2018 ……………............... 85

4.7. Lauku unpilsētas plaisa attiecībā uz piekḷuvi platjoslas pakalpojumiem Latvijā un atlasītajās ESAO valstīs, 2018.

4.8. Individuālie interneta lietotāji Latvijā, 2017. gadā vai gadā, par kuru pēdējo pieejami dati

4.9. Tiešsaistes pirkumi Latvijā un atlasītajās ESAO valstīs, 2018

4.10. Pamata vai augstākas par pamata digitālās prasmes Latvijā un atlasītajās ESAO valstīs, pēc dzimuma, 2017.

4.11. Plaisa starp laukiem un pilsētu attiecībā uz digitālajām prasmēm Latvijā un atlasītajās ESAO valstīs, 2017.

4.12. Uzṇēmumu pieslēgumi fiksētiem platjoslas pakalpojumiem Latvijā un atlasītajās ESAO valstīs, 2018. gadā vai gadā, par kuru pēdējo pieejami dati.

4.13. Interneta lietošana pēc atlasītajās ESAO valstīs, 2018. gadā vai gad̄ā, par kuru pēdējo pieejami dati

4.14. Apgrozìjums no tirdzniecības internetā Latvijā un atlasītajās ESAO valstīs, 2017.

4.15. Moderno digitālo tehnoloǵiju lietošana atlasītajās ESAO valstīs, 2017. gadā vai gadā, par kuru pēdējo pieejami dati

4.16. Nodarbinātība pēc uzṇēmuma lieluma Latvijā un atlasītajās ESAO valstīs, 2016

4.17. Moderno digitālo tehnologiju izmantošana pēc uzṇēmuma lieluma Latvijā un atlasītajās ESAO valstīs, 2017 ...

4.18. Paḷaušanās uz profesionālu pārvaldību un atlasītajās ESAO valstīs, 2017.-2018.

4.19. Prasmju nepietiekamība Latvijā, 2017

4.20. Pieaugušo ar augstāko izglītību ienākumi ESAO pēc studiju jomas, 2017

4.21. Uzṇēmumi, kas sastopas ar grūtībām noalgot IKT speciālistus, Latvijā un atlasītajās ESAO valstīs, 2019...

4.22. Kopējais augstākās IKT izglītības absolventu skaits Latvijā, 2013.-2017...

4.23. Uzṇēmumi, kas nodrošina IKT apmācības saviem darbiniekiem, Latvijā un atlasītās ESAO valstīs, 2012. un 2018. gads

4.24. Pieṇemšana darbā tiešsaistē pēc nodarbinātības grupas Latvijā un atlasītajās ESAO valstīs, 2018

4.25. Tiešsaistes pakalpojumu lietošanas tendences Eiropas Savienībā, 2010.-2019. gads

4.26. Personas, kas pierakstījās vizītē pie veselības aprūpes speciālista tiešsaistē, Latvijā un atlasītajās ESAO valstīs, 2012. un 2018. gads ........................ 111

4.27. Noderīgu atkārtoti izmantojamu datu atvēršanas (OURdata) indekss 2019 .... 114

\section{Nodaḷa 5 UZTICAMĪBAS VEICINĀŠANA DIGITĀLAJAI EKONOMIKAI}

5.1. Izplatītākie l̦aunprātīgā koda uzbrukumi Latvijā, 2018. gads ……........................ 124

5.2. Izplatītākie l̦aunprātīgā koda uzbrukumi Latvijā, 2020. gadā (1. cet.) ….................. 125

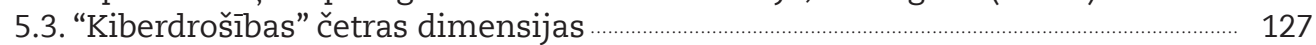

5.4. Digitālās drošības vadības struktūra Latvijā (2019.-2022. g.) ……............................. 128

5.5. Digitālās drošības politika Latvijā ................................................................. 130

5.6. Digitālās drošības pārvaldības struktūra Igaunijā .......................................................... 131

5.7. Ziṇotie personas datu pārkāpumi Latvijā ...................................................................... 143

\section{Nodaḷa 6 EKONOMIKAS UN SABIEDRĪBAS DIGITĀLĀS PĀRVEIDES IESPĒJU IZMANTOŠANA}

6.1. Produktivitātes atšḳirības atlasītajās ESAO valstīs, 2017. gads

6.2. Uzṇēmumu izdevumi pētniecỉbai un izstrādei Latvijā un atlasītajās

ESAO valstīs, 2018. gads

6.3. Inovatīvi MVU Latvijā un atlasītajās ESAO valstīs, 2014.-2016. gads ...................... 161

6.4. Patentu pieteikumi Eiropas Patentu birojam, 2017. gads …............................................ 162 
6.5. Pētnieki un jaunie doktora grāda ieguvēji Latvijā un atlasītajās ESAO valstīs, 2018. gads

6.6. Doktora grāda ieguvēji IKT jomā Latvijā un atlasītajās ESAO valstīs, 2013.-2017. gads

6.7. Tie 10 \% zinātnisko publikāciju, kas datorzinātnē tiek citētas visbiežāk atsevišḳās ESAO valstīs, 2018. gads

6.8. No starptautiskās sadarbības izrietošās zinātniskās publikācijas atlasītajās ESAO valstīs, 2018. gads

6.9. Valdỉbas finansējums un nodokḷu atbalsts uzṇēmumu pētniecībai un izstrādei Latvijā un atlasītajās ESAO valstīs, 2017. gads

6.10. MVU, kas inovācijas darbībās sadarbojas ar augstākās izglītỉbas vai valdības iestādēm atlasītajās ESAO valstīs, 2014.-2016. gads.

6.11. Uzṇēmumi, kas apgalvo, ka finansējuma pieejamība ir būtisks šḳērslis ilgtermiña investīcijām, 2018. gads

6.12. Bioekonomikas pienesums ražošanas pievienotajā vērtībā, 2010. un 2017. gads

6.13. Latvijas redzamā salīdzinošā priekšrocība, 2005. un 2015. gads

6.14. Mežsaimniecības produktu pievienotā vērtỉba Latvijā un atlasītajās ESAO valstīs

6.15. Pētniecības un izstrādes izdevumi pa nozarēm Latvijā salīdzinājumā ar ESAO valstīm, 2015. gads

6.16. Latvijas pētniecības un izstrādes izdevumi dabaszinātnēs un inženierzinātnēs katrā nozarēe

6.17. Latvijas eksports augsto tehnolog̣iju un vidēji augsto tehnologiju produktu jomā, 2010. un 2018. gads

6.18. Latvijas publikācijas tajos $10 \%$ dokumentu, kas citēti visbiežāk

6.19. Latvijas publikācijas tajos $10 \%$ dokumentu, kas visbiežāk citēti materiālzinātnēs un inženierzinātnēs

6.20. 3D printeru izmantošana ražošanai uzṇēmumos Latvijā un atlasītajās ESAO valstīs, 2018. gads

6.21. Latvijas publikācijas tajos 10 \% dokumentu, kas citēti visbiežāk viedās enerǵētikas jomā

6.22. Rūpnieciskās elektroenerǵijas cenas Latvijā un atlasītajās ESAO valstīs, 2017. gads

6.23. IKT pakalpojumu eksports no Latvijas un atlasītajās ESAO valstīs, 2010.-2015. gads

6.24. Latvijas publikācijas tajos $10 \%$ dokumentu, kas visbiežāk citēti datorzinātnē, elektroniskajā inženierijā un saistītās jomās.

\section{Nodaḷa 7 DIGITĀLĀS TRANSFORMĀCIJAS POLITIKAS: REKOMENDĀCIJAS VALDİBAS KOPËJAI PIEEJAI}

7.1. Digitalizācijas integrētās politikas satvars

7.2. Latvijas nacionālais attīstības plāns 219

\section{Tabulas}

Nodal̦a 1 LATVIJA DIGITĀLAJĀ TRANSFORMĀCIJĀ: IESPĒJAS UN IZAICINĀJUMI

1.1. Informācijas sabiedrības attīstības pamatnostādnes

2014.-2020. gadam: Darbibas virzieni.

\section{Nodal̦a 3 INFRASTRUKTŪRAS LATVIJAS DIGITĀLAJAI EKONOMIKAI}

3.1. Valstu mērḳi attiecībā uz platjoslas pārklājumu ESAO ............................................ 54

3.2. Latvijas sakaru tirgu galvenie dalībnieki .................................................................... 65

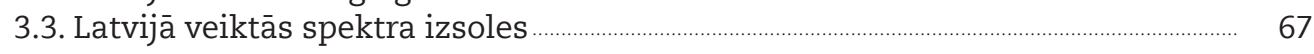


Nodaḷa 4 DIGITĀLĀS TRANSFORMĀCIJAS ATBALSTİ̌̌ANA STARP CILVĒKIEM, UZNĒMUMIEM UN VALDĪBU

4.1. Vairāk valdības datu ir kḷuvuši publiski pieejami .

Nodal̦a 5 UZTICAMĪBAS VEICINĀŠANA DIGITĀLAJAI EKONOMIKAI

5.1. Administratīvo pārkāpumu lietās pieṇemtie lēmumi ........................................ 141

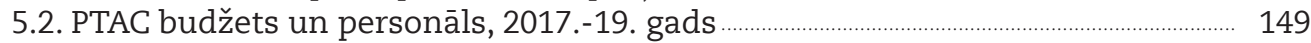

5.3. PTAC saṇemtās un atrisinātās patērētāju sūdzības laikā,

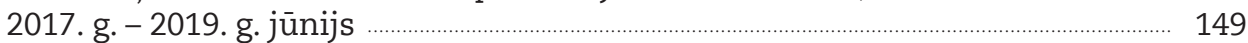

5.4. Ar e-komerciju saistìtās sūdzības, 2017. g. - 2019. g. jūnijs …............................... 149

5.5. Oficiālās patērētāju sūdzības par negodīgu komercpraksi laikā

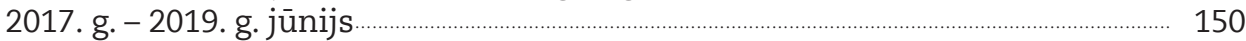

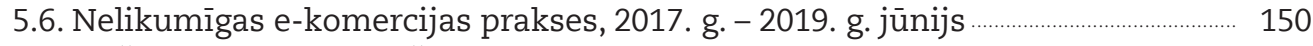

5.7. Iekšzemes un pārrobežu patērētāju strīdi ........................................................................... 153

Nodaḷa 6 EKONOMIKAS UN SABIEDRĪBAS DIGITĀLĀS PĀRVEIDES IESPĒJU IZMANTOŠANA

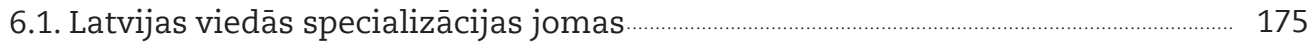

6.2. Finansējuma instrumenti viedajai specializācijai 2014.-2018. gads …................. 176

6.3. Viedā specializācija: Kompetenču centri un klasteri ................................................ 176

6.4. Atbalsts IKT neatbilst citu viedās specializācijas jomu vajadzībām ...................... 203

Nodaḷa 7 DIGITĀLĀS TRANSFORMĀCIJAS POLITIKAS: REKOMENDĀCIJAS VALDİBAS KOPĒJAI PIEEJAI

7.1. Informācijas sabiedrības attīstības pamatnostādnes

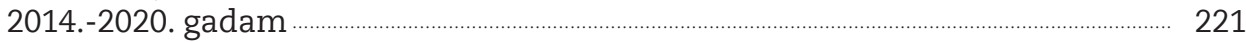

7.2. Nacionālo digitālo stratēǵiju pārvaldība ESAO valstīs ............................................... 224

\section{Ielikumi}

\section{Nodaḷa 2 GALVENĀS NĀKOTNES NENOTEIKTİBAS DIGITĀLAJĀ TRANSFORMĀCIJĀ UN POTENCIĀLĀS SEKAS LATVIJAI}

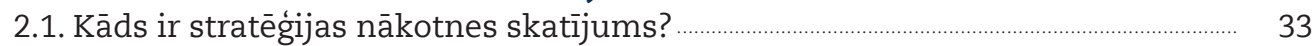

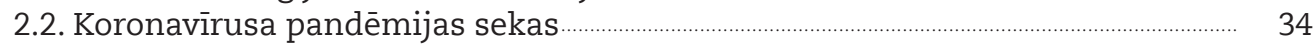

Nodal̦a 3 INFRASTRUKTŪRAS LATVIJAS DIGITĀLAJAI EKONOMIKAI

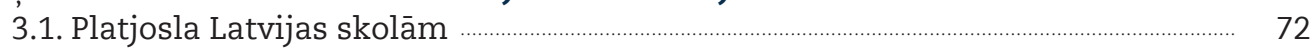

3.2. Politikas ieteikumi

\section{Nodaḷa 4 DIGITĀLĀS TRANSFORMĀCIJAS ATBALSTİ̌̌ANA STARP CILVĒKIEM,} UZN̦ĒMUMIEM UN VALDİBU

4.1. Attālinātā mācīšanās COVID-19 pandēmijas laikā.

4.2. Austrālija un Norvēgija izvēlas kopienā balstītas pieejas, lai veicinātu digitālo pratību pieaugušo vidū.

4.3. Pieejams plašs atbalsta pasākumu klāsts, lai palīdzētu uzṇēmumiem kḷūt digitāliem.

\section{,}

4.4. Digitālajai transformācijai ir nepieciešama plaša prasmju kombinācija ................

4.5. Izmaiṇas izglītības un apmācību sistēmā, sekojot izmaiṇām ekonomikā .......... 105

4.6. Vācija un Apvienotā Karaliste izmanto vienkāršotas procedūras IKT speciālistu nodarbināšanai no ārvalstīm ........................................................................... 106

4.7. Latvijas Informācijas sabiedrības attīstības pamatnostādnes ................................... 108

4.8. Nepieciešams noteikt skaidrus noteikumus, lai veicinātu medicīnas datu koplietošanu. 


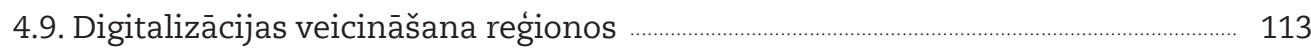

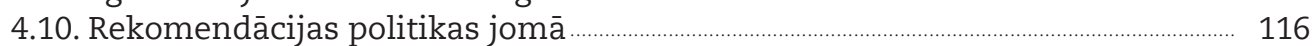

\section{Nodal̦a 5 UZTICAMĪBAS VEICINĀŠANA DIGITĀLAJAI EKONOMIKAI}

5.1. ESAO rekomendācijas par digitālās drošības risku pārvaldību

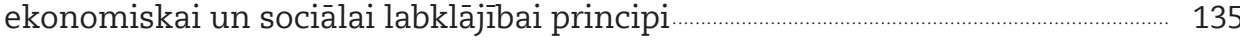

5.2. Politikas ieteikumi................................................................................................... 137

5.3. Latvijas DVI galvenās regulatīvās pilnvaras un darbības saskaṇā ar FPDAL ....... 140

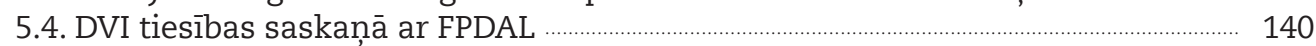

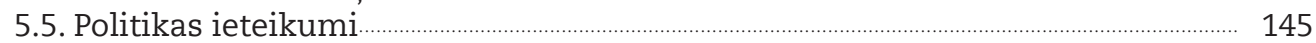

5.6. Digitālo patērētāju aizsardzības vispārīgie principi …................................................ 147

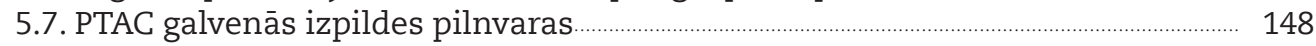

5.8. ESAO ieteikumi Latvijai par patērētāju aizsardzības uzlabošanu ............................ 155

Nodaḷa 6 EKONOMIKAS UN SABIEDRĪBAS DIGITĀLĀS PĀRVEIDES IESPĒJU IZMANTOŠANA

6.1. Zinātnes, tehnologiju attīstības un inovācijas pamatnostādṇu īstenošana ........ 165

6.2. Zviedrijas inovāciju stratēǵija ................................................................................................ 165

6.3. Dažādas pieejas, kas izmantotas pētniecības un izstrādes veicināšanai ............. 167

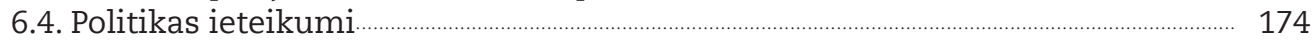

6.5. Viedā specializācija: Visaptveroši ieteikumi ................................................................. 177

6.6. Flandrijas Tehnoloğiju pārneses biroji (TPB) …................................................................... 182

6.7. Izaugsmes potenciāls: lielie dati labākai lauksaimniecības

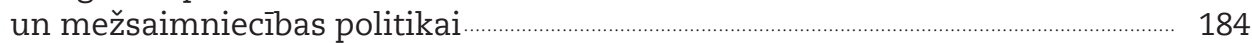

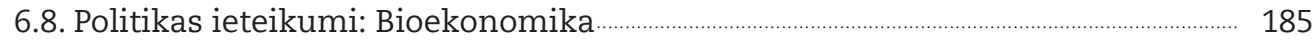

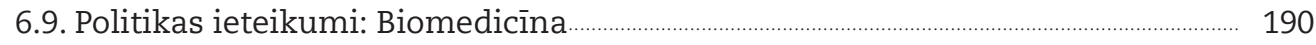

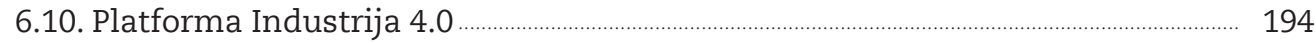

6.11. Politikas ieteikumi: Viedie materiāli un inženierzinātnes ....................................... 195

6.12. Digitalizācijas pienesuma palielināšana nākotnes viedajās pilsētās ................... 200

6.13. Politikas ieteikumi: Viedā enerǵija ..................................................................... 201

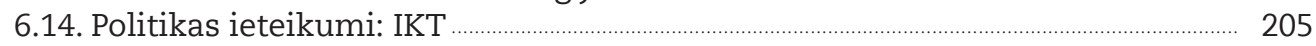

\section{Nodala 7 DIGITĀLĀS TRANSFORMĀCIJAS POLITIKAS: REKOMENDĀCIJAS VALDĪBAS KOPĒJAI PIEEJAI}

7.1. Politikas rekomendācijas valsts pārvaldes kopējai pieejai. 


\section{ESAO pārskati par digitālo transformāciju Digitalizācija Latvijā}

Digitalizācija Latvijā analizē jaunākās attīstības tendences Latvijas digitālajā ekonomikā, pārskata ar digitalizāciju saistītās politikas un sniedz ieteikumus par politikas saskaņotības palielināšanu šajā jomā, pamatojoties uz ESAO Going Digital integrētās politikas struktūru.

Pārskatā tiek izmantots stratēǵiska perspektīva, lai izpētītu trīs alternatīvus nākotnes scenārijus, kas var izveidoties globālās ekonomikas un sabiedrības digitālās transformācijas rezultātā. Tajā tiek pētīta arī sakaru tīklu un pakalpojumu pieejamība Latvijā, kā arī saistītās politikas un regulējumi. Turklāt pārskatā tiek aplūkotas fizisku personu, uzņēmumu un valdības tendences digitālās tehnoloǵijas izmantošanas jomā, kā arī izpētītas politikas, lai sekmētu izplatīšanu. Visbeidzot pārskatā tiek analizētas digitalizācijas radītās iespējas un izaicinājumi galvenajās jomās, sākot ar inovācijām un prasmēm un beidzot ar digitālo drošību un datu pārvaldību, kā arī novērtētas politikas reakcijas uz šīm pārmaiņām Latvijā.

Šì publikācija ir Going Digital in Latvia tulkojums, kas ir dalıa no OECD Reviews of Digital Transformation sērijas, kas publicēts tikai anglu valodā.

Šī publikācija ir ieguldījums ESAO Going Digital projektā, kura mērḳis ir nodrošināt politikas veidotājus ar instrumentiem, kas viņiem nepieciešami, lai palīdzētu viņu ekonomikai un sabiedrībai uzplaukt arvien digitālākā un uz datiem balstītākā pasaulē.

Lai iegūtu papildinformāciju, apmeklējiet vietni www.oecd.org/going-digital

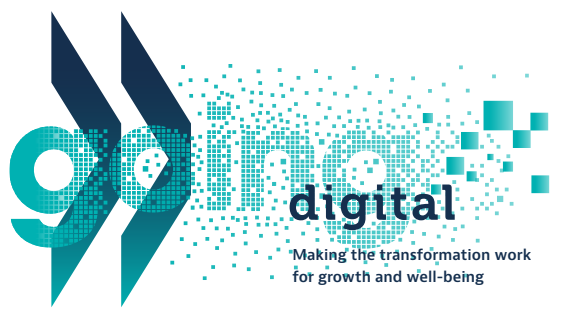

\section{\#GoingDigital}

PRINT ISBN 978-92-64-60703-3 PDF ISBN 978-92-64-57483-0 